\title{
AMERICA
}

AND THE NEW ERA

A Symposium on
Social Reconstruction

- EDTha Br.

ELISHA M. FRIEDMAN 


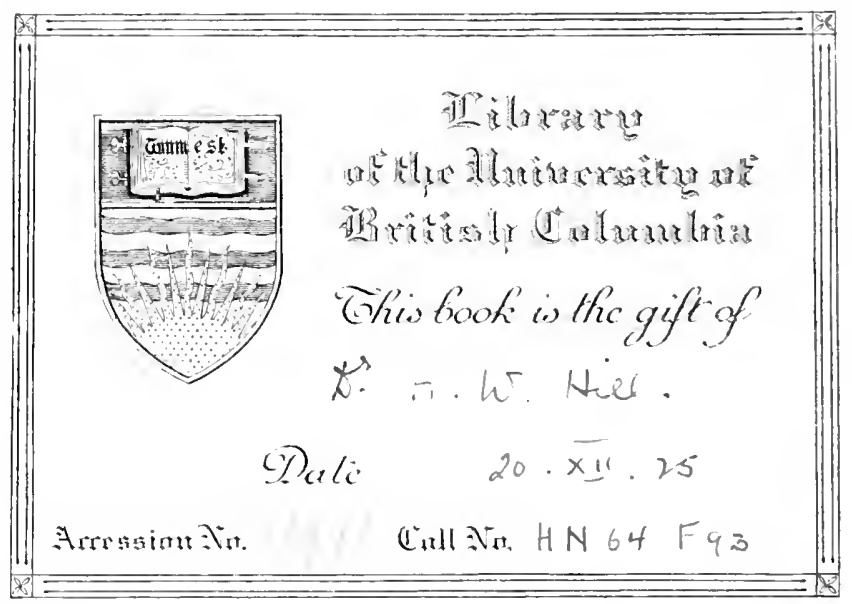




\author{
Digitized by the Internet Archive \\ in 2010 with funding from \\ University of British Columbia Library
}



AMERICA AND THE NEW ERA 


\section{AMERICAN PROBLEMS OF RECONSTRUCTION}

A National Symposium on the Economic and Financial Aspects.

Edited by Elisha M. Friedman.

With a Foreword by FrankLIN K. LANE, Secretary of the Interior.

LABOR AND RECONSTRUCTION IN EUROPE

By Elisha M. Frieduan.

With an Introduction by WILLIAM B. Wilson, Secretary of Labor.

INTERNATIONAL COMMERCE AND RECONSTR UCTION

By Elisha M. FriedMan.

With an Introduction by Joseph FreNcH Johnson, Dean of School of Commerce, Accounts and Finance, New York University.

E. P. DUTTON \& COMPANY 


\title{
A M E R I C A \\ A ND THE NEW ERA \\ A Symposium on Social Reconstruction
}

\author{
EDITED BY \\ ELISHA M. FRIEDMAN \\ EDitor of "AMERICAN PROBLEMS OF RECONSTRUCtion," aUthor \\ of "LABOR AND RECONSTRUCTION IN EUROPE," etC.
}

\author{
WITH A FOREWORD BY \\ HERBERT HOOVER
}

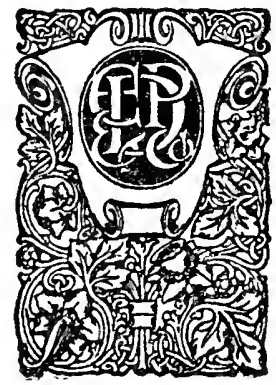

NEW YORK

E. P. DUTTON \& COMPANY 68I FIFTH AVENUE 
Copyright, I920,

BY E. P. DUTTON \& COMPANY

All Rights Reseroed 
To

THE PIONEERS OF DEMOCRACY

THE MANY UNKNOWN MEN AIND WOMEN

IN AMERICA AND ELSEWHERE

WHG ARE SILENTLY BUILDING

THE GREAT SOCIETY 
"Where there is no vision, the people perisheth; But happy is the people that keepeth the law."

-PROVERBS XXix:I8 


\section{PREFACE}

In an age of specialization, one's activities are necessarily delimited by the professional interest. However, the great war has affected more than the vocational superstructure of our lives. It has rocked the foundations of civilization, and compelled the revaluation of many standards far more vital and more basic than the vocational. This fact may explain, if it does not justify, this excursion afield of a student of economics.

The war has changed many of the conditions of living which demand analysis. Unlike the chemist or physicist, the student of the social sciences cannot vary the conditions of his experiments, but must wait until the processes of history afford him an opportunity to observe variations in phenomena, and to study their causes.

The war has upset some accepted articles of faith, but it has confirmed many others, which not only stood the test of war, but determined the victory. Many new needs have arisen and some old tendencies have become clearer.

We are entering a new era. We may do so blindly, or we may attempt to crystallize our ideas on the issues arising out of the war for the purpose of intelligently controlling social forces.

The problems of social and of political adjustment, and of the conservation of human resources, are neither less pressing nor less significant to the country than are the economic and financial questions, which have riveted the attention of statesmen and publicists during the past year. The little attention which the social problems have received is not a criterion of their relative importance in the life of the American people. It is characteristic of human nature to neglect those problems which, though they deal with the most fundamental aspects of the national life, lack the driving force of the economic motive.

This volume is a sequel to "American Problems of Reconstruction, a Symposium on the Economic and Financial Aspects." In 
the treatment of their subjects the contributors were requested to discuss:

I. What have been the effects of the war?

a. What pre-war conditions have become more clearly defined?

b. What new conditions has the war brought to light?

2. What should be our policy during the reconstruction period? Thanks for suggestions are due to Drs. Dickinson, Rogers and Wolman, and others of the group of men who gathered at the Cosmos Club during the war. The volume has benefited as a result of the advice of Dean William $H$. Welch, of the School of. Public Health of the Johns Hopkins University, and of my brother, David, particularly in the section dealing with the social aspects of medicine. Grateful acknowledgment is also made to President Frank J. Goodnow, Professors Charles H. Cooley, Franklin H. Giddings, M. M. Kaplan, T. I. Parkinson, Roscoe Pound, E. A. Ross, and Arthur J. Todd, and Mr. Abraham Flexner, for helpful suggestions.

Washington, D. C.,

The Editor.

Feb. 4, 1920. 


\section{CONTENTS}

PART I. PERSPECTIVES, SOCIAL AND POLITICAL

CHAPTER

I. The New Era and Social Progress

By Elisha M. Friedman 3

II. Some American Problems of the New Era

By Elisha M. Frieduan

PART II. SOCIAL PROGRESS VERSUS CYCLES OF CHANGE

III. The War and Social Evolution

By Charles A. Ellwood 3 I

IV. The International Mind; Its Character And Conditions . . By Horace M. Kallen

V. National Order and International Peace

By LiNDSAy ROgers

VI. Individualism in the New Social ORder

By Warner Fite

95

vil. War and Want. . By Jacob H. Hollander I 3

PART III. SOME ECONOMIC ASPECTS OF SOCIAL PROBLEMS

VIII. An American Land Policy By Richard T. Ely 127

IX. The Drift Toward the City

By Benjamin H. Hibbard I 5 I

X. The Immigrant and America

By Frederic C. Howe ${ }_{i} 6_{7}$

XI. Women in Industry . By Mary Van Kleeck 177 ix 


\section{PART IV.' THE NEW NATIONALISM}

XII. Social Progress and Political Administration . . . By Edward A. Fitzpatrick 193

XIII. The Constitution and Political Parties

By Victor J. WeSt

XIV. Developing the American Spirit

By Graham TAylor

XV. The War and American Ideals

By John Dickinson

XVI. The Spiritual Tradition in American Life By Francis G. Peabody

XVII. Religion in the New Age

By Edward Scribner Ames

PART V. THE CONSERVATION OF HUMAN RESOURCES

XVIII. HeREdity AND EUGENICS

By Charles B. Davenport 30r

XIX. The Child and Society

By Sophonisba P. Breckenridge 3 II

XX. New Demands in Education By Paul Klapper 323

XXI. Vocational Guidance and Vocational Education . . . . By James P. Munroe

XXII. Conservation of Health

By Hibbert Winslow Hill 353

XXIII. Food and Reconstruction By Graham Lusk 369

XXIV. Industrial Hygiene By J. W. Schereschewsky 397

XXV. Delinquency and Crime By William Healy 4I5

XXvi. Venereal Disease . . By Paul Popenoe 433

XXVil. Recreation and Play . By Henry S. Curtis 45 I

XXVIII. Nervous Strain and Mental Hygiene By E. David FrIEDMaN 467 


\section{ANALYTICAL TABLE OF CONTENTS}

\section{PART I. PERSPECTIVES, SOCIAL AND POLITICAL}

chapter

I. THE NEW ERA AND SOCIAL PROGRESS, By ELISHA

M. FRIEDMAN . • • • • • . • . 3

Characteristics of The New Era . . . . . . 3

The Nature and Meaning of Progress . . . . 7

The Methods of Achieving Progress . . . . . $\quad 9$

II. SOME AMERICAN PROBLEMS OF THE NEIV ERA, BY

ELISHA M. FRIEDMAN • • • . . . . . I5

The Nature and Limitations of Political Change . . ${ }_{5}$

Function of Public Opinion . . . . . . . . . 17

Political Adaptation . . . . . . . . . . . . 19

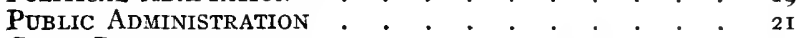

Class Relations . . . . . . . . . . . . . $\quad$. 22

RELIGION, NATIONALISM AND INTERNATIONALISM $\quad \cdot \quad \cdot \quad \cdot \quad 25$

\section{PART II. SOCIAL PROGRESS VERSUS CYCLES OF} CHANGE

III. THE WAR AND SOCIAL EVOLUTION, By Charles A.

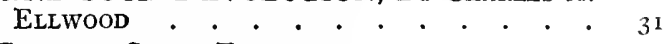

War as a FActor IN Social Evolution . . . . . . 3 I

The Three Stages of Human Culture . . . . . 31

War Not a Primtive Condition . . . . . . . . 32

The Development of War in Barbarism . . . . . 33

Modern War a Survival from BarbarisM • • . $\quad . \quad 34$

Cultural Significance of the Great War $\quad \cdot \quad \cdot \quad \cdot \quad \cdot \quad 34$

Possible Social Effects of the Great War . • . . 35

The Need of Rebuilding Our Civilization . • . • $\quad 37$

Is Lasting Peace a Realizable Social Ideal? - . $\quad 38$

The Real Causes of War $\cdot \cdot \cdot \cdot \quad \cdot \quad \cdot \quad \cdot \quad 38$

The Possibility of Progress Toward Lasting Peace . 39

The Recovery of Social Losses Sustained IN THE WaR 41

The Reconstruction Problem Before the American PEOPLE

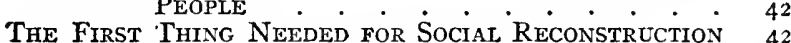

Political and Economic Reconstruction . . .

Educational ReconstrdCTION • • • • • • • • • 43

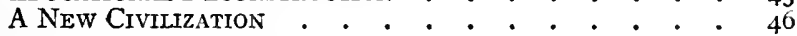

IV. THE INTERNATIONAL MIND; ITS CHARACTER AND

CONDITIONS, By Horace M. Kallen • . 49

Why Public Opinion Fails: The Basis of Social and

Political Thinking . . . . . . . . 50

Pre-War Internationalisms and Their Failure $\cdot{ }^{-} \quad 55$

Internationalism as a Problem of Psychology . . 59 
Internationalism and the Psychological Limits of Group Consciousness . . . . . . .

The Nature of Mind and the Machinery of Its Inter-

The League of Nations as an InStrument of INTERnational Mind • • • • • • • . • $7 \mathrm{I}$

V. NATIONAL ORDER AND INTERNATIONAL PEACE, By Lindsay Rogers . . . . . . . . 77

The WAR, Reconstruction, AND Revolution . . . $\quad 79$

The Duty of AMerica . . . . . . . . . . 82

The United States and International Peace . . $\quad 84$

Isolation MUST Be Abandoned . . . . . . . 86

The League of Nations A "Vehicle of Life" . . . . . . 87

A League of Peoples Not a League of Statesmen . . 91

Progress Through "The Search for Utopias" . . . 92

VI. INDIVIDUALISM IN THE NEW SOCIAL ORDER, BY WARNER FITE . . . . . . . . . . 95

The Old Individualism and the New Situation . . . 95 Individualism as a discredited theory . . . . 95 Special privilege defended as natural right . . . . 96 The ethical basis of individualism . . . . . 96 The new situation; not due to the war . . . . 97 The growth of the crowd . . . . . • . . 98

INDIVIDUAL LibeRTY AND Social ORganization . . . IOO Does organization imply a sacrifice of liberty? . . . I00

Democratic liberty based upon economic organization . IoI The end of organization; liberty or efficiency? . . . IOI The value of laissez faire . . . . . . . . . 102

EConomic Liberty . . . . . . . . • • . . $\mathrm{IO}_{3}$ Individualism favors private initiative and coöperation Io4 The trend toward state-responsibility . . . . . IO5

INDIVIDUALISM AND STATE-ENTERPRISE . . . . . 105

State-enterprise can be made individualistic . . . 105

State-enterprise must submit to competition . . . I05

The rights of private enterprise . . . . . 106

The rights of state-enterprise . . . . . . . I06

Economic functions to be dissociated from "sovereignty". . . . . . . . . . 107

"Sovereignty" incompatible with American ideas . I03

"Sovereignty" implies the German economic state roo

Economic functions to be dissociated from benevolence iro

Separation of function necessary for social order . I I I

Individualism as a principle of distribution . . II 2

VII. WAR AND WANT, By Jacob H. Hollander . . . . Ir3

The Neo-Social Philosophy of War . . . . . . II

The Older Doctrines . . . . . . . . . . II4

Statistical Evidence . . . . . . . . . . II5

War as a Socral Calamty . . . . . . . . II

WASTAGE AND DESTRUCTION . . . . . . . . . II7

The Initial Crash . • • • • • • • • • • . II7

Feverish Stimulatron • • • . • . . • . . II8

ReadjustMent Strain . • • • • • • • . . . II9 
UNEMPLOYMENT . • . • . . • . . . . I20

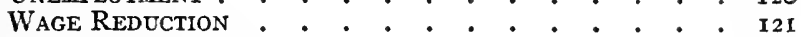

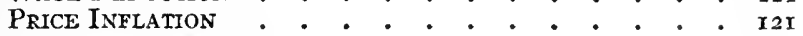

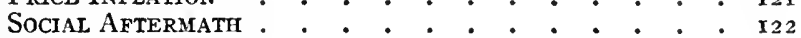

The Ultmate Fallacy • • . . . . . . . . 123

PART III. SOME ECONOMIC ASPECTS OF SOCIAL PROBLEMS

VIII. AN AMERICAN LAND POLICY, By RICHARD T. ELY . I 27

RECONSTRUCtion IN THE UNITEd States . . . . . . 127

ReCONSTRUCTION AND THE LAND . . . . . . . . $\quad$ I 28

Favorable Features in the Present Situation . . . 129

Unfavorable Features in the Presenl Situation • • I35

IdEALS • • • • • • • • • • • • • • • I37

Definition and Classification of Land : . . . 139

The Outlines of an American Land Policy . . . . 142

IX. THE DRIFT TOWARD THE CITY, By BENJAMIN H. HIBBARD . . . . . . . . . . . I5

The Drift to the City Not New . . . . . . . $\mathrm{r}_{52}$

The Problem Not Peculiar to America . . . . . 152

An Economic Problem Primarily . . . . . . . 153

The Geography of the Drift to the City . . . . ${ }_{54}$

IMPLEMENTS REPLACE MEN . . . . . . . . . ${ }_{57}$

Farms Grow Somewhat in Size and Much in Price . . I60

Price of Farms Rises as Population Falls . . . . 160

Where land Is the Basis of a Home, Population Is DENSER . . . . . . . . . . . . r6I

Many Workers Drawn to the City During the War . r6r

Readjostment of City and Country Population . . 163

Holn the RuRal Population . . . . . . . . $x_{4}$

Food Will Not Become Cheap in the Near Future . . 165

The Present Farms Should Be Well Manned Before We People the Wilderness . . . . . . 165

X. THE IMMIGRANT AND AMERICA, By Frederic C.

The Past

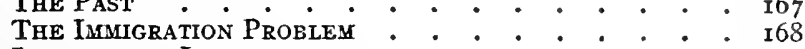

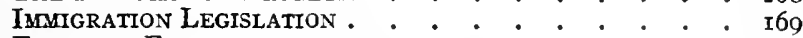

ECONOMIC ForCES . . . . . . . . . . . . . . . . . . . .

Shall We Have a Constructive, Selective Immigration PolICY? . . . . . . . . . . . 170

An Immgration CoMmission . - . . . . . . I72

Selection IN EUROPE . • . . . . . . . . . . 173

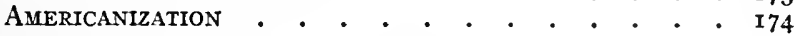

XI. WOMEN IN INDUSTRY, By Mary VAN KleEck • $\quad$ I77

Federal Activities for Women in INDUStry IN the War I78

WOMEN'S WORK RECOGNIZED AS Vital TO PRODUCTION IN THE WAR

Public Opinion Favorable to the War-Time EmployIENT OF WOMEN . . . . . . . . . 180 


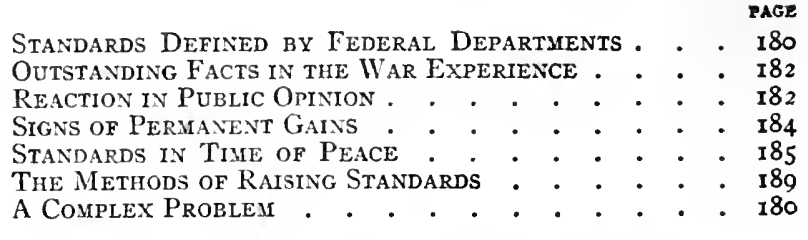

\section{PART IV. THE NEW NATIONALISM}

XII. SOCIAL PROGRESS AND POLITICAL ADMINISTRATION, By Edward A. Fitzpatrick . • • . 193

The Problem of Public Admintstration . . . . . 193

Inefficient public administration . . . . . . . 193

Russian experience . . . . . . . . . . . 194

The problem of administration in America . . . 197

AMERICA BeFore the WAR . . . . . . . . . . 198

Complacent America . . . . . . . . . . 198

A policy of drift . . . . . . . . . . . . . . . . I98

AMERICA DURING THE WAR . . . . . . . . . 200

Unpreparedness . . . . . . . . . . . 200

The draft administration: example of efficiency . . 20r

Decentralized administration effective . . . . 202

Avoiding the test of our national administration : 203

Transition PERIOd . . . . . . . . . . . 203

We won . . . . . . . . . . . . 203

Period of Reconstruction . . . . . . . . . 205

New programs . . . . . . . . . . . 205

Centralization of administration . . . . . . 205

The civil service reform movement . . . . . 206

Recognition of importance of public administration . 207

We train men for all callings except the public service . 207

Training teachers and training soldiers . . . . . 209

Learning by doing . . . . . . . . . . 2 I0

Democracy demands the best tools . . . . . . 211

The control of the experts . . . . . . . . $21 \mathrm{II}$

Service as public servant or as citizen . . . . . 212

The future . . . . . . . . . . . . . $2 \mathrm{II}_{2}$

XIII. THE CONSTITUTION AND POLITICAL PARTIES, BY VICTOR J. WEST . . . . . . . . . $2 \mathrm{r} 5$

NeCESsity fOR AMENDING tHe Constitution • • . 216

Greater powers should be conferred on the federal government

Relationship between legislature and executive needs readjustment

Necessity for Changing the Process of Auending the Constitution . . . . . . . . . . 216

Difficulty of amendment

Proposals to make the Constitution more flexible

Recent experience in the adoption of amendments

The Alternatives to Change by Amendient .

Wholesale revision by a constitutional convention undesirable

Expansion by judicial interpretation 
Limitation Set by the JUdiciary to the EXercise of Police Power by Congress . . . . . .

Under the power to tax the limit is as yet undetermined but is being approached

Under the power cver interstate commerce the limit seems to have been reached; differences in treatment of transportation and trading

Under the power to charter corporations there would seem to be no limit except the guaranties of private rights

Significance of the Attitude of the Supreme Court in THE ChILd-LABOR CASE . . . . . .

Any further grants of power must be conferred by amendment

Public discussion of changing the constitution is fostered Discussion of Public Questions Is Often Meaningless AND RaRety EFFEctive.

The political parties do not have definite platforms

Responsibility for the enactment and enforcement of public policy does not fall on one body

Party Leadership Is Not Identical WITH ResponsiBILITY AND Power . . . . . . . 226

Proposals to Correct This Defect . $\quad . \quad$. $\quad . \quad$. $\quad .226$

Coöperation between executive and legislature by granting members of the administration rights on the floor of the Congress

Coöperation by having the President choose his cabinet from members of the Congress

Advantages of a Congressional Cabinet

Technical expertness in administration

Legislative control of the executive more democratic

Party responsibility inside the government

SUMMARY

XIV. DEVELOPING THE AMERICAN SPIRIT, By GRAHAM TAYLOR . . . . . . . . . . . $23 \mathrm{I}$

The Spirtt of a People . . . . . . . . . . . . . $23 \mathrm{I}$

The Give and Take of Independence . . . . . . 232

A New American Consciousness . . . . . . . . . 233

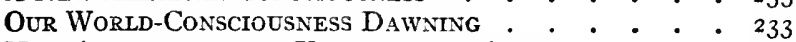

New Appreciation of Undervalued Assets . . . . $\quad 234$

SPIRIT of THE DRAFT . . . . . . . . . . . . 234

The Spirit to Assimmlate . . . . . . . . . . 236

SPIRIT of RETURNING Soldiers and SaIloRS . . . . 238

Worth Measured by Sacrifice . . . . . . . . 239

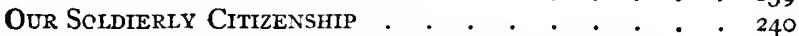

Standards of Leadership and LaW RaISed by War . . 240

EFfect of the World War on the Working World : $24 \mathrm{r}$

From Arms and the Man to Tools and the Man . . 242

A Democracy Safe for Itself and the World . : $\quad 243$

From Representative tc Direct Democracy . . . $\quad 243$

The American Spirit International . . . . . . 245 


\section{xvi ANALYTICAL TABLE OF CONTENTS}

CHAPTER

XV. THE WAR AND AMERICAN IDEALS, By JOHN DICKINSON . . . . . . . . . . . . . 247

The Purposive Nature of American Politics . . 247

Nineteenth Century "Idea Politics" . . . . . . 249

The Substance of Alerican Ideals . • . . . 253

SELF-GOVERNMENT . . . . . . . . . • . . 255

INDIVIDUAL LIBERTY . . . • • • • . • . 259

National Self-Determination . • . • . • . 264

XVI. THE SPIRITUAL TRADITION IN AMERICAN LIFE, BY

Francis G. Peabody . . . . . . . $27 \mathrm{I}$

Materialism ANd Ideaizsm in American Life • • 27 I

The American Character . . . . . . . . 272

The Spiritual Note in American Literature . $\quad 273$

The Spiritual Lessons of the War . . . . . . 274

The Churches and Their Spiritual Problems . • . 276

Education and the Spiritual Tradition . . . . $\quad 277$

The Spiritual Collapse of Germany . . . . . 278

Public Opinion and the Spiritual Tradition . . . 280

XVII. RELIGION IN THE NEW AGE, By EDWARd SCRIBNER AMES . . . . . . . . . . . . 285

A New Science of Religion . . . . . . . . . 285

The scientific study of religion in America . . . . 285

The psychology of religion . . . . . . . 286

The significance of adolescence . . . . . . . 287

Religion as social idealism . . . . . . . 288

Theory and Practice . . . . . . . . . 289

The place of doctrine in religion $: . \div \quad: \quad: 289$

The democratic idea of God.$: 0 .: \pm 290$

Religion and personality . . . . . . . . . $29 \mathrm{I}$

The Movements Which Give Promise por The Future : 291

The ideal religion does not belong to the traditional faiths nor to the new cults . . . . . 29I

The ideal religion belongs to the progressives of ail bodies . . . . . . . . . . . . 294

The new order will gain the support of the educated youth . . . . . . . . . . 295

The Demands of American Religrous Life . • . . 295

Reality . . . . . . . • . . . . . . 295

Democracy . . . . . . . . . . . . . 296

The use of knowledge : . . . . . . . . 296

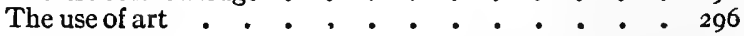

\section{PART V. THE CONSERVATION OF HUMAN RESOURCES}

XVIII. HEREDITY AND EUGENICS, By Charles B. Davenport zor Meaning of Heredity . . . . . . . . . . 30I MEANING OF SocIETY . . . . . . . : : : 303 TheORY of EUgenICS : . • . . . . 304 Methods Of INCREASTNG "The Best" StratNS : . : 305 MARRIAGE . . • . . . . . . • . . . . 306

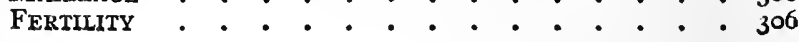


MARING HEREDITY WORK FOR SOCIETY . . . . . . 300

Other Social Applications of Heredity . . . . . 30 ,

IMMIGRATION IN THE NEW ERA . . . . . . . . 30n

xIX. THE CHIID AND SOCIETY, By SopHonisba P. BRECkINRIDGE

Child-Labor Legislation or Factory acts

EDUCATION

JUVENILE LABOR EXCHANGES OR VOCATIONAI SuPERVISION

Medical Inspection, School Nursing Service, and the SCHOOL VISITOR

Delinquent ChildRen

Dependent or Neglected CHILDREN

Non-Support and MOTHERs'-A ID Laws

$\cdot \cdot \cdot \cdot \cdot 3 \mathrm{I} 7$

PRE OFFANT MORTALITY • . • • •

INFANT MORTALITY AND FatheR'S EARNINGS . . . . . 318

Maternity Mortality . . . . . . . . . . . 318

Children Born Out of Wedlock . . . . . . . $\quad . \quad 318$

The Reconstruction Program . . . . . . . . 319

XX. NEW DEMANDS IN EDUCATION, By Paul. Klapper . 323

Education as the Adjusting Process in Life . . $\quad 323$

Education Adjusts Individual to the Fixed Order of THINGS

The Post-Belltm Program of Éducation Is Like the Pre-War Program

MOderN INTERPRETATION OF EDUCATION For Social EFFICIENCY .

Program for Physical Education . . . . . . . 325

Suggested Program for Physical Education . . . 325

EDUCATION FOR ECONOMIC ADJUSTAENT . . . . . . . 328

INCREased Period of Educational Control . . . . $\quad . \quad 332$

Elmination of Illiteracy . . . . . . . . . . . $\quad . \quad 332$

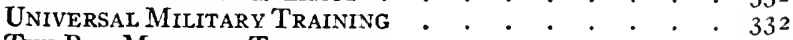

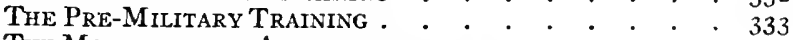

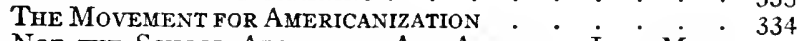

Not the School Alone bUt All American Life Must AMERICANIZE

Americanization Through Foreign Languages as iWeli as Einglish . . . . . . . . . . . 335

IMPRoved Professional Status of the TeAcher $\quad \cdot \quad \cdot \quad 336$

XXI. VOCATIONAL GUIDANCE AND VOCATIONAL EDUCAtion, By James Phinney Munroe . . 339

Education and the Adolescent . . . . . . . . 339

The Origin of OUR Haphazard System ...$\quad \cdot \quad \cdot \quad \cdot 340$

The Test of WAR .

The Adaptability of the Trained Man $\quad \cdot \quad \cdot \quad \cdot \quad \cdot \quad \cdot 34$.

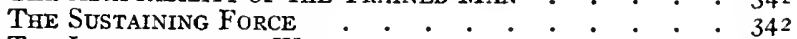

THE LESSONS OF THE WAR . . . . . . . . . $\quad . \quad 343$

The Chief End of Education . . . . . . . . $\quad . \quad 343$

OTher Lessons of THE WAR . . . . . . . . . . . 345

PSYCHOLOGIC TESTS. . . . . . . . . . . . . . .

TRAINING For SHIPBUtLIDING

Training of Mechanics and Technicians . . . . 347 
CHAPTER

Vocational ReHabilitation . • . • • • • • . 348

Education for the Child, Not the Child for Education 349

A Suggested Program . . . . . . . . . . 340

The Two Essentials: Aim and Incentive . . . 350

The Prevention of Human Waste . . . . . . $35 \mathrm{I}$

XXII. CONSERVATION OF HEALTH, Bx HibBert Winslow HILl . . . . . . . . . . . 353

Misconceptions on Health Conservation . • . . 353

Present Inadequacies of Public Health Work • • 353

Health and Evolution . . . . . . . . . . 354

Useless Efforts After Health . . . . . . . . . . 354

Health Conservation Necessarily Negative • . . 355

Elimination of PhiYsically UNfit . . . . . . . 356

Essentials of a Health Movement

Difficulties in Securing a Health "Morale" . . . 358

Principles of Future Health Work . . . . . . 358

Discussion of New Principles of Public Health Work 360

Universality of Action for Health Needed . . . 36i

WARNings on Health . . . . . . . . . . . 362

How Accomplishments in Health Must Come . . . 363

EDUCATION for Health . . . . . . . . . . . 363

Effect of the War on the Health Situation . . $\quad 364$

Nationalization of Medicine and Nursing . . . . 365

SUMMARY . . . . . . . . . . . . . 366

XXIII. FOOD AND RECONSTRUCTION, By GRAhaM LUSK . 369

PROLOGUE . . . . . . . . . . . . . . 369

The Fundamental Requirements for Food . . . . 372

The Relative Value of Different Foods . • . . . 375

The Division of Foods in a FaMmly's Dietary . . . 377

The Cost of a Family's Dietary . . . . . . . . 380

SOME FOREIGN CONDITIONS DURING THE WAR : . . . 382

Rationing in Belgium and Northern France - . 382

Rationing in Great Britain . . . . . . . 383

The Control of the Cost of Food . : $: 0^{*} \cdot 0^{*} \cdot 3^{86}$

In the United States . . . . . . . . . 386

In Great Britain . . . $: 0.0 .0 .0388$

AN INTERPRETATION OF THE FUTURE . : . : . : 391

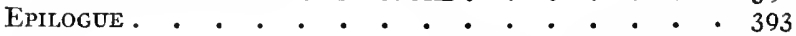

XXIV. INDUSTRIAL HYGIENE, By J. W. SCHERESCHEWSEY . 397

Man Power a National Asset . . . . . . . 397

SCOPe of the PROBlem . . . . . . . . . . . . . 399

APPEARANCE OF NEW INDUSTRTAL HealTh HazARDS . . 400

Nature of IndUStrial Health Hazards . . . . . 400

RESPONSIBILITY OF INDUSTRY . . . . . . . . . . 402

Conditions for Which the Public Is Primarily ReSPONSIBLE . . . . . . . . . . . 402

RESPONSIBILITY OF THE INDIVIDUAL IVORKER : : : 403

Progray for the IMPROVEMENT OF INDUSTRIAL HEALTh . 403

SCOPE and Linitations of Federal Agencies . . . . 404

Existing Powers of the Federal Government . . . 405

Health Surveys of IndUStries . . . . . . . . 406

Morbidity Statistics . . . . . . . . . . 407 
Medical aNd Surgical Supervision of Industrial

WORKERS . . . . . . . . . . . 408

Establishument of Minimum Health Standards . . . 400

IMPROVEMENT OF SANitation IN INDUSTRIAL CoMmunities 4 Io

Civil Industrial Establishanents OWNed and Operated BY the Federal Government . . . . 4 4II

Part to Be Played by States and Communities . . . 412

Education of the Public . . . . . . . . . . 412

XXV. DELINQUENCY AND CRIME, By William Healy 4 I5

A TASK For Constructive EfForT . . . . . . . 415

IMPORTANCE OF THE SUbJECT . . . . . . . . . $4 \mathrm{I} 6$

SCOPE OF Chapter . • . . . . . . . . . . 416

Present Weaknesses . . . . . . . . . . . 417

Historical Facts and Present Issues . . . . . . 4 I8

The reformatory idea . . . . . . . . 4 I 8

Probation . . . . . . . . . . . . . 419

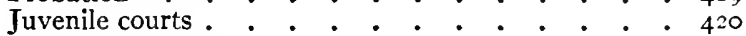

Other modern ideas . . . . . . . . . . 420

Changes in official attitude . . . . . . . 420

Recently Developed Tendencies . . . . . . . $42 \mathrm{I}$

Type of buildings . . . . . . . . . . 421

Gathering facts . . . . . . . . . 422

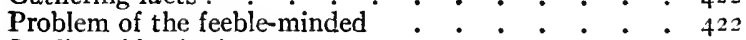

Studies of beginnings . . . . . . . . . . . 4423

Mutual welfare work among prisoners . . . . . 423

EFFECTS AND LESSONS OF THE WAR . . . . . . $\quad .423$

Influence of parental care . . . . . . . . . . 423

Intelligent discipline in institutions . . . . . . 424

Utilization of prisoners as soldiers . . . . . 424

Prisoners in useful occupations . . . . . . . 424

Other lessons . . . . . . . . . . . . 424

A Program for Constructitf Effort . . . . . . 425

A general program . . . . . . . . . . . 425

A federal program : . . . . . . . . . . 426

Best time for intensive treatment . . . . . . 426

Conditions of the discharged prisoner . . . . . 427

Parole of prisoners . . . . . . . . . . . 427

Treatment in prison . . . . . . . . . 428

Probation . . . . . . . . . . . 429

Court procedure with offenders . . . . . . . 430

Prevention of crime . . . . . . . . . 43 $\mathrm{r}$

Early treatment . . . . . . . . . . 43r

XXVI. VENEREAL DISEASE, By Paul Popenoe • • . . 433

Conditions RevEaled by THE WAR . . . . . . 433

Most infection from prostitutes : . . . . . . 434

Amount of infection among prostitutes . . . . . 434

Amount of infection among male civilians . . . 435

Infection among negroes . . . . . . . . . 435

Pecuniary cost to the army . . . . . . . 436

Efficiency of law enforcement . . . . . . . 436

Quarantine of diseased women . . . . . . . 437

Segregation discredited

Lack of protection for young girls . . . . . , 433 
CHAPTER

Lack of provision for feeble-minded . . . . . 438

Lack of hospital facilities . . . . . . . . . 439

Lack of follow-up work . . . . . . . . 439

The place of medical prophylaxis : . . . . 439

The patent-medicine evil . . . . . . . . 440

Appalling ignorance revealed . . . . . . . . 440

Few wholly new conditions . . . . . . . . 44I

Outline of AN After-War Policy . . . . . . . . 441

Continuation of the war program required . . . . 44I

Law enforcement . . . . . . . . . . 443

System of fines . . . . . . . . . . 443

Institutional care necessary . . . . . . . 444

Commercialized prostitution easily destroyed . . 444

Law-enforcement committees . . . . . 445

Medical measures . . . . . . . . . . . 445

Cases must be reported . . . . . . . 446

More clinics necessary . . . . . . . 446

Quack and nostrum must go . . . . . 446

Education . . . . . . . . . . . . 446

Protection of girls . . . . . . . . . . . 447

Recreation . . . . . . . . . . . . 448

SUMMARY . . . . . . . . . . . . . • 449

XXVII. RECREATION AND PLAY, By HENRY S. CURTIS . - . 451

Changed Conditions . . . . . . . . . 452

Play at the School . . . . . . . . . 453

High Schools . . . . . . . . . . . 454

College Athletics . . . . . . . . . . . 454

State Laws . . . • • • • • • • • • . 455

RuRal Recreation . . . . . . . . . . . 456

The Municipal Playground . . • • • • . . 457

The Cumulative Effect . . . . . . . . . 457

The Training of Teachers . . . . . . . . 458

The Community Center. . . . . . . . . . 458

MeMorial BUILdiNgs . . . . . . . . . . . 460

The Community Service Association. . . . . . 460

Commercial Recreation . . . . . . . . . 46I

The Recreation Comarission . . . . . . . 4662

Park Playgrounds . . . . . . . . . . . . . 462

THE OUtDOOR LIFE . . . . . . . . . . . . 463

The Effect of THE WaR . . . . . . . . . . 464

The OUTLOOK . . . . . . . . . . . . . 465

XXVIII. NERVOUS STRAIN AND MENTAL HYGIENE, BY E.

DAVID FRIEDMAN . . . . . . . . . 467

Tae Effect of the War on Mental Diseases . • . 468

Mental derangement in the army . . . . . 469

Types of derangement . . . . . . . . . 469

Psychoneuroses . . . . . . . . . . . . 470

Hysteria or suggestion neuroses . . . . . . 473

Neurasthenia or anxiety neuroses . . . . . . . 474

means of Reducing the Incidence of Mental Derange-

MENT IN THE ARMY . . . . . . . . . 475

TREaTMENT OF WAR NEUROSES . . . . . . . . . . 477

Causes of Menital Disurder in Civil Life . . . 478 
ANALYTICAL TABLE OF CONTENTS XXi

LESSONS OF THE WAR PAGE

The need for psychiatric clinics . . . . . . . . . . $\quad$. 479

Prophylactic measures . . . . . . . . . . 482

Feeble-mindedness controlled . . . . . . . 482

Delinquency checked and controlled . . . . . 483

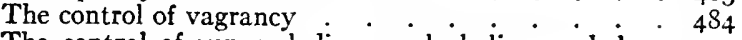

The control of venereal disease, alcoholism and drug addiction . . . . . . . . . . . 485

Heredity and the regulation of marriage . $\quad . \quad \cdot \quad \cdot \quad \cdot \quad 486$

Immigration . . . . . . . . . . . 487

Psychological tests for children and adults . . . . 487

Professional and popular education . . . . . . 489

Industrial prophylaxis . . . . . . . . . . 489

Social medicine . . . . . . . . . . . . . . . . 490

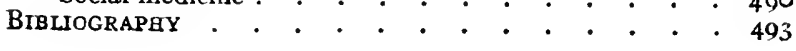




\section{ALPHABETICAL LIST OF CONTRIBUTORS}

PAGE

AMES, Edward Scribner ..$\quad \cdot \quad \cdot \quad \cdot \quad \cdot \quad \cdot \quad \cdot \quad \cdot 285$

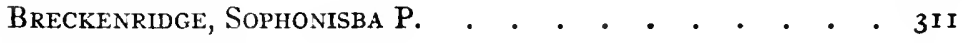

Curtis, Henry S. . . . . . . . . . . . . . . 45 I

Davenport, Charles B. • . . . . . . . . . $30 \mathrm{I}$

Dickinson, JoHN . • . • • • • • • • • • . 247

Ellwood, Charles A. . . . . . . . . . • . . . 3 I

ELY, RICHARD T. • . . • . • • • • . • • . . I27

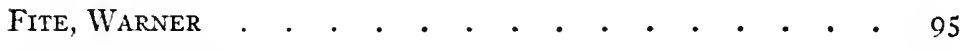

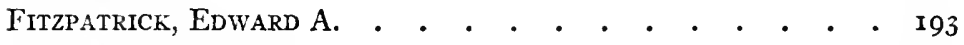

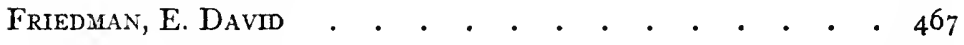

Friedman, Elisha M. • . . . • • • . . . . . 3 , I5

HEALY, WILliam . • • • • • • • • • • • • • $4 \mathrm{I} 5$

Hibbard, Benjamn H. . • • • • • • • • • • . I5I

Hill, Hibbert Winslow • . • • • • • • • • • 353

Hollander, JACOB H. • . . . . . . . . • . . II3

Howe, FRederic C. . . . . . . . . . . . . . . I67

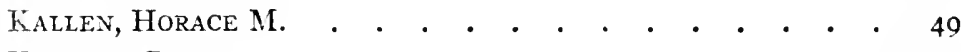

Klapper, Paul • • • • • . • • • • • • • . 323

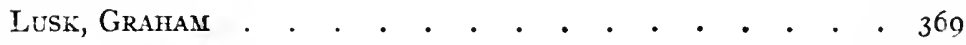

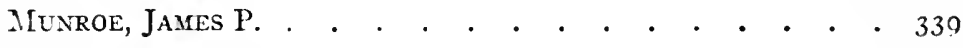

Peabody, Francis G. •.$\quad \cdot \quad \cdot \quad \cdot \quad \cdot \quad \cdot \quad \cdot \quad \cdot \quad \cdot 27$

Popenoe, Paul • • • • • • • • • • • • • • 433

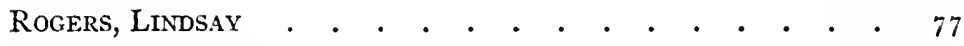

Schereschewsky, J. W. • • • • • • • • • • • 397

TAYlor, GrahaM • • • • • • • • • • • • • 23 I

VAN KleEch, MARY • • • • • • • • • • • • . I77

WEST, VICTOR J. • • • • • • • • • • • • • • 2 2 I5 


\section{FOREWORD}

\section{By Herbert Hoover}

Social Life is Organic.--An attempt to deal with the social problems of the new era leads to an examination of some basic concepts. Primarily, social life is organic and not mechanical. After centuries of trial and error, the human race, the survivor of æons of biological evolution, has developed divers social institutions to meet its needs. No over-night change can be grafted permanently onto a slowly developing world. To study our social life, we have sectioned it for convenience; we have broken it up into comprehensible bits. But life is more than the sum total of these concepts and society is something more than aggregations or groups of producers and consumers and capitalists. Almost every man plays each of these rôles at different times. And every sccial philosophy which opposes one of these classes to another is based on a false primary assumption.

As an analogy, let us recall the old scientific notions. We used to talk of physics and chemistry and biology as if they were separate realities. We now know that they are merely different ways of looking at the same natural phenomenon. The great progress in our knowledge of nature and in its application to human welfare arose from a unification of these disparate sciences and a truer view of life resulted from the study of the border fields, electro-chemistry, mathematical physics and biological chemistry.

Life is a complex whole, and except in the mind of the theorist, no simple formula can solve all the pressing problems of the present. Terms must not be confused with realities, or labels with conditions. We must face concrete facts, rather than attempt to apply doctrinaire generalizations. The ventures into the unknown have allurements, because unlike present conditions, their difficulties and injustices are not evident in operation.

In the crude historic processes of adaptation, government always lags behind social development. The industrial system de- 
veloped, and only generations later were factory laws enacted. The great corporations of to-day grew, and only years later were effective anti-monopoly measures adopted. The lag between the development of social functions and the creation of governmental machinery to deal with them is the period of acute unrest and agitation. Our governmental ethics lag behind private ethics. The political lobbyist and the ward politician thrived in a generation when his prototype had become extinct in business relations. American government is far less efficient than American business. But progress in making up the handicap, though slow, has been certain. If our pace is to be less tardy, we shall have to apply to our social and political problems the attitude that marks the successes of America, the attitude of the business man, of the engineer and of the scientist.

Scientific Method and Social Problems.--Because life is complex, integrated, organic, and ever-changing, our political and economic problems call for the application not of any set doctrine, or fixed formula, or principle of deduction, but of the scientific, inductive method. The facts, whatever they are, must be the basis of scientific social procedure. The one hundred thousand professional engineers in the United States, men trained in exact thinking and in administrative responsibility, who were drafted into civilian and military service during the war, vindicated the scientific attitude in dealing with problems of social organization. Unknown difficulties succumb to scientific analysis. When the engineers in the American Relief Administration undertook the novel task of feeding entire nations in Europe, there were no experts on the subject. But the application of scientific method to social problems produced the amazing result, that in spite of almost five years of continuous famine, the disease mortality among the children of Belgium was reduced to less than the pre-war normal. The problems facing America to-day, if attacked in the scientific spirit, will yield similar happy results.

Lessons of the War.-But the lessons of the war go further than child feeding. When civilization was threatened, and gruesome economies had to be effected, the mature adults made the sacrifices for they had less significance to the race future than had the children, who are the physical carriers of institutions and traditions, and who pass on the torch of civilization from the hands of the present generation. Again, in the chaos of Europe, 
the importance to stable government of widespread education and of a high level of literacy, was made apparent. Germany, lowest in illiteracy among the nations of the world, weathered her revolution with little suffering, whereas Russia, with a very high percentage of illiteracy, is paying in a most cruel way for the blighting ignorance, which the imperial régime fostered to insure its own perpetuation. Have we, in America, sufficiently taken to heart the two paramount lessons of the war-the place of popular education and child welfare in a self-governing society?

Industrial Unrest.-As an aftermath of the war, the world is in the throes of industrial unrest, here and elsewhere. The psychology of war was the expression of the herd instinct; every member of the community rallied to its defense. Social motives displaced personal motives. The industrial struggle was adjourned. The peace brought a return of the normal conflicts in society; these are not to be deplored. They need to be conducted under such limitations as will insure least harm to the social structure, whatever be its character. Industrial struggle must be confined by rules to insure fair play to the contending parties, as well as to the innocent bystanders-the unorganized public.

Industrial discontent is a natural consequence of the rise of the industrial system, just as agrarian revolts in France in 1789 and in Russia in r9I 7 were the outcome of unjust distribution of land holdings. We face the problem of the distribution of the products of industry. In our graduated income taxes we have grappled with the difficulties of the distribution of national income, and in our inheritance taxes, with the problem of the distribution of wealth.

In our further efforts to achieve just relations, we must bear some economic truths in mind. That part of the surplus of production over consumption that is available for compensation to labor may be increased not only by a more equitable distribution but by increased production. And the greater enjoyment of comforts by the average man of to-day over his ancestor of a century ago is due not so much to a more equal distribution, but as a result of mechanical inventions, to a vastly increased production per man. The old theory of a fixed wage fund is exploded. The more goods produced, the more there is to distribute. 
To increase production, the workman must be given an incentive to produce. Industry must be humanized. Labor must be regarded not merely as a cost of production, but as a living agent, with human instincts and social wants.

But no amount of syllogizing can overcome the basic human motive of the individual, of universally seeking to obtain for himself and his family the benefits of his effort and his ingenuity. Industry must be the resultant of two psychologic forces, the altruistic and the selfish. The attempt to run industry entirely on a selfish basis led to the evils of the factory system in the early nineteenth century. The attempt to run industry solely on an altruistic basis has led to the chaos in Russia to-day.

During the war large measures were taken on both sides of the battle-front to secure the mobilization of production and distribution for maximum use in the struggle. Vast sections of industry were effectively socialized. The success of these measures at that time was due to the patriotic impulse of war. But those who conducted these large operations were men of initiative and capacity, selected under the competitive system. The war impulses have passed and these organizations now face disaster from reduced productivity resulting in a rising cost of living and the need for subsidies for the common commodities of consumption.

There is no better example of this condition than the coal industry in Europe. Even omitting Russia, production has fallen from a rate of $600,000,000$ tons per annum at the time of the signing of the armistice, to a rate of $450,000,000$ tons recently. The coal industry is the life-blood of the modern state and it has proved a sensitive register of forces which diminish production and jeopardize the entire social fabric. Most European leaders of socialism realize the bankruptcy of their theories and are endeavoring to cover their retreat by ascribing the failure to other causes.

The Food Supply.-But although the United States is in an era of industrial development, our food production is a most vital item in our domestic economy and in our foreign trade.

The prime problem is to make agriculture economically attractive so that it nuay draw its quota of energy and ability from American life and keep pace with the rapid development of industry. In normal times the prices of farm products are deter- 
mined primarily by competition of the great sources of the world's food supply. Prices are thus only remotely regulated by the cost of production. The farmer must plant in advance and gamble on the demand. He cannot decrease his production to meet adverse contingencies with the facility that organized industry enjoys. Furthermore, the American farmer receives a smaller proportion of the consumers' purchase price for his product than the farmer of most other civilized countries. That is, the margin between the selling price of the farmer and the purchase price of the ultimate consumer is the widest in the world. Since prices are normally fixed by world forces, this margin comes predominantly out of the pocket of the farmer and not the consumer. The practical remedy therefore lies in decreasing the cost of placing the products of the farm into the hands of the consumer. Every decrease in this cost redounds to the benefit of the farmer.

One of the most effective measures in reducing the cost of distribution has been coöperation among producers. We have some successful marketing coöperatives, which have proved their value both to producer and consumer. But we have never developed the coöperation of farmers to the extent that Europe has. As coöperative marketing does not repress initiative or competition, the bogie of reducing output and increasing cost cannot be conjured up by the opposed interests. The economic value to the farmer of having a daily national price created by the ebb and flow of untrammeled trade in central markets has not been fully appreciated. In those commodities in which trading is unorganized neither the farmer nor the consumer can determine the right price and the margin between the consumer and the producer is wide. Wide margins are a measure of hazard. The war proved to be a great laboratory of experience and the subject demands an exhaustive investigation that the processes of distribution may be standardized and made efficient.

Americanism, an Attitude to Social Problems.--To the extent that some of our national problems cannot be reduced to a quantitative basis or resolved by scientific methods, we must turn to the inspiration of American history in order to find a mode of approach. And the history of our country is a story of the guaranties of freedom. The first amendments to the Constitution rewrote the Bill of Rights into our fundamental law. 
During the few years following the establishment of the Republic, rightly called by John Fiske the critical period of American history, we passed and then promptly repealed the Alien and Sedition Laws. And with the judicial interpretations of the Constitution the tradition of liberty was strengthened.

IVe must approach our problems in the light of our own history and our own experience and not with the prejudices of the crusted societies of Europe. America is a distinctive social personality, and personality is characterized by a peculiar reaction to problems, a unique way of doing things. The war revealed this individual note. Instead of forcing food cards on our citizens, the government tried democratic methods of rationing-voluntary abstinence from certain foods on specified days.

For generations the American people have been steadily developing a social philosophy as part of their own democracy. And in these ideals, it differs from all other democracies. This philosophy has stood this period of test in the fire of common sense; it is, in substance, that there should be an equality of opportunity-an equal chance-to every citizen. This view that every individual should not be handicapped in securing, within his lifetime, that particular niché in the communtiy to which his abilities and character entitle him, is itself the negation of class. Human beings are not equal in these qualities. But a society that is based upon a constant flux of individuals in the community, upon the basis of ability and character, is a moving virile mass; it is not a stratification of classes. Its inspiration is individual initiative. Its stimulus is competition. Its safeguard is education. Its greatest mentor is free speech and voluntary organization for public good. Its expression in legislation is the common sense and common will of the majority. It is the essence of this democracy that progress of the mass must arise from progress of the individual. It does not permit the presence in the community of those who would not give full meed of service.

Equality of opportunity and the maintenance of initiative may be attained not through the crystallization of economic classes arrayed against each other and exerting their influence by conflict nor through the transfer to governmental bureaus the distribution of either goods or ideas, but through the systematic prevention of domination by the few of the many and the stimula- 
tion of individual effort among the members of the whole comn:unity.

The Social Conscience.-The motivating influence to progress has been the American social conscience. The ethics of big business have risen since 1900 not alone as the result of legislative enactment and judicial decision, but also as a result of the awakening of the conscience of America. In the matter of trusts, railways, tariff and rural credits, there has been increasing public condemnation of pillage in the high places and a corresponding extra-juridical submission to public opinion. Our industrial development has outrun legal procedure and the lag is made less hurtful to the community because of the power of public opinion, a force more potent and pervasive than the law itself. An intervention of the public interest is usually avoided. Government investigation as an influence to business rectitude is distinctiy an American institution.

Of course opinion, after it has matured, is strengthened by legislative provisions. For example, the labor legislation of Kansas, like that of Australia, provides for the repression of the right to strike or lockout, for the compulsory settlement of labor disputes, for the determination of a fair wage and a fair profit, and as a final resort the conduct of the industry by the state. The experiment may succeed. It is, however, an experiment with many dangers, for it sacrifices a right of labor for the sake of problematical gains. The sacrifice of liberty is an insecure road to progress. If it does succeed it will again vindicate a broad tolerance of political experimentation by pioneering states for the benefit of the others in the Union. Furthermore, it will justify the comparative study of political procedure among our states and abroad. Much of our constructive legislation in recent years has been the product of investigation of the administrative systems of other countries, another feature of the scientific attitude in social work. The experiment may be worth while for the determination to the American people of its futility and any such determination is of value in social progress.

We should neither resent nor repress pioneering in politics. Lawful radicalism is often less dangerous than reaction, for radicalism is blatant and displays itself in the open. Unlawful rad:calism can be handled by the police. Reaction too often fools the people through subtle channels of obstruction and progressive 
platitudes. There is little danger of radicalism ever controlling the country with so large a farmer population, except in one contingency, the continued attempt to control this country by divers forms of our domestic reactionaries. 
PART I

PERSPECTIVES, SOCIAL AND POLITICAL 


\section{CHAPTER I}

\section{THE NEW ERA AND SOCIAL PROGRESS}

\section{By THE EDITOR}

Characieristics of the New Era.-What is meant by the new era and what are its distinguishing marks? The psychological element in the present situation is the desire on the part of a world just released from a nightmare of 52 months to regard the old era as closed and to think of a happy time in the future. Even if one makes full allowance for this factor, the new era does seem a reality. But may one truly say that the World War marked the beginning of this period? It is dangerous to fix any year as the beginning or the end of an historic age. In attempting to show how the fin de siècle spirit in politics, art and literature coincided with the close of the nineteenth century, Max Nordau in his "Degeneration" pointed out the difficulty of associating social movements with chronological landmarks. But there have been such accepted landmarks in the past. The sack of Rome in the year 476 is conveniently regarded as the end of the ancient era. The fall of Constantinople in 1453 brought on the Renaissance, a new era in art and literature. The French Revolution in 1789 ushered in the new era of individual liberty. And so in like manner the great war was more than a mere sign-post in history. It was itself a product of unstable forces whose realignment over a long period of time and in a less costly way would have brought on a new age. The great war hastened the coming of an era of the emancipation of suppressed peoples, of the guarantee of the rights of minority nationalities in the state, and of the democratization of industry. The process of socializing the individual was accelerated.

The new era manifests several distinct characteristics. Not the individual, but the group is the central concept of modern political thought. The battle cry of the French Revolution was "liberty, 
equality and fraternity," for the individual. Legally, this doctrine had been paraphrased in the state papers of the American Revolution, that all men were created equal, and had the inalienable right to life, liberty and the pursuit of happiness. Our day is no longer concerned in the same manner with the individual. The liberty of the individual to get drunk yields to the rights of society to prohibit drinking. The emphasis is now shifted to society. Its shibboleths are industrial democracy in Great Britain, communism in Russia, self-determination in Ireland, Central Europe and Shantung, and the League of Nations everywhere, except in the United States Senate.

This is a pericd of social gestation. The social woes of the day may be the pangs of the coming order. And the zeal for social reform may be the enthusiasm attending a new birth. Society is creating new forms of life. Economic groups are emerging and becoming distinct. The development of the labor organizations is a large step in this process. Group consciousness has been strengthered as a result of its expression in group organization and in the display of group power.

By the manifestation of their great power to attain their ends and of their irresponsibility to other groups in the community, labor organizations may hasten the formation of consumers' groups, whose united power as purchasers may be used to harmonize their conflicting claims with those of organizations of producers. In the absence of any effective and organized consumers' interest in the United States, the federal government has by the use of war-time powers presumed to determine how, for example, the price of coal to the consumer is to regulate the wages of coal producers. On the other hand, by the Treasury agreement of 1915 the labor organizations of Great Britain consented to a fixing of the wages of their members upon the condition that profits to employers be regulated by taxation. Society to-day is suffering from the display of power by the group that developed earliest, the producers, and will probably continue to do so until consumers, professional groups, and the salaried class, or society's overhead, are organized into groups with whose interests the forces of labor must be harmonized and by whose power the labor group may be controlled. Social responsibility and self-restraint have been slow to develop as a check upon the 
arbitrary use of group power, and as a result organized minorities by their acts frequently inconvenience the rest of society.

Coördination of power measures the degree of development of an organism, biological or social. Interdependence in function and specialization in structure are taken as standards of the stage of evolution. As a toddling child develops its muscles by crude practice before it coördinates them, so society is developing its classes and groups before it can harmonize them.

Again, in the new era the limits of social self-consciousness and of sympathy are being extended to include an ever wider social unit. There is a consciousness of the international group, humanity. As Hobhouse puts it, "there never was a time among civilized peoples when there was so much diffused sensitiveness to any form of social ailment." 1 The sense of world suffering when any of its peoples is hungry or thwarted in its national expression is evidence of an internationalism, which was never so understood as it is to-day. Internationalism dominates both the conscience and the policy of an ever growing portion of the world and to give expression thereto the nations are attempting to form themselves into a world organization. Men are conscious of ties to an increasing number of groups. Interests and relations of men are cutting across political lines. Non-political groupings, scientific, commercial and industrial, are increasingly transnational. Feace between the nations may mean not the cessation of war but a change of venue, from the national to the international arena, from the geographical to the economic basis, from military to industrial weapons.

Self-consciousness, whether of individual or social organisms, is a measure of evolution. For, as self-consciousness distinguishes humanity from other animal life biologically, so a self-conscious society represents a higher stage of development than does the society of the past. The principle that the growth of social self-consciousness is a step forward in the development of the race has important corollaries. Blind forces of the world of matter as well as of social and political tradition are losing their mastery over men. Adjustment is no longer made to a given environment but the environment is being molded to the needs

${ }^{1}$ Leonard T. Hobhoinse. Social Evolution and Political Theory. Columbia Univ. Press, 1913, p. 2. 
of humanity. Manipulation by man is replacing adaptation of man. The growth of social self-consciousness has been the prerequisite for the growth of social control of the forces about man. But social control implies conscious purpose and direction. Therefore, the man of the hour is not the radical but the administrator, not the man who breaks down the old but the man who shows us how to mold the new. The radical had a place in the old regime when accepted prejudices had to be broken up. He has less of a function in the new order, for society is more mobile now than ever before. When the environment is rigid, the danger is that progress may be too slow. When society makes the environment, the danger is that change may be too rapid.

A further mark of the present era is what might be called the new humanism, a transfer of interest from the processes of production to the conditions of life and of labor, an emphasis not upon commodities but upon the men that make them. This is but another aspect of increased social self-consciousness. We are thinking not entirely in terms of the material world about us, but in part in terms of humanity itself. We are in an age of reaction from the brilliant technical triumphs over nature, achieved regardless of social expense. Not an endless stream of production, purchased at the cost of the welfare of children, of the hard labor of women, and of dysgenic conditions, is the aim of society to-day. The world has changed its viewpoint from that of the mercantilist school of economists, and of the efficiency engineer, to that of the sociologist who interposes a new and more human scale of values. The shift in emphasis has come at a time when increased production is essential to make good the waste of war. "Work and save" may be changed from a piece of gratuitous advice to a practical modus vivendi if the psychology of the present labor unrest is understood.

Does the new era mean the repression of individualism? If by individualism is meant laissez faire, the power to do as one pleases-and this reduces to the privilege of the powerful to oppress the lowly, the freedom of the weak to be exploited by the strong-whether it be exemplified in the robber barons of the Middle Ages, the slaveholders of the eigiteenth and nineteenth ccnturies, or the unregulated manufacturing class of the nineteenth century, that kind of individualisn is being continually narrowed in extent. Men became free as their rights were re- 
stricted. The limits of the law enlarged the freedom of majorities as it abridged the rights of powerful minorities. In a social era the contacts of the individual multiply, his relations to other men increase in number, and he obtains freedom through association. The more individual he is the greater is the number of his contacts with society. The fullness of life consists in the number of conscious relations of the individual to society. He lives the most individual life who budgets his time as well as his income in the discharge of social responsibilities as much as in the satisfaction of personal needs. Because the social group affords the individual the greatest capacity for self-realization, he is freest in serving his group. Under such conditions, public service is not a duty but a means of self-expression.

The Nature and Meaning of Progress.-To what extent are the characteristics of the new era the signs of progress? In the view of the spokesmen of the defeated powers, the great war marks not an advance but a retrogression. Walther Rathenau sees as the fruit of the World War the Balkanization of Europe. Pessimists in other countries deny that mankind progresses, and affect to see in the afternath of the war a collapse of European culture, in a measure, such as followed the fall of Rome. They hold that mankind moves in cycles but not upward, that society changes but does not progress.

There are indeed difficulties which lend color to these denials of progress. The goal of civilization is not fixed but is continually changing with man's evolving ideals. And it is all the more difficult to measure reality against a shifting goal. Furthermore, social progress must be slow, and the advance toward the infinite ideals we cherish therefore sometimes seems infinitesimal. And finally, the period of social change is the generation or century, whereas human beings conveniently measure by the standards of their experience, months and years. Just as astronomical distance cannot be measured with a foot-rule, so the time factor of social processes cannot be reduced to the beatings of the human heart.

Some thinkers hold that progress is universal, inevitable, and the result of some natural force, the product of the innate instinct of humanity for perfection. But progress is neither inherent nor inevitable. Nations and civilizations in the past have decayed. Progress is not a gift of Providence. It is a result of 
efiort. Balfour says, and probably correctly, that "progress is no form of indestructible energy which, if repressed here must needs break out there, if refused embodiment in one shape must needs show itself in another. It is a plant of tender habit, difficult to propagate, not difficult to destroy, that refuses to flourish except in a soil which is not to be found everywhere, nor at all times." 2

Progress is not achieved at a uniform rate, nor equally in all fields of human activity, scientific, æsthetic, religious, political or economic. Progress in some particular direction seems to characterize a specific age or country. The existence and rate of progress are conditioned by many factors, the character of the physical environment, the nature and abundance of material resources, the success attained in utilizing them, the human element, the extent of its freedom and leisure, and of its vitality and restlessness, the nature of the social organization, its resistance to change, and the freedom of opportunity of the individual in it.

What are the factors of civilization whereby progress may be measured? The many standards that have been set up by thinkers of the past may be reduced to a basic one--the socialization of the individual, or to two-control of the physical environment for the benefit of society, and the self-control of man in his relations to his fellows. Or, in slightly amplified form, progress may be measured by the extent of-

( I) the extension of human knowledge and the application of science and art to the well-being of man in society,

(2) the utilization of insurance and mutual aid to eliminate extreme suffering, 3

(3) the exercise of freedom of thought and of expression and the tolerance of minority views,

(4) the improvement in the principles of conduct, and the establishment of justice,

(5) the abolition of hereditary or other unearned privilege, and the establishment of opportunity for self-development,

(6) the destruction of inequality between nations and between citizens of a nation,

${ }^{2}$ A Fragment on Progress, Arthur James Balfour.

"The test of civilization is the point below which its weakest and most unfortunate members are allowed to fall." 
(7) the respect for law and the stability of government,

(8) decision by compromise instead of by combat, or the substitution of rational persuasion for force,

(9) the widening of the social unit,

(I0) the belief in the Infinite as the ultimate inspiration to just and rational social conduct.

Reduced to terms of efficiency, progress may be measured by the cost to the individual of the functioning of society. Measured by any of the above standards, who can deny that society was on a higher level in I 900 than in 1800 , or than at any other previous age of history? And in spite of the many manifest and serious defects in the treaty of peace, there inheres, on the whole, greater possibility for progress in the new order than under the old regime.

The Methods of Achieving Progress.-Whatever value war may have had as a spring of progress in the past, its futility in this regard has been demonstrated by recent experience. War was effective in developing the martial virtues, only when a small proportion of the human race was involved, and when war was not so destructive as modern science has made it. It succeeded in fusing small tribes into a few great nations, when the national units had not yet been clearly defined.

War always selects the strong for death. The militaristic nation of one age is the decadent nation of the next. The Napoleonic Wars shortened the stature of the Frenchman by over an inch. The children born during the siege of Paris were neuropathic. The cases of locomotor-ataxia in Germany in the late eighties and early nineties were due to venereal infection in 1870 and $187 \mathrm{r}$. The great war, like all others, has left behind an army of diseased and crippled, of orphans and of underfed human stock. In a sense, war purges the race of the violent nations and leaves the peaceful to build civilization.

But the social evils of war match the baneful biological effects. Modern civilization is a complicated and delicate organism, nicely adjusted to conditions of close international coöperation. The war has broken up economic intercourse, caused pestilence and famine, repressed scientific achievement, demoralized those standards of conduct which conserve and perpetuate society, and eliminated the beneficent economic and cultural influences of nations 
on each other. The progress of the race may be set back generations as a result of the war, although in the breakdown of traditional barriers and in the general mobile state of society, during social crises, latent forces of progress do find expression.

As a result of the World War the philosophy of the superior race thrusting its culture and will upon others has received a setback if not its deathblow. Human development is taking place increasingly, not as a result of war between "superior and inferior" races, but as a result of peaceful contacts, of the conflict of ideas, and of the competition of enlightened opinion.

The biologist views social progress in terms of the struggle for survival and of the breeding of the fittest, but the sociologist would qualify the value of biological methods as applied to humanity. Natural selection was a cruel and wasteful process of adapting men to a given environment which called for brute strength and agility. But the physical development of men reached its present level eons ago. The biological process has since been replaced by the social process. Adaptation of man to the environment has largely been replaced by the process of creating an environment that suited men and of facilitating his adaptation thereto. Natural selection lacked a human aim, but purpose is a distinguishing mark of the social process. Natural selection was replaced by social selection, which operates through social medicine, law, custom, ethics, philanthropy and education. For selection in future will have as its duty not only to keep man at a level of physical development adequate to his needs, but also by the practice of communal aid, and by social amelioration to develop the essentially human traits of kindness and altruism. By extending the fullest opportunity for the mental development of the individual, the cultural horizon of man may be extended and the sum total of the intellectual assets of the race may be utilized for the common good. Society may attain these ends not by submitting to natural selection, but by setting up its own standards of selection, and by directing all its forces and institutions upon winning recognition for them. For "while the race has been relatively stagnant, society has rapidly developed, and we must conclude that, whether for good or for evil, social changes are mainly determined, not by alteration of the racial type, but by modifications of tradition due to the interactions of social causes. Progress is not racial but 
social. *** The struggle for existence is now conceived as a struggle between communities, and while it is admitted that in the community there is a certain suspension or mitigation of the war of all against all, it is insisted none the less that it is still through struggle, still through elimination, that progress takes place, only the elimination is now applied to communities as a whole; the weaker community goes under, and it is still well that it should go under." 4

The biologist would develop scciety by the methods of a Burbank. As one enthusiast ventured it, "Specify the kind of society you desire, and the eugenist will make it to order."

But, eugenics as a means of making a better society has its limitations. In theory, as Jordan pointed out, the replacing of mating through the agencies of spontaneous sympathy and affection by a rationalizcd selcction from a catalogued list of qualities. would mean the disappearance from the race of the element of romance which so colors and enriches life. In addition, there are the limitations of method. We have too little accurate knowledge of eugenics to enable us to make intelligent application of the principles. Its procedure is either unworkable, as sterilization, segregation, and restrictions on marriage, or else it constitutes an interference, unwarranted by the present state of our knowledge. We have not yet been able to reduce human traits to the "unit characters" of the eugenist.

It is true that, in a large measure, ability is hereditary. Galton's study of the histories of a large number of British men of science showed a genealogical persistence of intellectual distinction. The material in "Who's Who" shows a distribution of ability, laterally among the members of the same family and vertically through successive generations. On the other hand, many of the great men of history have had very mediocre descendants, and the "approach of a great man was in no sort indicated by scintillations along the genealogical track."

But, however fitful nature may be, surely genius is confined to no economic class. It is scattered throughout society. "There is nowhere in the land any home so remote, so humble, that it may not contain the power of mind and heart and conscience to which nations yield and history submits its processes. Nature pays no tribute to aristocracy, subscribes to no creed of caste,

"Hobhouse, idem. 
renders fealty to no monarch or master of any name or kind. Genius is no snob. It does not run after titles or seek by preference the high circles of society. It affects humble company as well as great. It pays no special tribute to universities or learned societies or conventional standards of greatness, but serenely chooses its own comrades, its own haunts, its own cradle even, and its own life of adventure and of training." 5

It is a failing of some students of heredity to ascribe superiority of traits to the class that has succeeded in amassing wealth. That is, accident of fortune is dignified as inherited virtue, or else adaptability to our present far from perfect civilization is taken as a test of merit or capacity. While it is true that "in a race subject to a severe struggle for existence, the types which are unsuccessful under the prevailing conditions will constantly be eliminated; but it is possible and more than possible that these types should include among them the most valuable stocks for the purposes of society." " Possession of wealth is not a measure of fitness to survive, nor is the two child system among the upper and middle ciass families a dying out of the fit.

Furthermore, the influence of the environment is as vital a factor in shaping character as heredity. Tuberculosis can not be fought as readily by proscribing the marriage of consumptives as by improving social conditions to prevent spread of the disease. The human race can be improved physically, not so much by breeding as by preventive social medicine. Again, the emancipation of women and the improvement of their economic status as a class and in general any other factor that will increase the range and freedom of choice of mates, will do more to realize the avowed aim of the eugenists than any attempt to make a new society by mathematical permutations and combinations of unit characters.

The function of eugenics is negative. It must content itself with preventing propagation of those having diseases or defects that are proven hereditary and that are not the result of the social conditions under which one generation happened to live. The positive aims of eugenics may be furthered by the "socializ-

"Woodrow Wilson, address at the Lincoln birthplace farm. Sept. 4, 1916.

"Hobhouse, idem., chapter on "Value and Limitation of Eugenics." 
ing of opportunity, which is the final significance and aim of social education."

The end of social education is progress, a directing of social change toward the realization by slow experiment of newly conceived goals. It means progress at a minimum cost to society. Such education must be universal and available to all who are capable of assimilating it. Primarily its aim is to conserve the current order-that is to compress into infancy, the period from birth to maturity, the experience of the human race, and of the particular group into which the individual is born. Education enables the individual to overtake his social group before his maturity-to make up his handicap. Education has a further duty, however. It must develop the pioneer of society, the research mind that can apply existing knowledge to charting the unknown-in the field of social relations as well as in the physical sciences. Besides the school, the agencies of education include the family, the state, the church, the trade union, the press, the theater, the library and all the institutions that make or reflect public opinion or the mores of the time. The limits which society sets on education mark the bounds of social progress. Therefore education must be free. Any restriction on the agencies of education hobbles racial development. If rational selection is to replace natural selection, if progress is to be direct rather than circuitous, continuous rather than cataclysmic, if progress is to be achieved at minimum cost, society will have to look to education, not only to transmit its tradition but also to shape its future. 


\section{CHAPTER II}

\section{SOME AMERICAN PROBLEMS OF THE NEW ERA}

\section{By THE EDITOR}

The Nature and Limitations of Political Change.-The war marked the flood-tide of idealism in America. Freed from the limitations on effort and aspiration that marked the pre-war period of settled ease and security, America during the struggle strove to a position of spiritual leadership in world affairs that recalled the exhortations of the ancient prophets. Only at the cost of social effort can a people rise to high levels of selfconsciousness, and when the stimulus is withdrawn a relapse sets in. Can the impulses of war-time America be harnessed to the problems of our daily lives? Perhaps so; if we define our national difficulties and think of them in terms of a conscious struggle for the realization of ideals.

Let us sketch the economic and political limits within which progress must be confined.

The time standards of the race are cons and millenia, of nations, centuries and generations, and of individuals, years and months. Of what practical value is this distinction? Primarily, that we are building for the ages, that American civilization is to be conceived in the light of long time. Impatience at the rate of progress is thus revealed as a human frailty. The time element in social progress becomes evident and gives your little man a truer perspective. Human standards of accomplishment are inadequate for appraising social movements. The great danger in an age of conscious adaptation is the likelihood of driving the social organism too fast and of pressing social changes at a rate beyond the capacity of the group for their assimilation. Even during revolutions the permanent changes are the ones 
that have come about slowly or that the people have long been mentally prepared for.

There is no infallible method of progress. However, the test of a civilization is its attitude to change. The more perfect a democracy, the less is the resistance to social change, the less the room for the radical and the greater the demand for the administrator. Minorities, which in the past obtained economic power, manipulated political power to fix their gains,- - the priestly class in ancient polities, the slave-owning class in Greece and Rome and in our Southern States, the feudal lords in the Middle Ages, and the manufacturing class in the nineteenth century. But universal suffrage is the key to any change favored by the majority, provided it is politically educated. America is treading no beaten path. As the men of the plains blazed a trail in the wilderness, so as a nation we are treading in the unknown. Every move from existing conditions may be backward as well as forward; it is an experiment, that must be conducted with a goal in view, pushed cautiously, and verified continually.

By observing experiments in social practice and political procedure abroad, and by the diversification of political experimentation in our various states-the North Dakota program as well as the social unit plan should be welcomed, not repressed-the country can select those methods that survive the competition of ideas, and that are both democratic and workable. Thus, the nation may achieve progress, slowly, at minimum social expense and without paying the price of periodic cataclysms like the Civil War. The world does not move like a column abreast but rather in Indian file, and all nations that are behind the pioneer have continuous alternatives, to follow or not, the experiments that have succeeded.

Frogress has been defined in terms of two standards-social justice, and opportunity of the individual for self-development. This field is bounded by two limits. The minimum standard of living in the country fixes the limit of international competition. As Lloyd George put it in the presentation of his budget for old age pensions in 1909 , any industry that cannot stand the overhead charges of social prophylaxis, insurance against accident, sickness, old age and unemployment, must drop out of the running. The other limit of social justice is the amount of reward that society must allow the individual to retain in order to draw 
out his capacity to exert himself to the limit of his powers. A very wide distribution of the annually accruing social surplus would be based on the curtailment of the relatively few large incomes and the increase of many small incomes, and would result in more spending for luxuries and in less saving for investment. Upon investments in industry depends the rapid increase in capital goods, the capacity for production, and the ever wider variety of satisfaction of human wants available to the masses. Civilization is built on the accumulated surplus of previous ages. A more equitable distribution of wealth would not necessarily be inconsistent with the accumulation of capital through saving, as the investments of the great number of French peasants have proven. But to achieve this result, a tax upon expenditure, not upon income, might have to be put into effect if the annually accruing, widely distributed social surplus is not to be dissipated. However, as Bowley has shown statistically for England, the equal distribution of all incomes above $\$ 800$ would hardly raise the level of living of the masses. On the other hand the removal of the incentive to work and to accumulate profits might diminish the total of the product available for distribution. ${ }^{1}$

Function of Public Opinion.-Having attempted to define the bounds of social progress, let us seek its driving forces. In a democracy like ours a free public opinion is as potent an agent for progress as any of the institutions for legislation. "Public opinion is more flexible and less mechanical than law, supplements it, and might be called a recruiting agent for filling up law's depleted regiments. However, being more flexible and more pervasive, it can search out and clean up chinks and crannies into which law may not penetrate, and withal creates less dust and commotion." 2

But public opinion is an instrument not only of social change but also of social control, not only of innovation, but also of conservation in the field of political principles. Democracy represents the survival of the fittest ideas, for the free competition of which democracy needs a free forum, a free press and free universities. The repression of ideas is an acknowledgment of their

${ }^{1}$ The Division of the Products of Industry, an analysis of the national income before the war. By Arthur L. Bowley.

${ }^{2}$ Theories of Social Progress, Arthur J. Todd. An excellent summary of theories in sociology. 
potency. And autocracy fears the outcome. Only they that have little faith in their ideals hesitate to put them to the test. But democracy is not a hot-house plant. It grew because it was the sturdy surviving product of competing ideas of social organization. Or, as Justice Holmes so ably expressed the thought: "When men have realized that time has upset many fighting faiths, they may come to believe that the ultimate good desired is better reached by free trade in ideas, that the best test of truth is the power of the thought to get itself accepted in the competition of the market, and that truth is the only ground upon which their wishes safely can be carried out. That at any rate is the theory of our Constitution. It is an experiment, as all life is an experiment. Every year, if not every day, we have to wager our salvation upon some prophecy based upon imperfect knowledge. While that experiment is part of our system I think that we should be eternally vigilant against attempts to check the expression of opinions, unless they so imminently threaten interference with the purposes of the law that an immediate check is required to save the country." "

Not only the ideas but the very substance of democratic society is dependent upon a vigorous public opinion. What is a crowd? People acting without a common will. A mob consists of people acting upon suggestion or by a superimposed will. But an organic community consists of people who act with a self-evolved will which has resulted from the fusion of their ideas. Not the flesh and blood of its citizens makes a republic, but the living traditions and aspirations which shape and dominate their conductits public opinion.

The more fully the will of the community is expressed, the more effective is a democracy. The frustration of the will of the minority and the unseating of its lawfully chosen representatives are denials of democracy and an unwarranted concession to the syndicalist of the futility of political methods in changing the spirit or institutions of a government. It is a bid for direct action and a vindication of violence. The expression of minority opinion makes easy the ungrudging acceptance of the will of the majority. The minority then has an intellectual stake in democracy. Even if its views are not accepted in full, they serve to moderate, to balance and ultimately to fortify the opinion

3250 U. S. 616. 
of the majority. And the minority stands ready continuously to undertake leadership if sanctioned by democratic tests. Democracy is the common mind in action. Repression of public opinion means the rejection of democratic norms of action, the casting overboard of the compass of the ship of state.

Political Adaptation.-In his lectures on constitutional government, Mr. IVilson laid bare the heart of political democracy. He said: "Government is a part of life, and, with life, it must change, alike in its objects and in its practices; only this principle must remain unaltered-this principle of liberty, that there must be the freest right and opportunity of adjustment. *** Political liberty is the right of those who are governed to adjust government to their own needs and interests." 4 But the conception on which our government is founded was static rather than dynamic, of equilibrium rather than of progress. The inherent principle is mechanical rather than organic. The theory of checks and balances was an heritage from British political thought during the period when the crown was being continually shorn of vested arbitrary power by the House of Commons.

We therefore have a government based on distrust and jealousy. The states are balanced against the federal powers; the legislative, executive and judicial are checked against each other. And the result is that we have divided power and responsibility. The system will always stand but won't always work. It is balanced but not directed. In a responsible government a test vote may cause the fall of a ministry in power so that an appea! may be made to the people in the ensuing election. Under our government "the will of the people as a whole is prevented from having at any moment an unobstructed sweep and ascendency." 5 The deadlock on the treaty between the Senate and the President hampered government business at a critical period in American history. The suggestion that the decision on the treaty be postponed fifteen months in order to give the electorate an opportunity to vote thereon would be a poor substitute for responsibie government, in which issues are decided as they arise. As the justly proud memories of having saved the Union give way to the vital and ever changing issues of the day, it is to be expected that

"Woodrow Wilson, Constitutional Government in the United States. Columbia University Press, New York.

'Wilson, idem. 
the Republican Party will not repeat its long, unbroken record of control of all branches of the national government after the Civil War, and that party differences of the executive and of the legislative bodies will be more frequent. And every election between presidential years that puts the parties of the executive and of the Congress in opposition increases the evils of the lack of responsible parliamentary government, and enables either branch of the government to hobble the progress of the country for two years. The delay in ratifying the treaty, with all its untoward consequences, is a striking example of the effect of the division of power and of irresponsible party government, such as exists in no other civilized country.

The absence of responsibility in government, the lack of a cabinet responsible to the people's representatives, has increased the bitterness of partisanship in the United States. In England, France, Italy or any of the European constitutional governments, a party is either in or else it is out. Parliamentary action is then clean-cut and decisive. Partisanship finds legitimate and effective expression in legislation until the party in power fails to hold the confidence of the majority of the parliamentary body. But with us a party may be half in and half out; an election may give it control of one branch of the government. Neither party can then be effective; both parties frequently seek an outlet for their frustrated political powers by idle denunciation, by malicious investigation of the acts of the other, by petty methods in blocking action by their opponents. The disgust for politics upon the part of the people is greatest under an irresponsible government. There is little cause for surprise that Prof. Hugo Preuss rejected the suggestion of the American Headquarters in the occupied territory that he model the German constitution after that of the United States. "Less than nine months later events proved I was correct," said he. "President Wilson found himself in conflict with the Senate on the question of the ratification of the treaty of peace."

Much of the half-baked and impractical agitation for the initiative, the referendum and the recall, is the immediate result of our irresponsive and undemocratic system. Direct government is urged as a substitute for representative government, because the latter has not been properly used. The methods of the New 
England town hall are unsuited to continental United States. Even if incorporated into our government these devices of direct government would be a poor substitute for responsible government, under which elections are based not upon the calendar but upon the issues as they arise.

Public Administration.-Concurrent with the attempt to make our government express more accurately the will of the people is the movement to perfect our machinery of administration. The functions of government have enlarged. Public opinion increasingly is sanctioning the extension of the sphere of government into the economic field. Social programs, such as the regulation of the labor of women and children, and social insurance are continually throwing a burden upon our administrative mechanism.

"Administration is legislation in action," as John R. Commons put it. Our legislation must therefore be drafted by experts whose experience enables them to foresee difficulties of administration and to prescribe definite and suitable provisions for carrying out the provisions of the law. Furthermore, experience in administration must continually be utilized in perfecting legislation. For legislation evolves. It is rarely perfect as drawn, but must be revised against practice. When an act is imperfectly or loosely drawn, the administrative officers by the use of wide powers practically usurp the function of legislators in the attempt to make good the defects of the law. A notable example was the excess profits act, which was administered by an advisory board that practically repealed some parts of the law and rewrote other parts.

To meet the growing scope of operations of the state, administrative bodies have been set up, which combine executive, judicial and quasi-legislative powers, such as the Interstate Commerce Commission, the Federal Trade Commission, the Shipping Board, the Federal Reserve Board, and other bodies which were created under the Wilson administration. With the extension of the administrative powers of the government, the need for ability in the public service has become increasingly apparent. The qualification for election to Congress is often a silver tongue, but the test of achievement is an analytical mind, an ability to criticize pending legislation. The hope of a democracy is a politically educated and discriminating electorate. The test of ap- 
pointment to office is often service to the political machine, which is a perverted measure of administrative capacity.

Our public service competes with business in attracting able men. The economic law of increasing returns has a psychologic as well as an economic application. It explains the diversion of ability in America into industrial life. The sweep and diversity of modern business, its international character, and the intricate problems of adjusting social relations, all have lifted the directing of business to a level which calls for the exercise of qualities of statesmanship. Big men do not have to enter political life to engage in affairs of national concern and of international importance. However, the difficulty should correct itself. As our population increases, our national problems become more complex and call for more and better public administration. On the other hand, a dense population has relatively fewer industrial opportunities and the surplus of human talent becomes available as in Great Britain and in continental Europe for the increased demands of public life.

Class Relations.-But our national problems are not primarily concerned with politics. As a condition of progress, the ultimate character of the racial stock of America matches in importance the methods of political adjustment.

The existence of clasśes is not to be deprecated. The richness of civilization depends upon the number and upon the diversity of the relations of individuals to society. The state is not the only institution to which its citizens are bound. The pluralistic state seems to be the goal of modern political philosophy. The increase of human relations increases the number of classes. However, the social classes of a democratic society are neither permanent nor hereditary. The natural variations of ability among human beings is inevitable biologically. And therefore under freedom of opportunity for the self realization of the individual, an aristocracy of intellect and capacity must arise. Its character may be fixed but its constituency changes. It is continually an aristocracy of social servants and not of exploiters; it is based on merit, not on material possession, on worth, not on wealth, and achievement and not on inheritance. To a large extent it will be hereditary, for no estate tax can be levied upon the inheritance of capacity. To enter the aristocracy of ability all are eligible and from it is expelled the generation that no 
longer qualifies. Snobbery is the artificial support sought by the members of a class that would retain the privileges earned by their forbears. A mobile society with an intellectual aristocracy is stable, for it is free from a sense of disputed domination on the one hand and of resented repression on the other. The existence of such a class of the select, under the free competition of ability, that is, the full opportunity for the development of the individual, acts as a powerful force for national progress. It develops latent powers and raises the general level of the community. Such a mobile aristocracy is to be found in the universities, in the professions, in the research institutions, and wherever achievement is subject to definite public tests, where the judgment of a large number of one's peers is possible, and where failure can not be covered by services of a supporting organization.

But some class lines seem to be permanent. Such is the color barrier. Biologically, conscious fusion of the white and the black races is unthinkable. The class relations have been and still are, largely, that of dominant and repressed group. But with the slow growth of liberal ideas and with the rise in the economic prestige, the cultural level and the political power of the negro, these relations will be untenable. No long range plan of adjustment of class relations has been suggested. Perhaps there is no single exclusive solution. Some negro leaders have suggested segregation in Africa or northern Mexico under subsidy of the white race. But if this solution cannot solve the problem of ten million black folk in the United States, it should at least act as a safety valve or overflow reservoir as anti-social pressure increases. At all events, America has an opportunity to develop a new phase of democracy, the living side by side of two races that must not and cannot fuse and are not in the relation of master and servant. Avowedly, any dual civilization in one region is socially costly. But the white and the black races in the United States must pay with compound interest the penalty of the selfishness of the southern planters and northern shipowners who profited by the importation of slaves. And perhaps future generations may have to grapple with the problem of the yellow race in the United States, if we do not profit by past experience.

On the other hand, our white immigrants cannot form permanent classes. Americanization means the development of com- 
mon traditions and common hopes for all citizens of the country. "A people not conscious of any unity, inorganic, unthoughtful, without concert of action, can manifestly neither form nor sustain a constitutional system. They can form no common judgment; they can conceive no common end; they can contrive no common measures." 6 Americanization is essential to our democratic purpose. The nation-state may be formed either by breaking up heterogeneous states, like those in Europe, upon the principle of self-determination, or else by the fusion into a new nation of diverse elements within the state. Long-established national lines in Europe made fusion difficult and fission necessary. But every immigrant into America exercises a voluntary choice and he has no right to expect to preserve intact in his new country the historic limitations of the old. However, the fusion of a new nation is a slow process. Amalgamation is quickest and most thorough when it is gradual and spontaneous. To hasten Americanization by the repression of foreign cultures defeats the end sought. The subject group, in defensive reaction, adheres more strongly to the old culture, whose disintegration is threatened. Herein lies the pragmatic sanction for a broad tolerance. A minority group that is granted freedom of choice naturally absorbs the ideals of the majority, responds to the same stimuli and soon merges culturally and ultimately physically as well. That this end may be attained it is essential that the minority be accessible to American influences, through the school, the press and other avenues of education, as well as by actually living the American life, by participating in our institutions, the trade or profession, the army and the numerous other social bodies. Loyalty is a by-product of work in and with the community. Service and not oratory is the test of loyalty.

Like all other groups, the Jew in America is merging with the rest of the population, adding like any other element in the community a distinctive contribution to the common culture, and being in turn invigorated by contact with other racial stocks. However, the lack of a reservoir of national life, such as is possessed by the American of Scotch or Dutch ancestry, retards the process of fusion of the Jew, for the surrender of his identity must mean the ultimate disappearance of his historic group. In other words, the members of any people that has lost its geo-

-Woodrow Wilson. Constitutional Government in the United States. 
graphical center have individually a social responsibility to maintain a common bond until, and in the hope that, its normal life as a people will be restored. The perpetuation of a portion of Jewry in Palestine should therefore accelerate the assimilation of the remainder, scattered as minorities amongst the nations. And if, in diminishing numbers, the Jews remain as separate religious communities in their various native lands, the quality of their contributions to local spiritual life may be enriched by the existence of a living Jewish center in Palestine which might radiate through them, consuls of the spirit, a new stream of energy such as issued in ancient days from Palestine, the cradle of the world's religious aspirations.

Religion, Nationalism and Internationalism.-Of the classes that seem to be permanent, or rather whose permanence is provided for under our Constitution, the religious groups stand out. But these classes in the community are gradually losing their fixity as religious ideals change. The God idea has grown with the development of civilization. From the animal or human visaged idols that symbolized divinity to the savage, to the divine family, the anthropomorphic conception persisted. God as a powerful king was the analogue of a monarchical order. In a democratic age, the Eternal Force that makes for Righteousness is conceived as "the ever continuing Creator with whom man coöperates." 7

The concept of religion likewise has changed. It originally dealt with man's relation to the unknown. But now Leuba calls the love of life at any and every level of deveiopment the religious impulse. Bender defines religion as the human impulse toward self-preservation, by means of which man seefs to carry his essential vital purposes through against the adverse pressure of the world by raising himself freely toward the world's ordering and governing Power when the limits of his own strength are reached.

The function of religion has grown along with life, for religion is a product of life and an inspiration to its fuller realization. And life has undeniably changed in the past two thousand years. And because the traditional religions have adhered to ancient ideals and symbols which do not express modern needs men every-

"Follett, M. P. The New State. A suggestive study of the psychology of politics. 
where are thirsting, like harts for the water brooks, for new spiritual expression. And this search is miscalled the religious indifference of the age. Modern religion does not diminish our faith. Indeed, the unknowable, the bourne beyond the senses, or their extension, the microscope and telescope, is enlarged with every new discovery. The scientist recognizes with true humility the littleness of our knowledge. Nor does modern religious thought deny immortality. In fact, the scientific principle, the conservation of energy, lends peculiar emphasis to the doctrine of immortality, a belief whose reality is supported by the universality of its adherence throughout history, in primitive as well as in civilized society, on all the continents and by practically all faiths. The belief in the immanent One is being continually strengthened by the researches in the nature of matter and energy.

The doctrine of salvation by faith was a simple formula. It did not meet life's problems but rather showed an easy escape from the need for solving them. Heaven was a concept for sublimating one's perplexities. The sphere of human thought and effort was shifted from the earth with its insistent problems to a region where there are none. The golden age of man was believed to be in the past; he had fallen from a blessed estate. Modein religious thought and social philosophy place perfection ahead, as a goal to be striven for, not as a memory to be sighed for. The old church dealt with the individual, his salvation, his future life. Our spiritual effort to-day is concerned with society, with the attempt to find just relations between men, between classes, between nations.

What is the application to America? Spiritual America cannot live by the idcals of ancient Rome or of medieval Europe. And the statistics of the unchurched show that it is not doing so. The countless creeds that have developed in the United States represent a ceaseless search, however unsuccssful, to find new values which reflect the spiritual needs of our own days. The formation of an American nondenominational church by John Haynes Holmes, the turning of the poor man from the church to the labor temple, the work of the Ethical Culture Movement for a generation, are attempts to synthesize the spiritual life of America in the light of our present social problems. The religion of America will integrate its diverse cultures. Very probably the moral tone and hard quality which the Puritans im- 
parted to American life and which have survived the assaults of competing religious ideals, will remain as a permanent influence with us. History records many a fusion of existing and ancient cultures. For example, rarely have two fused as have the AngloSaxon and the Hebraic. The cross-fertilization of the two in England produced the generation of Cromwell and Milton. In America, the grafting of the two gave us the spirit of the Puritans, the Quakers, and other Colonial nonconformists. Likewise the timbre of the historic faiths will probably persist and give a distinctive tone to the spiritual aspirations of America. They may become the agencies of American spiritual endeavors of the future. The Interchurch Movement in America is a current expression of this tendency.

The continual change of life evolves new ideals and new purposes, which no fixed standards of the past can satisfy. The resuit is the siow development of an American religion, whose prophets are the leaders of political thought and of social philosophy, whose symbols are the national ceremonies and social institutions, whose ideal is a nation exalted in righteousness and whose mission is to teach the world. Indeed, President Wilson's addresses during the war, like the addresses of Lincoln in our earlier great crisis, foreshadow the new religious endeavors of America. They have the inspirations and the appeal of chapters of Isaiah. Thus the state has not only been separated from the church; it is replacing the church. Ecclesiasticism, the mother of civilization, has seen her sons go forth from the parental roof, always against her will-philosophy, science, art, education, and finally government, each developing more freely thereafter, and therefore aiding more greatly in the progress of mankind.

The world entering the social era is turning to the Hebraic concept of a religion which is national in its constituency, but universal in its mission and in its message. An effective religion must be distinctive, must be limited to those of common tradition and common aspiration. The breakdown of the universal Church of Rome, rather, the rise of Protestantism, was the result of the process of differentiation of the peoples of Europe, the emergence of a national consciousness, and the desire to set up local spiritual leadership, in which the head of the state became the head of the church. The effectiveness of the ideals of a religion diminishes with the universality of its constituency. It 
shrinks like the greatest common denominator. This may explain why a universal church failed to prevent the World War.

In the social era we are entering upon, the world is accepting the old Hebraic ideals of social justice, of freedom within the law, of continuous adaptation of religion to the realities of life. ${ }^{3}$ In the mobile age in which we are living, when opportunity for the exploitation of men and by classes is increased, the prophecy of Micah is more appropriate than ever- "He hath shewed thee, $\mathrm{O}$ man, what is good: and what doth the Lord require of thee but to do justly, to love mercy and walk humbly." These are the tasks for the here and the now. To-day, our justice must be more impersonal and more abstract than in former ages, for it affects not our kinsmen within our gates but the unseen foreigner, the coolie of Asia, the peon of Latin America, the kaffir of Africa, whom the cable and the steamship have put into the service of stockholders of distant countries.

Salvation by faith and the dodging of life's problems by referring them to a heaven and a hereafter have little significance in a world which God, through man, is working to perfect. And so nationality is being conceived as a spiritual force, as religion in a new garb. The eighteenth and nineteenth centuries guaranteed the individual his religious rights-liberty of consciencebut the twentieth century is guaranteeing national rights-liberty of association for expressing the group spirit in action. When the conscience of the nations will be touched, when love of country will be subjected to the sanctions, not of national aggrandizement, but of rational social ethics, when the old Hebraic notion of Torah, "the law," and of social responsibility for our actions, will be accepted internationally, rather than the doctrine that the state can do no wrong, when the nations will beat their swords into plowshares and their spears into pruning hooks, then again, perhaps, a universal church may be realized. The ideals of a genuine league of nations may color the content of a world religion-a new relating of the hearts of men to the Infinite God, who has led man through the struggle of the ages, and raised him from a beast of the fields to set him a little lower than the angels.

${ }^{\circ}$ C. F. Kent and J. W. Jenks. The Making of a Nation-The Beginning of Israel's History.

L. Wallis. Sociological Study of the Bible, 
PART II

SOCIAL PROGRESS VERSUS CYCLES OF CHANGE 


\title{
CHAPTER III
}

\section{THE WAR AND SOCIAL EVOLUTION}

\author{
By Charles A. Ellwood \\ Professor of Sociology, University of Missouri.
}

War as a Factor in Social Evolution.-Probably no single factor has had such influence upon the evolution of human groups, especially political groups, as war. Hence whole social and political philosophies have been based upon the fact of war. To discuss war in general, accordingly, as a factor in human social evolution would necessitate the setting forth of the most important chapters in anthropology, history, and sociology. This is especially true of the Great War, which requires the combined resources of all the social sciences for its explanation. What, then, is the relation of war to social and cultural evolution? What is its place and meaning in human history? Is it something universal and inevitable? Or is it transitory and, with fuller social development, avoidable?

The Three Stages of Hunan Culture.-Anthropologists tell us that the whole history of man may be roughly divided into three stages-savagery, barbarism, and civilization. Savagery, in which man is a mere child of nature, living off the wild fruits of the earth and the animals he can kill and eat, making no attempt to control his own destiny, lasted for the race at least one hundred thousand years, archæological evidence shows. To this day some belated human groups still survive in it. Barbarism, a transitional stage, in which man begins to cultivate the soil and raise domestic animals, but soon turns his attention to preying on his fellowmen as an easier method of gaining a livelihood than the mastering of physical nature, began in Europe

1 Ph.B. I896, Cornell University; Ph.D. I899, University of Chicago; studied at Berlin and Oxford; Professor of Sociology, University of Missouri, Ig00_; author of works on sociology and social psychology and of various monographs on cultural anthropology. 
about seven or eight thousand years ago with the coming of neolithic man. Civilization began only with the keeping of historic records, with man's coming to social self-consciousness, and with his beginning of control or mastery of the mental and social elements in his life.

Civilization, in the strict sense, is, then, a very recent development in social evolution. Its beginnings are not more than four or five thousand years old for any people and for most European peoples scarcely two thousand years old. No people has yet achieved anything like complete civilization. Among all peoples we find still surviving more or less of the typical institutions of barbarism.

War Not a Primitive Condition.-The first thing to remember in a scientific view of war is this fact of the undeveloped condition of civilizaton together with the fact that anthropology shows the beginnings of military institutions to be coeval with the development of barbarism. The common assumption, still largely prevalent and almost universal in the eighteenth and nineteenth centuries, that the primitive state of mankind was one of constant warfare has been completely discredited by the progress of anthropological knowledge. The most primitive peoples of which we have knowledge are essentially unwarlike. ${ }^{2}$ In other words, the peoples whom, by a strange misnomer, we call "savages" are found upon scientific investigation to be relatively peaceful; that is, they rarely engage in conflicts with other human groups. Even in the upper stages of savagery serious and extensive conflicts between groups are rare.

Much more must comparative peace have obtained among primitive men in the early stages of social evolution. The very conditions of primitive life were such as to necessitate comparative peace among human groups. Their struggle was mainly with the brute world and with physical nature. Moreover, human populations were too small and too scattered to constitute a cause for serious conflicts between them. Even when groups came into contact, if we can judge from the evidence of existing savages, their relations were probably more often friendly than hostile.

${ }^{3}$ For example, the Veddahs of Ceylon and the Eskimo of the Arctic coast of North America, two very primitive peoples in widely different cnvironments, are among the most unwarlike peoples known. Illustra. tions might be multiplied. 
The primitive social condition of man, then, could scarcely have been one of habitual warfare. This conclusion is confirmed by the findings of both archæology and biology. There is no clear evidence of warlike implements in the earliest paleolithic remains. There are also few examples in the world of life below man of conflicts between the groups of the same animal species. Conflicts are usually between different species. Even the most predatory animals rarely attack members of their own species.

The Development of War in Barbarism.-Thus disappears the dogma that war is the "natural" condition of mankind and with it the belief in the inevitability and universality of war as a social condition. We now know that war became habitual and prevalent among many people owing to special conditions which arose in the stage of barbarism. At the advent of barbarism the beginnings of agriculture made possible an increased and stable food supply and consequently a large increase in population. The world was rapidly filled up. Peoples began to encroach upon one another's territorial limits and so upon one another's food supply. These new economic conditions led to numerous conflicts between groups. Then, as the brute world was largely subdued, human groups came to fear no enemies so much as other human groups. A selection was thus started among groups on the basis of war, those having the greatest efficiency in warlike weapons or organization having the best chance of survival. With the advent of barbarism, then, we find a great development of warlike implements and of military organization and traditions, for the safety even of peaceful groups came to depend in a large degree upon skill in either offensive or defensive warfare.

Moreover, the groups which were most successful in warlike enterprise soon discovered that an easier way to obtain food than through the slow and tedious methods of primitive agriculture was to plunder their neighbors. There thus grew out of the military tradition predatory traditions, which while they obviously could not be equally practiced by all peoples nevertheless came to be held in honor by all barbarous peoples.

Militancy and predatoriness were thus the chief traits of barbarism. Out of them grew its typical institutions, such as slavery, class exploitation, aristocracy, fixed social classes or 
castes, polygamy, ceremonial politeness, barbarous class display or luxury, and (in some cases) cannibalism. The chief social values emphasized by barbarism were those of power and pleasure, especially the power and pleasure of the ruling classes. It was an age of unmitigated group egoism and of the rule of force.

Modern War a Survival from Barbarism.-Now, there is evidently considerable overlapping in the different stages of human culture. Most of the typical institutions of barbarism survive in the earlier stages of civilization. Cannibalism is an exception and seems always to have been confined to certain barbarous tropical peoples. Such institutions as slavery and fixed social classes we got rid of but yesterday, while even to-day we are trying to rid ourselves of autocracy, class exploitation, and polygamy. Moreover, "predatoriness" still characterizes much of our business, our politics, and even our personal relations. It is not surprising, then, that war, the central institution of barbarism, should still survive among us, who are only in the early stages of true civilization, with considerable of its pristine vigor.

Cultural Significance of the Great War.-The place and the significance of the Great War in the history of the development of civilization must now begin to be manifest. Either it was a great struggle to get rid of those institutions of barbarismautocracy, militarism, and war itself-or else it marked a relapse of our civilization toward barbarism. These alternatives, however, are not mutually exclusive in a civilization as complex as our own. Let us consider first the possible measure of truth in the last alternative.

Human culture is built up on a basis of habit. ${ }^{3}$ The higher phases of culture involve the acquirement of exceedingly complex habits far removed from the human instincts. These habits require for their support appropriate traditional standards and beliefs. Hence the higher phases of culture require considerable watchfulness in order to maintain them. Civilization easily reverts toward barbarism, especially in its initial stages before civilizing traditions are fully established.

There is considerable evidence to show that for two or three decades before the Great War the standards, attitudes, and

${ }^{3}$ Cf. the author's Introduction to Social Psychology, pp. 63, 201; also his article, "The Educational Theory of Social Progress" in The Scientific Monthly for November, 1917. 
values of barbarism showed signs of reviving in Western civilization. This was to be seen not only in the literature and art of the period but especially in its politics, its business, and its ideals of life. Power and force came to be exalted, and "success" was often the only required standard. Gradually the various groups of our civilization drew apart into hostile camps and the appeal of certain elements was more and more to force. By these elements conciliation and good will were stigmatized as mere weakness. Peace was sought only in a balance of egoisms, that is, in a balance of power, of armaments, or of selfish interests. The doctrine of the "big stick" became popular. Power politics, Machtpolitik, was held to be the only practical sort in international relations. Predatory business practices came to be countenanced increasingly among certain elements in an economic system avowedly based upon self-interest, while these same elements prostituted the state to the end that they might dominate world markets. In all of these developments Western civilization was reverting toward barbarism, for it was deserting the basis of higher civilization which is mutual goodwill, understanding, and coöperation. It was moving toward an unstable social and international order. The nineteenth century thus sowed and nourished the seeds of both world war and world revolution.

On the other hand, it may be said that predatory business, commercial and political imperialism, and power or pleasure standards in personal conduct were no more prevalent in the decades immediately preceding the Great War than in earlier periods. Indeed, a larger element than ever before in all civilized nations saw the danger of these things and strove to avert it. Though they were unsuccessful, we need not assume that there was even a temporary reversion toward barbarism. The appearance of such reversion was due merely to the fact that progress in true civilization had brought into sharper relief certain long-existing standards and practices which now came to be characterized as "barbarous."

Possible Social Effects of the Great War.-Whichever view we adopt we cannot escape the conclusion that it was the mores, the traditions and standards, of barbarisin in our business and in our politics-surviving and embodied more especially in the autocratic, militaristic German state but more or less prevalent 
everywhere in our civilization-which brought about the Great War. To some this has seemed a discouraging conclusion, and they therefore shrink from drawing it even when confronted by the facts. It is quite the reverse if carefully considered. AIl civilization is a matter of acquired habit and its higher phases are built up only through thought and effort. If the Great War has succeeded in thrusting the soul of our civilization before our eyes, it will be worth all it has cost. Men have always learned from calamity, and doubtless they will continue to do so. However great have been the evils of war, we must admit that men have learned from it in the past the need of social organization, of social unity, of efficient government and social control, and of the virtues which make for self-sacrifice. ${ }^{4}$ They may possibly learn from it in the present not only these things but also the need of careful study of social conditions and of careful planning for the future that we may rid ourselves of those fatal weaknesses in our civilization which made possible the Great War and so avoid future calamity.

It is not necessary that men should continue to learn through calamity, even though in the past they have learned chiefly in no other way. Whatever truth there may be in the "crisis" theory of thought, it is also true that the human mind can look ahead, see a "crisis" imaginatively, and avoid it by anticipation. We no longer need pestilence to teach us to look after the conditions of public health and sanitation. So, too, it may be hoped, we no longer need the calamity of war to teach us to look after and eliminate those general conditions in our civilization which breed war, whether between nations or between classes. When once we have thoroughly learned that social evolution must be intermediated by thought and effort, that progress comes not automatically ${ }^{5}$ but only through intelligent purposes, we will abandon the tendency to social drift, and enter upon a policy of mastery over the conditions of our social existence. We will then see that social effort for the establishment of true civilization can never be relaxed without grave danger, for the delicate fabric of such a civilization is continually threatened by "crises"; that to win the victories of peace, not less than those of war, we need

${ }^{4}$ Cf. Introduction to Social Psychology, pp. 43, 97, 98; also, Todd, Theories of Social Progress, Chapter XIX.

${ }^{\circ} \mathrm{C} f$. Todd, Theories of Social Progress, pp. I00-112. 
right social organization, social solidarity, good government, and the self-sacrificing virtues. Thus intelligent thought and effort may obviate the necessity of learning by calamity, and conscious, deliberately planned, social changes may come to take the place of unplanned, cataclysmic changes brought about by calamity.

The civilization of the nineteenth century was essentially unstable, as it was based on individual and national self-interest. Its instability at length precipitated the Great War. But the war has exposed the insecure foundations of that civilization, and there is no reason why we should not build a better one upon securer foundations. Thus the war may lead to a great step forward in social evolution if mankind can learn its lessons aright. Intelligent effort put forth for the next generation will bring about a much higher social development than anything which the nineteenth century witnessed, but such higher social development is conditioned upon intelligent effort.

It is highly important that all this should be understood at the present time because history shows that the tendency after a victorious war is for the victors to relax their efforts and rest content with their military achievements. Thus victory may often have more insidious dangers than defeat, and a war may be won in a military sense only to be lost in a moral and social sense. This was obviously what happened in the case of the Germans after their military victory over France in I870-7I. It may happen in our case after the Great War unless we take to heart its lessons. We entered the war with lofty idealism, determined to make the struggle one against militarism, autocracy, and imperialism, and to establish peace, democracy, and international right. But with the coming of military victory there has been a dangerous tendency to rest content and to revert to our old ways of thinking and living.

The Need of Rebuilding Our Civilization.-"Why reconstruction?" we hear asked on every side. The answer is because the war has revealed serious weaknesses in our civilization along every line and that if militarism, autocracy, and imperialism are to be overthrown and peace, democracy, and international right enthroned we shall have to rebuild our civilization. The mores, the traditions and standards, of varbarism in our industrial, political, and general social life still threaten to make impossible the establishment of peace, democracy, and justice 
and so to wrest from us the fruits of our victory. True civilization is only just beginning. Its great work and achievements still lie ahead. We must, if we would safeguard its development, replace our tolerance of drift by a policy of mastery over the social conditions of our existence; for social evolution in a progressive direction is not an affair of happy accidents but of conscious purposes and intelligent effort.

Is Lasting Peace a Realizable Social Ideal?_-"But why reconstruct with the end of attaining lasting peace, an impossible ideal?" it may be asked. "Man may have been originally unwarlike, but the conditions which with the advent of barbarism brought about war are permanent. The world is now filled with peoples. There is constant pressure of the population upon the food supply, and this will continue indefinitely. In any case, competition for the goods of life will lead peoples to demand more territory and to aggress upon one another. This will continue to lead inevitably to war. The only way to prevent this in any degree is through each nation arming itself to protect its own, or, in the case of small nations, tbrough alliances with more powerful nations. Thus through a balance of power, of armaments, of selfish interests, an armed peace may possibly be maintained over more or less long periods. That is the best we may dare to hope."

Thus argue those who would justify the policy of continuing competitive national armaments and who hold in theory that war is a necessary and inevitable method of social evolution.

The Real Causes of War.-But the scientific student of social evolution finds many unproved assumptions and much ignoring of facts in such an argument. Running through it, in the first place, is the assumption that human nature is wholly egoistic; an assumption discredited by common experience and refuted by modern science. Again, there is the assumption in the argument that external conditions of geography, food, population, and general economic interests absolutely determine the policies and behavior of masses of men, especially nations, toward one another. But anthropology and history show that many other factors enter. About half the time economic interests seem to be the dominant factors in producing war; but religion, dynastic ambitions, political and moral ideas, and racial antipathies are hardly less prominent. Finally, there is the 
assumption that these economic factors are not subject to human control and cannot be changed.

As to facts, history shows that the area of peace, that is to say of settling disputes by unwarlike methods, has constantly enlarged. Groups which once resorted habitually to war to settle their differences now would no longer think of doing so because they are now parts of a larger organization, a larger social unity, built up partly by the pressure of material interests, partly by widening civilization, and partly by broadening sympathy and good will. Again, ordinary observation of social life shows that whether conflicting moral or material interests lead men to fight depends altogether upon their aims, standards, and previous habits. What is considered a violation of national honor, for example, in one age or nation may not be so considered in another. Germany's population, to take another example, found greater difficulties in the eighties in meeting its material needs than in the second decade of the present century; but, though the economic conditions of Germany had greatly improved, she precipitated war in I9I4.

On account of such facts and many similar ones, sociologists in general are practically unanimous in concluding that the real causes of war are always in the mores-in the cultural traditions and social standards of peoples. Where the mores of a people are non-militant no war results no matter what the external geographic and economic conditions may be. On the other hand, with warlike mores the most trifling things may be the occasion of war. And warlike mores arise and flourish under those economic, intellectual, and moral conditions which characterize the stage of barbarism-conditions which must change if civilization continues to progress. Thus we come again to the conclusion that war is a survival from the stage of barbarism and that the Great War through which we have just passed was due to the survival of, or reversion to, the mores of barbarism in Western civilization, especially in Germany.

The Possibility of Progress Toward Lasting Peace.-The vital thing in making progress toward world peace is a change in our cultural traditions, in our mores. We must replace the mores of barbarism in our politics, business, and general social life by the mores of civilization. This can easily be done if sufficient interest can be aroused among the free peoples of the world 
to go at the problem intelligently. But to be permanently successful such a change in our mores must be accompanied by many changes, both objective and subjective, in the whole complex of our civilization; for the mores always develop appropriate institutions and are always supported by external conditions.

What some of the changes are which are necessary to build up a permanently peaceful civilization we shall attempt to outline presently. We wish at this point only to emphasize that nothing in our scientific knowledge of social evolution forbids us to believe that war is avoidable; on the contrary, it points decidedly to the belief that wars of every sort are preventable. Social progress is fundamentally a learning process, ${ }^{6}$ and man has only just begun to learn how to master social conditions. It is probable that war is not more difficult to get rid of than pestilence or alcoholism and will yield to essentially the same methods. A more accurate analogy is perhaps to be found in the getting rid of slavery and class exploitation. Just as slavery came to an end with the overthrow of a social and economic system supported by it, so it is probable that international war will go down in a struggle against national imperialism and armaments.

This is not to predict that the Great War will end wars or will even be the last world war. That depends altogether upon how much the peoples of Western civilization have been able to learn, or can yet learn, from the war just closed. The mores of barbarism still have lost none of their prestige in certain quarters. Local wars and civil wars, in any case, would seem probable yet for a long while. But unless the peoples of Western civilization have reached the point where they can no longer learn from calamity, a most improbable assumption, it would seem that with better understanding of the laws of human living together and better acquaintance with one another the era of bloody struggles between nations, classes, and races must soon draw to a close. In the meanwhile, it has become the highest ambition of the socially intelligent to get rid as rapidly as possible of the survivals of barbarism among us and to aid in laying the foundations of a true civilization.

- For elaboration, see the article above referred to on "The Educational Theory of Social Progress" in The Scicntific Monthly, November, 1917. 
In our planning for social reconstruction, then, we can and should aim at building, if possible, a permanently peaceful civilization. Upon the upbuilding of such a civilization depends the safeguarding of democracy and of all the higher interests of mankind. It is the privilege of America, in the new era before us, to serve in this cause. It will not be out of place in concluding this chapter to outline briefly, from the standpoint of our scientific knowledge of social evolution, what would seem to be some of the important next-steps in human progress.

The Recovery of Social Losses Sustained in the War.-First let us remark that we should lose no time in recovering and reestablishing the social gains we had made before the war. Chief among these are our political, our moral, and our intellectual freedom. Various sinister influences had made inroads upon these before the war, and the military necessities of carrying on the war led to still further encroachments upon them. Freedom in the intellectual, moral and political realms is the indispensable preliminary to carrying out any rational plan of social reconstruction. For the mind is man's chief organ of adaptation, and when the mind is not free it cannot function. Social psychology shows that intercommunication is the chief method of reciprocal adaptation between individuals. As soon as freedom of thought and of public discussion are abridged the whole machinery of social adjustment in a group will be hampered; it will become impossible to compare ideas and hence to reach rational judgments regarding social policies. Free thought, free discussion, free formation of public opinion, free selection among social policies and social leaders are accordingly the indispensable means of normal progressive social evolution. ${ }^{7}$ Where these are in whole or in part denied, perverted social development is bound to result, and social disaster either in the form of social strife or of civic degeneracy is certain.

War hysteria, emotionalism, and intolerance have seriously impaired intellectual freedom for the time being in certain elements of our population. The effect of this has been aggravated by the military censorship of the public press which in great groups numbering millions must necessarily be the chief means of intercommunication and public discussion. Freedom of public criti-

'For elaboration, see Introduction to Social Psychology, Chapters VII and VIII. 
cism, moreover, was limited by law. Such measures of repressive control may be necessary in war time, but in peace they destroy moral and political freedom and interrupt the normal course of social evolution. Hence a preliminary task in rational social reconstruction, especially if we wish to build a free, democratic society, must be the immediate restoration of all conditions necessary for intellectual, moral, and political freedom, that is, especially, of the freedom of public criticism, of public discussion, of the press, and of the formation of public opinion.

The Reconstruction Problem Before the American People.To this every democratically minded American would probably agree; but many would apparently have reconstructive efforts limited to the restoration of general social and political freedom and to measures designed to promote the economic prosperity of all classes. The reconstruction bills thus far introduced into the American Congress, indeed, deal exclusively with economic matters. Though much broader reconstruction programs have been adopted by other governments, our congressmen apparently think that nothing else is called for. But the war has revealed fatal defects and weaknesses in our social life. We need not merely a larger house but a better house to live in. The trouble with most schemes of reconstruction is that they aim to build upon old foundations a civilization similar to the one which has brought calamity upon the world. Knowledge of social evolution would show the unwisdom and the futility of such plans. Rather, as the editor of this volume says, "a new edifice, a new system of living" is called for ${ }^{8}$ and he rightly reminds us, "The reconstruction problem of a nation cannot be treated piecemeal. It is an organic problem and can only be approached as a unit." 9 Most rightly, too, he says, "The ultimate aim of reconstruction is not increased production, nor is it a more equitable division of the world's goods." ${ }^{10}$ It is better human living.

The First Thing Needed for Social Reconstruction.-In the light of the facts of social evolution which were outlined in the first half of this chapter, what is the first thing needed for effective social reconstruction? Obviously it is moral renewal, or rather, moral development. If the real nature of a civiliza-

${ }^{8}$ American Problems of Reconstruction, p. 27.

- Ibid, p. 22.

${ }^{10}$ Ibid, p. 37. 
tion is determined by its mores, its traditions and standards, and if the mores of barbarism still survive among us, then it is idle to talk of any social reconstruction unless we change our mores, that is to say, our values and standards of living. Until we get rid of hyper-nationalism, imperialism, militarism, political immorality, and other insecure stones laid in the foundations of our civilization, stable reconstruction will be an impossibility. We must change our values and standards. The whole power and pleasure ideal of life, whether for groups or for individuals, must be replaced by a more humanitarian standard of values. The Great War showed clearly enough the inadequacy of the happiness ideal of life for the individual, and equally clearly that the power ideal, whether for groups or for individuals, belongs to the brute-like ages of the barbarous past. It also showed that the unit of our moral thinking cannot be either the self or the national group but must be humanity at large. But the war reaffirmed the service ideal of life and the development ideal as safe practical guides for social living. Thus it confirmed the best ethical thinking of the past two thousand years-thinking to the general level of which our civilization has never risen, owing to the survival among us of power and pleasure standards.

The service ideal and the development ideal are really two sides of the same ideal of life-the development of humanity. But it must be emphasized that the development of the individual is for the sake of service, first the service of the family and of the community, then the service of the state and nation, and finally the service of humanity at large. This is the social view. The development of self or even of the nation, we now see, is not an end in itself, but is rather for the sake of the service of humanity. The watchwords of the new era must be human service and human solidarity. Our fathers tried to build a world upon self-interest, individual and national. The world which they built has gone down with a crash. We now see that self-interest is not enough for a secure foundation. We must try to build our world upon the broader principle of social and international solidarity. But to do this we must stop thinking dominantly in terms of self, of class, or even of the nation. We must learn to think in terms of humanity.

Political and Economic Reconstruction.-If we do this, if we 
thus transform our values from those of barbarism into those of a humanitarian civilization, reconstruction along every needed line will follow easily. But if we do not make progress toward such a transformation of our mores, even our political and economic programs of reconstruction will fail. Thus, for example, the great idea of a League of Nations to guarantee the peace of the world and to promote the general welfare of humanity will fail unless it is backed by the general perception and acceptance of the solidarity of mankind. Yet it is manifest that such a world organization in some form has become indispensable. ${ }^{11}$ Civilization, once local, has now become world-wide. Contacts have multiplied between peoples without a corresponding development of the machinery of control. Hence international anarchy has resulted. We have an interdependent world, and to be safe we must have some form of world organization and government. Yet nothing is clearer to the student of international affairs than that as long as the nations continue to think dominantly in terms of national selfinterest and the balance of power, such an organization will have insuperable difficulties. We must change our mores if the League of Nations is to become a reality.

Again, within the nations we can scarcely hope for a rebirth of democracy as long as the politics of self-interest and of class interest continues to dominate. For democracy is not laissez faire individualism nor mere egalitarianism. It is fundamentally fraternalism, and so rests upon rational likemindedness, mutual understanding, mutual sympathy, and good will among all classes. ${ }^{12}$ The dominance of class interests in our politics means, sooner or later, the rise and spread of Bolshevism and the defeat of all programs of social reconstruction. The fate of democracy is bound up with the development of higher humanitarian civilization.

Economic reconstruction cannot succeed without a transfor-

${ }^{11}$ As these words are written, Lord Robert Cecil at the Peace Conference in Paris is reported in a press dispatch as saying: "A league of nations is an essential part of modern civilization. It is absolutely impossible to proceed on the old arrangement, everybody pulling for his own side without any regard for the others."

${ }^{12}$ An elaboration of this idea will be found in an article by the writer on "Making the World Safe for Democracy" in The Scientific Monthly for December, 1918 . 
mation of our mores. Economic justice cannot be established upon the basis of the self-interest standards which have hitherto dominated our business world. Nor can working-men and their employers get together in harmonious relations to build the prosperity of the future as long as they are ruled by selfish and by class interests. The efficient coöperation in work demanded by the new era can be achieved only through the recognition of a solidarity of interest transcending that of class. Not until we have a business and an industry which are primarily for service rather than primarily for profit can we have industrial peace and good will between economic classes.

Even the rebuilding of our physique as a nation will require this envisaging of and loyalty to the welfare of humanity, for it is not so much the health and physical vigor of the present generation with which we must be concerned as that of future generations. And that means unselfish consideration of the welfare of little children-to see that they are well born, that they are born in sufficient numbers, and that they grow up amid healthful and wholesome surroundings.

Educational Reconstruction.-But how can the mores be transformed? The answer is that through all human history they have been transformed in but one way, and that is through the process of learning. For the mores are our social standards, values, and ideals. War itself has often transformed the mores, but only because it has taught men through its hard lessons. In times of peace the mores can best be transformed by that organized, systematized process of learning which we term "education." Hence the all-importance of education in the work of social reconstruction. We do not refer merely to the work of the schools but to all organized effort to spread knowledge, to mold opinion, to form standards, and to develop socially advantageous habits. It is in this way that we have changed the moral standards of our people regarding the use of alcoholic beverages. It is in this way that we are beginning to combat successfully the multitude of other social evils which beset us. Hope for the future lies solely in this peaceful method of transforming our mores and rebuilding our civilization, for war, whether civil or international, destroys more than it creates.

The study of social evolution shows, in a word, that the key to successful social reconstruction lies in social and political 
education, using that phrase in its largest sense. For such education the agencies of the press, the public forum, the church, and the home are doubtless important; but the public school system is central and fundamental. The reconstruction of our educational system, so as to make it a better instrument for social and political education, is, then, the most important reconstructive work of all. ${ }^{13}$ We must have a socialized education in our schools. By this we mean not so much vocational training, important as that may be, but education for citizenship. The attempt to establish democracy without social and political education in our schools is, as has been well said, either a farce or a crime. It is nothing short of treason to democratic institutions, and so to the nation itself, to send forth young men and women from our schools who know little or nothing of the responsibilities, duties, and privileges of citizens in a democracy and of the social conditions and ideals necessary to safeguard democracy. Yet this is what we have been doing. Even the young men and women who are graduated from our colleges and universities have spent so little time on social studies that they have, as a rule, acquired little social knowledge of the broader sort and almost no discriminating judgment in political and social matters. Hence few are fitted for social leadership; yet competent social leadership is manifestly what we need above all in social reconstruction.

We must demand of our schools, then, that they train for citizenship above all; that they produce not the type which makes the slacker, the profiteer, the exploiter, whether in war or in peace, but the type marked for social and national service. Our schools must accordingly inculcate not only social knowledge but the service ideal of life. The service ideal of life must, indeed, be considered the heart and core of socialized education; and in some ways the Great War did more in a few months to inculcate that ideal than our schools have done in a generation. Thus the war itself has pointed the way to the most necessary reconstruction of all.

A New Civilization. - The war thus leaves the student of social evolution not without large hopes. Whatever its losses,

${ }^{13}$ A full discussion of "The Reconstruction of Education upon a Social Basis" will be found in an article by the writer in The Educational Review for January, I9I9. 
it has awakened us. It has clarified our ideas and shown us the path we must take if we would avoid even greater disasters. Mankind has thus far learned chiefly by calamities. The crisis through which we have passed, if we will not forget it, will prove a stimulus to call forth our noblest constructive efforts. It may mean the birth of a new civilization. Aristotle had the theory that the purpose of tragedy was to purge the human soul. So the tragedy of the Great War may possibly purge our civilization of the influences which have lingered in it from the barbarous past and which have threatened its disruption. Through making us take thought it may possibly enable us to build a new and a true civilization, one based upon the recognition of the solidarity of humanity and with service rather than power as its final standard. 


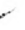




\title{
CHAPTER IV
}

\section{THE INTERNATIONAL MIND: ITS CHARACTER AND CONDITIONS}

\author{
By Horace M. Kallen ${ }^{1}$
}

Member of the Faculty, the New School for Social Research, New York City

In his defense of the essentially unpopular composition of the Body of Delegates or Assembly provided for by the Covenant of the League of Nations, the president of the United States, with an irony that was all the more ineffable for its unconsciousness, justified the provision on the ground that the Assembly was the means on which the framers of the Covenant were "depending primarily and chiefly upon one great force, and this is the moral force of the public opinion of the world-the pleasing and clarifying and compelling influences of publicity; so that intriguers can no longer have their coverts, so that designs that are sinister can at any time be drawn into the open, so that those things that are destroyed by the light may be promptly destroyed by the overwhelming light of the universal expression of the condemnation of the world." The rhetoric and the sentiment are, as is customary when Mr. Wilson is their source, both very lofty; their accuracy is cast in deep shadow and grave doubt by the proceedings of the very peace conference at which they were uttered. Most of that conference was. of course, quite secret, but in the two instances in which publicity was invoked against imperialism and oppression, the light it let in destroyed nothing; it only turned liberals sick. The instances are those

${ }^{1}$ A.B. Harvard, Ig03; Ph.D. Igos; studied at Princeton, Oxford and Paris; taught at Harvard University, Clark College and University of Wisconsin; author of William James and Henri Bergson, The Structure of Lasting Peace, The League of Nations To-day and To-morrow, The Book of Job as a Greek Tragedy, Chapter in Creative Intelligence. 
of Japanese piracy in China and Italian aggression in Dalmatia. In both, the issues were altogether unambiguous and explicit; justice could dictate but one settlement; and that the opposite of the settlements made. If the peace treaty is adopted as it was first delivered to the Germans, it will ordain for Central Europe a collection of difficulties of the same kind as are involved in Dalmatia and in the Shantung peninsula. These, if the League of Nations holds, will necessarily come by means of its agencies before the bar of public opinion for settlement. In view of the fact that the Interallied Conference was itself a rehearsal and prototype of operative conscious internationalism, what hope is there that future settlements of international disputes will be more decent or cleaner? The issues between Italy and the Jugoslavs, between Japan and China, were not, it must be remembered, issues between the Allies and their enemies. They were issues between friendly states, just done with a joint war against a common enemy. Everything in the general situation ought to have made for a clean and honorable adjustment. It did not. Public opinion, moreover, was as derelict as "statesmanship." The "moral force" on which the most moralizing champion of the League of Nations depends failed the very first time it was invoked. Why?

Why Public Opinion Fails: The Basis of Social and Political Thinking.-In the right answer to this question is to be found the answer to the question as to the success or failure of the League of Nations or any other overt form of conscious and organized internationalism. It is an answer that has many institutional aspects-historical, economic, religious and personal-but its core is psychologic. The question is at its foundations one regarding the quality, content and behavior of men acting under largely autogenous conditions in aggregates and groups. "Public opinion" is a form of this quality, content and behavior. Its natural growth, development and decay, its artificial generation, working and control, are primarily psychological events, involving limits set by the character and conditions of mental action. At the present writing, it may be as compelling as force itself, but the proposed machinery of the League of Nations is as little likely to be able to utilize its compulsion as a windmill in Holland can use the compulsion of the water power of Niagara Falls. The reason is simple. Thus far there exists no effica- 
cious international mind which can constitute a norm for the shifts and changes of public opinion, and the stated form of the machinery of the League is not calculated to provide the conditions upon which an international mind may arise and establish itself. It is a machinery primarily irrelevant to the daily life of the masses of men, merely a collection of political devices, designed according to the traditions of international political contacts. They are not capable of making public opinion perform the work assigned to it. They do not harness it up. They do not provide an inevitable correlation, an obvious relevancy between it and the problems and functions of the League. How basic and imperative this is may be gathered not merely from the failure of justice through default of public opinion during the peace conference, but from the effective whining (amid general public approval) of United States senators about sending American boys to lose their lives for Czecho-Slovaks or Chinamen. The American public and its senators are no more internationally-minded than Italians or Japanese, and the Covenant of the League of Nations is hardly designed to make them so.

It must not, however, be inferred that the critical defect lies in the conception of the League itself. The critical defect lies in the mental set, the habits of appreciation and misprision of its framers. These habits, again, imply a background of interests and attitudes, both conscious and unconscious, of appetites, preferences, hatreds and aspirations that constitute the social minds of the groups which the framers represent. The stuff of these minds is a congeries of institutions and ideas whose animating and cohesive forces are these passions of men. Now, broadly speaking, the avowed and consciously assigned symbol or name for this complex of institutions, ideas and customs, is "democracy." Opinion is current that the war has been fought "to make the world safe for democracy," and democracy has in the course of the fighting acquired the sanctity of a miracleworking relic. This sanctity appears, on the surface, as a function of the menace which democracy has undergone and is exposed to on the one side at the hands of monarchism, on the other, at the hands of "Bolshevism." As against monarchism, democracy is a recent and upstart thing. As against "Bolshevism," it is somewhat more reverend as an institution, but is 
almost a twin as an idea. As an idea, supplying terms and standards for political thinking, it became active in the 18th century. As an institution, it was implanted in Europe and America by the force of two revolutions-one in the British colonies of North America, and one in France. It set the "sovereign nation" against the "sovereign king," government by consent against government by authority, representation of masses of electors against direct control by the classes. The vital need which it expressed and gave form to was a need primarily for land. It arose as the popular political embodiment of an individualistic agricultural economy, in which the ostensible unit of political action was the land-owner or farmer, living off his land through rent or through toil, the self-sufficient citizen of a self-sufficient state. In America there was any amount of free land to be had for the taking, not by speculators alone; in France the revolution became irrevocable with the expropriation of the feudal landlord. In England and the rest of Europe, however, the recovery of the land by the people was much slower and more doubtful; its culmination in England was prevented by the war and the war seems to have been launched on the continent to forestall its initiation there. The democracy which the war was supposed to have made the world safe for is the political aspect of an agricultural economy.

This is the democracy that allied policy is defending on the European continent against a type of democracy taking shape in England, Russia and Central Europe. The latter is a different and new form of democracy, which public sentiment in America is inspired to regard with the same horror and reprobation as class sentiment in England regarded the American type of democracy until practically the end of the eighth decade of the last century. ${ }^{2}$ It is a democracy based on a very different economic order. This very different order is the order of industry. Under it the farmer or landowner does not inhabit the soil he cwns and draw his living direct from it. The soil produces only "raw material" which is transferred to the mill or factory where the mass of men and women, working at machines, serve together in changing it into the finished product. Their interest in the

${ }^{3}$ Cf. S. O. Adams: The British Traveler in America-Pol. Sc. Quartcrly, June, Igr4. British Interests and Activities in Texas; Amer. Civil War from the British Point of View-Hist. Teachers' Mag., May, IgIS. 
land from which the raw material comes is therefore not singular and individual, but collective. So is their interest in the machine, so is their interest in each other. ${ }^{3}$ For in industry a shortage of raw material, a defect in the machine, a failure of any one worker to do his part in the industrial process, jeopardizes the livelihood of all. Now at the same time that the democracy which is the political aspect of the older agricultural economy was winning its slow and precarious way against monarchism and feudalism, the economy of industry was displacing the argicultural system. But at the same time that it dislocated the feudal overlord politically through suffrage, it gave his successor a new place economically through industry and finance. Soon it became apparent that the victories of democracy in politics caused no modification in the economic supremacy of privilege. Capitalism developed into merely the feudalism of industry, it replaced the overlord's direct control of politics by an indirect or invisible control. Reaction against it took form as a new system of ideas embodying a program of life. These ideas, very diverse and even contradictory, are generally called "socialism." They bear to the industrial economy the same relations that democracy bore to the agricultural economy. They spread as ideas while democracy was taking root as an institution.

Now, at the beginning of the 2oth century, democracy had barely established itself, only to find itself challenged by new institutions and systems of ideas and conceptions that are as sharply oppugnant to it as it had been to the old feudal and monarchical systems. Its economic foundation has slipped away from under it even while it was fighting for its place upon them. In fact, to win its own fight it was compelled to modify its political principles. In the course of the war the character and institutions of government underwent greatest change in those countries which were industrially most developed. Both the United States and Great Britain were compelled to create new engines and methods of operation in the accumulation and distribution of raw materials, in manufacture, transport and trade, and in the administration of labor problems. Such engines were, in the United States, the Food Administration, the

This was realized from the beginning of the industrial revolutiou. $C f$. Robert Owen's Communism and the Coöperative Moventent. 
War Industries Board, the Shipping Board and the War Labor Policies Board, and analogous organizations in Great Britain. Italy and France, on the other hand, having primarily an agricultural economy, were politically changed in negligible degree by the necessities of war. The changes were all such as were compelled by the relation of the machine to raw materials and to men. For the purposes in hand they were tantamount to a change in the control of the political mind. The proportion of industry to agriculture being smaller in the United States than in Great Britain, the change was less profound and lasting with us. Here most of the agencies of war-control began to be dissolved soon after the fighting stopped, and the reversion to pre-war conditions is spontaneous, disorderly and energetic. In this regard, the comparative brevity of American participation in the war is also a factor. On the other hand, the modifications of the British political structure give every sign of being lasting, and of being far from ended. They were radical, and they show that Britain is moving also by means of governmental action toward the goal which Russia and Central Europe are seeking by means of revolution. Britain is, of course, the most highly industrialized country in the world. The proportion there of agricultural to industrial activity is negligible.

It would be difficult to overestimate the revolutionary implications of the changes here sketched, or the irony and paradox of their motivation. These changes are revolutionary changes brought about by the initiative of governments themselves. Their innovating, remoter cause was, of course, the menace of external aggression against the integrity of the state. Their more immediate causes are to be found in the restiveness of workpeople under wartime coercion and duress. But their most efficacious determinant was the realization of the bearing of nutrition, sanitation, freedom of movement and participation in industrial government upon the morale necessary for the maximum of productivity. This realization itself, however, could not have come about without the suspension of the ordinary business motive of production-production for speculative gain-and the substitution therefor of an invariant profit based on conversion costs, with a distribution of all essential materials regulated not by purchasing power but by need. For once the processes of production were to some degree set free from the hin- 
drances of the price-system and their capacity under this condition was shown to be indefinitely extensible.

Pre-War Internationalisms and Their Failure.-To become permanent contents of the minds of men, group relations must be relevant to their daily lives, and consciously felt as conditions lastingly governing interests, habits, thoughts and emotions.

How basic this relevance and its conscious acknowledgment are, may be observed by surveying the comedy of pre-war internationalism itself. For this internationalism, massive as it often was in emotional volume, and profound and extensive in intellectual content, was irrelevant both to men and governments. It is significant that the r 9 th century, in its ideology par excellence the century of internationalism, was in its conscious action largely nationalist, chauvinistic, and finally imperialist, the link between these tendencies being "democracy." The reason is very simple. Nationality had, partly because of the idealism of the I8th century cosmopolitans, partly through the tyranny of dynastic imperialists, become the emotionally precious and practically relevant association for freedom of the inhabitants of Italy, of Germany, of Greece, of Hungary, of Serbia. It stood for the natural, immediate group-form through which democracy could be secured and maintained. The fathers of the men who won the freedom and defined the social personalities or spirits of these sovereign states did not know them as sovereign or as states. Nor would the sons of these fathers have made them such if the foreign master's oppression had not restrained their freedom and bound their action in just those respects in which the substance of nationality consists. Repression led to overvaluation of the repressed; overvaluation to action in rebellion; action to the reënforcement of overvaluation. Hence the extraordinary self-adulation of the Germans and the imperialism of the Italians. Hence the present as well as historical brutality and megalomania of the Poles, the ardors and follies of imperialism of the Czecho-Slovaks and the Jugoslavs, the irreconcilability of the Irish, the restlessness of the Egyptians and the Hindus, the entire self-contradiction in which the belligerents find themselves at the end of the great war. Nationality has been the dominant social energy in the political consciousness of Igth century Europe. National liberation or national aggrandizement has been its conscious goal. 
Across these confluent streams of interest, and often counter to them, ran others, not in the same way consciously implicated in the substance of men's daily lives. Basic was the stream of economic internationalization set flowing, constantly enlarged and speeded up by the pressure of machine-production. The very clothes men wore and the food they ate came from countries other than their own. Wool and silk and cotton, hides and rubber and sisal, meat and wheat and fruit, were foreign-grown or foreign-made or depended on foreign fertilizer or foreign tools. The very machinery with which they prepared these things for use depended on materials they could not find at home-on tungsten or chromite, for example, or manganese. They lived, from the very foundations of their lives, internationally. But while they lived internationally, they thought and felt, or in the actual struggle for freedom they had learned to think and feel, nationally. It needed a terrible war to expose this incompatibility and to render thought and organization and feeling relevant to the conditions of life. ${ }^{4}$

The war has been too brief to establish this change as social habit, and no machinery has grown up during the course of it to maintain the same effect. The peace conference is an apt illustration of the inertia of habit, and of its power to withstand the internationalizing effects of the war. Only upon a single social group has this economic internationalism had a lasting and reorganizing influence. This group is that of the international financier and monopolist entrepreneur. The domination of finance, the interlocking of directorates, the attempt to eliminate the waste of competition led to international standardization of exchange, and to price-fixing in steel, munitions, fuel and foodstuffs. The great national industrial trust-magnates, being compelled to come into conscious contact with competitors in the international field, soon found a means of international adjustment which is peaceful and coördinative, and remunerative to all. To these, national war and peace alike yield profits. They stand, more internationally-minded than ever.

With labor, on the other hand, the situation is almost precisely reversed. The ownership and management of industry

- Cf. H. M. Kallen: The Structure of Lasting Peace-Chapter IX; and The League of Nations To-day and Tosmorroze-Chapter IV, B. 
and finance was possessed of no ideas and no program. It was internationalized by circumstances, and whatever theory of internationalism defends and justifies this development has come as a defense and rationalization of a fait accompli. For workingmen, contrariwise, a theory was provided at the outset. Circumstances have been very slowly, almost imperceptibly, subsequent. The range of the laborer's attention, so far as it influences his action, is limited almost completely by the particular business of holding his job. In the beginning he was conscious of his fellowworkman only as a competitor who might take his job away from him. It took him some time to learn that his mate might also be a comrade with whom to unite for help to keep his job. It took him more time to learn the strength and relevance of a number of unions, organized into a craft, and in America he is discovering, very slowly indeed, the necessity of extending the range of his group solidarity to the whole of his industry. What sort of event can move him, say, in the iron and steel industry, to establish as habit and as sentiment a conscious international agreement that would parallel and meet the conscious international agreement of the ownership and management? Or in any other industry? Or simply as between workman and workman? In point of fact, the struggle between the various classes of laborers is far stronger and more bitter, because more conscious, than the "class struggle" between labor and capital. This was recognized at the very outset by the theorizing champions of labor. They called upon it to become "class-conscious." "Workingmen of all the world," they cried, "unite: you have nothing to lose but your chains." And they organized the Internationale, and they declared war upon capitalism and nationalism and war, and year after year they met and debated. Yet they made no noticeable impression on the mass of the world's workers. They compromised with nationalism and with war, and war between their respective nations broke up even their disputatious community into its national components. The true gains of liberty for the workers of the world were made at those points where came necessary action in the crises of routine in the daily life-the points of actual resentments against actual injustice or exploitation. The real unification of the workers came through the trades-union and their real class-conscious- 
ness by way of conscious warfare and negotiation with their employers. And in all this their nationalist sentiment remained unmodified.

Side by side with the actual economic internationalism, in most ways, indeed, prior to it and underlying it, has been the internationalism of scientific enterprise, of science pure and applied. Without these the world's industrial expansion would have been impossible, and the community of their maintenance and advancement has been one of the great steps in the adventure of civilization. Nothing has been freer, less selfish or more joyful and spontaneous than the mutuality of scientific investigation and creation. For a generation international scientific organizations of all kinds have been meeting periodically to advance knowledge and perfect technique. What they created was an undemiscible organic asset of civilization as a whole, the unearned capital of past experience in which no individual and no nation could have any proprietary right. In this, the world's science or the world's technology, the mind should, if anywhere, be truly international. Yet how tangential this most important yet imponderable basis of industrial society nas been to the active emotional life of organized societies may be gathered from the attempt at the outbreak of the war to analyze its organic unity into national constituents of which it was declared to have been composed and to assert national superiorities. In this episode, indeed, the comedy was supreme. And it was an illuminating comedy, because it showed more clearly than perhaps anything else could that the substance of internationalism was not a body of knowledge, no matter ho $v$ valuable, but a certain set of the organism, a form of habitual mass-feeling and behavior. All else was derivative and secondary.

To see how ridiculously secondary, one need only consider the peace movement. Peace and disarmament have been from the beginning dominant elements in the international socialist programs. The national socialist parties of both belligerents and neutrals formulated well-considered and logical peace-programs. Upward of a score of national and international "bourgeois" peace societies had been engaged for a generation in propaganda and instruction. There had been the suave duplicity of the Hague Conferences, and the hopeful ineffectuality of arbitration treaties. The coming of war exploded all this splen- 
did structure of aspiration like a bubble and rendered its supporters the easy victims of the malice and spleen of patrioteers and the reprobates of the public sentiment these had the means and the powers to arouse.

In sum: At its foundations, society had been internationalized to an unprecedented, almost miraculous degree. The great agent of this process is the automatic machine. Steam and electricity had brought the various associations of men within easy visiting, speaking, writing, and even, through the cinema, seeing distances of each other. In the upper air of civilized livingin the arts, the sciences, music and philosophy-there had been developing a rapid and genuine interpenetration of mind. The rag-time of New York and the waltzes of Vienna, the conclusions of the Pasteur Institute and the discoveries of the Rockefeller, the latest novels from Berlin and the latest plays from London, the latest operas of Petersburg and the most daring movies from Los Angeles, were almost simultaneously discussed, enacted, read, or played in all these places. There was a free trade in spiritual achievement, an interpenetration of minds, a comfortable consciousness in each place of the quality of the others, which had the true aspect of internationalism. Nevertheless, it needed only that a crisis become manifest for this interpenetration to fall apart, and for a nationalism narrow to the point of idiocy to dominate the lives of peoples.

Internationalism as a Problem of Psychology.-The modern very genuine internationalism of the spirit had been as inefficacious as the ruling Christianism of earlier times to prevent a warfare which, far from being a struggle for self-preservation, has been for the belligerents a process of self-mutilation and for the neutrals a condition of privation and suffering. The reason for the inefficacy of this internationalism lies in the fact that it is the superstructure of the house of life, not its foundation. The institutions and interests that are its substance are not those men go to war over. And men do not go to war over them because they are of a nature such that their national value is enhanced only through their being shared and approved by other nations, only through the degree in which they achieve an international significance. The measure of a Goethe's greatness in Germany is his recognition by the world that is not Germany. So no less with English Newton or Italian Dante or 
French Pasteur. The things men go to war over, on the contrary, are the things at the root of life, those things without which the others could not come to be. They are objects supposed to be enhanced by exclusive possession, not by internationalization. The difference between them and the others goes to the very foundations of civilized living. This is an adventure in a world which was not made for us, but in which we happened, and grew. "To live in it at all, not to speak of living in it well, men had to change it, and civilization is the name they give to the accumulated changes they made and continue to make in it. All their changes in the external world are intended to sustain the internal quality of the diversified total of human life. This sustenance consists of food, clothing, shelter, defense against enemies, natural and human. Where the sustenance and defense are adequate, the inward quality of men manifests itself freely in the creation of those spiritual values that we call the cultures of peoples. The achievements of civilization fall, broadly speaking, into two classes-tools, designed to use and to humanize the raw material of nature; and cultures, designed to utter and to elaborate the inward qualities of human nature. Tools tend to uniformity everywhere: a knife or a steam engine is the same in Russia as in America. Cultures tend to diversify everywhere: languages, literature, music, differ widely from Russia to America. Tools are inventions compelled by the necessity of adapting external nature to human uses. Cultures are free creations of the spontaneous spirit of men. Tools and materials are capable of being property, private, exclusive possessions. Cultures, though of particularistic origin, are impossible unless they are commonly held and uttered." But in the possession of tools and materials rest the indispensable conditions for that liberation of the spontaneous energies of men which create cultures. It is over tools and materials, property rights, concessions, spheres of influence and such that nations go to war. Those are the things involved in the greatest relevance to the original nature of man, to his basic instincts and primary needs, in which he is the near kin of the beasts of the field. His consciousness of those things tends to be exclusive and narrow. Left to himself, he will ignore their causal connections, the ground and conditions of their increase and development. Like the animals, he will respond pugnaciously to any attempt 
to share them. When these instinctive responses are elicited and reinforced by interested systematic propaganda and a kept press, his international consciousness, being on a more superficial and higher level of mind, will be swept completely away. When that happens, war comes. If then the great and genuine international consciousnesses have failed to keep particularistic nationalism in check it is because the international institutions which are the substance of society's various interests are not in themselves deeply grounded in the original nature of man, because they lack weight and because they are without relevance to the more massive and primordial habits of response on which the continuity and cohesion of society depend. The problem of bringing to be a stable and growing international mind is the problem of correlating all responses in a conscious way to basic international institutions. Its solution is essentially a matter of causing the habits and interests of men singly and in the mass to span, consciously in their action, not only what they see and touch, but what is dynamically connected with what they see and touch, although unseen and out of reach. It is a problem of extending the arc of habitual attention to international dimensions, of making men feel, and think, and consciousiy react to, the international implications of the immediacies of their living. When the average wearer of a Panama hat or rubber shoes will habitually and with friendliness feel and think these articles in terms of the lands and people and machinery without which they could not have come to his hand, when he will habitually think of himself as depending on them and them on him, and on stated occasions will act on this thought, then a truly effective international mind will be in existence, and an effective international public opinion will be available for political purposes.

Internationalism and the Psychological Limits of Group Consciousness. - That there are obstacles to the establishment of such a state of mind is recognized. But they are by no means insuperable. They are mostly consequences of the workings of special interests, of inadequate education, misdirected attention. They are not fatal defects of the constitution of mind itself. That has its limitations, but it has also a compensating elastic plasticity which the external conditions existing in nature and those established by institutional organization mold into habits 
of interest and response. It is upon this that the hope of early Igth century nationalism rested; this that has made possible the modifications, of the social order necessitated by the advance of machinery toward complete domination over social activity.

Now the best ancient political thinking took its stand, unconsciously, of course, upon the limitations of the mind, and all authoritative political thinking still has this only in view. The state was built upon the conception of these limitations, and political perfection was made a matter of limits implicated in observed human nature. Plato's Republic rests on these implications; Aristotle's delineations of an ideal state derives from them. "A state," declares the latter, "when composed of too few is not as a state ought to be, self-sufficing; when of too many, though self-sufficing in all mere necessaries, it is a nation and not a state, being almost incapable of constitutional government. For who can be the general of such a vast multitude, or who the herald, unless he have the voice of a Stentor? A state only begins to exist when it has obtained a population sufficient for a good life in the political community: it may somewhat exceed this number. But . . . there must be a limit. What should be the limit is easily ascertained by experience. For both governors and governed have duties to perform: the special functions of a governor are to command and to judge. But if the citizens of a state are to judge and to distribute offices according to merit, then they must know each other's characters; where they do not possess this knowledge, both the election to offices and the decision of lawsuits will go wrong." 5

The ideal state, it will be seen, was limited in size by the maximum range of the sense organs and the possibilities of immediate contacts in the routine of the daily life. Social cohesion was held to be dependent upon the intimacies of contact, upon the neighborliness of a community where everybody could know everybody else. For purposes of common action, the aggregate had to be within reach of an orator's voice, and within the vision of a general's eye. The limits of a really adequate free community were, in point of fact, the limits of direct sensory conmunication. Aristotle seems to regard most of the defects

- Politics, VII, 4, I326b, translation of B. Jowett. 
of ancient states as due to the growth beyond this limit set by the natural processes of herd action.

Although political communities immeasurably greater than any Aristotle knew have succeeded in functioning, modern experience, both industrial and political, has amply confirmed this observation. The failures, already noted, of the various internationalisms are confirmations-the failure of the workingman Internationale to establish class-solidarity among the workers; the difficulties of unionization in the same trades and the bitter antagonism of workers on different levels of technological skill; the loose and unintegrated quality of such units as the coercion of events has succeeded in bringing about-they are all confirmations. Span, duration and intensity of attention are required for the establishment of habitual response to public events. This response is most complete, lasting and profound when the stimulus evoking it impinges directly upon eye or ear or any of the other senses. Even the instinct responsive to the herd as such can be moved to thoroughgoing action only by some kind of immediate sensory contact, no matter how unregarded. And "herd-instinct" also has only a limited span. A point is reached where the stimulus no longer can get beyond the threshold. Persons on the outskirts of a crowd are freer from the infection of its moods and purposes than those at the center.

Consequently, the farther from home an issue is, the less likely it is to command attention and consideration. In the hierarchies of representative government such as Americans suffer and endure under, indifference grows with remoteness, and to the general public, no issue can be a live issue until it has become a local issue. This remains true in spite of the expansion of community by the facilitation of communications. Men mind only what they must, and what they must, is first of all what is physically and continually compelling them to mind it. The problem of the internation is in no essential different from the problem of the nation. If, for example, the tariff could have been made everywhere the same local issue that it was in particular places, it could never have been the instrument of exploitation and usurpation the predatory interests have made of it. But because attention lapses with physical or emotional remoteness, politics becomes a profession of the predatory or the 
incompetent, and invisible government has its way with the institutions of the state. And it will continue to have its way until political institutions become relevant to the real interests -i.e., to the supply of food, clothing, shelter, to free and creative self-expression, to insurance against disease and accidents - which are involved in the immediacies of the daily life. This means, of course, that the affairs of the nation must be at home and pressing in the business of the neighborhood. But in this business politics is a special interest, tangential and peripheral: beyond, not within, the focus of attention, because in form and method of operation irrelevant, as we have seen, to the direct, inevitable preoccupations of the lives of men. And while, as we also have seen, the unconscious tendency is for these preoccupations slowly to alter and reconstruct those forms and methods to the point of relevancy and, in crises, such as wars, to reconstruct them swiftly by executive fiat, war and loss of liberty are, nevertheless, a terrible price to pay for speed and efficiency, and in view of the tremendously easier methods attainable through the conscious control which follows awakened attention, the hardships and suffering of slow unconscious readjustment are unnecessary.

In relations between states the situation just described is repeated. The problems of contact are very greatly remoter from the masses of men. The neighbors who in those relations really quarrel or live amicably together are the men at the dangerpoints of international impact-primarily the international financiers, the great monopolists of production or distribution, and the engineers and production-managers who are their indispensable agents. These are the men who possess, as we have seen, a genuine international mind, who stand really above nations and gain alike through their wars and peacetimes. The diplomatic offices of governments are their servants, and diplomacy is secret. Secret diplomacy is international invisible government, and quite apart from considerations of tradition, superstition and inertia, is possible only because the affairs which are its subject matter do not enter until too late among the daily concerns of the local communities whose combined interests are the body and soul of national life. Any device that should make international relations physically and continually local and present would go a. long way toward the establishment 
of a habit of international-mindedness, and thus toward supplying Mr. Wilson's "moral force of the public opinion of the world" with the dynamic relevancy the lack of which up to date renders that moral force impotent.

The Nature of Mind and the Machinery of Its Internationalization.-Such a device would need to invoke an integrated and harmonious response from both the static and plastic aspects of human nature. It would need to take form as an institutional arrangement such as would effect a conscious alteration of the social mind. Let no one pause at this point to cry "Change human nature! Impossible!" The human part of human nature is precisely the changing part; it is the animal part which is the only part that, on the basis of the record, can be said not to have changed. The record referred to is, of course, the record of history and anthropology. If the biological and geological records be also considered, the body of man is no less in flux than his mind. And his mind is all flux and change enchanneled in certain patterns by the organism's vital needs. These patterns are the instincts, the primary appetites and interests, to satisfy which, the fundamental economy of society has come to be. They are intrinsically no more than so many specific sets of the organism-so many modes of attention and response. Their being may involve feeling or appetition, but nothing like the thing that is usually called mind. Mind comes into existence when each of these patterns of response impinges upon an object and spans or envisages it; when the combination of response and objects are integrated, or constellated, or otherwise united, into the specific mental set in which consists the dynamic law of individuality in men. Some of these patterns of action are a priori correlated with things in the world beyond the skin-the lungs and air, the eyes and light, the apparatus of digestion and food-and so on. Mankind is by nature compelled to mind these things. They are its basic primordial mind. But this stuff of mind is not always present in quantity or quality. The correlation is constantly being upset-upset, in view of disease and congenital deficiency, on either side of the equation. The institutions of society, the secondary correlations which are involved in the growth of inventions, the division of labor, the specifications of the social functions of individuals are all consequences of this instability of the primary correlates. 
Civilization is the measure of the disharmony between the original nature of man and original nature. It is a succession of very different adventures in minding and the farther away it gets from primary concerns, the freer and more individual it becomes. The mind consisting of these primary concerns is what is called common sense. Being nearest to the instinctive life, being a set of the organism determined by the seasonal cycles of nature, common sense consists of a view of the visible world as it appears to the senses and as its seasons govern the food supply, and of the basic social institutions whose principle of cohesion lies in the processes of nutrition and reproduction. From it radiate the other ways of minding, the religious, the æsthetic, the scientific. It is more lasting than they, but it also changes. It underwent critical change with the establishment of the Copernican system in astronomy and another with the establishment of the Darwinian system in biology. Both systems are modifications, please note, of sensory experience by interpenetration with matters invisible and remote. They modify sensory experience to the point of contradiction. Yet they endure, and gain strength, because they yield control of the causes and hence of the effects which are the desirable objects of our instinctive life.

Common sense is far more rigid than the other institutions of civilization which modify it, and common sense has since the Renaissance been acquiring a progressively greater mobility. When one turns from the social-and that is always nearer to the animal mind-to the minds of individuals, the plasticity and lability, particularly under the conditions of machine culture are great indeed. An individual's mind is more conspicuously and dominantly than a society's what he minds. Men are not born with minds. Men achieve minds, and they achieve minds by minding-beyond and above those objects of mind to which they must attend with all men, which make up their commonsense-particular objects. Inheritance may within limited cases indicate a disposition to certain kinds of mind, but it indicates only disposition, organic set, not achievement. Inherited aptitudes such as those for music, painting or mathematics (demonstrable cases for inheritance can be made only for these three) may be thwarted or repressed, and the possessor of any one of these may become butcher or baker or candlestick maker, 
according to the objects which, for the satisfaction of his original nature, he is compelled to mind. What he minds becomes his mind. And when that kind of mind is attributed to him, the attribution means that his attention is absorbed by that kind of thing. To say that a man has a musical mind is to say that the thing he is most awake to, the thing he surrounds himself with, talks about, works and plays with, is music. $\mathrm{He}$ has a musical mind because he minds music more persistently, thoroughly and pleasantly than anything else. If it were medicine or carpentry or machinery that he were preëminently minding, then his mind would be medical or carpenter or mechanical, as the case might be. His attainment of his mind is a process of habituation in, and facilitation of reaction to, the subject matter. It is the result of education and wont and use. These it is that give definition and specific form to an original plastic material which may become with equal success any one of a thousand things in this, our civilization. Men are in their original nature very much more alike than the social differences between them suggest. The remarks of Rousseau on their inequalities are as pertinent after Gobineau and Nietzsche and Chamberlain as before. Most of the vocational and other regarded differences between men are eventual and artificial, not primary. All are witness to an indefinite capacity for differentiation. This is why animals grow and men are educated.

What is of importance here is the obvious fact that the differentiating agent is in this connection not inherent but external. What defines a mind is its object, not the organic set or pattern of response to the object. This, while it underlies that overtone or timbre of mind which we call personality and in which consists the ultimate distinction between one man and another is, instinct for instinct and impulse for impulse and appetite for appetite, the same in all men and fuses them in the common sympathy of the herd. That is true also of intellect, which is a mode of response to the chain of relationships, causal and substantive, in which all objects minded are implicated, and by means of which they are most effectively used and controlled. This is why mind is so commonly confused with intellect, which is regarded as mind in the abstract. But there is no such thing as mind in the abstract, and there is no thinking which is a thinking about nothing at all. The color and 
inportance of all processes of consciousness are due to their content, not to their quality "as such." Minds are acquired, changed, clouded, confused, cleared, and made up simply by the manipulation of their contents. It is content that is paramount.

In view of these considerations what devices could make the true causal nexus of international relations a constant factor in men's minds, such as would move them habitually in-its confirmation, extension and enrichment? The obvious ones, which have been much in the public eye, are publicity and the League of Nations. In point of fact, the latter is held to be a device, most of all by Mr. Wilson, for securing the former. But nobody who knows the bold and the subtle ways in which the agencies of publicity are controlled and manipulated in behalf of secret and special interests, nobody who has followed the development and technique of international propaganda during the war and the peacemaking, can fail to regard such an emphasis on publicity as either extremely naïve or extremely sinister. "During this war," writes Mr. Walter Lippmann, ${ }^{6}$ "the deliberate manufacture of opinion both for export and for home consumption has reached the proportion of a major industrial operation. . . The technique must be investigated if the judgment of peoples are to escape persistent exploitation. When the story is told, it will cover a range of subjects extending from legal censorship to reptile press, from willful fabrication to purchase of writers, from outright subsidy to the award of ribbons. It will include entertainment, and a vast amount of stimulated snobbishness, and the right way of conducting sight-sceing tours. The art of befuddlement engages able men and draws large appropriations. There are in practically all countries Ministries of Befuddlement generally presided over by personal representatives of the leading statesmen. What they emit makes unconfused dealing between nations most difficult." The attainment of adequate publicity would require a definition of the powers and penalties attached to the procuring and dispensing of news that would be tantamount to the fixation of personal responsibility for each and every item published in the same way as they are now fixed in America for political advertisements. It is doubtful that such a control could be established, even nationally, yet without it, the subject matter of •"The Political Scene," New Republic, March 22, 1919. 
international discussion and adjustment is bound to undergo befuddlement at the hands of special interests.

Propaganda and publicity assume, moreover, the literacy of the populations to which they are directed. Between literacy and the capacity of peoples for self-government there is a direct and measurable ratio. And the industrialization of society can hardly be said to have had a hindering influence in that connection. International compulsory literacy is, however, no ideal to hope for in the near future. Yet it is sine qua non of the international mind. It takes us at once to the prior and fundamental question of the educational systems of the various states and the treatment of international relations within those systems. Whatever men make their vocation, its background, value and bearing on their self-respect and sense of freedom are to be found in the associational system of which the acts and interests and perceptions of the daily life are the solid ever-present nexus. To establish this system permanently as the "appcrception-mass," the funded mentality, of the masses of men would have to become a primary concern of the national educational system. Furthermore, the symbolic association through words and other modes of making the absent present, would need to be reënforced by the direct personal contacts with the absent. An international, comprehensive exchange of both teachers and pupils would be necessary, the travelers becoming in their communities, on their return, sensory nuclei of international experience. The institutions and processes of education are, however, themselves everywhere the subjects of manipulation in behalf of special, vested interests. Churches, political parties, benericiaries of privilege, protagonists of special subjects of instruction like Latin or Greek, pedagogical experts, patriots, all strive consciously or unconsciously, not to help the growing child to freedom and self-realization, but to make it over into the faithful image and servant of what they are themselves. They use the educational institution simply to reproduce themselves. As a consequence, initiative and invention and discovery in history, religion and economics particularly, appear in the schools as acts of rebellion. Originality is penalized and spontaneity suppressed. Truth is made subservient to prejudice.

Education must be freed from its exploiters before it can become adequately the instrument of international-mindedness. 
The way of liberty is herein the same as in all other aspects of human endeavor. It is through the autonomy of the art of teaching and the practice of research, an autonomy that should take form in organization of international scope, that should bring to pass international coöperation in the development, particularly of the social sciences, such as history, economics, sociology. So, perhaps, education might be freed of its incubus and the youth of the world set free for the internationalmindedness which is its greatest hope and most precious heritage. So the original nature of man, the needs for food, clothing, shelter and security, would find their gratifications in a consciously apprehended international nexus of events in the daily life and the oppugnant interests of culture and economy might be reconciled, at least in the realm of ideas.

Such a reconciliation would, however, provide only a set or atmosphere for the daily life. It might be crystallized universally as in the past it has been sporadically, in the form of a body of internationalist belief and temper and yet come to no efficacious realization in action. This requires further organization-the creation of institutions which shail enchannel action, shall necessitate conscious co-national response to international objects. It need hardly be repeated that such institutions must be close to the sensible immediacies of men's routinal interests, to the importance of the day's endeavor in shop or field or factory, at the table or in the theater. Nor need it be again emphasized that these immediacies are not political but economic, that a man votes but once or twice a year but that he does his work and eats his food and wears his clothes every day. The creation of an organization which will instill in men the habit not only of feeling and perceiving the world's economy internationally but of each doing his share in the conscious control of international affairs, is indispensable to the firm establishment of an international mind. Now habit depends on the constancy and coerciveness of the stimulus that evokes the response out of which habit develops. It depends on the repetition of the response, and finally, on its value as a gratification and free expression of a complex of inner impulses and as a mode of successful adaptation to the external world. The obvious action which would bring home the international implica- 
tion in the daily life is the vote. Universal suffrage in industry, frequent election of industrial representatives, frequent meetings for the purpose of checking up their action, would finally, with the right educational background, establish a habit of international-mindedness. The coming of such a habit is necessitated by the nature of machine industry: the present use of foresight in accepting the social and political implications of that industry would ease the change and spare mankind much hardship and, perhaps, bloodshed.

The League of Nations as an Instrument of International Mind.-It is interesting to inquire, in conclusion, to what degree the Covenant of the League of Nations exercises this foresight and meets the conditions indispensable to the establishment of international-mindedness. Broadly speaking, it falls into two distinct and not clearly related parts. One of these looks backward. It sums up and tops off the method of international contacts as those have developed in the tradition of diplomacy. It is careful of political sovereignties and the status quo. Its preoccupation is with international disputes and the settlement of them without resort to war. The agencies of settlement are an Assembiy, a Council and a Court. All are designed to be agencies of sovereign governments rather than representatives of self-governing peoples. Their essential action is limited by the rule of unanimity and by prescribed referendum to national governments. The masses of men are without any share in the naming or selection of them or in the determination of their policies. They are remote from peoples, in actu responsible to governments alone. Only a very high degree of conscience and public spirit, a degree that the party politicians and agents of financial imperialism who have thus far held power over war and peace have shown themselves entirely incapable of, can prevent the deliberations of the Assembly from being anything more or better than the deliberations of a Hague Conference, and the operations of the Council anything more than the operations of a military alliance of the most powerful.

These operations are, however, limited by a set of principles which look straight to the dominant influences in civilization. The principles are assembled and stated in Article XXIII. 
"Subject to and in accordance with the provisions of international conventions existing or hereafter to be agreed upon, the members of the League:

"(a) will endeavor to secure and maintain fair and humane conditions of labor for men, women and children both in their own countries and in all countries to which their commercial and industrial relations extend, and for that purpose will establish and maintain the necessary international organizations;

"(b) undertake to secure just treatment of the native inhabitants of territories under their control;

"(c) will intrust the League with the general supervision over the execution of agreements with regard to the traffic in women and children and the traffic in opium and other dangerous drugs;

"(d) will intrust the League with the general supervision of the trade in arms and ammunition with the countries in which the control of this traffic is necessary in the common interest;

"(e) will make provision to secure and maintain freedom of communication and of transit and equitable treatment for the commerce of all members of the League. In this connection, the special necessities of the regions devastated during the war of 19r4-rgi 8 shall be borne in mind;

"(f) will endeavor to take steps in matters of international concern for the prevention and control of disease."

The application of these principles would come directly home to the daily lives of the plain men and women of the world and could conceivably meet with ease the ultimate irreducible psychological conditions of the establishment and maintenance of a genuine international mind. But there is every sign that their application, if the present rulers have their way, will be bureaucratic rather than popular, and that both national and international governments are charged with paternal good will rather than with the responsibility of public servants. The peace treaty provides explicitly for the machinery and procedure by which only the labor clause of Article XXIII is to be applied. And that also makes governments predominate. As against workmen and employers, governments are represented as two to one, and hitherto, when governments were represented in international affairs, the interest really represented was that of high finance. Both the projected annual international labor conference and the international labor office are in effect packed against labor. They 
do, however, provide a wedge for the actual entry of international concerns into the workman's daily life. They provide it, however, grudgingly, as a concession to the coercion of the inescapable implications of this circumstance. "Men and women and children who work," said Mr. Wilson in his speech presenting the first draft of the League Covenant to the Plenary Session of the Peace Conference, "have been in the background through long ages, and sometimes seemed to be forgotten, while governments have had their watchfui and suspicious eyes upon the maneuvers of one another, while the thought of statesmen has been about structural action and the larger transaction of commerce and of finance. Now, if I may believe the picture which I see, there comes into the foreground the great body of the laboring people of the world, the men and the women and the children upon whom the great burden of sustaining the world must from day to day fall, whether we wish it to do so or not; people who go to bed tired and wake up without the stimulation of lively hope. These people will be drawn into the field of international consultation and help, and will be among the wards of the combined governments of the world. There is, I take leave to say, a very great advance in the mere conception." One wonders, in view of the militant history of labor, of the bitter steps, from strike to strike by which it forced itself into the "foreground" and compelled attention to its rights and needs and deference to its power, at the naïveté-or something more sinister-which converts a belated and coerced placation into generosity and benevolence.

In point of fact, the Covenant of the League of Nations contains in itself, explicitly enacted into law, the duplexity which marks the changing structure of society in each of the greater sovereign states. It was inevitable that it should. The men to whom its final form is due are old men, over sixty. Their minds grew up and the pattern of their political thinking got fixed in the days when the political democracy which was establishing itself was still sufficiently well rooted in the agricultural economy that was its ground. Their lives have been spent in the contemplation and manipulation of this democracy. To the new conditions created by the growth of industry under machine production, they deferred only as they were compelled to. The labor movement as distinguished from the political movement 
was to them an obstruction, not the basis of an ideal. They crushed it when they could and compromised with it when they had to. They have done everything to it except understand it. For understanding it they had become too old. Their habits of attention and action had become fixed, and what they did habitually and spontaneously was irrelevant to the new conditions which were overtaking and rendering obsolescent the political forms wherewith they were preoccupied. So far as their relation to the conditions of real social growth were concerned, they were functioning in a vacuum. It is this condition of mind that these old men have carried over to the peace table, this that has governed their framing of the covenant of international polity. They framed the most they were able to frame; that is, a mere reproduction of the pattern of the national polity of "democratic" industrial states. They have not made "invisible government" difficult, to say nothing of impossible; they have not ruled out manipulation by vested interests; they have not cut under the foundations of international misunderstandings. Nor have they provided the conditions which would create the habit of international-mindedness. Their covenant emphasizes rather than mitigates the opposition between political forms and economic interests.

On the other hand, it does provide an organized and legal machinery through which the considerable already-existing funded mentality of internationalism, both in the world of culture and the world of affairs, can get leverage to make itself efficacious. It advances this internationalism from the merely sentimental rôle that was its lot in the past, gives it a sanction and a status under the law of nations whereby it may, if it is watchful and persistent enough, convert its foresight into institutions wherewith reconstruction of the world's political superstructure in conformity to its industrial foundations may be made more gradually, more easily, with less waste, with less pain. Whether it will come about so, or violently, rests to-day exclusively with the financing and employing groups. That the reconstruction is inevitable, we have already seen. We have seen it in the changes that government has undergone in industrial countries; in the history of industry itself; in the history of labor and of capital. We have seen it come about in a series of changes that have been slow, wasteful, full of suffering, 
because they were the unplanned readjustment to continually recurring strains on the political and economic structure of society. These readjustments are symptomatic of the necessary direction of change. Analysis of them points to a comprehensive "preparedness program" leading to industrial democracya program resting entirely upon the implications of the industrial organization. Unless the organization be destroyed, the realization of these implications can not be prevented; it can only be hindered and obstructed. Hindrance and obstruction can lead only to class embitterment, to warfare and, finally, to the worst features of revolution. This is the alternative to a common understanding, discussion and progressive readjustment by means of a democratic machinery of conscious and coöperative control. In the plan for a national industrial council with its implications, the English have tried to meet the inevitable with appropriate foresight, perhaps too late. Internationally it is not, however, too late. The Covenant of the League of Nations provides a point of departure for just such a progressive readjustment and inter-accommodation as the controlling conditions of international economy demand. What is needful is a program of amendment planned step by step to reconcile the economic with the political order and to bring the individual citizen-worker to the point of habitual action with respect to international affairs; to bring him to the point, that is, where the captains of finance and of industry have been for two generations. 



\section{CHAPTER V}

\section{NATIONAL ORDER AND INTERNATIONAL PEACE}

\section{By LiNDSAy ROGERS ${ }^{2}$}

Associate Professor of Political Science in the University of Virginia

History rarely repeats itself; conditions cannot be exactly the same, ideals vary, national aims differ, and a precedent can seldom furnish an effective argument in a discussion of present conditions. But if the lessons and morals of history are rare, we may, nevertheless, draw from the past much inspiration and light. Great epochs and deeds and men urge us on towards the never attainable goal of perfect government and if, in forming conclusions, we must avoid the too plausible snares of historical parallels, we may at all events find in the past hints that will sift the valid from the invalid or at least serve aptly to introduce a discussion of present politics.

For the times in which we live the French Revolutionary period-the favorite source of political parallels and nomenclature-is the familiar precedent, yet to derive much light the sequence of events must be ignored. There was the long, hard, and finally successful struggle of the allied powers against Napoleon who, like William II, challenged the liberties of Europe and attempted to dominate the world. The United States remained neutral, and her various proclamations were landmarks in the development of international law. But before the Napoleonic wars the French Revolution had run its course, and against its excesses Edmund Burke, the friend of America but the foe of tyranny in whatever form, uttered his eloquent and even prophetic philippics, just as now, forward-looking

${ }^{1}$ A.B., Johns Hopkins, rgr2; Ph.D., rgr5 ; LL.B., University of Maryland, I9I5; adjunct professor of political science, University of Virginia, 1915; author of several works in political science and public law. 
although perhaps less eloquent statesmen are opposing the theories and crimes of Bolshevism. May they not err, as did Burke, in ignoring the existence of intolerable wrongs, ${ }^{2}$ or as Tom Paine aptly put it, in pitying the plumage but forgetting the dying bird? But, in a sense, the present struggle has carried French Revolutionary theories to their logical completion and the Allied Nations are pledged to secure their success. Writing at the beginning of the war, Emile Boutroux, the philosopher, remarked that the Declaration of I 789 proclaimed, "as also had America, that men are born free and equal in their rights and that they continue so. The French theory of nationality consists in extending to nations that which, in this maxim, is affirmed of individuals"; and without exception the powers which met at Paris agreed that, in Mr. Wilson's phrase, "all welldefined national aspirations shall be accorded the utmost [possible] satisfaction."

More than a century of time and a series of wars have been necessary for the fruition of this principle; and the very fact of the wars serves to show the failure of the Holy Alliance-the experiment in international government made by the powers after the defeat of Napoleon. Then as now after checking a menace to civilization, the victorious states dreamed of enforcing peace. Apart from the motive of the confederation, the similarity is more than casual. Then the monarchs wished to secure their thrones and check the rise of self-government; now the Entente Allies wish to preserve their liberties against the excesses of Bolshevism, whether they spread from Russia and Germany or are induced by continued crushing expenditure for war purposes. With the Holy Alliance the United States was but indirectly concerned; yet it was in answer to this union of sovereign princes that Canning "called the new world into existence to redress the balance of the old" and the Monroe Doctrine was announced. Now it seems likely that Canning's boast may have a belated-but perhaps for that reason a more successfulrealization.

Even those who believe that the lamp of the past does not burn with a light suitable to jllumine the present will recognize

'What Burke, were he alive, would think of Bolshevism has been outlined in an interesting article by Professor Dicey, "Burke on Bolshevism," Ninetecnth Century, August, 1918. 
that in the events between the American Revolution and the Monroe Doctrine is to be found much that gives the years of the war and the coming peace a greater interest. Certain it is that the present and future-and America's share in them-are the most hopeful, the most portentous, and mayhap (even with Germany defeated) the most dangerous times in which men have lived. What is the duty of America? What shall we do that the future poet may say, as Wordsworth truly said of himself and the French Revolution-

Bliss was it in that dawn to be alive

But to be young was very heaven?

\section{The WaR, Reconstruction, AND Revolution}

A week before the outbreak of the war, Sir Edward, now Viscount Grey, told Sir M. de Bunsen, the British ambassador to Austria, that the possible consequences of the situation were terrible. "If," he said, "as many as four Great Powers of Europe-let us say Austria, France, Russia and Germany-were engaged in war, it seemed to me that it must involve the expenditure of so vast a sum of money and such an interference with trade, that a war would be accompanied or followed by a complete collapse of European credit and industry. In these days, in great industrial states, this would mean a state of things worse than that of $\mathrm{I} 848$, and, irrespective of who vere victors in the war, many things might be completely swept away." 3

Strong as this language is, Lord Grey erred on the side of understatement; for great and permanent changes, the extent of which no man can foresee, will come, either by blood or b: due process of law, in the social orders of all the warring natons. America, for the most part, does not realize the simple trith that when Germany declared war against France and Russn, she lighted the fires of revolution, not only in the Central Powers and Russia, which we fear as a vague menace, but in the Entente Nations as well. The world is in flux; the problems of reconstruction are as difficult, as compelling, and as important as the issues over which millions of men have fought. No matter what

- Sir Edward Grey to Sir M. de Bunsen, British White Paper, No. 3, July 23 , I9I4. 
the terms of the peace treaty are, whether it secures restitution, reparation, and security for the future, a settlement that promiscs to be lasting, and a League of Nations, there will be peace without victory unless reconstruction leads to freedom. The war was fought partly to make the world safe for democracy; its outcome will not be satisfactory unless democracy is made safe for the individual.

This is the ideal to be striven for, but whether or no it is reached the economic order of modern states will be completely transformed. Even assuming that labor parties or the proletariat do not force the hands of the government by political or revolutionary means, crushing taxation to meet the costs of the war will operate heavily on the property of the wealthy and even of the well-to-do, with the result that a dead level will be gradually approached. And the fact that private property was saved from complete destruction by armies raised by compulsion, will furnish an irresistible argument for all sorts of economic measures favoring the members of those armies-control of prices, stimulation of wages, unemployment and other forms of insurance, pensious, and probably a conscription of capital to pay the costs of the war as there was a conscription of man power to fight bittles and to furnish material.

In the United States, as I have said, there has been manifested but a faint realization of the fact that the social order must experiance vast changes. Here the problem is looked upon largely as involving a simple change from a war to a peacc basis; of resuming business as usual; of reëstablishing the status (uo ante bellum, and the transition period feared by all Europan nations and particularly by Germany is not expected to br serious. This is only natural because our participation in the war was not sufinciently prolonged and did not require enugh sacrifices either to make the necessary economic readjustnent a revolutionary process or to shadow by death the future life of every family. This is not to say that all the resources of America in men and material were not pledged to the winning of the war. They were; but in England and France women in industry were numbered by the millions while ours were numbered by the hundred-thousands. Our European allies suffered from hunger and cold while we put up with temporary inconveniences. They mortgaged all their resources while ours have barely been 
scratched. Their hospitals and cathedrals were bombed while we were only slightly worried by submarines off the coast. They sent every available soldier to the front while we could comb our man-power with great regard for dependency and industrial claims. And finally, their casualties suffered in a fortnight of heavy fighting are hardly equaled by our total losses. It is this personal sacrifice, universal in England and France and only occasional in the United States, that is most important. There is little wonder, then, that England and France were more consecrated to the war than the United States and that particularly in the former reconstruction is looked upon as involving a spiritual principle rather than a simple economic readjustment. No one in England would desire, were it possible, simply to go back to the conditions of I9I4; they are gone forever. In the uncharted future will be gained or lost the complete fruits of the military victory won at such great cost.

The men who have come back from the front are fully determined to have greater political privileges and economic opportunities than any democracy has ever yet vouchsafed its citizens, and there is equally the determination in England, among those who have stayed at home, that men who have hreathed the freer air of common sacrifice must not be forced to return to the stuffy atmosphere of self-interest; that England must be made a nobler and better place for them; that political and economic principles must be tested and revised to insure that reconstruction will mean the greatest possible measure of liberty and happiness to the individual, and that, finally, the Machtpolitik which the armies of freedom have combated in all quarters of the world will not again be permitted in the fierce competitive individualism that, before the war, was common not only to England but to all modern democracies. Reconstruction viewed thus would purify England, eliminate what was bad, invigorate what was good, and a true renaissance would establish the British Empire more firmly and completely on the moral basis of freedom.

On the other face of the shield, as I have intimated, can be read unmistakable warnings that this must be done. The war brought into prominence three great ideals and for them millions of men have suffered. A league of free nations-the realization of the ideal that the war just finished has been a 
war against war and that the world is safe for peace-loving people-is within our grasp if we choose to take it. Germany's vision of world hegemony, of a vast Mittel-Europa that she would dominate, has been shattered, but in defeat the peoples of the Central Powers, like those of Russia, will likely suffer far more from democratic excesses than from the success of hostile armies. These two ideals are widely different but the tyranny is the same. The leaven of democracy has had results; but instead of enjoying a rebirth of freedom Russia and now Germany have plunged into abysses from which they will emerge only at a cost comparable to that incurred while they were carrying on hostilities. The menace to other nations, if not so immediate and challenging, is nevertheless grave. How far will Bolshevism spread before it is conquered? The terrible sufferings of four years, the tempered spirit of France, and the wine of victory have strengthened her further to resist. But will she always? England's long cherished liberal institutions will make her problems less acute, but there is the danger that the economic materialists will look upon reconstruction solely as a question of reëstablishing industry and securing a larger share of the trade of the world and will pay no regard to the heritage of freedom which is essentially the ideal for which Britons fought and died. Reconstruction, if it is to suffice, must dedicate the country to freedom. It must mean a new birth of happiness and of patriotism learned in the trenches, based on fellowship and love, and thus immune to the germs of revolution.

\section{The Duty of America}

In the United States the need for courage and vision is less immediate but still important. Laissez faire and Machtpolitik must alike be discarded as guiding principles of statecraft. Liberties given up for the duration of the war must be restored. We must try to prolong and to dedicate to new and national purposes the moral forces which pledged our resources to securing a better internationalism. They have checked a menace. They must go on and secure a better future. American losses have been sufficient to justify, even if they do not make inevitable, a new spirit. Lives were given not for the old but for the 
new America that it is within our power to make. Nor will we be without specific, difficult problems, for peace has found us as unprepared as did war. Three million men must be absorbed in various trades and professions and we may be in for a period of unemployment and perhaps acute depression. The industrial system in the United States is not so perfect that the germs of Bolshevism may not find lodging places. Conscription has made a vital difference. Had the voluntary system been adhered to, national obligations would not have been so great; but the state demanded the men it chose and sent them to Europe. It cannot now deny them a fair measure of freedom and happiness.

This, then, is the test. Shall the United States be worthy of the sacrifices that have been made for its honor and international safety? The compulsion is not so great as in the case of European democracies. Our losses have not been so severe. The menace from crimes committed in the name of democracy is not so imminent. But, had it been necessary, the United States would have passed through any ordeal. The country was pledged to victory; that it did not need to endure consecration by the blood of countless sons may make the spirit of reconstruction less compelling, but the opportunities are just as great, and uniess they are realized it will be impossible to secure that better internationalism which can only rest upon national order. As President Wilson wrote a year ago (March 20, 1918):

"The days of political and economic reconstruction which are ahead of us no man can now definitely assess, but we know this, that every program must be shot through and through with disinterestedness; that no party must try to serve itself, but every party must try to serve humanity, and that the task is a very practical one, meaning that every program, every measure in every program, must be tested by this question and this question only: Is it just; is it for the benefit of the average man, without influence or privilege; does it embody in real fact the highest conception of social justice and of right dealing without respect of person or class or particular interest?

"This is a high test. It can be met only by those who have genuine sympathy with the mass of men and real insight into their needs and opportunities, and a purpose which is purged alike of selfish and partisan intention." 


\section{The United States and International Peace}

The most important political event of the last two centuries and one of the most momentous happenings for all time was the advent of the United States into the family of nations. Of great importance was the influence of the American Revolution and the ideals of the American Constitution on political liberty everywhere-in France, Spain, Italy, Germany, and Hungary. The war we have waged to make the world safe for libertyloving peoples was, in part, the culmination of this influence. But the birth of the new republic was important, also, in the field of international relations, for the latter years of the eighteenth century marked a transition period in the development of international law and diplomacy. The code governing the relations of nations was still in a formative state. Diplomacy was in its infancy. There were no established principles to be respected by warring powers and the rules laid down by writers on international law were very far from constituting an accepted body of laws.

With a marked difference existing between the principles governing the relations of individuals and those controlling the intercourse of nations, a splendid opportunity was afforded to exercise a very potent influence on the development of international law and diplomacy. There were no hampering traditions, no awkward precedents, and our geographical position was peculiarly propitious. The new nation had been born in bloodshed. But the wise statesmen in the early dawn of our existence considered war as a contingency to be entered upon only when every other measure had been tried and found wanting. From the time of the adoption of the Constitution to the War of 1812 , the republic was repeatedly bullied by England, insulted by France, and defied by Spain. Its treaties were openly violated and yet peace was maintained up to the conflict with England. Expediency, it is true, dictated this course, but already a sense of the moral damage of war was beginning to spring up and American political leaders showed their appreciation of the fact that, if the ideal of a peaceful and successful nation was to be preserved, international relations would have to be based on 
reason and justice and not simply on the sanction of a half-drawn sword.

It is not unnatural, therefore, that the founders of the Republic became ardent expounders of the law of nations and that, due to American initiative, there have been many substantial contributions to the international code. Of Washington's famous proclamation of neutrality (April, I793), the leading English authority on international law, the late W. E. Hall, wrote one hundred years later that it constituted "an epoch in the development of the usages of neutrality," for "it represented by far the most advanced existing opinions as to what those obligations were, and in some points it even went farther than authoritative international custom has up to the present time advanced. In the main, however, it is identical with the standard of conduct which is now adopted by the community of nations." The United States has, similarly, made important contributions to the laws governing extradition, expatriation, warfare on land, and freedom of the seas. ${ }^{4}$ At the same time it has been a consistent advocate of better international organization and coöperation, whether they were secured by treaty or by congresses-indeed, an advocate of arbitration, and of peace in the western hemisphere under the Monroe Doctrine. In the United States, furthermore, various anti-war propaganda organizations found their work most fruitful. An example of trust without armament was set by the undefended Canadian frontier. Finally, there was the judicial settlement of differences between thirteen-and later forty-eight-states. "The day will come," wrote Robert R. Livingston, "when all disputes in the great Republic of Europe will be tried in the same way, and America will be quoted to exemplify the wisdom of the measure."

What is America's present duty when the peace of the world, the safeguard of civilization, is the stake? She is confronted by the problem of preserving national order, of making reconstruction lead to freedom, and of justifying democracy by having it mean well-being and happiness for the people. The ideals are impossible of attainment without international peace, for as Lord Bryce has said, "If we do not make an end of war, war will

"For a discussion of these contributions to international law, see Ernest Nys, Les Etats-Unis et lc Droit des Gens (Brussels, 1909). 
make an end of us," and the fires of revolution lighted in July, I9I4, will spread no one knows how far, when fanned by another great world conflict. This is not the place to urge a particular scheme for a League of Nations or American adherence to it, but there are certain general propositions and necessary lines of action which it may be well to set forth as indicating the present international duty of the United States.

\section{Isolation Must be Abandoned}

The first is that no attempt must be made to resume the false pretense of isolation which was abandoned when this country declared war. America must frankly recognize both its opportunity and its duty in Weltpolitik. And this must be the case for a reason, which, it seems to me, is more important and more compelling, although less inspiring, than that given in President Wilson's great Boston address. America is needed, he said, because she is impartial, because her motives cannot be suspected. She gave the war a leaven of idealism. Men lifted their heads and fought for a vision. She cannot now draw back, admit her insincerity, and say that in selfish and powerful isolation she will have no concern with the affairs of Europe. The old world, crying for peace, pleading for a way out of its rivalries and dissensions and balance of power theories, cannot be rebuffed by America's refusal. But noble and true as these sentiments are, it seems to me that there is a more practical argument. The development of modern science, particularly as applied to warfare, has ended for all time American isolation. Neutrality will be impossible-just as it was impossible in the war now overwhen the balance of power in the world and human freedom are the stakes. But if neutrality is impossible, if the United States is to be inevitably drawn into the next war, surely it is the better wisdom to contribute the utmost possible toward removing the causes of disputes and to be concerned with old world problems, not in any meddling, entangling spirit, but because concern and solution will eliminate the occasions of war. Nor should it be forgotten that the resort to arms will be delayed and probably avoided if the great and powerful new world is pledged to redress the balance of the old on the side of justice and right. 


\section{The League of Nations a "Vehicle of Life"}

But the abandonment of isolation carries with it a number of important responsibilities. Not the least of these relates to a problem of machinery. But it is, nevertheless, fundamental. Approval can be secured only if the proposal is urged by the disinterested representatives of the United States. They can take the initiative in the matter. They have it in their power to make a contribution to international law greater than those of the early days of the Republic. I refer to the necessity for the powers, whether or not in session at Paris, to realize that the world is not static; that there must be change, and that they must provide for the modification of the treaties or engagements they negotiate. Only thus can new problems be cared for. Yet, up until the present time every peace conference intended apparently that the treaties agreed upon would be perpetual.

John Stuart Mill's article on "Treaty Obligations," published by the Fortnightly Review in 1870 , is an authoritative statement of an extremely difficult international problem. The basis of Mill's article was the fact that at the time he wrote there was evident a marked disregard of treaty obligations, chiefly by Russia, and in some cases justifiably. The congress of European states had in $18 \mathrm{r}_{4}$ and $\mathrm{r} 8 \mathrm{r} 5$ agreed upon a set of treaties which regulated the external and some of the internal affairs of European nations. These treaties were intended to last for all time. Imposed by the victorious states at the conclusion of the war-just as treaties will now be imposed by the victorious Allies-the terms of the engagements "were regulated by the interests and relative strength at the time of the victors and vanquished and were observed as long as those interests and that relative strength remained the same." Alterations, however, took place in these elements, and the powers began to refuse to regard such provisions as were displeasing to them. Public opinion in some cases sustained this action, in other cases the violation of the treaty was not deemed sufficiently serious to justify a resort to war. "Europe did not interpose when Russia annihilated Poland, when Prussia, Austria, and Russia extinguished the republic of Cracow, or when a second Bonaparte 
mounted the throne of France." No one blamed Prussia and Austria when, in 1813 , they refused to live up to the treaties which bound them to Napoleon and pledged them to fight in his ranks. Since Mill wrote, there have been many additional illustrations of treaties that were torn up without the general disapprobation of world opinion. In I 886 Russia withdrew from certain provisions of the treaty of Berlin of 1878 ; only Great Britain protested. Roumania's treatment of her Jewish subjects was in violation of this same treaty. In rgo8 Austria annexed Bosnia and Herzegovina and in I9 I I Italy declared war against Turkey in violation of the treaty of Paris of March 30, 1856, by which England, Austria, France, Prussia, Russia and Italy undertook to respect the territorial integrity of the Ottoman Empire.

These are only a few of the many instances that could be cited. An anti-British writer devotes a whole volume to breaches of Anglo-American treaties. Even when disregard is justifiable and is condoned, the effect is bad. A general distrust of treaties is engendered. There is no reason to believe that the agreements to be made at the present peace conference will have any greater sanctity or will be adhered to more scrupulously than engagements in the past. The tendency is as pronounced as when Mill wrote, and his solution is as valid.

"What means, then," Mill asks, "are there of reconciling, in the greatest practical degree, the inviolability of treaties and the sanctity of national faith, with the undoubted fact that treaties are not always fit to be kept, while yet those who have imposed them upon others weaker than themselves are not likely, if they retain confidence in their own strength, to grant a release from them? To effect this reconcilement, so far as it is capable of being effected, nations should be willing to abide by two rules. They should abstain from imposing conditions which, on any just and reasonable view of human affairs, cannot be expected to be kept. They should conclude their treaties as commercial treaties are usually concluded-only for a term of years."

Mill's first caveat against unwise conditions is too big a subject for discussion here. The exact nature of the terms to be imposed will be determined by a compromise of conflicting views and men naturally differ as to what form the compromise should take. President Wilson in one of his English speeches admitted 
his lack of hope that "the individual items of the settlement we are about to attempt will be altogether satisfactory." "And yet," he added amid cheers, "if we are to make unsatisfactory settlements, we must see to it that they are rendered more and more satisfactory by subsequent adjustments which are made possible. So we must provide the machinery of readjustment in order that we may have the machinery of good will and friendship."

The League of Nations, if it is inaugurated, will insure a better regard for treaties by guaranteeing them. But the guaranteeing of treaty arrangements that are unsatisfactory or unjust can only breed dislike and distrust of a League of Nations. No matter how powerful and competent a League is formed, it is of fundamental importance that all the treaty engagements be temporary, either for a definite term of years or, if it should be deemed inadvisable to fix a date for revision, that clauses be inserted making it possible at any time for powers which are dissatisfied or aggrieved to present their cases before a body with authority to recommend a repeal or amendment of the treaty provisions that are deemed obnoxious. If the League of Nations is given only very limited authority, an attempt will thus be made to avoid treaty violations like those in the past. If there is a strong, competent League of Nations, it will be a League that will allow for change and through periodic revision of treaties it will make less likely the use of collective force in order to prevent a disturbance of the peace and compel compliance with regulations that have become obsolete and whose enforcement would be an injustice.

There is no greater fallacy in international relations than the idea that the world is static. We recognize the contrary when we allow for the amendment of the Constitution of the United States and the repeal of Congressional statutes. One trouble with previous international settlements and with dreams of perpetual peace like that of the Holy Alliance-the failure of which is now cited to confute the advocates of a League of Nations-is that they did not allow for any change. They wished to preserve for all time the then existing international order. And yet, if there had not been change in international relations we should have had no Belgium, no separation of Norway and Sweden, no united Germany, no united Italy. Racial problems in the 
Balkans have always been known to students; but who, ten years ago, would have prophesied that in igig we would determine what political recognition is due the Czechs and Slovaks and Ruthenians and Jugo-Slavs? Other equally unforesen problems will come up in the future. Territorial adjustments will be necessary. Protectorates and vassal states, created by the conference, will be ready to cast off their swaddling clothes, and there is continually the necessity for change in commercial treaties. It should be frankly recognized that, like national constitutions and legislation, international enactments are not for all time. It may be wise to make change difficult; to be certain that hasty, ignorant passion is not translated into the public law of nations. But there should certainly not be the attempt to put international treaties in the same class with the multiplication table.

We hear much about a League of Nations involving an impairment of sovereignty and limiting national action, but the greatest impairment of sovereignty is a treaty made for all time. Frequently its existence is forgotten until sudden'y, with no warning, a state is confronted by repudiation or ky being held to arrangements that seriously oppose its national interest. Nor is there anything more deadening to an intelligent interest in foreign affairs than a series of treaties which assume a static world and do not provide for change. On the other hand it is difficult to conceive a greater educative value than would result from the periodic revision of international treaties. Constitutional changes taking the treaty-making power from the executive and requiring legislative approval are relatively unimportant compared with a lack of interest on the part of the people. It has been notorious that peoples have known little and cared less about international problems. If there is hope for the future of international society it is dependent upon a well-informed public opinion, eager to right wrongs that exist and fully aware of the importance of interstate dealings. In domestic affairs, through somewhat hard experiences, the people have learned that the possession of great power without knowledge does not avail them as much as knowledge with less power. If, as President Wilson said in his address to the Peace Conference on a League of Nations, "the fortunes of mankind are now in the hands of 
the plain people," they should, by periodical revision of treaties, be given an opportunity to know what those international problems are. There is no more effective bar to democratic control of foreign policy than international arrangements made to bind succeeding generations.

\section{A League of Peoples Not a League of Statesmen}

Furthermore, it is the manifest duty of the United States to insist that the "plain people" be given a voice in the determination of their fortunes. Democracies have not always been distinguished by pacific intentions but there is now everywhere such a sickness of war that, if the people have the power, they will not, at least until memory is dimmed, be inclined to use it to endanger the peace of the world. In the past the democratic instinct has been frequently proved correct. Public opinion checked Lord Beaconsfield in the late seventies when he was eager to support Turkey even at the cost of war. British democracy was more correct than the foreign office in its estimate of the American Civil War and the South African War. In the United States public opinion has an intrenched position since only Congress can declare war and all treaties, to be binding, must be submitted to the Senate. It is well that this is the case since, with these two exceptions, an almost absolute control of foreign affairs has been gradually assumed by American Presidents. Our foreign policy is conducted under conditions that are thoroughly undemocratic. Diplomacy proceeding. "frankly and in the public view"-the first of the war aims enumerated by Mr. Wilson in his epoch-making address of January 8, 19r8will mean as great a change for the United States as for the Allies. ${ }^{5} \quad$ Reforms are essential, but of perhaps greater importance is education. Public opinion must be keenly alive to all international affairs and must have the information on which to base intelligent decisions. This can be more easily achieved if provision is made for international progress and change. Coupling to this provision the representation of the people, not merely of governments, in a world legislative or advisory con-

- For a fuller development of this opinion, see my article "Presidential Dictatorship in the United States," Quarterly Review, January, I9I9. 
gress, the United States will contribute toward a notable advance, both in maintaining national order and its equivalent in a broader sphere, international peace.

"What is the Third Estate?" asked Sieyès in his famous pamphlet. "Everything" was the answer. "What has it been in politics until now? Nothing. What does it ask? To become something." That is what a present pamphleteer could say with reference to foreign politics; and to preserve national order will be futile unless the masses of the people are given real representation in international affairs. The United States gave the world a splendidly successful illustration of the virtues of republican institutions and of the peaceful settlement of interstate differences. It now has the greater opportunity of democratizing the international government which is to be instituted because the masses of the people, through Mr. Wilson and other statesmen, have spoken in no uncertain terms.

\section{Progress Through "The Search for Utopias"}

"Whenever great intellectual cultivation has been combined with that suffering which is inseparable from extensive changes in the condition of the people," wrote Lord Acton, "men of speculative or imaginative genius have wrought in the contemplation of an ideal society a remedy, or at least a consolation, for evils which they were practically unable to remove." ${ }^{6}$ Plato, Plotinus, Sir Thomas More, Fenelon, Campenella, Harrington, Rousseau, Kart-all have had their ideal societies. "The scheme of a philosopher," Lord Acton went on to say, "can command the practical allegiance of fanatics only, not of nations." A plan of regeneration will not be matured "unless a new notion of happiness is joined to the sense of present evil."

The statesman is nothing more, according to Burke, than the philosopher in action; and, remarkable as it now seems, Senator Henry Cabot Lodge, in addresses delivered three and four years ago, showed that he was such a statesman, that, like President Wilson, he believed that visions of ideal societies are the beacons to guide our footsteps along the paths of progress, and that only by striving after Utopias can advances be made. Answering the

\footnotetext{
-Essay on "Nationality," The History of Freedom and Other Essays, p. 270 .
} 
objection that the idea of a League of Nations was impracticable, Senator Lodge declared (June 9, I9I5) that "it is better than the idea that war can be stopped by language, by speechmaking, by vain agreements which no one would carry out when the stress came, by denunciations of war and laudations of peace, in which all men agree, for these methods are not only impracticable, but impossible and barren of all hope of real result. It may seem Utopian at this moment to suggest a union of civilized nations in order to put a controlling force behind the maintenance of peace and international order; but it is through the aspiration for perfection, through the search for Utopias that the real advances have been made."

To hold fast to these principles is America's final opportunity and duty. The war has been won and our ideals have triumphed on the battlefield. They can be maintained and peace can be secured only by "the establishment of the idea of public right as the governing idea of European politics." Mr. Asquith, in the early days of the war, took this phrase of Gladstone's and declared that it "meant the substitution for force, for the clash of competing ambitions, for groupings and alliances and a precarious equipoise - the substitution for all these things of a real European partnership, based on the recognition of equal right and established and enforced by a common will." The entry of the United States into the war made a world partnership possible and we cannot now draw back for, as Mr. Wilson eloquently put it in his address to Congress asking for a declaration of war:

"We have no selfish ends to serve. We desire no conquest, no dominion. We seek no indemnities for ourselves, no material compensation for the sacrifices we shall freely make. We are but one of the champions of the rights of mankind. We shall be satisfied when those rights have been made as secure as the faith and freedom of nations can make them."

These rights cannot be secure without the help of the United States, and to keep before it this pledge is America's transcendent duty.

May I, 1919. 



\title{
CHAPTER VI
}

\section{INDIVIDUALISM IN THE NEW SOCIAL ORDER}

\author{
By Warner Fite ${ }^{1}$ \\ Stuart Professor of Ethics, Princeton University
}

The Old Individualism and the New Situation

\section{INDIVIDUALISM AS A DISCREDITED THEORY}

One who ventures to represent the cause of "Individualism in the New Social Order" just after a majority of the United States have voted for a bone-dry amendment may be pardoned for feeling like an Eskimo at the Peace Conference-his presence in the discussion appears to be a mere formality. On a superficial view, at least, one may doubt whether the individual has ever been estimated more cheaply. Never, it would seem, has he been reckoned more deliberately as an impersonal item in the cost of national prosperity or prestige. Nor can one see that the self-determination of the individual is much considered in the program for peace. The "liberty" which is promised is chiefly the liberty of nations. In the ideas proposed for internal "reconstruction" one hears little about individual freedom, much about social unity. The point seems to be that an individualistic social order has been tried and found wanting. "Individualism" and "laissez faire" thus stand for ideas for which few respectable persons now wish to be responsible.

${ }^{1}$ A.B., I889, Haverford College; Ph.D., I894, University of Pennsylvania; since 1894 instructor, professor, and lecturer in philosophy and psychology at Williams College, University of Chicago, University of Texas, Indiana University, Harvard University and Stanford University; at Princeton University since I9I5; author of "An Introductory Study of Ethics," 1903; "Individualism," I9II. 


\section{SPECIAL PRIVILEGE DEFENDED AS NATURAL RIGHT}

Yet it is no less true to-day than when John Stuart Mill made the assertion in $1859,{ }^{2}$ that an individualistic order of society. has never been tested. Those who speak of the "outworn individualism of the older order" are probably thinking no further back than the Inter-State Commerce Law. Going still further back, say to the times of Elizabeth or of Cromwell or of the East Indian Company, they will find that monopoly and privilege were the order of the day and also that the individual rights which throughout the course of history have been opposed to social reform have rarely been the "natural rights" for which an individualist stands (i.e., rights determined by a fair test of individual abilities), but prescriptive rights based upon hereditary privilege or upon the personal favor of rulers. What they now condemn in the individualism of the age just past, they may casily discern to be not really an assertion of individual right, but of vested privilege, chiefly the highly illogical privilege of unlimited freedom associated with limited liability. What we now call "individualism" is mainly corporationism. Apart from the special powers and immunities conferred by incorporation, it is not easy to see how our Rockefellers and Carnegies and Harrimans could have come into being. When, on the other side, we look at the newer movements and note that for the most part they are movements of self-assertion on the part of classes of men who have hitherto played a subordinate part in the social order, it becomes a fair question whether, under the guise of socialism, communism, or even syndicalism, we have not now a more determined and comprehensive assertion of "the rights of man"-and ultimately of the individual man - than we have ever had before.

THE ETHICAL BASIS OF INDIVIDUALISM

What is the ethical basis of individualism? When a man has leisure to think, he thinks about himself. Thus he proves that he is a person rather than an animal or a thing. And when he is released from the pressure of fear or want he begins to assert himself and his right to live and, if you please, to enjoy. Moral-

'In the essay On Liberty. 
ists, both of the stricter and of the more liberal sort, will probably agree upon this. To the Puritan, however, always fearful for the souls of others, the fact of self-assertion or enjoyment spells "decadence." Such, in essence, is the house-mistress who is scandalized by her maid's silk stockings; the manufacturer who sees in the demand for a Saturday half-holiday only a relapse from industrial virtue; and, I should add, of all those who welcomed the war as a relief from "the individualism of the age." To the more liberal moralist, this consciousness of self, concern for self, and assertion of personal rights, including the right to live and to enjoy, mark, however strange the initial manifestations, a step toward a more liumane ideal of life. But the more humane moralist will still be, on one point, pitilessly strict; he will insist that the self-assertion be responsible; that he who asserts himself shall know what he wants and how he proposes to come to terms with the others constituting his social environment. For if the individual is to assert himself he must be ready to face issues.

He must also be prepared to find the issues constantly developing. The mistake of the older individualism, which came from the eighteenth century, lay in supposing that individual rights could be defined once for all. The historical and evolutionary standpoint of the later nineteenth century has revealed that man is constantly creating new conditions for himself and thus new problems. Hence a definition of rights which sufficed for the United States in 1830 will not serve for 1919. Further reflection upon the existing state of things raises on the subjective side questions of right not previously considered. On the objective side, there are unforeseen changes in the economic structure of society and these are accompanied by physical changes of the face of the earth-railways and canals, for example-which the economic activity has created. Individual rights must then solve the problems created by the newer conditions or perish.

\section{THE NEW SITUATION; NOT DUE TO THE WAR}

Such a problematic situation confronts us to-day. It has not been created by the war. The war has at most accelerated the coming of a crisis already in view. Five years ago it might have seemed, perhaps, that, in the Constitution and the Declaration 
of Independence, the social philosophy of the American people was based upon the conception of individual liberty as the foundation-stone. To-day it seems that all the plans proposed for the future tend towards state-socialism. But the contrast would be based upon a superficial view. It has been a generation or so since we really prided ourselves upon individual liberty. Our "real-politiker," notably in the wave of imperialism following the Spanish War, had already begun to treat the ideas of the American Revolution with benevolent compassion. For a generation past our ethical and social philosophy has been marked by a scorn of individual rights, a contempt for personal and "private" virtue, and an emphasis upon the duty of selfsacrifice on behalf of social unity. These theoretical tendencies have expressed themselves in practical movements for vocational education, for "scientific management" in business, and in the universal demand for "efficiency." These practical demands have been motived, more or less obscurely, by a Hegelian metaphysics, issuing in a social absolutism which has been known since I9I4 as "the German theory of the state." The reaction a few years ago from absolutism to pragmatism has made little practical difference. It is still the social, the common, good that dominates. Some years before we conquered the Germans in the field, the German view of life had already conquered us, and the one conquest has marked only the completion of the other. ${ }^{3}$

\section{THE GROWTH OF THE CROWD}

Such a change of front is never merely the product of abstract philosophy. Those who argue sagely that since human nature remains the same, wars will go on forever, forget that though human nature remain the same the world in which we live-and just because we live in it-will not remain the same. During the past century the world has changed enormously and the change has been concurrently social and physical. To express the social significance of the change in one word, we may say that the world has become crowded. The multiplication of wealth arising from modern industry has resulted, more or less

${ }^{3}$ The German theory of the state is nowhere more clearly represented to-day than by the dean of British philosophers, Bernard Bosanquet, in his Philosophical Theory of the State. 
in accord with the Malthusian law, in a vast increase of population both in Europe and in America. At the same time the instruments of communication which are fundamental to modern industry and commerce (and no less so, by the way, to modern science)-the railway, steamship, and telegraph-have resulted in crowding the world in a spiritual sense; in the sense that one is conscious these days of so many more neighbors. Who is my neighbor? The answer to this question is not a matter of the number of persons one meets in the flesh, but of the number who are individually brought to one's consciousness-for example, in the metropolitan daily, circulated through the rural free delivery. We may decline responsibility for Harry Thaw; the newspaper, however, makes us responsible. It is therefore beside the point for the newer social theory to condemn the older individualism for its "isolated individual." The older individual was indeed isolated as compared with the modern individual, even if he lived in a European city. To-day no one is isolated.

It is thus a condition as well as a theory that confronts us to-day. The change in popular social philosophy has been a reflection of changed social and physical conditions. And when it is said that the older individualism, based upon the conception of personal rights and distributive justice, has been shown to be false, all that can be properly urged, as a basis of fact, is that the conditions have changed; not that the conceptions have been shown to be meaningless, but only that their meaning for the newer conditions has not yet been thought out. But quite the same may be said for the social philosophy which merges all good into a "common good." The common good, as I have suggested elsewhere, ${ }^{4}$ is mainly a refuge from perplexity. No good that concerns a number of persons is ever indiscriminately common. But when the problem of distribution becomes too much for our powers of discrimination, we find a way out in the assumption that the good is the good of all alike. And the result, when formulated, perhaps, in terms of "the greatest happiness of the greatest number" (which means nothing) or of "everybody to count for one and nobody for more than one" (because we do not know what kind or how much of a one), bears the mark of "scientific simplicity."

An individualistic society is, accordingly, to-day as in the

-Individualism. I9I I, pp. $294 \mathrm{ff}$. 
eighteenth century, a problem to be solved. And to-day it seems to be a question of economic liberty rather than merely of political liberty. Since I am only an outsider in the economic field, I shall have to content myself with offering some general considerations which suggest themselves from the standpoint of ethical and social philosophy.

\section{INDIVIDUAL LIBERTy aNd SOCIAL ORganization}

\section{DOES ORGANIZATION IMPLY A SACRIFICE OF LIBERTY?}

First I shall point out that there is no necessary incompatibility between individual liberty and organized society. This sounds like a commonplace. Yet the real commonplace, I think, is the prevalent assumption that the "higher interests of society" will necessarily demand a sacrifice of freedom; that such a sacrifice is a universal human necessity, and therefore that one must be prepared to submit to it. One might rather suppose that a completer organization of social relations would diminish sacrifice. But this would be putting the matter too simply. We must admit that something has been lost, in opportunity for the development of individual capacity and taste, by the removal of industry from the home. From the standpoint of the consumer, however, the losses have been unimportant, and we should not now gain in the direction of living our own lives by returning to the practice of making our own clothes (i.e., of having the women of the household make them) or our own furniture, or by contenting ourselves with the music that could be produced at home, or with the resources of our private library. Those who grieve for the independence of "the good old days" forget that the good old days, especially our own pioneer days, were mainly days of privation, of unremitting toil for the bare necessities of life; days, not of spiritual leisure but of abject slavery to the needs of the body. The parsimonious morality of the Puritan fathers is a reminder of such conditions. A nearer view of their lives, as recorded by Charles Francis Adams in his "Three Episodes in Massachusetts History" is apt to recall the saying of Hobbes, that the life of man in a primitive social order is "poor, mean, nasty, brutish," if not also "short." In Europe, as in 
America, life under the older economic conditions was a constant war of self-preservation against nature; and war with nature is as little favorable to development of taste, liberty of opinion, and respect for individual rights as international war.

\section{DEMOCRATIC LIBERTY BASED UPON ECONOMIC ORGANIZATION}

Individual freedom presupposes economic freedom. The freedom of the spirit presupposes freedom from pressing bodily wants. The freedom of the Athenians seems to have rested upon a basis of slave-labor. Our own Magna Charta, the definite beginning of present-day Anglo-Saxon freedom, stood for the freedom of a landholding aristocracy. Modern democracy is an attempt to provide freedom for all. But the only tangible basis for the hope of universal freedom lies in making nature play the part of slave-labor; that is to say, in the development of industrial intelligence and in the economic organization of society.

\section{THE END OF ORGANIZATION: LIBERTY OR EFFICIENCY?}

It does not follow, however, that the increase of wealth which issues from a better economic organization will bring about an increase of freedom, or that organization in any field necessarily brings freedom. One of the indictments brought against modern society is that it tends not towards individuality but towards a distressing uniformity; not only of dress and of the furniture of living-which is of minor importance-but a uniformity of opinion, which is unwholesome for a self-governing people. Our American democracy is marked by a primitive resentment and fear of peculiarity. One may even suspect that the large number of states voting for the probibition amendment is to be explained by the desire of many states not to be peculiar. All depends, then, upon the ideas guiding the organization; whether the ideas are those of administrative "efficiency" or of individual need. A postal service organized for administrative simplicity is one thing; organized for the greatest variety of need it is quite another. The one need not necessarily cost more than the other except in thought. Assume that the librarian of a public library prides himself chiefly upon the unsoiled appearance of the books 
upon his shelves and upon the enforcement of the rules limiting their use-in short, upon maintaining the sovereignty of the librarian; the private individual will probably decide that freedom of reading requires a private library. My college library permits me to take home as many books as I wish and to keep them until called for. It asks only for a periodical accounting and a prompt return when notice is sent. This gives me a large freedom of reading at the cost of a slight responsibility. But the responsibility is necessary, and it is only so far as the individuals composing a society become more responsible that we may expect a more completely organized society to yield a greater individual freedom.

\section{THE VALUE OF LAISSEZ FAIRE}

What has just been said presupposes that freedom is only for the socially responsible, and for each only so far as he is socially responsive. It is thus far in line with that tendency of present social philosophy which demands that every one become a socially organized being and would deny all rights to the "private" individual; that is to say, to any individual so far as he lives within himself. But this is far from being all that is necessary for individual liberty. Liberty of opinion, for example, is not fully provided for by the right to express an opinion which one is ready to defend; one must also be at liberty to remain silent, or to entertain ideas which one is not quite prepared to defend. In other words, one must have liberty to think. And to think, in the only way in which one can really think, is to think privately.

A point to be remembered in all plans for social organization is that each one's capacity for responsibility is limited. Few of us are equal to the responsibility of driving an airplane. We do well to dodge the automobiles. One may ask whether the great difficulty of life to-day is not that precisely through the multiplication of social relations our powers of responsibility are being greatly overstrained. It has been suggested by Windelband that the frantic individualism of Nietzsche was a revolt against the "mass-consciousness" of modern life. When the theme of social unity has been exhausted we shall come to see that an important element in any well-ordered social life is a 
large provision for laissez faire; as a means of nervous equilibrium, on the one hand, but, on the other hand, as a condition of all that we call culture and spiritual life. For to-day, as ever, the voice of the spirit is heard not in the crowd, but in the "still, small voice." Freedom through responsibility is not enough; we must also have freedom from responsibility.

Yet let us note that this is, once more, a question of the ideas guiding social organization. If we really desire the freedom of privacy and laissez faire, we can get it by planning for it. The mistake of the older doctrine of laissez faire lay in assuming that we could have freedom-freedom of competition, for example, in commerce-without providing for it; that we could have laissez faire by means of laissez faire. What is called for to-day, in the name of individualism, is an organized laissez faire.

\section{ECONOMIC LIBERTY}

Thus far we have considered the individual chiefly as a consumer and a gentleman. The more difficult questions confronting us to-day are probably those which concern his economic freedom, partly still as a consumer but chiefly as a producer. I believe that the idealistic ethics of the past generation ${ }^{5}$ has tended to overemphasize the importance of producing, including the importance of the profession or career, as a requirement of a morally serious life. Yet one can hardly conceive of a worthy human life in which the desire to create should be unimportant. Socialists would have us believe, perhaps, that when the government takes charge of production we shall all be gentlemen-consumers. The more probable event is that an increase in the possibilities of leisure will be neutralized by an extension of economic wants. Now the logic of production by the methods of to-day seems to point to large-scale production. Whether further development of these methods will point in the same direction is at least worth asking. The logic of large-scale production seems to many persons to point to production by the government. If this ideal is to be realized, we have before us the not very enlivening prospect of becoming a nation of bureaucrats and government employees, a nation of Teutonic Beamter.

'Following the self-realization ethics of T. H. Green. 


\section{INDIVIDUALISM FAVORS PRIVATE INITIATIVE AND COÖPERATION}

To this outcome there is a characteristically individualistic alternative, which is still in accord with the logic of large-scale production-the alternative of coöperative production. This might well find its basis and starting-point in coöperative consumption. The distinctly individualistic reply to the newer demands for organization would be a social order of coöperative enterprise. This would be not one all-embracing coöperative order but many, as many as there are diverse groups of individuals with special aims for which they find it worth while to coöperate. The idea of such a society is embodied to-day in the organization of churches and charities and of privately endowed colleges. Such organizations, with the possible exception of the churches, are likely to be condemned by apostles of the newer social order as illogical. This objection is urged to-day in the West against the privately endowed colleges on behalf of the state-university idea. By illogical is meant, evidently, that the particulars are not derived $a$ priori and deductively from a universal. In plainer terms, illogical means that the many cooperative enterprises owe their origin and initiative to individual needs and desires and not to a universal scheme of social organization. In this Teutonic sense an individualistic society is perhaps necessarily illogical. It should be noted, however, that the logic which derives particulars from a central and universal authority is the logic of Greek and medieval rather than of modern thought. Modern thought tends to accept the particular facts of experience upon their own authority. The deductive method survives to-day chiefly among mathematicians. It may be instructive to note that the deductive scheme of relations, by which all individual enterprises are referred to a central authority, bears a remarkable resemblance to the patriarchal order of society. In brief I would suggest that those who appeal to the "logical" character of a society organized upon the basis of a central authority are simply repeating a patriarchal habit of thought organized by Aristotle into a system of logic. 


\section{THE TREND TOWARD STATE-RESPONSIBILITY}

It seems, however, that among the American people, not excepting those who are loudest in denunciation of monopoly, there is too little desire for a genuine economic independence, too little willingness to incur the duties, responsibilities, and above all, the risks of coöperation. The attitude of the trade unions is typical. They are ready to share the profits of capital but they are unwilling to take any of the risks. And the same is true of the private consumer. In economic matters it seems that no one has the time for self-help. The one remedy proposed for any evil at present is government control, or government ownership-let the government assume the responsibility. We have only to propose government control for the churches to remove from current social ideas the last trace of what is distinctively American.

\section{INDIVIDUALISM AND STATE-ENTERPRISE}

\section{STATE-ENTERPRISE CAN BE MADE INDIVIDUALISTIC}

Such being the case, the question before us is, whether government control or enterprise can be made compatible with the idea of an individualistic society. My answer would be: Yes, provided that the enterprise is guided by the individualistic idea; provided that it ministers to individual desire and individual taste rather than to a vaguely "common" good. It is not easy to state concretely what this would be. I must content myself with noting what, in some important points, it should not be.

\section{STATE-ENTERPRISE MUST SUBMIT TO COMPETITION}

First, then, if there is to be government enterprise, we must insist that the industry in question stand upon its own feet financially and pay for itself without the privilege of monopoly. Theoretically, there should be as little objection to government enterprise in business as there is to public education and the state university. The saving point is that the public institution should not be permitted by the exercise of special privilege to suppress the private. There may be some undertakings, such 
as railways and telegraph lines, which are essentially monopolistic whether public or private. Leaving them aside, we may lay down as an individualistic principle of state-enterprise that wherever possible it should stand or fall on the basis of free competition. ${ }^{6}$

The Rights of Private Enterprise.-To any such program objections will be raised from two sides: first on behalf of "the rights of private enterprise." It will be urged that the savings effected through the mere size of government, state, or municipal enterprise constitute an unfair advantage from the standpoint of competition. But if a municipal grocery, or coalyard, or iceplant, or a state-owned chain of department stores or factories can really produce and sell more cheaply than the private concern, then it has proved its right to exist. I am inclined to think that something of the kind is imperatively necessary to reduce the cost of handling goods, which constitutes so large a part of the cost of living. Curious claims are made on behalf of private enterprise. The "patent insides" of the country papers are full of denunciations of the mail-order houses on behalf of the rights of local merchants. Under the late fuel administration the coal dealers of one small town claimed the right to suppress a local coöperative coal club. A genuine individualism knows nothing of the rights of private enterprise as against public enterprise. Each has the right to an open market and nothing more. And the rights of the producer are the same as those of the consumer. The consumer's right to consume is based upon his ability to induce the producer to produce and sell to him. The producer's right is based upon a similar possibility of presenting an inducement to the consumer. Any other right is not a natural right but an artificial privilege.

The Rights of State-Enterprise.-The other objection will be raised on behalf of the rights of state-enterprise. For in excluding monopoly we probably leave out just what makes stateenterprise seem most attractive to the majority of those who believe in it. Their idea seems to be that the advantages now held by private monopolies should be simply transferred to the

- I leave out of account the question whether a state university may compete by offering free tuition and say that, at any rate, it should enjoy no other advantage. 


\section{INDIVIDUALISM IN THE NEW SOCIAL ORDER IO7}

state for the benefit of "the people." That these advantages which under private monopoly are nearly always somewhat temporary and precarious may be made secure, monopoly is to be legalized as state-monopoly. In brief, the purpose of state-enterprise is to cure by force the evils of competition.

A seemingly decisive precedent for state-monopoly is furnished by our postal service. But the post-office, however efficient in some respects, offers just the strongest argument for doubting whether we are yet competent for further extensions of government enterprise. As an economic undertaking no one seems to know whether the post-office pays or not. The postage paid by the average citizen-the postage that he pays directly-plays so small a part in his budget that he is indifferent to it. In the absence of competition there seens to be no way of reaching a final judgment. One hears much of the evils of competition, but how the values of life in the economic or in any other field are to be determined without reference to competition has never yet been shown. Any judgment of value is a judgment of competition. Any teacher who has before him the task of grading a set of examination papers knows that his judgment of the first is bound to remain a matter of some doubt until he has read at least the fifth or sixth. In any department of life we need competitive standards, not only to keep us up to the mark but to know where the mark should be. If government enterprise is to be much extended it must face some kind of competition or issue in universal waste.

\section{ECONOMIC FUNCTIONS TO BE DISSOCIATED FROM SOVEREIGNTY}

This brings me to the second proviso: If government-enterprise is to be made safe for individual liberty it is imperative that it be divorced, once for all, from the superstition of sovereignty. I believe that this rather than any economic idea underlies the assertion of a governmental right of monopoly: namely, that submission to competition is incompatible with the power and dignity of a sovereign state. The working of the idea is admirably illustrated by the censorship embodied in cur postal service. Some years ago Mr. Louis F. Post pointed out that this censorship was not equaled for summariness by anything outside 
of Russia. The political possibilities of such a censorship are at least apparent. A few months ago the theory of censorship was beautifully expounded in an editorial statement that no sovereign state could be expected to distribute literature hostile to its own policy. We have only to identify the policy of the state with that of the administration to make the postal censorship wholly incompatible with political liberty.

Other marks of sovereignty in connection with the postal service are found in the rather exceptional penalties imposed for robbing the mail. I do not deny that these are what make the transmission of mail so admirably safe or that they have a certain utilitarian justification. Yet one idea underlying them seems to be that, while stealing, say, from the delivery wagon of a department store is an offense of one citizen against another, stealing a letter is an offense against the government. Whenever the government enters a transaction we seem to meet, in addition to the other persons, a new person, with sovereign rights and special interests, which are at times moral and religious. Thus when Mr. McAdoo assumed control of the railways he felt called upon to exclude liquor from the dining-cars and restaurants, on the ground, as he explained, that the sale of liquor by the government was morally improper. He found it morally proper to extend the privilege of half-fare to clergymen throughout the country, including among the clergymen the officials of the Women's Christian Temperance Union.

"Scvereignty" Incompatible with American ldeas.-I speak of the "superstition" of sovereignty. The idea is an echo of the divine right of kings and goes back to the days when Louis XIV could say that the state was himself, when the only intelligible explanation of authority as regards others seemed to imply ownership, and when legitimacy of authority was a question of descent. It has come to us through the courts, over the head of the Constitution, as a survival of the ancient philosophy of law. It still appeals to the "legally minded," to those who can conceive of neither legal nor moral obligation except as imposed by some external and absolute source of authority. And since they must find sovereignty somewhere, our own mode of government is explained as implying "the sovereignty of the people."

But "the sovereignty of the people," if it means anything, means that the government is not a sovereign. The government 
versus the people-this was the issue facing the makers of our government, and their main effort was to get rid of sovereignty. For this purpose they undertook to curtail the powers of government wherever possible. Their fear was that any government possessing extensive powers was likely to become a sovereign; that is to say, a personality with interests of his own and absolute rights. Their policy rested upon the idea that the state is not a person but an association, an association for the maintenance of order and the transaction of necessary public business, and the government is an administrative agency. This has been the traditional American theory of government. It is also the individualistic theory.

"Sovereignty" Implies the German Economic State.-Conditions have changed, and it seems that the powers of government can be no longer curtailed; nay, that, if we know what we are about, an extension of government power may be made both safe and beneficent. Yet the recent course of events has demonstrated that the "wisdom of the fathers" was not without insight. We have a pious horror of "the German theory of the state." The German state is supposed to manifest itself by its omnipresence and omni-interference, under the sign of Verboten. I believe that many Americans are beginning to feel the omnipresence of "the government" and I wonder if the constant reminder that "the penalty for infringement is" so much fine or imprisonment is so very different from Verboten. If we are to avoid becoming a German state, we must recognize clearly that the German state is nothing more than the legitimate development of the idea of sovereignty. If we are to be true to the idea of a democratic state, we must be clear with ourselves that in a democratic state the government is a representative agency with no powers beyond the letter of its instructions and that a government bureau or government enterprise is limited to the functions assigned to it, precisely as a physician or a lawyer is limited. The lawyer is called to draft a will, the physician to cure a disease. Neither is thereby vested with the function of sovereignty over the client's moral life or economic expenditure. Upon grounds of "public policy" we may submit to a certain interference with morals, but this we shall entrust to the magistrate and the policeman. 


\section{ECONOMIC FUNCTIONS TO BE DISSOCIATED FROM BENEVOLENCE}

This leads to a third and last consideration. I do not say that we can dispense either with a certain "police power" or with a certain paternalistic regard for the "common" welfare. A completely individualistic social order is an ideal necessarily somewhat distant. What I do say, is that if the functions of government are to be enlarged the economic functions must be clearly separated both from the police power and from the benevolent functions. Economic functions must be organized, in other words, on the basis not of brotherly love but of distributive justice. This raises an important question. By distributive justice I mean that the user must pay the cost and be charged only with the cost. However, I am aware that the cost theory of value is at present out of date. When I ventured to suggest some years ago at a social conference that the alternative to the cost principle was the principle of brotherly love the suggestion was treated as unscientific. Yet I believe we need only glance at the adjustment of railway freight rates as between different points and between different classes of commodities, for some years past more or less of a government function, to see that the adjustment is influenced very largely by the principle of silencing complaint and of making everybody happy. We lower the rate on coal because there a high rate "works hardship," that is, on coal the rate is felt. On the other hand we raise the rate on hats and shoes because there it is not felt. Moreover, we "equalize" the rates between points unequally located on the principle of making Peter contribute to the wellbeing of Paul.

The economist is likely to attribute such adjustments to the working of the impersonal economic principle of "what the traffic will bear." This represents the more modern theory of value, according to which the value of an article is measured by its utility to the consumer, not by the cost to the producer. My answer to this would be that in the individualistic logic there is no such entity as impersonal "value." Value is determined by a relation between buyer and seller and the proper measure of value depends upon whose point of view is to be taken. The seller of goods who has the buyer at his mercy may quite 
rationally consider "what the traffic will bear," since at prices above this point no goods can be sold. The buyer of goods with the seller at his mercy may with equal reason measure value by cost. Now it is to be remembered that a railway commission, armed with full powers, is precisely in the position of such a buyer-assuming that the commission represents the traveling and shipping public and not the holders of railway securities. The assumption may indeed be questioned. In the case of a government-owned railway there should be no such question. On any individualistic theory of government the purpose of a government railway should be exclusively to represent the traveling and shipping public, who should pay the cost of the service rendered, with due allowance for the permanence and improvement of the railway service, so far as this can be ascertained. To assume for a government railway the point of view of what the traffic will bear is once more to create a sovereign personality-either an autocratic sovereign who uses the railways for purposes of indirect taxation or a benevolent sovereign who uses them for the purpose of "equalizing the burden."

Separation of Function Necessary for Social Order.-It may be asked why a state railway may not be regarded as the railway of all the people and as such entitled to earn dividends for the national treasury. I may reply by asking why a state opera, not earning dividends but requiring a subsidy, should not be regarded as the opera of all the people. It is pretty certain that the working man would look upon such an institution as a benevolence extorted from him on behalf of the lovers of music, just as, on the other hand, wealthy tax-payers now look upon public playgrounds, used mostly by the poor. What shall we say of a tariff on woolen goods? Or of a "great mercantile marine" - whose marine is it to be? Or of a country-wide flat rate on second-class mail matter on behalf of "culture"? Individualism holds it to be desirable that each pay for his own culture. I will not deny that, on grounds of public policy, it may be desirable for the state to assist culture. All that I maintain here is that if the extension of the functions of the state is not to result in social, economic, and political confusion there must be no importation of extraneous motives, either of taxation or of benevolence, into economic enterprise. If the government is to assist in the circulation of second-class literature, let it 
do so openly. Let all the people pay, and know what they pay, in the form of a special appropriation out of public funds. Let it not be charged to the users of the postal service as part of the cost of their service.

Individualism as a Principle of Distribution.-These considerations I commend not only to those who as a matter of temperament or of personal philosophy prefer an individualistic society but to all who are contemplating any serious extension of state responsibility. The gospel of recent years has been the gospel of the common good. Now, the common good works well enough within the family, though not even here without qualifications. It may present no great difficulties in larger groups, such as municipalities, as long as the idea of the common good is applied only to a few matters, such as schools and hospitals. But when the idea is extended to cover all of social and economic life, then we face either chaos or the need of a definite principle of distribution. Can we, then, in the search for a distributive principle, dispense with the question of individual rights? 


\section{CHAPTER VII}

\section{WAR AND WANT}

\section{By JaCOB H. Hollander ${ }^{1}$}

\section{Professor of Political Economy in The Johns Hopkins University}

In a great art gallery of my own city hang two noble paintings, about which may always be found clustered a group of thoughtful spectators. "Peace" and "War" they are named. The central figure of each is a mother with clinging babes. The one is benign and bountiful, a veritable alma mater-telling of a smiling landscape with flocks grazing on the hillsides, with children playing about the doorways of simple cottages and youths and maidens strolling in the meadows, with the fruit and grain of a fertile husbandry, and over all, contentment and happiness. The other figure is grief supreme, with tragic anguish showing in every lineament, and with an unseen background of ravaged fields, smoking ruins, torn cattle, disheveled women, and slain men. Death stalks abroad and misery broods lowering and stark.

The appeal of Gallait's genius is aided by the message of intimate literature. Peace is the

"Dear nurse of arts, plenties and joyful births,"

and War, the

${ }^{1}$ A.B., Johns Hopkins, I89I, Ph.D., I894; associate professor finance until 1900, associate professor political economy, I900-1904, professor political economy, Ig04-_ ; secretary, Bimetallic Commission, I897; reorganized the finances of Porto Rico, under President McKinley; investigated public debt of Santo Domingo under President Roosevelt; financial adviser of Santo Domingo, I908-I9I0; since July I, I9r8, acting as umpire between the Coal Operators and Mine Workers of Maryland and Upper Potomac Districts under the Agreement of May 6, I9I8; author, among other works on economics, of "The Abolition of Poverty" (I9I4), "Citizenship and Welfare" (I9I9) and "War Borrowing" (1919). 
"... horrible discord . . .

Black . . . as night,

Fierce as ten furies, terrible as hell."

Such thoughts are of our every-day consciousness. We think rather than quote "war is hell," on the one hand, and "let us have peace" on the other.

The Neo-Social Philosophy of War.-Not the least amazing result of the great struggle from which the world is barely emerging is an incipient dissent from this accustomed state of mind. Still inarticulate in the main, it shows itself in a manner of reservation that war is not altogether to the bad. This implication that out of carnage may come some measure of gain plumes itself as an intellectual distinction. It poses as a longer outlook and a wider vision. It assumes an acquaintance with history, a hobnobbing with economics, a dalliance with sociology. The précieuses of philosophy are its intimates; social evolution and economic determinism its lingo. The market-place may still shudder at war and jubilate at peace; but the up-to-date seerundisturbed by the gusts of the moment-finds in the larger consequence of war not merely the somehow good but a specific social gain. In simple terms his doctrine is: Once the smoke of battle cleared, war or the effect of war is economic advantage to society and in particular to the social class who at best walk insecurely on the brink of economic dependence.

The Older Doctrines.-There is, indeed, some social philosophizing in support of this contention. In the past hundred years-to go back no further-at least three theories have been enunciated in the terms of which war may be interpreted as, if not a condition, at least an incident of economic progress. These concepts may be described as the theory of recurrent overpopulation, the theory of social evolution, and the theory of personal fortitude and industrial diversity.

To the raw Malthusian, convinced that population increases more rapidly than subsistence, war is the greatest of the positive checks whereby mankind is saved from recurrent famine and starvation. It involves indeed the slaughter of thousands, but only in the way that a sacrificial offering averts the misery of millions. War in short is a safety-valve whereby society escapes the pressure of over-population. 
To the social evolutionist of strict biological mold, war is the principle of natural selection working out in the social world. It is the struggle for existence tending to the survival of the fittest in the domain of mankind. Accompanied by a harvest of misery and anguish, it becomes nevertheless the process whereby the human race, economically no less than physiologically, ascends the scale of progress.

Less remote than either of the foregoing is the doctrine of war as a civic leaven and an industrial fillip. War is the corrective of the flanneled fool, the preventive of the muddied oaf. It establishes the great virtues-courage, fortitude, patriotismin their true values. By it industrial life is saved from lapsing into a wanton ministry to frills and furbelows, and thrift and selfdenial emerge as the nation bends to the country's defense.

Statistical Evidence.-A considerable body of plausible evidence has been mustered in support of such contentions. In Great Britain, the testimony of the Ministry of Labor is that there has been a "steady decline in destitution during the war," and a marked decline as compared with antebellum conditions. "The general upheaval at the beginning of hostilities was responsible for an increase in the amount of poor relief, but this was a temporary movement only, reaching its maximum before the end of August, r9r4. Since then, service and other calls upon man-power have had their due effect, and the figures have steadily fallen, the total of paupers of all categories"-casual paupers, paupers in receipt of outdoor medical relief only, lunatics in asylums and other classes of paupers-at the end of September, I9I 7 , being nearly 19 per cent smaller than in $19 \mathrm{r}_{3}$.

The foregoing data are confirmed by figures relating to the work of the 'Distress Committees formed under the Unemployed Workmen Act of 1905. "The number of persons in England and Wales receiving relief from these committees during September in each of the five years under consideration were as follows: I9I3, 436; I9I4, 4, I4I ; I9I5, 44; I9I6 and I9I7, nil. Thus, after a large increase consequent upon the outbreak of war, there was a rapid fall in the claims put forward, and before the end of the second year of war (in June, I9I6) they had altogether ceased." 2

\footnotetext{
"The Labor Gazettc, prepared and edited at the offices of the Min-
} istry of Labor, February, I918, p. 52, 53. 
This for the country at large. With regard to conditions in industrial centers, the average rate of pauperism in thirty-five selected urban areas shows a steady decline throughout the war period, the average rate in December, I9I 7 , being 27 per cent. lower than in July, I9I4, the month immediately preceding the outbreak of war.

As to conditions in the United States there is some evidence of the same tenor. The Bureau of Social Statistics of New York City, organized under the Mitchell administration and unhappily abolished since, collected with great diligence typical data as to the extent of dependency and destitution in New York City during the years I9I4, I9I5, I9I6, and I9I 7 covering family relief, homeless men and women, applications for free lodgings, dispensary cases, hospital cases paid for by the department of public charities, free burials, commitments of children, and chattel loans. These returns were then reduced in each group to an index number relative to conditions in 1916 , and these various indices were ultimately combined-in accordance with recognized statistical methods-into one general index of dependency. This dependency index fell from 252.5 in December, I9 4 , to I23.6 in December, I9I 5, to 102.7 in December, 1916, to 85.3 in December, I9I7. In other words it appears that the amount of general dependence in New York City at the end of I9I 7 was only one-third of that existing at the end of $1914 .^{3}$

Data of the same worth are not available as to the social groups above the dependence line-the skilled and unskilled wage-earning classes. It is likely, however, that the curve of industrial well-being follows closely that of social dependence. The same forces which bring about employment among the unemployed effect more intense labor demand, rising wage rates, full-time and over-time work, among the already employed and the partially employed. To this must be added the effect of concentrated industrial activity and direct governmental intervention. It is certain that for wage classes generally money wages have undergone marked advance during the war. Whether as compared with higher commodity prices real wages estimated in goods consumed and services enjoyed have increased is subject to some doubt. But even here the evidence, partial and

${ }^{3}$ I. M. Rubinow, "Dependency Index of New York City, I914-1917" in American Economic Revicw, December, I9I8. 
inconclusive as it may be, points to increased consumption, more lavish expenditure, larger savings, and a higher standard of subsistence.

For the immediate duration of the war, then, and in the area of belligerency rather than in the zone of hostilities, it is likely that the volume of social dependence was reduced and that some temporary gain even accrued to those above the poverty line.

War as a Social Calamity.-Opposed to this concession is the deep-rooted, traditional sense of mankind that war is a bitter social calamity, that it works peculiarly to the economic injury of wage-earning classes, and that it does these things by reason of (I) its wastage and destruction, (2) its feverish stimulation, and (3) its social aftermath.

Wastage and Destruction.- Nothing need be said of the great untabulated social losses-the unrecorded, unrecordable deductions from the well-being of the race, such as devastated areas, outright fatalities, the maimed and the mutilated, stricken homes, widowhood and orphanhood, the moral laxity and the religious unsettlement of nations warring and warred against; or of that which to those who have consecrated their lives to the search for truth is the greatest injury of all-the undermining of intellectual idealism, the denial of scientific variety, the mockery of world altruism. These woes may neither be inventoried nor catalogued. They make up a great total of "illth," only to be left out of the reckoning from sheer lack of a common denominator. The world is the poorer for such calamities and all who live in it suffer because they have happened.

It is with the palpable, tangible effects of war upon the rellbeing of the wage-earning classes that our inquiry lies. In how far, if at all, is the toiler in the United States the worse for the events of the world convulsion?

There are obviously three successive stages with respect to which such a question must be put: (I) the outbreak of the war, (2) the progress of the war, (3) the sequel of the war. The wage-earner was affected by the crash which marked the outbreak of hostilities; he was caught up in the rush and eddy of war endeavor, and he will be entangled in the undertow of afterwar readjustment.

The Initial Crash.-It is the price of the economic intarde- 
pendence of the modern world that a convulsion suffered in one part is transmitted and felt in every other quarter. Commerce, trade, and finance are of all social elements perhaps the most sensitive. War, even rumor of war, sends a swift tremor through the whole structure. This is what transpired in the summer of I9r4. Financial markets and industrial centers alike felt the world spasm, and stoppage of work, partial or complete, reduced employment, labor discharge, lower wages, were immediate consequences. There was a brave but futile attempt to ignore the shock with the slogan "business as usual"; but industry could not lift itself by its own boot-straps, and everywhere there were the stresses of economic pressure. The old markets disappeared. The accustomed channels of trade were clogged. Normal production was suspended. The labor world suffered in this exaggerated form the economic depression and the social losses incident to panic and crisis, with pressure upon charitable institutions increasing, bread lines forming, and all the denials and sufferings of hard times making themselves felt.

Feverish Stimulation.-The second phase of the war drama in its social effects began as the nation raced to the task of beating plowshares into swords. Swift preparation for the national defense became the determining concern. Cantonments must be built and war contracts placed. Munition plants sprang up, shipyards multiplied, mills speeded up, agriculture extended, and every effort concentrated upon maximum production. With the world imperiled there could be no delay. The old canons of business restraint and financial caution were thrown to the winds. First production and secondarily cost became the rule of industry. Instead of the gradual revival and slow recovery from business depression of post-panic history there was a swift awakening, a veritable industrial call to arms as the electric spark of the nation's danger fairly sensitized its industrial organization.

In the labor world the results were remarkable. Unemployment and part employment were swiftly mopped up. Sharp wage increases were demanded in the war industries and as quickly granted. The rapid transfer of workers from less favored occupations transmitted the impulse to the outer reaches of the wage-earning world. What an amazing history could be written, as dramatic in some parts as it is absurd in others, of the 
economic experiences of American labor in this period! Pay envelopes swelled to proportions undreamed of. Family incomes mounted far above middle class budgets. Women, even children, received more than heads of households had before dared to demand. Everything moved in endless chain progression.

When the pace was threatened, and labor disturbance and industrial interruption became imminent, government agencies intervened; sometimes wisely lest at any cost there be reduction of output, sometimes sentimentally in the attempt to validate crude or unestablished social theories, but always with the result of increased wage levels.

We are still much too near the event to estimate fairly the net result of this activity. Certainly it raised, if only for the time being, submerged industrial groups-the unemployed, the underpaid, the normally unemployable-from the morass of dependence and poverty to the firm ground of self-support. More than this, it permitted the larger body of wage-earners to glimpse standards of well-being far beyond anything theretofore attained. The windfall may have been husbanded. Too often, it was unwisely and recklessly squandered. But if that social philosophy be sound which makes the development of wants the condition of social progress, even a carnival of spending is not without its ultimate benefits.

Like every other feverish stimulation the gain was achieved, however, at excessive cost. There is no short cut to general economic improvement. The individual may profit by the chance event. War brides will confer beatitudes upon the laborer as upon the enterpriser. But bargaining equality once attained, wage-earners as a class are likely to advance and to retain their vantage only by the hard road of greater efficiency, increased production, intelligent thrift, and rational expenditure.

Item by item war time industry failed, as it must always fail, to do any of these things. There was increased production but not of the goods and services that minister to the wants and conveniences of men. Commodities were created, not utilities. There was little thrift and much waste. "Easy come easy go" became the rule of working-class economies. Class feeling was intensified and the gospel of work was displaced by the creed of exploitation and advantage.

Readjustment Strain.-As swiftly as the bolt of war struck, 
as swiftly-by blessed compensation-came the beginning of its end, and with it the arrest of war-time industry and war-time labor standards. Before the gun fire had fairly died away, the mill furnaces were banked. Cancellation of orders and discharge of workmen took the place of over-time work and large-scale production. War in its tense, industrial aspect was over and labor faced the trials and strains of readjustment and reconstruction.

The elements which make the laborer's well-being difficult and insecure in the passing of an industrial state from war back to peace may be summed up as unemployment, wage reduction, price inflation, and, negatively, the restricted social activities of the state.

Unemployment. ${ }^{1}$-After-war unemployment is due in part to the stoppage of war industries; in part to the demobilization of armed forces and war-time administration; in part to the restricted production consequent upon the reduced purchasing Fower of the wage-earners so discharged. Much of this is inevitable. Munition plants cannot continue making shells, nor emergency factories, gas masks. Armies must be demobilized and administrative bureaus disbanded. The labor supply thus abruptly released cannot, under the most favorable circumstances, be immediately absorbed. The phrase "waiting jobs" is for any but the individual laborer a kindly figure of speech. Jobs cannot wait. They are either filled when vacated or they cease to be. If they are filled, the return of the absentee involves a displacement of the temporary incumbent; if they have been abolished, restoration is uncertain and conditional.

Organized labor will struggle bravely, and in a measure successfully, against this drift. It will be able to substitute parttime employment of an entire labor force for outright unemployment of some part of that force. It will be able to resist unnecessary encroachment upon its wage scales. Most important of all, it will be able to maintain its existence as an instrumentality for collective bargaining. But the larger penalties it cannot escape. The labor market will be temporarily glutted-

${ }^{1}$ The following paragraphs have been incorporated by the writer in an address on "The Laborer's Hire," delivered as one of the Weil Lectures, 1919. at the University of North Carolina, and since published in a little volume American Citizenship and Economic Welfare (Baltimore, 1919.) 
acutely during the period of readjustment; appreciably thereafter-and unemployment and part-time employment must result.

Wage Reduction.-It is not only from the unemployment or reduced employment resulting from demobilization that working class incomes are bound to suffer. Peace pricks the bubble of war gains, be they excess profits or bonus wages. With the nation's existence in the balance there is neither time nor warrant for that competitive higgling which in the long run is the safeguard of society. War loans and war taxes supply seeming limitless funds; and the government, always a generous industrial employer, is, under the critical stress, less than ever disposed to drive a hard bargain. The rule of commercial employment is different. The margin is scantier, the pressure stronger, the competition fiercer. Just as profits pass from the years of plenty to the years of famine, so the labor world confrorts the changed conditions of a reduced social surplus and a more drastic division.

Price Inflation.- The hardships of unemployment and the sufferings of falling wages are exaggerated by the persistence of inflated prices. It is a seemingly inevitable consequence of war financing, be its chief reliance borrowing or taxation or a rational combination of the two, that there is injected into the exchange mechanism of the country a volume of fiat credit or a mass of additional circulating medium in excess of that required by the increase in production or by the greater activity of trade. ${ }^{2}$ The result is a sharp, continuous, widespread rise in prices-wholesale and retail-extending far beyond the range of those goods immediately subject to war demands and of those the supply of which has been reduced by war operations. Such a rise will be restrained but not prevented with respect to a limitea number of commodities by governmental price fixing. But the general trend is unaffected. The commodity index number of the United States Bureau of Labor rose from Ioo in February, I9 I5, six months after the outbreak of the war, to I I in February, rgi6, to 155 in February, I9I 7, to 208 in September, I9r8. The corresponding figures for retail food prices are I0I, 106, I33, and 78 .

With the termination of war this rising movement is arrested

'See the writer's War Borrowing: A Study of Treasury Certificates of Indebtedness of the United States (I9I9). 
and prices tend to decline. But the descent is in the nature of a gradual fall rather than an abrupt drop-a fall held in check by the continuation of heavy government borrowing, and affecting wholesale prices first and retail living costs but slowly thereafter. The wage-earner is thus caught between the upper millstone of slackening employment and reduced wages and the lower millstone of sustained prices. Eventually equilibrium will return; but the interval is a costly, painful one, fraught with possibilities of enduring mischief as to living conditions and moral stamina. ${ }^{3}$

Social Aftermath.-Unemployment, lower wages, threatened living standards are positive injuries. The largest ill from which the wage-earner will suffer as a result of the economic sequel of war is negative - the impairment of the state's power to engage in those projects of social betterment which have become the distinguishing marks of economic progress. The spread of education, the wiser provision for dependence by programs of social insurance, the plans of reclamation and conservation, the increase of public improvements, better highways, fitter dwellings, more libraries, museums and galleries_all that sound public policy might do to make residence in town and country more wholesome and more lovely-all these are deferred for decades to come by the incredible squandering of the world's wealth in war expenditure and by the mortgaging of its future accumulation in war indebtedness. The injury done extends beyond the wage-earner to his children and to his children's children. A fractional part of the billions that have been wasted might have realized for the present happiness and the future betterment of the world's masses things beyond our imaging. Rapine, murder, mutilation are but the spectacular horrors. This is the real social tragedy of the war.

From the days of Plato, social optimists have described ideal commonwealths wherein there was no want. Such Utopias were fashioned as fantasies or as satires. At last, in our day,

${ }^{3}$ Contrary to reasonable expectation and largely in consequence of the Treasury's continued use of fiat credit involving an outright domination of the Federal Reserve Board's policies, the course of prices in the United States has continued upward, practically without interruption, for sixteen months since the armistice, having risen to 249 for wholesale commodity prices and to 200 for retail food prices in February, I920. 
the abolition of poverty had loomed up as an economic possibility, definitely within reach, if only society had desired it sufficiently and had been willing to pay enough to achieve it. ${ }^{4}$ It is here that the vista of social betterment, cherished by the economic philosopher, has been pitifully obscured by the world's aberration. Leaving out of consideration the incredible losses of economic effort, such as wasted soils, ruined cities, slaughtered workers, and omitting the miserable social consequences of modern warfare, such as dependence, widowhood, moral laxity, industrial sloth, outright destitution, the attention of the political economist is held by the colossal war expenditure and the gigantic war debt. An amount far smaller than that which each of the principal nations involved has up to this time expended in outlay or incurred in debt would have been enough to effect those material improvements and to institute those agencies of relief which the best thought agrees would accomplish epoch-making advance in social well-being.

The Ultimate Fallacy.-The economic pessimism of a century ago foreshadowed a cyclical arrest of economic production with the increase of mankind, and the resulting threat of retrogression has from time to time been revived in economic justification of war. Even though masked in the more respectable phrases of biological analogy this doctrine of decimation as the efficient corrective of social ills is repudiated alike by public sentiment and by expert opinion. Were it true that natural selection, working raw and unaided in social evolution, would extinguish the evil of poverty, the process of elimination would yet be so wasteful and so brutalizing as to insure its rejection as a social policy. But as a matter of fact the survival of the physically fittest through the operation of modern warfare is attended by the direst aggravation of poverty. Indeed, the very assumption of such a process is a mass of wastage and wreckage - the slaughtered, the maimed, the widowed, the orphaned-among which survival is possible only at the expense of continuing misery and want suffered by the downtrodden. It is a brutal fatalism rather than any scientific warrant which associates economic betterment with the recurrence of war.

So also as to the more subtle phase of this vicious fallacythat the wage-earning classes will gain in well-being from the 'Compare the writer's The Abolition of Poverty (1914). 
industrial stimulations and economic intensities of war. A momentary, insecure spurt, paid for bitterly and in many fold, is the most that can be claimed. Mankind can not escape the economic penalties of its political madness. Thrift, industry, the accumulation of capital, social responsibility-the elements which in the long run condition economic progress-are the very negations of what war involves. To the victor as to the vanquished war can only mean present suffering and lost opportunity. 


\section{PART III}

SOME ECONOMIC ASPECTS OF SOCIAL PROBLEMS 



\title{
CHAPTER VIII
}

\section{AN AMERICAN LAND POLICY}

\author{
By RICHARd T. Ely ${ }^{1}$ \\ Professor of Political Economy, University of Wisconsin
}

Reconstruction in the United States.-In general, the meaning of reconstruction is building again. We hear of it most frequently in connection with the European post-war situation, and it often signifies building from the ground up. This is especially the case in the devastated regions of France and Belgium, but very generally the disturbances of the war in the belligerent countries of Europe have been so great that reconstruction carries with it the idea of profound changes. We in the United States, however, have suffered very little, comparatively speaking, in loss of life and fortune, and the destruction of property in our country by enemies within our borders has been something that is negligible.

But reconstruction carries with it spiritual as well as mental ideas. We have this in mind when we say that in our own country the old world has passed away, and we are living in a new world. The new world is a world of ideas and our future economic life during the coming generation will be an age of reconstruction, even if mere material forms and forces undergo little change. It is too early to tell exactly how profound has been the destruction of the old world of ideas, but it is certain that in essential respects the future will be unlike the past. We have

${ }^{1}$ A.B., Columbia, 1876, A.M., 1879; Ph.D., U. of Heidelberg, 1879; student at Halle, 'Heidelberg, and Geneva; head of department of political economy, Johns Hopkins, I88I-92; professor of political economy, University of Wisconsin, I892-_ ; lecturer, University of London, 1913; president, American Economic Association, I899-1901; president, American Association for Labor Legislation, 1907-8; secretary, American Association for Agricultural Legislation; author and editor of works on economics. 
glimpses of a better future and a vision for which we have waged war. While we have in this country suffered little loss, we have been willing to stake our lives, our fortunes and our sacred honor upon success in our war for civilization and the destruction of autocracy. We know now better than ever before the real importance and force of Rousseau's "general will." We are filled with the desire to construct a democratic world which will be a reconstruction of our old world. We want a world of equality of opportunity, but we should remember that this is the only kind of equality that is constructive. Often enough have we seen the havoc of destruction wrought by revolutionary striving for equality of fortunes. Democratic equality of opportunity means opportunity for all in proportion to their capacity and it signifies a field for leadership.

Reconstruction and the Land.-When we consider the land in the United States, we find that during the World War there has been no destruction. Probably on the whole, there has been progress in knowledge and in method. The limiting factor during the past four years has not been land, as so many mistakenly suppose, but, first of ail, labor. Capital has been scarcer than land, but it is not apparent that in agricultural production there has been an appreciable deficiency of capital. When we turn our attention to the construction of buildings upon the land, we find a prohibition on the part of government, because capital has been desired for governmental purposes and because the need of labor in essential industries has been still more pressing. Doubtless, if a wise man could bave had complete control of the agricultural iand of the country during the World War, he would have put an appreciable percentage of it out of use altogether, say ten per cent., and have concentrated the labor supply upon the better land remaining, say ninety per cent. As it was, we have had to spread a diminished labor supply over the old area, possibly slightly increased, and have made cultivation more extensive. Tractors have come into greater use, and we have learned how to make an existing supply of labor accomplish somewhat greater results. There has been some gain in this respect, although probably not so marked as during our Civil War. It is probably true that there has been some exhaustion of the soil which would not have taken place except under the conditions of war. It will be seen, therefore, that the 
reconstruction is comparatively slight, and what we need is construction; in other words, we find ourselves in a situation where it is important to push forward improvement along lines of development which had already been begun before 19r4. The problem before us is the right policy for the twentieth century.

Favorable Features in the Present Situation.-Obviously we should know where we now stand with respect to the land. What are the good features and what the bad features in our human relations to the land of the United States? The writer has traveled widely in different countries, and has for years given careful attention to the actual facts in the parts of the world that he has visited, and at the same time he has availed himself of data gathered by others. He does not hesitate to affirm that the American situation with respect to the land is the best that the world has ever known, while at the same time he affirms with equal convictions that at present there are many evils capable of remedy, and that we need a well-thought-out American land policy in order to conserve the good that we have, and to bring about further improvements. The experience of the entire world, our own country included, shows that a laissez faire policy of drift brings disaster. It is necessary that we should adopt at the earliest possible moment a conscious control of our natural resources, in order to attain certain cleariy perceived ends. We must know what we want, and we must take appropriate measures to attain the desired ends. There is no greater problem before the twentieth century than the problem of man and his relations to the land.

What do we mean by a land policy? A land policy means definite aims and the adoption of appropriate means for attaining these aims. It signifies a departure from individualism and an abandonment of the idea that each one in merely following out his own interests will promote adequately the interests of society. The purpose of a land policy is to bring about a situation such that while in the main pursuing his own ends the user of land will at the same time act in general harmony with the interests of society as a whole. Social planning is implied in a land policy, and this planning must go far beyond what we understand by city planning; not merely that the plan must extend to the rural land, but it must be more profound in its aims than city planning ordinarily is. 
A land policy takes as a starting point the existing situation with respect to the land; land as here used being equivalent to all natural resources of the country. It examines the processes of evolution by which the existing situation has been reached and proceeds to develop a conscious program of social control with respect to the acquisition, ownership, conservation and uses of the land of the country and also with respect to the human relations arising out of use and ownership.

A land policy then includes a discussion of the inheritance of landed property and the use of credit in the purchase of land. It includes all those social agencies, private and public, which have to do with the land; for example, land mortgage companies and the federal land banks. A land policy includes regulation, actual or contemplated, of the ownership and use of mineral resources, water power, of transfers and leases and many other things which upon reflection will occur to the careful reader. Social control embraces then the relations among men arising from the economic and social aspects of land. The degree of control varies, but becomes more intensive as times goes on and with an ever increasing emphasis upon social welfare. It should be understood, however, that social control is not always governmental or public in nature. Social control proceeds from private or non-governmental agencies and from public opinion, as well as from agencies of a governmental sort.

We have not proceeded far in the United States in the development of a land policy, and even the concept of a land policy will to many seem just a trifle strange and unfamiliar. It appears perhaps a little paradoxical that the situation in the United States is better than in other countries, although we are behind many of them in the development of a rounded-out land policy. Our happy situation is due, on the one hand, very largely to the bounties of Nature, and, on the other hand, to a more or less spontaneous working out of democratic purposes. Increasingly we have desired that the land of the country should be widely distributed in ownership, and that the owner should be very generally the user. Our history has known large land grants, but they have met with increasing disapprobation. While nearly all of the land has at one time been owned by the people collectively, that is to say, by the government, national or state, our aim has been to bring it into private possession and to build 
up a class of independent land owners, each one having a sufficiency for support in the case of farm land, and each one having a suitable site for a home in the case of urban land. This general democratic purpose in its earlier phases reached its culmination in the homestead law passed during the Civil War which gave to any one who would occupy and cultivate it a quarter section or one hundred and sixty acres of land. We have also on the whole encouraged the equal distribution of property among children, and have wanted to discourage the concentration of landed property by means of primogeniture.

Our solutions have been rough and ready and, therefore, very imperfect. A quarter section, for example, is a suitable farm in the Mississippi Valley, but altogether an unsuitable area in the less fertile plains of the arid West. We have taken a certain area without stopping to consider that equal areas mean widely divergent resources. A careful examination of the conditions leads to the conclusion that land must be first classified before suitable areas for homesteads can be ascertained. Fortunately, a good part of our land has been fairly fertile, and except in the far West, one hundred and sixty acres have been very generally what is called an economic holding-that is to say, a sufficient area to support the farm family. It thus happens that for the most part in this country we have family farms and a wide diffusion of landed property.

Our system of taxation with respect to the land has also been a good one in its influence upon land ownership and use. Where the American system is well developed and administered, as it is in many of our states, for example, Wisconsin, it is probably the best that the world has ever seen. We tax land upon its full selling value whether the land is used or unused. We put upon urban land a large part of the costs of the street improvements and various utilities constructed at public expense in the streets, for example, sewers, and sometimes the water supply; also frequently expenses for æsthetic purposes as parks and finely built boulevards. This is the great American system of special assessments, distributing burdens in proportion to benefits. It is applied frequently in rural districts, especially in the case of drainage, but everywhere it is capable of still further development. The burden then resting upon the land is so great that the owners of land are constantly exercising themselves with 
efforts to put the land to the bighest possible economic use. We have to consider not only the annual burdens in the way of taxation and special assessments on the land, but the interest upon the selling value of the land. A moderate single-taxer in Germany said to the writer at a meeting of the Verein für Sozialpolitik in I9I I this: "Society already has in the United States an ownership of the land which may amount to one-third or one-fourth interest. You already have all that we in Germany want." Probably we have gone as far as we can well go along this line in the way of bringing land into use. We hear ridiculous tales about the unused land in the United States, but pretty generally the land that in the economic sense is capable of use is already in use, and it would be a great waste of resources to bring at present the unused land into use.

Certain terms in general use are apt to mislead the unwary. The term arable land means literally land that can be plowed. This doubtless would take in a good part of the Desert of Sahara and millions of acres of land in the United States so devoid of the essential elements of economic production that a jack rabbit might not find it easy to get support on an entire quarter section. The terms improved and unimproved land as employed in the Census Reports of the United States have also misled many. Land is regarded as unimproved unless it is regularly mowed or plowed. The most magnificent pasture land not regularly cultivated, and especialy if it never has been broken up, would be regarded as unimproved land. Frequently a writer will call attention to the fact that in the farms of the United States $40,000,000$ acres are enclosed, but not cultivated by their owners. Some of this land is altogether below the economic margin of cultivation, but a great deal of it is pasture land in the fertile valleys of the Ohio and Mississippi. Frequently it could be put to no better use. Wood land is also unimproved, but frequently it could, on the whole, be put to no better use than the present. Much of this land not improved is not being withheld from social uses by the owners, but rather as the writer's colleague, B. H. Hibbard, has well said, "It is being held by the Almighty for future geological development." 2

\footnotetext{
${ }^{2}$ See B. H. Hibbard's review of Dr. F. C. Howe's "High Cost of Living" in the American Economic Revicw, September, 1918, p. 602.
} 
The best succinct statement of the utilization of land in the United States is that given by $\mathrm{O}$. E. Baker, agriculturist, and H. H. Strong, Assistant in Agricultural Geography, both of the Office of Farm Management of the United States Department of Agriculture, Washington, D. C. This is found in a paper presented by Mr. Baker at the meeting of the American Association for Agricultural Legislation in Richmond, Virginia, December, I9I8, and reprinted in the Yearbook of the United States Department of Agriculture for I9I9. Mr. Baker estimates that of the land area of the United States about forty-five per cent. is fitted for the profitable production of crops, and that consequently more than one-half is unfitted for the profitable production of crops, and this is owing to either rough topograrhy, deficient rainfall, low temperature or infertile soil. The amount of absolute desert consists of about 40,000,000 acres, and otherwise the estimated 55 per cent. of land unfitted for crop production is to some considerable extent used for the production of timber and for grazing live stock.

The situation in the United States with respect to tenancy and ownership is probably better than in any other one of the great countries of the world. Even with the best system of land ownership in an old country a considerable percentage of the land would be occupied by tenants. Tenancy means very often in the United States that the land is passing from an older to a younger generation, the teuant being a son or son-in-law or some relative. Farmers retire gradually from the farm with advancing age, and tenancy is frequently the best possible arrangement for their retreat from the farm and the oncoming of the new generation. Surveys have been made in southern Wisconsin which show that, as a rule, where these surveys have been made tenancy signifies this transition of ownership from generation to generation. Tenancy in a case of this kind means health, and it also means conditions of health when the tenant is climbing the agricultural ladder and ascending from a lower to a higher status as from farm hand to tenant and from tenant to owner, from owner of a mortgaged farm to owner of a farm free from mortgage indebtedness. Probably after a country has reached its full development, we should expect at least 30 per cent. of 
the farmers to be tenants under conditions like those just described. $^{3}$

The present writer has taken the position that with the aid of proper social agencies it is now easier than it ever was before to acquire a valuable farm. This has been confirmed by Hon. George E. Roberts, Assistant to the President, The National City Bank, New York City, who in a letter to the writer expresses himself as follows:

"I agree with you that the hardships of the pioneers fully offset increased cost of land to the beginner now. My father was a native of this state (New York) and went to Iowa as a young man while it was still a territory. As the easiest way to get there, he took a sailing vessel from here to New Orleans and went up the Mississippi River. I can myself remember when live hogs sold around $\$ 2.25$ to $\$ 2.50$ per hundred weight. That was during the period following the panic of 1873 and before the resumption of specie payments, January I, I879, and the low prices were the basis of the Greenback movement which swept a number of western states at that time. Furthermore, I recall being told by a substantial farmer, whose statements were entirely reliable, that before the Civil War he hauled dressed pork from Webster County (of which Fort Dodge is the county seat) to Dubuque (200 miles) and sold it at \$1.50 per hundred weight."

There are failures now and there were failures, many and many of them, in earlier days. The writer as a boy in western New York saw a stream of people leaving for the West for the fertile fields of Illinois and Iowa, but many returned with broken fortunes, and sometimes with impaired health and rarely did reports come back of any marked success. We are apt to forget the failures in the present success of the farmers in the fertile Mississippi Valley, but we should recall the days of the farmers' discontent, which found expression in all sorts of organizations for radical reform like the Wheel and Alliance and the great

'This subject has been further treated by the author and his colleague, Prof. C. J. Galpin, in a paper called "Tenancy in an Ideal System of Land Ownership," presented at a joint meeting of the American Economic Association and the American Association for Agricultural Legislation, held in Richmond, Virginia. December, I918, and printed in the Papers and Proceedings of the Thirty-first Annual Meeting of the American Economic Association as a Supplement to the American Economic Revicw for March, I9I9, and also as Bulletin No. II of the Publications of the American Association for Agricultural Legislation. 
Populist Movement which scored many a political triumph.

It is true that it takes longer now than in the earlier days to become a farm owner, although with advancing life tenancy still decreases. On the other hand, we must ask ourselves what we mean by farm ownership. To own a farm now means far greater wealth than it did to own a farm thirty or forty years ago. What would the Iowa, Illinois or Kansas farmer in the time of distress when corn was at times being used for fuel think of the present prosperity of the farmers in Iowa, where there are three-fourths as many automobiles as voters? ${ }^{4}$

Unfavorable Features in the Present Situation.-While it is true that in many parts of the country tenancy, as a rule, is good, there is a great deal of tenancy that is bad. Sometimes this tenancy is bad in its effects because it leads to soil exhaustion and poor productivity, and still more frequently is it bad because of its general economic, political and social effects. Where land is held in great estates with little or no opportunity for the acquisition of ownership of land by tenants, it discourages accumulation on their part, and in those cases we have a large class of residents whose interests in schools, churches and in all of the higher cultural side of life are weak. The dwellings and surrounding grounds in such cases are apt to be inferior and poorly maintained, and the community life to be on a low plane. All these evils are accentuated where tenancy is accompanied with absentee landlordism. We find much evil tenancy also in parts of the country where there is a wide separation between the class of land owners and the class of tenants. This particularly applies to our South, where the tenants are often negroes.

The evil in the situation is, that we have made no proper legislative and administrative provision for the great amount of tenancy. Older countries, for example, England and Scotland, are far in advance of us because tenancy has been of such long standing and because experience has shown that it cannot without disaster be left to itself.

An evil of a general character in the situation is found in the excessive individualism of the farmer. He does not coöperate with his fellows as he should, and he has not been educated to take a broad social view. He has carried over his individualism

- See B. H. Hibbard's article, id., p. 606. 
from an earlier period, in which the economic life is individualistic, to the modern period in which our life has become largely socialized. That the farmer himself has not become correspondingly socialized shows itself in the farmer's inadequate and generally unsuccessful attempts at collective action and in the case of the retired farmer who in the villages and small cities so often does not play the rôle that he should because he does not know how to enter sufficiently into community life.

One great evil in the situation with respect to the land of the United States is, that settlement has not been carefully planned, but has been very largely the haphazard result of private efforts of individuals and companies in their endeavor to make a profit in buying and selling land. We can take any new section to illustrate this evil situation. We find that the rural settlements just like urban settlements are not planned out with respect to each other, and even the internal arrangements of the single settlement are not carefully planned in order to achieve the best results. Upper Wisconsin is probably being settled as scientifically as any other section in the United States, and possibly is above the average in its arrangements as a result of the many helpful social agencies which are planned to help the settler; yet here we find that settlements are widely scattered, causing needless cost of roads, of schools and of all social utilities. At times there is some attempt at orderly settlement within the single colony, but even here at best it is worked out with reference primarily to individual gain. This does not mean that we do not need the effort of individuals seeking proper gain, but we have no social arrangements which put the striving of individuals for gain upon a high social plane and which coördinate private and public interests. We are still trying individual solutions of problems which are largely social because our thought has not been sufficiently socialized.

A very great evil in the present situation is the dishonest land dealer - the land shark as he is called, who exploits ignorance, inexperience and economic weakness, and has done and is doing an incalculable amount of harm, wrecking the lives of untold thousands. The land shark has a large field when dealing in land which is not socially controlled. Universal experience demonstrates that the ordinary man is unable to make a wise selection of land, and particularly in a country with which he is 
not thoroughly familiar. This is a case in which the purchaser cannot individually protect his interests, but where he requires the aid and protection of social agencies, both private and public. The investigation of failures which the writer has been making for years shows that the most frequent cause is poor selection of land. The waste in social resources as well as in shipwrecked lives is something incalculable, and we can have no satisfactory land policy which does not protect the purchaser of land in his purchases against fraud and misrepresentation. We must have positive social agencies not merely to protect against a poor choice of land, but to aid in a wise choice.

Ideals.-A land policy as defined above must be based on certain ideals. We must have before us certain definite predetermined ends. Individual action alone cannot produce a social policy, but social action means social ideals. What do we desire with respect to the land?

First, we desire widespread ownership. Ownership of land gives a stake in the community and promotes good citizenship. It affords a solid basis for progress. Other things being equal, the larger the number of land owners in a country, the better the land situation in the country. The land owner is in a favorable condition for the assertion of his independence, and land ownership is a stronghold against tyranny.

In the second place, our American ideal is opposed to such large individual holdings of land as to create a landed aristocracy. We have democratic ideals with respect to ownership, and we want, as a rule, the man who uses the land to be the owner of the land or to have reasonable hope of attaining ownership. We want the farmer to have an "economic holding" which will support him in a fair degree of comfort and enable him to educate his family. Our ideal, however, does not mean equality of ownership. Rich farmers are desirable in every community because they help the prosperity of the smaller farmers. They are able to take a leadership in the improvement of stock and in the introduction of new devices which the one who has simply an economic holding cannot take. In the fertile Mississippi Valley forty acres may be an economic holding, and, generally speaking, farms of smaller size are not socially desirable. On the other hand, the farm of one thousand acres is pretty nearly the maximum and a relatively large number of farms of this size 
is undesirable. New Zealand is aiming to establish a maximum size of farms of four hundred acres when the land is of "the first class." This policy seems to be pretty generally approved in that country. It would seem wise by various measures like progressive taxation to work toward a maximum of one thousand acres of first-class land in the United States. Experience shows that confiscatory taxation is not needed, but that a moderate progression in the rate of taxation exercises a gentle but permanent pressure, sufficient to produce the results aimed at.

In the third place, to attain our ends we must make it easy to acquire the ownership of land in both country and city. Much has been done, but far more can be done to aid the climber on the agricultural ladder of land ownership. We have our building and loan associations in cities, and we have our federal land banks to aid the rural land owner. It is the opinion of those who have given attention to the subject that credit agencies should be largely developed to aid the prospective land owner.

Private and public effort are both required to attain our goals. The actual and possible private agencies are many. The wealthy landlord who has an appreciation of his social mission will help his tenants to acquire land. The number of those land owners who are conscientious in this respect is far larger than the superficial observer is apt to think, and the number is happily growing. Sometimes the owner of a farm helps the tenant to acquire ownership of the farm that he is renting, and probably still more frequently does he help him in the acquisition of another farm for the cultivation and ownership of which his tenancy has given him a training.

Private combinations of individuals are helping men to acquire land ownership. We have in addition to the building and loan associations the private land settlement and building companies which help the landless to become land-owners, and it is noteworthy that the business of these land companies is being conducted, on the whole, upon an increasingly high plane. In many parts of the country the average settler brings with him a good deal less than a thousand dollars, and when he joins a good company he rapidly acquires the ownership of a farm, or in the case of cities, the ownership of a home.

But in the more advanced countries of the world the political units of society, nation or city, play an ever increasing rôle in 
the attainment of ideals of land ownership. The land business is becoming more and more a function of the state. A good example would be afforded by New Zealand, where the government helps the citizen to acquire the ownership of homes in city and country and does so by buying and improving land and selling it on the long-time amortization plan of payment. Ireland is a conspicuous illustration of governmental help in the acquisition of land ownership by the farmers, the old landlords having been bought out and the land sold to the farmers on long-time payments and under such favorable conditions that the annual payments are less than rent was formerly.

In the fourth place, we desire a socialized population-rural and urban. The attainment of this purpose can be helped by wise planning, making it easy for citizens to act together. It also implies a consciousness that the ownership of land carries with it a social mission.

In the fifth place, we desire a wide distribution of the increment of land values and a sharing of them both by individuals and society collectively. Where land is widely distributed among owners and where the American system of taxation, as described above, prevails, distribution of land values and of their increments is excellent. Where widespread tenancy exists, where the landlords are largely absentees and where it is difficult to climb the agricultural ladder, there is an undesirable distribution of land values and of their increments.

Definition and Classification of Land.-As already stated, land is used as equivalent to natural resources, and it is in this sense that we employ the term when we speak of an American land policy. The concept, land, is one that is extremely complex, and until we thoroughly grasp this fact we can make but indifferent progress in dealing with the problems of the land. There are variations in the nature of products, in the methods of securing them, in the relative degree of exhaustibility of the products of land, great variations in the rewards given to labor and capital in the appropriation of products, great variations likewise in the power given to the owners of land to control the action of others. An illustration in the difference in reward would be afforded by the owner of a farm embracing a hundred and sixty acres of land in a good dairy region in New York State, and the owner of the most productive mines in the Mesaba Iron Range, 
or by the owner of a site of a great skyscraper in the Wall Street district in New York City, and the owner of a little home in a country village in western New York. An illustration of the difference in control is afforded by the ownership of the shore lands of a harbor of a great city and the ownership of the shores of one of many islands in one of the Canadian lakes. Differences in the exhaustibility are illustrated by short-lived oil and natural gas wells and by good agricultural land, the fertility of which may be maintained for thousands of years, as in China, if not permanently.

In addition to differences in the kind of products we have quality variations with respect to each kind. Agricultural land affords the simplest illustration. This has already been mentioned in the discussion of the size of farms and of the economic holding. The quarter section is a good sized farm in most parts of the fertile Mississippi Valley, but two thousand acres in western Nebraska may be a small farm, and in states farther west ten thousand acres may be too small for an adequate homestead. It becomes then apparent that we can say little about land in the abstract.

The very first step to be taken in the elaboration of a land policy is based upon a full appreciation of the significance of the complexity which the concept land carries with it. The greatest obstacle at the present time to the development of a land policy is found in the panaceas and formulas for the easy solution of the most difficult of all modern problems, namely, the land problems. The problem is complex because human relations arising out of the connection of man with the land are complex. It is necessary to emphasize this because in every field of economic life the enemy of constructive policies is the man with simple formulas which are advanced as cure-alls.

To understand the complex nature of land it will be helpful to cite a legal definition of land, and for this purpose we will take the one given in Tiedeman's "Real Property":

"Land is the soil of the earth, and includes everything erected upon its surface, or which is buried beneath it. It extends in theory indefinitely upward, usque ad coelum, and downward, usque ad orcum. Under the term land, therefore, are included the buildings, made so under the doctrine of accession, and the 
trees and other things growing upon the land, under the doctrine of acquisition by production, as well as the minerals which may be embedded in the earth. If water runs over the land, the ownership of the land gives a right to the use of the water, but does not create therein a permanent right of property. The property consists in the use." 5

Let us add what the same author says about the elements composing land, in order to give a fuller idea of the contents of this legal concept:

'The term 'land,' in its broadest sense, includes not only all substances comprising part of the solid body of the earth, but all fluids and gases, metallic and non-metallic substances, located beneath the surface of the soil, as well as the soil and subsoil upon and immediately beneath the surface of the earth, and the erections on the surface, of a permanent and fixed character. The solid, crystalline bodies, forming part of the substance of the earth, and the liquids and gases, which do not possess a definite geometric form, that are put to commercial uses, because of their value to mankind, are generally denominated 'minerals,' to distinguish them from the soil and subsoil and other elements of the term 'land' possessing no peculiar value." ${ }^{8}$

It will be noticed by one familiar even with the elements of economics, that the legal concept land includes a good deal that economists call capital, but even with all possible deductions, it is apparent that the concept land embraces many widely different constituent elements.

There is not space in this paper to give a complete classification of land such as the author has elsewhere attempted to present. ' Only a few suggestions will be offered in this place. Land may be classified as arid or humid. It may be classified with respect to the appropriation of natural gifts which may be either sub-surface appropriation, as in the case of underground mines, or with respect to surface appropriation or utilization.

-Tiedeman, Real Property, \$2, p. 4.

- Ibid., \$3, p. 5.

'See Foundations of National Prosperity by Ely, R. T., Hess, R. H., Leith, C. K., and Carver, T. N., pp. 53-57. 
This latter classification is one of the most important. Under it we have such sub-classes as natural and artificial forests, natural pastures, arable land, shore lands, lands under water, various kinds of water, as brooks, rivers, ponds, lakes, etc. Another important point of view from which we may classify land is based upon density of population, and this gives various kinds of rural and urban land. Land may also be classified with respect to actual and desired forms of ownership, giving us common ownership, private ownership, and public ownership. One of the most important classifications has already been mentioned, namely, that based upon quality, giving us land of the first class, second class, etc.

It has already been mentioned that the experience of the world proves the impossibility of a laissez faire policy of government with respect to our natural resources. The experience of the world throughout the centuries shows that it leads to chaos and social ruin. We must treat land, on the whole, as a public utility, in other words, as property affected with a public interest and as property that needs varying degrees of social control; this social control, on the whole, becoming more and more intensive with the progress of society. It is also apparent to one who studies world experience and refiects upon the nature of our problems, that legislation can do no more than to mark out the broad general lines of progress through control. The land resources are so infinitely varied, and at the same time the differences among the men who have to deal with the land are so great that general principles with flexible application are required in any satisfactory land policy. There are not only the local peculiarities in any one of our American states, but also the differences in population as we pass from one section to another. In a state like Wisconsin or Iowa, there is a comparatively homogeneous population, while in a southern state like Mississippi there are racial differences of the deepest significance which must be taken into account in the establishment of right relations between man and the land.

The Outlines of An American Land Policy.-What kinds of arrangements must we then have for the establishment of a sound American land policy? If we study the experience of foreign lands, we find some experimentation which is a warning to us, and some which offers helpful suggestions. Ireland and 
New Zealand are two countries perhaps as instructive as we could study. Ireland has had land courts to fix rents, but while these courts have been helpful in certain cases, they do not afford, on the whole, much encouragement to us in the United States. The Irish Land Commissions, especially the Congested District Board, however, give an illustration of a kind of control which seems to be adapted to our own country. It acts in accordance with general principles, applying them to concrete cases, and enters into helpful relations with individuals and assists them in getting on to the land under favorable conditions, in cultivating it and gradually in acquiring ownership.

New Zealand also is a country which, in its short life, has had a rich and varied experience, offering many suggestions. We see in New Zealand how democracy in land ownership or the limited and regulated freehold has triumphed over what has been called socialism in land policy as exemplified in attempts at the general introduction of public ownership with the use of the land under a system of leasehold. The fee simple title of the land has won a decisive victory in New Zealand, but the policy of limiting the individual to four hundred acres of first-class agricultural land has been introduced, and gradually New Zealand is approaching this maximum limit in individual ownership. At the same time the small owners are favored in taxation, a moderately progressive tax being used which does not approach confiscation even in the case of the largest holdings. Moreover, in New Zealand the government buys and sells land in order to promote what is called closer settlement and to make easy the acquisition of land and of homes both in city and in country.

But we need not go to New Zealand to find the kind of an institution necessary to the establishment of an American land policy. We have in our own country commissions for dealing with economic problems, and we learn that these commissions are most successful when they have very large powers to apply broad general principles to concrete cases. We have our railroad commissions and our industrial commissions as illustrations. The first great step in the establishment of a sound land policy in the United States will be taken when we establish land commissions in our states and also a federal land commission. These commissions will be parallel to our railroad and industrial commissions. 
The main work in the United States must always be done by the states, and this cannot be emphasized too strongly. The federal government, however, is the owner of extensive tracts of land and also is involved in interstate relations. The federal government has also an educational function with respect to the land. It is able to do a great deal in the way of experimentation and stimulation. A federal land commission would follow along the lines of the general development of federal policies as seen, for example, in its relations to education. An illustration is afforded by the Reclamation Service, of the Department of the Interior, which coöperates with the states and develops the federal lands, especially by means of irrigation and drainage, and which is now endeavoring to establish closer and more intimate relations with the states, especially in putting returning soldiers and sailors on the land. It is important to lay the emphasis always upon the activities of the states and not to allow any federal proposals to obscure the greater rôle that the states must play and thus to halt local initiative.

What are some of the measures with which our land commissions must concern themselves? We may mention, first of all, public ownership and private ownership. We must always have a great deal of public ownership, which will vary in relative amount in different states. Apart from privately owned farm wood lots, the forests must be publicly owned and administered. There is a world wide experience, including that of our own country, to substantiate this proposition. Forests should cover large areas of absolute forest land, and especially should the mountain sides and sources of streams be very generally protected by a forest cover. It is only the federal and state governments that can make a selection of the large tracts which in the public interest should be covered by forests, and it is only these governments that are in a position to make plans covering one hundred and fifty years; and such a length of time is required for the establishment of sound forest policies.

The private ownership of certain kinds of land on account of their nature and of their strategic situation carries with it the possibility of oppressive social control and even monopoly exploitation. Banks of streams, shore lands and waterholes in the arid West afford illustrations. No better description has been 
given of an actual situation than that afforded by an article by Professor Romanzo Adams, of the University of Nevada, entitled "Public Range Lands-A New Policy Needed." \& Professor Adams in this article portrays the actual conditions in Nevada where there is great concentration of ownership because a few men control the land adjacent to water, and thus have exclusive control over the public range lands lying far away from available water. The ownership of the land containing bodies of water controls the use of the public range lands, thus bringing about the virtual private appropriation by a few of public property. Very bad conditions of ownership have resulted. Bad rural labor conditions have also followed, the laborers being migratory and traveling about from state to state, working now in wheat fields, now in orchards; and without encouraging opportunities to acquire permanent homes of their own.

Public ownership of sources of water, careful regulation and well planned development under the administration of a good land commission would create a large number of small owners. A socially desirable distribution of the land resources of Nevada could multiply homes and promote better social conditions as well as closer settlement, whereas laissez faire policies must perpetuate conditions which are undesirable in our twentieth century democracy. But public ownership should go a step farther in Nevada and in other parts of the country where conditions are similar and include within its scope the open range lands. These are now largely publicly owned, and this public ownership should be retained. The use of these lands is necessarily extensive, but it needs regulation in order to prevent a destructive use and bring about the maximum use as pasturage. What can be accomplished in this direction is illustrated by the federal control of pasturage within the national forests.

Professor Adams, in the paper to which we have referred, states admirably in the following words a conclusion of wide general application:

"The national government should retain the ownership of those public lands which are situated in Nevada and which are more valuable for range pasturage than for agriculture or other purpose, and should regulate and control the use of such lands

- See the American Journal of Sociology, November, Igi6. 
in such a way as to conserve and utilize their value more fully and with primary reference to the creation and maintenance of conditions favorable to social welfare." 9

Economists who have given special attention to the subject are probably now in pretty general agreement with respect to the desirability of public ownership of mineral resources, so far as general principles for a new country are concerned. Private ownership has had many undesirable consequences. One is the existence of "swollen fortunes," to use the term of the late President Roosevelt, and at the same time this private ownership has encouraged the wildest speculation and promoted the conscienceless exploitation of the general public by means of getrich schemes. There has been a disproportion between effort and reward which has cultivated a gambling spirit and turned many away from those steady occupations which are socially more desirable. At the same time private ownership in mining districts has too often been accompanied by bad labor conditions and frequent turmoil. What is the wise land policy now that the mineral treasures have so largely passed into private ownership? It is to retain public ownership of them where it still exists. Whenever any publicly owned land is alienated, mining rights should be retained. This is being done more and more in our own country. An effort should be made also to recover mineral rights where this can easily be done, and there are many ways of accomplishing this purpose by taxation and condemnation. Our space is too limited to go into the intricacies of this subject, but, while striving to increase public ownership, we should always keep faith with private owners; and that means we should seek progress without confiscation. Through suitable commissions a general control should be exercised over mineral resources, and where there are very large profits, they are reached, as other gains are reached, by income and inheritance taxation.

But public ownership should also embrace lands which are below the margin of profitable utilization by private owners. This land in private ownership is a source of constant temptation and affords a fruitful field of activity to the land sharks. Ruined lives of humble people and fertile seed-ground for Bolshevism result. It should be the function of land commissions to exclude from private sale to settlers sub-marginal land, and to justify

- See Prof. Adams's article, ibid., p. 329. 
this the state must stand ready to purchase the land at its real value for public use, which would very often be forest use.

We have seen that tenancy is normal and desirable, provided only that it is good tenancy. Our laws and institutions must encourage good and discourage bad tenancy. We find, furthermore, that, in general, unregulated tenancy is in so many cases bad tenancy that no old country has been able permanently to tolerate it. It is apt to lead to deterioration of soil and to undesirable social conditions. One of the aims of a land commission must be the careful study of tenancy as it exists. The commission should aim to regulate tenancy and promote, so far as may be compatible with the laws, good tenancy and recommend changes in legislation wherever these may prove to be needed.

One of the main functions of a land commission will be, on the one hand, to promote a wise selection of land by desirable settlers. When we get the good land and the good settler together, we have taken a great stride forward in successful settlement.

The land commission should also be watchful in regard to the terms of purchase and see that the credit conditions are favorable. One of the most frequent causes of failure is found in too short terms for payment of mortgage indebtedness. Perhaps there is no other cause responsible for so many failures. The excessive optimism of the purchaser, as well as of the seller, leads to the expectation that land can be paid for in far shorter periods than is commonly possible. Ireland affords a good illustration of the need of long-time amortization plans. As the great Irish Land Acts have been passed for the land purchase, the amortization period has been lengthened until it now reaches sixty-eight years. In this country, where the earnings are higher, probably twenty-five years is a suitable period. We now have our federal land banks, but those can only be used for the payment of half the assessed value of the land and one-fifth of the value of the improvements. We need better credit facilities, and one of the functions of the land commission should be to help the settler secure the advantages of whatever facilities exist and to help bring about such improvement in credit facilities, both for the purchase of land and for the purchase of equipment, as may be possible to secure. 
Probably no one who has not made a careful study of the subject has any adequate concept of the astonishing development of helps afforded to farmers, settlers included, in a state like Wisconsin. It is a matter of general knowledge that we have had a wonderful development of agricultural education, and that we have our county agents to help the farmers in their counties. Probably it is not so widely known that we have soil surveys, and where these are developed, as they are in Wisconsin, they are a great help in the selection of land. A good land commission will find one of its chief functions in enabling the settler and the would-be settler, as well as the farmers in general, to make use of existing agencies.

The land business has been and is one which does not, generally speaking, stand very high in public estimation. There is, however, among those in the real estate business a strong movement to put it on a higher plane. It should be a profession. The purchaser of real estate needs expert advice, as truly as a man in legal difficulty needs a lawyer, or a man suffering physically needs a physician. The real estate men in their conventions have repeatedly passed resolutions in favor of a licensing system which would help to weed out the dishonest dealers and establish certain minimum qualifications.

It is desirable that our educational institutions should offer courses for all those who wish to become experts with respect to the land and deal with the land as property owners or as agents. English experience shows that this is not an unattainable ideal, and it is one which meets with much favor in the United States. However much the state and other public agencies do, the greater part of the effort in the settlement of the land and in the development of the land within the frame work of a desirable land policy must come from private initiative. We have thousands of men with large experience in dealing with the land; and to take another illustration from that part of the country which the writer has recently investigated we have our Director of Immigration in Wisconsin. This Director of Immigration is doing splendid work in helping the settler get on the land in the right way and also in getting the right kind of settlers into the state. But we have hundreds of interested private parties with special knowledge engaged in the land business. All that public authority can do is to help here and there, to establish general 
control and to promote private effort, to encourage the improvement of sound private action and to discourage wrong private action, aiding in the conviction and punishment of fraudulent action.

While it may seem like a radical statement, it becomes apparent from what has already been stated, that the buying, selling and improving of land, including the construction of dwellings, must become one of the great functions of the modern state. ${ }^{10}$ This is confirmed by world experience and is necessary as a means of preserving private ownership as a basis of good citizenship and warding off that dangerous radicalism which in the modern form of Bolshevism always attacks, first of all, the private ownership of land.

Finally, emphasis must be laid upon the fact that our public administration lags behind legislation. An inadequate civil service, rather than legislation, is a great obstacle in the United States to every constructive program for economic and social development. We could almost say that if we only have good administration, legislation will take care of itself. Whether we are discussing the future of the railways or the development of our resources, we encounter almost at the very beginning of our inquiries the lack of good administrative machinery as an obstacle to progress. We cannot do the things that we would like to do, because we do not have suitable administrative contrivances and trained and capable men engaged in the administration of public affairs. In some way or another, we must draw into the public service an adequate proportion of the talent of the country. This talent must be suitably trained and must find as desirable a career in the service of society, as a whole, as that afforded by private employment. It is easy to arouse enthusiasm in a campaign by promises of legislation which it is alleged will bring about vast benefits almost overnight; but it is hard to interest people in the comparatively slow processes of good administration. He who is able to convince the American voter that the main lines of progress must be administrative in character will be one of the greatest statesmen America has ever known, and will take rank with our chief leaders in the promotion of progress.

${ }^{10}$ Here again we use "the state" in its generic sense, as referring to political units in general. 
. 


\section{CHAPTER IX}

\section{THE DRIFT TOWARD THE CITY}

\section{By Benjamin H. Hibbard ${ }^{1}$ \\ Professor of Agricultural Economics, University of Wisconsin}

It may as well be admitted at the outset that there is very little information on the subject of the drift to the city during the period of the war. Such information as we have on the whole subject is based mainly on the findings of the Federal census, and in consequence is now nearly a decade old. Concerning the census figures, it must further be admitted that they are hard to interpret beyond the mere fact that a given portion of the population is to be found in the country and the small town, and that a given number are engaged in agriculture.

As shown below there are undoubted and interesting facts revealed in these figures, but there are covered up in them a greater number of facts which are being wanted as never before. The census tells where people are at a given time, in what country or state they were born, and in what occupation they are engaged. We are now vitally interested in the question as to what number were born on farms and are now somewhere else; how many born in town are on farms at present; why farmers and their children leave the country districts for the towns and cities. These most interesting, intimate, and vital questions will probably never be answered by the census reports. They will be made the subject of inquiry by special students of rural affairs, and will be reported in small representative samples. Thus far such studies are but just begun.

${ }^{1}$ Benjamin H. Hibbard, B.S.A., Iowa State College, I898; Ph.D. University of Wisconsin, I902; Professor of Economics Iowa State College; Expert Special Agent in the Bureau of the Census; Professor of Agricultural Economics, University of Wisconsin, 1913; author of articles on Farm Tenancy, bulletins on Marketing Farm Products, Farm Credit, etc. 
Since we have little information concerning the movement of country people to the town during the past three or four years, the best that can be done is to survey the situation for the period at which information is available, namely, the time of the last census. With this as a background, it will be possible to make some observations and suggestions pertaining to the conditions created by the war, even though they are known in only a general way.

The Drift to the City Not New.-The alarm over the decrease in the rural population is not new. Xenophon complained that the Greeks loved the city rather than the village. Varro was sarcastic in his testimony that the Romans had similar weaknesses. The elder Mirabeau was eloquent in his recommendations of country life and pathetic in his delineation of the destiny of the farm people who moved to town. During the middle period in English history the politicians and poets lamented bitterly the exodus from country to town. But the movement went on for centuries. In America even, the question is not altogether new. It is brought forcibly to attention at this time because it is spread over more territory, and because it has proceeded at a little swifter pace in recent years than formerly. Yet the population of many of our country districts decreased considerably during the Civil War decade and has never since recovered the loss. In Iowa, a comparatively new state, the decrease in farm population began as early as 1875 , and not a census has since been taken which has not shown fewer people in some of the counties.

The Problem Not Peculiar to America.-The problem is by no means local in its present aspects. France has for years been alarmed at the widespread and persistent decline in the number of people in her rural departments. A census taken not long before the war disclosed an acceleration of this movement, and a body of scientists and philanthropists got together in a "Congress on Rural Depopulation." It was shown that one of the rich departments had been losing in population since $185 \mathrm{I}$. Within fifty years following that date there was a loss of about I 2 per cent. But since I9OI, a period of agricultural prosperity, the rate of loss has been 50 per cent. greater than the annual rate for the preceding half century. For France as a whole the 
rural population during the sixty years between 1846 and 1906 decreased $162 / 3$ per cent.

In Germany the loss of people from the farm communities has for years been a sore point with the agricultural party. Its leaders blame everybody, the manufacturers, the railway administration, the countryman himself. The manufacturers hold out false inducements concerning pay; the government is culpable in that its railway service is designed to coax the agricultural laborers away from the land; the commuters' trains gather up thousands of villagers every morning and at a good rate of speed, for a small fraction of one cent a mile, whirl them into the industrial centers where they work during the day, to be brought back in the same manner in the evening. They live in the country but their interests have all moved to town, and like Lot, who "pitched toward Sodom," they are in danger of finding themselves swallowed up entirely by the city.

One of the concerns of England to-day, as before the war, is the dearth of competent farm labor, and this trouble is put forward as an explanation of the poor use, or lack of use agriculturally, which is made of some of her farm land. But fret as Englishmen may, the count from time to time shows fewer people in the village and on the farm, while London, Manchester, and Birmingham are more populous at every census. Were it not for the situation in France and Germany with their much lauded protective tariff on farm products, England would furnish a splendid "awful example" of the effect of free trade on rural life.

An Economic Problem Primarily.-The question of rural population is not primarily one of sociology. True the sociologist may show that the size of the family in the country is smaller than it was a few decades ago. No doubt it is, but the country has always provided a surplus of people above its needs. It has furnished the majority of prominent business men and professional men of the town, and until it ceases to recruit the ranks of these callings, and therefore uses its children in its own community, the size of the family will not be the limiting factor in the density of rural population. The real occasion of the thinning in the rural ranks is not lack of recruits, or excess of casualties; it is desertion. To change the military figure, it is 
not due to the frequent visits of the undertaker or to the infrequent visits of the stork, but to the alienation of the affections of the new arrivals by city relatives. However, this is in the main justified by the economic status of the two communities. The city offers greater immediate inducements. The city more and more needs added workers; the country is learning to get along with fewer. (See figure I.)
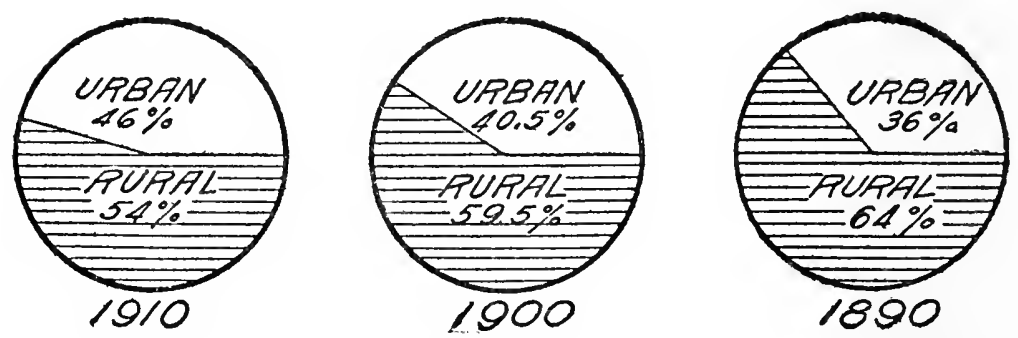

FIg. I.-Decrease of Rural Population I 890 to I9Io. Rural population includes all towns of less than 2,500 inhabitants.

The Geography of the Drift to the City.-In two main sections of the country the rural numbers had shrunken prior to I9ro. (See figure 2.) These are first, the East-New England and large parts of the Middle Atlantic States-especially rural New York; and second, the greater part of the old settled districts of the two North Central divisions of states. This section includes a large area, equal approximately to seven out of the twelve states, and, moreover, from the standpoint of present knowledge, much the more productive portion of this greatest of all agricultural empires.

In the first mentioned of these two sections of country the decline in rural population is accompanied by a decline in general agriculture. There were fewer farms in rgro than there were ten years before. There were fewer cattle, fewer horses, fewer swine, fewer sheep; there were fewer acres of grain, fewer acres of hay. Taking as a sample eight counties of New York in which the decrease of rural population was greatest (see figure 3 ), it is found that the number of farms decreased during the ten years from 1900 to 1910 by 1,303 , or $4.1 \%$. At the same time the average size of the farms has increased nearly 4 acres, 
At the same time the number of work horses per thousand acres of improved land increased a little. Thus the men decreased in numbers, but their power to do work increased by a considerable

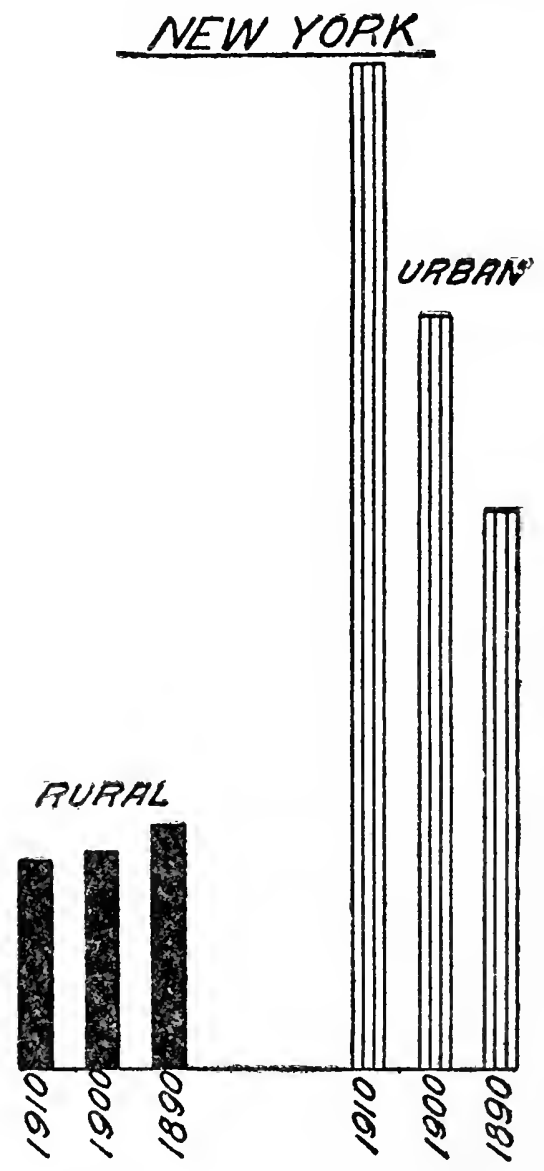

Fig. 3.-Changes in Rural and Urban Population of New York. Rural population includes all outside of incorporated towns.

percentage. Possibly there was left on the farms a dearth of good help-the cry is always that such is the case-but those who remained were getting greater results per man than was ever before obtained. 
Turning our attention to the West, we may notice that the area within which the country population showed a decline stretched from Columbus, Ohio, to Lincoln, Nebraska, and from St. Paul, Minnesota, to St. Louis, Missouri. The situation is quite unlike that in the East, though not in every particular. For instance the number of farms declined, and at rates not greatly dissimilar, $2 \%$ in Ohio, $4.6 \%$ in Illinois, $5.1 \%$ in Iowa. However, the number of acres of land in farms underwent little change and the number of improved acres still less. Hence the size of the farm increased in Iowa, for example, about five acres; in Illinois, about five acres. And on these farms the amount of produce did not grow less. True there was between rgoo and rgro a decrease in the number of cattle, but dairy cows grew more numerous; hogs decreased somewhat in number, but have since recovered. The quantities of corn, oats, and hay, of milk and butter, were and are on the increase; even the supply of wheat did not fall off greatly and has since passed all previous records. The improvements on these farms are growing better every year. Houses, barns, fences, and groves improve steadily. The value of the farm as a whole was more than doubled in ten years. Better roads, telephones, rural mail delivery, and interurbans bring new comforts and eliminate the old inconveniences. But in spite of all increased facilities, the people move to town. In Ohio in 1890 the average number of rural people per farm was 7.I; in rgIo it was 6.r, or exactly one person fewer. In Iowa for the same twenty years the decrease was from 5.9 persons per farm to 5.I, a decline four-fifths as great as that in Ohio. In Illinois the decrease was from 6.7 persons per farm in 1890 to 5.9 persons in r9ro, the same as that shown in Iowa.

Implements Replace Men.-The most significant change in farm property here was, as in the East, the advance in the value of farm implements; for the two North Central divisions of states this increase amounted to $74.9 \%$. In Illinois it was $64 \%$, in Iowa $65 \%$. This means an increase, not alone in the number of machines, but in effectiveness of machinery corresponding very closely to the increase in value. In other words the farmers and farm laborers of the Middle West were equipped with tools for farm work one and three-fourths times as well as they were ten years earlier. The increase in the expenditure for labor during the decade in the two North Central divisions of 
states was $76 \%$, which represents almost altogether advance in wages per man and not an increase in the number of men.

This movement has not been confined to the decade just past. It has been going on for a much longer period, and amounts to a struggle for the mastery of power. The evolution of the plow will serve as an illustration. Even within the short history of a state like Iowa, the most primitive methods have been employed. The spade had been used for turning the sod, though not to a great extent. The usual equipment during the early years was a yoke of oxen and a simple walking plow cutting some twelve or fourteen inches. This outfit was sometimes handled by one man, but often it took two, and when a horse was hitched ahead of the oxen, making the famous "spike team," it was by no means rare for the guidance of this curious mixture of motive power to require two men and a boy. And with all this effort from one to two acres of land were plowed in a day, as a rule a long day. About the period of the Civil War the ox lost prestige as a draft animal and was succeeded by the horse. This evolution came about not by accident, but rather because men were scarce and their services dear. Hence it was thought to be good business to give them more effective tools and so get more out of the men themselves. The farmer of this period, say I 865 to I 880 , plowed ordinarily with two horses, and turned from two to three acres a day. Then came another forward step, gradual indeed, and the three horse plow, frequently a riding plow, became the commonest kind in use. It was but a mere detail to change the single plow to the gang plow, and with four horses the farmer, very often the same one who had done his part in plowing a single acre a day, now plows five acres. The last step in the process up to date is the tractor plow with which men have plowed forty acres in a single day, and for show purposes, three engines hitched to a gang of fifty plows, at Purdue, Indiana, plowed an acre in four and a quarter minutes.

The same course of development has been run by the cultivator. Men are still living who have used the hoe as the main means of cultivating a corn field. They did a good day's work if they hoed a half-acre. Then came the double-shovel plow, and with one horse three or four acres could be cultivated in a day. Next came the one-row cultivator, now commonly in use, 
and with it a man cultivates from six to ten acres a day. But there are two- and even three-row-cultivators in use. With the hoe it was all a man could do to raise eight or ten acres of corn a year. With modern equipment six times that amount is a very ordinary undertaking.

We may take at least a glance at the reaper. Since the Civil War the cradle was in use on both sides of the Mississippi River. Then a man did well to cut two acres a day, and another man did exceedingly well to bind it after him. With the reaper, which came into use about that time, a man and two or three horses cut ten acres a day, but it still took the same amount of help for binding. It required eight men to cut, bind and shock ten acres a day. With the self-binder of to-day this can be done by two men. Thus within the memory of men now living the amount of man-power required to harvest an acre of grain has been reduced five fold, or $80 \%$.

Within the limits of this paper it would be impossible to give even a meager sketch of the many mechanical means by which the feeble physical powers of the man with the hoe are multiplied. Besides plows, cultivators, and reapers, there are harrows, planters, seeders, windmills. There is the aid of the ox, the horse, the steam or oil engine, the electric motor. And they all mean more land farmed by one man, or in other words, fewer people per square mile of rural territory.

The increased use of farm implements is reflected in the added use of horses, which was evident in the decade from I 900 to rgro. During that time other classes of livestock decreased, while horses gained in numbers. At that time the cities were making rather less demand for horses than formerly, and the inference is plain that they were used on the farm. They were used in connection with the increased number of implements, which the farmers had purchased. The increase in horses and implements was the counterpart of the decrease in men and the increase in acres per farm. In Illinois the number of horses on farms increased between 1900 and I9 Io over I60,000, or I $3 \%$. In 1900 the number of horses per farm was 4.6 ; in 1910 it was 5.5. In Iowa the increase was almost exactly one horse per farm. This meant that, with the added equipment, one man was doing about a fifth more work than he was doing a decade earlier. 
Farms Grow Somewhat in Size and Much in Price.-It is then not surprising that the farms are a little larger than formerly. In the Middle West, outside of the districts influenced by the proximity of cities, the size of the farm has grown steadily larger. This is not so true in the East where conditions do not favor large scale farming to the same extent. But in Illinois the size of farms for the past thirty years has been increasing slowly for the state as a whole, with a more rapid increase in the better portions. In Iowa the average size of farms has increased 23 acres in thirty years and the movement seems to be still in progress. This increase in size of farms is roughly coextensive with the area over which the population is decreasing. It by no means applies to the country as a whole.

One of the economic wonders of recent years is the increase in the price of farm land. It more than doubled in the ten years under consideration for the entire country. But these sections of the West where the price has risen the most rapidly and reached the highest point, excluding the truck farming districts, are just where the rural population has shown the greatest decline. This is not so clearly the case in the East where complications arise on account of the disuse of a considerable acreage formerly in farms. Throughout the country west of the Hudson River the decrease in population on farms has accompanied an increase in the size of farms, which fact added to that of generally increasing land values augments the rise in value of the farm as a unit.

Price of Farms Rises as Population Falls.-The increase in the size of farms points strongly to the continuous movement toward a more efficient unit. A more efficient unit means economy of the labor factor, or, in other words, fewer people on a given area. The rise in the value of land seems to be coincident with a decrease in the number of people living upon it. Land which is being efficiently used is manifestly more valuable than similar land not so economically used. It may seem somewhat paradoxical, but it is true, that in the Middle West the population varies inversely with the land values. In Ohio, for example, the number of rural people per thousand acres of farm land, in the ten counties showing the lowest average value of land, is 73.4 ; in the ten counties showing the highest average values per acre (excluding as not comparable those containing 
large cities) the number of rural people per thousand acres of farm land is 70.6 , or 2.8 fewer. The same test applied to Illinois shows in the ten counties of low priced land 44.5 rural people per thousand acres of farm land, and in the ten counties with the high priced land, but 37.7 , or 6.8 fewer people on the thousand acres of farm land. The same holds true of Iowa. Varying the test for Iowa, and viewing it from the standpoint of tenancy, it appears that in the ten counties of highest percentage of tenancy there are 27.5 persons per thousand acres of farm land, while in the counties of lowest tenancy there are 34.5 persons per thousand acres of farm land. The tenant is a much younger man on an average than is the owner. A larger percentage are just beginning married life and the numbers in their families are small. Since the tenants are predominantly on the high priced land results similar will be found.

Where Land Is the Basis of a Home, Population Is Denser.The conclusion seems inevitable. There are more rural people living in those districts where land is used primarily as the foundation for a home and not as an investment. Where it is capitalized at the highest possible figure and put upon the market either for sale or for rent, it falls into the hands of men who exploit it commercially and in doing so handle as many acres as their means and skill will permit, pushing the number of acres as high as possible for each rural laborer belonging to the family, either as a member of it, or as a hired helper. This unconsciously reduces the number of rural people living on a given number of acres. It is a part of the same set of forces which leaves the poor land in the hands of owners and puts high priced lands in the hands of tenants. On the poor land competition is not so strong. The land may easily be worth more than it is selling for. The farmer of mediocre ability can make a living. Moreover the purchase price is not so great and one of modest means is able early in life to make the payments necessary in effecting a purchase. The size of the farm remains smaller. All of the circumstances work toward a relatively large rural population on low-priced land.

Many Workers Drawn to the City During the War.-Before offering suggestions to remedy the depopulation of the country, it may be assumed that the rural districts have suffered equally with the city in the proportion of young men withdrawn for 
military purposes directly. On the other hand the unprecedented demand for workers in the cities, in munition and ordnance factories, and in the hundred and one industries closely associated with the war, these demands, accompanied by offers of wages higher than farmers felt able to pay, resulted in drawing away from the country great numbers of laborers. This is one of the explanations of the shortage of farm labor during the past two seasons. For instance in the state of New York, in July, 1918, the number of employees in one-third of the factories of the state, considered representative, was 25 per cent. above the I9I4-I9I5 average. ${ }^{2}$ At the same time wages were I Io per cent. above the level of the earlier period.

While the demand for labor in the factories and the percentage of employment of laborers was unprecedented, the number of men working on farms was below normal. There are no figures showing the employment on farms for July, r9r8, but in April, 1917, before the number employed in factories was at the maximum, a decided shortage of farm labor was reported. The shortage at that time for the state of New York as compared with a year earlier was 16 per cent. An increase of workers of I 5 to 25 per cent. in factories is in strong contrast with a decrease of 16 per cent. in agriculture. The situation was not essentially different the country over. While farmers paid more and more for help they were always outbid by the manufacturers, who could rely on a definite income out of which to meet expenses farther in advance than the farmers. The manufacturers make contracts for future deliveries; the farmers, with the exception of a few products, have had no guarantee. Farming is almost never a business which pays big profits, and when it is put up against the competition of manufacturing which for the time is enjoying unusual prosperity, it finds great difficulty in standing the strain. It is true that the farmers as well as the manufacturers were making more money than usual. As employers they had not only to compete against the industrial bidders who knew no bounds in the wages they would pay, but in an exaggerated degree they were handicapped by the seasonal character of the work they wanted to have done. When em. ployment is slack the employer who can offer part-time work is not at a great disadvantage because men will accept such terms

${ }^{2}$ New York Dept. of Labor bulletin, December, I9I8. 
as they can get. During the past two or three years the manufacturing businesses have been able to offer almost uninterrupted employment. The farmer, on the other hand, has felt that he was paying more than he could really afford during the time when he had to have help and so has reduced the payroll promptly at the close of the busy season, that is to say by December Ist, and has done his work during the winter months for the most part alone. This fact has helped to send more men to town, in response to the offer of high wages.

Readjustment of City and Country Population.-Now comes a reaction. The boys are coming home from the Army. The factories are employing fewer men. Readjustment must be made. Two very popular parts of the readjustment program are the proposals to facilitate a flow of town people and of the unattached to unoccupied land and to aid in replanting farm-bred soldiers back in the country districts.

The first proposal has the active backing of several influential men in the government. The second plan is being handled in a measure by the state employment agencies.

With respect to putting peopie on uncultivated land there are several considerations to be taken into account. In the first place the consumer favors it because it promises more food at lower prices. In the second place it appeals to many land-hungry people who imagine this to be a last chance to get hold of a piece of land before the price gets entirely out of reach. On the other hand the farmer of the day has a somewhat different point of view. He sees in the new settler of the unoccupied land a competitor. $\mathrm{He}$ also sees that the movement of agriculturally minded people to new land means fewer laborers for land already under cultivation, and labor is already scarce.

Coming back, then, to the main topic, it may be said from the standpoint of depleting the rural population the war was undoubtedly a decisive element. With the usual strong pull of the city on the young people of the farm; with the attraction of these young people into the towns and cities by the exceptional wages of the past two years; with the reluctance of the farmers to pay wages sufficiently high to attract them back; with the devices of all sorts by which a given amount of work can be done by fewer men; with all of these forces drawing men and women away from agriculture, the conclusion seems inevitable 
that in point of numbers the rural population has received a set-back.

Undoubtedly people will continue to move from country to town for generations to come. Nevertheless, it is a fact of fundamental import that our cities have within comparatively few years become self-perpetuating from the standpoint of population. They now increase without recruits from the country. Does this mean that immigration from the city back to the country is to begin? That the country could use a few city men cannot be doubted, but that it could profitably assimilate great numbers of them is hardly probable. The city-bred man is capable of learning the ins and outs of farm life, but he is usually unwilling to serve the necessary apprenticeship. He is unwilling to leave his associates of the city for the comparative isolation of the country.

Hold the Rural Population.-What the country needs is not an influx of non-agricultural people, but a firmer hold on its own people, its own boys and girls. Farmers' organizations which increase farm prosperity, which make farm life more attractive, will prevent depletion of the ranks. Home comforts, beautiful door-yards, and a relief from household drudgery, making the life, especially of the farm women, more congenial, will do more to keep the population of the country from declining than all possible schemes of colonization with recruits from the city. Many have hopes that good roads, automobiles, and the many conveniences which city people usually enjoy will, if extended to the country, lead farmers to remain contentedly in the country. This theory looks well on paper, but it does not seem to have worked out so well in practice. Since the outward comforts fail to keep farm populations satisfied in the country the suggestion is strong that it was not, and is not, the desire for superficial comforts that has resulted in rural depopulation. Probably depopulation is not the right term. Certainly it does not apply to any considerable part of the farm territory. What has actually happened is a readjustment of population, and until more evidence is available it is safe to assume that the motives underlying this readjustment are complex. Economic considerations count in a major way. The hard life of the farm women is likewise a major consideration. Of importance, yet hard to measure, is the educational advantage of the town over 
the country. The social attractiveness of town life counts with many people. If farm life is to hold its own against city life, it will have to be as attractive, all things considered, as is city life, but only to the number of people needed on the farm, not to all those who may happen to be born there. To be as attractive it must yield as great financial rewards as the same people have reason to hope for should they move to town; it must afford a social life not greatly inferior; it must not exact of the different members of the farm family tasks too irksome or exhausting.

Food Will Not Become Cheap in the Near Future.-We must cease to worry about the mere decrease in the numbers of farm people. The concern over this matter has usually been based on one of two things, either it is because the country is assumed to be a better place in which to live, or it is feared that if the relative number of farm people should decline food will be dearer. If people will move to the cities, so much more surely must cities be made fit places in which to live and rear children. In the question of food, there is little danger that starvation will stare us in the face so long as the power of the soil remains. As to the price of food no one need hope that it will be cheap while everything else is dear. Food must remain sufficiently high to make it desirable on the part of farmers to produce, and at that level there need be no fear that food will be lacking.

The Present Farms Should be Well Manned Before We Pea. ple the Wilderness.- The thinning out of the ranks of farmers due to the use of improved methods makes new rural school, church, and social problems. The reinstatement of a large number of farm people who have left the country, so far as possible in their old neighborhoods, is a process that should precede the artificial peopling of the wilderness. And finally, the lament over the mere decrease in numbers of country people should give place to a study of why people leave the farm, and whether or not it is socially desirable to try to prevent the movement. A little further analysis showing how many from a given neighborhood or state who leave the farms go to other farms, as in Canada, or go into work which contributes indirectly to farm life and farm prosperity would be enlightening. It is not yet time to deplore the farm population situation. 


$$
\text { , }
$$




\title{
CHAPTER X
}

\section{THE IMMIGRANT AND AMERICA}

\author{
By Frederic C. Howe ${ }^{1}$
}

Formerly Commissioner of Immigration at the Port of New York

The Past.-Immigration to America falls very definitely into two periods: that of the so-called old immigration and of the new. The distinction ordinarily made between these two periods is that the stock of the old immigration was English, Scotch, Irish, German and Scandinavian, while that of the new immigration is preponderantly Italian, Russian, Jewish, Polish, Hungarian and Bohemian. The former is Anglo-Saxon and Teutonic; the latter is Slavic and Latin.

But the real distinction is not only ethnic, it is also economic. The old immigration, extending over the first two hundred and fifty years of our life, found an unpeopled continent upon which it gradually settled itself. Year by year and generation by generation the stream of immigration moved westward, breaking its way on the prairies and in the forests, until the land had all been appropriated, that is about 1890 . In the early days the settlers took from thirty to sixty acres of land. That was all an individual could cultivate. He could not keep his sons, nor could he keep a helper, for the free lands of the west drew away the agricultural worker and even the indented servant, who

${ }^{1}$ A.B., Allegheny College, I8\&9, A.M., i890, L.L.D., i916; Ph.D., Johns Hopkins, 1892; studied at Halle, Germany; practiced law in Cleveland, I894-1909; president, Sinking Fund Commission, I904-5; special United States Commissioner to investigate municipal ownership in Great Britain, Ig05; professor of law, Cleveland College of Law; lecturer on taxation, Western Reserve University; lecturer on municipal administration and politics, University of Wisconsin; director of People's Institute, New York, I9I I-I9I4; Commissioner of Immigration, port of New York, I9I4-19I9; director, Conference on Democratic Control of the Railroads, I919-; author of books on taxation, municipal government, and the war. 
only needed to pass beyond the line of settlement to find a home of his own.

There was no immigration problem up to about 1890 . People Americanized themselves through their identification with the land. They had a stake in the country. They had something to build for, to leave to their children. And there was little return migration to Europe during these years.

About 1890 , however, the current of immigration began to drift to the south of Europe and from that time down to the outbreak of the war immigration was preponderantly from south and central Europe. The Italian migration came from southern Italy. The Hungarians, Poles, Bohemians and Balkan peoples went to the mines, the factory towns and the big industrial centers. They built our railroads; they mined our coal; they opened up our resources in the copper and timber regions of the far West. In a sense the new immigration worked for the old immigration which had previously arrived on the scene.

This new immigration had no stability. It moved from place to place in search of a job. It remained a loose, fluid element in the population, often impoverished by industrial depression, and usually congregated in settlements which afforded companionship and self-protection.

This new immigration, too, is transient to a considerable extent. From it come the "birds of passage" who go to and come from their old home to the number of 600,000 a year. The majority go for a visit but many go to remain permanently in their native land.

The Immigration Problem.-The immigration problem arose with the occupancy of the land and natural resources of the country. It was the consequence of floating industrial labor population which had no stake in the land. It overcrowded the labor market and raised a protest from organized labor, to which it seemed a menace. In addition the old immigration socalled-the Anglo-Saxon, Teutonic stock-took alarm at the menace to the Protestant religion, to Anglo-Saxon institutions and to the ethnic composition of America resulting from increasing immigration from south and central Europe. For the fecundity of the new immigration was greatly in excess of that of the old inmigration. The Slavs and the Italians bred more rapidly than did the Anglo-Saxon stock. There was danger, and 
a real danger, too, that in a generation or two America would be preponderantly changed in race and new in stock. In I9 Io the population of many industrial cities-New York, Boston, Cleveland, Chicago, Milwaukee, Pittsburgh-was from seventy per cent. to eighty per cent. composed of the foreign born, or the children of persons of foreign birth.

Immigration Legislation.-Our immigration legislatir. ${ }^{-1}$ has been a reflection of these conditions. For eight generations there was little interference with the free flow of immigration into the country. The stock was preponderantly from the British Islands. There were land and opportunity in abundance. The states of the west were eager for population. They desired to develop their resources. There was no immigration problem.

With the shift of immigration to central and southern Europe, the authorities of cities and states protested against the maintenance of aliens who became a public charge. Thereupon "selective legislation" was enacted for the purpose of keeping out persons who were physically, mentally or morally unfit. This legislation was not restrictive in purpose; it did not consciously aim to limit immigration. Its aim was to exclude aliens who were shipped here from the charitable institutions of Europe or to prevent immigration stimulated by steamship companies or foreign governments. Up to I9I 7 there was no restrictive legislation on our statute books at all. In that year, however, the so-called "literacy test" was adopted, which was the first restrictive measure enacted by Congress. Its avowed aim was to limit the volume of immigration. The literacy test, arbitrary as it is recognized to be, was aimed directly at the "new immigration" from southern and central Europe. For illiteracy in these countries is very high. It runs from forty per cent. to seventy per cent. And it has been estimated that the literacy test would probably reduce immigration by approximately 300,ooo to 400,000 persons a year. In addition to this test there was an increase in the number of causes for exclusion and in the stringency of the administrative measures for exclusion of persons afflicted with dangerous, contagious, and loathsome diseases, persons of immoral tendencies, and more recently persons who believed in anarchy or who advocated the overthrow of government or the destruction of property.

Economic Forces.-The motive of immigration to America 
has been and is to-day almost exclusively economic. Only a small number of persons have come to America to escape religious or political persecution. It was the material poverty of the masses of Europe on the one hand and the economic opportunities in America on the other that explain the steady movement of population from Europe to America. A study of immigration from the seventeenth century down to date shows that the rate of immigration was determined by economic conditions in Europe. Immigration came from the countries in which famine, destitution and a low standard of living prevailed. And it came in greatest volume when economic conditions were at their worst. The heavy emigration out of Ireland coincided with the potato famine. It was hunger, destitution, land enclosure, and the oppressions of the land-owning aristocracy that in fifty years' time drove half the population of Ireland to America.

Immigration before the great war came from southern rather than northern Italy. It comes from oppressed Poland, from Russia, from the Balkan States, from Armenia, Turkey and Syria, rather than from France, Germany, Switzerland and Denmark. People rarely leave a country if they own any property. The slight emigration out of France is traceable to the fact that more than half the population of France is in some way identified with land ownership through the prevailing system of peasant proprietorship. The same fact explains the light emigration from Switzerland, Holland and Denmark. Of recent years emigration out of Germany has been checked by the relatively high standard of living in that country and the many measures adopted by the government for keeping its people at home.

Up to the present time, therefore, America has been peopled purely at the will of Europe. She has been peopled from the countries of the lowest standard of living and of the lowest literacy. Instead of adopting a policy of conscious selection of races, groups and individuals, we have permitted economic conditions in Europe to determine the kind and volume of immigration for us. This is the cardinal fact of recent immigration to the United States.

Shall We Have a Constructive, Selective Immigration Policy? -In my opinion the time has come for a complete reversal of our immigration policy. Just as the era of old immigration ended with the enclosure of our public domain, so the era of new immi- 
gration was terminated by the European war. There are undoubtedly many millions of people in Europe who are waiting eagerly for an opportunity to migrate to America. They are waiting most eagerly in those regions where the economic pressure is severest, in central Europe, in the Balkans, in Italy. France will keep her people at home. Great Britain is purposefully adjusting her emigration policy. She is sending her emigrants to her own colonies. The emigration out of Russia, Bohemia, Poland and Germany will depend upon the rapidity of the recovery of these countries and the economic opportunities which they offer. Even assuming that but one per cent. of the population of Europe seeks to come to America, this portion would number four million people. This undoubtedly is a low estimate.

It may be inquired, how can the impoverished people of Europe get away; how can they pay the necessary transportation charges? This is less of an obstacle than it seems. Probably three-fourths of the immigrants to America have their transportation paid by friends or relatives in this country, who send them steamship tickets or money, who "grub-stake" them on arrival, who find them a job, and recoup themselves out of the earnings of the immigrant relative. With the accumulation of high wages during the last five years in the United States the alien laboring here will find no difficulty in meeting the expenses incident to emigration to America on the part of his friends in Europe.

A heavy emigration out of the country is also probable. Its volume has been estimated by the Department of Labor at $\mathbf{I}, 300,000$. When we consider that there are approximately $18,000,000$ foreign born persons in the United States and that almost all of them have been without information from relatives and friends for five years, it is probable that the emigrant outgo will greatly exceed the estimated $\mathrm{I}, 300,000$ when transportation facilities are available. It is possible that from $3,000,000$ to $5,000,000$ aliens will return to Europe in the next few years and that of these a considerable percentage will remain there. Their savings are larger than ever before. Depreciated exchange rates have enhanced the value of the dollar. They believe that land will be cheap and opportunities will be greater for a man with a small amount of capital in their own country than in the 
United States. In addition many races and peoples feel that they are under suspicion or on sufferance in America and they long to get back to their native land to escape from the status of the alien. Many will respond to the patriotic motive to return and rebuild the newly created states in Europe.

These are some of the factors which enter into the necessity for a new immigration policy, a policy which should aim toward conscious, intelligent selection, which looks to a quantitative determination of the volume of immigration, which aims to prevent the misery and suffering incident to sending back those who have unwisely come, and quite as important, which seeks so to adjust the immigrant to America that he will become as integral a part of our institutional life as the early immigration which came to America during the first two hundred and fifty years of her life.

An Immigration Commission.-Our immigration laws have been enacted under pressure, the pressure of employers interested only in low wages and in a glutted labor market, and of steamship companies interested in the alien as a profit-making commodity. These influences controlled our immigration policy for upwards of twenty years. More recently organized labor has insisted on a restrictive policy. It seeks to limit the labor supply and to protect the existing standard of wages and of living. The man who has a job is fearful that the man without a job will disorganize his union, reduce his wages, and send him to the bread-line. Aside from these conflicting economic forces there has been no attempt to formulate an immigration policy as we formulate a commercial, shipping or industrial policy. We have permitted our stock to be determined first by the economic condition of Europe, on the one hand, and the conflict of employers and laborers in America on the other. The question of our ethnic and economic needs, of the kind of labor we should have and of the races from which they should be taken, has been completely ignored. Any program which aims to control these factors is impossible under such laws as we now have upon the statute books.

The first essential to a proper flow of immigration is flexibility. We need some governmental agency that will study immigration and control it in the interest of America on the one hand and of the alien on the other. The war has given us examples of such controlling agencies in the food administration, fuel 
administration, price-fixing commissions, and the various war boards. An immigration commission should represent labor, agriculture and industry. In order that it may be directly responsible to the President, it should function through the Departments of Labor, Agriculture and Commerce. Possibly the Secretaries of these three Departments might constitute the commission, while their deputies would perform the actual administrative work. This commission should have power to decide the volume of immigration that is permissible within a given period, such as six months or a year, depending on the economic needs of America at the time. They should ascertain whether we need miners or agricultural workers, or whether female labor should be admitted. They should cope with an industrial depression just as they should relieve a labor scarcity. By periodic announcements they could advise prospective immigrants in Europe and their friends in America as to the number of aliens who would be admitted within a specified period. Embarkation from foreign ports could be readily controlled by our consular agencies, as it was during the war. There is no difficulty about the administration of such a flexible measure.

Such a commission should have many other powers, chiefly of an advisory character. It should be an Americanizing agency, aiding the immigrant on landing, looking after him at his final destination, linking him up with employment bureaus, public schools, health administration and other agencies that aim to improve his condition. It is obviously impossible for any agency actually to control the goings and comings of an alien after he reaches this country. That would be an impossible task, for it would lead to the supervision of millions of people and probably would not function as well as does the free flow of aliens who are aided by their friends in this country.

Selection in Europe.-A second function of such a commission would be that of a careful selection of aliens in Europe. This is a difficult problem. It is at variance with all of our traditions. Yet this is the policy successfully adopted by Brazil and to a limited extent by Canada and Australia as well. Brazil has been developed by upwards of two million Italians from northern Italy within the last generation through agencies of the Brazilian government which selected aliens in Italy, which gave them financial aid, which supervised their passage to 
Brazil, and upon their arrival placed them upon a piece of land ready for cultivation. The north Italian went to Brazil. $\mathrm{He}$ became a permanent resident. On the other hand the south Italian came to America and became a floater, a bird of passage. Canada deliberately selects her immigrants from the British Islands, as do the Australian colonies.

In connection with the proposed immigration commission, inquiry offices might be opened in the principal emigration centers of Europe, perhaps in connection with the consular service. They should be supplied with information about America and the officials in charge should under general directions make a preliminary examination of prospective emigrants. The officials might examine the physical condition of the emigrant and so prevent many a person from reaching America who is excluded upon arrival. The officials could pass upon the matter of his general industrial fitness. They could carry out the orders of the immigration commission to the extent of encouraging the migration of agricultural workers, mechanics or types of immigrants who were wanted at that time. They might encourage immigration from some countries and discourage it from others. It would be possible without legislative inhibition to stop the migration from Asia by such administrative decrees. The international difficulties of discriminating against Japan and China or any other race could be obviated through executive control as herein indicated. The ultimate responsibility for the decrees would be lodged with the President, who is responsible for his appointees.

By such machinery America could inaugurate a selective process in immigration, a selection determined not by hundreds of individual immigration inspectors at the American ports of entry, but according to a thoroughly formulated immigration policy. Our immigration policy should look, not alone to the industrial and economic needs of America, but to the future ethnic composition of the country as well. For there is reason for the belief that under unrestricted immigration the predominance of Anglo-Saxon traits and institutions will be lost in a few generations' time.

Americanization.-Within the last few years America has turned her attention to the Americanization of the alien. Federal, state and municipal governments and many private agencies 
are coöperating in this work. The purpose has been to divest the alien of his native language, customs and traditions and to engraft upon him a knowledge of English and the customs and traditions of America. For the most part it has been exclusively an educational campaign carried on through night schools or with the aid and coöperation of employers. Such an Americanization program meets little response from the immigrant. He resents it. He looks upon it as a conspiracy to increase his productive power and to take away from him the love of his native land, which remains dear to the average alien in this country. Moreover, it is very difficult for a mature man, who has worked from eight to ten hours a day, to attend a night school. $\mathrm{He}$ is too tired, too dull. And he wants his own leisure to use as he wills. He resents such intrusion into his free time. The results of most educational experiments in this field have scarcely justified the effort.

But the failure is due to other conditions. The immigrant from central and southern Europe has failed to Americanize himself and his children because of economic and industrial conditions. The new immigrant has no stake in the country. $\mathrm{He}$ lives in a tenement. He works here one month, elsewhere the next. He rarely goes to the land. He owns nothing except his savings, which he frequently carries in a belt around his person. He may be here for years. Yet he feels no identification with America because he owns nothing in America. $\mathrm{He}$ is, for the most part, a migrating worker.

Yet the strongest ambition of most aliens is the ownership of a house or a piece of land that will give them the social or economic status that they did not have at home. The great majority of those who come are peasants. The great majority of them would ultimately go to the land if they could do so under conditions that guaranteed social companionship and a livelihood after they had reached the land. The European alien, especially from Italy, Hungary, Poland and Russia, is land hungry. Yet because of the isolation he will not work as an agricultural laborer and he does not want to be a tenant-a status from which he has just escaped.

Real Americanization must have an economic foundation, and must revolve about three factors: (I) a system of labor distribution, (2) a banking and credit system which will receive and 
protect the savings of the alien, (3) the utilization of such bank savings to aid the alien in acquiring a farm.

Under such a program the tide of immigration to America would be consciously controlled in the interest of America. It would be adjusted to our changing economic and social needs. Its volume would vary with prosperity or industrial depression. Women could be encouraged to come. Farm hands could be selected and directed to their destination. Far more important, the alien would be aided to become a permanent, self-respecting member of the community in which he settled. The Government would coöperate with him where coöperation is most needed. He would be helped by the Department of Labor, protected in his savings which would be used to aid him in acquiring a farm, in building a home, in identifying him with America. Until we adopt some such economic agencies, and until we view the immigration problem in its economic aspects, we must expect a floating, migratory alien population, which constitutes a menace to our labor standards and to our best traditions as well.

History tells us how to Americanize the alien. For three centuries we Americanized him by giving him a stake in the country, we gave him a piece of land. Through this he Americanized himself. In our future immigration policy we must take a leaf from past experience and adjust our governmental agencies to the identification of the immigrant with America through economic bonds. 


\section{CHAPTER XI}

\section{WOMEN IN INDUSTRY}

\section{By Mary Van K LeEcK $^{1}$ \\ Formerly Director, Woman in Industry Service, United States Department of Labor}

No condition of our entrance into the war was anticipated more clearly or with more unanimity of opinion than the necessity for the increased employment of women. No such clearness or unanimity exists in the views held as to the position of women in industry after the war.

The experience of Great Britain in the three years of war before our entrance into it had demonstrated the reliance of the nation upon women's work to maintain industrial production. The British had put their experience into print. Reports of the War Department listed and pictured in photographs the varied processes, including heavy labor, in which women were "successfully" employed. The Ministry of Munitions published in a series of bulletins the conclusions of its Committee on the Health of Munition Workers, with definite recommendations on hours of labor and working conditions. These were based on the idea that good conditions for the workers were essential to production, and that these conditions and their effect upon output could be determined by statistical measurement. This general picture of the British experience was more or less clear in the

${ }^{2}$ A.B., Smith College, I904; directing industrial investigations for the Russell Sage Foundation, I908-1918; lecturer and instructor in industrial problems in New York School for Social Work, I9I4 to I9I7; in January, 1918, appointed director of the Women's Branch, Industrial Service Section, Ordnance Department, U. S. A.; in July, I9I8, appointed director of the Woman in Industry Service, U. S. Department of Labor, and member of the War Labor Policies Board; beginning August, 19I9, resumed position of director of the Department of Industrial Studies, Russell Sage Foundation; author of several reports on women in industry; contributor to the Survey and other magazines. 
American mind when the United States declared war against the Imperial Government of Germany in the spring of I9I7.

Federal Activities for Women in Industry in the War.-The Federal Government soon recognized the necessity for increasing the employment of women. Early in the summer of I9I7, the Committee on Women in Industry was organized by the Committee on Labor of the Advisory Commission of the Council of National Defense. To rally all the force of the many women's organizations to the support of the Government, the Council also organized the Woman's Committee, one division of which dealt with problems of women in industry. In August, I9I7, the Storage Committee of the War Industries Board, in anticipation of a shortage of labor in the stores depots of the Army and Navy, had an investigation made of the possibility later of employing women in men's places in the warehouses. The conclusion of this investigation was that the successful employment of women would require adjustments and changes in processes and conditions of work which could not be completely determined in advance but which would need continuous experiment and supervision. It was suggested, therefore, that a Women's Bureau be organized in the War Department, to deal not only with the employment of women in the comparatively restricted occupation of manning the warehouses, but to give continuous attention to their work in all the varied forms of production for which the War Department was responsible.

To this suggestion can be traced in part the decision of the Ordnance Department in January, 1918, to organize a Women's Branch as an integral part of its Industrial Service Section. This section was organized because the experience of those early months after our entrance into the war showed beyond doubt that conditions of labor were as vital to production as the availability of raw materials, and, therefore, the Ordnance Department, charged with responsibility for so large a production program, could not do otherwise than take cognizance of labor not primarily for the protection of the workers but to insure continuous production.

Finally in the Sundry Civil Bill passed in June, 1918, Congress authorized the establishment of the Woman in Industry Service as part of the War Labor Administration of the Department of Labor, and its director became a member of the War 
Labor Policies Board, thus giving recognition to the interest and concern of women not merely in the problems of women in industry but in the entire labor policy affecting both men and women workers.

Later the Railroad Administration organized a Women's Section, and the Navy relied first upon the Committee on Women in Industry of the Council of National Defense, and later upon the Woman in Industry Service of the Department of Labor for reports upon which to base action on the employment of women in navy yards.

Women's Work Recognized as Vital to Production in the War. - The fundamental reason for establishing a Woman in Industry Service as part of the War Labor Administration was defined in a statement by the Secretary of Labor when he submitted to Congress his estimate of funds required for I9I9. "It is undoubtedly true," he wrote, "that the Department of Labor exercises all of its powers with reference to wage-earners of both sexes and of all ages. It is also true that the best administration requires that the various services of the Department which are bere outlined be conducted by including within the work of each service all questions regarding women as well as men. But the great importance of the employment of women in most essential war work and the development of special matters of policy with respect to such employment make it important to establish a special service devoted to the subject of women in industry."

Comparison of this statement with the earlier and unsuccessful appeal to Congress to establish a women's division emphasizes the new effect of the war. In I9I6, a bill backed by the largest women's organizations of the country was introduced into Congress for the purpose of establishing a women's division in the Department of Labor. The duties of this division as defined in the bill were to have been to "investigate and report to the said department upon all matters pertaining to the welfare of wage-earning women, and . . . especially (to) investigate the questions of the competitive influence of women in the several industries, the adjustment of modern industrial mechanism and management to the physical and nervous organization of women, and the influence of industrial employments upon the subsequent home life of wage-earning women." 
The appeal was on the basis of the protection of women in industry, especially of their health, and emphasis was laid upon the need of considering the effect of their employment upon home life, while the phrase "competitive influence" implied the possible danger to standards of wages and hours through the competition of women with men. Congress failed to pass this bill. The favorable action finally taken came more than a year after the United States entered the war and was based upon "the great importance of the employment of women in most essential war work."

The contrast is significant. It gives the key to understanding the opinion and policy affecting women during the war and explains the apparent change which came when the armistice was signed.

Public Opinion Favorable to the War-Time Employment of Women.-In the interest of production for the necessities of war the whole nation united in approval of the more extensive employment of women. The groups of women and the few men who in the past had urged that women be given greater freedom in the choice of their occupation rubbed their eyes in astonishment as position after position hitherto barred to women through custom or prejudice was filled by a woman, and that, too, with the approval of the most conservative believer in the tradition that the household was the sole legitimate sphere of women's activities. Meanwhile those groups who had struggled for many years for measures of protection for women in industry looked on with grave misgivings lest standards already attained should be broken down, and lest no similar safeguards should be established in the new occupations. The strength of those who advocated proper safeguards lay in the fact that experience was demonstraling both here and abroad the necessity for these measures of protection not merely for the sake of the workers but in order to increase production by safeguarding health and efficiency. Safeguards formerly considered merely as measures of social reform were coming to be regarded as the "mechanisms of efficiency."

Standards Defined by Federal Departments.-These "mechanisms of efficiency" were defined by the Chief of Ordnance in a circular known as "General Orders Number I 3 " and issued by the Ordnance Department as suggestions to arsenal commanders 
and manufacturers of munitions. The same document was issued simultaneously by the Quartermaster General as a guide to manufacturers having contracts with the Quartermaster's Department. Coming from departments of the Government responsible for production, they emphasized again that it was in the interests of increasing the output of the nation at war that action to control conditions of employment was projected, and that the conditions prescribed were recommended because experience had shown that they made for more rapid and more satisfactory production.

These conditions applied to men as well as to women. The subjects covered were hours of labor, standards in workrooms, wages, negotiations between employers and employees, and, in addition, special considerations affecting the employment of women and minors. The regulations were not rigid. They were in the form of suggestions only and they were declared, in the introduction, to be not "rules of conduct," but rather "a fairif tentative-basis for action." Clear emphasis was placed, however, upon the desirability of the eight-hour day, the elimination of overtime, the half-holiday on Saturday, and the observance of one day of rest in seven, protection against hazards and provisions for comfort and sanitation, the maintenance of wage standards and the setting of minimum rates "in proper relation to the cost of living" and the need for "methods of joint negotiations between employers and groups of employees." These standards were reẽnforced by a similar statement issued in the name of women in Industry by the Committee on Women in In. dustry of the Council of National Defense, and later the whole subject of industrial relations was authoritatively dealt with in the recommendations of the National War Labor Conference Board. These recommendations were issued as a Proclamation by the President when in 1918 he appointed the War Labor Board to be the highest court in industrial disputes for the remaining period of the war. All of these statements of policy or standard issued by departments of the Government in this period agreed in emphasizing the necessity for equal pay for women who were doing the same work as men.

After the organization of the War Labor Policies Board the conditions of employment of women became one of the important subjects for discussion between representatives of all of the 
departments of the Federal Government having responsibility for production during the war.

Outstanding Facts in the War Experience.-It would require many words to trace adequately the history of women in industry during the war. The picture would include a view of the many varied tasks which they undertook in arsenals, navy yards and munitions plants and how the policies and standards set up by the Federal Government affected the actual conditions of their employment; what methods were adopted by the Women's Branch of the Ordnance Department, the Women's Section of the Railroad Administration, and later by the coördinating activities of the Woman in Industry Service of the Department of Labor to safeguard the interests of women workers and to make their work effective for the nation at war; and how successful the women were in their new occupations. But it is not America at war, but women in industry in the period following the war which is the subject of consideration and the facts about women's work before the armistice are relevant only in so far as they reveal the tendencies and conditions which constitute the peculiar problem ahead for women in industry.

Three vital facts stand out in a retrospective view of the war period. First, the Government formulated a policy, including in it and thus reënforcing many measures advocated before the war as a necessary protection for women workers, and the sanction of the Federal Government was given not only to protective measures but to the demand for a new status for women as defined in the principle of equal pay for equal work. Second, administrative agencies in the Federal Government such as the Woman in Industry Service were developed in recognition of the fact that adjustments in industry cannot be made through paper statements but demand continuous supervision and study to insure the application of policies and standards. Third, women demonstrated their capacity for a much wider range of occupations than were open to them in the days before the war and in some plants, although not in the majority of them, they were actually paid the wages of men.

Reaction in Public Opinion.-These seemed for a time to be revolutionary changes, affecting fundamentally the public attitude toward women's work. With the signing of the armistice, 
however, these gains apparently vanished. In some instances men demanded that their women fellow-workers be discharged. The Cleveland Street Railway men, for instance, took this stand, and less conspicuous examples were found when a group of foundrymen on strike in a Minnesota town made the discharge of five women, employed as core-makers, the first of their demands. Resolutions were passed by one central labor union in a large city calling for the return of women to their homes now that the war was over. Public opinion generally seemed to expect the withdrawal of the women, to make way for the returning soldier. This general opinion was based on the assumption that the majority of women in the war industries had never been wage-earners before, were employed not as an economic necessity, but for patriotic reasons, and had taken the places of men who had gone to the war. The fact was that the overwhelming majority of women in munition making and other occupations during the war had been wage-earners before the war, and were working to support themselves and often, also, to care for dependents. Nor was the replacement of men by women so simple a thing as to make possible the reëmployment of returning soldiers by the easy way of discharging women. The war industries, expanding, had created new positions never held by soldiers or any one else, before the employment of the women. In other instances, men above or below the draft age had taken the places of drafted men, and the places of these older or younger men had been taken by women. Or the process had been changed, so that the job was no longer the same, although this was less frequent here than it appears to have been in Great Britain. Finally, the soldier did not always want his old job back. Analysis of the situation made it clear that a program for women in industry in the reconstruction period could not be based upon the simple assumption that patriotism demanded the return of his job to the soldier and that therefore the women workers were expected to withdraw. Nor could the soldiers' unemployment problem be solved by the withdrawal of women.

The fact that these obvious considerations were so generally disregarded by the public seemed to demonstrate a discouraging fact. It seemed to prove that the change in public sentiment, which had thrown open the doors of opportunity for women, had 
been only apparent. Opportunity was only another name for the necessity for using women in war production. Public opinion was focussed upon the necessity for war production. The effect was temporarily to break down barriers, but when the necessity had passed, the opinions which had imposed limitations upon women's choice of an occupation before the war, were found to be unchanged and as potent as ever.

Signs of Permanent Gains.-This, however, is probably too gloomy a picture, out of perspective because the events are too close for a true view. Gains there certainly have been, and these will be permanent. A cross-section of opinions may be found in speeches in Congress in February, I919, occasioned by the discussion of the Sundry Civil Bill which appropriated $\$ 40,000$ for the continuance of the Woman in Industry Service of the Department of Labor. Said a gentleman from Kentucky, "I think there is a problem in connection with women in industry; whether it is going to continue a permanent problem in America I do not know. I am still old-fashioned enough to hope that the men of America may continue in a large measure to provide for the women of America without forcing them into industry. But in some instances they have been forced into industry and some have gone of their own predilection, and as a result of the conditions war has produced, a great many are now there."

Said a gentleman from Illinois: "We went into the war and called 4,000,000 men into the Army, and a good many more into the various civil services connected with the Army. Did the women of the country hold back? Did they do their share? Did they in many cases take the place of the men who were called into the service and perform the necessary work in order that the Government might do its proper function in providing for the Army and taking care of its share of the work? In every branch the women responded nobly. They did work which without them could not have been done for lack of labor. Are they not entitled to have the conditions under which they have gone into this work properly investigated? [Applause.] Have they not responded in such a way that we can do our little part toward knowing whether they have proper treatment and work under proper conditions? They have not held back. While I do not believe in extravagant appropriations, I think we can 
afford to give $\$ I_{50,000}$ toward investigating and knowing the conditions under which they labor in this voluntary work which they have assumed and without which we could not have successfully taken our part in the war." [Applause.]

A few days before this discussion a representative from Wyoming, where women have voted for fifty years, explained on behalf of the Committee on Appropriations the reason why, of all the war emergency bureaus, the Committee had recommended an appropriation for the Woman in Industry Service alone. "There is a condition affecting women in industry," he said, "that is rather more acute now than it was during the period of the war. Then the women were sought for in industrial activities. Now there are said to be some men so inconsiderate of the superior claims of the so-called weaker sex as to insist that they, the men, get back the jobs they abandoned and which women took. To a very considerable extent there must be a diminution of the activity of women in certain industries. There must be a readjustment, and there is great need for intelligent work along that line now, as there will be in the future."

The gallant hope that women may be supported by men; the recognition of real achievement by women during the war, and the vital importance to the nation of their share in production; and the need now for readjustment-these views voiced in Congress represent the main currents of opinion which are usually present in discussions of this subject now. But added to the opinions expressed is the fact that the next Congress did actually appropriate money to continue the Woman in Industry Service and that it remained the only war emergency service to receive an appropriation in this fiscal year. In that fact was reflected not only recognition of the problems of women in industry but an appreciation of the new political strength of women, due to the large accessions to the ranks of voters with the spread of woman suffrage since the war. Added to all this, is the uncontrovertible fact that women have a record of achievement in industry during the war which must uitimately have its influence upon the attitude toward their opportunities.

Standards in Time of Peace.-Shortly after the signing of the armistice, the Woman in Industry Service of the Department of Labor issued a statement of standards for the employment of 
women, designed to afford a practical platform of action for women in industry in the reconstruction period. These standards are as follows:

\section{Hours of LABOR}

I. Daily Hours.-No woman shall be employed or permitted to work more than eight hours in any one day. The time when the work of women employees shall begin and end and the time allowed for meals shall be posted in a conspicuous place in each workroom, and a record shall be kept of the overtime of each woman worker.

2. Half holiday on Saturday. - The half holiday on Saturday should be the custom.

3. One day of rest in seven.-Every woman worker shall have one day of rest in every seven days.

4. Time for meals.-At least three-quarters of an hour shall be allowed for a meal.

5. Rest periods.-A rest period of 10 minutes should be allowed in the middle of each working period without thereby increasing the length of the working day.

6. Night work.-No woman shall be employed between the hours of to p. m. and 6 a. m.

\section{WAGES}

I. Equality with men's wages.-Women doing the same work as men shall receive the same wages, with such proportionate increases as the men are receiving in the same industry. Slight changes made in the process or in the arrangement of work should not be regarded as justifying a lower wage for a woman than for a man unless statistics of production show that the output for the job in question is less when women are employed than when men are employed. If a difference in output is demonstrated, the difference in the wage rate should be based upon the difference in production for the job as a whole and not determined arbitrarily.

2. The basis of determination of wages.-Wages should be established on the basis of occupation and not on the basis of sex. 
The minimum wage rate should cover the cost of living for dependents and not merely for the individual.

\section{Working CondtTions}

I. Comfort and sanitation.-State labor laws and industrial codes should be consulted with reference to provisions for comfort and sanitation. Washing facilities with hot and cold water, soap and individual towels, should be provided in sufficient number and in accessible locations to make washing before meals and at the close of the workday convenient.

Toilets should be separate for men and women, clean and accessible. Their numbers should have a standard ratio to the number of workers employed. Workroom floors should be kept clean. Dressing rooms should be provided adjacent to washing facilities, making possible change of clothing outside the workrooms. Rest rooms should be provided. Lighting should be so arranged that direct rays do not shine into the workers' eyes. Ventilation should be adequate and heat sufficient. Drinking water should be cool and accessible, with individual drinking cups or bubble fountain provided. Provision should be made for the workers to secure a hot and nourishing meal, eaten outside the workroom, and if no lunch rooms are accessible near the plant a lunch room should be maintained in the establishment.

2. Posture at work.-Continuous standing and continuous sitting are both injurious. A seat should be provided for every woman employed and its use encouraged. It is possible and desirable to adjust the height of the chairs in relation to the height of machines or work tables, so that the worker may with equal convenience and efficiency stand or sit at her work. The seats should have backs. If the chair is high, a foot rest should be provided.

3. Safety.-Risks from machinery, danger from fire, and exposure to dust, fumes, or other occupational hazards should be scrupulously guarded against by observance of standards in state and Federal codes. First-aid equipment should be provided. Fire drills and other forms of education of the workers in the observance of safety regulations should be instituted.

4. Conditions needing correction.-Work is more efficiently 
performed by either men or women if healthful conditions are established. It is usually possible to make changes which will remove such hazards to health as the following:

(a) Constant standing or other posture causing physical strain.

(b) Repeated lifting of heavy weights, or other abnormally fatiguing motions.

(c) Operation of mechanical devices requiring undue strength.

(d) Exposure to excessive heat or excessive cold.

(e) Exposure to dust, fumes, or other occupational poisons, without adequate safeguard against disease.

5. Prohibited occupations.-Women must not be employed in occupations involving the use of poisons which are proved to be more injurious to women than to men, such as certain processes in the lead industries.

6. Work dress.-Work dresses with caps and comfortable shoes are desirable for health and safety in occupations for which machines are used or in which the processes are dusty.

\section{HOME WORK}

No work shall be given out to be done in rooms used for living or sleeping purposes or in rooms directly connected with living or sleeping rooms in any dwelling or tenement.

\section{Employment Management}

1. Hiring, separations, and determination of conditions.-In establishing satisfactory relations between a company and its employees a personnel department is important, charged with responsibility for selection, assignment, transfer, or withdrawal of workers and the establishment of proper working conditions.

2. Women in supervisory positions.-Where women are employed, a competent woman should be appointed as employment executive with responsibility for conditions affecting women. Women should also be appointed in supervisory positions in the departments employing women.

3. Choice of occupation.-The opportunity for a worker to choose an occupation for which she is best adapted is important in insuring success in the work to be done. 


\section{CoÖperation OF WORkERs in Establishing STANDARdS}

The responsibility should not rest upon the management alone to determine wisely and effectively the conditions which should be established. The genuine coöperation essential to production can be secured only if provision is made for the workers as a group, acting through their chosen representatives, to share in the control of the conditions of their employment. In proportion to their numbers women should have full representation in the organizations necessary for collective bargaining.

The Methods of Raising Standards. - This outline is not based on theory but on the practice of the best plants which has been already tested and found not only feasible but efficient. The statement, however, does not cover the vital question of the means of making these practices more general in industry. $\mathrm{Ob}$ viously several factors will play their part. The state government through enforcement of labor laws, the federal government through investigation of conditions and education of public opinion, employers through voluntary adoption of progressive measures, and the working women through their united efforts in their trade unions are all to be counted upon in the future because real gains have been achieved through them in the past. Possibly a new force will soon be added in the International Labor Office, functioning as part of the League of Nations.

A Complex Problem.-As a reconstruction problem, the status of women in industry is complicated. As workers, women will be affected by the incalculable changes which are talking place in industrial relations and in all the complex developments of the labor probem. As women, they have the added difficulties of an economic position less favorable than that of men, with only a grudging recognition that they have a normal place as wage-earners. At the same time the pressure of rising costs imposes upon women increasing burdens in doing their share to maintain, and, if possible, to raise the standard of living of their families. As wage-earning mothers often underpaid and overworked, they face a double burden of responsibility which has far-reaching social consequences.

No single program has been offered which covers all these complexities. Fortunately women face the new era with a larger 
measure of political power than they have had in the past. As workers, they seem destined to have more economic power. But for women in industry, as for all workers in these United States, the times have not yet produced a clear vision of the future. The more forceful, therefore, becomes the necessity for taking those steps which are clear and establishing now those standards of hours, wages, and working conditions which are not only "mechanisms of efficiency" for industry but also measures of protection for women workers and for society of the future. 
PART IV

THE NEW NATIONALISM 



\title{
CHAPTER XII
}

\section{SOCIAL PROGRESS AND POLITICAL ADMINIS- TRATION}

\author{
By Edward A. Fitzpatrick ${ }^{1}$ \\ Secretary, Wisconsin State Board of Education
}

THE PROBLEM OF PUBLIC ADMINISTRATION

This paper deals with the problem of public administration in relation to social programs and public welfare. In ordinary times public administration attracts comparatively slight attention, but in war time it overturns ministries in Europe, and in the United States is the basis of drawn battle between the President and the Congress. In ordinary times public administration works without public notice; in times of disaster the "actual government," the administration of public business, is exposed behind the scenes. Steamboat inspection, for example, attracts no attention, but when an Eastland disaster occurs public administration is revealed in its true importance. Efficient administration determines whether the things we have striven for collectively shall come to pass. It determines whether the law shall be effective in promoting public welfare.

Ineficient Public Administration.-Inefficient public adminis-

${ }^{1}$ Ph.D., Columbia University, Doctor's Diploma in School Administration, Teachers College; New York Training School for Public Service: Teacher, New York City public elementary and high schools; investigator, immigration, Federal Commission on Industrial Relations: investigator and legislative representative, Wisconsin State Poard of Public Affairs; director, Socicty for the Promotion of Training for Public Service; Major, U. S. A. and draft administrator of Wisconsin; "Secretary of the State Board of Education, WVisconsin, I919-; editor, "The Public Servant," "Universities and Public Service," the "College and the City," "Experts in City Government"; author, "Educational Views and Influence of DeWitt Clinton," "Budget-Making in a Democracy." 
tration may aggravate the very conditions it is intended to correct. A weak or inefficient administration of charitable and penal laws may result in the increase of poverty and crime. Lax and incompetent administration of public schools may give the semblance of learning and character molding without actually doing so. A weak or lax administration of public health laws may result in increased physical disability, disease and deathrates. Of this whole field of public administration we are not only uncritical but we manifest very little interest indeed, and yet it operates in our name and presumably with our sanction.

In industry machinery ordinarily receives slight attention if it runs. I $\hat{\imath}$ is only recently that business men have seen the necessity of continuous attention to the machinery of plants. This is even more true of the personnel. Unless good operating conditions are secured, the factory closes down because of strikes or high costs. Modern business learned by competition the lesson that politics will ultimately learn by crises, the importance of administration. When the factory is shut down, modern business realizes the importance of the machinery and of personnel. Crises and disasters will teach the public business the same salutary lesson.

The demands of the war brought the problem of public administration into bold relief. With the very life of the nation at stake, public administration had to be efficient, or rather had to get things done at all cost. The regular administrative machinery was frequently limited to its pre-war functions while new administrative agencies were created to do the new work. In foreign countries ministries were overturned on questions of administration and not of policy. The Asquith Ministry in England was overturned on administrative questions relating to the conduct of the war. The seven changes in ministry in France were made on the same basis, to secure a coöperating coalition cabinet, the condition of good administration.

Russian Experience.-It is very difficult to bring the problem of administration clearly before a people when things are running reasonably well. Under stable governments, administration is likely to be taken as a matter of course. It is only in crises that the problem of administration is sensed. It is for this reason that the Russian situation is particularly enlightening to the present inquiry. The prevailing chaos in Russia made 
some form of organization necessary and compelled attention to the machinery of administration. From the standpoint of this paper, it does not matter what one thinks of the principles of the Bolsheviki or program of the Soviet Republic.

From out of the Russian haze there has come sufficient information to indicate that public administration has broken down. When things were running smoothly in bureaucratic Russia, the problem of administration was subordinate and hardly recognized. But under the disturbed conditions, the matter of public administration became the fundamental problem for the de facto government. This is equally true of the breakdown of the inefficient bureaucracy of old Russia or of the efficient bureaucracy of old Germany. In Russia the national plant was shut down and the machinery demanded immediate attention, or, more directly, as Lenine says in his Program Address in 1918, the Bolshevik party has convinced Russia and secured power. "And now," he says, "it is up to us to manage Russia." Elsewhere he says, "The problem of management of administration has become the central problem of Russia."

Lenine sees clearly that the capacity to win crowds, to suppress opponents if necessary by Red Guard methods, to make laws, to have power, are subordinate in the Russian situation. The primary thing is management, which depends upon the "capacity for practical organization," or, as we would say in America, the ability to get things done. In the assault on capital, the Red Guard attack is viewed merely as the attack of light cavalry. "We have also heavy artillery at our disposal," says Lenine, and this "heavy artillery" is nothing else than the methods of management-an amazing insight in view of what we have heard from Russia. While Lenine does not reject the Red Guard methods for the suppression of the counter-revolutionists, he says, "The Bolsheviks will not be so stupid as to give preëminence to the Red Guard methods." For the ultimate success of the constructive problem before the Russian people is dependent upon efficient administration. Methods of suppression are purely negative and can achieve no permanent good.

What does this arch enemy of the bourgeoisie propose to do? He proposes to engage bourgeois specialists at bourgeois prices to do the important constructive work of the Soviet Republic. Trained men must be had in the administration. And in this 
conclusion, Lenine shows his political cleverness, if not his statesmanship. To engage bourgeois specialists to do the important work of practical organization and administration clearly is a compromise with Bolshevik principles. It is a defection from the principles of the proletarian state; it is a step backward by the Soviet state. These are all Lenine's expressions. ${ }^{2}$ But he sees also that certain and rapid progress is dependent upon his capacity to get men trained in the scientific technique and research. ${ }^{3}$

Then, practical politician that he is, Lenine frankly faces the situation in which the soviet state finds itself, and justifies this compromise with bourgeois principles thus:

"Let us take up the question from the practical side. Let us assume that the Russian Soviet Republic must have a thousand first-class scientists and specialists of different departments of science, technique and practical experience to direct the work of the people in order to accomplish most quickly the economic rehabilitation of the country. Let us assume that these greatest 'stars' must be paid 25,000 rubles each. Let us assume that this sum must be doubled (supposing premiums to be granted for particularly successful and rapid accomplishment of the most important tasks of organization and technique) or even made four times as large (supposing that we must get several hundred better paid foreign specialists). Well, then, can this expenditure of $50,000,000$ rubles a year for the reorganization of the work

${ }^{2} \mathrm{cf}$. "We were forced now to make use of the old bourgeois method and agree to a very high remuneration for the services of the biggest of the bourgeois specialists. All those who are acquainted with the facts understand this, but not all give sufficient thought to the significance of such a measure on the part of the proletarian state. It is clear that such a measure is a compromise, that it is a defection from the principles of the Paris Commune and of any proletarian rule, which demand the reduction of salaries to the standard of remuneration of the average workers-principles which demand that 'career hunting' be fouglit by deeds, not by words."

$s$ "To conceal from the masses that attracting bourgeois specialists by extremely high salaries is a defection from the principles of the Commune, would mean that we had lowered ourselves to the level of bourgeois politicians who ruled by practicing deception. To explain openly how and why we have made a step backward and then to discuss publicly ways and means to overcome our deficiencies, is to educate the masses and to learn from experience, to learn together with them how to build Socialism." These quotations are from Lenine's Program Address, 1918. 
of the people according to the last word of science and technique be considered excessive or unbearable for the Soviet Republic? Of course not. The vast majority of the enlightened workers and peasants will approve such an expenditure, knowing from practical life that our backwardness compels us to lose billions, and that we have not yet attained such a high degree of organization, accounting and control which would cause the universal and voluntary participation of these 'stars' of the bourgeois intelligentzia in our work."

The Problem of Administration in America.-This is the problem of administration as the Russian Premier sees it. It is the problem that is before every public official. The United States will take a great step forward in public affairs when those charged with the political administration and responsibility see as clearly as Lenine the secret of good administration, and have the courage to act on this conviction. Even in free, democratic America we are just a little surprised when a Republican appoints a Democrat to a prominent position in the public administration or vice versa. And we are quite indifferent, when, in our bipartisan boards or even on the vitally important peace commissions, the spokesman of the majority does not, in the public interest, select the strongest available representative of the minority.

Whether you get into office by revolution or heredity, by popular election or appointment, the problem of administration is ever present. It is just as important that it should be considered when things are running smoothly as when they are not running at all. When the sovereign power is in your possession, the important thing is to utilize it for the public welfare. Kerensky had seized the central authority, but he was powerless because he had no control of the administration.

Easy-going America, either indifferent to the government or absorbed in politics, dissipates its national energies because its laws frequently remain futile expressions of good intentions, or else are poorly administered. Able and honest men are put into office and fritter away their zeal and effort because they do not understand public administration. The principle of rotation in office sweeps them out of office when they have just completed the elementary course in public administration. The problem of administration in orderly, peaceful, democratic 
America is the problem of the selection of trained men, exactly as it is in chaotic, revolutionary, oligarchic Russia.

\section{AMERICA BEFORE THE WAR}

Complacent America.-We were easy-going, prosperous America. Go-as-you-please seemed to be the national motto, for we had abounding faith in our destiny. We were possessed of an optimistic fatalism and were "stepping lively" toward an unplanned goal.

Had we not successfuly conducted this democratic experiment of ours on a continental scale for more than a century and a quarter? Did not Gladstone admit "that the American Constitution was the greatest document ever struck off by the mind of man at one time"? Was not universal manhood suffrage a success? Had we not solved the difficult problem of federating our states under a strong central government? In short, were we not living under the best of governments and certain of the success of democratic government?

We were complacent. The policy of drifting had no serious detrimental results.

A Policy of Drift.-It is true we had no active social policy either in the nation, in the states, or in our municipalities. But why not leave well enough alone? Because of the integration of manufacturing in centers of population, industrial conditions were calling insistently for treatment and we took some stopgap measures. Even though the problem was forcing itself upon our attention all over the country and ultra-radical groups, such as the I. W. W., were growing, we never took pains to work out a public policy. Such policies as were developed were left to a more or less inefficient administration for execution. In agriculture, the national attitude was things-will-be-all-right-in-theend. Land tenantry was developing at a rapid rate, particularly in the South. The marketing problem was receiving only the most scant attention. Agricultural organization on coöperative principles was only beginning to be discussed. A national or state agricultural policy had nowhere been formulated in the United States. When a leading American banker said that we were a nation of "economic illiterates," there was no dissent. A happy phrase had been coined to describe a regrettable condition. 
We had no economic policy because, in the last analysis, we did not know.

Voices of protest there were! Voices of criticism! But they were crying in the wilderness. They were lost in the chorus of prosperity and self-satisfaction. Nevertheless, they were not quieted and they would not be still. Toward the end of this period, the new forces in American life, active, constructive, progressive, developed a political party that almost won control of the national government. These forces were politically constructive, creating definite political programs and plans for governmental reorganization. They had back of them tremendous moral forces in American life, culminating in the formation of the Progressive Party. There had gathered about them a kind of religious fervor.

The American people were greatly interested in political questions, particularly at election times; greatly interested in questions of machinery for registering public opinion, but manifesting slight or no interest in public administration. Perhaps this is notably shown at this time in the attitude of the American people generally toward the budget. The Taft Commission had developed a considerable interest in the question of the budget. The time was ripe during the first administration of President Wilson to translate this public sentiment into law and administration, but not the slightest interest of the public could be aroused. If we are to have a social program, adequate funds must be provided through the budget to finance it.

The slight interest in public administration took expression in the so-called "standardization movement." The administrative agencies of government had grown up without any particular plan or purpose. It was the "accumulation of indolent years." But the controlling idea of the reform was not a study of administration with reference to function and purpose, but a purely mechanistic standardization of position based largely on the prevailing organization. The results of mechanical standardization were much better than the chaotic conditions which it hoped to improve, but practical politicians often rejected the proposal because some of the faithful would lose their jobs or have their salaries reduced. The standardization movement did perform one great service. It revealed the wide variety of service, particularly technical service, that modern government needs. The 
standardization movement was closely tied up with the movement for centralization which is elsewhere described in this chapter and was a part of the same mechanical philosophy which underlay the dehumanizing of scientific management at that time.

It need hardly be added that during this period public service was not a profession and that frequently public officers were merely pawns in the game of politics, of which rotation in office was one of the well-understood principles. Civil Service Reform was existent, but hardly effective. It was, at best, negative. Its object was to get into public office the "least incapable of candidates." Government service at this period was not inaptly called "a cult of the incompetent." While Civil Service Reform did help to create a public opinion of the elite which condemned the use of public office for partisan purposes, this public opinion was not effective in actual governmental administration. That there were at this time notable instances of good administration in the country is unquestioned, but nobody will be bold enough to say that the conditions over the country were satisfactory. In the large, the picture here presented is true to tendencies and facts. The publicity received by the city administration of Mayors Blankenberg in Philadelphia and Mitchell in New York, and of Governors McGovern in Wisconsin and Cox in Ohio, makes them stand out in their excellence, chiefly because it was the surrounding shadows that brought out their high lights.

\section{AMERICA DURING THE WAR}

Unpreparedness. - When the war came to us, our military unpreparedness was evident. But our unpreparedness we soon learned was not in a strict sense military; it was industrial and educational. The "right face" and "left face" of training in camp is an utterly insignificant part of modern warfare. What is called military training is subordinate. Preparedness for modern warfare is a national preparedness-educational, physical, industrial, and agricultural. Modern preparedness consists of maintaining in health the individuals that make up the nation, technical training in chemistry and related sciences, effective and administrative handling of large problems, scientific agriculture as a basis of food production. This is not a system of military 
training as we understood it before the war, but a reconstruction of our whole educational and industrial system.

Dr. Ettinger, superintendent of schools in New York City, adopted a principle of school administration that is of general application. He held, with reference to fire drills, that pupils should be trained in their daily dismissals to do the thing that they will be compelled to do in case of emergency. Therefore every dismissal of the school was a fire drill. As a result it was easy to empty the school building of over a thousand children in less than three minutes. The same holds true of military training. The best preparation for peace is likewise the best preparation for war. Peace demands healthy individuals; peace demands the highest technical skill in handling the industrial problems of every-day life; peace demands the highest administrative skill in the daily service of government, of industry, and of agriculture. If such conditions exist, then preparation for war is a relatively slight matter.

The best proof of this principle is the draft administration. The conventional method of raising an army was to have recruiting offices widely distributed over the country, in charge of soldiers. The glamor of the uniform was intended to be a large factor in voluntary enlistments. Various other volunteer efforts were used to supplement these means of raising an army. The net result of such recruiting was a restricted group of individuals who went to the army largely under the impulse of the moment, sometimes for reasons not directly connected with service to the country.

The Draft Administration: Example of Efficiency.-The emergency in which the country found itself at the beginning of the war made it desirable that some other method should be devised to raise large numbers of men in shorter time than by the volunteer method. The selective draft was developed for this purpose. Practically over night a nation-wide administrative organization extending down to every county in the country was created. To this administrative machine, made up of almost 5,000 local boards, 500 district boards, numerous medical and legal advisory boards and boards of instruction, was assigned the duty of selecting men for service. The sole determining principle of the acceptance or rejection of the individual was the interest of the nation. The problem before the boards was to 
raise armies with the least interference with industrial, family, and social relationships. In achieving that duty, the whole administrative machinery of the draft did a wonderful service. As General Crowder well said: "The great thing they were called upon to do they have done. The vaunted efficiency of absolutism of which the German Empire stands as the avatar can offer nothing to compare with it. It remains the ultimate test and proof of the soundness of the intrinsic political idea upon which American institutions of democracy and local self-government are based."

Here was an example of effective pubic administration, utilizing the executive ability and administrative talent of the people at a time when the passion for public service was at white heat.

Decentralized Administration Effective.-The success of the draft administration was due to several factors. One was the plan adopted which has been briefly described and is a matter of national experience. Had the Secretary of War approved the plan submitted by the general staff, involving the use of the Post Office Department and of our regular federal judicial machinery, we should very likely at this time be raising the first contingent of troops and the Germans might have reached Paris. The Crowder plan, with its bold recital of the military obligations of citizenship, with its even more bold faith in the justice and administrative sense of the American people, with its system of supervised decentralization, made for the success of the draft administration. The clearness of the nation's objective in war made for administrative success, particularly as compared with the confused objectives of normal times. There is this difference between peace and war. In war we know what we want to do; in peace we do not. Moreover, in war the purpose is single and simple, to secure victory; in peace the purpose is complex and multifarious, to further the common welfare. In looking forward to a period of reconstruction, definiteness of social objectives must be kept in mind. Competent, far-seeing leadership is necessary to make objectives clear; men trained in administration will make them realities.

The draft was most effectively administered in states where, before the war, there had been built up reasonably good administration. Efficient state government during the war was a large factor in utilizing the reserve of administrative ability in the 
state. Governors were in charge of the draft administration in each state and draft administrators kept in touch with public sentiment by a sense of responsibility to the governor. This combination of lay and expert service furnishes the safe balance in administration. Executive officers of draft administrations were tested for their experience, before being commissioned in the army. Correspondence courses were continually conducted for members of boards. Visits by inspectors were aimed primarily to be educational, not critical. The system of supervised decentralization was a great success. And the administrative genius of General Crowder, General Johnson and their assistants consisted in replacing the highly centralized system of the ordinary military procedure by the system of supervised decentralization. This lesson may well be applied to the public administration of the civil service.

Avoiding the Test of Our National Administration.-The war situation put a strain on the ordinary administrative machinery that it could not well stand. Therefore, instead of assigning the problem of food conservation during the war to the Department of Agriculture, where it properly belonged, an independent Food Administration was created. So, too, instead of assigning the problem of fuel conservation to the Department of the Interior, a separate organization, the Fuel Administration, was created. Similarly, instead of attempting to regulate the railroads under private management through the Interstate Commerce Commission, the railroads were taken from their owners and managed and administered by the Government itself. The same procedure was followed in creating the United States War Labor Board and the United States Shipping Board, instead of assigning their duties to the Department of Labor and the Department of Commerce, respectively. ${ }^{4}$

\section{TRANSITYON PERIOD}

We Won.-We won. That is the central fact of the transition period. The nation had been in the war a little over a year and

"New York Globe, July 19, I9r9: "It is no disgrace to any one to say that the jobs the war brought were bigger than any jobs which had heretofore existed in political life in England and that the acid test proved too much for many men who would have had brilliant and unblemished careers in softer times." 
a half and had almost gotten up full steam. The losses incident to starting were accepted as a matter of course, and criticism of serious defects was mild. We had not reached that point in the war when inefficiency and delay cost the lives of the boys at the front. However, the increasing numbers in our casualty lists, even a month old, was creating a public opinion that would have revealed the facts about our system of public administration. The acuteness of the problem would have become evident if the members of the national legislature had the right of interpellation. But Congress was almost as uninformed as the public generally. If the war had continued we should have reached a point when, as in other countries, the interest of the nation would be centered on the question of administration. But we won and we therefore forgot all the travail of the year and a half of war. The answer to all criticism and to all programs for improvement was, "We won."

There was an ugly fact that tempered somewhat the intoxication of our success. That was the fear of Bolshevism. The Russian corner of the world was on fire. Sparks were flying everywhere and smaller conflagrations were raging in Austria, Hungary, and in various parts of Europe. World-wide propaganda was organized to spread Bolshevism. During this period Bolshevism continued its methods of terrorism, but was attempting to do the constructive work that must necessarily be done if Russia was to become a nation in the eyes of the world.

The American press and other agencies for forming public opinion used this fear of Bolshevism as something to conjure with. By the notoriety given to the Bolshevik movement and by the verbal violence of the opposition, we were advertising and promoting it. If the newspapers had given us news instead of rumor and "specials" that had to be denied the next. day, we could have kept our imagination within bounds and our fears would have been allayed. The truth of this observation is being confirmed frequently in the testimony before the Lusk Committee of investigation into radical and revolutionary propaganda.

The events in Europe made the period under discussion a period of doubt, of hesitation, and of watchful waiting. Terrorism was tried in the United States by the I. W. W.; people held their breath. The vigorous action of Ole Hanson in Seattle 
came as a reassuring sign to the business of the country. There gradually developed the attitude that nothing need be done, that there was no need for reconstruction and that we might safely return to our pre-war basis. With the upset condition of the world, this can only be a temporary conclusion.

\section{THE PERIOD OF RECONSTRUCTION}

New Programs. - The heart of the world has been touched by the issues of the war. New hopes, new aspirations, and new faiths fill the world. Industry is leading the way in sensing the situation and taking steps to win the coöperation of labor in the common enterprise. There is developing a solidarity of interest between labor and capital which was not known before the war. This may well be taken as the motive of our social life. Coöperation is more and more supplanting the "irreconcilable conflict of classes."

Accompanying the peace treaty is a labor program that must have a salutary influence on all the countries affected by the war. All sorts of political programs are being suggested. The programs of one country are having an influence on other countries, as for example, the program of the British Labor Party on the United States. But if these programs are to be made effective, there are certain essentials to be kept in mind.

Centralization of Administration.-The up-building of public administration is perhaps the greatest need of the American democracy. Ordinarily we lose ourselves in the mechanism of administration; we cry for simplicity of governmental machinery. It is often urged that the condition of good public administration is centralization of administrative agencies. This is frequently a delusion. The principal argument used for the centralization of power is that responsibility is thereby developed. By increasing the power of administrators, by placing more employees under their direction, by giving them larger duties, the outward appearance of conflicting authority is avoided or the means of settling such conflict is provided. But a centralized administrative agency may be disjointed, chaotic, and divided. Esprit de corps or morale in a centralized or decentralized administration is the principal thing, and with either form of organization, efficient results can be secured. It is not at all clear 
that more efficient results can be secured with centralized rather than with decentralized agencies, particularly if, as in the draft administration, provision is made for supervision.

The argument for thoroughgoing centralization of administration is the argument for autocracy, always, however, on the assumption that the autocracy is going to be beneficent or that it can be effectively controlled. Supervised decentralization develops more good administrators and promotes greater attention to all the parts. Placing our faith in mechanism is misplacing it. It has been often said that able men can administer bad machinery to secure good results, whereas inefficient men will achieve poor results with the best machinery. The reliance on public administration must finally rest on trained men. With men well informed and experienced in their fields of knowledge, and actuated by a passion for public service, poor administrative machinery may be made to serve the beneficent aims of wise legislation. Incompetent men-not dishonest nor corrupt-only aggravate the conditions which law aims to improve.

The Civil Service Reform Movement.-That we recognize the problem of improving the public administration is abundantly indicated by the movement for civil service reform. And yet, the civil service movement does not meet the necessities of the situation. It has been primarily negative rather than positive. It has moved in the realms of ideals rather than of practical administration.

An indication of its lack of success is the fact that after forty years of effort the net result in the United States is that the federal Civil Service Commission is merely advisory to the President, who may at any time, by executive order, over-ride the principle of merit as the commission determines it; that of the forty-eight states, only ten are even nominally under civil service laws. A further indication of the practical failure of the Civil Service administration to-day is that there is a paucity of literature on civil administration. It is only recently that a textbook on "Public Administration" has been written, and that deals largely with the legal aspects of administration. The excellent beginning by President Goodnow, of Jobns Hopkins, on "Administrative Law" has not been followed up. Such literature, as we have, has grown spontaneously and largely independently of civil service commissions and of civil service reform associa- 
tion. Still another defect of the civil service reform movement is that it has failed to interest the new generation in its program and in its work. Its followers are largely the men who got their inspiration from Carl Schurz and George William Curtis.

The civil service reform movement, aided by the Civil Service Commission, must become positive and constructive. It must have a program that will help public administration to bear the new burdens that are placed upon it by making provision for the preparatory training for public service and for a continued training of men in the public service.

The civil service reform movement should provide that the books on civics in our common schools and high schools, and on political science in our colleges and universities, give adequate attention to the problems of public administration. It must stimulate and cultivate general popular appreciation of the importance of good administration and of its dependence on expert service. It must see that the conditions and compensation of public employment invite young men to make public service a career. It must urge and provide for the establishment of training schools for public service in our educational institutions.

Recognition of Importance of Public Administration.-Conditions during and after the war have emphasized the need for public administration. There is increasing recognition that inefficient government administration costs too much in money and in public welfare. The study of labor turnover in public administration would reveal the same wasteful conditions as in industry. The money loss is large and important, but is insignificant compared to the effects on public welfare.

We are realizing increasingly the enormous burdens that are placed on public administration by the additional powers assigned to government during the last decade. Not only has there been an expansion of government powers in new directions, but there has been increasing complexity in the functions that government has exercised for some time. Accompanying this expansion and growing complexity of government administration, delicate and subtle questions, which an older generation thought were beyond the sphere of government, have thrust themselves forward for solution, in the matter of industrial relations and public health.

We Train Men for All Callings Except the Public Service.- 
Secretary Lane brings into sharp contrast the idea of a trained public service and the conception of the public service that is prevalent in many quarters:

"One can't govern by divine inspiration though that seems to be the idea some people have. They seem to think that, inasmuch as we have erected a certain form of government, some benignant Higher Power will give to indolence and incapacity and ignorance a revelation by which our paths will be straightened and our work directed and done. I am constantly having men urged on me for office who never had a real thought and never have done a real day's work. Both their sponsors and themselves seem to think they can run a sort of wireless tower up into the air, send out a C. Q. D. or an S. O. S. and receive full instructions from some vast somewhere that will enable them to hold their jobs."

But how are we to get a trained public service? We have assumed that men need special training for the bar and the bench, for the press, and for every other skilled service in modern life, and yet we rashly assume that the men who are to control the conditions of our living in society need not be trained. President Lowell, of Harvard, in discussing this problem, has written an indictment of the educational system of the country:

"We no longer believe in America to-day that a man who has shown himself failly clever at something else is thereby qualified to manage a railroad, a factory, or a bank. Are we better justified in assuming that an election by popular vote, or an appointment by a chief magistrate, confers, without apprenticeship, an immediate capacity to construct the roads and bridges, direct the education, manage the finances, purify the water supply, or dispose of the sewage of a large city; and this when it is almost certain that the person selected will not remain in office long enough to learn thoroughly a business of which he knows little or nothing at the outset? In industrial enterprise, in business concerns, the use of experts of all kinds is, indeed, constantly increasing. They have revolutionized some industries, and are indispensable in many more. Nor do we merely seek for men who have gained experience in practice. In one 
profession after another we have learned to train them carefully in the theory of their work, taking them young and educating them for it as a distinct career. Sixty years ago, for example, there was scarcely a school of applied science in the country, but now they are everywhere, and they can hardly turn out students fast enough to supply the demand. They are ever adding new departments, while our universities are creating new specialized schools, and thus adding to the number of professions. We are training men to-day for all services but that of the public."

Shall we train for all callings and not for the public service? And yet it is into the hands of public servants that we put the direction of all the economic and social agencies and the regulation of the conditions of modern community life, railroads, street cars, factories, manufacturing, health, hours of labor and education. Shall we leave the administration of these in the hands of the amateur? Shall we train every sort of engineer except the city engineer? Shall we in the education of our lawyers neglect the teaching of practical administration, in spite of the fact that many will become the public servants of to-morrow? Shall we neglect in our medical schools the teaching of public health to the importance of which every community is now keenly alive? Is there, during the impending period of reconstruction, any more immediate social duty than to train men for the public service?

Training Teachers and Training Soldiers.-There are two fields in which we have recognized the need for training for service. We train teachers and we train soldiers. We have some splendid institutions for training teachers, but, by and large, American schools fail to meet the responsibility of education in a democracy. The slender pecuniary reward in teaching is an expression of our lack of faith in trained public servants whose work is indispensable to the present and future welfare of the nation. As Professor Thorndike warns us, "The society that lets incapables teach it, while its capable men and women feed, clothe, and amuse it, is committing intellectual suicide."

In training soldiers we provide a nation-wide machinery of recruiting for the army. We have West Point for training soldiers and Annapolis for training sailors. After four years of training at these institutions the graduates enter the army or 
navy. The army provides a definite program of continuous training for the subsequent ten years. During the war we utilized every method of modern education to make possible the expansion of the army. We were on the alert to pick men out for further training. During the war the enemy could be pictured; the danger was easily visualized; the machinery for creating public opinion could be effectively utilized for the purpose of developing trained men, because there was concrete need to save the country from the foe. In peace times, the problem is less obvious. But men of vision will see that the enemies of the nation, ignorance, poverty, disease, are nevertheless real, and that we need to utilize in combating them all the agencies of modern education. Perhaps training for civil service will be as fully provided as for military service. Perhaps public administration will seem as vital as military defense.

Learning by Doing.-The fear of those promoting the movement for the improvement of public administration has been that the theorizing and bookishness of the academic school would be carried over into this field. We should then produce doctrinaires, theorists, dreamers. But these dangers have been foreseen and the remedies have been clearly announced. A committee of college professors said:

"In this new educational movement another step must be taken-that of educating college authorities to the real nature of work in the social sciences. We are asked to interpret the life around us, asked to interpret it out of books which are antiquated before their ink is dry. We must demand greater opportunity to study our phenomena at first hand."

Training men for public service must be carried on by field methods. The pupil must learn by doing, not in the artificial environment of school or college, but in life, with its actual problems pressing for solution. There must be an intimate relationship between the university and the City Hall or the State Capitol. Practice must be vitalized by theory; theory must be reinforced and revised by practice. This new apprenticeship must be supervised in the interest of the student in training. "By doing his share in the associated activities," says Professor 
Dewey, "the individual appropriates the purpose which actuates it, becomes familiar with its methods and subject matters, acquires needed skill, and is saturated with its emotional spirit."

Colleges are beginning to realize this. The Western Reserve University has in its School of Applied Sciences a Division of Municipal Administration and Public Service in which this principle is recognized. Other examples are the Public Service Division of the College of Commerce and Administration at the University of Chicago, the School for Health Officers at Harvard University and the Massachusetts Institute of Technology, and the School for Commonwealth Service at the University of Oregon.

Democracy Demands the Best Tools.-It is urged that government by experts is bureaucratic. Does this criticism imply that the highly complex and technical functions of modern democratic government must not be performed by trained men? Must public service in these days of highly specialized technique be assigned to men unskilled in the required specialty? If we are serious about the business of democracy, we must believe earnestly, as President Lowell put it, that "democracy needs the best machinery that can be found, the best tools that can be discovered; and the best tool the world has yet produced is a highly trained human brain."

Only thus can democracy function or achieve its public purposes.

The Control of the Experts.-But the administration of public affairs by trained men does introduce the fundamental problem of control of the experts and the avoidance of tendencies to bureaucracy. To check this danger contacts between the expert and the non-expert must be provided. The experts must convince representatives of the public of the wisdom of their action. The laymen need not be specially trained in these fields, but they must be men of broad knowledge, of good judgment, and of critical sense. Ordinary provision for this interaction between the laymen and the experts is provided by a board of representative citizens in control of departments, or by political appointees, or by advisory committees on special subjects.

Even in present government, the machinery for the discharge of faithless or inefficient experts in the public service is simple 
and effective. Our public officers, the laymen charged with the responsibility of dismissal, should know of the service rendered by departments and should have the courage to cause the dismissal of public servants who are not adequately serving the community. Legislatures must take seriously their responsibility and control over administrative departments and must scrutinize requests for funds, not in terms of the expenditures of previous years merely, but in terms of service rendered by the department, and of current social needs. Budget making ought to be a searching inquiry into the activity of departments during previous fiscal periods. This is the heart of the democratic control of administration and unless it is performed with intelligence and upon adequate information we are risking the foundations of democratic government.

Service as Public Servant or as Citizen.-A final and seemingly conclusive argument is made against the case for a trained public service, and that is, can specially trained men get jobs in the public service? Let us assume that the trained men either do not enter public service or that they stay a very short time. Such men, trained primarily from the point of view of the public and having the public service at heart, can as laymen do much for the cause of government. At any rate, because of their knowledge, they can as citizens render a great service to public administration. They can infuse private business with a sense of social responsibility and the exclusive, anti-social conduct of business they control, at least, will be actuated by an attitude of coöperation with government.

In these times the opportunity for rendering service has a great appeal to men and women and undoubtedly large numbers will actually enter the public service. But public service must be so organized that it can hold these men; it must pay them adequately. The public service, like private business, must look after the welfare, continued training and opportunity for promotion of its employees and officers. Furthermore, distinguished public service should receive increasing public recognition. We must, in our schools and elsewhere, teach the opportunities and responsibilities of public office and public employment. We must develop community organizations to coöperate with the public administration.

The Future.-Walt Whitman, in addressing America, says: 
"The measur'd faiths of other lands, the grandeurs of the past, Art not for thee, but grandeurs of thine own,

Deific faiths and amplitudes, absorbing, comprehending all, All eligible to all."

This is very much the view of President Wilson. It is the view of all forward-looking people. It is the view of everybody who has faith in the future of America. But America will not serve this great purpose, will not be the vehicle of these unmeasured faiths and grandeurs unless another dream comes true, and that is the dream of ex-Justice Hughes: "My dream of America is America represented in public office by its best men. All laws and programs are vain without efficient and impartial administration." 



\title{
CHAPTER XIII
}

\section{THE CONSTITUTION AND POLITICAL PARTIES}

\author{
By Victor J. West ${ }^{1}$ \\ Professor of Political Science, Leland Stanford Junior \\ University.
}

While it is generally recognized that "reconstruction" will involve economic changes of far-reaching significance, the necessity for changes in our governmental organization is generally not quite so apparent. Nevertheless, before we have completed our program of reconstruction we are likely to witness readjustments in government of fundamental importance. If we are not forced entirely to recast our ideas respecting the proper sphere of governmental activity in general, we may at least be obliged to alter our conception of the relative scopes of the federal and state governments. There may have to be a new division of powers. Otherwise we can hardly expect to deal effectively over the whole United States with problems of conservation, transportation and industrial regulation, which no longer can be handled by the states alone, on the one hand, or, on the other hand, by the federal government alone under prevailing conceptions of its powers. Moreover, we may have to acquire a new set of ideas regarding the organization of our various governments - the relationship between the Congress and president, between state legislatures and governors, between the legislative and administrative agencies and the judicial tribunals. Perhaps we shall find ourselves obliged to incorporate into our system of government some such plan of legislative and execu-

${ }^{1}$ Ph.B., University of Chicago, 1905; instructor in politics, Northwestern University, I9IO-I9I3; assistant chief, Illinois Progressive Service, Chicago, I9I3; special investigator, Bureau of Efficiency, Washington, I9I8; teaching at Leland Stanford Junior University since 19I3, now Professor of Political Science; author, with Edgar E. Robinson, of "The Foreign Policy of Woodrow Wilson, 19r3-19r7." 
tive coöperation as characterizes the governments of England and France. ${ }^{2}$

Necessity for Amending the Constitution.-Proposals for these changes suggest the necessity for amending the Constitution of the United States. At the present time the probability of securing such amendment seems greater than it did a decade or so ago. Time was when the Constitution seemed, to many, an instrument practically unamendable except in those periods of great revolutionary feeling which produce violent changes. ${ }^{3}$ It was pointed out that up to the end of the first century after the adoption of the Constitution over I 800 propositions to amend that instrument had been offered in the Congress, of which only fifteen had been adopted. ${ }^{4}$ Of these, ten were framed in connection with the adoption of the main body of the Constitution. Of the remaining five one was made necessary by a defect in the method of choosing the president and vice-president which early became evident, and three of the others, almost the only changes in the Constitution since the days of "the fathers," were the result of the Civil War and were practically forced upon a large part of the nation.

Necessity for Changing the Process of Amending the Constitution.-So difficult was the Constitution to amend-such extraordinary majorities were required to adopt changes-that it seemed to be true that a minority, indeed a very small minority, of the voting population could "persistently and successfully" thwart "the well-matured, long and deliberately formed will of the undoubted majority." 5 That a democratic nation should continue to tolerate such a political anomaly almost passes credulity. Nor did this feature of our system escape criticism. In recent years it has been proposed frequently both in and out of Congress to change the process of amendment in order to secure a greater flexibility in our fundamental law. The most

"Frederick A. Cleveland, "Can Democracy be Efficient? The Mechanics of Administration," a chapter in Elisha M. Friedman's symposium, American Problems of Reconstruction, p. $4+7$ (I9I8).

${ }^{3} \mathrm{~J}$. Allen Smith, Spirit of American Government, ch. iv. (Ig07).

"Herman V. Ames, "The Proposed Amendments to the Constitution of the United States During the First Century of Its History," in Annual Report of the American Historical Association, 1896, Vol. II, p. 19.

${ }^{5}$ John W. Burgess, Political Science and Comparative Constitutional Law, Vol. I, p. 152 (I891). 
interesting and the most democratic of these is probably the one introduced in I912, under which the Congress, by a majority vote of both houses, might submit an amendment to the people which would go into effect after being adopted by a majority of the voters in a majority of the states. Amendments might also be proposed by ten states, acting either by popular vote or through their legislatures. ${ }^{6}$ There is enough difficulty in such a method to make it certain that no really fundamental change will be accomplished without adequate consideration. At the same time the method is obviously more democratic than the present one, and would undoubtedly make our Constitution a more flexible instrument of government, one which serves us instead of hampering us.

However, there have recently been some superficial signs that the Constitution is not so difficult of amendment as was at one time thought. The Sixteenth Amendment, the income tax amendment, was passed by the Congress in July, r9o9, and had been ratified by the necessary number of state legislatures by February, I9I3. The Seventeenth Amendment, that providing for direct election of senators, was ratified in even a shorter length of time; it was adopted by the Congress in May, I9r2, and its ratification was proclaimed a year later, May 3 I, I9I3. The prohibition amendment, the Eighteenth and latest, passed the Congress December 3, I9I7, and was proclaimed January 29, 1919. Three amendments in the space of ten years seems to suggest that the amending process itself is not so difficult. Nevertheless it may be pointed out that over four hundred reso-

"The text of this proposal is as follows: "The Congress, whenever a majority of both Houses shall deem it necessary, or on application of ten States by resolution adopted in each by the legislatures thereof, or by a majority of the electors voting thereon, shall propose amendments to this Constitution to be submitted in each of the several States to the electors qualified to vote for the election of Representatives, and the vote shall be taken at the next ensuing election of Representatives in such manner as the Congress prescribes, and if in a majority of the States a majority of the electors voting approve the proposed amendments and if a majority of all the electors voting also approve the proposed amendments, they shall be valid to all intents and purposes as a part of this Constitution." Introduced by Senator R. M. La Follette, August 5, roI2. Congressional Record, Vol. XLVIII, p. IoI77.

"Mr. Frederic J. Stimson, speaking of this proposed amendinent in I907 said, "I doubt ... whether such an amendment would be agreed to by three-fourths of the states." Frederic J. Stimson, The American Constitution, p. 2I I (IgOS). 
lutions proposing amendments were introduced into both Houses of Congress during that time. ${ }^{8}$ Moreover, it should be noted that the attempt to make possible a federal income tax was at least twenty years in coming to fruition, while the direct election of senators was proposed nearly a century ago and advocated continuously during the thirty years' period previous to its adoption, nearly every state in the union having adopted resolutions asking for such an amendment. ${ }^{9}$ The long struggle for prohibition is too well known to lead any one to suggest the adoption of the Eighteenth Amendment as an example of quick and easy constitutional change.

It seems probable therefore that we shall be obliged to make some such change in the amending process as has been suggested above before we can make the Constitution more responsive to public needs. A public movement to stimulate interest in such a change would be an effort worthy of the patriotism and statesmanship of our most gifted leaders. The proposal of I9I2 needs to be brought forcibly to the attention of the voters of the United States.

The Alternatives to Change by Amendment.-The alternatives to changing the amending process in order to secure more easily some desirable revision of the Constitution are either wholesale revision by a convention called for that purpose by the Congress at the request of the legislatures of two-thirds of the states, as the Constitution provides, or continuation of the process of judicial interpretation with its manifest inequalities and uncertainties. The former, if not out of the range of probability entirely, seems of exceedingly doubtful practicability. It is asking a great deal more of the state legislatures that they apply for a convention with unlimited power to propose amendments than that they vote "yes" or "no" on amendments already proposed by another and independent body. Moreover, it may be urged that a proposal for wholesale revision is unwise. If the convention should present a complete new constitution its acceptance

${ }^{8}$ Of course, in many cases the same subject was covered by several resolutions, and most of the proposals were reintroduced in the same form in each of five Congresses. Perhaps these four hundred resolutions represent about forty distinct proposals to amend.

${ }^{\circ}$ Charles A. Beard, Amcrican Government and Politics, p. 242 (1910); Frederic J. Stimson, The American Constitution, p. 208 (Ig08). 
would be extremely unlikely in view of the traditional prestige of the present instrument. There would be greater possibility of accomplishing needed changes by submitting one proposal at a time, each at a separate election. For, indeed, it is not claimed that the Constitution is in need of change in more than the few particulars noted generally above.

Of those purposes which must be accomplished by constitutional amendment some, even if desirable, have no immediate and direct connection with problems of reconstruction. Such, for example, are the proposals for direct election of the President and of judges of the United States courts and for lengthening the terms of office of the President and of the members of the Fiouse of Representatives. Others, looking for the most part to direct exercise of police power by the Congress, are of utmost importance in the readjustments of the very near future. Such, for example, is the recently adopted prohibition amendment. In the same class are the proposals to confer power on the Congress to deal with industrial disputes, with the labor of women and children, with manufacturing, with negotiable instruments, with marriage and divorce, with the conservation of water power and of mineral and other natural resources-in brief, those fields of activity in which state regulation is admittedly inadequate, on account either of lack of uniformity or denial of power, and in which it is necessary that the nation, either by itself or in coöperation with the states, may legislate effectively. These are matters which the Congress is now probably powerless to control through any means at its disposal; if the Congress is to act with respect to them the Constitution must be changed.

Limitation Set by the Judiciary to the Exercise of the Police Power by Congress. - The Congress may now exercise police power only indirectly-except in the District of Columbia and in the unorganized territory of the United States. The chief means in its control for the indirect use of police power are found in its powers to regulate interstate and foreign commerce, to lay and collect taxes, and to establish and maintain a postal system. The last named is of very limited usefulness for the purposes in view. Though effective as a means of eliminating many wrongs, it does not-as has been suggested-go so far as to make "the very act of using the mails a sufficient foundation 
for bringing any person, firm or corporation within the sphere of federal control." ${ }^{10}$ The most that can be done is to deny, either by fixing rates or by outright fiat, the use of the mails for certain purposes.

The extent to which the Congress may go under the power to tax is as yet undetermined. Taxation was employed effectively to regulate the manufacture of oleomargarine and the issue of notes by state banks. Undoubtedly there are wide possibilities in its use, for, subject to the limitations that the Congress is not free to use every kind of tax and that, in general, taxation must be uniform, it would seem that "the legislative authority may resort to the power of taxation for any motive which seems to it to be proper." 11 The power of taxation may prove to be the most useful means of dealing with the problems of conservation and for controlling manufacturing and matters incidental to manufacturing, e.g., the labor of women and children.

Heretofore the chief power invoked by the Congress when it has sought to act in the interest of the public health, safety and morals has been its control over commerce with foreign nations and among the several states. Under this grant it has dealt with contracts, combinations and conspiracies in restraint of trade ( 1890 ), with the traffic in lottery tickets (I895), with the adulteration and misbranding of foods and drugs (1906), with the traffic in women for immoral purposes (I9IO) - the statutes on these being directed against persons and corporations engaged in interstate business. And in the regulation of carriers and matters incidental to carrying, the enactments include not only the establishment of the Interstate Commerce Commission with its powers over rates and services, but also the regulation of hours of labor, employers' liability, safety appliances, etc. ${ }^{12}$

For some years it seemed, indeed, that the commerce clause was the royal road to the police power. A distinguished student had observed, ". . . If, under the interstate commerce clause, the federal government is to control, not only commerce itself,

\footnotetext{
${ }^{10}$ Henry L. West, Federal Power. Its Growth and Necessity, p. 132 (I9I8).

${ }_{11}$ Frank J. Goodnow, Social Reform and the Constitution, p. 275 (IIII).

${ }^{2}$ James T. Young, The Nea American Government and Its Work, ch. ix (19I5); Henry L. West, Fedcral Power; Its Growth and Necessity, ch. vi-viii (1918).
} 
but the persons who conduct it and the fortunes which are in part derived from it, it may as well control the marriages of the parties thereby enriched and the legacies they may leave to their children. There is no bound or limit to this path short of absolute control by Congress of the people and all their domestic affairs." 13 This is a rather extreme view and must be put down to the author's somewhat justifiable alarm over the rapid expansion of Congressional power at the time he wrote. For it is apparent now-as it must have been then-that it is one thing to fix hours of labor on interstate railways and quite another thing to determine conditions of marriage for persons engaged in interstate commerce. Indeed, the Congress seems to have approached very nearly the limit of its powers in this direction. The Supreme Court has stated the principle very broadly thus: "It is of the essence of this power (i.e., to regulate interstate commerce), that where it exists it dominates. . . The fact that carriers are instruments of intrastate commerce, as well as of interstate commerce, does not derogate from the complete and paramount authority of Congress over the latter or preclude the federal power from being exerted to prevent the intrastate operations of such carriers from being made a means of injury to that which has been confided to federal care. Wherever the interstate and intrastate transactions of carriers are so related that the government of the one involves the control of the other, it is Congress, and not the state, that is entitled to prescribe the final and dominant rule, for otherwise Congress would be denied the exercise of its constitutional authority and the state, and not the nation, would be supreme within the national field." 14 Thus rates may be determined for intrastate shipments when the relation betwcen state and interstate charges are so close that the former aifect and influence national trade. Some years earlier, in a clearer case but by the same reasoning, the Federal Safety Appliance Act of 1903 was held to apply to vehicles used in moving intrastate traffic. ${ }^{15}$

The power of the Congress over carriers is very wide but it is not complete. The railroads do not escape regulation of course

${ }^{13}$ Frederic J. Stimson, The Amcrican Constitution, p. 213 (1908).

${ }^{14}$ Houston Railway Co. v. U. S., 234 U. S. 342, at 25 I (1914). Justice Hughes wrote the opinion.

${ }^{15}$ Southern Railway v. U. S., 222 U. S. 20 (I9II). Justice Van Devanter wrote the opinion. 
-between the Congress and the state legislatures they are in fact over regulated. The difficulty now is in determining just when the states are entitled to act. In this particular field a proposal to amend the Constitution to take away from the states what power they have and confer on the Congress complete power over all railroads meets with considerable favor. It is possible, however, that judicial interpretation may yet accomplish the same end. The Congressional power over navigation is much wider than its power over commerce by land, indeed so wide that the distinction between interstate and intrastate navigation has practically disappeared. It is true that recently this has been made to rest to some extent on the maritime jurisdiction of the federal courts rather than on the interstate commerce clause. Yet its early extension was based on the latter and the logic of the early cases, if followed consistently, would have resulted in all probability in the recognition of as wide and complete power in the Congress as it now enjoys. ${ }^{16}$ The same reasoning applied to commerce by land would result in the same extension of power.

In the matter also of police regulations not concerned with the incidents of transportation but with the subjects of commerce and the methods of business the Congress has apparently gone as far as possible. The attempt to reach the evil of child labor by prohibiting the products of child labor to pass into interstate commerce met with failure when, by the narrow majority of five to four, the Supreme Court declared the Child Labor Act of I9I6 invalid. ${ }^{17}$ The principle by which the limit of Congressional action is determined is well stated by the court: "In each of these instances (i.e., the laws respecting lotteries, impure food and drugs, white slavery, etc.) the use of interstate transportation was necessary to the accomplishment of harmful results. In other words, although the power over interstate commerce was to regulate, that could only be accomplished by prohibiting the facilities of interstate commerce to effect the evil intended." That is, the Congress may not prohibit interstate commerce in anything which in itself is harmless and from the

\footnotetext{
${ }^{10}$ Frank J. Goodnow, Social Reform and the Constitution, pp. 39-75, (IgII).

${ }_{12}$ Hammer v. Dagenhart, 247 U. S., 25I (I9I8). Justice Day wrote the opinion. The dissenting opinion was written by Justice Holmes and was concurred in by Justices McKenna, Brandeis and Clarke.
} 
transportation of which from one state into another no harm results. It should be noted, however, that the very strong dissenting opinion declared that "it does not matter whether the supposed evil precedes or follows the transportation. It is enough (i.e., to support that action of Congress) that in the opinion of Congress the transportation encourages the evil." The change of one member in the personnel of the Supreme Court might change the views of the court on this subject.

There is another avenue open to the Congress by which it might arrive at the goal of federal regulation of industry and commerce. That is its power to charter corporations to carry on an interstate business. It has been argued, with an imposing citation of precedent and authority, that the Congress has power to create corporations not only to engage in transportation between states, but to engage in interstate business, i.e., buying and selling, and incidentally to that business to engage in manufacture, and once having created such corporations to exempt their operations from any state regulation. It is believed that the Congress has the power to license individuals for the same purposes that it could charter corporations, and thereafter control them for such purposes in the same way. Operating thus by incorporation and license, so it is claimed, the "Congress has full constitutional power to create a system of interstate commerce under complete federal control, to include within that system the manufacture or other production of goods to be passed in such commerce, and to protect this system, in all its details, from any species of state interference." 18 If this conclusion is sound it would seem possible for the Congress to assume control not only of child labor, but of all other labor problems, and to fix not only the conditions under which interstate transportation is carried on but also the conditions under which articles intended or likely to pass in interstate trade are manufactured.

Significance of the Attitude of the Supreme Court in the ChildLabor Case.-Perhaps, therefore, it is just as well that the Supreme Court has taken the stand indicated by the child labor decision. It may be that before permitting the Congress to adopt a long list of suggested proposals for federal legislation ${ }^{18}$ Frank J. Goodnow, Social Reform and the Constitution, ch. iii (I9II). 
we should pause and consider carefully whether we really wish the Congress to go any further in the fields heretofore left to the states. If the Supreme Court should now take the same view with respect to the extension of power by way of taxation, incorporation, etc., as it has regarding the use of the interstate commerce power, we should be obliged to confer additional jurisdiction upon the Congress by the process of amendment. This would have the great advantage of forcing these fundamental questions before us in such a way as to stimulate public discussion, because on their solution public opinion might have some influence. Moreover, it would be far wiser to permit the Congress to march boldly down the open road of a definite constitutional grant of power toward the admittedly desirable goal of federal control of some matters, rather than to force it to proceed furtively, first by one path and then by another, behind the cover of subterfuge and very largely in the dark of judicial vagueness, toward the undoubtedly undesirable goal of complete federal control of all transportation, trading and manufacture.

This brings us to another phase of the problem. Our babit of looking to the courts for the interpretation of the Constitution, our clumsy process of amending that instrument, and our practises in the matter of the time of holding elections, effectually preclude the possibility of true public discussion of the most vital of public questions. With elections coming at fixed intervals whether there is a true issue to be fought out or not, with amendments made by legislative bodies chosen for other purposes, and with legislation approved and disapproved, advanced and halted, by a tribunal so far removed from popular control that it might almost as well be on another planet, there is little opportunity for positive control of public policy by the voters. What problems of reconstructoin were discussed during the election of rgr8? Yet the Congress elected at that time will be obliged to deal with little else. In what elections and in how many districts was the question of national prohibition a determining or even a contributing factor in the election of members of the Congress or of the state legislatures? That amendment was adopted by a Congress which had no mandate of any sort to do so and ratified by state legislatures whose election in 
scarcely any case depended upon the views of the candidates respecting national prohibition.

Therefore it will be a good thing to focus public attention upon the necessity for amending the Constitution in certain particulars. For it will force those great engines for converting public opinion into public policy, the political parties, to stand for something definite. If it is impossible to distinguish Democrats from Republicans nowadays, even by the names they call each other, it is partly because, though all members of the Congress are generally either Democrats or Republicans, they are elected at times when it pays both sides either to be non-committal or to advocate the same thing, and partly because on many really vital matters which depend on Constitutional interpretation the parties have almost no chance of controlling the results. In other words, it is so easy for a party to escape responsibility for public policy that parties do not assume it. Parties do not have to stand for anything in particular and therefore they do not do so. For this reason our elections are meaningless.

Discussion of Public Questions Is Often Meaningless and Rarely Effective.-Alone of the great free peoples of the world the Americans, with their genius for politics, have failed to understand the place and purpose of parties in national life. Even our political leaders, though they were violently partisan, have rarely understood the inevitability and necessity of parties or the true purposes of parties. The exceptions are so conspicuous as to make the general attitude only the more obvious. Nobody was more surprised than the Democratic majority in the 63d Congress when its titular leader forced it, through three sessions, to enact-not completely, it is true, but in its most important features-the program of legislation which as a party it had advocated in a purely perfunctory fashion in the preceding campaign.

The solutions of the great problems of our future, involving Constitutional changes and Congressional enactments of farreaching consequence, ought not to be undertaken without public discussion. They can only be discussed with valid purpose if the existing parties or some new parties take them up and make of them party programs. Parties will not do this-except spasmodically-as long as they have no true responsibility. Parties cannot be held responsible in this country until a change is 
made not only in the particulars noted above but also in the relations between the executive and the legislative branches of the national government. Direct primaries, abolition of the spoils system, corrupt practices legislation, etc., may cure some evils of partisan politics, but they do not reach the heart of the situation.

Party Leadership Is Not Identical with Responsibility and Power.-The difficulties of the American party system and its contrast with other systems has been well expounded by an able observer who sums up his argument in these words: "The party organization has existed outside the government and from its exterior position has sought to control the government. The party has not been organized in the government, as the English party is organized within the English government. In England there is identity of party leadership with governmental responsibility and power." 19 This statement hits the center of our problem. Party leadership, the chief influence in winning elections, is organically unrelated to the governmental responsibility for carrying out the program on which the election was won, because it is exceedingly difficult for party leadership to identify itself with governmental responsibility when governmental responsibility is divided. Party leadership in order to be in the government, in our system, must be either in the Congress or in the President; it cannot be in both at once. Because it is at any given time in only one of the coördinate branches of our government party leadership is likely to be ineffective in the other branch. That it is otherwise is mostly accidental. It is much more effective if it stays outside the government and influences both branches. What is needed is a closer coopperation between the Congress and the President resulting from a change in our system which would make it unnecessary for an unofficial and irresponsible party organization to operate outside the government.

Proposals to Correct This Defect.-Heretofore proposals to accomplish this coöperation have usually assumed that the chief necessity was that the members of the cabinet, i.e., the heads of the executive departments, should have the privilege of appear-

${ }^{19}$ Andrew C. McLaughlin, The Courts, the Constitution and Partics, chs. ii and iii (1912). See also Frank J. Goodnow, Politics and Administration, ch. vii, (1900). 
ing before the Houses of Congress, to present a budget, to propose legislation, answer questions and defend the conduct of their departments. ${ }^{20}$ It would seem that the Congress might, by change in its rules, permit executive departments certain rights on the floor of the two houses just as they now have from time to time before the various Congressional committees. However, if such privileges are to be made secure to cabinet members against the whims and vagaries of Congressional pride, an amendment to the Constitution is necessary, an amendment which would break down absolutely the principle of the separation of powers, and leave before us all the possibilities of the parliamentary system.

It may be pointed out that the proposal to "gear in" the executive with the legislative branches of our government by changing the rules of the Congress to permit examination of and explanation by cabinet members on the floors of the two houses ${ }^{21}$ is defective in two important particulars. In the first place it would not bring together the responsible leadership in the Congress, the committee chairmen, with the responsible leadership in the executive branch of the government, the President. It would bring the President's advisers and executive agents into the presence of the Congress and there would undoubtedly be gain in the increased opportunity for criticism and public debate. But it would not take away the necessity for private consultation between the President and the committee chairmen for the purpose of reconciling differences. In other words, it does not provide for the "identity of party leadership with governmental responsibility and power." It may be inquired: What would happen if the Congress should disapprove entirely of a program submitted by the cabinet or by a single department head? Would the secretary or the cabinet resign? Certainly not; the heads of administrative departments are responsible to the President, not to the Congress. If we are to have a "responsible" cabinet it must be-as long as our elections occur at fixed intervals-responsible to the Congress and through

${ }^{20}$ Edward A. Fitzpatrick, Budget Making in a Democracy, chs. viii, ix, (I918).

${ }_{21}$ This proposal is ably expounded by Frederick A. Cleveland, "Need for Readjustment of Relations between the Executive and Legislative Pranches of Government," in, Frederick A. Cleveland and Joseph Shafer, Democracy in Reconstruction, pp. 423-446 (1919). 
the Congress to the people. Therefore it must be made up of persons over whom the Congress has some control directly. It must be apparent that the suggested plan would, in case of disagreement between executive and legislative branches, only serve to emphasize the separation between them instead of to bring them together.

In the second place, it would not relieve the President of the necessity of appointing heads of departments for political reasons and for purposes connected with the enactment of an administration program of legislation. Sound principle would require that such officers be chosen on account of their experience and qualifications for supervising the performance of the functions of the respective departments. As long as responsible and open connection cannot be established between the legal and political leaders of the two branches of the government, the President, if he is to have effective influence in the shaping of public policy, is obliged to secure support for his program in the best way he can. The resort to the expedient of using the heads of the departments for this purpose and at the same time expecting them to be the most efficient and expert administrators of the public service is the greatest political error of which we are guilty. The two qualities rarely go together. If a cabinet member succeeds in one purpose he inevitably fails in the other; usually he succeeds only indifferently in either.

There is the third objection to the scheme; it requires the Congress to further subordinate itself to the President in the matter of initiating legislation. This is not only asking considerably more of the Congress than can reasonably be expected of it, but also is entirely contrary to the interit and spirit of democratic institutions. Democracy demands not only control of the activities of the government by the people through the branch of government nearest to the people, but also that the control be positive. The Congress through a responsible leadership ought to take the initiative in legislation.

There is an alternative to this method of securing better coöperation between executive and legislature which is rarely suggested or, when suggested, dismissed as impossible. There is nothing to prevent the President from choosing his advisors, his cabinet, from among the members of the Congress. The character of the "cabinet" as a body is not determined by the 
Constitution; it might be made up of the leading members of the Congress, particularly the heads of the important committees, or of such committees, to the numier of ten, as are most intimately concerned with the work of the respective administrative departments. There would be no legal objection to such advisors, or cabinet members, having offices in the respective departmental buildings, and, with the backing of the President, directing the broad general features of departmental policy.

Advantages of a Congressional Cabinet.-Such a change would be revolutionary but the results would justify it. Apparently it would accomplish the desired coöperation, and in a way to emphasize the responsibility of the party in power. In addition it might be expected to produce two other desirable results. In the first place, the executive heads of departments could be chosen without so much regard to their political qualifications. They would be primarily administrators and would give their attention to securing efficient public service rather than to advising on questions of public policy and to advocating and defending the policy of the administration in the Congress and elsewhere. The public service would be aided in another direction; the intimate connection of influential members of the Congress with the affairs of the departments would inevitably enlighten the rest of the Congress on the fundamental necessities of sound administrative organization and practice. Haphazard, almost wanton, Congressional interference with appointment and routine might be expected to disappear.

In the second place, the Congress might be expected to assume the position in our system which the legislative branch in a democratic state should enjoy, i.e., a position of dominance in the formulation and direction of public policy. When the Congress, through the influence of its leaders with the President, exercised some real control over the administration, as well as over the enactment of laws, and when the enactment of new public policy by the Congress followed from the consultations of its own leaders with the President, and not from the deliberation of a body outside the Congress, then a seat in the Congress might once more become an ambition worthy of gifted aspirants for public honor. And, moreover, the Congress would become once more the arena of political contest-we might expect our great leaders to develop there and the debates to take 
on an importance worthy of a body representative of a selfgoverning people. Criticism would be effective because directed at the persons responsible for the public policy. Competition for positions of leadership-the chairmanships of the committees-would become spirited; no longer would ambitious incoming members be content to permit the rule of seniority to crowd them into the background.

The details of the scheme here outlined need to be worked out, and some of the advantages claimed for it may require to be further demonstrated. But its chief merit should be obvious -it would centralize responsibility for the direction of public policy. Thus it makes it possible for party leadership-through Congressional majorities-to identify itself with this responsibility. The great desideratum, party responsibility inside the government, would thus be secured. No longer could a majority party escape responsibility for either legislation or the direction of administration. No longer could parties possibly remain without programs of legislation. It should therefore be apparent that no consistent program of reconstruction has any chance of being formulated, much less adopted, unless it is worked out in the councils of responsible parties.

Summary.-To summarize, then, this discussion of the constitutional and political phases of reconstruction, we may point out that (I) some important features of reconstruction cannot be accomplished without an addition to the powers of the federal government; (2) the Congress has probably reached the limit of its powers by the process of judicial expansion of the Constitution; (3) change in the Constitution to grant new powers, and constructive legislation to solve the great problems before us ought not to be undertaken without adequate public discussion; (4) discussion is probable only where the parties assume the responsibility for formulating and advocating consistent programs of public policy; (5) party responsibility for both legislation and administration can be secured only by better coöperation between the President and the Congress; (6) the way to secure this coöperation is to abandon in practice the idea of separation of powers and give the Congress greater direct control over the government. 


\title{
CHAPTER XIV
}

\section{DEVELOPING THE AMERICAN SPIRIT}

\author{
By Graham TayloR ${ }^{1}$
}

President, Chicago School of Civics and Philanthropy; Resident Head, Chicago Commons Social Settlement

The spirit of a people like that of a person is as intangible as it is real. "Spirit" is descriptive, not definitive. It describes life, which cannot be defined-and more. For, spirit describes life reacting upon its environment. There is in it much, if not all, of life and its antecedents and surroundings. It is not only the atmosphere of life, but includes the influences which cause the life to react. In it are not only successive states of mind and feeling, but the temper and the tendencies of the times and the standards and ideals which they beget. Spirit is dynamic, not static-a moving equilibrium. As old George Herbert long ago divined:

\section{"Man is all symmetrie,}

Full of proportions, one limbe to another,

And all to all the world besides:

Each part may call the farthest, brother:

For head with foot hath private amitie,

And both with moons and tides."

The Spirit of a People.-More than the sum of all its parts is the spirit of a people. It is not an accumulation, nor an aggregate, nor a composite, but a third something, a product of

${ }^{1}$ A.B., Rutgers College, 1870, A.M., 1873; D.D., I888; pastor, I8731892; professor, social economics, Hartford Theological Seminary, I888-92, Chicago Theological Seminary, I892-; founder and resident warden Chicago Commons Social Settlement, $1894-$; president, Chicago School of Civics and Philanthropy Ig08-; author and contributor to magazines. 
inter-action, of an ever blending process, the trend of innumerable, inextricable influences and elements, both subjective and objective, both obvious and incalculable, both transient and permanent. Its group expressions we call "the family spirit," "the spirit of the house," "the class spirit," "esprit de corps," "morale," "public sentiment." But the spirit of a people is more than all these, and is even more than their national spirit.

The American spirit demonstrates this. "Separatists" from church and state, most of the early colonists were called and called themselves. And yet they showed how reluctant they were to separate themselves from their old home ties by calling the new towns they built and the new states they founded after the old ones in which they were born and brought up. They called the very land of the new world a new England and christened a new Hampshire, a new London, a new Bedford, a new York, and many another new town with the old mother names. So the French colonists claimed their new Orleans, the Dutch their new Amsterdam. All over the continent this rechristening has gone on, as one nationality after another has replanted its old home ties here. The new world end of their lines of descent was thus connected with the old world source of their origin and heritage. These early memories, ideals and aims, though often obscured, were never entirely lost even while the pioneers were absorbed in the conquest of the continent, and their successors in the development of our material resources.

The Give and Take of Independence.-No more self-contained has the spirit of America been in its results than it has been independent of its sources. Just as much of its independence came from others, so also much of it has gone to others. Our Declaration of Independence and some of the very words in which it was embodied root back in the forerunners of revolutionary France, and still further back in the souls of Britain's great commoners, who believed what John Locke declared eighty-six years before Thomas Jefferson wrote America's Declaration: "Men being by nature all free, equal and independent, no one can be put out of this estate and subjected to the political power of another without his own consent."

Back to the lands which gave it birth, and to many another, the spirit of American independence has gone to pay its debts to the old world's peoples struggling for liberty. Without its 
reflex influence neither the French republic nor Britain's democratic politics and colonial policies can be accounted for. Without the refluent tides of immigration flowing past Liberty Enlightening the World, it is hard to account for the spirit and hope which have incited Russia's half-emancipated serfs to supplant their czar by their soviets, and the Poles to renew their age-long struggle for independence, and the Czecho-Slovaks to unite in their republic. Even the return of a few Italian and Slavic emigrants to their native villages is said to have initiated the transformation of living conditions. The new internationalism which is welding nations, great and small, into a league that may prove to be the parliament of peace and the federation of the world is the strangest of all the world influences exerted by America, which has been the most individualistic and isolated of all the great peoples of the earth.

A New American Consciousness.-The world war registered the birth of a new American consciousness-national and international. Hitherto we have been more conscious of having a country than of being a nation, of having a cosmopolitan population than of being one people. We natives have thought of our foreign-born populations, vast as their proportions have become, more as industrial assets or liabilities than as the fiber entering into the warp and woof of our national fabric. Foreign-born voters have been considered less as constituent elements of our permanent political life than as the temporary gains or losses of our political parties. We knew that there were Italians, Poles, Bohemians, Russians and people of many other nationalities among us, but as a nation we have hitherto known little and cared less about Poland, Bohemia and Russia and the other oppressed countries whose exiled people were our neighbors, employees, business associates, fellow citizens and friends.

Our World-Consciousness Dawning.-We have been self-conscious, but nationally only semi-conscious and internationally almost unconscious. But the world war has suddenly awakened us to the consciousness that many nationalities living in the land do not constitute one nation and that our nation is only one of many peoples having to do with each other in the family of nations. Thus our world consciousness is dawning upon us. As the discovery of America, by disclosing the other third of the earth, awakened Europe to the extent of the world, so the threat- 
ened destruction of Europe awakened America to a new appreciation of its own spirit and to a new consciousness of dependence upon the spirit of other peoples. The life and death struggle of free peoples abroad has intensified our consciousness of the liberty we have at home, but only to arouse us to see that our freedom cannot stand alone. As Abraham Lincoln reminded our fathers that this country could not exist "half slave and half free," and sent them into the struggle for the union of the states, so Europe's war for freedom shocked us into realizing that liberty cannot survive on earth with the world half enslaved by autocracy and half free in democracy. Thereupon we made common cause with all free peoples. Then the world war became our war for our own freedom and for the world's.

New Appreciation of Undervalued Assets.-Rich and varied are the heritages which all the foreign-born bring with them from the old world to the new. Short-sighted and foolish we have been and still continue to be in discouraging and even repressing them in cherishing the value of their own speech and song, their folk-lore and their folk-games, their love of liberty and their patriotic passion to free their fatherlands and to enjoy and defend their American freedom.

The enlistment and selective service experience which came with the war was like the rediscovery of America both to our foreign and native-born people. The passionate hope of the Poles for the independence of a free Poland was fanned into a flame of devotion to American independence. Their sons at first flocked to the colors, paused to take out their first papers, so that they could enlist as Americans, and then when debarred by being technically "alien enemies" because subjects of Austria, they marched away in legions to join the Polish national army. So the Bohemians and other sons of free Slavia drew from America their own inspiration to incite their fellow-countrymen across the seas to break the Hapsburg yoke which so long had held together in bondage their monstrously incongruous and tyrannous empire. So, too, Americans of Italian, British, Armenian, Greek and even Turkish birth responded to the call to arms in a way that surprised all America and amazed all Europe.

Spirit of the Draft.- In his second report on selective service, Provost Marshal General Enoch H. Crowder thus graphically describes this great national experience: "Truly we were the 
melting pot of the world; and the cosmopolitan composition of our population was never more strikingly disclosed than by the events of the world war. Then the melting pot stood in the fierce fires of the national emergency. And its contents, heated in the flames, either fused into the compact mass, or floated off as dross. The great and inspiring revelation here has been that men of foreign and native origin alike responded to the call to arms with a patriotic devotion that confounded the cynical plans of our arch-enemy and surpassed our own highest expectation. No man can peruse the muster-roll of one of our camps, or the casualty list from a battlefield in France, without realizing that America has fulfilled one of its highest missions in breeding a spirit of common loyalty among all those who have shared the blessings of life on its free soil. No need to speculate how it has come about; the great fact is demonstrated that America makes Americans."

But General Crowder is not unmindful of the fact, to which the whole country was rudely awakened, that "thousands of friendly and neutral aliens, who refused to aid their adopted country in time of need, had made the United States their home for many years, had acquired a comfortable livelihood and had enjoyed to the fullest extent the benefits and protection of our country."

Slackers they were indeed, but so all the rest of us have been in our care and concern for our immigrant people. We have been so slack in the care and the information we have given to multitudes of our foreign-born neighbors that when we needed their citizenship and soldierly service we discovered for the first time our folly in leaving so many of them to be "aliens" so long. They have been slack in taking out their papers because we have been slack in not teaching, encouraging and urging them to do so. We have left the ward politician, the paid retainers in political campaigns and the liquor interests to prompt and guide too many of them as to their citizenship. Prior to the war few besides those who had a personal, partisan, political or financial interest in "making citizens" took any effective interest in the Americanization and assimilation of our cosmopolitan population.

In charging a jury in a trial of an alien-born citizen under the espionage act, Federal Judge Amidon of North Dakota issued 
his own confession of neglect in a warning to the whole country. Addressing the prisoner, he said: "I do not blame you and these men alone. I blame myself. I blame my country. We urged you to come. We welcomed you. We gave you opportunity. We gave you land. We conferred upon you the diadem of American citizenship. And then we left you. We paid no attention to what you have been doing. And now the world war has thrown a searchlight upon our national life, and what have we discovered? We find all over these United States, in groups, little Germanies, little Italies, little Austrias, little Norways, little Russias. These foreign people have drawn a circle about themselves, and, instead of keeping the oath they took that they would try to grow American souls inside of them, they have studiously striven to exclude everything American and to cherish everything foreign. The figure of my country stands beside you to-day. It says to me, 'Do not blame this man alone. I am partly to blame. Teach him, and the like of him, and all those who have been misled by him and his like, that a change has come.' There must be an interpretation anew of the oath of allegiance. It has been in the past nothing but a formula of words. From this time on it must be translated into living characters incarnate in the life of every foreigner who has his dwelling-place in our midst. It does not mean simply that you will not take up arms against the United States. It goes deeper far than that. It means that you will live for the United States and that you will cherish and grow American souls inside of you."

The Spirit to Assimilate.-This war experience calls for a consistent and effective national policy for naturalizing, educating and assimilating the strangers within our gates who seek the right to live and labor with us. It is unjust, alike to the individual alien, to this country and to the country whence he came, to allow a man to expatriate himself without declaring his intention regarding his citizenship. He should be required, therefore, within a reasonable period either to qualify as a citizen of the United States or give good reason to the government why he should be permitted to remain in this country as an alien. The justice of such a requirement has been demanded not only by native-born and naturalized citizens, from among whom an undue proportion of drafted men had to be drawn, but also has 
been affirmed by not a few of the foreign-born who neglected naturalization or were neglected by those who should have represented the nation in inducting them into citizenship.

This may be done far better, without the compulsion of threatened deportation, or of the industrial boycott and blacklist, by due process of law, which must draw more than it drives, if aliens are to become good citizens. All school teaching should be required to be in the English language and from English texts. Every incentive, facility and urgency to learn English and prepare for citizenship should be brought to bear upon every adult foreign-speaking inhabitant. To do so with the avowed or implied intention to suppress the use of their native speech is sure to meet with failure and resentment. How else can we at first impress them with their interest and ours in becoming English-speaking American citizens, except through the only language which they understand? How can we avoid arousing their suspicion that they are being subjected to the same cruel suppression of their natural instincts here in America as they have suffered in the suppression of the Polish language by Germany? What could make them more reluctant to become citizens with us than the threats of employers to make an unreasonably speedy knowledge of English a condition of employment, or than the menace of extreme measures to prohibit the public use of any language but English in the press, on the platform and in the pulpit?

Far more effective will it be for the American spirit to express itself in fraternizing with our foreign-born neighbors and in affiliating their great racial organizations. Let the widest and most sympathetic hearing be given by English-speaking Americans to the expression and interpretation of the spirit and aspirations of all foreign-born and foreign-speaking peoples among us. Let the press give widest publicity to their struggles here and abroad for liberty and progress. Let their best spokesmen be invited to speak at American patriotic meetings to interpret them to Americans, while America is being interpreted to them. Thus through our own and their own speech and song may we best impress and be impressed with the worth and glory of American citizenship.

To this end all support should be given to the efforts being made to correlate, standardize and bring into closest coöperation 
all official and voluntary agencies seeking to promote the good citizenship of our foreign-born people by teaching them English and training them in the principles and practice of citizenship. ${ }^{2}$ The public school is the best center and clearing house for all Americanization.

Spirit of Returning Soldicrs and Sailors.-The return of nearly four million men from military and naval service overseas and from cantonments at home to reënter civil life-most of them to resume their citizenship, many thousands to fulfill their intention to become citizens-is one of the most portentous political and industrial events in the history of our country. There is no parallel to it, not even in the experience of the Civil War. For, during the Civil War soldiers were kept in close touch with the country's internal affairs while in service. They were more closely identified with its party issues and organizations by their fight over the principles and policies at stake. But by this war these millions of men have been detached either in fact or in prospect from their homeland and have been disconnected from all parties. Party issues and organizations have never been so irrelevant as during this struggle in which the whole people were at war for the national defense and all parties supported the government in winning the war abroad. There is an occasional reminder that the soldiers of the Civil War largely ruled the country for thirty years after their return home north and south. There is an accompanying warning against such a "reconstruction period" as followed and dimmed the glory of the union and emancipation which that war won. But few realize what a transition is marked, if not created, by the reëntrance of such a large proportion of our citizenship upon the civic and industrial life of the nation.

The simultaneous resumption of active participation in public affairs and private business by so many men in the prime of life and with the vigor of a new impulse cannot fail to be a crucial test of their spirit not only, but of that of our whole people. These men at arms have been prompted to think and feel of the relation between their soldiering and their citizenship.

${ }^{2}$ Toward this consummation devoutly to be wished, the Carnegie Corporation will valuably contribute through its country-wide Study of Methods of Americanization by a staff of specialists devoting two years to the investigation. 
They have been prompted to ask themselves how as citizens they may conserve what they risked their lives to save and what their comrades died to assure. Loyalty becomes all the more a ruling sentiment after having been a daily experience in the army and navy. Law may have proved to be the best friend of us all when obedience to it became the safeguard of every man's life and essential to the success of all. A new sense of belonging to the nation must come to our soldiers and sailors out of the experience of having had the future of the nation committed to their devotion.

Worth Measured by Sacrifice.-The point of view of these soldier citizens has been shifted very surely, however imperceptibly, by having been detached so long from the issues of the homeland. From the little contacts and personal interests which had absorbed them hitherto they got away where they were led or compelled to see and feel things in the large. For the first time many of them saw their home town and their state from a distance and the United States as a whole nation, and a great one among the peoples of the earth. They backed far enough away to realize as never before what the institutions of their country meant. Their sacrifices to protect American institutions prompt these men to challege the part their own influence and work may have played in the worth of the homeland. A new estimate must come out of such an experience. Things essential must stand out in contrast with what is merely circumstantial. Permanent values must outweigh temporary advantages. The resources of mind and heart and spirit will surely be seen to be as valuable personal and public possessions as material resources, if not worth a great deal more.

This challenge of things as they are cannot fail to raise questions in the minds of those who think the question as to what they themselves should and might be individually and as loyal citizens. Such questions cannot fail in turn to challenge the man himself and those he associated with, and the political party and its local organization which claimed or sought his support. When the soldier or sailor comes back, can he help looking around to see how things really are, how they measure up to or fall below what he thought he was risking his life to save? If he has any self-interest in what he is coming back to, or any concern for his town and country, which cost the sacri- 
fice of so much life and resource to defend, will he not feel like taking more of a hand in making his town and country worthier of it all?

Our Soldierly Citizenship.-This by no means infers that all, or even any number of them, have ceased to seek their own self-interests, or have dissociated themselves from their former associates, or have disowned their former loyalty to political principles and party affiliations, or much less, have become ideally public-spirited or well versed in public policies. Indeed most, if not all of them have much to learn to catch up with what has been happening since they went away. In reckoning with the soldier-citizen vote it is not to be forgotten that we are reckoning with more men than ever before who have attained a new and deeper experience in things fundamental and essential while in the service of their country. Public welfare will certainly be seen by very many of them to be the end to strive for and parties only the means through which that end is to be sought. After what they have seen and suffered they will not easily be persuaded, much less deceived, by any movement to sacrifice the end to the means. Least of all will they seek their own ends by creating a soldier class, which would be so alien to American citizenship. They are more likely to judge that party to be the best which serves the country the most, and that organization to be the worthiest, whether it be political, social or religious, which builds the community up out of itself. If these soldier citizens do thus judge, they will set a higher standard of progress, up to which the party or the fellowship, the church or the cause which claims their allegiance and support, must square. To this higher standard they will be constrained to hold themselves when temptations to laxity may come with their release from military discipline and with the lesser incentives that civilian life may have, in contrast with the highkeyed tension of the march, the camp, the trench and the rush over the top through no-man's-land.

Standard's of Leadership and Law Raised by War.-Soldiers have been impressed, as never before in civil life, with the necessity of able and trustworthy leadership. They have trusted their lives to their commanding officers, from the general down to the lieutenant. They knew the difference between the more and less efficient officer. Will not this prompt them to give a new rating 
to candidates for political office? Will they feel safe in trusting a national, a state, a county, or a city administration to men whose character and capacity, training and experience do not measure up to the trust which may be committed to them? Will party preferment, or the power of patronage, justify the choice of civil officials-a police chief or a health official, an alderman or a mayor, a governor or a president?

Cleanliness in body and camp, in kitchen and in hospital always and everywhere, made all the difference between sickness and health, even between life and death, to our soldiers and sailors. Against drink and vice the army and navy command fought for the very lives and the efficiency of the men abroad and at home. War camp community service cleaned up zones for safety miles around every cantonment and station. Whole towns and cities which had ignored the perils of drink and vice were compelled to protect the nation's defenders however indifferent they had been to the safety of their own sons and daughters. Clean play and good times were not only encouraged but promoted in the social "huts" and hostess houses at camp and in soldiers' and sailors' clubs and pleasure resorts at neighboring towns or terminal points. Will our returning soldiers and sailors as citizens be tolerant toward dirty streets and alleys, dirtier and more dangerous vices and habits and still deadlier disorderly resorts and crime-breeding, disease-spreading vice districts at home? These protective war laws have demonstrated themselves to be such safeguards in peace that the legislatures of an astonishing majority of the states have ratified the constitutional amendment submitted to them by Congress prohibiting the drink traffic throughout the United States. It remains to be seen whether the experience of our soldiers and sailors in camp and at the front will make them as citizens loyal to and defenders of this war law for peace.

Effect of the World War on the Working World.-When the storm of war broke out of a clear sky there was nothing for every imperiled nation to do but to face the front. But it soon became apparent in every country at war that the front was no stronger than the rear, that the firing line was no more of a defense than the factory and the farm, that the man behind the machine and the plow was as truly a defender of the nation and a winner of the war as the man behind the gun. And, just 
as success at the battle fronts awaited the coöperation of the armies under the unity of command, so competition between employers and employees, between profits and wages, between government work and private enterprise had to be subordinated to the unity of purpose for the winning of the war. The army and the navy learned how success and even survival depended upon coöperation. Neither at the front nor at the rear, on the firing line nor in the munitions factory, over the top nor in the line of communication could the country tolerate selfish, personal interests, competition or profiteering or class strife in industry. Here, as in every other country at war, it was the war of the whole people. Like the other nations and their governments, ours had to face forward with our advancing troops not only, but had to follow the women and children and the men who were left at home, back to their workshops and farms, back to protect motherhood and childhood, back to make national problems of housing and health, employment and the standard of living, education and recreation, work and play, the promotion of moral and religious standards.

From Arms and the Man to Tools and the Man.-Will our soldiers and sailors returning to industry, and the workers who have been manning the works at home, dare risk so much of their own wellbeing and the public welfare as heretofore, to the unrestricted competition in trade and the unrestrained class struggle? After having a place for every man and seeing every man in his place, will they longer consent to have the government keep its hands off the employment problem and let the unemployed survive the struggle for existence only by the charity of their fellows? Witnessing action on a big scale, seeing things done for the common good against all odds and obstacles, these men will never be as patient or indifferent to the lack of public enterprise and efficiency as most communities and many industries are, to their own undoing. During the war these workers knew less than ever before of dividing lines or interests separating, much less antagonizing, them by party, class, race or creed. They knew themselves and each other, as did most employers and capitalists, only as loyal men in the service of their common country. Will they return to the precarious conditions and the disturbed relations of peace times which they escaped in war times? After serving the whole people and stand- 
ing for the common welfare will these men for their own sake and their country's sake tolerate private gain at public expense, exploitation by the few at the cost of the many?

After fighting for democracy against autocracy abroad will these soldiers of democracy submit either to the autocracy of individuals in industry or the equally despotic and dangerous autocracy of any class? Will the people of the nation longer be satisfied with any political democracy which does not include more democratic control over the conditions under which men and women labor; over the means of settling their differences and assuring their safety and peace; over the standards which measure their satisfaction in life, their leisure and pleasure, their equipment and progress? If any one is doubtful of what answer to expect to these questions, let him be reminded of the worldwide revolts against autocratic injustice in industry and the struggles for industrial democracy. Let him fathom the deep determination to stop at nothing short of laying anew the foundations of civilization upon an uncompromisingly democratic basis. Then let him challenge the most fatuous American optimism with this question: Can America hope to escape the urge of the whole working world?

A Democracy Safe for Itself and the World.-Some way of balancing property rights with personal rights, commercial interests with labor's standard of living, private gain with public welfare, must be found to make the coming democracy safe for itself and for the world. None can foresee how much government control will hereafter be exercised over the great common interests which we have not dared leave in private control as hitherto, but there are great problems which both capital and labor must face and help settle in the period of reconstruction. Standards of living and working conditions which American labor has struggled successfully to establish upon a rising scale will not be allowed to be lowered or checked without a class struggle such as the country has never seen. And yet in the uncertainty as to trade conditions at home and abroad, individual employers are forced to face the acute problem of meeting the situation which confronts them. American labor and capital alike are beginning to act upon the conviction well stated by the London Nation: "No self-respecting nation can go back after this war to the state of things which makes the proper development of 
the body and mind the luxury of a small and privileged class. This reparation at least we will make to the thousands to whom their country has given nothing and from whom she has taken their all. It shall never again be said that it is not until they are needed for the terrible uses of war that any care is taken of the mass of the youth of the country."

From Representative to Direct Democracy.-Before the war the great majority of the American people was content with a democracy which guaranteed more or less self-government, with a free vote, free speech and a free press. There has been a rapidly increasing minority, however, among us as among all free peoples, which has taken democracy to mean more than all that. The freedom of our republic as founded in the Declaration of Independence and in the Constitution of the United States remains intact and more deeply imbedded in our soil than ever. But the superstructure has been changing, and the more rapidly during the few years before the war, as though preparing the way for still greater changes that may follow. These changes thus far have been all in one direction-from a representative government, safeguarded by many checks upon the people's action anywhere except at the polls, toward a more direct democracy. The people's direct participation in their local, state and national governments, through the direct primary, the referendum, initiative and recall and by the direct election of senators at the polls, seems to mark a tendency so prevalent as to be irresistible, whether for better or worse. Hesitancy and reactions there are here and there, but such advances of people's rights seldom or never move backward.

Blind or treasonable to democracy itself are those who will not safeguard self-government against the peril of willful impatience which overrides or evades law and seeks to legislate or seize control in the exclusive interest of any class without regard to the rights of the whole people. Class rule is not democratic but autocratic. So is majority rule if it ignores or denies the rights of the minority. However much these forms of misrule at the start appear to be for the individual rights and larger freedom of the masses, they can end only in the loss of personal liberty. Blind or stupefied are they also who ignore or resist the great changes which are now in the making both for the industrial and political future of free peoples. No greater 
task has ever been exacted of the American spirit than peacefully to readjust our whole great people to these fundamental changes in the structure of our national life. Hopeful tokens of the spirit to do so are appearing in the spheres of our educational, social, industrial and legislative action. Basic in realizing that hope is the American sense of fair play, which through most of the storm and stress we have experienced has been generous enough both to act and wait upon the belief that we can honestly differ and yet be reconciled to live and work together.

The American Spirit International.-Unconsciously but none the less actually we have been preparing to recognize and fulfill our international relations by welcoming to our shores and admitting to our citizenship greater multitudes of people from other nations than were ever entrusted to the control and destiny of any nation. The allied struggle for the freedom of the oid world fatherlands from which the citizenship and the army of the new world republic have been recruited so largely, assures for the United States a new and far closer international relationship, both political and industrial, than we have hitherto desired or thought possible. Moreover our international complications have actually welded more elements of our population together in a community of feeling for our common heritage of liberty and human rights than have ever before been fused into one patriotic spirit.

After fighting and fellowshipping with brave men of other nations our returning soldier citizens are not likely to defend that narrow nationalism at home against which they fought abroad. After making common cause with the free peoples of the earth for the common good and to that end sharing with them our very food and other necessities of life, the ministries of our nurses and doctors and every social and religious agency, will not our American people continue to stand for an international policy in peace as they stood for it in war? After being allied with the allied peoples, who, like our revolutionary forefathers, staked their lives, their fortunes and their sacred honor to win the liberty of the world, we surely cannot withdraw from that "association of the peoples," prophesied by Mazzini, which is the only guarantee of the world's peace and progress, if not of our own national unity and safety.

If a new internationalism of the peoples undergirds conf- 
dence in the world's future, a new catholicity of their religious faiths overarches its hope. A democratic world can be founded and perpetuated only upon the democracy of religion, with its self-surrender for the common good, with its equality of human brotherhood under the common divine fatherhood, with its ideal of each for all and all for each. And here in democratic America where individualism and the sects have run their extremest course and have strangely but surely issued in the trend of the American spirit toward inter-church federation, a common faith is arising which gives the best hope of uniting all faiths and loyalties in common action for the common good. 


\title{
CHAPTER XV
}

\section{THE WAR AND AMERICAN IDEALS}

\author{
By John Dickinson ${ }^{1}$ \\ Of the Division of History, Government, and Economics, \\ Harvard University
}

The Purposive Nature of American Politics.-In these days, when men pride themselves on realism, one who talks of ideals must be at pains to make his meaning understood. In the present discussion the word is used simply to mean a goal of action, an end at which men aim, an object of purposive conduct which is called ideal because it is conceived in the mind as the runner's goal post is perceived physically. In this sense all people have ideals. Some are of a private, peculiar nature, cherished by only an occasional person and foreign to the general run of minds. With these we shall not be concerned; but only with such as direct the striving of men in numbers and represent the object of collective as well as of individual effort. These common ideals of numbers of men make up what, taken together, may be called the ideals of the nation. They are the goals toward which its policy tends and the stimulants which put energy and intelligence into its politics.

A specializing bent of mind might wish to group ideals of this kind into classes, as for instance those which pertain to the individual himself and those which pertain to the group of which he is a member; those which are economic in character and those which are political; and so on. But ideals of these different sorts

${ }^{2}$ A.B., Johns Hopkins, I013; A.M., Princeton University. I9I5; Ph.D., I919, and Gordon MacDonald, Fellow, 1915-16; Charlotte Elizabeth Proctor, Fellow, 1916-17; Chief, Latin American Division, Bureau of Research, War Trade Board, I9I7-18; Ist Lieut., U. S. A., attached to general staff until Jan., 1919; taught at Amherst College, 1919, Harvard University, 1919-. 
are so closely interrelated and have so complicated a hidden influence on one another that it is impossible to keep them apart. All that can be done is to select a single viewpoint from which to discuss them; and for the purposes of this discussion that viewpoint will be political. Our interest is in the political aspect of the ideals of the American people and in the bearing of the war upon those ideals viewed from the angle of politics.

Mr. Delisle Burns in his recent little book has pointed out that most ages and countries have had their characteristic political ideals. ${ }^{2}$ Through the involved network of fate and chance which makes up so much of human history there has always run a thread 'of conscious human purpose. And yet I believe that it is justifiable to insist that when one speaks of ideals in connection with American history the term should be used with at least a different emphasis from that which is appropriate in connection with the history of most other countries. For in the history of most countries such ideals have at best borne a relatively small part. They have been only partially explicit and only partially effective-gleaming only intermittently through a web of events which had very little to do with them and guiding the course of occurrences only in connection with blind, unconscious forces which in the main were stronger than they. The part of conscious collective purpose was small.

But in American history, on the other hand, conscious collective purpose has played the leading part; the history of America is definitely the history of men consciously fighting their way through to the deliberately chosen objects of their will rather than the mere movement of blind world forces working themselves out in human material. Will, conscious will, deliberate will, purpose, resolution, and faith in men's power to achieve their goal-these are exactly the words which strike the keynote of American history. The success of the prohibition amendment is simply the latest instance of it.

There has been much debate as to the place that purpose can play in history, and the stately eloquence of Burke has given classic expression to the view that human institutions must grow unconsciously and cannot be constructed; but almost at the moment when Burke was writing to this effect, a group

${ }^{2}$ Political Ideals. Their Nature and Development, by C. Delisle Burns. Oxford Univ. Press, 1915. 
of American gentlemen were deliberately constructing at Philadelphia a set of institutions which have proved among the most stable and successful in history. To be sure, as has been amply pointed out, they found their materials at hand, they did not create them out of nothing; but what constructive workman does more? Enough that they sorted them, selected from them, and combined what they thought would serve their purposes; for in doing so they brought several new things into the history of the world.

And this is only the chief instance of our American habit of refashioning matters to our hearts' desire. American history is full of others. At every step we have boldly thrown off traditions which could not account for themselves to reason. In an authoritarian age we set up a government resting on no more secure foundation than the will of the people. We extended democratic institutions with success over a continental area which we were told spelled ruin to free government. We fought the most tremendous civil war in history and proclaimed a general amnesty. We went to war to liberate a neighboring people and took no price from them for our pains. We handed back the Boxer indemnity. We concluded a series of arbitration treaties which promise to mark an epoch in world peace. Whatever other instances might be alleged, the tendency at least is clear.

Nineteenth Century "Idea Politics."-And yet the history of politics in the last century has been on the whole a history of ideals everywhere. Conscious collective purpose was a long while in coming dominantly on the stage, but when it did come it came on many sides. America simply had a century and a half's start of the old world. The eighteenth century did for Europe what the seventeenth had done for the colonies. Philosophy and the awakened consciousness of peoples swept away traditional and authoritarian politics there as effectively as an undeveloped continent and the three thousand miles of the Atlantic had eliminated them here. The politics of the nineteenth century were the politics of ideas.

And on the whole that was perhaps the most hopeful thing about the century, for it indicated the growing power of thought, of intelligent purpose, of men's intention to be to a greater extent masters of themselves and not merely the tools of "his- 
torical forces." But like most bright things it had a dark side. As men tried to work their will upon the world they came to be conscious of natural forces standing in the way, and so there grew up that very theory of inexorable "historical forces" which is fundamentally opposed to deliberate voluntary policy. The result was a curious syncretism. Men were urged to get together and consciously further the action of these bistorical forces. Karl Marx's argument is an example of what I mean. He argued that the whole course of history was tending irresistibly toward the social revolution, that the social revolution was historically inevitable, and that therefore men should get together in order by all means to bring the social revolution about. Why an inexorable law should need deliberate human volition to enable it to act Marx did not make clear.

If it were a matter of logical inconsistency simply, this form of argument could be dismissed; but a more serious trouble with it was that it taught men to go to history rather than to common sense for their purposes. They had gained the point where they realized that politics meant having purposes and setting about achieving them; and it was well enough to look to history to supply a criterion of the means best fitted to that end. But they went further and inferred that history should dictate the purposes. Some examples of the extremes to which this tendency led are amusing, as the argument that because Stephen Dushan ruled certain territory in the fourteenth century, Serbia is justified in striving to incorporate that territory in the twentieth; or because Greeks once governed in Constantinople and Asia Minor, the present Greek kingdom must expand in those directions. These are instances of outlying implications of the idea; a more direct consequence of it is such a belief as the one now current in many quarters that history shows that states have always pursued only their own narrow, selfish interests; that therefore they can pursue only their own narrow, selfish interests; and that therefore they ought to pursue only their own narrow, selfish interests. An argument of this kind directly denies that steady course of progress which is the outstanding lesson taught by an intelligent study of history.

The most unfortunate result of this way of thinking is that it sets men scheming for ends which they neglect to criticize. Now criticism of the end to be striven for is as much a part 
of conscious action as criticism of the means to attain that end is, and it is particularly necessary where a number of individuals are all attempting to realize ends at the same time; for only by criticism which reaches down to fundamentals can such ends be brought into harmony. Ends which are simply set up, whether in history or in mere desire, carry with them no guarantee that they are ends which others who make conflicting claims can be called upon to recognize. But such recognition is the only basis of harmony; and to have it requires that your ends, from whatever source presented, should first be scrutinized and approved at the bar of common reason and of men's common sense of justice.

Now this is just what was not done with most of the ideas which guided the politics of continental Europe in the nineteenth century. These ideas were for the most part clearly enough conceived goals of political action drawn from history or desire; but many among them could give no good account of themselves to an unprejudiced sense of right. There was accordingly rich and various conflict among them; and idea-politics on these terms set in train as much blood and war as the frank forcepolitics of the preceding period. The final flower of this sort of politics was Germany's dream of world domination. That grandiose scheme presented in relief the characteristic merits and defects of the idea-politics of the period. Here was an ideal painstakingly read from the course of world history, which in the eyes of German scholars was threading its way up to the consummation of a German hegemony. Here was a goal which unconsciously appealed to a people's sordid cupidity but was consciously tricked out to thrill all their fine emotions. Everything was present except a little intelligent criticism of the ideal in the light of common sense, which would have served to explode it in five minutes.

It happened that the German ideal ran athwart our own, and we went to war. The clash provoked comparison and criticismcriticism not only of German ideals but fortunately of our own also. For there are two ways of dealing with such a clash of ideals-one of them a healthy way and the other far from healthy. To say on the one hand with Mr. Justice Holmes that so far as human beings can know any ideal may be as right as any other and that truth is simply the opinion of the side which 
can lick its opponent ${ }^{3}$ is to nullify the operation of common sense in the world and to invite the appeal to arms on all issues. If you adopt that theory force must come to play a much wider part in the world than it has played already. Happily, there is another way of dealing, and that is for both sides to subject the conflicting ideals to frank mutual analysis in order to separate the presuppositions and uncover the fundamental issues involved. For, relativists to the contrary notwithstanding, the common sense of mankind does recognize a number of simple principles which men not heated by passion or sophisticated by interest accept about as readily as they accept the proposition that two plus two equals four. Now, when the really fundamental issues in a conflict have been uncovered, it becomes comparatively easy to apply one or another of these simple nirst principles to the case; and the side which will not yield to a judgment of public opinion so arrived at is sure to be worsted because it will have against it the preponderant sense of the world. That is what happened to Germany. That is the simple ultimate reason for her defeat. She was striving for a goal which was at variance with men's common sense of right, and the preponderance of men threw themselves upon her and crushed her.

But if ideals are to be thus weighed and judged in the court of reason, neither side must be too proud to cite its ideals before that bar. Every nation must be willing to examine, criticize, and, if need be, amend its goals and purposes. It must not look upon them as holy fetishes or be afraid to bring them into the light; and that is why it has been fortunate that during the war there has been a tendency and willingness among us (even if not so great a tendency and willingness as we might have wished) to subject American ideals as well as German ideals to criticism. And now that the war is over, the tension relaxed, and those impeding causes at last out of the way which could not but prejudice our judgment somewhat in the heat of the struggle; now that we are about to take up again our broken thread of days and resume our normal course and gait, perhaps we could not begin better than by reflecting on what the war seems to have taught us in regard to our American ideals and the bearing of those ideals on the days ahead of us.

"Article on "Natural Law," in Harvard Lave Revicw, November, IgI8. 
The Substance of American Ideals.-What are our American ideals? In one sense, of course, they are variously numerous, but in another they may be all included in one name. They represent simply that circle of aspirations toward a larger human fellowship, a wider opening of opportunity for all, a happier and sounder common life, which are to-day inadequately enough connoted by the word "democracy." 4 The common element in current democratic aspirations is an insistence that all men have a right to participate in whatever is noble and dignified and valuable. The democratic attitude rejects the idea that these best things are to be set apart for the private property of any exclusive class; the road to them must be opened wide to all who will enter it; and democracy has confidence enough in human nature to believe that most men will enter it if through economic adjustments, adequate education, and enlightened politics they are given the chance. Not that all of us who think we pursue the democratic ideal would put the thing exactly so or are even fully conscious of these implications of democracy; many, following their own lights, may even sometimes seem to go in quite different directions; but if you seek to bring the scattered efforts and separate aims into one general whole, you can do it only by interpreting them in the light of some implicit general end such as that above described. That is the one key which will unlock the secret of their multiplicity an give them consistency and a meaning.

But what right have we Americans to claim such a goal and purpose for ourselves? This is obviously a goal which quiet thinkers have been proposing to the world for a very long while, but in which organized groups and practical men have not often shown an interest; what right have we practical Americans to claim that we have adopted it? Simply the right given us by the predominant tendencies in our history. Surely American history is a history throughout of efforts to open up opportunities to men, efforts which shine through tendencies of an opposite character, even growing out of those tendencies themselves, and always increasing in force and fruitfulness up to the climax of our participation in the world war. Our occasional lapses into imperialism and the vast growth of the pecuniary régime among us seem rather to have resulted from national neglect and

'See Cooley's Social Organization, p. 86. 
from momentary outbursts of well-intentioned emotion than from deliberate national purpose. Whenever we have acted from deliberate purpose and whenever the nation has put its conscious spirit into its policy our actions have pointed the other way. The steady extension of the suffrage; the policy of free education, which goes back to the beginning of our history; the constantly increasing participation of the people in the operations of our government; the homestead policy which opened up the great West; the prohibition movement-these things represent the purpose of America. So many nations now enjoy popular government, so many other peoples have won free speech and religious freedom, that to-day we have to remind ourselves that it was America who found the trail to these things, that we first in the optimistic vigor of our faith made great experiments that have come to be commonplaces in the order of the world.

It might seem to the casual view that having won these large preliminary conditions of opportunity in our earlier years as a nation, we had since relaxed our purpose of guarding it from new dangers and of guiding it into right courses. But that would imply an unfair understanding of our recent history, an understanding contradicted by such things as the anti-trust movement, the movement against political corruption, the campaign against vice, and the widespread spirit of social reform. It is not that our purpose has waned but only that the means we have adopted to realize it have often been little fitted to that end. Always they have been crude, often stupid. These things have been done better in many other countries. You will hear it said and with truth that our social legislation is far behind the mark set elsewhere; but even this is so for a reason which is itself a ground of hope. For this instinct in America for social betterment is an instinct grounded in the people themselves and not trickling down to them from an enlightened clique above; hence it is often blundering and unintelligent, but it is all the more earnest, vigorous, effective. It needs guidance and direction, and it is frequently wrong-headed in resisting such aid; but this instinct for social betterment is solid and permanent and fixed in the national character.

But just because the ideals of America are thus so largely instinctive, they are subject to a peculiar danger: they focus 
themselves on crude catchwords and slogans, and there are few catchwords which do not involve contrary implications. Almost every ideal which is bound up with the most cherished aspirations of the American people bears within itself a dualism and an ultimate conflict-liberty, equality, opportunity, independence, all can be made to mean the most opposite things. They have a sense in which all are angles and aspects of that larger and more harmonious order after which the heart of America is seeking, but they all may bear another sense that is out of joint with such an order. It is with these conflicting meanings of our primary ideals that the minorities who bid for leadership among us are wont to play, emphasizing whichever interpretation suits their current purpose. And so in the name of liberty we have often been led where it has not increased our liberty to go, and our pride in national independence has been used in ways not compatible with the true independence of nations. The great service of the war has been to bring into relief these conflicting implications in our basic ideals; and we should not omit this opportunity to understand their dualism and the choice of meanings and interpretations that is necessary if we are to take the path toward a future of life and not of death. Accordingly I intend to take up three of the most representative and inclusive American ideals-popular government, individual liberty and national self-determination-and examine what light the experiences of the war have shed on their implications.

Self Government.-We believed, and rightly, that much of what was most obnoxious and intolerable to us in Germany's conduct and designs originated in her form of government. A close autocracy of wide powers can set a whole people to the accomplishment of purposes which if left to themselves and the leading of their own common sense they would never adopt; and so we rightly held ourselves approved in our traditional belief that a free government propelled and operated by the broad forces of public opinion is essential if you are to count on political reasonableness and fair dealing. The war worked to strengthen our sense of the importance of governmental forms.

We have always had a very strong sense of that importance. Whenever an abuse or some condition which seemed to require remedying has been called to our attention, almost our first impulse has been to tinker the machinery of government and to 
tinker it in the direction of giving more immediate power into the hands of the people. The tendency of our political development has been not merely to extend the suffrage, but to make more offices elective, to decentralize authority, and finally with the coming of the initiative and referendum to hand over the actual operation of one branch of the government to the voters. We have come to look on the direct participation of all the individual citizens in the carrying on of government as not so much a privilege as a right. We have accordingly often treated it in the light of an end in itself, something to be striven after as one of the objects of reform, rather than as simply a means toward reform, to be judged by the results that might be expected to spring from it. At least that was our attitude before the war.

With our entry into the war our government was practically transformed into a dictatorship. Executive agencies which were responsible only to the chief magistrate and which exercised the most pervasive and inquisitorial authority over citizens were suddenly brought into being. The quality of Congress having been tested, ways were found to circumvent that body in the interest of efficiency. Wider powers than government had ever exercised before were concentrated in the hands of a few individual men, not elected, not responsible themselves to the people, and serving entirely at the pleasure of one man.

And so we were brought face to face with one of those antitheses which set men thinking. We were engaged in combating autocracy abroad; what of the dictatorship that we were setting over ourselves here? Was not our government becoming Prussianized? It is to the credit of our intelligence as a people that this cry was not often raised in circles other than Congressional; we seemed to realize instinctively if not consciously what was demanded by the situation, and we accepted it. But now that the leisure has come to us to reflect, we should not let slip the opportunity to relate our experience to our general view of govermment with the idea of revising that view if we should find revision necessary.

The war taught us that there are times when authority must be concentrated in order to give it effectiveness and force, or better still, that if authority is to have effectiveness and force it must be concentrated. There are things which one man or 
two men can do that a public meeting cannot do. When it is the will of the people that those things should be done, one man or two men must be given the authority to do them. In other words, it is the ends that count; government is a means to ends, and its forms must be fitted to the ends aimed at.

If we keep our thought on this matter of the ends to be attained as the final consideration, there is slight danger of falling into Prussianism. The ends are for the people and the people alone to determine, and no form of government can be tolerated which tends by its character to undermine insidiously that prerogative of theirs. The Prussian government was of a sort which did undermine it, and did away with it; that government clothed itself with mystic sanctions and made itself the master of public opinion: The people were not free to conceive and formulate their popular purposes. The ends of government were not theirs to fix. How far the censorship and espionage system in this country during the war tended in these directions, this is not the place to consider; for the censorship and the espionage system have no necessary connection with the concentration of governmental authority that we are here dealing with. What I want to emphasize is that forms of government are only means to the accomplishment of the people's purposes and nothing absolute in themselves; and they must be flexible to the needs of changing situations. No one would maintain that the close concentration of power which we found necessary in time of war would be desirable or beneficial in the peace time ahead of us, nor is there visible danger of its surviving. But our war experience should shake us out of the fetish worship of governmental machinery into which some of us seem to have slipped. If we give more care and attention to the things we want government to effect and put more energy into getting government to effect those things, problems of governmental mechanism may perhaps be solved with less friction and with more fruitful results.

It might seem that what has been said has been directed against the liberal elements in American politics. That has not been my meaning. This is a thing wherein liberal and conservative have alike been at fault. If liberals have erred in unduly valuing mere popular participation in the government, reactionaries have erred even less intelligently in insisting on the in- 
herent right of existing governmental forms to go on existing. That governmental forms should change and develop is of the essence of the matter; only it is doubtful whether we can lay down any stricter formula for their development than that of fitness to fulfill the people's purposes. They are means, not ends. If we choose to regard them as ends, we shall get husks instead of grain. To this extent the war should have clarified our conception of popular government.

But it has done more; for our experience has made one novel and suggestive contribution to the machinery of popular government. One of the striking features of our war organization was the extent to which the government acted through the medium of voluntary associations of citizens formed to represent it in fields in which they were peculiarly well situated to act. The War Industries Board was the center of the most elaborate machinery of this kind, but the principle is discernible in every branch of service. There was no assumption of control in these cases by professional government employees, but the people who were actually engaged in some line of activity, say rubber importing, undertook to control it for the time being in the interest of the government and in coördination with governmental policy in other fields. They made themselves agents of the government, so to speak, in the management of their own affairs and consented for the occasion to regard their private business as a public trust. ' The service of labor groups in this direction was particularly noteworthy. Now, here is the very essence of popular government--not government by an alien force, however representative, but direct self-government in the interest of the whole community and carried out through consultation and compromise with all those other groups and interests that make up the community. The machinery for this consultation and compromise was defective, as owing to the newness of the thing it was bound to be; and so undoubtedly there was not a proper coördination of effort. But it is the idea that is significant, for it points the only way in which a self-government worthy of the name is possible. Self-government must be government from within and not from without. It means voluntary adjustment of your point of view by reference to the point of view of your fellows. It means acting from something broader than your selfish standpoint, without being made to do so. And that is just what was 
done by the voluntary associations of laboring men and business men through which the government so largely acted.

Of course it was too much to expect this system of coöperation to be carried over into the peace era. We have yet to learn as a people that the peace-time duties of government are even more critical than its duties in war. The emergency is believed to have passed; we can now all afford to be selfish again. Impatient men grew disgusted with the endless conferring and consulting and compromising which voluntary coöperation among people unused to it entailed. Keen-sighted men grew angry at the general stupidity which stood in the way of establishing a proper coördination of function. And so the thing has gone; but it has left behind it a suggestion and a hope. For it is by education to willing and conciliatory coöperation of this kind between groups and individuals, and not by initiatives and referendums or checks and balances, that real popular government must come if it is to come ultimately.

Individual Liberty.-But popular government, so our argument ran, is simply a means to ends. What of the ends? The war has raised this question sharply in the discussions it has incited on the subject of individual liberty. Perhaps the best approach to the matter can be made through two partial and inadequate conceptions of liberty which the situation developed.

On the one hand we have heard much about liberty from business interests and political reactionaries. The liberty so insisted on is simply governmental noninterference with private concerns. But as the argument is often put it implies a direct denial of the principle of conscious community action. It would lead to a state of affairs where only "natural forces" operated -in spite of the fact that human history is just the record of successful group action to defeat and control natural forces. But of course the conservatives would not go so far as this, by any means. What they object to is almost entirely governmental interference with economic relations. But this restriction at the economic boundary is a purely arbitrary one. The very thing that government is for is to interfere, regulate, and supervise. If it is to interfere with burglars, regulate coinage, and own and operate highways-things all of which conservatives would have it do-why forbid it to interfere with stock transactions, regulate terms of employment, and own and operate railways? Be- 
cause, says the business man, such actions undermine the free initiative of individuals; and if we then go on and ask why the free initiative of individuals should not be undermined, we shall probably be told that to do so is not to the best interest of either individuals or the state. So that really it turns out to be not some abstract right of liberty but the best interest of individuals and the state that is the thing to be looked to.

The other conception of liberty which the war has brought forward is that of many conscientious objectors, social revolutionaries, and radicals of other colors of opinion. Their conception takes a positive angle, just as the reactionary's took a negative angle. Liberty means to them not the absence of interference but the power of self-expression. This power is regarded as invested with supreme value, and to it other ends are to be sacrificed. Groups are to be formed for the conscious furthering of common ends, but the thing is to be all more or less on a voluntary basis. The right of physical compulsion is questioned. The practical futility of this conception must be apparent, but it is questionable whether it can stand the test of even a theoretical analysis. Consider a number of such isolated voluntary groups existing side by side. The time is sure to come when the purposes of some of them will be incompatible with the purposes of others. If now there is no common superior, empowered to arrange a compromise and enforce it by compulsion, a clash will result between the groups and force will be resorted to after all. Only, instead of being the force of a common power representing both groups, it will be the force of the interested groups themselves. This would be to introduce within the nation exactly that condition of unorganized anarchy which the lesson of the war has taught us so clearly ought to be done away with as between nations.

The likelihood of disagreement and conflicts between groups is increased rather than diminished by the view which the radicals usually take of self-expression. It is an unbridled physical expression, a physical expansion of the personality bound to bring about encroachments on others, that they usually mean. And here is the real crux of the problem. If liberty is to be interpreted to mean unrestrained power to do things which cramp the opportunities of others, obviously liberty is something which cannot belong to all but only to a few. The few may be se- 
lected by some process of customary recognition, or frankly by force; that is the only difference between radicalism of this type and the most hidebound conservatism. Obviously neither view is compatible with democracy, which insists above everything on freedom of development for all.

But how, it may be asked, is freedom of development possible for all? Does not the development of one necessarily cramp and restrict the development of others? If there is to be a solution of this palpable antinomy it is to be found in the meaning of the word development. There are kinds of development which do undoubtedly require that the development of one should be effected at the expense of the development of others. Are there other kinds? Can opportunity, self-development, self-expression be so interpreted that it shall be physically possible for all to share in them?

They can be; but only by a critical sifting of the ends of development, the channels of expression, the directions of opportunity. The only sort of development which is compatible for one and all alike is development in intelligence, development in the esthetic sense, and development in mutual fellowship and comradeship. For such development an adequate economic basis is necessary. An intelligent, beauty-loving, and beauty-creating life, a life full of affection and friendship, is possible only on a certain level of economic subsistence. For all to partake to the limit of their powers in such a life all must stand at ieast on. that level of subsistence. To this end reform must assume an economic direction. But it must always be remembered that the economic reform is simply a preliminary, simply a means and not an end; that unless it looks ahead of itself to something further it may very easily defeat its purpose. For if we limit our view to economics, and regard economic improvement as mainly the end to be aimed at, we emphasize a conception of development which is in danger of becoming exploitative. If the possession of economic goods is to be itself set in the light of an end of development, and if that development is to be free and untrammeled, obviously the development of one individual will necessarily clash with that of others, because of the nature of economic goods, which is such that what one has another cannot have. Much of the conflict in our present society between individuals and between classes is undoubtedly because neither party looks 
beyond economic wealth or sees that it is simply a means to ends which are defeated by the rivalries and the exploitation which result from mistaking it for an end.

And so one of the great problems for the future of democracy and one on the solution of which the future of democracy may almost be said to depend is to get men to recognize the properly subordinate position of economic interest. It is a tool, a necessary, indispensable, invaluable tool of civilization and of progress. Steady improvement in the means of production and, above all, a steady increase in the annual product, are essential to a broader and better life for all. But simple private possession of a portion, great or small, of that product is not of final value in itself, even to the possessor. The psychic satisfactions which it yields are what render it valuable. These satisfactions may be of a worthy or of an unworthy kind. They may be the satisfaction of base wants, or of vulgar ostentatiousness, or of a thirst for power. Or they may be the better and finer satisfactions of a desire for knowledge and beauty and service, and it is these satisfactions that afford the canon of just distribution.

These matters have been very urgently brought to our attention by the war. The improved economic position of labor has summoned us to take thought of the future when, if our hopes are achieved, that position will be made securely permanent. But what is to come of it? Are our laboring men simply to be put in a position to squander more money in cheap and vicious amusements, transient pleasures, things which bring no refreshment to the soul and add nothing to the common civilization or to individual happiness? Are they to be bred in a materialistic economic conception of life which will make them potential enemies of each other and of all other members of society? Admit the materialist conception of life and plutocracy becomes infinitely preferable to democracy; for its materialism is at least more subtle, rarefied, and delicate. The sole ground of democracy is the dignity of human nature; and the dignity of human nature refuses to be marked up in dollars.

There has been a growing danger in the America of recent years that life will come to be regarded too dominantly in economic terms. Perhaps the danger is not so strong now as it once was. It originated naturally enough in the boundless 
economio opportunities open to a small number of settlers possessed of an undeveloped continent. Almost unlimited economic betterment was then possible for one man without trenching on the opportunities of another for like betterment. And so we came to look on betterment of a man's economic position as an accurate test of his worth, industry, integrity. The first century of our national history was a century of this naive "Poor Richard" philosophy. It was given a great impetus by the sudden opening up and development of the West after the Civil War. Politics, art, journalism, religion, home life, everything was flooded with easy-gotten money. But the very process which brought about this vast material prosperity put an end forever to the possibility of the old-fashioned American kind of equal economic opportunity. For old-fashioned America was gone. There was no longer a frontier, no longer a West where any one might carve out a fortune by his worth and effort at the expense of no one else. The country was filled up, and hereafter the indefinite economic expansion of one man could be gained only at the expense of other men. In a society such as we have grown to be since the disappearance of the frontier a mainly economic conception of life has thus got to be a dangerous conception. And yet the old view, Poor Richard's view, has naturally enough persisted. There is still too much tendency among us to regard success as "making your pile." There is still too much tendency to interpret that broader opportunity for which all democrats are striving as the opportunity of every poor boy to grow up into a millionaire. At our present stage of economic development it is impossible for every poor boy to grow up into a millionaire. To dangle such a goal before him is to breed a frame of mind which leads to discontent and ultimately to anarchy. So long as this conception threatens to dominate, liberty is in danger; for liberty so conceived is dangerous. A broader economic opportunity is needed; but not an opportunity for the indefinite personal economic betterment of individuals-rather the opportunity of such an economic position for all that each may develop those capacities of his for which economic wealth is simply the basis and the condition.

If there is any solution for this problem, any protective measure that we can take, it lies through education. President 
Lowell in his recently published annual report shows a happy consciousness of this. Warning us against a "materialistic reaction" from the war, which he thinks is to be expected, he says:

"Among the strongest agencies to prevent such a relapse ought to be our colleges and universities, which should feel more than ever before their duty to keep before the minds of young men the eternal values and spiritual truths that endure when material things pass away."

But it is not merely from the colleges that the remedy can come. For while in the main college men are our leaders, still in a democratic country leadership does not so much give the tone to those who are led as take it from them. A leader must speak the language of the community he is to lead and must voice its dispositions and aspirations if his leadership is to be effective. If leadership to a higher and cleaner scheme of life is to come from our college men, the way for it must first be prepared in our common and secondary schools. They occupy the key position. It is there that the native human instincts for the better values must be awakened and nourished in the minds of the general run of men while they are still plastic and impressionable. It is then that the pace must be set and the tone given. The question of education in our common schools is of all questions now facing us the most vital to the future of American democracy.

National Self-Determination.-The experiences of the war have unquestionably done much to weaken the spirit of selfish individualism among us. When Mr. Wells was in this country fifteen years ago, he was struck by what seemed to him an utter absence among Americans of any consciousness of the state. ${ }^{5}$ The war has brought that consciousness to us definitely. For two years we have lived together as a true community, making mutual sacrifices to our common good in all directions, and focusing our attention on common concerns. The effect, of course, has been to foster a state of mind with which selfish individualism is not consistent. And so there are those who look to a continuance and growth of this state-consciousness as the best preventive of threatening internal clashes. Patriotism is to close "The Future in America, ch. ix. 
up the divisions between individuals and classes. And the value of the schools in this process is appreciated. The schools are the places in which to inculcate patriotism. They are to be the instruments and machinery of a process of Americanization.

There is in this movement that which calls to our deepest traditions. National independence was our earliest political ideal of nation-wide scope. It has been the mainspring of our foreign policy for almost a century and a half. We have tended to regard ourselves after the manner of our Puritan ancestors as a peculiar people set apart for a mission of dominant importance in the world. Our independence and security have accordingly been looked on as our highest interest. Hence Washington's policy of no entangling alliances, hence the Monroe Doctrine, hence Mr. Blaine's illuminating remark about "abroad." There is no national ideal to which a more effective appeal can be made than love of country, its independence and its national interests.

But here again we have one of those ideals which is susceptible of a dual interpretation. What do we mean by independence? What do we mean by national interest? Obviously the words need definition.

There is a view of national interest among us which has been definite and clean-cut since the days of Hamilton, a view which is the more important since it has prevailed not here alone but at many other times and places. Let it be expressed in the words of Hamilton's biographer:

"Hamilton," says Mr. Oliver, "viewed mankind and natural riches as material to be used with the greatest possible energy and the least possible waste for the attainment of national independence, power, and permanency. A means to this end was certainly the prosperity of the people, but the end itseif was the existence of the nation. . . Human society was something nobler than a mere convenience, a nation greater than the sum of its subjects. One of the duties of the state was the well-being of its citizens, but the duty of every citizen was the well-being of the state." ${ }^{8}$

Here certainly is an ideal of political action which transcends and subordinates individual interests. But there is that about it which requires amplification. If the prosperity of the people

- F. S. Oliver, Alexander Hamilton, pp. 450-452. 
is only one of the ends of the state, what are some of the other ends? Its permanence, power, and splendor? But what is the value of these things? They would seem to be valuable only in so far as the state itself is valuable, and the state itself would seem to be valuable only in so far as it makes in the long run for the happiness of its citizens. It would appear in fact that the ideal which Mr. Oliver expresses may mean either of two things. On the one hand it may mean that the present temporary prosperity of a people is not to be maintained at the cost of the ultimate ruin of a state which by constitution and ideals bids fair to advance their permanent prosperity. Present ease is not to be preferred to future good. The importance of this consideration was well illustrated in the months before we entered the war. There were then voices among us which counseled inaction because of the opportunity our neutrality gave us of reaping profits which a belligerent status would wipe out. But a longer vision perceived that present sacrifice was necessary to guarantee future security. In this sense the wellbeing of the state-that is to say, of the community, future as well as present-was distinct from the temporary well-being of the individuals at that moment composing it. In this sense the well-being of the state is undoubtedly to be preferred to the well-being of individuals, and Hamilton's view is justified.

But this is not the usual meaning of that view nor its natural one. Its natural meaning is that there is a present interest of the state distinct from that of its citizens. Military power, a favorable balance of trade, the presence of the flag on the seven seas, and the influence in international councils brought by these things are valuable in themselves without regard to any connection that they may have with the present or future prosperity of the people. National honor, national glory, national grandeur are the true ends of the state. This attitude of unanalyzed emotion undoubtedly dominates the most enthusiastically patriotic among us. But surely this is romantic politics run mad, and if followed out will lead inevitably where romanticism always leads in practice. It rests on exactly the German theory of the state-that impossible, mystical theory which Emperor William himself once expressed by saying that after the last German had died fighting for the 
fatherland, the German state would still endure. To an American such words carry no meaning.

It is difficult to see, then, how we can avoid accepting Jefferson's statement that "the only orthodox object of government is to secure the greatest degree of happiness possible to the general mass of those associated under it," " taking this of course to apply to future generations as well as to the present. Such a definition applies in the field of foreign as well as of internal politics, and it sheds light on the ideals of national interest and national independence.

The group of individuals who compose a state have interests which conflict and interests which do not conflict with the interests of other similar groups, much like the separate individuals within a group. Some of the conflicting interests are of a mainly ideal character-a religion, a system of government, loyalty to a dynasty or to a race ideal. More often they are material. In regard to these material interests at least, we do not express the truth quite accurately when we say simply that one group has interests that conflict with the interests of another group. Group solidarity in respect of material interests is not so real as that. What really happens is that individuals within one group have interests that conflict with the interests of individuals within another group. Each group, acting through its government, considers whether these interests are vital enough to the group as a whole to warrant making a group issue of the matter. If they are so considered, resort is had first to diplomacy, and perhaps ultimately to war. The matter is thus reduced to what is really a clash between individuals. The groups appear as judges. Only, while within the group there is only one judge, as between members of the two groups there are two judges.

Now it is generally recognized that within a group clashes between individuals are undesirable, not merely because they weaken the group in its position of rivalry with competing groups but for the more honorable reason that they tend to crush some individuals for the benefit of others, which is not in accord with democratic principles. Hence, as has already

'To Vander Kemp, i8r2. Jefferson's Works Congressional ed., Vol. VI, p. 45 . 
been said, a democratic state cannot afford to look with favor on interests which tend inevitably to such clashes-for instance the interest of personal economic aggrandizement. There is no obvious reason why the same principle does not hold good of clashes between groups. When groups clash it is individuals who suffer. And furthermore the successful emergence of a group from such a clash for material stakes does not mean necessarily economic improvement for the whole body of its membership or even for a majority of its members. The prize may be won for only a small number, a special class within the successful group. In such a case we have this small class profiting at the expense not merely of the members of the defeated group but of the other members of their own group as well. This is probably what would have happened in Germany had Germany been victorious in the war. The mass of the German people would have had their outworn political limitations fastened upon them more securely than ever and would have borne the major burden of an immensely increased debt besides, for the benefit of the comparatively small number of individual Germans interested in the army and foreign commerce.

But even if we admit the inherently improbable case in which all the individuals composing a group would profit from the issue of a successful conflict, such profit would simply be extorted from the members of the defeated group. Profit of this kind is not justifiable on democratic grounds. Men organized in groups are no more warranted in preying on their fellows outside the group membership than are individuals in preying on one another within the group-that is, not unless it can be shown that the idea of right and justice does not run across group lines.

Now this last proposition is exactly what tends to be maintained by a type of thinkers not all of whom by any means are to be found in Germany. The idea is that different national groups represent irreconcilable types of civilization, whose differences are more valuable than their agreements, and which can only endure at one another's expense. There is no potential ground of harmony between them. Each group is warranted in insisting on its own ideals, traditions, and customs, however these may trench on the like privilege of other groups. And each group would seem to be entitled to further the extension 
of these ideals and customs at the expense of the territory and material possessions of others. Groups, unlike individuals, are under no obligations to recognize each other's claims, or to arrive at a settlement based on a recognition of a right binding on both because common to both.

It is this idea which lies at the basis of much present-day insistence on national independemes. Mr. Usher has put it plainly:

"National independence is fundumen.tly the right to decide for ourselves what is essential to chi scnor, our safety, and our prosperity. .. . The right to choose is our most precious heritage. ... In last analysis we can never allow other nations to decide for us what conduct conforms to our ideals." 8

It is hard to understand this point of view unless we hold that American ideals form a closed system having no common ground with the ideals of right and justice held by other nations. If there is such common ground why not seek to find it? Surely we should not allow other nations to decide our conduct for us, but for that very reason can we insist on more than that we and they should together agree on our mutual course of conduct toward one another? If there is any common recognition of right among men in general how should a nation any more than an individual be justified in insisting on following its own standard of conduct purely?

In short, it is evident that there are two theories of national interest, two kinds of national independence-a tory view and a democratic view. The one leads inexorably to contention, conflict, strife; one might almost say, it makes a duty of them. The other recognizes the value and the possibility of agreement and coöperation between nations as between individuals. National independence no more means the unlimited right of nations to do what they please than individual liberty means the unlimited right of individuals to do what they please. Nations, like individuals, are members of a community and are not independent of the community's common sense of right.

Americans above others should recognize this truth, first because in spite of certain lapses it has in the main been at the

${ }^{8}$ R. I. Usher, The Challenge of the Future, pp. 74-75. 
basis of our foreign policy, and second because we are not yet much involved in those interests and combinations which tend to obscure it. Moreover, it springs directly from the fundamental democratic principles which are at the heart of our internal politics. A nation which is internaily a democracy cannot with more safety pursue a tory foreign policy than it can tolerate industrial autocracy within its borders. The things are not compatible. If our democratic ideals are to mean anything they must be thoroughgoing.

The ideals of a nation are closely bound up with the ideals of living held by the individuals who make up the nation. The tone and spirit if not the content will inevitably be the same in both. And so by way of pointing the connection and of emphasizing again the direction which our individual ideals of living must take if our national hopes and the hopes of our fathers are to be achieved, let me conclude this discussion of ideals with words of that supreme realist, Francis Bacon:

"It will not be amiss to distinguish the three kinds, and as it were grades, of ambition in mankind. The first is of those who desire to extend their power in their native country; which kind is vulgar and degenerate. The second is of those who labor to extend the power of their country and its dominion among men. This certainly has more dignity, though not less covetousness. But if a man endeavor to establish and extend the power and dominion of the human race over the universe, his ambition is without doubt a more wholesome thing and a more noble than the other two." 9

'Novum Organum, I, 129. 


\title{
CHAPTER XVI
}

\section{THE SPIRITUAL TRADITION IN AMERICAN LIFE}

\author{
By Francis G. Peabody ${ }^{1}$ \\ Plummer Professor of Christian Morals (Emeritus) in Harvard \\ University
}

Materialism and Idealism in American Life.-It has been frequently affirmed by critics of American life that it is dominated by motives of materialism. The signs of wealth which are so conspicuous, the skyscrapers and ostentatious homes, the rapid accumulation of vast fortunes, the vulgar prodigality of living and the extraordinary prosperity of great numbers of wageearners-all these signs of the times have made a deep impression upon foreign observers, who contrast these characteristics of American life with the fixity and thrift of the less fluid civilizations of Europe. One of the most distinguished of German economists has thus expressed himself: "The youthful civilization, the incompleteness of conditions, the extraordinary chance of gain in a land which thus far seems inexhaustible, place in the foreground the 'self-made man,' completely devoted to the making of money. Precocious children and immature youths throw themselves into the chase of the dollar. The people have energy but no deep culture. . . . Life is all work, speculation, hustle, gain or loss." Another German critic offers an equally unqualified judgment: "Beyond striving for gold the Americans have no ideal. They think everything can be achieved by gold." To the same effect was the conclusion of the novelist, Von Polenz, after a hurried journey which he describes in "The Land of the

${ }^{1}$ A.B., Harvard, I869, A.M., I872, S.T.B., I872; D.D., Yale, I887, Harvard, 1909; LL.D., Western Reserve, I907; Parkman professor of theology, Harvard, I88I-6; Plummer professor of Christian morals, I886-igr3; Emeritus, 19I3-; author of The Approach to the Social Question (1909) and other works. 
Future": "The daily life of Americans," he remarks, "has the great effect of monotony. Life has lost its finer shadings, or what artists call its atmosphere."

There is certainly much to justify these discouraging observations. The growth of fortunes, the expansion of trade, the cost of living, the pace of life, the unparalleled wages and corresponding extravagance of many wage-earners-all these marks of American life, made the more conspicuous by the vulgar notoriety procured through the sensational press, may seem to demonstrate a condition of irremediable and debasing commercialism. Yet no one can review the history of the United States without observing, beneath these evidences of a shrewd, acquisitive, money-getting and money-loving civilization, a spiritual tradition which is not less characteristic of American life, and which in times of need or strain, like the emergency of war, rises into consciousness and takes command of popular decisions. It is a most impressive fact that the early migrations, which like successive waves flooded across the American continent, were not movements of invading armies, or adventures of reckless freebooters, but of protesting pietists, self-exiled to a new world for conscience's sake. Among the sand-hills of Massachusetts Bay the Pilgrims and Puritans sought liberty to worship God according to their own convictions; through the passes of the Alleghanies tramped the Moravians, singing their hymns; English Quakers named their Commonwealth after William Penn, and called their chief settlement the "City of Brotherly Love."

The American Character.-A spiritual tradition so original and authoritative as this could not fail of permanent effect, and as its consequence the American people, though they have been extraordinarily successful as traders, and are gravely tempted by their prosperity, have remained peculiarly susceptible to motives of moral idealism.

The signs of this inherited inclination are unmistakable, and may be noted among the ordinary practices of American life. The organization of religion, for example, has been from the beginning maintained in the United States on a scale of unparalleled munificence, without governmental subsidy, by the voluntary offerings of citizens. More than 200,000 places of worship, valued at more than a billion dollars, represent the external and obvious testimony to this spiritual tradition. The administra- 
tion of philanthropy is a second example of the same spirit and has distributed with unapproached prodigality the voluntary generosity of private citizens. The institutions for higher education illustrate the same quality. State universities are a modern innovation. The earlier endowments represent the moral responsibility of private benefactors, dedicating their commercial gains to intellectual and spiritual ends. National policies and decisions, again, which have been not infrequently regarded by other countries as Quixotic in their magnanimity-the return of an indemnity to China; the early negotiations with Japan, which have given that proud nation confidence in the purposes of the United States; the policies of the "Open Door" and of the "Square Deal"- these and many other evidences of the national character disclose a quality of candor and disinterestedness which is altogether inconsistent with the conception of a completely commercialized and materialized civilization. No candidate for public office in the United States can afford to ignore this spiritual susceptibility in his constituency. He must either be, or at least pretend to be, a moral reformer, and array his party or group on the side of Justice or Brotherhood or Peace. American voters are quite as much sentimentalists as they are partisans. They demand a Cause which is convertible into the language of the spirit.

The Spiritual Note in American Literature.-The same marks of the spiritual tradition are to be observed in the literature of the United States. The writers, either of prose or verse, who have most completely won the hearts of readers have been, in effect, teachers of morals or interpreters of piety. Longfellow's "Psalm of Life," Whittier's "Eternal Goodness," Lowell's "Vision of Sir Launfal," Bryant"s "hanatopsis," Holmes's "Chambered Nautilus"-verses like these speak the native Ianguage of plain Americans, and appeal to a national character for which Duty, Faith, and Eternity are commanding motives. The Puritan tradition, with its Eiblical background, even if it be in its manners and customs outgrown, and even regarded by the modern spirit as a subject for condescension or derision, still controls the raoral instincts of the unsophisticated majority of Americans, and satisfies their literary judgment with the unobscured and undefiled ethics of their favorite poets. Such was the strain of sentiment which gave distinction to the words 
of Abraham Lincoln and is now heard again in the moving addresses of Woodrow Wilson. The best in American style is the product of familiarity with the Bible. When one passes from popular literature to its more serious and subtle expressions, it is again a striking fact that the most permanent and constructive influence on mature American readers has expressed the same susceptibility. Emerson, with his singular detachment from the world of affairs, and his satisfaction with the life of contemplation, remains the most conspicuous witness of the persistent loyalty of the American mind to its spiritual tradition. Nature to him is alive with God; and even the dark experience of sorrow is illuminated by his firm conviction that "What is excellent as God lives is permanent." In an unpublished letter, written in 1863 to a friend whose only son had been killed at Port Hudson, Emerson, after expressing, in touching language, his personal sympathy, rises to a comprehensive affirmation which might have been addressed to sorrowing parents to-day: "I think daily that there are crises which demand nations, as well as those which claim the sacrifice of single lives. This is perhaps one; and one whole generation might well consent to perish if, by their fall, political liberty and just life could be made pure to the generations that follow."

Here, then, coexist in American life these conflicting traitsa boisterous and unsatiated inclination to commercialism, and a hereditary strain of idealism; the qualities of a shrewd trader and the qualities of an ethical enthusiast; the habits of business and the susceptibility to moral appeal. In this conflict of types is the crucial problem of the American character. Which of these tendencies is to become controlling? Is the commercial tradition to suppress and submerge the spiritual inheritance, so that the country even if it gain the world may lose its own soul; or may it be proved that the lust of money-getting and moneyspending is after all a whirling eddy on the surface of the stream, disguising its course and imperiling navigation, while beneath it the deeper current of national life sweeps on to broader ends?

The Spiritual Lessons of the War.-It must be admitted that these critical questions have not yet found an unquestioned reply. The temptations of prosperity, the opportunities of gain, the unprecedented rate of increase both in profits and in wages which the exigencies of war have promoted, have induced a kind 
of intoxication, both among employers and employed, which, as income has multiplied, has only excited the craving for more. And yet these years of war, which have offered such temptation to profiteering, have at the same time revealed in a most impressive manner the force of the spiritual tradition in American life. Something of the same character occurred at the beginning of the Civil War in I86r. Writing of the first call of Lincoln for volunteers, Carl Schurz reported: "It is impossible to describe the electric effect these occurrences produced upon the popular mind in the United States. A mighty shout arose that the Republic must be saved at any cost. It was one of those sublime moments of patriotic exultation when everybody seems willing to do something and sacrifice something for a common cause; one of those ideal sunbursts in the history of nations." These words might have been written for the present crisis. The same surge of popular emotion has been experienced; and no thoughtful citizen can recall the voluntary sacrifices and munificent generosity of the time without a reassuring conviction that the heart of the nation is sound. The almost universal consent to accept responsibility for a Cause which might have seemed remote or Utopian; the unhindered enforcement of military conscription; the prodigous expenditure of men and money for the reinforcement of the Allies; and still more impressively the abrupt changes in personal conduct-the self-denial in food, not because flour and sugar could not be had, but because they were needed over-sea; the strange silences of motorless Sundays; the glad acceptance of unprecedented thrift-all these restraints and sacrifices have demonstrated that a people whose ancestors endured the hardness of a wilderness for conscience"s sake have not, even under the softening influences of modern life, altogether forfeited their birthright. The gallantry of millions of youths marching to the front has been fairly matched by the selfeffacing service of other millions who have had to stay at home. Few lives, either of men or women, have continued to be what they were. Public service, unpaid and absorbing, has enlisted busy men who would have thought it inconceivable that their own affairs could be abruptly laid aside. Millions of women have abandoned their ordinary habits of comfortable ease and narrow interests, and have answered the imperative summons to unremitting tasks of self-effacing generosity. Business has 
been subordinated; self-indulgence has been uninviting; social distinctions and ambitions have been forgotten; ostentation has been a sign of disloyalty; war loans have been imperative in their call both to rich and poor, and private problems or sorrows have become insignificant in the presence of the vast disaster which had overtaken the entire world. What a testimony is given by this unconstrained and universal dedication to unselfish service of the fundamental qualities in a nation which had seemed to many critics hopelessly devoted to selfish gain! How perplexing must be this evidence of national character to those observers who fancied that nothing but self-interest could draw such a nation into war! It is not surprising that our Chief Magistrate, returning from the momentous deliberations of the Peace Conference in Paris, was led in his first utterance to express the pride he had felt in the universal recognition of the motives which had encouraged intervention of the United States. "In the name of the people of the United States," he said, "I have uttered as the objects of this great war ideals, and nothing but ideals. . . They [the Allies] saw that America not only held ideals but acted ideals. . . . And now these ideals have wrought this new magic, that all the peoples of Europe are buoyed up and confident in the spirit of hope."

The Churches and Their Spiritual Problems.--If, then, the spiritual tradition in American life is historically justified, and if in times of national emergency or strain it reasserts itself as living and potent; if in the crises of national life "imponderable" motives were found to be weighty and decisive, what can be done to maintain these spiritual inheritances in their vitality and efficiency among the ordinary concerns of a nation at peace? The first and most obvious instrument of the spiritual tradition is in the hands of organized Religion. Churches are primarily sustained to express the spiritual life, and in all their varied ways of utterance and symbolism to refresh that life of the spirit at the sources of its power. The founders of the American Republic lived close to these sources of the spiritual life. It must be admitted, however, that in the momentous crisis from which the world is now just emerging, the churches have not maintained their authoritative control over the thought of the time. They have seemed to many minds to be concerned with issues which are technical or remote or unreal, or even completely uninter- 
esting. These millions of young men who have been suddenly confronted by the supreme problems of life and death have had neither time nor patience to consider the subtleties of theologians or the controversies of ecclesiastics. A few great themesa living God, a soul in communion with Him, the temporariness of the physical life, and the permanence of the spiritual lifethese verifiable realities of their own experience in the trenches have made the prevailing interests of the churches, their orthodoxies and heresies, their limitations and exclusions, seem like relics of an ancient era, which can have only antiquarian interest for men of to-day. With a spiritual exhilaration wrought out of profound and immediate experience, these youths are now returning to the world which they have saved, and the churches must either meet their new frame of mind or must abandon all hope of being their guide and counselor. "They went away," a wise observer of them has said, "as boys; they are returning as a Day of Judgment." Organized religion must, therefore, if it would be to the new generation what it was to their forefathers, deal with its own problem of reconstruction. It must turn from many affairs of administration and exhortation which have preoccupied the minds of priests and preachers. It must set quality before quantity in belief, reality before orthodoxy, the joy of service before the pride of sect. Religion legitimately desires to serve these returning soldiers, but it must first prove itself to be that kind of religion which a returning soldier will think it worth while to serve. A reconstructed church must take its place in a reconstructed world if it hopes to perpetuate the spiritual tradition in American life.

Education and the Spiriual Tradition.-The second agent of the "imponderables" in the life of the new world must be found in a reconstructed Education. War, with its stern scrutiny of the real resources of nations, has laid bare two facts which threaten the very foundations of our educational systems. It has been discovered, in the first place, that an astonishingly large proportion of the American people is not educated at all. The founders of the American Republic were educated men, and the maintenance of their ideals depends upon trained intelligence and moral discipline. A democracy rests on the education of its constituency. An illiterate democracy is a contradiction in terms. Yet when the draft required for war was universally applied, it 
revealed an alarming proportion of young men who could neither read nor even understand the military orders which they were required to obey. Examination in the various cantonments on "ability to read and understand newspapers and write letters home," applied to $1,55^{2,256}$ recruits, discovered that 386,196 men, or 24.9 per cent, were unable to meet this test. Nor was the distribution of this illiteracy gratifying to those states where education had been long attempted, and schools and colleges were most abundant. The best showing was not in the older commonwealths of the eastern border, but, on the contrary, in the vigorous life of the far West. The most immediate lesson of the war, in other words, for the future of America, is the absolute necessity, as a condition of self-preservation, of a reduced illiteracy and a universal acquaintance with the English language. ${ }^{2}$ How can the spiritual tradition of the country survive in communities which are in effect foreign in speech, in habit, and in affection? The problem of Americanization begins with a training in American history, literature, and ideals, and this great task justifies not only large expenditure but adequate legislation and resolute enforcement.

The Spiritval Collapse of Germany.-Education, however, even if universal, may violate the spiritual tradition by being directed to other ends. As the material prosperity of a country expands, education may be made an instrument of commercial gain rather than of ideal aims, and in promoting political ambition may forfeit the life of the spirit. That is precisely what has occurred in the most tragic way in the experience of Germany. It is a most impressive fact that if one seeks for the deepest sources of modern idealism, he will find them in the classic period of German philosophy. It was Kant who opened for the thought of his time a way of escape from the externalism of British philosophy, and established the conduct of life on the rock of the Moral Law. It was Fichte who inspired Cole-

${ }^{2}$ Congress has very tardily realized the peril to American civilization involved in a condition in which "frve and a half million persons over ten years of age cannot read anything in any language;" and eight and a half millions "cannot read a newspaper, sign, or letter in the English language;" and a Senate bill of January 29th, 1918, proposes "for the purpose of coöperating with the several States for the promotion of education," to appropriate for the year 1920 , and annually thereafter until 1926 , the sum of $\$ 12,500,000$. 
ridge and Carlyle and Emerson, and through them gave to English readers a new confidence in the spiritual significance of Nature and of human life. The principles of international peace were set forth by Kant in I 795 in words which might have been written in 1919. "No peace," he wrote, "shall be valid which secures material for a future war. . . . Standing armies shall be abolished. . . . The rights of nations shall rest upon a fellowship of free states." The strength of a country, or what Charles Sumner called "The true greatness of nations," was proclaimed in ringing words by Fichte to be, not in political expansion, but in spiritual service. "Seek not," he said to Germany, while Napoleon was still master of Berlin, "to conquer with bodily weapons. Yours is the greater destiny, to form an empire of the mind and overcome a dominion of physical force." What is it then that has sown the seed of arrogant militarism and moral decline in Germany but the abandonment of teachings like these and the acceptance of a creed of force and a lust for power? Instead of Kant and the Moral Law, Germany has turned to the Superman and Blond Beast of Nietzsche; irstead of Fichte and the Commonwealth of the Spirit, Germany has accepted the economic determinism of Marx, the class-conflict and industrial revolution. Here is the fallacy of progress, the mad delusion which has possessed a people having a hereditary right to a great spiritual tradition. The Germany of Goethe and Schiller, of Kant and Beethoven, has been forgotten, and national destiny committed to the doctrine of might and the ambitions of trade. What a lesson is here for any nation which is confronted by the same issue, between power and principle, between education for war and education for peace, between the victories of the flesh and the victory of the spirit! The possibilities of commercial leadership at the present time offer to the United States a dazzling temptation to follow the path of Prussia, and to stake the future on the irresistible force of numbers and wealth. The Tempter sets America on a high mountain of isolated power, where the kingdoms of the earth seem at its feet, and says, as of old: "All these things will I give thee if thou wilt fall down and worship me." It is a moment when Americans should recall with peculiar emphasis their spiritual tradition. If they are to be saved from the shipwreck of national aspiration which has shattered the proud anticipations of Germany, it must be by 
maintaining the ideals which Germany has forsaken and despised. Popular education must reinforce social and personal morality. The world will be safe for democracy only when it is a world trained to believe that a man's life consisteth not in the abundance of the things which he possesseth. "To some Americans," an observant Englishman has lately written, "it may seem that the world lies at her feet if they refrain from involving themselves too deeply in international concerns. But the picture is a mirage. America is great by reason of greatness of soul, by force of ideas, and not by reason of national wealth or power. If she loses her pride of place in the world of ideas, she loses all that makes of her people a nation."

Public Opinion and the Spiritual Tradition.-There remains, behind these agencies of a spiritual tradition which churches and schools represent, the much more pervasive and determining force of the prevailing public sentiment in the masses of the people. Much must be recognized in the temper of the present time which vitiates the social atmosphere and vulgarizes the aims of American life. Wages easily made and recklessly spent; profits greedily increased; the cost of living absorbing anxious minds; conflicts of capital and labor; racial antagonism and local partisanship; economic and international competition-all these characteristics of the time tend to drive from the foreground of national interest the spiritual tradition, and to place there an undisguised self-interest and a rapacious ambition. There is much to justify Burke's protest against what he called "the tyranny of democracy," and which he held to be the most dangerous of all tyrannies, because its decisions admitted no appeal.

And yet, among the wholesome lessons which mitigate the tragedy of war, one of the most obvious and most reassuring is the new outlook on life, the larger horizon of responsibility and desire, the inclination to idealism, which millions of Americans, both at home and over-sea, have come to accept and to cherish. The very dimensions of the problems confronting each American citizen contribute to this enlargement of his mind, and make him in an unprecedented degree a citizen of the world. The vicissitudes of nations whose very names were a few years ago quite unknown to him, and for whose destinies he had been completely unconcerned, now crowd into the foreground of his 
thought as they are recounted in his daily newspaper, and call him from his own local interests, and even his national problems, to unfamiliar emotions of sympathy or compassion or generosity for the troubles of the world.

Along with this education in international sympathy, the war has trained Americans in a new habit of mind concerning their own affairs. They have given to their country vast sums of money and unstinted service, but neither of these testimonies of loyalty has seemed worth mentioning compared with the supreme sacrifice of life itself which their husbands, sons, and brothers have made. And now that the war has ended, they are not likely to sink back again into the satisfaction of mere moneymaking and money-spending. They have had a glimpse of happiness which comes from unselfish and unambitious service. They have revived the spiritual tradition in American life, and have rediscovered the sources of democracy. It is most interesting to observe that as one new demand of reconstruction follows another, the public response to these demands for money and service does not slacken. The sense of social responsibility has been so enormously quickened by the profound experience of war that it seems likely to remain effective. Social distinctions have become impracticable at a time when the humblest citizen may become a commanding officer, and the millionaire may be in the ranks. Uses of money have been discovered which are far more satisfying than the accumulating of more money. In short, the social theory of the relation of the individual and society has become verified on an unprecedented scale as the secret of personal and social welfare. No thoughtful individual expects to solve the problem of his own life except in service of the common good. This is the fundamental significance of the astonishing increase of interest in social regeneration and transformation which the present age is witnessing. Turbulent and extravagant as are many of the exhortations and expectations now so freely uttered, this is at least unquestionable-that they represent an unprecedented movement of social responsibility, and testify to the vitality of the social conscience. Even though reckless reformers may not be prudent or wise, they are at least not thinking wholly of themselves. They are using great words-Humanity, Internationalism, Brotherhood; and even when organized for better wages or industrial revolution, they 
rally under the banners of Liberty, Justice, the Right to a Human Life. In so far as they are idealists the sense of deliverance from themselves gives them courage and happiness. This is what justifies patience and hope in observing many social undertakings of the time, which may appear indiscreet, or untimely, or even pernicious. They are at least signs of spiritual vitality. They register the emancipation of great numbers of plain minds from sordid commercialism, and the direction of their thought to the hope of a better world. A dream of Utopia may be better than satisfaction with things as they are. There are risks in the turbulent movement of a rushing stream, but there are more subtle and malarial risks in a stagnant pool. The social and industrial agitations of the time, even when they seem to be mere outbursts of disorder, testify to a susceptibility among Americans to any suggestion of its spiritual tradition.

There may, even, issue from the readjustments of industrial life which now seem imminent a new babit of mind about the accumulation of money, which will reinforce in an unexpected manner the new idealism. Either by revolution, through the forcible expropriation of capital in some countries, or by evolution, through cumulative taxation of incomes and estates in other countries, it may be reasonably anticipated that swollen fortunes will become more rare and the disposition to accumulate them less encouraged. It may not be probable that poverty will be abolished, but it seems likely that the chasm between rich and poor will be narrowed; that wage-earners will have more and non-producers will have less. In other words there may be less use for money in ensuring personal happiness or future bequest; and more use for money, either by consent or by compulsion, for public service and the general welfare. May not this discovery, that one must expect his surplus income to be taken from him by the state, encourage him to accept the other alternative, of disposing of it himself; and is it not conceivable that a social order without extreme differences of condition may free the minds of many people from the cares and burdens of money-getting and money-keeping, and direct their attention to more satisfying uses of life?

Such are some of the reflections which the dramatic events of the present time suggest as prophesying a revival of the spiritual tradition in American life. The churches, the schools, the col- 
leges and universities, and the lessons of the war, all have their part in this reconstruction of the American spirit. It will remain true that so productive a country and so self-confident a people is still in grave danger from their own prosperity, and may easily be tempted to sacrifice thoughts to things, and ideals to possessions. Yet, if the events of these tragic years of war have brought a great Empire to destruction through the abandonment of its ideal aims, how much more ruinous would be the same misguided amoition in the case of a Democracy! A government for and by the people cannot endure unless the desires of the people are chastened and refined by their spiritual tradition. The stability of the American Republic is to be secured not by conquest of others but by self-conquest. As the things that are seen prove temporal, the things that are not seen may be recognized as eternal. America is not a loose aggregation of states, but a firm habit of mind. The leader of the British Labor Party has lately stated this truth in words to which America way well listen. "Democracy," Mr. Henderson writes at the conclusion of his "Aims of Labor," "will be effective in proportion to the vitality of its spiritual and moral faith. Only a democracy built on the highest form of character will prove to be that instrument by which the world is to be saved." 



\title{
CHAPTER XVII
}

\section{RELIGION IN THE NEW AGE}

\author{
By Edward Scribner Ames ${ }^{1}$
}

Associate Professor of Philosophy, The University of Chicago, and Minister of the Hyde Park Church of Disciples, Chicago

\section{A NEW SCIENCE OF RELIGION}

Scientific investigations of religion are notably difficult to make. The phenomena are so bound up with profound emotional reactions that it is hard to achieve sufficient detachment for proper observation. Not infrequently the attempt to attain the necessary objectivity results in withdrawing from vital appreciation of the experiences themselves. In American life religion has suffered so much from controversialists, pro and con, that it is almost impossible to get a hearing, as yet, for fair and sane considerations of it. So long as its orthodox claims rested on uncriticized customs and beliefs, and the contentions of the "liberals" likewise were based upon equally dogmatic grounds, there could be little real progress toward genuinely constructive conceptions.

The Scientific Study of Religion in America.-During the last fifty years, however, American scholars in various fields have disclosed new, fruitful facts and interpretations. This is particularly well recognized in textual and literary criticism of historical documents, in the study of comparative religion, especially where the Hebrew culture was most closely related to that of other oriental peoples, and in the history of Christianity in its successive epochs and its numerous sects. Also from un-

${ }^{1}$ A.B., I889, Drake University; D.B., I892, Yale University; Ph.D., 1895, University of Chicago; Professor of Philosophy, Butler College, I897-I900; author of "The Psychology of Religious Experience," I9I0, "The New Orthodoxy," 1918. 
expected sources, as from the studies of more primitive races, their language, art, social organization, laws and ceremonials, has come new insight into the nature and function of religion in the life of man. The most recent subject of inquiry affecting profoundly the understanding of spiritual experience, is that of the psychology of religion. This involves not only the experimental, individualistic investigations of the laboratories, but also the discoveries of social psychology.

The Psychology of Religion.-In the psychology of religion American scholars have been foremost not only as to priority in the study, but as to the range of problems treated and the extent of their publication. ${ }^{2}$ The entire history of this science falls within the last two decades. The results already attained justify the conviction that reigion is emerging from the prescientific stage of custom and authority into one of rationalized idealism and practice. Just as there has come to be a scientific treatment of ethics or moral conduct, based upon a more adequate psychology, so religion is on the way to a similar liberation and illumination. In ethics, for example, those who know the recent literature cannot be mere partisans of intuitionalism or utilitarianism. Similarly those who are aware of the nature of religion as shown by a study of its genesis and growth in individual and social experience cannot be sectarians or dogmatists.

Religion, like all other subjects of psychological inquiry, is approached through the characteristic behavior which belongs to it. Mind is shown in outward conduct. This is true even of the lower animal forms. White rats have been studied with good results by noting their behavior in a maze. The maze is a complicated set of runways, blind alleys and possible short cuts, which affords the means of testing the varying ability of individuals in going from the entrance to the food box by the shortest route. The time required to make the first trip, as compared with the shorter periods of successive efforts, measures the learning ability of each animal. Similarly the minds of children are revealed by their facility in mastering specific problems. Playing games, competing in athletic contests, as well as reading, writing and figuring, reveal in outward and tangible ways their

The evidence of this may be seen in the recent volume on this subject by Professor George A. Coe, in which a comprehensive bibliography is given with far the greater number of titles to the credit of this country. 
inmost nature. It is not difficult to know whether they are bright, or dull, or average. Their honesty, courage, patience, industry, ambition, kindliness and persistence are shown. The recent elaboration of mental tests for men in the army and in industry confirms the same principle. Character is thus made accessible and describable. The so-called spiritual qualities are no exception to this law. A man's attitude of reverence, fear, sympatby and faith may be known in the same language of deeds and habits. The study of emotions through outward expression, first by Darwin and later by William James and others, opens the way to a scientific understanding of the profoundest experiences of the soul.

Recent investigations have been vital and fruitful through similar examination of religious behavior. The ceremonials of primitive peoples and the rituals of more advanced societies present the ideals and aspirations of the human heart writ large. The mimetic dances, processions, chants, decorations, folk-tales, hymns, creeds, temples and cathedrals give unmistakable expressions of the inner life. Rightly to appraise these in their whole setting and emotional coloring is to enter the inmost shrines of man's worship.

The Significance of Adolescence.-One of the most fruitful investigations for the new appreciation of personal religious experience has been that dealing with the period of adolescence. It has been abundantly proved by Starbuck, Hall and others that it is between the years of twelve and twenty-four that persons are most susceptible to the appeal of religion. While there is no one religious instinct, or "sense," or faculty, it is not difficult to trace the development of religious feeling and thinking to this epoch when the whole nature is transformed by the new impulse of love and loyalty. Then the boy and girl pass over from the more self-centered and external attitudes of childhood to spontaneous, self-assumed interests in other persons and in social institutions. When one falls in love the world of human relations appears in a strange and fascinating light. A fresh, surprising interest awakens. The sense of the larger life dawns. Patriotism blooms. The recruits of all the armies in the world are drawn from boys impelled by the romantic love of country and by an ideal cause. Our own soldiers have just given a marvelous illustration of this fact. They rose to the great call 
with a zest and idealism which awed and inspired the world. They were adolescent youths stirred by the elemental forces of their deepest natures. The same mighty urge lifts them in times of peace to the adventures of unselfish social service, missionary enterprise, scientific pursuits, and patriotic statesmanship.

This tender, outreaching sympathy and impulse of adolescence to serve the whole world, to relieve suffering and to bring happiness, is one of the deep springs of religion. It has been particularly intense in the great religious geniuses. They may indeed be thought of as exceptional individuals in whom this adolescent quality remained impelling and dominant throughout life. As a young man deeply in love with a young woman will sacrifice and labor, bear hardship and long servitude like Jacob of old, so one's soul may go out for one's country, for humanity and for God.

Religion as Social Idealism.-Professor Cooley, in "Social Process," 3 has well defined the essence of religion as "the expansion of the soul into the sense of a Greater Life." $\mathrm{He}$ adds, "One who has developed a spirit of loyalty, service, and sacrifice toward a social group has only to transform this to a larger conception in order to have a religious spirit. Indeed, it is clear that the more ardent kind of social devotion, like that of the patriot for his country in extreme times, is hardly distinguishable from devotion to God. His country, for the time being, is the incarnation of God."

Religion is a complex of activities and emotions, an organization of attitudes and habits, in the service of commanding ideals. The ideal is necessarily relative to the stage of development. The early nomadic Hebrews had no such exalted hopes as those which inspired the best of the nation in the time of Isaiah. But each level of culture has its characteristic needs and values. These central values elicit organization for their realization and this organization reacts to enhance and affirm the values. Man's gregariousness and constructiveness coöperate with his impulses of affection and his forward reaching imagination to create a better society. That is the source of the new movement in the higher life of America to-day. The soul of the people is stirred to extend kindliness and neighborliness with justice and knowledge to all classes and to all peoples. Newer and larger ideals

${ }^{8}$ P. 75. 
are forming. They are the signs of new and greater spiritual values. The mind and will are struggling to achieve an organization, a form and a system, in which these values shall be preserved and further developed. It is a vast task. It is concrete and practical. Religion, in its healthy expression, has always involved political, economic and social relations. At the present moment the conception of a League of Nations is only the modified and instant embodiment of one aspect of the kingdom, the "democracy" of God. It is the current illustration of the way in which natural, instinctive tendencies develop into tentative, working plans and ideals.

\section{THEORY AND PRACTICE}

Religion, then, according to the scientific investigation of it, may be said to arise from human nature itself, not from any one part, but from the whole of it. The various instinctive tendencies to self-preservation and fulfillment, hunger and love, fear and curiosity, sympathy and constructiveness, are blended in its development. But an additional fact of far-reaching importance is the relation in which thought is found to stand to these instinctive tendencies. It is now seen to be, in a sense, secondary. The impulse, the need, the unconscious propulsion born of the instincts, sets the tasks which quicken reflection and generate ideas. Ideas arise in the course of action. They occur in human experience where tendencies to act conflict, or encounter obstacles. In lower forms, adjustments are made by inherited tendencies or by very simple "trial and error" types of behavior. If the animal can not survive through these it perishes.

The Place of Doctrine in Religion.-With man a larger brain and an accompanying capacity for memory and for greater experimentation in novel situations make for greater flexibility and adaptation. Necessity through pressure of circumstance and urgent need leads to reasoning and invention. This is true in the more advanced stages of human life and in complex social movements. Man's thoughts can only be understood in connection with the situations and the occasions which called them forth. Applied to religion it follows that religious conceptions and doctrines are also conditioned by the exigencies out of which they arise and are therefore not to be regarded as having uni- 
versal meaning or validity apart from those conditions. Thus the familiar notions of the Trinity, Miracles, Man, Sin, Heaven, Hell, Salvation and Damnation belong to a pre-scientific, autocratic, and otherworldly order. They had significance in the time to which they belonged, but they have now either lost or changed their meaning. Professor McGiffert, in his book, The Rise of Modcrn Ideas, has shown how this gradual transformation of thought has taken place.

The Democratic Idea of God.-Just at this time there is interesting confirmation of this influence of social movements on man's thinking, in the changing idea of God. We have come to be acutely aware of the incongruity of cultivating loyalty to democratic ideals when our religion constantly employs autocratic and imperialistic ideas. Before the war Professor Overstreet published significant articles in the Hibbert Journal ${ }^{4}$ on "God As the Common Will," and "The Democratic Conception of God." During and since the war much has been written to express the conflict of the traditional terms and the new ideals which have burned into men's souls during this world tragedy. Traditional Christianity cherished an autocratic conception of God. His will was regarded as supreme. His counsels were secret and not to be questioned or criticized. Man was dependent and his great virtue was complete obedience. Human beings could escape from their desperate plight only through a miracle of Divine grace. The church and a mysteriously sanctified priesthood afforded the channel by means of which the transcendental quality of saintliness became available. The new social consciousness does not depend upon supernatural sanctions. It recognizes the inherent power of man to take some initiative, to create ideals and to find means for their realization. Men are co-workers with God. God docs not achieve his purposes alone. The relation is no longer that of king and subject, of master and servant, but it is rather that of fellow citizens, of compatriots, of members of a free, voluntary association. God is the common will of all those striving for the attainment of better things. The divine life is the associated life of the group, in which each individual participates and by which he is also quickened and sustained. Each member contributes to the whole and derives life from it.

*Vol. XIII. 
Religion and Personality.-All values of religion are undergoing a transformation in keeping with this fundamental change. As yet there is much confusion. Many religionists retain the conceptions of the traditional system while in reality they are busy about the enterprises of social service. It is not entirely clear to the average church member just what relation his interest in reforms has to his religion. He is usually told from the pulpit that such causes as temperance, social hygiene, Red Cross and education belong to the category of "good works" but have no "saving power" in themselves. Genuine religion is supposed to flow from an inner emotional experience which may well enough express itself in works of charity, but which is not in any sense bound up with these practical concerns. The new social conscience furnishes increasing evidence that this consciousness is generated in social experiences themselves. Patriotism arises through the instincts of sympathy and gregariousness. It is strengthened by accumulating experiences of heroism and sacrifice. One comes to love what one works for. Men are more and more devoted to the building of a better society on earth and this devotion has come to have religious value. The concrete relations in the family, neighborhood and nation; in one's profession, business, or research; in the enterprises making for the safety of childhood, the elimination of disease and the securing of fullness and freedom of life generally - these are the relations in which the ultimate and final values are realized. The development of personality-intelligent, sympathetic, vigorous personality, for all classes and conditions of people, is the coming conception of the religious ideal. And the value of this personality is not to be estimated in terms of its perpetuation after death, but in terms of is fruitfulness and noble satisfactions in this present world. Such an empirical, practical religion draws strength from modern science and is one with social idealism at its best.

THE MOVEMENTS WHICH GIVE PROMISE FOR THE FUTURE

The Ideal Religion Does Not Belong to the Traditional Faiths Nor to the New Cults.-When one looks about in American life to find religious movements which give promise of fulfilling the demands of the new day, the conviction deepens that no one of 
them answers the need. The older systems are survivals from a distant past and only continue because they are sustained by the inertia of great human traditions. They are on the defensive at every point where they come into contact with the true modern spirit. The Roman Catholic Church is mighty in numbers and in wealth, but it is autocratic and archaic. It perpetuates most picturesquely the form and the ceremonial of the old court of the Cæsars with certain changes of names and symbols. It is not democratic, though it deals with many poor and humble people. It instills the habit of obedience and subjection to external authority. Protestantism is not radically different from the mother church in its fundamental conceptions, though it has substituted another authority, that is, the Bible, and has lost outward unity. The main doctrines of God and man, of nature and sin, of self-sacrifice and atonement are not essentially modified. In both systems God is remote, perfect and arbitrary. Human merit is as filthy rags before him. The human will is of itself impotent and man's wisdom is but folly. Any real values which humanity may enjoy are imported from a foreign, supernatural realm.

Scarcely more promise of satisfaction can be found in the programs of the "liberal" religious bodies. Though they have had remarkable individual leaders and have enjoyed a very high level of scholarship and culture their power is waning. In spite of great wealth and exceedingly broad terms of fellowship they cannot recruit their ministry from their own churches nor maintain their congregations in the most populous cities. It is likely that they lack vitality because they are so largely movements of protest. As the old order against which they cry out loses its significance, the protest also fails of interest. The unitarian cause could have little to commend it in a society where there were no trinitarians. Independent congregations which have reached extreme isolation from all denominational attachments by a process of dissent from one doctrine and practice after another, may experience a certain joy of consistency, but they are individualistic and aloof in an age when the need of coöperation is most insistent.

Of the distinctively American religious movements, in the sense of having their origin in this country but not in the sense of embodying characteristically American ideas, the Spiritualists, 
Mormons and Christian Scientists are radically different. The first two already appear as strange episodes in the religious life of the nation and the third is destined to share that fate in the end. Spiritualism belongs to the sphere of suggestion and hypnosis, which are being brought under scientific explanation with the developments of modern psychology. The greatest experts, like William James, who have studied the phenomena, have remained sceptical and unconvinced by the claims of this cult or of individual mediums. Mormonism is an interesting illustration of the belated appearance of a new cult adopting all the ancient claims of special revelations, visions, miracles, and divine authority, at the moment when, at the more advanced levels of culture, a truly scientific conception of life was beginning to prevail.

It is important to remember in the presence of such phenomena that human society presents at any moment a condition comparable to the stratification of the earth's surface. Different geological ages are represented by the different strata. Similarly human society in a given city or nation contains enormous cultural differences. At this moment in New York or Chicago one may see almost primitive groups, ruled with marvelous rigidity by the customs of the clan. Superstitions worthy of the remotest savages abound. Miss Jane Addams has given a striking example of this in her account in the Atlantic Monthly ${ }^{5}$ of the Devil Baby at Hull House. Coexistent with this primitive type may be found in the same community persons of the emancipated, civilized stage of human evolution. Between these extremes are to be found all degrees of enlightenment. Perhaps the total population may not be truly represented by a pyramid whose broad base is the vast majority above whom the numbers rapidly diminish in an ascending scale of culture to the apex. But the persons who are illiterate or equipped only with the rudiments of an education are vastly in the majority over those who have any vital acquaintance with history and our larger social inheritance.

Christian Science, although the latest of these modern cults, in reality belongs to the pre-scientific age. Its devotees do not represent the highest strata of mental development. They do not employ methods of science and they do not express that

${ }^{5}$ I9I6. 
social sympathy for the needy and unfortunate masses which is certainly an essential quality in genuine Christianity; indeed, in all religion. This movement is not renowned for its philanthropies, for its educational programs, or for any constructive social measures. It remains as individualistic and as remote from practical life as the older orthodex faith toward which it assumes an unwarranted air of superiority and modernity. In common with other health cults it has struck a popular chord in its attacks upon an immoderate use of drugs and in its appeal for courageous and confident living. In the rushing life of America, it appeals particularly to weary middle-class women and to certain leisure class persons, as well as to the neurotic. To the many Jews in Christian Science it represents a soft compromise with the faith of the majority. It is also made impressive to the susceptible portion of the public by a luxurious display in building temples and by the clever and powerful organization of its finances. But it lacks the convincing intellectual grip and sane practical idealism necessary to cope with the religious needs of the American people.

The Ideal Religion Belongs to the Progressives of All Bodies.Greater hope of deliverance for the bound and confused soul of this nation lies in the great unfolding of thought and spiritual aspiration which characterize the progressive, constructive movements in the established religious bodies. These are known as modernism among the Catholics, as Liberal Judaism among the Jews and as Higher Criticism among Protestants. Higher Criticism is not an adequate designation for the progressive tendency in the Protestant bodies, but it may be taken as the symbol of the larger movement because it deals directly with the fundamental conceptions of the Bible upon which Protestantism rests. The doctrine of evolution is a common possession of these liberals of all parties. But more important than this is the common social idealism which pervades them. They are all guided more by the desire to meet the needs of men in the actual relations of their daily life than to maintain institutions and forms of the past. The men of these advanced positions find themselves in closer sympathy and intellectual agreement with the liberals of other groups than with the conservative, unscientific minds of their own traditions. And the comradeship they feel is not that of simple tolerance as may often happen between socially 
experienced men of different cultures. It is the understanding insight of those who have found deep and solid ground through a knowledge of the history of all human institutions and who share the common hope of a great democratic faith for mankind. The great movements for the federation of churches and for scientific religious education are led by men of this spirit.

The New Order Will Gain the Support of the Educated Youth. -The views of history, of evolution and of social reconstruction which were so new and startling to the passing generation, schooled as that generation was in the traditional, orthodox religion, are now being received as matters of course by the rising body of youth who have been educated from childhood in the atmosphere of the modern scientific interpretation of life and society. They have no feeling for the "Warfare Between Science and Theology." They cannot understand the excitement which Robert Ingersoll created all through the nation. That was due to the impact of a brilliant, rebellious soul upon the hard, dogmatic belief of the past. He would cause little stir now. Minds which grow up in the high schools and colleges of the present time where evolution rules in all subjects are saved much of the strain which came to those who had to learn to reinterpret all of the important interests of life. The fortunes of religion in the state universities of the United States as compared with the denominational colleges are significant in this connection. It has often been observed that the state institution, with its greater freedom, developed a more vital regard for the essential qualities of character and genuine religion than did the school which was controlled by denominational agencies and employed strenuous means to induce the conventional type of religious experience. Doubtless the secular university lacked much through unorganized treatment of the native idealism of youth, but at least it did not impose anything which later would have to be uprooted.

\section{THE DEMANDS OF AMERICAN RELIGIOUS LIFE}

The religious idealism of America thus hastily sketched may be summarized by indicating its conspicuous characteristics.

First, it is marked by a keen sense of reality. It rests upon deep foundations in human nature. The successful chaplains in 
the American army were those who went beyond the formalities of their office and dealt with the men in natural, vital ways. They conducted vaudeville entertainments and boxing matches, but they held religious services in a frank, sincere spirit. They got close to the men in private, helped them with their correspondence and other intimate things, and did not shrink from danger when natural human need called them. The same quality of service is demanded of the ministry to-day. Naturalness, sincerity, intelligence and earnestness are essential to it.

Second, American religious idealism is social and thoroughly democratic. It appreciates the hunger and restlessness of the masses of laboring people. It deplores the fact that the Church seems to them a capitalistic institution. Such interpreters of Christianity as Professor Rauschenbusch, while identified with religion themselves, have been the severest critics of its surviv-. ing forms of autocracy and otherworldliness. The new dreams of social justice do not rest upon inherited rights, but upon the claims for equal opportunity and demonstrated merit. In the new order the old barriers of race, creed and privilege are melting away under the warmth of the companionship engendered by practical coöperation. There is reason to believe that the fierce war between capital and labor as well as other class conflicts will disappear in the new era before that fraternity which enlightenment and efficiency require.

Third, this religious idealism is thoroughly committed to education and to scientific knowledge as essential to its own fulfillment. It is encouraging to remember that religious organizations have founded most of the institutions of higher learning in America. They continue to be the patrons of scholarship in spite of the reconstructions which knowledge brings to all creeds and customs. There is a deep conviction that men must know the truth and that the truth will make them free. Neither is it any longer expected that this truth will be discovered in some final and static form. The very essence of science as of religion. itself is to open larger and larger vistas of growth and achievement. Men have come to realize that they pursue a "flying: goal," always partially attained but enlarging as it moves before them. And this conviction does not depress them but inspires them with greater ardor and joy.

Fourth, practical religious idealism has much need for art and 
for forms of art produced out of its own needs and creations. The old order preserved the attitudes of surrender and dependence before an all-powerful Ruler. The new order demanu's other songs and pageants and dramas to express its creative hope and faith. The old looked away to the remote heavens. The new takes account of its immediate community, maintaining due respect for the far horizons. It cherishes the symbol of strong, resilient youth rather than that of emaciated hoary age. The change is well expressed in the contrast drawn by Professor Mecklin in the Passing of the Saint, in the American Journal of Sociology: ${ }^{6}$ "It is no accident that we must seek our modern saints, those who most nearly fulfill the rôle of Anselm or Bernard or Damiani, in men and women that for the most part are not identified with institutional Christianity. It is our Lincolns, our Florence Nightingales, our Booker $\mathrm{T}$. Washingtons that seem after all to have caught and interpreted the universal human values of the age."

- January, 1919. 

PART V

THE CONSERVATION OF HUMAN RESOURCES 



\section{CHAPTER XVIII}

\section{HEREDITY AND EUGENICS}

\section{By Charles B. Davenport ${ }^{1}$}

Director, Station for Experimental Evolution; Director, Eugenics Record Office, Cold Spring Harbor, N. Y.

Meaning of Heredity.-The biologist, particularly the geneticist, who deals with the inheritance of traits, no doubt is led to lay more stress upon heredity than those who know nothing about it. Nevertheless he can contribute vitally to the solution of the problems of social reconstruction. For him, heredity is that which makes one man like another man and which likewise accounts for a large part of the dissimilarity between men. Brothers, twins, are more similar in appearance and behavior than men from the different anthropological races because such close relatives are derived from the same germinal material; while the germinal materials of the different anthropological races are very dissimilar in the same way as, and for the same reason that, the germinal materials of a fox terrier, a Great Dane, a collie, and a bull dog are different. Now, just as the difference between these different races of dogs is found not only in their form but also in their instincts, just so the differences between different anthropological races are due to germinal differences that affect not only form and color and details of physical features but also instincts and temperament. The differences between the various European races and the less noticeable

${ }^{1}$ A.B., Harvard, I889, A. M., Ph.D., I892; taught zoölogy, Harvard, I890-Igor; associate professor of zoölogy and embryology and curator of Zoölogical Museum, University of Chicago. I901-I904; director, Station for Experimental Evolution of the Carnegie Institution; organizer and director. Eugenics Record Office, since 1904; director, Biological Laboratory, Brooklyn institute of Arts and Sciences, since I898; author of several works on heredity and eugenics. 
differences between a Yorkshire man and a Lancashire man are due to this same cause.

The first hope, then, that the biologist has for the new era is a fuller and franker recognition of the congenital dissimilarity in form and function of men.

The widespread heresy that people are born alike, with the same potentialities and consequently capable of being trained to react in just the same way, will be instantly opposed by every parent who has reared three or four children to maturity. The parent knows that, though he may have given all of ihem the same opportunity and training and may have treated them essentially alike, still from the very beginning they have been different. This difference between brothers and sisters has indeed been regarded by those ignorant of biology as evidence against the truth of heredity. Such a view belongs to a bygone era when we spoke of heredity as the resemblance of children to their parents. This era has, however, now long since passed in scientific circles and we now recognize that any resemblance there may be between parents and children is due not to the fact that the parents have in some way influenced the traits of their children but to the fact that parents and children are parts of the same germinal material. For not all of the fertilized egg (out of which the adult parent was developed) is used up but some of it remains behind as the germ cells of that parent, kept in a sort of trusteeship by the body of the parent for the next generation. The reason why the children of one father and mother are not all alike is because the germinal material is not homogeneous. The germ cells carried by a mother are unlike because the germinal material is a hybrid material owing to the fact that it is composed by the past union through many generations of dissimilar germ plasms coming from biologically dissimilar strains. Thus when the brown-eyed parents are both derived from a mixture of a brown-eyed and a blue-eyed strain they have not only brown-eyed but also blue-eyed children. This is no argument against, but rather strong evidence for, the action of heredity in this case. Since heredity controls in such a marvelous way the details of form and behavior one marvels that society has been so slow in taking advantage of this tremendous natural force. If we seek a Utopia in which health and cheerfulness and self-control shall be widespread or nearly universal 
we can get it much more certainly than in any other way by taking advantage of heredity. We can purify our body politic of the feeble-minded, the criminalistic, and the wayward by using the knowledge of heredity that has been already acquired. We can hardly do so in any other way. We may hope, therefore, that in the new era the sociologist and the legislator will consult the biologist; or, rather, that the biologist will come out of his laboratory and state the truth as he has learned it in such a way as to influence the development of society.

Meaning of Society.-To the biologist man is only one of the hundreds of thousands of species of animals with which the world is peopled. To the inquiry why is man on the earth, the answer must be because he cannot help it. Man is here for the same reason that the planet Mars is in the sky, that the starfish clings to the rocks of the seashore, that wolves prowl through the northern timber, and that chimpanzees accompanied by their wives and little children wander through the jungles of Africa. When man stopped wandering through the forests and adopted agricultural habits or became a dweller in villages his gregarious instincts led him to formulate certain standards which he and his fellow man would have to meet if society were to be maintained. Provided with complicated speech and with a remarkable capacity for ideation, he began to formulate rules of social conduct. He said: "Nobody in this community may kill another man, or run off with his wife, or steal his $\operatorname{dog}$ or his war implements, or do anything else which is against the common interest of the community." In any such community, however, it soon appeared that while the most of the members had a capacity for controlling their instincts for the sake of common good, yet there were some individuals who had no self-control and acted only in accordance with their instincts and their selfish desires. In primitive communities such anti-social individuals were generally put to death and with them died not only the anti-social individual but the germ plasm he carried-the potential beginnings of a whole line of anti-social beings. In our highly organized communities of the 2 oth century we have precisely the same situation still persisting. We have men and women of all degrees of self-control and ability to inhibit their individual personal desires for the sake of common good. In some communities where weak inhibitions are the rule we have, indeed, the ideals 
of self-enjoyment, of full expression of the emotions and the carrying out of instincts and desires. But in the past such communities have shown that they possess the elements of social decadence. Such communities have been weak and easily overwhelmed by other neighboring communities in which self-control was strong and in which inhibition of the individual's desires for the sake of the common good was highly developed. It is because of the experience of the race that in socially well-developed communities the elders label the feeble-minded and the feebly inhibited as bad persons and seek to have them segregated, put to death, or banished. If the feeble-minded and the feebly inhibited are few in number in the community they have no recourse but to yield. But where their numbers approach those of the highly socialized they may turn and put to death the bourgeoisie, the successful, the talented and the self-controlled, and usher in an epoch when every man is free to exercise his instincts and to enjoy his selfish pleasures without regard to his fellow man.

In our own country at the present time, in most communities, the mentally developed and the strongly inhibited are still in control. Convinced of the righteousness of their ideals and provided with the power, they seek to do away with the feebleminded and the feebly inhibited that they, and like-minded neighbors, and their children, and their children's children may enjoy peace and prosperity through the coming centuries. To secure this end they have tried the nostrums which the sociologists have proposed and too often they have failed. There is evident now a tendency to turn to the biologist for assistance and his advice is this: If you desire to purify the body politic of the feeble-minded and the feebly inhibited you must eliminate the germ plasm which produces these ineffective and antisocial strains.

Theory of Eugenics.-Accepting as the experience of preceding generations that the intellectual, the highly socialized and the self-controlled are "the best" and assuming the power of a community to secure the best, then the eugenics program consists simply of this: The elimination of the worst strains and the promotion of the best strains. The method of the eugenicist for bringing about this result is this: Foster the marriage rate of "the best" strains: secure, as far as possible, that persons belong- 
ing to such strains shall mate with others who belong to similar strains. Encourage in these best matings the production of many children to the end that the best strains shall maintain their predominance in the community so that the numerical supremacy of "the best" may remain undisputed. On the other hand, repress the reproduction of the feeble-minded and of the uncontrollable by preventing their marriage if possible or by reducing the number of children that come from marriages outside the circle of "the best." Let us consider in more detail some of the ways in which these two great aims of maintaining the superiority of the best strains and eliminating the worst strains may be brought about. First of all, however, we must recognize that persons that belong to the worst strains are sentient beings and unnecessary pain must not be caused. Against them individually nothing may be done which will hinder their happiness, except in so far as the greater happiness of the whole community is concerned. But over their reproduction an organized society certainly has the right of control. Whether it is strong enough to exercise that control or not is another question.

\section{Methods of Increasing "The Best" Strains.-In order to secure} a maximum increase of "the best" strains it is necessary that so far as possible such strains should be mated. The control of matings is one of the greatest difficulties with which organized society has had to cope. Different methods have been evolved in different places. In some "primitive peoples" the elders of the tribe arrange matings. In other socially well-developed countries, like China and some countries of Europe, the parents make the selection. In other countries, like Great Britain, and especially in its colonies, the external control of matings has been in large part abandoned and mate selection left to the instinct of the young man and woman. Which of these various methods is the best method is not perfectly clear. Probably the best method for one country would not be best for another. Where young people have little control over their emotions it is doubtless better for the elders to determine mate selection; but in a highly inhibited strain this matter may well be left to the young people. Attention is called in passing to the fact that what may have been a good method in New England in the eighteenth and early part of the nineteenth centuries is not necessarily a good method in parts of the country where 80 per cent of the popula- 
tion are of the warmer-blooded races of southern and southeastern Europe.

The whole matter of mate selection has become greatly complicated in our country by the development of great cities and the consequent breaking down of communal life. In these great cities young men and young women meet each other primarily as industrial and economic rivals and the ideals of the family have largely disappeared. The more self-controlled of the young people tend to live rather isolated lives; they have comparatively little opportunity for getting intimately associated with the opposite sex. Efforts have been made in certain cities to bring young men and young women together in social intercourse but the difficulties in the way of doing this on a large scale are very great. The selection of mates has been much interfered with by the separation of the sexes in education, especially in the later years when such selection is most apt to occur. Co-education increases the range for mate selection of the more ambitious and educable part of the population.

Marriage.-The mores, the customs, of our country and of a large part of the more highly organized world, especially north-western Europe, its colonies, and certain primitive peoples, call for the life union of mates in the institution of marriage. The ideals of different communities differ, however, so that in countries like China and India and eastern Europe, there may be a more or less permanent union of a man with two or more women. The mores of north-western Europe, however, are those toward which civilization seems to be tending, partly because of the undemocratic nature of polygamy. Though there are those who maintain that with the mores of polygamy racial progress can be made more rapidly than otherwise, yet such is the importance of preserving marriage mores that the eugenist assumes the desirability of monogamy and seeks to discover the best eugenic procedure under it.

Fertility.-It is not enough, however, that young people should become acquainted and marry and that the mate selection should be a proper one. The carrying out of the eugenic program requires that there should be a fair-sized family of children derived from such a marriage. While voluntary childlessness in marriage is probably rare, yet restriction of offspring is all but universally practiced in the union of "best" strains. This is believed to 
have an economic cause, since children are no longer an asset, as they were in colonial times, but instead are a financial burden carried by the parents for twenty or more years. Various plans have been proposed for obviating this difficulty and encouraging the production of large families. There are those who maintain that the state should care for the children; that there should be nurseries under state care where the children might be reared and schools where they might be trained out of contact with their parents. Such a proposal is blind to the facts of heredity which make it quite certain that nobody can understand a child as well as its parents who, being of the same strain, have the same tendencies and instincts. Also this proposal fails to recognize that nothing can replace, in the care of children, the parental instinct.

In the coming era in America the ideal must be inculcated among "the best" strains of having a minimum of four children. This number will practically only replace the preceding generation since two persons of that generation are involved in making the family, one child may possibly die in early life, and one child will probably not reproduce. Where it is economically possible, families should be even larger than this. The barrier to large families should be diminished in all possible ways. Primarily proper ideals as to relative values must be inculcated-that it is more important to bring a healthy child into the world than it is to leave it a financial endowment. Good health, vigor, and mentality will more than offset limitations in patrimony. The stimulus of a growing family has often been the means of success to a young man who would otherwise have made a failure. Lack of capital is often more than compensated for by mutual assistance of a band of brothers and sisters. The education that a younger child receives from the elder children, and which the elders gain reciprocally by instructing, is often as important as the expensive, prolonged education of the university. To normal parents there is absolutely no pleasure in life which can equal that of watching the development of their own children.

Again, the economic hindrances to the raising of large families should be reduced as much as possible. The remission in income taxes of the parents should cover the cost of maintenance and education per child. What parents would otherwise pay in taxes they should apply towards the support of the children. The un- 
married or childless should pay double or treble taxes to make possible this relief of the parents of large families. Especially, inheritance taxes should be graduated with relation to the number of children remaining; the larger the number, the smaller the inheritance tax rate.

A corollary of the principle of increasing the fertility of "the best" strains is that of reducing the fertility of the "inferior" stock. Under present conditions the inferior stock is much more productive than the superior stock. Simple arithmetic shows that if this process continues the time will come when the inferior strain will be much more numerous than "the best" stock.

The measures necessary to reduce the strength of inferior strains are: (r) Propaganda of sex control among the "inferior" stock; appealing to their cupidity to increase economic ease by having fewer children. (2) Sterilizing representatives of the clearly anti-social or criminalistic strains. (3) Segregating the feeble-minded, wayward, etc., during the reproductive period. (4) Passing laws against the marriage of feeble-minded, insane, epileptic, alcoholic, criminalistic, etc.

Making Heredity Work for Society. - The geneticist recognizes that every child is a unique mosaic of hereditary factors. By virtue of his particular factors every child has a set of traits which firs him for a particular niche in the social organization. Since the young person has nothing to do with determining his traits it is the duty of society to find the proper niche for every kind of person. Otherwise society will have a failure on its hands to support. For example, the sculptor will usually make a success only in his special work. Society should feel the duty of maintaining art, even when it has no heroes to celebrate, so as to have the artist available when he is needed. Similarly it is reason enough for developing institutions for providing the public with music that we have in our population persons who are uniquely equipped to compose beautiful music. On the other hand, there is not apt to be a lack of demand for great executives, inventors, literary men and persons capable of hard and prolonged manual labor. Also there is apt to be no dearth of men to meet this demand since this country is, at present at any rate, provided with strains which are producing them in large numbers. The principal difficulty is in finding the man who is best fitted for the job we have to offer. Here is where heredity 
can be of assistance. For the capacity of the untried man will be revealed through a study of his juvenile promise and his family history.

Other Social Applications of Heredity.-Not only in finding the man with the gifts required for a particular work but also in detecting the potential feeble-minded, the criminal, etc., the student of heredity can be of great assistance. Experience indicates that two feeble-minded parents produce only feeble-minded children. Conversely if we are certain that the parents of a given child are both feeble-minded we anticipate that the children will be so. Similarly, not merely environment but family history should be studied to learn whether a given child will probably become an evil doer.

The facts of heredity may well be of assistance in the legal profession, especially in the criminal law. Some day it will be recognized that in cases of doubt the best test for the mating of two persons is to be afforded by comparing the physical and mental traits of the persons in question and of their close relatives.

Immigration in the New Era.-It is not sufficient that a community or a state should purge itself of the "inferior" strains. It must guard itself against the immigration into the community of persons carrying "bad" germ plasm. It is blindness indeed for a country to admit with little question a million immigrants of whose germ plasm or family performance it knows absolutely nothing. Our country does not proceed in this way in importing breeding animals, such as horses or bulls or sheep. Such animals imported from Europe are almost invariably accompanied by a long pedigree. Perhaps in regard to people we are still under the influence of the theory of the colonial governor who welcomed the overflow from the prisons of London to Virginia on the ground that the better conditions in the new world would counterbalance their innate handicaps. Is this theory justified? Let the mountain whites of southwestern Virginia; let the Ishmaelites of Kentucky and Indiana; let the slums of Sydney (Botany Bay), Australia, answer. The choreics who left Long Island and went to California produced a strain of choreics there. The descendants of the Jukes of the Hudson River valley who went to Minnesota form a little Juke colony there. The thousands of children picked from the gutters of New York and sent to the 
Middle West have made such a reputation in their communities that some of the central states now require a bond from the Children's Aid Society that their sendings or wards shall not become charges on the state. Blinding their eyes to the consequences of their acts, our ancestors sought personal ease and wealth by exploiting the gentle-faithful, and intellectually undeveloped denizens of central Africa, to do their work and have left to their descendants a problem of hybrids with tendencies toward drunkenness and rape and social disorder which will remain with them to the end. Our nearer ancestors have lured from Europe some of the least ambitious and most gullible to build railroads and mine iron and coal for the lowest wages and they have bequeathed to the later generations what the future will bring forth. It is for the biologist to get out of his closet and proclaim from the housetop the necessity of at least maintaining the mediocre quality of germ plasm that we have in this country and of preserving it from any further dilution. We should know something about the hereditary capabilities and past performance of the human breeding stock we import. 


\section{CHAPTER XIX}

\section{THE CHILD AND SOCIETY}

\section{By Sophonisba P. Breckinridge ${ }^{1}$}

Assistant Professor, The University of Chicago; Dean, Chicago School of Civics and Philanthropy

The outbreak of the war found certain efforts in behalf of children fairly well organized. These efforts were directed toward the control or elimination of evils which had become apparent in all industrially advanced communities, as constituting serious perils to the well-being of the nation.

Child-Labor Legislation or Factory Acts.-Through the enactment of so-called "factory acts" or child-labor laws practically all civilized countries have agreed to resist the evil of premature and excessive labor on the part of children and young persons and to secure for all from twelve to sixteen years of childhood and protected adolescence up to the eighteenth year. England led in the formulation of such legislation, ${ }^{2}$ beginning in 1802 with a "Health of Apprentices Act" and developing its protective laws until all mines, quarries, factories, workshops, mercantile establishments, and theaters came under national legislative regulation and until the localities were authorized to give protection to the little street trading boys and girls whose occupation led them into crime, beggary, and immorality. It was recognized that agricultural and domestic workers were still to be brought under the protection of similar measures.

In the United States, legislation drafted after the English

'A.B., Wellesley, I888; Ph.D., University of Chicago; assistant professor, household administration, University of Chicago, I908_; dean, Chicago School of Civics and Philanthropy; secretary, Immigrants' Protective League; chief, Division on Adjustment of Homes and Family Life. Carnegie Study of Americanization; author of several books on the child and the home.

${ }^{2}$ Hutchins and Harrison, History of Factory Legislation. 
model had been enacted in most states. In general, the age below which children were to be excluded from wage-paid work was fourteen years, with a few backward states still accepting twelve years; the educational minimum was hovering between the fifth ${ }^{3}$ and the eighth grade; normal physical development was being required; and there was a growing demand that employment should already have been found before the child should be authorized to leave school.

In the adolescent group protected by these laws were those between fourteen (or twelve) and sixteen and from fourteen to eighteen or even twenty-one in especially dangerous occupations in a few advanced jurisdictions. ${ }^{4}$ With reference to these, the length of the day's work, the portion of the day within which employment was lawful, the probibition of night work, and the nature of the employment allowed, were all matters of legislative regulation. The administration of these laws wherever it was intended to make them effective was entrusted to a specially created staff of factory inspection.

For many years it was realized that because of the varied forms in which these laws were enacted by the different states, the different standards of efficiency in the administrative organizations, and the different degrees to which the child-employing industries controlled state activity, a federal child-labor law alone could do justice to the industrial organization and give to the children in the more backward states the measure of protection desired by the more advanced communities. In I9I6 a federal child-labor law was finally enacted, recognizing sixteen as the age below which children should not be allowed to work in the mines and quarries, fourteen as the minimum for employment in manufacturing, and fourteen to sixteen as the age during which the young persons should not be allowed to work more than eight hours a day, or forty-eight hours a week, or between the hours of $7 \mathrm{p} . \mathrm{m}$. and $6 \mathrm{a} . \mathrm{m}$. Goods made under conditions violating these provisions were under the law to be excluded for thirty days after manufacture from interstate commerce. The enforcement of this law was entrusted to the Children's Bureau in the Department of Labor, and for the first time there existed a national agency capable of standardizing and unifying the

${ }^{8}$ U. S. Children's Bureau Publication No. Io.

E.g., messenger service in New York. 
activities of the entire country in behalf of the right to childhood. This act was, however, on June 3, I9r 7 , held unconstitutional ${ }^{5}$ by a vote of five to four justices on the Supreme Bench as a misuse of the federal power over interstate commerce to prevent child-labor within the respective states. A war-time measure taxing the products of establishments violating the standards laid down in the earlier act has, however, been enacted as an item in the revenue bill; and this incapacity of the federal government will undoubtedly be permanently overcome so that a way will be found of giving to all the children of the United States that protection demanded by all civilized communities.

Education.- The importance of universal elementary education in a democracy has been so obvious that the provision of school facilities has always been a matter of concern to the states and to the federal goverament, and the grant under the Ordinance of 1787 to the school fund of the states created from the Northwest Territory ${ }^{6}$ of the sixteenth section (one square mile) of every township, was an expression of this conviction on the part of the founders of our government. While educational legislation was enacted by the various states, its administration in many states was left to the school district, and the attention of the school authorities had been, until a comparatively recent date, devoted to the problem of obtaining adequate school facilities, so that the necessity of efficient machinery for securing universal attendance had not been recognizeả. Conditions have changed, however, and there is a well-nigh universal requirement that children between the ages of seven and sixteen shall attend school unless they are over fourteen and under the pressure of poverty to become wage-earners. The duty of granting the so-called "working papers," authorizing a child to leave school to go to work, is commonly laid upon the school authorities. As in most of our states these are local rather than state authorities, there is great irregularity and uncertainty in the

'U. S. Children's Bureau, Child Labor Division, Circular No. 2, Decision of the United States Supreme Court as to the Constitutionality of the Federal Child Labor Law of September I, I9I6.

W. C. Hammer, U. S. Attorney for the Western District of Nortin Carolina, Appellant, v. Roland H. Dagenhart, and Reuben Dagenhart and John Dagenhart, Minors, by Roland H. Dagenhart, their Next Friend. Supreme Court of the U. S. No. 704-Oct. Term, 1917.

-Journal of Congress (Philadelphia, I801), Vol. 10, p. 21. 
enforcement of these statutes and many children fail to enjoy the rights formulated for then by the state law.?

It is now understood that the compulsory school laws and the child-labor laws are interdependent and that weakness in the administration of either prevents effective enforcement of the other. The creation of a national Department of Education which shall serve as an agency for national control, supplying to all children a national minimum of education, is now urged by the educators and has been made the subject of proposed federal legislation. Already, in fact, the inability of the states to provide those opportunities which are necessary as the nation develops industrially, has led to the policy of the federal "grants in aid." Under the so-called Smith-Lever ${ }^{8}$ and Smith Hughes ${ }^{9}$ laws, coöperation is established between the fecieral government and the various states for the purpose of stimulating interest and of developing resources of instruction in agricultural, industrial, domestic, and other vocational lines.

Juvenile Labor Exchanges or Vocational Supervision.-It has become obvious that however efficient the child-labor legislation may be its effect is a purely negative effect. During the past two decades evidence has accumulated to the effect that there was hideous waste not only in the early employment and in the overwork of children but in the failure to adjust, even when their first employment was not unlawful, their early working life to their adult industrial careers. The blind-alley job, the ugly demoralization resulting from shifting from job to job, the treatment of young persons as "legitimate objects of economic exploitation instead of as subjects to be regarded by the social conscience," ${ }^{10}$ the conception of the juvenile as primarily a wageearner instead of a citizen and workman in training-these numerous evils had become evident sources of poverty, demoralization, and distress through the manufacture of under-employ-

${ }^{2}$ Abbott and Breckinridge, Truancy and Non-Attendance in the Chicago Schools; U. S. Children's Bureau Publications Nos. I2, I7, 4iI.

${ }_{3} 38$ Statutes at Large, Part I, chap 79.

- 39 Statutes at Large, Part I, chap II4.

${ }^{10}$ Report of British Departmental Committee on Juvenile Education in relation to Occupation after the War, Cd. 8512. See also Gt. Britain Royal Commission on the Poor Laws and Relief of Distress, Report, 1909 (Cd. 4499); Keeling, The Labor Exchange in Relation to Boy and Girl Labor; Finding Employment for Children Who Leave the Grade Schools to Go to Work (Chicago School of Civics and Philanthropy). 
able and unemployable adult individuals, incapable of bearing their share, whether domestic or industrial, of the national burden.

Medical Inspection, School Nursing Service, and the School Visitor.-As the school at least undertakes to secure the attendance of all children between certain ages unless they are seriously handicapped or excused for justifiable cause, the school becomes the agency through which certain supervision over the health and general well-being of the children can be maintained. Effcient medical supervision is, of course, necessary for the prevention of the spread of contagious diseases, and the school nurse is found to be an effective instrument in lessening the volume of absenteeism. As many children come from homes the conditions of which interfere with their ability to take advantage of the opportunities offered, the home and school visitor, sometimes known as the visiting teacher, is being added to the staff of special workers, through whom the school attempts to add to the efficiency of its classroom instruction. Through the child-study department the better classification of the children likewise reduces the waste resulting from using but one method in handling children of widely differing mental capacities.

Delinquent Children.- The juvenile-court laws, enacted in all but three of the states-Connecticut, Maine and Wyoming-constitute another body of statutory enactment for the protection of children. ${ }^{10 a}$ Under the earlier law children under seven or perhaps under ten years of age committing offenses against the law were treated as other offenders were treated-apprehended, detained, tried, convicted, sentenced, and punished in the manner in which adults were treated; often in company with adult and habitual offenders. Gradually provision was developed for the substitution of reformatory for penal methods. From I899 on the states began to enact laws providing for the creation of special tribunals for the hearing of children's cases, for separation during detention, and for the substitution of educational for both reformatory and penal methods of treatment. The development of juvenile probation staffs and of psychopathic clinics in connection with these courts and the establishing of institutions for the care of delinquent boys and girls have been conspicuous features in the policy of most states since the year 1899 , when ${ }^{10 a}$ See U. S. Children's Bureau Publication No. 65. 
the first of these acts was passed by the Illinois legislature.

Dependent or Neglected Children.-The laws providing for the establishment of juvenile courts include among the groups over whom these tribunals shall exercise jurisdiction not only delinquent but dependent and neglected children as well. ${ }^{10 \mathrm{~b}}$. These are children whose parents are dead or whose parents are unfit because of physical or moral defects so that the children do not receive "proper parental care." The courts are ordinarily given power either to supervise the children, leaving them with their parents, and thus to become, through the probation officers, public assistant parents as it were, or to remove the children from their natural parents and to place them either in institutions or in other homes.

The more efficient care of dependent and homeless children was one of the problems to which the late President Roosevelt made a conspicuous contribution. Concerned with the effects of institutional care on the impressionable child and convinced that every child had an inalienable right to a reasonably efficient home life, he held at the White House in I908 a Conference on the Care of Dependent Children, by which resolutions were adopted declaring that-

"Home life is the highest and finest product of civilization. . . . Children should not be deprived of it except for urgent and compelling reasons. Children of parents of worthy character, suffering from temporary misfortune, and children of reasonably efficient and deserving mothers who are without the support of the normal breadwinner, should, as a rule, be kept with their parents, such aid being given as may be necessary to maintain suitable homes for the rearing of the children. This aid should be given by such methods and from such sources as may be determined by the general relief policy of each community, preferably in the form of private charity, rather than of public relief. Except in unusual circumstances, the home should not be broken up for reasons of poverty, but only for considerations of inefficiency or immorality. . . .

"As to the children who for sufficient reasons must be removed from their own homes, or who have no homes, it is desired that, ${ }^{10 \mathrm{~b}}$ Idem. 
if normal in mind and body and not requiring special training, they should be cared for in families whenever practicable. The carefully selected foster home is for the normal child the best substitute for the natural home. Such homes should be selected by a most careful process of investigation, carried on by skilled agents through personal investigation and with due regard to the religious faith of the child. After children are placed in homes, adequate visitation, with careful consideration of the physical, mental, moral, and spiritual training and development of each child on the part of the responsible home-finding agency is essential." 11

Non-Support and Mothers'-Aid Laws.-These laws are often supplemented by two other types of laws: (I) Laws making it a penal offense, whether felony or misdemeanor, for a husband and father to abandon or "efuse to support his family, or for a parent to contribute to the delinquency or dependency of his children; and (2) laws authorizing the payment of so-called "mothers' pensions," or public allowances, to deserving mothers whose husbands are either dead or incapacitated. Prosecutions under the first group of statutes are heard sometimes before juvenile courts, sometimes before specialized "courts of domestic relations," and sometimes before ordinary tribunals. ${ }^{12}$

The authority to grant aid to deserving mothers is often conferred, as in Illinois, on the juvenile court, but is sometimes recognized, as in Massachusetts, as in fact a form of public "outdoor relief" and entrusted to the relief officials of the locality or of the state. As with educational statutes, such laws constitute a "mockery of the poor" unless they provide for state supervision and unless adequate appropriations are assured, which can never be expected so long as the local agencies are entrusted with the administration.

Prevention of Infant Mortality.-During these later decades the infant mortality rate has been accepted as perhaps the most illuminating index to the social well-being or social maladjustment in any community. Through the publications of the Chil-

${ }^{11}$ See Proceedings of the Conference on the Care of Dependent Children, held at Washington, D. C., January 25, 26, I909, pp. 9-10.

${ }_{12}^{2}$ U. S. Children's Bureau Publication No. 63. 
dren's Bureau, created in I9I2, the attention of the nation has been called to the hideous waste of the 150,000 preventable infant deaths annually.

Infant Mortality and Father's Earnings.-Data recently collected make it clear that while these deaths are due to many causes-bad housing, municipal neglect, ignorance on the part of the mothers, mother's employment outside the home, and mother's work within the home-a conspicuous relationship between the earnings of the father and the infant's prospect of life is discernible.

The Sixth Annual Report of the Chief of the Children's Bureau, for example, summarizes the data obtained in eight cities of widely different composition, summing up the "result of six years' study, in so far as infant welfare and income are jointly involved." 13 The death-rate for babies whose fathers earned less than $\$ 450$ was 167.8 per 1,000 births, or more than one in every six. When the fathers earned $\$ I, 250$ or more, the death-rate dropped to 64.3 , or one in sixteen. It may be expected that in the reasonably near future a minimum wage for fathers of families will constitute an important item in any constructive program of child welfare.

Maternity Mortality.-Attention has also been directed by the same bureau to the fact that every year about 15,000 mothers die in childbirth from causes largely preventable and that this "number is small compared to the number of those who suffer preventable illness or a lifelong impairment of health." ${ }^{14}$ Needless to say, this loss is immeasurable. In the words again of Miss Lathrop, "it does not stop with the loss of the life or of the vigor and efficiency of the mothers. It extends in general to the well-being of her home and children, and in particular to the motherless child who faces a peculiarly hazardous existence." The prevention of this excessive maternal mortality involves the problem of making universally available and universally desired adequate care at childbirth and before.

Children Born Out of Wedlock.-The unmarried mother and the child born out of wedlock have been the subject of widespread interest and of legislative enactment. The barbarous provisions of the ancient "bastardy acts" intended chiefly to

${ }^{13}$ Sixth Annual Report of the Chief of the Children's Burean, p. I2. ${ }^{14}$ Ibid. 
protect the taxpayer from being charged with the support of the mother and the child have yielded in many states to statutes intended to approximate the status of the child born out of wedlock with that of the legitimate child. Norway assumed in enacting the so-called Castberg law the leadership among civilized communities in providing that the child born out of wedlock should enjoy the rights of inheritance enjoyed by legitimate children, should be allowed to assume the name of either parent, and should be entitled to claim support from that parent better able to give support. ${ }^{15}$ In some states, as Massachusetts, the duty of support imposed on the father is the same as that laid on the father of legitimate children, ${ }^{16}$ while in North Dakota illegitimate children are legitimatized; and both the workmen's compensation acts in many states and the United States statute providing allowances for the families of soldiers and sailors recognize the claim of the illegitimate child.

The Reconstruction Program.-It is therefore clear that the war found a fairly elaborate program developed, intended to secure to children those rights essential to the development of an intelligent, competent, efficient, and progressive democracy. The working out of this program was enormously retarded by the structure of our government and the necessity of securing legislation and of erecting administrative machinery in each of the several states. And it must be admitted that even when fairly adequate laws had been enacted, the efficient administration was practically limited to the great cities. A few federal agencies were concerned with problems affecting children, for example, the Bureau of Education in the Department of the Interior, and, after 1912, when the Children's Bureau was created in the Department of Labor with power to "investigate and report ... upon all matters pertaining to the welfare of children and child life among all classes of our people, and . . . especially to investigate the question of infant mortality, the birth rate, orphanage, juvenile courts, desertion, dangerous occupations, accidents and diseases of children, employment, legislation affecting children in the several states and territories," a beginning was made in developing a national attitude toward these problems. The situation was, however, at best chaotic and confused.

${ }^{15}$ U. S. Children's Bureau Publication Nos. 3I, 42, and 66.

${ }^{10}$ Massachusetts Act of 1913 , chap. 563 . 
The effect of the war was, of course, greatly to confuse the issue that had been more or less clearly drawn. In the face of a lessening of labor power by the return of many alien residents to render patriotic service in their national armies and of the enormously increased demand both for industrial and agricultural labor, the value of the school life to the child, the importance of giving him the chance for growth, seemed questionable to many school officials, factory inspectors, and parents. Children were in many communities encouraged to leave school and to enter the labor market.

When the fathers had gone into the service or when the cost of living soared, mothers found themselves under the pressure of necessity or subject to a patriotic call and entered industry in large numbers. Due to these and other causes there seems to have been a considerable increase in juvenile delinquency, especially stealing among the boys and immorality among the girls. ${ }^{17}$

Confusing influences affect, too, the estimate of physical wellbeing. When the casualty lists were reporting the deaths of thousands and the maiming of other thousands, when starvation of whole peoples was resorted to as a recognized instrument of war, the question of adequate and skillful care of the young bodies of growing children often seemed remote. Not for a long period of time will the facts registered in the records of the draft boards and of the medical and psychopathic examiners of our selective army affect our understanding of the relation between the protection of the physical and moral vigor of our growing children and the national vigor of our adult life.

These experiences of relaxation of the child-labor and school attendance laws, of family separation and increased juvenile delinquency were common to the people of the United States and the other countries from which we have information. ${ }^{13}$ In England the outbreak of the war was followed by a serious dislocation of industry, and for a considerable time the volume of unemployment among young persons was very great, due to the fact that many formerly employed were dismissed and that many others left school to render a patriotic service for which no opportunity

${ }^{17}$ Sixth Annual Report of the Chief of the Children's Burcau, p. I9. See also U. S. Children's Bureau Publication No. 60.

${ }^{18}$ Leeson, The Child and the War: Being Notes on Juvenile Delinquency. See also U. S. Children's Bureau Publications Nos. 27 and 39. 
was offered. This condition was changed after a time to one in which the supply of juvenile labor was inadequate and greater pressure was put on the schools to loosen the hold they had obtained with such difficulty. As these young people often went into repetition work on automatic machines or into agriculture, they have labored in occupations in which no preparation is given for adult employment and they come now to the period of demobilization unfit and disqualified-constituting one of the serious costs of the war.

The ending of the war discovers all the warring countries probably faced with the necessity not only of rehabilitating their wounded and maimed soldiers, but also of restoring their homes and rebuilding the agencies found so essential to the protection of child life and development.

It is to be hoped that the building-up of a better program will take on a national character. It may be that labor standards embodied in the constitution of the proposed League of Nations and formulated in treaties to which the United States becomes a party will become the supreme law of the land.

Several national agencies have been developed which can assume responsibility for the formulation of standards. The Public Health Service has inaugurated highly important service in the mountain regions in connection with the widespread prevalence of trachoma among the mountain children of Kentucky, Tennessee, and North Carolina; and the American Red Cross, through its Home Service work under the Civilian Relief Department, has accumulated an inestimably rich body of material on which a sound national program can be built.

In considering the formulation of such a program, if it would be adequate, there is necessary a national attitude that may be described in the following paragraph taken from a discussion of juvenile employment after the war issued by the British Ministry of Reconstruction ${ }^{19}$ for the use of the British agencies and applicable to conditions in the United States and to other aspects of the child's welfare as well as to the efforts to prevent the economic exploitation of the child's labor.

"What is needed, in fact, is not the mere application of the expedients outlined in the preceding pages, but something like ${ }^{19}$ Juvenile Employment during the War and after, p. 73. Report of an Enquiry. Foreword by the Minister of Reconstruction. 
a conversion of the public mind to a new conception of the significance of the adolescent worker, and, therefore, of the treatment appropriate to him. It is the recognition that the conditions of juvenile employment, if they are to be judged wisely, must be judged with reference, not to the immediate exigencies of industry, but to their effect upon the future development of the boys and girls affected by them. If the community would make the most intelligent use of the human energies which are the ultimate source of all wealth, it must take a dynamic, not a static, view of adolescent labor. To the educationalist such a statement is, of course, a platitude. But on purely economic grounds it is equally incontestable. The economic considerations applicable to the work of boys and girls are radically different from those applicable to adults. It is the difference between capital and income, between the orchard just planted and the grown trees which yield fruit year by year. In the case of the adult the most important economic question is, for the individual, the obtaining of the best remuneration, and, for society, the obtaining of the best service, in the immediate present. In the case of the adolescent such questions are as inappropriate as would be the attempt to harvest crops in spring. On the one hand, the years between fourteen and twenty-one must not only pay for the maintenance of the boy during that period, but must prepare him for maintaining himself in independence in manhood. On the other hand, from the point of view of the community, the adolescent worker is a potential parent and potential citizen, and its future well-being will depend upon his obtaining in youth the economic qualifications needed to enable him to lead a life of self-respecting independence in manhood." 20

${ }^{20}$ England found time in the midst of war to enact a new educational bill more progressive in its features than any yet enacted by Parliament, providing for compulsory school attendance until the age of fourteen and for $35^{\circ}$ hours of annual attendance at continuation schools until the eighteenth year is reached. 


\title{
CHAPTER XX
}

\section{NEW DEMANDS IN EDUCATION}

\author{
By PaUl Klapper ${ }^{1}$
}

Associate Professor of Education, College of the City of New York; Director of Extension Courses

Education as the Adjusting Process in Life.-Education has been defined in various ways by writers, its functions have been formulated until it either includes all of the benign influences of life or limits itself to the instructional tasks of the formalized school. But in all these definitions of aim or formulations of function, there is basic agreement-education seeks to adjust the individual to life. Theoretically, at least, education is dynamic and progressive, anticipating the needs of the individual and developing his power to meet life's new demands.

Education has therefore conveniently become the scapegoat in times of social disapproval of existing institutions. National weakness of many sorts is frequently laid at the door of education. Social and economic failings are readily explained in terms of educational shortsightedness. A priori, it follows that education ought to be a constantly changing process, striving to keep abreast or ahead of the forward movement of civilization.

Education Adjusts Individual to the Fixed Order of Things.But in the actual business of life, education seems to exercise no such determining force. It either lags behind or ignores the multifarious processes of adjustment to life. Educators try to play safe. They never anticipate the next step in progress, they never influence changing conceptions and ideals of life. They

${ }^{1}$ A.B., College of the City of New York, I904: M.A., N. Y. U., I907, Ph.D., I909; associate professor of education, College of the City of New York, Ig07; director of the summer session; director extension courses for teachers; member, advisory committee of Bureau of Attendance and Child Welfare, New York City Public School system; author of several works on education and methods of teaching. 
wait until the change is clearly and unmistakably achieved, and then strive in a formal way to adjust the individual to the new mode of life. Every lesson for education that the war taught us might have been anticipated. No additional data were necessary to warrant the conclusions then that seem inevitable to-day. Education, the adjuster to life, has always been last on the stage of life.

The Post-Bellum Program of Education is Like the Pre-War Program.-The program for post-war education is still illdefined. Much is written on it. Writers insist that the war has taught us much concerning "the new education." Schoolmen peer into the nebulous regions of educational reform, see no guiding star and revert to the old order with discouraging regularity and promptness. The colleges are making slight modification in their entrance requirements; Latin is being classed among the luxuries of education; an additional course in science is prescribed; the study of American History and Government is made mandatory; a course in social science is introduced into the program of every student-these are the most significant changes in over ninety per cent. of the colleges since the dissolution of the Students' Army Training Corps and the return to a civilian basis. Almost all institutions strove with unparalleled effort to return to the pre-war basis. In secondary and elementary education changes are just as meager and just as devoid of vital purpose. There is no clear vision of new needs.

Before we attempt to formulate the program for educational reconstruction we must dissipate the erroneous notion that the war has radically changed the average person's ideals and mode of life. He merely lives the life he has lived. In spite of much shouting and of many programs there are no signs of the creation of a new social order or of an effective quickened sense of humanity. Progressive education is advocating its pre-war program with renewed vigor for two reasons. First, it finds that its former program supplements naturally and effectively the plan of economic and social reconstruction now advanced by responsible leaders. Secondly, the exigencies of the war, during which social needs were most keenly felt, showed clearly that this educational program met fully and intelligently our existing significant national needs.

Modern Interpretation of Education for Social Efficiency.- 
This educational program is based on a socialized conception of the function of education. We must realize that only as each individual is thoroughly developed is he truly socialized; that social efficiency is the product of individual efficiency. Educators in the past conceived of social efficiency as the result of the complete subordination of the individual in order to make human beings similar in desires and attainment. According to present conceptions social efficiency results from a complete development of all the worth-while powers and capacities of an individual. In the older sense, social efficiency resulted from repression; in the modern sense from self-expression.

Program for Physical Education.-To achieve complete selfexpression, education must assume responsibility on a scale heretofore unknown for the physical welfare of the future citizens. Vast hordes who were found physically unfit for military services were merely victims of the conditions of modern civilization. Eyestrain, undetected, continued until it resulted in progressive myopia; catarrhal conditions of the ears were disregarded until hearing was seriously impaired; weak arches, neglected through lack of exercise, broke down completely; malnutrition was tolerated until the body, reduced in vitality, lost all power of resistance to disease. The Board of Health of New York City estimates that of $1,000,000$ children of school ages in the city, approximately 200,000 , or one-fifth, are underweight and suffering from malnutrition. Of 9,000 children examined in one New York City district, 3,000 were found suffering from malnutrition. The significance of this physical subnormality is intensified by the fact that most of its causes are remediable. Unless thorough and complete provision for physical education is made we cannot hope for a citizenry vigorous enough to meet the personal and social obligations of the future.

Suggested Program for Physical Education.-The outline on the following page sums up the various elements that must be included in a complete program of physical education.

It is evident that the school building must meet the standards of ventilation, lighting, heating and cleanliness that are direct coefficients of health. So long as children spend the school day in ill-ventilated, artificially lighted rooms, crowded beyond capacity, we are playing present economy against future wellbeing. Not only the school building itself, but school adminis- 


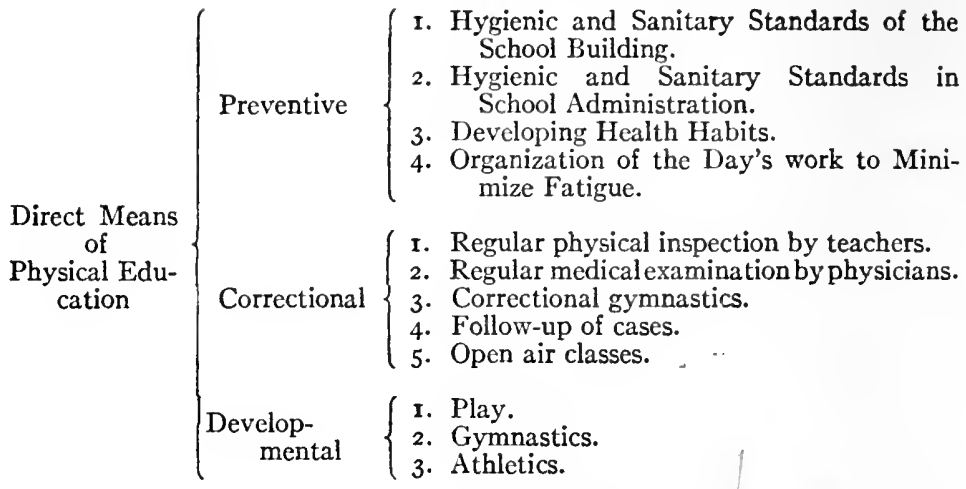

Indirect Means ( I. Systematic instruction in hygiene, social as well as indiof

Physical Education vidual.

2. Sex education.

3. The inculcation of a social sense.

tration must adjust its machinery of management so that health is constantly guarded. There must be no promiscuous interchange of supplies and books. Children must not pile coats and various garments in unseemly piles in the rear of classrooms, nor should children be crowded in halls or on stairways. There must be daily inspection of hands, faces, ears, hair, eyes, teeth, shoes and clothing, so that by dint of repetition children acquire proper habits of personal cleanliness. Their program of studies must be carefully planned so that unnecessary fatigue is not produced by a sequence of studies which keeps the body too long in a sedentary posture, reduces the tone of the muscles and drains nervous energy. School authorities must exercise every care to check all those conditions which prevent the child from developing into a healthy, active adult.

A correctional program for physical education must be added if we are to save those who are already the victims of maldevelopment. There must be regular physical inspection by the teachers, whose professional training should include the taking of physical measurements. At least once each school term teachers should make simple tests of the vision and the hearing of each pupil and records of height and weight. In this way subnormal sight or hearing would be detected at once and malnutrition would be 
reported to the parents or proper agencies. In addition school children should receive periodically a complete medical examination by a physician. Heart, lungs, throat, nose, eyes, ears and feet should be examined and posture, weight and height should be noted. The results of these examinations should be made the basis of correctional measures to be carried out by parents and teachers. Thus parents are told that the hypertrophied tonsils of their children need immediate medical attention, and the teacher is shown the correctional exercises to be given to children suffering from flat-foot. To reap the full benefits of such a system of physical inspection and medical examination, follow-up agents should be employed to see that parents and teachers carry out the recommendations of the medical examiner. Without the follow-up provisions such examinations degenerate into a system of cards and records, while the child continues to suffer progressively the consequences of his bodily ailments.

Open air classes were originally organized for tubercular children. To-day we realize that the sanitarium and not the school is the place for them. The few existing open air classes now contain the ænemic, the weak and the convalescent children who need open air treatment. In such classes the whole régime of the day is carefully planned, the course of study is modified, frequent rest periods in reclining chairs are provided, proper nourishment is supplied, correctional exercises are given, medical examinations are frequent, and complete, intelligent records are kept. Evidence thus far gathered shows clearly that the ænemic and physically subnormal child in the open air class makes greater gains in weight, blood count, and general health than it would make in the regular classroom or at home. The improvement has been so gratifying that educators are now asking that the open air class be tested with physically normal children. The open air class is still in the experimental stage, but it is a field in physical education that gives promise of no little benefit.

It is obvious that a program of physical education must provide ample opportunities for physical development through play, gymnastics and carefully supervised athletics. Play space and proper supervision must be secured for our developing youth, especially in our urban population. Education that limited its responsibility to mental development is a thing of the past; it 
now concerns itself with every aspect of child life. Educators to-day realize that they must provide for the complete day of the child, for its play as well as for its study.

In addition to these direct agents of physical development, certain measures that have an indirect influence on health must be emphasized in education. Hygiene must be taught, not the old type lessons in anatomy replete with names of bones, muscles and nerves and the detailed study of the structure of the organs. We must teach social and functional hygiene which emphasizes forces that conserve health; it tells of the carriers of disease, of food preparation and food values, of habits of personal cleanliness, of individual conduct that makes for community health. Hygiene properly taught is but another aspect of community civics. It follows, therefore, that sex education which seeks to establish a scientific, impersonal and respectful attitude towards matters of sex must be included, informally and indirectly, of course, in the education of youth. The study of hygiene from this functional rather than structural viewpoint inculcates in the developing mind a growing social sense and a deeper understanding of human interdependence.

This program of physical education, with suitable modifications, is applicable to all ranks of education,- to elementary, secondary and collegiate education. The price of physical fitness is eternal vigilance during the period of plasticity when the body yields to formative and corrective influences. No cost is too great to produce a generation free from preventable weakness and maldevelopment.

Education for Economic Adjustment.-The World War showed clearly that German national strength lay not so much in the possession of raw materials, not in military organization, not in a large population, but rather in the development of human skill. This fact is significant to us Americans. The movement for conservation of resources in Roosevelt's administration showed clearly that some of our leaders were alive to the dangers that beset a nation that wastes its raw materials. We have since developed measures to conserve forests, minerals, soils, water power,-in short all the inanimate materials of production. We have neglected the human elements-labor and skill.

Germany has long realized that the fertility of her soil was tapped by generations of intensive cultivation; that her raw 
materials are limited. Imperial Germany realized that her problem of conservation was immediate and vital. She achieved phenomenal success not by restricting the use of raw materials, but rather by developing the skill of the individual. Her slogan became: Each German must be a most useful and usable citizen in all the activities of peace and war.

We are rapidly awakening to the waste involved in unrealized and undeveloped human skill. We have too long allowed our schools to turn out their annual toll of graduates without preparing them for a definite economic function because of the fatuous conceit that we have no social classes. If education is to adjust the individual to life, to socialize him completely, then education must become as vocationalized as society. America to-day demands an education which is differentiated and which is formulated either in terms of individual capacities or immediate individual economic destinies.

This new type of education demands a complete reorganization, as is shown in the diagram on the following page.

Education as reorganized in this scheme plans to give the necessary foundations in reading, writing, language, arithmetic, geography, history, civics, through a uniform course of study for six years. This elementary course is not an eight-year course impoverished, but the result of a carefully selected curriculum which emphasizes the socially necessary facts and constitutes the irreducible minimum for the humblest of society. Throughout these six years, children's interest and aptitudes must be noted and parents' desires and economic status recorded.

Such data will help to determine at the end of the sixth school year which of the two types of Junior High School the child is to enter, the Prevocational School or the Academic School.

In the Prevocational Schools the child attends for a longer day, 6 to 7 hours. It receives ample instruction in the academic subjects like geography, history, English, mathematics, drawing, etc., but as far as possible these are related to vocational work. About fifty per cent. of the school day is devoted to pre-trade work, industrial, commercial or domestic. The child that selects the industrial pre-trade work spends a term or more in each of a number of trades, e.g., electric wiring, molding, tool-making, cabinet-making, plumbing, etc. At the end of the three years the child has had pre-trade training in four or more trades-a 
高

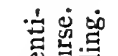

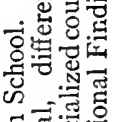

昰

.

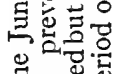

胥

害热

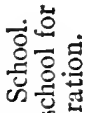

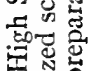

.ํㅠㄹ

कैं के.

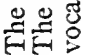

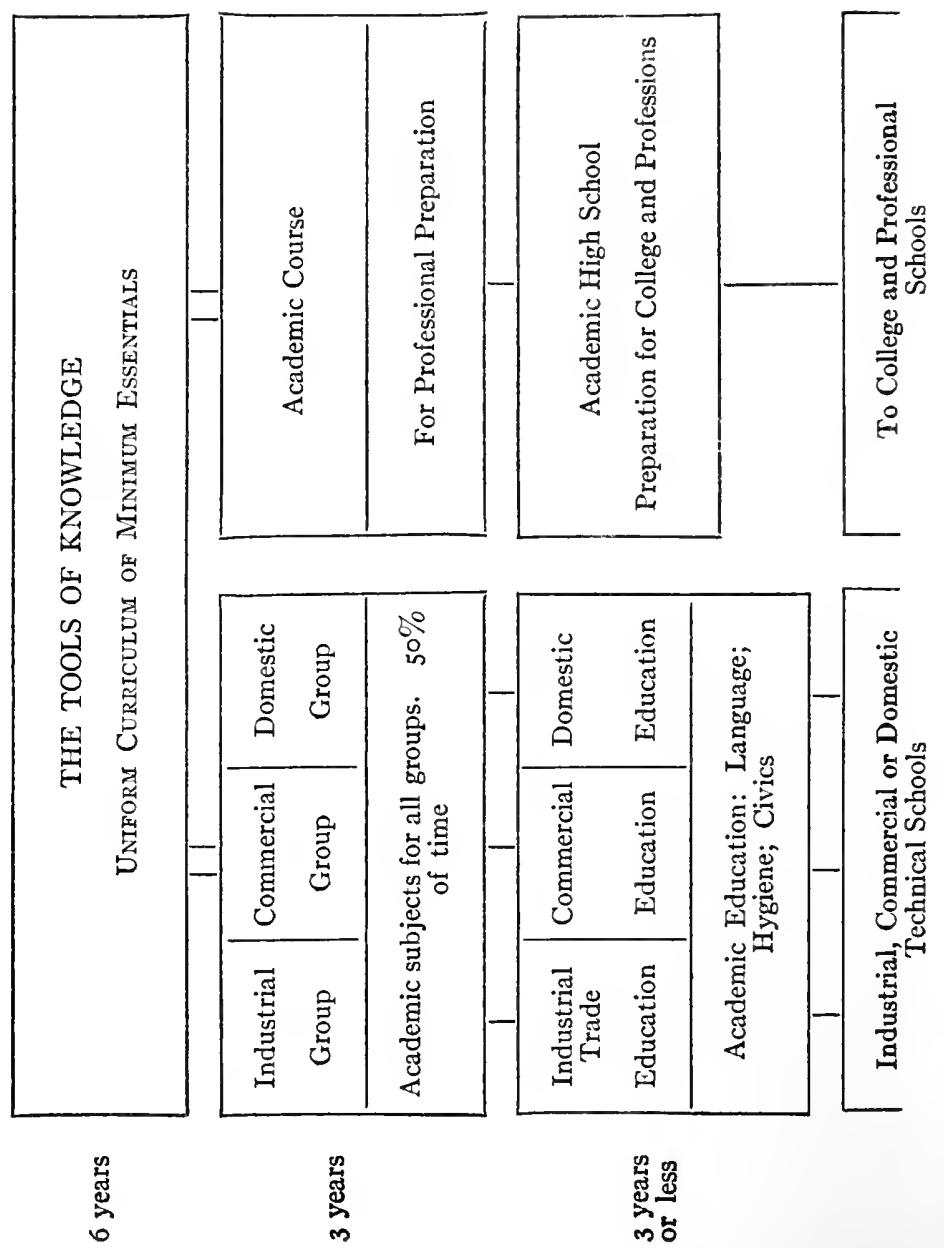


body of experience of no little utilitarian and disciplinary value. The child has had ample opportunity to express its aptitude and interests. The teacher can soon tell whether its capacities warrant a continuation in the trades, in commercial or in domestic pursuits. The child has had, concurrently with this pre-trade training, academic instruction which does not shut it out of the academic senior high school should its desires or the economic status of its parents change. Similarly, the child in the academic junior high school, if found unsuited for this type of work, can be transferred to one of the vocational courses with little loss. At the end of the junior high school period the child continues its education either in the academic senior high school or in one of the vocational schools. The length of this course is determined by the ability of the child and by the demands of the chosen calling.

In addition to this interrelated and graded system that seeks to care for the young, supplementary trade, vocational and academic schools, must be maintained to enable every ambitious adult to realize most fully his potentialities. Evening trade schools, short unit courses, continuation schools, classes in shops and mercantile establishments, slack season schools-the many agencies which seek to arouse ambition and give the worker a conception of a higher life, must be encouraged at community expense.

Such a system of education is truly democratic, for it seeks to give to each an equal opportunity for development and to attain the highest social destiny of which he is capable. Education of this type is motivated by maintaining constant and intimate relation with life's needs. Individuals are not thrust into the economic turmoil unprepared for a specific calling. But at no time is this educational system subservient to a policy of vocational determinism. The plan is flexible. After the first six years, pre-vocational schools devote three years to vocational findings through a differentiated but not a specialized course of study. Every child has ample opportunity to express himself; every child capable of development is given enough of the academic elements to enable it to transfer easily to a purely academic senior high school. In addition, the child receives that type of vocational training which prepares it for the vocational school. This, then, is a definite organization which appeals to 
every variety of mental capacity and economic need and proceeds on the theory that the greatest social efficiency results from self-expression rather than from training according to a fixed social standard.

Increased Period of Educational Control.-Post-war education must help to elevate the general social standard of the American people. Educational reformers are therefore urging an increased period of educational control of each individual until the age of eighteen. The age limit for compulsory education is now about fourteen in most states. But the complexity of modern life and the need for vocational preparation make necessary a continuation of educational control beyond the age of fourteen in order that American youth may be guaranteed opportunities for a cultural and vocational education for the four years after the formal school period. In every city and school district a strict educational census should be maintained of boys and girls up to the age of eighteen so that the authorities can tell at once who are continuing school work, the nature of their studies, how many are employed, the character of their work, the number pursuing vocational preparation, the number unemployed, the extent of unemployment, the frequency of occupational changes for each individual, the reasons for these changes, the extent of delinquency and a variety of data of inestimable worth to a community vitally concerned in its citizenry of to-morrow. Such a census is costly, yet not so costly as our present futile efforts at social reclamation.

Elimination of Illiteracy.--Illiteracy, regardless of age, must be eliminated for reasons of national safety. Mental tests conducted in the army during the period of active warfare indicate that approximately 20 per cent. of the adult population is unable to read or write the simplest instructions. Sons of native born are not a small part of this group. Classes to reduce this illiteracy must be organized in shops during usual working hours as well as in the evenings. Without a substantial national subsidy and even legal enactments, illiteracy will undoubtedly continue.

Universal Military Training.-It is natural to find the educational camp divided on the question of universal military service. Those who have simple faith in the vision of immediate universal brotherhood are, of course, opposed to universal military train- 
ing. Others who see in the Treaty of Peace an old-fashioned settlement of diplomats and in the League of Nations another sorrow for angels demand universal military training for national safety. They argue that improved health, keen sense of social obligation, love of country, as well as national protection, will result from a program of universal military training.

The Committee on Education of the Reconstruction Commission of the State of New York has taken the position commonly adopted by educators with respect to military training in the United States. The State of New York prescribes military drill under the New York State Military Commission for all boys between I 6 and $\mathrm{r} 8$. One and one-half hours are spent weekly by these boys in armories; in addition special limited camping opportunities are provided during the summer. About one-third of all the boys of the prescribed age, who are in private or public secondary schools, receive these drills but the remaining twothirds in industry cannot be reached. The Reconstruction Commission through its committee urged the abolition of the weekly military drill and substitution of compulsory attendance for two weeks at camps maintained by the state during the summer. The time should be spent in long hikes, rowing, swimming, archery or target practice, base-ball and tennis. In addition to the sports, camp cooking, personal and community hygiene and simple woodcraft should be taught. The boys should be in uniform, under military discipline, and should be called "Junior Citizens." They should be impressed with the thought that the compulsory camping is not a guaranteed vacation but a period of state service.

The Pre-military Training.-Compulsory attendance at this type of camp has much to recommend it. Hour for hour, the boys would be giving the state more time than under the present law. One and one-half hours per week for forty weeks total only sixty hours. Two full weeks or fourteen days of fourteen working hours would be equivalent to 196 hours. The concentrated nature of the work and the newness of the experience would serve to increase the value of attendance at these camps.

Military authorities are not in favor of teaching military technique to boys under eighteen. They ask rather for young men of health and vigor, of keen sense and power of ready response. Kecent events show that this type of recruit requires 
only a short period of months to become an efficient fighting man. Attendance at camps for two weeks for three successive years will improve the health of the recruits and create an impelling desire for outdoor life.

This form of military camp life will teach the boys modes of coöperation in community life, obedience to duly constituted authority and the need for laws and regulations as safeguards of personal liberties. It will give the city boy the benefits that come from life close to nature. The variety of camp activities can be so planned as to reveal personal capacities of the boys. This knowledge will determine the kind of service which each will render to the state for it is not necessary nor desirable that all be trained for duties at the front. In a word, these state camps can be so administered as to secure for all boys, in full measure, the vitalizing influences of training for national service and give the nation a body of young men ready to take up the special and technical rôles of its defenders.

The Movement for Americanization.-Every national crisis brings forth a host of superficial reformers and hysterical amateurs who befog issues and befuddle the minds of men. The World War found us, as it did England or any peace loving people free from imminent military attack, in a state of military unpreparedness. The professional patriots, confusing military with spiritual unpreparedness, filled the atmosphere with cries and warnings about "Americanization, A polyglot people, A babble of tongues, The need for a homogeneous people." People really believed that because it is cosmopolitan our population lacked in courage, love of country and gratitude for the opportunities and liberties which our political institutions guaranteed. There was no doubt of our lack of military preparedness. But what people went forth to make the supreme sacrifice with less protest, with clearer understanding of the issues involved and greater willingness to carry out the sacred mission which national exigency had imposed upon them, than the American people? What army had better discipline and greater courage than our own?

Not the School Alone But All American Life Must Americanize. -Unless we start with a clear understanding of conditions we are not prepared to discuss the meaning and scope of the movement for Americanization in education. Contrary to popular 
clamor, our schools have done their patriotic task of Americanizing very well. We want them to do better; to make the meaning of democracy more articulate; to inculcate love of country based on the understanding that our democracy, though not the best that can be, is the best there is. To enhance the effectiveness of the processes of Americanization we must make every force in American life an agent of Americanizing the newcomer and his children. We must make industry more representative. Production must be socialized so that labor not only is given a just share of the produce but is also made to share in the responsibilities of production. Labor must be represented in the conduct of industry. The failure of industry must be laid at the door of labor as well as capital just as the success of industry must redound to the glory of labor as well as capital.

Local communities must be made more autonomous and selfgoverning. Participation in federal and state government is too indirect and too incidental to be a vital part of the political life of a people. Municipal and town control must be reorganized so that each citizen is made personally responsible for the good government of his community. Where the city is large, this end must be achieved by subdividing it into smaller political units in which the individual is not lost. Unless the daily life of the citizen Americanizes, the Americanization which the school alone can produce will result only in patriotic platitudes.

The school must continue its Americanization. It can do this by making its instruction in history and civics more vital, by applying both subjects to the daily life of its young citizens. Through pageantry and proper celebration of national holidays, it may reach the adults as well as the child. Through its lessons in hygiene and ethics, through its vocational instruction, vocational guidance and placement it can teach the growing youth that democracy aims to guarantee equality of opportunities to its citizens.

Americanization Through Foreign Languages as Well as English.-The problem of illiteracy must be approached without unwarranted attack upon the native language of the immigrant. Too many think that the acquisition of our vernacular is the guarantee of Americanization. We must remember, that desirable as it is that we be a people possessed of a common tongue as well as of common ethical and national ideals, few adult for- 
eigners can ever master our language sufficiently to make it an effective medium of expression and communication. Language is only a medium. If the foreign tongue can be used as a successful means of Americanization, it must not be spurned. For the vast majority of adult foreigners, the foreign rather than the American press will be the agent for building up new loyalties and clear comprehension of American life.

Improved Professional Status of the Teacher.-Of cheap reforms there is no end. However, pioneers with both vision and capacity are limited. Educators may have their dreams but the realization of them is determined by the character of the teachers. Much must be done to retain our most effective teachers and to attract the most promising students who graduate from secondary schools.

Salaries must be raised to the competitive level of the living wage in allied professions or in skilled trades. Adequate salaries with attractive minima and maxima, with regular annual increments for the proficient teacher, must be established. The annual contract must give way to a guaranteed tenure under which the question of reappointment is settled definitively after a probationary period of two or three years. Appointments must be placed on a civil service basis and be free from the influences of local politics or social and religious classes.

Proper remuneration and appointments based on ability will enable educational authorities to set up higher standards for admission to the profession and will create a new status for the teachers. Tens of thousands of elementary school children are receiving instruction from teachers who cannot meet the requirements for college entrance. Other children, equally numerous, are under the direction of teachers with no professional training. The requirements of high school teachers are of necessity somewhat stricter, but here, too, the need of raising standards is immediate and urgent.

Furthermore, greater democracy in educational administration is needed. Teachers are the only agents in our educational system who apply the course of study to the children and actually put into practice the policies formulated by their superiors. But the teacher is rarely consulted about course of study or policies. Few institutions in our democracy are more autocratic than education. Few skilled workers are treated as un- 
democratically as teachers who train the nation of to-morrow for life in a democracy. Teachers of experience and of ability must be made part of the councils charged with formulating educational policy, courses of study and administrative procedure. Without this democratic reorganization, teaching cannot acquire its full professional dignity. Our whole program of educational reorganization must in the final analysis be worked out by the teachers of the country. Our plans for social reconstruction may be wise, our vision far-seeing, our purpose sincere, our enthusiasm unbounded, but they all count for naught unless our teachers, too, are wise and far-seeing and sincere and possessed of that boundless enthusiasm which springs from absolute faith in the ultimate success of their common endeavors. 
- 


\title{
CHAPTER XXI
}

\section{VOCATIONAL GUIDANCE AND VOCATIONAL EDUCATION}

\author{
By James Phinney Munroe ${ }^{1}$ \\ Vice-Chairman, Federal Board for Vocational Education
}

Education and the Adolescent.-The World War has given startling testimony to the fact that the American system of education, excellent in many ways, fails, nevertheless, to meet as it should the chief needs of adolescent youth. The field of elementary education has been in most of the states measurably well covered and America's generous provision for higher education, both public and private, is the envy of the older nations. High schools, too, have been set up with a comparatively lavish hand in many communities; but their courses have been planned as a rule to accommodate the few who are going to college rather than the many who must leave school, at the latest, before their eighteenth year. Consequently, during the important period between fourteen and eighteen, in which mental acquisitiveness is keenest, vigor and enthusiasm most marked, and the social instinct at the highest point of impressionable activity, our youth have been in large measure ignored by the organized forces of education and left to those haphazard influences which, confronting the adolescent on the street, in the shop, on the loafers' corner or in his own home, not only fail to educate him, but, too often, break down his native interest, ambition and even character. At a time of life when the social forces, were they mobilized into forms of education meeting the needs and interests of

${ }^{1}$ B.S., Massachusetts Institute of Technology, I882; secretary of faculty, r882-9; member firm, James S. Munroe and Co., r889-; treasurer, Munroe Felt and Paper Co., I897-, president, 1910-; president, National Society for Promotion of Industrial Education, I9IoI9II ; vice-chairman, Federal Board for Vocational Education, member, technical and educational societies; author of several works on education. 
youth, could be of maximum service, the great majority of boys and girls are abandoned to influences which at the best are non-formative and at the worst are dangerously anti-social.

The Origin of Our Haphazard System.-It is easy to trace the origin in America of this serious educational limitation. The English settlers who gave direction to our teaching plans regarded education as a privilege to be reserved chiefly to ministers and magistrates and to be dealt out only very sparingly to those others who, for one reason or another, must perhaps be given the rudiments of knowledge. Gradually the opportunities for attending college were extended beyond the gentry, and slowly the amount and extent of elementary education were increased. But the rank and file of nineteenth century folk were eminently practical and believed strongly in the importance of facts. Consequently, while the colleges and their preparatory institutions-those private academies many of which in the process of being painfully absorbed into the public high schools inoculated those schools with their own traditions-continued to accept without question the classical training imported from the English universities, the children of the "common" schools were disciplined by facts and by birch rods, one scarcely less distasteful and ineffective than the other.

Thus was established a gulf between the purely informational, disciplinary schooling of the pre-adolescent child, and the linguistic, pseudo-philosophical training of the college youth; and one of the most interesting chapters in the educational history of the United States is that concerning the various types of bridge built, or attempted, to span the adolescent chasm. Some of these plans were fantastic; many were futile; but they were all regarded merely as a means to tempt the comparatively rare feet, first of the ambitious boy, and later of the educationally or socially ambitious boy or girl, to cross the abyss between the common school for the many and the university for the few.

Only an occasional teacher perceived that genuine education is a life-long process, that its needs vary with the environment, capacity and opportunities of each person to be educated, and that the duty of a school is to provide as far as possible for each child and youth the special light and leading needed for his particular path. There have been, of course, many spasmodic attempts to make education comprehensive and effective; there 
have been Hegelian outbursts, manual training experiments, and attempts of many other sorts to give the child for whom college is impossible some kind of substitute, either ethical, practical, or both. Moreover, many high schools have gradually differentiated themselves into rather plainly marked bridges (though still bridges) leading respectively to the classical college, the technical school, or the vague domain of "business."

The Test of War.-All of this left us as a nation unsatisfied and as individuals more and more impatient concerning secondary school training; but not until our school systems found themselves put to the test of world-wide war did we begin to realize the meagerness of our provision for the adolescent, and to get at least a glimpse of what ought to be done for the eager, active, rapidly developing boys and girls in their " 'teens."

The war showed that some of our fears in the matter of education were to a large extent unjustified. The fact that most of our boys had never had other than a woman teacher had not resulted in making them effeminate; the fact that the small minority able to go to college had been, too often, lapped in a strange mixture of outworn classicism, highly specialized athletics, and modern luxury, had dulled neither their native wit nor their fundamental manliness. In spite of its ineffective educational system the United States had produced a breed of youth heroic in spirit and capable of both military leadership and military discipline.

But the war and its sequelæ are showing other things in the matter of education which are far less satisfactory. The selective draft unearthed, for example, a percentage of general illiteracy and of particular illiteracy in English that startled even those familiar with such statistics; it gave evidence of widespread physical deficiency, both constitutional and acquired. The war uncovered a shocking inability on the part of millions among a supposedly "handy" people to use ordinary tools or to perform simple manual processes; it made clear that the vast majority of American youth is quite aimless as to the choice of a specific vocation, lacks any interest in economic, civic or ethical problems, and is devoid of any curiosity as to the meaning and purpose of human living.

The Adaptability of the Trained Man.-On the other hand, the war seems quite clearly to have demonstrated that the man 
trained in one vocation is able to acquire, provided his experience has not been too narrow, and provided he have sufficient incentive, almost equal efficiency in some wholly new vocation. A nation to which, because of its geographical isolation, all the arts of war were almost ludicrously strange, found it possible to put itself, within fifteen months after entering the conflict, upon a war basis so complete and effective that it could strike the decisive blow in the struggle with a nation the most highly organized, from the military standpoint, that the world has ever seen. Certain moral advantages had much to do, of course, with the determining part which the United States was privileged to play; but the chief reason why Germany recognized its complete military defeat in the early fall of I9I 8 was what must have been to its Junker leaders the astounding revelation that a non-military nation, provided it have the impelling spirit and be backed by adequate men and money, can accomplish in less than two years more than a war-mad nation had been able to do in a half century of ceaseless energy bent solely towards the single end of military conquest. This not only is the supreme lesson of the war but is also the surest guarantee against an attempted repetition by any nation of such a scheme of dominion as the German mind had so patiently and cunningly conceived.

Contradictory as it may appear, the fact that the United States was so lacking in effective education and the fact that it was able so to transform itself vocationally as to meet with signal success a stupendous and unexpected demand, are both potent arguments for vocational guidance and vocational education. While, on the one hand, the war exposed our educational deficiencies, it demonstrated, on the other, that the men who finally succeeded in producing the remarkable transformation in the vocational energies of the nation would have been powerless to do so had they not been conspicuously successful in their own vocational careers. The war was organized and won by men who, before being summoned to these strenuous war-time activities, had been thoroughly proved in the no less arduous and difficult vocations of peace.

While, of course, a few came to Washington to take advantage of the nation's extremity, the overwhelming majority of those who flocked thither in I9I7 and I9I 8 were men with no other aim than that of placing all they had in ability and experience 
at the service of the Government. After considerable delay, the trained men gradually worked to the top, assumed command, and in the end organized the material and human resources as well as the moral forces of the United States so effectively as to make this country the determining factor in the defeat of the Central Powers. Similarly the young men who had made themselves vocationally able or who were preparing themselves in school or college for vocational service, rose, through the hard testing of camp and field, to that military leadership which as a complement to the regular military and naval forces gave such a brilliant account of itself from July to November, I9I8.

The Sustaining Force.-This complex fighting machine would have been powerless, however, had it not been sustained by a parallel organization of the vocationally trained men and women of the United States to feed the armies, produce the supplies, manufacture the munitions, organize the transportation, build the ships, minister to the dependent and the disabled, and perform all the other services as essential to victory as is the fighting force. Many of the vocations thus mobilized, such as that of food supply and of the making of military clothing, were peace vocations intensified and specialized; but many of them were peculiar to war needs; and while the former required only a higher organization, the latter demanded new abilities. There is reason to believe that they would have completely fallen down had it not turned out that a man who is well trained in one vocation can function equally in any other when the stress is serious enough and the goal high enough to lift him, in zeal and fervor, out of the old, known vocation into the unknown, new one.

The Lessons of the War.-The two fundamentals which insured America's prowess as a fighting organization were a sufficiency of vocationally trained men and women and an aim vivid enough to enlist and to coördinate their utmost energies. Vocational training would in itself have been inadequate had it not been stimulated by the single, supreme, and clearly understood aim of saving civilization from the onslaughts of the Hun. The war has unmistakably taught that to achieve great results one must have not only training but also a definite and stimulating goal.

The Chief End of Education.-In the conviction that a recog- 
nized and absorbing aim is a necessary spur and, in most cases, the only spur required to arouse interest and ambition, the advocates of vocational guidance and vocational education believe that the safest foundation upon which to build that social efficiency and that coöperative attitude of mind which together constitute good citizenship is the natural desire of every normal youth to establish himself as a real, competent factor in his community. They believe, furthermore, that, with this end in view, the chief business of education should be to assist the pupil to "find himself" in the way best suited to his capacity, inclinations and probable opportunities. They are strongly fortified in this by many illuminating experiences of the war. Making due allowance for the exciting and sustaining power of the inflamed "crowd-mind," it is nevertheless certain that the chief reason why millions of young men not only cheerfully accepted the draft or eagerly enlisted in advance of it, but also manfully endured the hardships of camp life and the fatigue of the dull and often menial duties of army and navy life, was because they had clearly before them the inspiring goal of this grueling endeavor. Moreover, in the schools for officers, young men successfully pursued difficult mathematical and other studies that in college would have been, in many instances, beyond their will to master, because they could plainly perceive the reward, in honor and in opportunity, of their persevering effort. And, finally, all gladly endured both physical and mental strain because they were able to see that substantially everything they underwent had its direct and almost immediate effect in increase of physical stamina or of military efficiency.

While times of peace can never elicit the special incitements of a period of war, there is no reason why there should be any such astounding difference as has just been witnessed in this country between youth preparing for military service and youth getting ready for civil life. The main elements-the boy's native ability, his zeal to accomplish, his desire to serve and to "get on," as well as his inexhaustible vitality-are present in peace times just as in war times, and the problem of education is to find and to apply the stimuli necessary to bring those already existing qualities into active, continuous and effective use. To achieve this result, two things obviously are necessary. First, that the boy's personality, his abilities and probable range of 
interests, may be understood; and, secondly, that he be given a goal as direct, understandable and, in its way, exciting as that of getting ready to "lick the Hun." That is to say, the boy should be as carefully "picked" for his civil vocation as it was attempted to pick him for his military duty, and his peace vocation should be rendered as interesting as were his war activities.

Other Lessons of the War.-Besides this fundamental lesson, a number of other valuable contributions towards the sound development of education resulted from the various experiences following the entry of the United States into the world conflict. Among these perhaps the most typical are those associated with the choice and assignment of personnel, the building of ships, the preparation of mechanics and technicians for the army, and the rehabilitation of the disabled.

Psychologic Tests.-In the selection of personnel, which is, of course, from another aspect, a large part of the problem of vocational guidance, the experience of the War Department would seem to show that psychology has a wider application than had been heretofore admitted in helping to determine the capacity of an individual for a definite line of activity. The intelligence tests so largely used in the personnel department of the service resulted in keeping out many "misfits" and, to a certain extent, discovered the special fitness of others whose capacity, without those tests, would probably have remained unknown. Perhaps their greatest practical use was in eliminating from the crucial test of actual battle officers of all ranks who had not the stamina to stand the strain.

Interesting and valuable as this experience with the intelligence tests was, the field was too limited and the period of trial was too short to justify the hope that similar methods will go very far towards solving either that long standing riddle, the test of qualification for college work, or that larger problem, the fitting of the individual into the most appropriate place in economic life.

Tests based, as those of the army were, partly on accepted principles of psychology and partly on organized common sense are, of course, a long step forward from the purely arbitrary standards of the college entrance examination or the haphazard guesses of the usual employer. Every advance towards scientific method in dealing with social problems is a distinct gain. Yet 
no educational institution and no business organization can measure and tabulate its complex requirements in any such definite way as was possible in the case of an army of $4,000,000$ engaged in the temporary and highly specialized work of modern warfare, in which the methods of attack and of defense had been remarkably standardized as the result of nearly three years of field experience.

Since every vocation calls for some of the fundamental mental traits which the army intelligence tests were measurably successful in determining, they can be made of genuine service in vocational guidance provided they are looked upon merely as a starting point from which to go forward out of the comparatively simple domain of "intelligence tests" into those practically unexplored territories which are named, but which are not explained, by the terms business aptitude, industrial fitness, capacity for leadership, etc.

Training for Shipbuilding.- When the United States decided to take part in a war three thousand miles away; a problem even more urgent than that of raising an army was that of providing, in spite of submarine destruction, a merchant fleet large enough to carry the army to Europe and to maintain it there. In addition, vast tonnage was required to supply America's allies with food and munitions. It was comparatively easy to lay out the yards, but to build ships presented almost insuperable difficulties, for shipbuilding had been neglected in the United States since the Civil War. The answer to the problem was found, first, in producing standardized, fabricated ships, in which the processes were reduced to terms with which American workmen were already familiar; and, second, in seeking men skillful in processes akin to those required in shipbuilding and in training them, by short, intensive courses, along special lines so as to make a ship carpenter, for example, out of a house carpenter. To carry out this general plan, two devices were used: that of establishing certain shipyards schools for training considerable numbers of picked men-foremen and teachers for green hands-and that of setting up, in public schools in close proximity to shipyards, evening courses in such subjects as green hands needed to make themselves efficient in their daily work in the yard. Similar schools for intensive training were created all along the seacoasts and lake-shores of the United States to prepare in as 
short a time as possible men-preferably with some maritime experience-needed by the thousands to serve as navigators, engineers and sailors in the merchant fleet.

The chief vocational lessons learned from this experiment were: (I) the grat value to the learner of a new trade of trade experience, even though not closely related; (2) the effectiveness of intensive teaching focussed upon the particular group of things to be learned; (3) the far greater progress made by a learner "on the job" as compared with that made by one taught out of books or in a "laboratory;" and (4) the adaptability of a normal man to almost any vocation provided it be within his powers, that he be properly trained, and that his interest in it be thoroughly aroused.

This adaptability was demonstrated to a marked degree in the comparative ease with which the average "doughboy" shifted from one army task to another, and especially in the success with which thousands of officers, many of them without vocational experience of any kind or with experiences wholly remote from those of military life, not only met grave responsibilities, but passed readily and effectively from one to another of a wide range of activities.

Training of Mechanics and Technicians.-This vocational flexibility was equally characteristic of the tens of thousands of mechanics and technicians hastily trained to meet the extraordinary demand of the war for resourceful men skilled in a variety of industrial occupations. It was planned, of course, to draw the men needed for such technical service in the army from the corresponding occupations in civilian life, giving the unskilled or half-skilled special army training for the peculiar demands of the military service. But the vast numbers of drafted and enlisted men to be dealt with and the urgent need for skilled men in establishments producing munitions and other supplies of war, made impossible the carrying out of this scheme, except to a limited degree. As a result-first in the army schools and later in the special schools for soldiers established by the War Department-there was usually little or no relation between a man's previous occupation and the war-time service for which he was being trained; yet most of this unassorted material adapted itself to circumstances, and many a house-painter, for example, made a fair army electrician and many an electrical 
worker qualified as an efficient layer-on of "dope" for airplane wings. The closest approach to fitting the civilian to the army vocational service was through the plan, entered into heartily by the school authorities in many sections of the country, of giving young men who volunteered for such service before being called to the colors, intensive evening school training for mechanical or technical army occupations along the lines in which those young men were already engaged in the earning of their daily bread.

Vocational Rehabilitation.-One of the most illuminating experiences growing out of the war and bearing upon the subject of vocational training is that of the European countries, of Canada and, so far as it has progressed, of the United States in the rehabilitation of soldiers and sailors disabled by wounds or disease. The prinary purpose of this training was to maintain military efficiency by making disabled men competent to do vocational service of some kind behind the battle lines to which, in most cases, their disability prevented them from going back. But this purely military purpose soon developed into a wider effort-which seems likely to be measurably successful-that of returning at least ninety per cent. of the men disabled by war back to civilian life not only as efficient as they were before, but in many cases more so. The experience of Canada and of the United States seems to make it perfectly clear that almost any handicap from wounds or disease may be overcome, on the one hand, through proper medicine, surgery and therapy, and, cn the other hand, through giving the disabled man the special type of training needed not only to overcome his handicap but to lead him into that vocational path which is more or less clearly marked out by his native capacity, his interests and his background of experience. Humiliating evidence of the haphazard character of American education has been presented in our short experience with soldiers and sailors disabled in the war. A not inconsiderable proportion of them have not even an apology for an education; a still larger proportion had no training antecedent to or concurrent with the pursuit of their former occupations; and the majority of them are pathetically eager for the specific opportunity which the Vocational Rehabilitation Law provides for them to fit themselves, at government expense, for a vocation chosen and carried on under expert guidance. 
For a majority of these boys this is their first chance; because, before the war, all they could do was to drift, as most of them did, into some "job" without any knowledge of its good or bad possibilities or of other lines of activity which might have been better suited to their individual abilities. If these youths, selected through the draft for their physical, mental and moral fitness, at an age when they should have been at the peak of vocational fitness, show such lack of training, of aim, and of understanding of the vocational field, how much greater must be the need of the country as a whole for sound vocational guidance and adequate vocational training. And in view of the war's proof of the vocational flexibility of the properly trained man, how incalculably the supplying of that need would add to the material and moral resources of the United States.

Education for the Child, not the Child for Education.-The lessons of the war in matters of education merely emphasized what students in this important field have long advocated, namely: to study the individual in order to fit him into a place in his community in which he is likely to be of most value to society and to secure, therefore, the greatest happiness for himself; to provide every practicable opportunity for boys and girls to understand the broad territory of the vocations; and to change the direction and emphasis of general education so that instead of attempting, as it has for centuries, to lay down a priori more or less fixed curricula and to bend all children to such cramped standards, it shall provide opportunities for training as wide and varied as are the capacities of the human mind, and the demands and interests of modern life.

A Suggested Program.-To carry out this sound educational program, certain specific provisions, the lack of which has been very greatly emphasized by the experiences of the war, must be striven for in every community in the United States. First, every child should be compelled to receive as much elementary education as it is capable of profitably using. To that end every child from its entrance into school should be studied as an individual, tested in order to determine, as far as may be, its mental range and power, and assisted in every way to carry out the principles of hygienic living, mental growth and choice of occupation.

Secondly, every child, especially in the adolescent period, 
should be given every opportunity to understand what true citizenship is and be taught to realize that the main foundations of effective citizenship are the ability to earn a living in ways suited to individual capacity, and the desire, at the proper time, to marry and bring up a family. Consequently, the term vocation must in all this teaching be so widened as to cover not only all fields in which it is possible for a normal youth to earn a livelihood, but also the no less important fields of home-making and of political and social service.

Thirdly, every community, or at least every group of communities, should provide facilities for the effective training of all its boys and girls along those vocational lines which are suitable to that community, and should see to it, also, that they have practical education in matters of health, home-making and citizenship.

Fourthly, the shop, the farm, the store and the other productive agencies should coopperate with the school so that those vocations may be made real to the child; the home should work with the school so that, together, they may create responsible and intelligent homemakers; the civic and political forces of the community should unite with the school to lead youth early into active participation in the work of citizenship; and above all the church should coöperate with the school in order that the boy and girl, in adolescence when idealism is strongest, may be permeated with the conviction that work and home making and civic duty are futile unless based upon and guided by the fundamental virtues.

The Two Essentials: Aim and Incentive.-Through such cooperation the school life of the child will take on new meaning. There will be supplied the two essentials now usually lacking in education: a definite aim and an active incentive towards real study and real work. Boys and girls have naturally a great curiosity towards life, a strong desire to take active part therein, a laudable ambition to bear their share in the labors of the world. But what life means, what they may contribute towards social progress, how they may make the most of themselves and of their opportunities, nobody-from the youth's point of viewseems to know or care. What wonder, then, that the adolescent boy and girl drift, lose ambition, form idle habits and fail to 
develop interest and initiative. In most cases the good forces that make for economic and moral success are inherent in the growing youth; but for want of understanding, guidance and any definite stimulus and goal, those native impulses run to waste or turn into anti-social channels leading to mischief, to misdoing and even to crime.

The Prevention of Human Wasie.-To prevent as far as possible this shocking waste of human energy and well-being is one of the most serious and immediate tasks of the reconstruction period. Laws and ordinances, forms of government, societies for promoting this and for prohibiting that, all are worse than useless unless the coming generation is given a "square deal." For his own protection and still more for that of society, every individual in the growing generation is entitled to such an education as he personally is fitted for and can put to the best social use. He should have a succession of competent persons, in addition to his parents (for they, unfortunately, are often as ignorant as he) to study him, to advise him, to assist in placing him, and to follow him up until it is certain that he is prepared to stand securely on his own feet. And that series of advisers should be able to use the schools, the homes, the industries, the churches and all the other organized good forces of the community as places in which really to educate that growing boy by giving him opportunity not merely to memorize facts, but also to do things, to get experience, to try himself out in life on a small scale preparatory to making his way on the largest scale for which nature cut the pattern of his "faculties." Vocational guidance does not mean the finding of a remunerative job for a boy; vocational education does not involve the setting up of a few poorly-equipped "play" shops; but together they mean the intelligent analyzing of a boy under real conditions of study, work and play so as to find out what he actually is capable of becoming, and the providing of genuine and generous opportunities for him to fit himself, not simply to earn a living, but to live.

The war has magnificently demonstrated that the youth of the United States can be depended upon in a great, definite emergency. But in modern democratic life every hour is an emergency; and the responsibility and the privilege of education 
is to mobilize the oncoming hosts of boys and girls adequately to meet those daily crises by teaching them what life means, and by helping every one of them to find that work in the community through which they can give the best service and can secure, as the natural reward of such service, the greatest good out of life. 


\title{
CHAPTER XXII
}

\section{CONSERVATION OF HEALTH}

\author{
By HibBert Winslow HiLl ${ }^{1}$
}

\section{Executive Secretary, Minnesota Public Health Association}

Misconceptions on Health Conservation.-We cannot conserve that which we have not; and physical health as a national characteristic is yet to be developed; therefore we must face the fact that the "health" our publicists ask us to conserve is rather a mental concept than any actual condition of any concrete number of people who are already physically perfect and whose preservation in that state should be our great concern. So long as the status of physical undevelopment, or mal-development, of the nation remains what the war-surveys revealed; so long as even our most perfect specimens are subject at any moment to wreck, more or less total, by the inroads of infection lying loose about us; above all, so long as the propagation of the unfit physically, and even more important, of the unfit mentally, continues without check, so long will there be not a conservation, but a mere salvage; not a prevention of disease, but a mere patching up of the diseased.

Present Inadequacies of Public Health Work.-Conservation of health relates to that individual so often called in other conservations the ultimate consumer. In this matter of literal life and death he is far too often not the ultimate consumer but the

${ }^{2}$ M.D., Toronto University, I893, D.P.H.; taught at Toronto University, I894-5; conducted public health investigations at Louisville, Philadelphia and Brooklyn; Director, Brooklyn Board of Health, 1896-8; Director of Laboratory, Boston Board of Health, I898-1905; taught at Harvard Medical School; Assistant Director, Minnesota State Board of Health and Assistant Professor of Bacteriology, University of Minnesota, I908-1912; Director of Institute of Public Health, London, Ontario, 1915; Dean of Faculty of Public Health, Western University, I916-; Executive Secretary, Minnesota State Board of Health, I9I $4-$ 
ultimately consumed. We admit thus at the outset that public health work as it is to-day has, in its terrible inadequacy, clouded its truly numerous minor victories by far more numerous disasters and defeats.

Health and Evolution.-Notwithstanding this, health is not by any means merely an unreal hypothesis. There is in all biology a tendency to the normal-a force of some kind, recognizable, but unexplained as yet, such that vitality, when pushed aside from the normal line, is ever seeking to get back to iteven more, to move along it, developing and improving-the resultants being in the individual what we call health, and in the race, perhaps, what we call evolution. This tendency to health and this driving on to further evolution mean, if they be indeed identical, that efforts at conservation of health are really efforts at an even greater end-a coöperation with that group of nature's forces which we recognize as those which have tolled the original ameba all the long way to manhood. Public health becomes, then, not a mere effort at "the knocking off of decimal places from the current figures of morbidity and mortality," but really an apotheosis of the struggle for existence of the individual into the much nobler struggle for existence of the whole human race.

Useless Efforts After Health.-Conservation of health, then, is not a conservation of a widespread condition now existing. So far as it is an effort to "aid nature" positively it is a conservation (if you like to give so great a name to our puny efforts) of a fundamental tendency which is in itself so strong that such assistance is like "assisting" the spring tides to come in. Fancy a five-year-old boy "helping" a mile-long freight train on its way by pushing on the rear of the caboose! The train will move on its appointed path, regardless of the baby hand adding its tiny aid. The destination of the train, the rails and roadbed upon which it moves, its schedule, are no more far removed beyond the ken of the solemn toddler straining himself to help than are removed from us the ultimate destination of the human race, the laws it moves by, the power which, as we are cognizant from the results, drives it on always.

The "vital force," whatever it may be, that knits a broken bone is no more under the attending surgeon's orders than is the "vital force" which brought his patient into the world in the first place or keeps him going in it. When that "force" ebbs, 
who shall supply its failing powers? Is it more possible to add to, promote, increase, develop, or what not, those forces in health where they are at their best than in disease where they are at their worst? The surgeon does indeed attempt to clear the path for this "force" to act, to make the conditions as favorable as he may; but there his powers cease. Just so in health; we cannot develop or promote or assist this force of nature. Our efforts so to do are sadly ludicrous when not disastrous. But we can, at times, remove obstructions from its path. This negative "conservation," this clearing of the track, is open to us, at least in some, at present, rather minor aspects. We canrot make a tree grow, but we can prune, direct, remove obstructions, and more or less let reach the tree those factors nature makes essential, water and soil and sunlight. Also we can more or less protect the tree from biological assailants-the cribbing horse, the locust, and the tussock-moth-at times.

Health Conservation Necessarily Negative.-Thus we must realize in all active public health procedure two lines of effort, the negative, prevention; the positive, that which, in theory at least, would develop to a higher plane the health we may already find at hand. But analyses of all health enterprises show quickly that, however brave the words in which we dress them, those measures which are not preventive are as a rule mere dreams, the idealizing of a noble thought, indeed, but, put in practice, nothing more whatever. Consider all our "conservation" methods from prenatal supervision through every phase of baby and child welfare to isolation of venereal adult cases. What are they but a clearing of the track for nature's trains, a letting in of sunlight, soil, and water upon the tree, or a protection against biological invasion?

There is, it is true, one other and very definite thing the human race can do for its own welfare. When it finds the "tendency to normal" has been lost, that a particular strain has so far deviated from the normal line-as in hereditary feeblemindedness-that the return to that normal line is hopeless, it.can stop that strain entirely, "prune off the errant limb," and, like that stern old soldier who "made a wilderness and called it peace," take credit to ourselves that if we have not cured, corrected, saved, we have at least abolished what was not wanted. This form of "conservation" is indeed "negative," yet it is a 
form sternly demanded at the present time; most obviously against the feeble-minded but also against other undesirable strains of human deviates. It is true that practical problems in deciding just what kind of deviation, and just what extent of deviation in each kind justifies abolition, at once arise; but the dangers and the difficulties of the only path before us that leads us from destruction should not turn us from it to that destruction.

Elimination of Physically Unfit.-Therefore any really comprehensive program of what we all have more or less hazily in mind when we say "conservation of health" must take for its fundamental principle the prevention of the birth of those whose physical or mental defects would unfit them for the world-wide struggle with infection and other adverse factors in our lives. It is but common sense to reject the applicant for military service whose feet or hands or head are such that failure in soldierly duties is practically assured. It surely is only the same good sense applied to the same problem at earlier stages in the individual's career to reject as a recruit for the world's warfare that child equipped so faultily that his career cari be but failure for himself and detriment, sorrow, and economic loss to others.

Such Spartan principles are quite unlikely to be welcomed. We might, we certainly would, apply them to any breed of beast, or bird, or fish which we, the lords of all creation, desired to cultivate. But when we turn to look at our own race we find ourselves suddenly abashed. No longer lords, we then seem to ourselves to be the lowest and most hopeless in the scale, more helpless to aid ourselves, more inert, more slavishly bound hand and foot, more visionless, than any crawling worm upon God's footstool, although along the very lines we proudly, blithely, ruthlessly apply to other species. It would pay us infinitely more in cash as well as otherwise to exercise our knowledge of heredity upon our race rather than on our race horse; but we breed our unfit millions by the million, and then with charity but not with intelligence patch up, prolong, and conserve the unfit we produce! Our child welfare movements are intensely idealistic, altruistic, greatly conceived, and often immensely useful, so far as they apply to saving good material lost otherwise from sheer neglect and ignorance. But the prevention of the birth of many of those born, upon whose preservation, once they are born, mis- 
guided effort wastes itself in vain, is even a more worthy, a more truly noble service-the more so that its rewards are intellectual, negative, abstract, not emotional, positive, or concrete.

Essentials of a Health Movement.-For such a program, for the whole program of prevention, negative and abstract, a mere clearing of the track, as it must necessarily be, the greatest national need is a morale we do not yet possess, morale to face the issues, and to persist like the hard-bitten, heavy-burdened, slow-moving soldier of Bairnsfather's cartoons, without spectacular victories, or any quick, obvious results; for this is a campaign which, like that in Belgium, has for its end not glorious additions to the wealth and prestige of the nation, but only a mere restoration of its normal life, a mere removal of an intolerable invader. To insure "morale" there must be first some great, some simple, some all-compelling principle condensed into a word like "Liberty" or "Defense," some slogan which in itself fits naturally to the human mind. No artificial cry, however carefully cultivated, will carry on great human movements long against a powerful opposition or through a prolonged campaign. Given a slogan, confidence in the leaders comes next, then confidence in the weapons, and finally organization, discipline, concerted movement.

For world-wide public health, we have not yet any of these essentials in concrete form. A thousand slogans where we should have one; leaders leaning each in his own direction; weapons imperfect, undeveloped, fragile; organization, discipline, concerted movement, still mere dreams. Our appeals to human sentiment are faulty in many instances. We have too many words for health endeavors, and these diffuse our forces. Such words as hygiene, sanitation, good health, can never be made living, breathing slogans like "Liberty," "Defense." A concrete enemy is needed which our peoples can visualize and fight. It is difficult to inspire a whole nation with a picture of an ideal situation to be reached through centuries by a continuous race effort at self-development.

Any appeal for race advance made to the individual on the score of benefit to himself is useless for it is too intellectual, too much a matter of distant, cold-blooded calculation. Appeals to individual interest can, it is true, be made with great effect to him who himself suffers or expects to suffer disease and dis- 
ability in his own person, and this is proved by the extensive use of accident and health insurance policies. But imagine asking that individual to take out a policy of health or accident insurance upon some other person (the cash returns of which would go to that other person) on the ground of benefit to the man who paid the premium! That such benefit exists can be demonstrated truly, yet it would be very hard to make the average citizen see it. But such "policies for the other fellow" could be sold on altrustic grounds. The very man who would laugh to scorn the idea that he was benefiting himself by paying the other man's premiums would generously help the other man in many instances although he were quite convinced he did not thereby help himself at all, indeed, perhaps just because he was quite thoroughly so convinced.

The appeal for public health that has proved the least appealing is that which is based on the self-interest of the individual-that based on the benefits to himself to be obtained by helping others. Explain it as you will, the appeal for public health which gets the most response is the altruistic one-the appeal to help the other fellow even at what seems one's own expense entirely.

Difficulties in Securing a Health "Morale."-Now, this is just where the difficulty of the program of true conservation lies. It is a straight, head-on collision with the emotional bent of the human factor. This bent requires action, positive, aggressive, showing returns that are quick, obvious, concrete. How little enthusiasm is shown towards saving a thousand babies compared with that elicited by knitting a thousand pairs of socks! The one is negative, abstract, shows nothing to the eye; the other shows-a thousand pairs of socks!

Compare the sufficiently difficult demand "Save the sick baby" with the sterner yet infinitely wiser slogan "Prevent the unfit baby!" As the value of the product increases from socks to racial perfection the appeal of their respective slogans lessens and the bulk of effort elicited lessens also in strictly converse measure. Placard the country with the cry, "Knit socks," and the whole country knits; placard the country with "Let us reach physical perfection," and who would read it twice?

Principles of Future Health Work.-The policy and mechanism of conservation, then, as it must be to-day, is just that policy 
and mechanism which we might apply to, say, the Mississippi. We do not try to aid the forces that make the river flow from Minnesota to its final destination. We know it would be absurd to try to render any such aid. In all this foclish world none has yet advocated anything quite so foolish as that proposition. But we do remove obstructions, drain unnecessary marshes and lagoons, control the channel, even supervise the floods.

These things, and these only, can we do for the tides of overflowing human life around us. We cannot add to the tendency to health or physical progress, for that is the nucleus given to us by nature, but we can give that tendency free play. We know what is bad, what can more or less be obviated, but we know not how to help other than by removing hindrances. This is a hard saying in the face of propaganda, widespread and blatant, withal very earnest, which preaches this and that royal road to health. Nature provides the only road, and no effort of ours can approach the pressing, pushing, energy and exhaustless power of that tendency to move along it-that tendency to health-which nature itself supplies. It is ours to remove obstacles, and of these, if we eliminate the reproduction of the unfit, infection, the invasion of the premises by outside vicious agencies, remains the greatest factor. In order that prospective Chinese "lily" 1eet should reach their normal, no stimulation oi other aid to nature is required; mere release from the bonds holding them to abnormal feebleness and in painful suppression is all-sufficient. But they must be released before that tendency to normal has been deviated by the bonds too far. So our race needs, not conservation of its health, but rather prevention of its disease; not liberty, but release from slavery. If we strike off its chains there will be no need to worry further. Nature once free will take care of all else save in those instances where nature itself is now too twisted and bent aside and where removal of the thus hopelessly twisted from our universe remains our only course.

The Great War has brought into the open three great public health principles, epitomized as follows:

Infection is the greatest physical enemy of the fiuman race, greater than war, and, like war, must be abolished.

A league of nations against the germs that cause infections is needed quite as much as it is needed against war, or other world-wide evil. 
Organization for such world-wide effort as the abolition of infection would entail must be an organization which will include the inoividual citizen, just as if the organization were for peace or for democracy.

Discussion of Ncw Principles of Public Health Work.-To discuss the first-this war has demonstrated fully the fallacy of the preposterous, but very natural, teaching, so widespread before the war upset it, that physique, good health, "obeying the laws of nature," would prevent infection. We have had a world-wide demonstration that our picked men, clothed, fed, exercised just to develop that high health and boundless vigor which, it is often claimed, protects against infection, succumbed to every infection to which they were exposed (unless specifically immunized against it) as readily as any "sedentary clerk" or "puny gutter snipe."

We need not quote the figures for syphilis or gonorrhea in the army, or the figures for influenza, or for mumps, measles, scarlet fever; they are too well known to all, for our men, of the best and most vigorous age and physique, succumbed to these exactly as any civilian would. On the other hand, it is no use to claim unusual conditions, strain, excitement, etc., as reasons which offset even their high physique and health, thus "lowering their resistance," for they did not succumb to any diseases against which they were immunized specifically as they were against smallpox or typhoid fever. These two were the greatest curses of all ancient armies, and the latter was the great curse of every army up to the end of the nineteenth century. Nor did they, normal or abnormal, succumb to any disease, the infection of which was not introduced amongst them. Compare the fearful ravages of typhus fever amongst the Serbs with its absence from our troops. What is the explanation? Certainly not the greater cleanliness of our men (fancy talking about cleanliness in the trenches, crawling with vermin!). It was merely that the typhus germ was present in Serbia but was kept out by strenuous exertions from the western front.

In brief, the war has shown on a great scale what public health, but practically without a hearing, had preached before, that prevention of infection, not cultivation of health, is our one great weapon (apart from specific immunity) against our greatest enemy, infectious disease. The soldier who "caught" influ- 
enza was no more protected by his "vigor," nor any more subject to disaster from his "abnormal" life than the civilian was protected by the relative "even tenor of his ways," or destroyed by his "flabbiness." Infection and infection only controlled the influenza situation, military and civilian-offset alone by an as yet unaccounted for immunity at times, which certainly had not the least relation to general physique or vigor.

The war no more developed these principles than it developed syphilis or gonorrhea. The prevalence of the latter for a time was by the general public indignantly attributed to war conditions, but every one is convinced now that in civilian circles these diseases were and are twice as numerous as in the army. Just so the principles of infection and immunity were not changed by the Great War but merely were emphasized on a huge scale and with an appalling weight of evidence which came right home to almost every family, for almost every family had some direct connection with the war. Moreover, if this were not enough, the influenza in civilian circles brought the truth still closer home, wiping out the vigorous, healthy man and woman of the most vigorous ages and leaving relatively untouched children, the aged, and the tuberculous!

Universality of Action for Health Needed.-Now, it is this very widespread teaching of these principles by these terrible first-hand demonstrations to every race upon the globe and all within four years, the bulk of it in two years, that makes what we have called the second great outcome of the war, a league of all humanity to fight infection, something not wholly dreamy or idealistic, as in the pre-war days it might have been. Public health has long been rather something imposed upon the people than springing from them. It has borne the stigma of all "high-brow" efforts at health organization, that it came from universities and governments as something offered like salvation; although not like salvation, offered free, but to be paid for at what seemed a woeful price for something the people did not want. Have we not all for years looked on with envious eyes while road and ditch appropriations passed at relatively high figures through every village council and state legislature, while protection of pigs and cattle was provided on great scales, and while public health received a miserable pittance, and even that rather a tribute to the persistence of those who asked the 
funds than in recognition of the value of what they sought them for? But now the situation has changed, or is beginning to change. The public has learned from the Great War and from the even greater influenza that public health is something that should form as definite an ideal of every life as "Liberty" or "Defense." It seems to me therefore that the way is clearing for a real league of nations, a spontaneous league, springing from the masses.

Our third great point-an organization of the individuals for defense against infection, as whole nations have organized as individuals for war, promises even now a realization, through the voluntary societies, consolidated and ramified so broadly under war conditions. The formation of voluntary Public Health Associations all through the country shows something of the trend towards making public health, like government in general, a thing that, springing from the governed, is approved and welcomed by them.

Warnings on Health.-What these movements will finally bring forth, our future years will tell, but we have made so many false moves in our public health that cautious watchfulness of every offered lead is highly necessary. Disease has been attributed so often to God and devil, evil smells, "poor health"; sacrifices, incaintations, "cleanliness," and "hygiene," have been so overworked in the effort at offsetting these alleged causes, that human nature has wearied semewhat of the long parade of inefficient effort. Can we point now to any better doctrine?

Surely yes! We do know certainly that disease without infection is so rarc that we might leave it to one side, except in infancy; and there improper feeding is the chief source of damage, excepting always that nuch greater one-the production of the child who should not have appeared at all. We find also some equally sure ground in such immunity, natural or acquired, as can be demonstrated in diphtheria, in smallpox, and in typhoid fever, etc. In these $f$ ew diseases, we can surely preach with safety a simple duty---immunize the race against them.

But very many diseases still remain against which natural immunity is rare, and artificial immunity is not yet developed to the point of general application. Against these diseases (alas, including the most serious ones, syphilis, gonorrhea, tuberculosis, pneumonia, influenza and many others) our only weapon so far 
is to avoid infection, and this we cannot do in modern life unless infection itself be absent. Hence for these diseases our only war cry can be "Abolish all infection."

How Accomplishments in Health Must Come.-What are our weapons? At the present time the real situation is that we have no weapons worthy of the name. We have no army trained to war on "germs," or only a very tiny nucleus of one, far less in its proportion to what is needed than the trained military men we had before the war were to the army that went into France and won its way to peace. The mechanisms for making headway against disease and death that now exist here or abroad, in any civilized country, remind us of the pictures we used to see of coast defense artillery before the war changed things, when shortage of artillerists compelled conducting all the drills with half the needed men replaced by wooden posts to mark the places that should have been filled by soldiers.

Tuberculosis is the one important disease against which any really widespread effort has even yet been truly thought of seriously. If the work done to date were even twenty per cent. efficient, there would be no more cases in 1950. But it is only one per cent. efficient, and at this rate of "progress" we will not see tuberculosis disappear before the year 2 roo. If we had a mechanism that cut infection with tuberculosis fifty per cent., that is, was only fifty per cent. efficient, we need have no new cases after r930! It would cost money; but we spent one and a half million dollars' worth of ammunition in one hour and a half in one small battle of the hundreds that were waged in the Great War! For just one-twentieth the annual cost of our overseas army we could wipe out tuberculosis from the United States in less than seven years.

But now comes the crucial question of "morale" which Napa leon said ranked in value three parts as against one of mechanism. How shall we arouse our 100,000,000 people to war against enslavement by infection as they were recently to the war agains: enslavement by other men?

Education for Health.- The idea of liberty from oppression had to be taught mankind through tedious generations, and it is not learned fully yet. The idea of freedom from infection may take whole tedious generations yet to come. But can we not make now that beginning which must some day be made if 
ever the day of freedom from infection shall really dawn? The introduction into the schools of teaching, fearless and definite, not of traditional hygiene but of the real facts as the best leaders know them, is the first step, and this requires the teaching of the teachers in our normal schools. We must have fearless, concrete doctrines, pruned of all superfluities, simple, direct and true; in all these points contrasting, especially in the last, with most of what is now preached and taught in the name of health. We must have these doctrines taught everywhere, especially to the preachers and teachers of the race. Once this is done, once the whole race is roused, infection can be made to disappear in ten years' time.

Conservation of health has three main lines of operation: first, prevention of the unfit; second, the proper feeding of the fit in infancy, and third, prevention of infection; and requires, first, a new, simple teaching of these fundamentals, and second and third and last, efficient action. The war has emphasized the importance of these items because it has turned attention to unfitness, to unnecessary losses of the fit in infancy, and to the widespread disabilities due to infection. Never before has the world's observation been so focussed on these subjects as at present. The influenza epidemic, even more, has helped to place infection in its proper place in popular estimation; but the greater, although naturally correlative, result has been the general recognition that our present equipment for achieving what these demonstrations have made it obvious we must promptly seek is wholly inadequate for meeting one-tenth of the demands.

Effect of the War on the Health Situation.-The war, from the American standpoint, halted too soon for the full benefit of these by-products of it to have the full weight which they promised to attain; full many a promising development was checked in full career. Nevertheless, the anti-venereal movement received its first real impetus from war conditions, which brought the subject out into the open and furnished an excuse for its detailed display. The anti-tuberculosis movement, already fairly widespread before the war, also received a share of the advantage of pitiless publicity on evil. In practice, these have resulted in better financing of public health procedures, and a growing respect for public health activities, the latter checked somewhat by the influenza failures. The war and the influenza have em- 
phasized also something, again not new but never before so widely understood, concerning the inadequacy of therapeutic service in civilian circles, as well as the inadequacy of public health.

The only thing without which a modern army cannot exist is the medical service which years ago was hardly recognized as more than a sort of philanthropic movement grudgingly suffered by the combatant as a concession to civilian feelings. It is quite clear now to all careful students, that but for medicine (used in its widest sense, including in it all the sciences tributary to medicine as well as therapeutics) the Great War could not have been. This is perhaps a doubtful compliment unless it is seen to mean that medicine has grown to be big business in the very best of senses, a necessary item in the conduct of any great enterprise. Nothing could have proved this more quickly or more conclusively than the war, but once established under those strenuous conditions the need for parallel service to civilians is quickly understood.

Nationalization of Medicine and Nursing.-Thus, as another by-product of the war, we shall see some form of expansion of our "private medical practice" of the pre-war days into a national service-on just what lines remains a matter for evolution. Here, again, nothing new has been developed but the war has impressed the needs of it, and also, in part at least, pointed the way to do it. Even before the war medical education was paid for largely by the state, not by the students, because no body of students could by their fees begin to meet the expenses of a modern medical school. Even before the war, the view was growing that this education thus furnished by the state should be utilized rather for public benefit than for private enterprise. Finally, the men in the army have become accustomed to free medical service of the highest type, not as a pampering gift but as a sober factor in a business proposition. When they return to civil life they are quite unlikely to relish the existing methods of private distribution of medical service as it is to-day. We see then not public health alone but all therapeutic service nationalized and extended to the individual citizen as real rights, as rights that he demands, not something thrust upon him.

Not only has the civilian-soldier learned what to demand, but the civilian-medical-officer, returning also to his old life, has 
learned from his war experience "a thing or two"; the value of prevention; the value of constant watchfulness of healthy men, to detect early signs of illness; the value of going, so to speak, in search of sickness, rather than of lying back and waiting for it to be brought to him, as in civilian practice. In brief, the civilian of the future will be a great deal more receptive, the public health man and the therapeutist much more aggressive, than in pre-war days.

The ending of the war was a debacle for many sociological movements that had reached the last steep ascent to climaxes long sought-and those outlined above suffered with others. Just for this reason, just because our half-done work was left at loose ends, just because we rose high enough to see the promised land and then had to descend, the need for strenuous effort to overtake the gifts that peace snatched from our grasp is all the more insistent. In some respects, at least, the influenza may take the war's place as a driving force, an insistent advertisement, and an "instant need," sufficiently to prevent the slump we fear in physical regeneration movements.

Summary.-Of all the measures open to us now-and not one should be turned aside as useless-those which to me seem far the most important are two: A new, real, teaching of the real facts in the public schools; and a real living organization of the whole citizenship for public health. This means, first, an organization for the abolition of infectious diseases, since this is the most immediate and practical step at once attainable, and then the development of marriage laws, prenatal supervision, and education of all girls in infant care, with the double object of preventing the unfit baby and providing that the fit one does not die. To make these measures effective, nationalization of medical and nursing service, with great expansion of both, especially the latter, must ultimately be sought from the state, or better, from the hands of some great body bearing to the state somewhat the same relation the Red Cross bore to the army in the war.

Indeed, I think that we need two governments, one like the present to govern, to directly control the activities of the race, to deal with its affairs as a racial unit in the world, exercising police powers, operating courts, a representative government, but consisting in a necessarily small body, holding the visible control 
which comes to them from the people. The other government, informal, without police powers, yet recognized by the government first described, would have as its chief business, not the conducting of the affairs of the nation as a nation but the supervision of its individual citizens, and would consist not of a selected group representing the rest, but of that "rest" itself.

Perhaps the Great War will furnish no greater outcome, after all, than this-a definite and designated body, of the whole people, helping the individuals of that body, individually, to attain the highest physical welfare attainable to the human. 



\title{
CHAPTER XXIII
}

\section{FOOD AND RECONSTRUCTION*}

\author{
By Graham Lusk ${ }^{1}$
}

Professor of Physiology in the Cornell University Medical College, Scientific Director of the Russell Sage Institute of Pathology, Representative of the United States on the Inter-Allied Scientific Food Commission, in Paris, Rome and London, 1918

\section{PROLOGUE}

In the early days of I9I6 the writer estimated that the cost of food for the population of the United States was not less than $\$ 6,000,000,000$ per annum, or twice the amount of the gross earnings of all the railroads of the country. This computation was based upon the assumption that a family of five persons paid not less than $\$ 25$ a month for food when the father received $\$ 60$ a month in salary. The price of food computed by "The Annalist" and based upon the price of twenty-five food commodities entering into a family's dietary scarcely changed during I9I4 and I9I5. By I9I8, however, the price of the same foods had doubled when compared with the pre-war cost. Assuming the first calculation to have been correct, it would follow that the sum expended for food in the United States would now be

* This article was completed March I, I919, and political events in Europe and the rising cost of living in the United States since that date verify the conclusion on the important relation of food to general economic conditions.

${ }^{1}$ Ph. B., Columbia University, I887 ; Ph.D., Munich, I891 ; A.M.. Yale, I896, Sc.D., I908; professor of physiology, at Yale, 1895-8; at University and Bellevue Hospital Medical College, 1898-1909; at Cornell University Medical College, Igog-__- Scientific Director of the Russell Sage Institute of Pathology; representative of the United States on the Inter-Allied Scientific Food Commission in Paris, Rome and London, 19I8; author of several books on nutrition and contributor to scientific journals. 
$\$ 12,000,000,000$ per annum, or on the basis of $\$ 50$ a month for a family of five individuals. Confirming this is the estimate of $\$ 2,693,750,000$ as the cost of food to the people of the United States for the second quarter of the year of 1918 given in the Official Statement of the United States Food Administration, Oct. I, I9r8, p. 3. Such an expense would aggregate $\$ 10,775,-$ 000,000 per annum. The average price of 294 variable commodities, as compiled by the Bureau of Labor, has also very nearly doubled since the beginning of the war. An astonishing parallelism between the cost of food and the cost of general commodities here manifests itself.

There are no absolutely reliable statistics regarding the present value of family incomes in the United States, but the Bankers' Trust Company of New York, in a pamphlet prepared to stimulate the Fourth Liberty Loan, apportioned approximately the family incomes of the people for the fiscal year ending June 30 , rig. In the case of the farmer these figures naturally include the value of the food which he and his family raise and consume on the farm. The figures are as follows:

FAMILY INCOMES IN THE UNITED STATES FOR FISCAL YEAR ENDING JUNE 30, I9I9

\begin{tabular}{c|c|c|c}
\hline Family income & $\begin{array}{c}\text { Number of fam- } \\
\text { ilies in group }\end{array}$ & $\begin{array}{r}\text { Total incomes of } \\
\text { families in group }\end{array}$ & $\begin{array}{r}\text { Percentage of } \\
\text { total family } \\
\text { income of } \\
\text { U. S. A. }\end{array}$ \\
\hline$* \$ 1,000-\$ 2,000$ & $21,375,000$ & $\$ 40,615,063,500$ & 77 \\
$* 2,001-3, \infty 00$ & $1,375,000$ & $3,850,000,000$ & 7 \\
$* 3,001-4, \infty 00$ & 246,950 & $938,454, \infty 00$ & 2 \\
$* 4,001-5,000$ & 144,050 & $677,035,000$ & 1 \\
$* *$ Over $\$ 5, \infty 00$ & 359,000 & $6,769,447,500$ & 13 \\
Total........ & $23,500,000$ & $52,850,000,000$ & 100 \\
\hline
\end{tabular}

*Included in these groups is the income of wage-earners other than family beads.

**Average per family, $\$ 18,850$.

If one divides pro rata the total cost of twelve billions for food among these families it may be computed that approximately eleven billions is paid by the wage-earners who have a total annual income of forty billion dollars. It is evident, therefore, that the great mass of the people of the United States expend 
at least one-quarter of their income for food. Fifteen per cent. of the population of the country consists of farmers producing food not only for the 85 per cent. engaged in other industries but also for the hungry millions of Europe. The Department of Agriculture has long and ably represented the interests of the food-producing classes. Its Office of Home Economics has also rendered important service in advising the general public as regards the fundamental principles of nutrition. During the war period the United States Food Administration, established under Mr. Hoover, has acted in the interests of consumers as well as producers in efforts which were closely coördinated with those of the Department of Agriculture. In this way the consumers, not only of this country but also those of the inter-allied world, were efficiently protected, and without this control it might have been that the war would have been lost through unbridled speculative competition for the necessities of the people.

The war brought with it a great educational propaganda as to the nature of food and it would seem desirable to present in this paper the most recent conceptions as to the food necessities of a people. During the war our own country has been a land of plenty in comparison with the impoverished lands of Europe. This is readily understandable when it is realized that, of the $450,000,000$ inhabitants of Europe, 400,000,000 have been involved in a long and exhausting war, and that the European neutrals have suffered for lack of food almost equally with their neighbors.

The war bas presented an intimate view of large communities in destitution-witness Belgium, Northern France, Poland-and of a nation on rations dividing equally among its inhabitants its meager stores of palatable foods, as happened in England. The war has taught how an intelligent state may effectively protect its citizens from famine. The control of the cost of food by the state has raised difficult questions which are far from a satisfactory solution but which are of the highest importance. One need only mention the recurrent troubles regarding the fixing of the retail price of milk in the cities to understand the necessity of reaching some solution of this problem. The cost of food is one of the principal charges for operating a human machine and upon it depends in part the wages of the worker and, therefore, the cost of the product of his labor. 
An attempt has been made in this article to present a discussion of the principles outlined in the previous paragraph. No apology is made for the use of simple scientific language. The ideas cannot be otherwise expressed.

\section{THE FUNDAMENTAL REQUIREMENTS FOR FOOD}

Before the war the questions of the science of nutrition were generally considered to be of academic interest only. Large numbers of people were in a state of chronic undernutrition, although a certain few were evidently the product of overeating. It had ever been thus and doubtless would ever so continue. During the war the first problem confronting the Allies was that of giving food to the Belgians. The Germans also, after an early victory was denied them, had to look carefully into their food resources. Now, the human machine has to be fed with fuel just as a machine fashioned by the hand of man must be fed. Our lives are dependent on the fact that we burn up food in our bodies and that this burning of food gives us heat (calories) to keep our bodies warm, and also gives our muscles the power to work, just as burning coal drives the steam engine. The laboring man who does the hardest work is the greatest consumer of food.

The amount of power in a fuel can be determined by burning it and measuring the quantity of heat it gives off. We measure the heat by noticing how much it can warm water. A calorie is just as much a unit of heat as is a pound a unit of weight. A calorie is the quantity of heat which will raise one kilogram of water from $0^{\circ}$ to $\mathrm{I}^{\circ}$ Centigrade or raise one pound of water $4^{\circ}$ Fahrenheit. It is of interest to know how many calories must be present in the food for the maintenance of the life of an individual. This has been the subject of much study.

At the outbreak of the war the food requirement for children was generally underestimated and in October, rgr6, the rations allowed to children were increased both in Belgium and in Germany. The work of Du Bois ${ }^{2}$ showed that a boy of twelve or thirteen years of age, when resting in bed, produced 25 per cent. more heat than would an adult of the same height and weight,

${ }^{2}$ Du Bois, E. F.: Archives of Internal Medicine, 1916, xvii, $\$ 8$. 
and Gephart ${ }^{3}$ found that the boys of St. Paul's School ate more food than accorded with previous conceptions.

The Inter-Allied Scientific Food Commission, at its meeting in Paris in March, I9I8, fixed the probable requirements of food for individuals of different ages as follows:

Relative

Calories Food

"Average man"

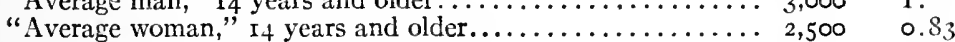

Boy or girl, ro to 44 years old................... $2,500 \quad 0.83$

Boy or girl, 6 to ro years old $\ldots \ldots \ldots \ldots \ldots \ldots \ldots \ldots \ldots \ldots \ldots, 100 \quad 0.7$

Boy or girl, o to 6 years old $\ldots \ldots \ldots \ldots \ldots \ldots \ldots \ldots \ldots \ldots, 1,500 \quad 0.5$

Total for such a family...................... I ,600

It was agreed by the Commission to calculate ro per cent for waste, which took into account both loss from deterioration from a national standpoint as well as loss from waste in the individual kitchen.

If one allows the whole Io per cent of waste to an "average family" of five it would require 12,800 calories per day "as purchased." This would amount to 90,000 calories per week. The food consumed by this family would be nearly that taken by four adult men (more accurately 3.87 men), a point to be remembered if the father is the only wage-earner. The ages of the children presumably preclude them from being wageearners.

If a workman does the hardest kind of physical labor, I, 000 calories of food fuel may be added to the daily ration, and if he is over six feet tall 300 calories additional may be added to his food for the maintenance of his iarger body.

In the spring of 191 8 the English divided their laboring classes into three groups for the distribution of supplementary rations of pork, as follows:

Class $\mathrm{F}$-Men engaged in mines, quarries, metal manufacture, shipbuilding and ship repairing, gas and coke manufacture, transport workers, navvies, boiler stokers, and firemen.

Class E-Men engaged in heavy bodily work in agriculture, forestry, and fishing.

Class D-Practically all men engaged in bodily labor, except

- Gephart, F. C.: Boston Medical \& Surgical Jourmal, 1917, clxxvi, I7. 
when, as in case of jewelers and watchmakers, their work, though manual, was essentially sedentary. This class included postmen, policemen, firemen, coast guards, and men employed on sanitary services, roads, gas, water and electricity supply. Doctors and veterinary surgeons come in this class.

It is probable that these classes would have been satisfied as follows:

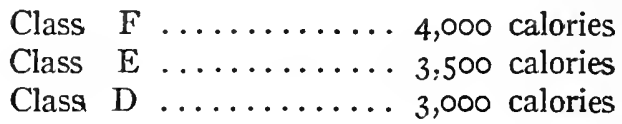

Besides these classes there exists a large number of sedentary workers, such as clerks, who work with their heads rather than their muscles and whose requirements are less than 3,000 calories daily.

An average man is 5 feet 8 inches in height and an average woman is 4 inches shorter. A woman of the same size as a man has a heat production which is 7 per cent. less than that of a man, and the average woman does less work than the average man. Among the munition workers at the Woolwich Arsenal in England the women ate three-quarters the amount of food taken by the men.

From the factors accepted by the Inter-Allied Scientific Food Commission it became possible to calculate the number of calories required annually by each allied country. The calculation for the United States in 19r8 is given below.

PROVISIONAL ESTIMATE OF THE CALORIC REQUIREMENTS PER DIEM OF THE UNITED STATES OF AMERICA

\begin{tabular}{|c|c|c|c|c|c|}
\hline Age in Years & $\begin{array}{l}\text { Number of } \\
\text { Individuals }\end{array}$ & $\begin{array}{c}\text { Calories } \\
\text { Per Person }\end{array}$ & $\begin{array}{c}\text { Man } \\
\text { Value }\end{array}$ & $\begin{array}{l}\text { Calories in } \\
\text { Millions per } \\
\text { Day }\end{array}$ & $\begin{array}{c}\text { Per } \\
\text { Cent }\end{array}$ \\
\hline $\begin{aligned} 0-5 & \\
6-13 & \\
\text { 14-18 } & \text { Male } \\
\text { I4-I8 } & \text { Female } \\
\text { I9t } & \text { Male } \\
\text { I9t } & \text { Female }\end{aligned}$ & $\begin{array}{r}14,384,000 \\
15,003,000 \\
5,129,000 \\
5,084,000 \\
33,770,000 \\
31,073,000 \\
104,443,000\end{array}$ & $\begin{array}{l}1,500 \\
2,300 * \\
3,000 \\
2,500 \\
3,000 \\
2,500\end{array}$ & $\begin{array}{l}0.5 \\
0.77 \\
1.00 \\
0.83 \\
1.00 \\
0.83\end{array}$ & $\begin{array}{r}21,576 \\
34,507 \\
15,387 \\
12,710 \\
101,310 \\
77,683 \\
263,173\end{array}$ & $\begin{array}{r}9 \\
13 \\
6 \\
5 \\
38 \\
29 \\
100\end{array}$ \\
\hline
\end{tabular}

*Average of 2,100 calories between 6-9 years, and 2,500 calories between 10-1 3 years. 
This amounts to 2,520 calories per day per person "as utilized." For the whole people for the year it reaches 96 million million calories "as utilized," or 105.7 million million calories "as purchased."

If, now, one divides the children under eighteen years of age into groups of three and gives to each group a father and mother, one obtains $13,200,000$ families of five and there remain $21,070,000$ men without dependent children and $18,373,000$ women in a similar position. Estimating the food requirement "as purchased" by the family at 90,000 calories a week, and by adult men at 3,300 per day and by adult women at 2,750, one arrives at the following computation:

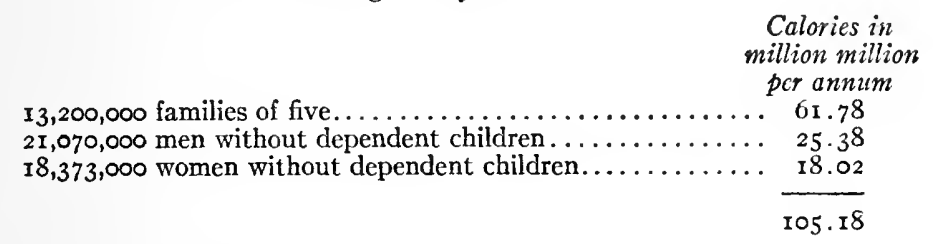

THE RELATIVE VALUE OF DIFFERENT FOODS

The Inter-Allied Scientific Food Commission, which held three sessions in Paris, Rome, and London, respectively, in the spring and early summer of 1918 , voted as follows:

It is not desirable to fix a minimal meat ration in view of the fact that no absolute physiological need exists for meat, since the proteins of meat can be replaced by proteins of animal origin, such as those contained in milk, cheese, and eggs, as well as by proteins of vegetable origin. The Commission, on the other hand, resolved to fix a desirable minimal ration of fat75 grams ( $22 / 3$ ounces) per "average man" per day. The ration will be made up of (a) fats of vegetable origin and (b) fats of animal origin. If the amounts of fat of vegetable origin are insufficient for this purpose it may be necessary to maintain a certain stock of animals to furnish this fat.

At the time these resolutions were passed the British meat ration for the civilian population had been cut to $\mathrm{I} / 4$ pounds per person per week, as against an average per capita consumption of $2 \frac{1}{2}$ pounds before the war. No evil effects had followed this reduction.

If the matter be left to personal choice of ordinary foods there 
is no danger of there being too little protein in the dietary of an average man, provided he is able to purchase 3,300 calories which, allowing for waste, would give him the 3,000 calories be actually needs.

All fats have the important property of a slower discharge from the stomach and a slower absorption in the intestine than have sugar and starches. Whereas the absorption of the latter may be completed in four hours, the maximal absorption of fat is not reached until the sixth hour after food ingestion. On account of this a mixed diet "stays by" one for a longer time than if a diet free from fat be taken.

A diet may contain sufficient protein, fat, starch, and calories of energy and yet be unable to maintain normal life unless it contains also certain unidentified substances called vitamines, which are present in natural foods. Three of these are conspicuously in evidence. They are best understood by studying the so-called deficiency diseases caused by the absence of vitamines from the diet. Thus, a lack of the water soluble vitamines, such as exists in diets made up mainly of highly polished rice or highly milled grains, produces beri-beri, a profound nervous disorder which can be cured by administering an aqueous extract of peas, rice polishings, wheat bran or of the evaporated solids of milk or of whey. Lack of jat soluble vitamines, such as exists when vegetable and pork fat are given in diets which are free from greens, results in stationary or delayed growth in the young and in the development of a redness of the eyes known as xerophthalmia. This disturbance appeared among the children of the Rhine district during the war at a time when there was a great scarcity of milk and of butter fat. The cure is to give milk or butter fat or the fats contained in the liver or in the kidneys of animals or in the eggs of fowl, or to eat a considerable quantity of spinach, lettuce, beet tops, and the like. By eating the green substances of the field the cow gains through the milk glands a large quota of this life preserving, growth promoting vitamine. Her milk contains both the water soluble and the fat soluble vitamines and also proteins of very great value for the growth of the young and for the preservation of the adult. And if the milk be made into cheese of various flavors the palatability of bread taken with it is greatly 
enhanced. Truly, the products of the dairy farm have not hitherto been properly appreciated. ${ }^{4}$

Lack of the antiscorbutic vitamine in diets which are free from fruits, fresh vegetables, or tubers, such as potatoes, results in scurvy. The Food Committee of the Royal Society notes that before the onset of definite symptoms of scurvy there is a period of debility and weakened resistance to disease; and that the occurrence of debility in any body of troops without sufficient cause should at once direct the medical officers' attention to the sufficiency of the diet. Lemon juice (not lime juice), orange juice, fresh vegetables, potatoes, germinated peas, beans and lentils, and canned or dried tomatoes will prevent scurvy. Prolonged boiling (stewing) destroys the antiscorbutic vitamine. Hess finds that the younger and more tender the green vegetable the greater its vitamine content; these also require only a short time for cooking.

This discussion brings out the following points:

(I) The high importance of the dairy farm.

(2) The importance of fruit culture.

(3) The importance of fresh vegetables.

A modern state ought therefore to protect the welfare of its citizens through directive arrangements which shall assure to all a diet that is properly composed.

It may be interesting to note what kinds of food fuel will be taken by a family in the United States, which is well nourished, when supplied with 90,000 calories a week, as calculated from the accepted standards of the Inter-Allied Scientinic Food Commission.

THE DIVISION OF FOODS IN A FAMILY'S DIETARY

Bread is the staff of life. The population of the United States consumes about five bushels of wheat per capita per annum. This amounts to 300 pounds. It is usually milled at seventythree per cent. and, therefore, yields 220 pounds of flour and 80 pounds of fodder in the form of "red dog," shorts and bran. One pound of flour contains I,6ro calories, so that each inhabitant consumes 354,000 calories in the form of flour per annum. 1918 .

McCollum, E. V.: The Newer Knowledge of Nutrition, New York, 
This gives 6,800 calories weekly "per person" or 970 calories per day, and for a family of five would amount to 34,000 calories per week, or 38 per cent. of the 90,000 calories required. A pound loaf of white bread contains $\mathrm{I}, \mathrm{I} 80$ calories. Therefore, if the family is to receive 34,000 calories in wheat flour made into bread, it requires 28 pounds of bread per week to satisfy its requirements.

If the 80 pounds of the milled products of wheat were fed, with hay and other roughage, to dairy cows, it would yield, according to Armsby, ${ }^{5} 55,000$ calories annually in the form of milk. This would give to the family of five 5,275 calories in the form of nine quarts of milk per week or $1 / 3$ quarts of milk per day. If milk were taken to this extent it would furnish six per cent of the calories needed per week.

From five bushels of wheat, therefore, the American family can obtain 44 per cent of its food requirements. It is obvious that upon the price obtained by the farmer for wheat, by the miller for flour and for the wheat offal which he resells to the farmer, may depend the cost of nearly half the necessities of life. Thus, in Des Moines, Iowa, thirty years ago bran was either thrown into the river in large quantities or cost, delivered, $\$ 4.50$ a ton. In May, I 18 , bran cost $\$ 39$ a ton in the same locality. During this period the price of milk rose from five to twelve cents a quart.

The matter of cattle fodder is not as simple as stated above for the wheat crop may vary from about $600,000,000$ bushels in I 9 I 7 to over $1,000,000,000$ bushels predicted for 1919 , the latter being double the normal requirement for our own population. Furthermore, wheat offals are fed to beef cattle, sheep, and pigs as well as to dairy cows, and this live stock is also fed with corn, barley, and rye, or with the milled products of the same. On account of this fodder the available milk supply is above the quantity derivable from the five bushels of wheat, as calculated above, and milk production ought to be so regulated as never to fall below $2 \frac{1}{2}$ quarts of mill per day for a family of five. If this cannot be effected by other means legislation should be invoked to secure it. The writer believes that a family of five

${ }^{\circ}$ Armsby, H. P.: The Conservation of Food Energy, Philadelphia, I9I8, p. 31 . 
should not buy meat until it has bought three quarts of milk. This is exclusive of the milk required to make butter or cheese.

Very valuable studies of the food supply of the average American family have been made by Henry C. Sherman. ${ }^{5}$ The results are based upon studies made upon ninety-two different families. I have used his figures, which show the actual relative quantities of the different types of food eaten, and have calculated what food might have been bought by the typical family which obtained 90,000 calories weekly. This may be considered as representative of the much heralded "American standard of living," which is really the standard of the better paid class of labor.

OPTIMUM NUTRITION OF TYPE FAMILY, TWO ADULTS AND THREE CHILDREN, FURNISHED WITH 90,000 CALORIES WEEKLY, AS PURCHASED IN NEW YORK CITY

\begin{tabular}{|c|c|c|c|c|}
\hline & $\begin{array}{c}\text { Percentage } \\
\text { of total } \\
\text { calories }\end{array}$ & Calories & $\begin{array}{l}\text { Amount of typ- } \\
\text { ical food }\end{array}$ & $\begin{array}{c}\text { Cost in } \\
\text { New York } \\
\text { City } \\
\text { Jan., I9I9 }\end{array}$ \\
\hline Meats and fish. & I6. 54 & 14,900 & I5 lbs. beef. & $\$ 6.75$ \\
\hline Eggs........ & I. 75 & $\mathrm{I}, 500$ & $\mathrm{I} / 2 \mathrm{doz} . . .$. & .95 \\
\hline Milk.... & 8.11 & 7,300 & I 1 qts. . & I. 76 \\
\hline Cheese. & 0.94 & 850 & $1 / 2 \mathrm{lb} .$. & .20 \\
\hline Butter and other fats. . & 10.29 & 9,300 & $\begin{array}{l}\mathbf{2} / 3 \text { lbs. butter... } \\
\text { I Ib. lard...... }\end{array}$ & $\begin{array}{r}\text { I. } 19 \\
.31\end{array}$ \\
\hline Grain products.. & $37 \cdot 79$ & 34,000 & 28 lbs. bread... & $2 \cdot 5^{2}$ \\
\hline Sugar and molasses. & 10.78 & 9,700 & 51/2 lbs. sugar. . . & .55 \\
\hline Vegetables.......... & 9.03 & 8,100 & 26 lbs. potatoes. . & .87 \\
\hline Fruits.............. & 3.87 & 3,500 & $\begin{array}{ll}2 & \text { Ibs. prunes... } \\
5 & \text { lbs. apples. }\end{array}$ & .24 \\
\hline Nuts..... & 0.27 & 250 & $1 / 10 \mathrm{lb}$. peanuts... & .02 \\
\hline Miscellaneous. . & 0.63 & 600 & Condiments, etc... & $.2 \mathrm{I}$ \\
\hline & 100.00 & $90, \infty 00$ & & $\$ 16 . \infty$ \\
\hline
\end{tabular}

The foods mentioned above, such as beef for example, are merely types given for the purpose of obtaining relative simplicity. Under "meat and fish" would come pork, mutton, veal, chicken, and all kinds of fish.

This diet contains $23 / 5$ ounces of fat "per person" per day, or $31 / 3$ ounces "per man" per day, a liberal amount (see p. 375).

- Sherman, H. C.: Chemistry of Food and Nutrition, 2nd edition, New York, I9I8, p. 386. 
According to this calculation the quantity of grain products actually bought by the American family of five corresponds to the quantity of flour derived annually from 25 bushels of wheat milled at 73 per cent and the quantity of milk purchased amounts to eleven quarts, instead of the nine quarts which are producible from the bran evolved in the process of milling 25 bushels of wheat.

\section{THE COST OF A FAMILY'S DIETARY}

A cost of food amounting to $\$ \mathrm{I} 6$, as computed in the table already given, would imply a family income of at least $\$ 40$ a week or approximately $\$ 7.20$ a day (90 cents an hour) for an eight-hour day or for a 44-hour week for the workingman. The cost of the food would then be 40 per cent of the income. If the father's income be less than this, as frequently happens, there are three alternatives: ( 1 ) to cut the quantity of meat ordered, or (2) to have the mother engage in remunerative employment, or (3) to spend for food out of a rational proportion to the total family income.

The contrast of $\$ 16$ a week for food for a family of five with $\$ 4$ a week for food for a single man or with $\$ 3.20$ a week for food for a single woman is startling in its emphasis upon the cost of maintaining family life upon which the welfare of the nation depends.

If this family of five, living on a liberal scale in New York City, were representative of the average American family and paid $\$ 16$ weekly for 90,000 calories, the cost of the food amounting to $173 / 4$ cents per thousand calories, one could calculate that, since the nation requires 105.7 million million calories per annum, the value of its food might reach, at present New York City prices, $\$ 18,762,000,000$ per annum, which is beyond the sum of about twelve billion dollars as estimated and cited in the earlier part of this paper. Twelve billion dollars would signify a cost of II $1 / 3$ cents per thousand calories.

If, in the dietary given above, one computes the aggregate cost of the animal products, such as meat, fish, eggs, milk, cheese, butter, and lard, it is found that it reaches 69 per cent of the total amount paid for food, although these products contain only 38 per cent of the total calorics. On the contrary, bread, sugar, potatoes, fruit and nuts, representing 62 per cent of the fuel 
value of the food for the human machine, are purchasable for 3I per cent of the total cost of the food.

Beef, which contains I 7 per cent of the calories, costs 42 per cent of the total sum expended.

The relative costs per $\mathrm{I}, 000$ calories are as follows:

Animal Pronucts

Cost per I,00o cals.
Vegetable Pronucts

cents

Meat............... 45

Eggs............... 63

Milk.............. 24

Cheese............. 23
Cost per 1,000 cals.

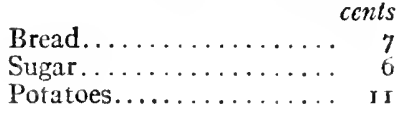

The quantity of meat provided in this diet is 3 pounds "per person" per week or 4 pounds "per man" per week, surely a very large amount. One may well question whether an accurately informed social conscience wculd tolerate the consumption of such an amount of meat.

Such a dietary is not a poor man's diet. This may be illustrated by the greater economy in foods by people living abroad. Thus, in England before the war the working classes, in comparison with our own people, took less meat, milk, and eggs, more bread ( 50 per cent of the total calories), more cheese, and the same amounts of butter, lard, and vegetables. The influence of family income upon the quantity of meat in relation to the quantity of bread bought is easily understood, for to produce butcher's meat means that grain must pass through the animal with a considerable loss of its energy and at a variable cost in labor. The end result is that, for the calories yielded in meat, the cost is many times the cost of cereal. A vegetarian diet is an economical diet. Restricted income means meatless days, but fortunately no harm results from abstinence from meat, especially when milk, eggs, and cheese are available.

Readjustment of the materials forming the American dietary so that the quantity of meat taken would be 5 pounds instead of I 5 pounds, with a larger weekly consumption of bread and cheese, would bring the New York City price of the food taken from $\$ 16$ to $\$ 10$ per week for a family of five or to approximately twelve billions per annum for the nation. This would correspond to a wage scale at present prices of $\$ 4.50$ a day for the adequate provisioning of the family of five. 
Rationing in Belgium and Northern France.-We may now properly turn from the consideration of the nutrition of a population, such as that of the United States, to a review of the means by which life may be sustained in nations hard pressed by war. War has produced food conditions similar to those endured in the extremest poverty.

In the early months of her occupation of Belgium Germany requisitioned not only cattle and food but also the larger part of all the raw materials in the country, thereby greatly reducing manufacture. Belgium, before the war, had a population of $8,000,000$ and comprised the most highly industrialized area of the world. Of the population of $7,400,000$ on April I, I9 17, $1,700,000$ were in the "bread line," entirely dependent on public charity, and another $1,000,000$ were being aided by supplemental distribution of food. At the outset of the war the Germans took from the people of northern France their harvest and cattle. Of the 2,000,000 inhabitants of northern France under German control in I9I 7 Hoover ${ }^{7}$ writes:

"It is obvious that there must be an enormous percentage of destitution, and, in fact, a discussion as to what proportion of the population is destitute becomes merely a definition of what constitutes destitution." Writing in r919, Hoover says:

"If the 70,000,000 Germans were to shed the tears of Niobe for the next thousand years they could not wash away the human misery for which they have been responsible in Belgium and northern France alone."

In April, I9I 7, 2,000,000 people were taking their daily soup ration in Belgium. In the great cities of Antwerp and Brussels 35 per cent of the inhabitants went to the canteens where each person received a pint of soup and 330 grams $(2 / 3$ pound and 800 calories) of brown, whole wheat bread. In preparing the soup 1,200 grams ( $22 / 3$ pounds) of peas, beans, rice, and 400 grams ( 14 ounces) of bacon and lard were used for an individual in the course of a month. The soup cost two cents and the bread three cents and yielded together 1,000 calories, or half

'Hoover, H.: Benevolent Departnent, A Report of the Commission for the Relief in Belgium, April I, I9I7. 
the day's ration. Either a second issue was provided in the evening or the equivalent in foods was given to take home. This amount of food was just enough to hold body and soul together in a non-working, destitute community. As Hoover said, "The wheat loaf has ascended in the imagination of enormous populations as the positive symbol of national survival." Children's canteens, with the provision of milk for children under three years of age and for sick children who were older, were also provided. The community was therefore kept alive on a ration containing unmilled wheat, pea or bean soup, with a little pork fat. The populace did not fancy rice and would not eat it even when hungry. Perhaps the peas and beans offered some antiscorbutic vitamines, which were also supplemented at times by home grown potatoes. There was no good source of fat soluble vitamines in this diet, except, as has been stated, in the milk which was given to children under three years of age and to weakly children as well.

Rationing in Great Britain.-Although France before the war produced sufficient food to supply the wants of her population, Great Britain was able to produce only one-half or less of the food needed for her people. Before the development of modern trade, under which the United Kingdom has obtained food in exchange for manufactured goods, the population was half that at present, which was the number capable of being supported by home agriculture. Credit for the system of rationing in Great Britain must be divided between the Food Ministry of Lord Rhondda and the Food (War) Committee of the Royal Society. The quantities of meat, fat, and sugar which were available were only one-half the quantities used before the war and these were all rationed, rich and poor being allowed to purchase equal amounts. The quantity of meat allowed to the civilian population of England and Scotland in March of rgr 8 was about the same as that given to the inmates of the poorhouse in Helsingfors, Finland, in 19ro, and the quantity of fat was about that allowed in Voit's celebrated diet for a poor laboring man. The reduction in the quantities of available meat, fat, and sugar amounted in value to the elimination from the diet list of onefifth of the food available before the war. To compensate fo: this, the tillage area was increased by $4,000,000$ acres and intensive agriculture produced bountiful crops of potatoes and other 
staples, while wheat imported from America added to the bread supply. The daily consumption of bread grains rose from 9 ounces before the war to I9 ounces per capita.

Bread was not rationed but plans were in readiness so that in case of necessity it could be rationed at a moment's notice. The policy of the Ministry of Food was to furnish bread freely to the working population. The principles adopted in Great Britain were as follows:

I. Wheat, rye, and barley were reserved for human consumption. Feeding them to live stock or using them for the production of beer or whisky was forbidden.

2. It was forbidden to kill a milch cow without a permit, and the milch cow received priority in the distribution of fodder.

3. Home grown beef was slaughtered at an earlier age than before the war as the customary fattening of the animal was out of the question.

4. Oats were rationed among the farm horses and other horses doing "war work."

Notwithstanding these restrictive policies, the number of live stock in Great Britain did not decrease during the war except a slight diminution in the number of pigs.

The question of the relation of the distribution of the products of the soil between man and beast became a burning one in Germany in the early months of the war. In England, Prof. T. B. Wood worked out the following relative cost of meat in terms of fodder which animals eat: ${ }^{8}$

"An average cow during her life eats 27 tons of dry fodder and produces $2 \frac{1}{4}$ tons of dry buman food in the form of milk, veal from her own calves, and cow-meat from her own carcass. Hence, I 2 pounds of dry fodder are required to produce I pound of dry luuman food. The cow eats hay and grass and concentrated foods, like bran and oil cake.

"A pig eats 7 pounds of barley ( 6 pounds dry weight) and produces I pound of pork, containing half its weight in water. Hence, here again it requires I 2 pounds of dry fodder to produce I pound of dry human food; but the pig consumes a product which can be made into barley bread, and hence competes with man for a precious bread-making grain.

'Taken from Lusk: Scribner's Magasine, December, IgI8. 
"A fowl eats roo pounds of corn and meal during 18 months, and produces 180 eggs and $4 \% 2$ pounds of food when killed. The relation between dry fodder and dry human food is $I 4$ to $I$.

"A sheep eats 600 pounds of dry fodder in a year, and produces 28 pounds of meat. Here 24 pounds of dry fodder produce I pound of dry human food. Blit a sheep also yields ro pounds of wool, which is invaluable and is supplementary to the food value of the animal.

"Finally, a fat ox eats 8 tons of dry fodder during three years of life, and produces 800 pounds of beef, or 250 pounds of dry human food. The astonishing value of 64 pounds of dry fodder for the production of I pound of dry human food is revealed. To produce the roast beef of old England requires more than five times the quantity of fodder that is required to produce the same food value in the form of milk, veal, and cow-meat. A fattened ox is indeed a costly product. For example, if a steer weighs at the start I,OI 6 pounds, at the end of three months of fattening he may weigh $I, 226$ pounds, and if during the period he has eaten 196 pounds of fodder weekly, the dried fodder used in the production of I pound of human food will amount to 55 pounds. But if the process of fattening be continued, as is usually the case, then at the end of another three months the animal may weigh $I, 275$ pounds. If the fodder during this interval has amounted to 224 pounds weekly, it may be calculated that roo pounds of dry fodder yielded only $I$ additional pound of dry human food. It was evident that the fat ox was too extravagant a product for England to maintain. The fodder, which was none too plenty, was needed for the herds of dairy cows, and for this reason an effort was made to divert the fodder supply for their benefit.

"If one studies the question of pork production, very interesting side-lights are thrown upon the situation. The original German scheme of food control failed miserably on account of the following circumstances: The price of barley was fixed at 4 cents a pound, and the farmers were ordered not to feed their barley to pigs. Since 7 pounds of barley produced $\mathrm{I}$ pound of pork, it would cost the farmer 28 cents' worth of barley to produce a pound of pork, which product was selling at the time in Berlin for $5^{6}$ cents a pound. The farmer could, therefore, get 8 cents a pound for his barley if he fed it to pigs, instead of 
getting 4 cents a pound if he sold it for bread for his fellow man. The commercial instinct proved more powerful than the patriotic, and much grain was given to the pigs. The authorities found this out too late and the whole people suffered from the folly of the scheme.

"Now the 7 pounds of barley that produce I pound of pork might instead have been taken to the miller and have yielded flour for 5 pounds of barley bread, and sufficient barley bran which, if fed to pigs, would have given half a pound of pork. It is certainly desirable that barley be taken to the miller. In order to force this the government of Great Britain fixed the price of barley at $3^{\mathrm{I}} / 2$ cents per pound, and multiplied this by $8 \mathrm{~T} / 2$, which gave 30 cents as the fixed maximum price obtainable by the farmer for a pound of pork. It was an absolutely essential point in the general scheme of things to fix the relation of prices in such a way that the effort of the farmers should accord with the welfare of the nation. I heard it stated that by such methods as these a yearly economy of bread grains was effected which was the equivalent of thirteen weeks' supply. It is, therefore, axiomatic that in times of scarcity one must not give to pigs food which can nourish human beings.

"The English realized the foolishness of importing 7 tons of grain to produce I ton of pork, when the importation of $I$ ton of pork from America would save ship tonnage for the transport of American soldiers and war materials necessary to restore order and civilization in the world."

These principles are of fundamental application.

THE CONTROL OF THE COST OF FOOD

In the United States.--Early in December, 1918, Mr. Hoover made a statement in London regarding American food prices which may be summarized as follows:

The economic plane of the United States was established through the drain of our markets by the Allies during r9i6-17 before we came into the war. The prices of certain materials were subsequently controlled and they were sold at these prices to the Allies, to our own consumers, and to the United States 
Government. The following table gives some indication of the results of the control of prices:

$$
\begin{array}{cc}
\begin{array}{c}
\text { Price before } \\
\text { control }
\end{array} & \text { Price } \\
\text { Dce. I, I } 18
\end{array}
$$

Wheat (No. I Northern at Chicago, per bu.)...... $\$ \$ 3.25$

$\$ 2.26$

Live hogs (average, Chicago)............... 20.00

$17 \cdot 5^{\circ}$

Corn (Chicago)....................... 2.20

I. 40

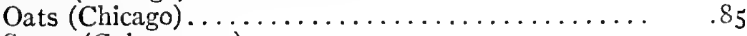

Sugar (Cuban raws).................. 5.90

Steel (per ton)........................ 100.00

Copper (per roo lbs.)................. 35.00

A fall in the price of wheat from $\$ 3.25$ a bushel to $\$ 2.26$ saved the consumers in the United States $\$ 500,000,000$ per annum, and without control there is no telling to what price speculators might not have carried wheat. On the other hand, the guaranteed price of $\$ 2.26$ to the farmer assured to him an increase of 123 per cent above the pre-war average price of wheat per bushel.

The guaranteed price for wheat paid to the British farmer was greater than that paid to the American farmer, and the prices for oats and barley were 70 per cent greater in England than in America.

The following analysis of the cost of a quarter of wheat (480 pounds) at Liverpool may be taken from Mr. Hoover's statement:

$\begin{array}{rrr}\begin{array}{c}\text { Before } \\ \text { the war }\end{array} & \begin{array}{c}\text { During } \\ \text { the war }\end{array} & \begin{array}{c}\text { Increase } \\ \text { inpercent }\end{array} \\ \$ 7.75 & \$ 17.25 & 123 \\ 2.00 & 2.50 & 25 \\ 1.00 & 1.00 & 0 \\ 1.00 & 6.00^{*} & 600 \\ & \$ 26.75 & \end{array}$

*Including \$2.25 war insurance.

Prices to American farmer.............. $\$ 7.75$

Charges of American railways..........................

American middlemen, storage chares, etc.............

British shipping................. I.\$

It is evident that the profits in these transactions went to the American farmer ( $I$ ) to induce him to extend his acreage and (2) to enable him to pay labor, which was scarce and high. American middlemen were prevented from profiteering.

Mr. Hoover further states that the financial inducements to the American farmer have been such as to increase the pre-war annual exportable surplus of fat products, such as pork, from $600,000,000$ pounds to a present exportable supply of $3,500,000$,oo pounds. Profiteering and speculation were removed from 
the packing houses by government control. The Allied buyers were instructed to calculate their prices to the packers on the basis of one-quarter of a cent a pound profit to the packer over and above his costs of labor and raw material. The audit of the accounts of the great packing companies during the first year of American food control showed $7 \frac{1}{2}$ per cent earned on their capital. On the beef business the prices arranged with the Chicago packers for beef for the Allies and for the United States Army covering the six months ending about December I, I9r8, showed an absolute loss, which was only recovered upon by the by-product business. Mr. Hoover concludes by stating:

"As I view the world's food assets at this moment, I am convinced that the extra marginal surplus from the United States is of priceless value to the immensity of human life at stake between now and the next harvest. To sacrifice the margin of American production by reducing the American farmer by 10 per cent-which would be 6 per cent when it reaches the English consumers-would be the rankest of folly."

The diagram (Fig. I) indicates the course of grain prices at Chicago since the guaranteed price for wheat went into existence on September I, I 9 I 7 .

In Great Britain.-The British Ministry of Food entered into an extensive scheme of food control in July, I9I7. At the close of the war only about 6 per cent of the total expenditure for food was effected under open competition.

The prices of cereals, meats, milk, etc., which might be charged by the wholesale dealer and the retail dealer were fixed. The prices paid to the farmer for his produce were fixed in such a way that agricultural labor had to be expended for the welfare of the human consumer. Thus, it was forbidden to feed to live stock grain edible by human beings. The price of barley was fixed so that it was unprofitable for the farmer to feed it to his pigs. It was forbidden to kill a milch cow which gave milk in profitable quantity. The price of cream was placed so low in relation to the price put on milk that no cream was obtainable (except for invalids on a physician's prescription). The price of butter was fixed at a low point for the same reason. Furthermore, the price of bread was held down by a state subsidy, 


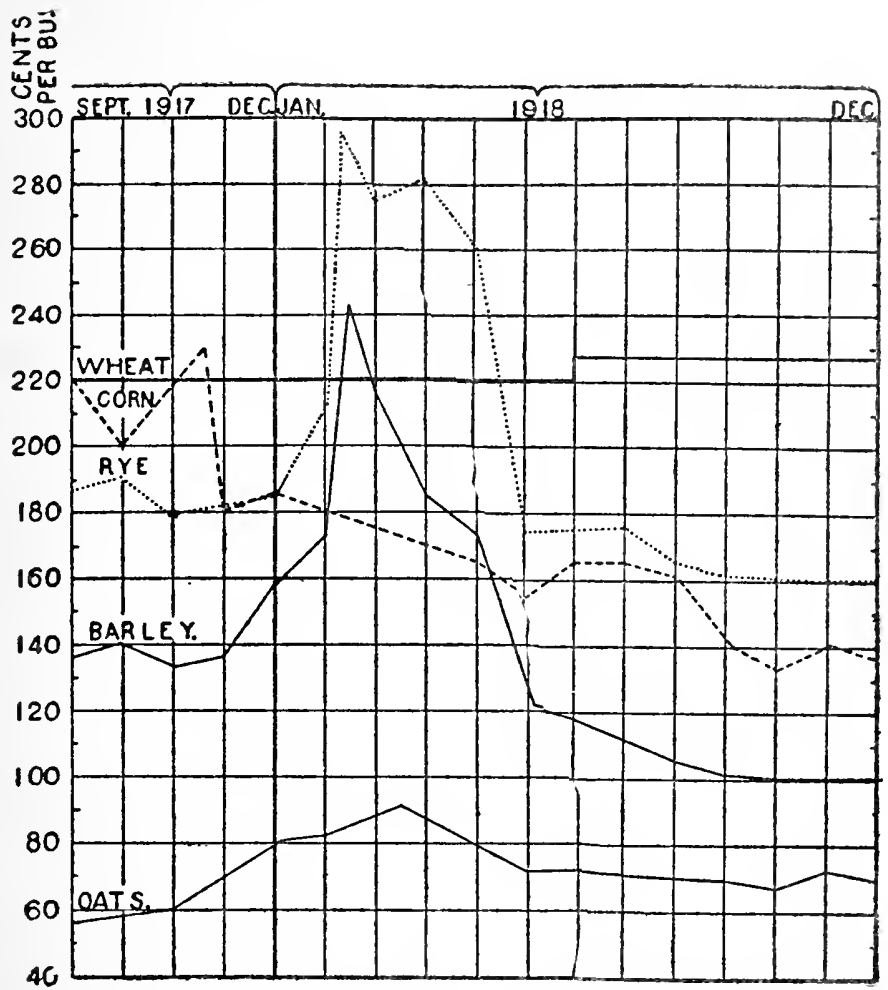

FIG. I.-The course of grain prices at Chicago from September I, 1917, to January I, 918 .

which reduced the cost of imported wheat to the consumer. Thus, the price of flour was less than the price of chicken feed. Assuming the cost of food to have beet Ioo in July, I9I4, the Ministry of Food estimated that it reached 205 in July, I9I 7 , when food control was inaugurated, and vas only 216 in October, I9I8, the last month of the war. On the contrary, textiles and leather, which reached the index number of 234 in July, I9I 7 , rose to $3^{\mathrm{I}} 3$ by October, I9I8. By legal eractment rents remained stationary from the declaration of war. There is no question but that the comparative stability of food pries diminished the social unrest which comes from increasing th: cost of living beyond the capacity of the wage to support the worker. 
In France and in Italy there was no restriction upon the price paid for beef. Thus, in October, I9I8, the price of milk in Milan was I 2 cents a quart and of meat $\$ 1.00$ a pound, whereas in England milk cost the same as in Italy but the British farmer was paid only 36 cents a pound for his beef, which was rationed evenly among his fellow countrymen. The Italian farmer, therefore, had a far greater inducement to slaughter his cattle than had the British farmer, and the result was that both the Italian and the French lost a third of their live stock during the war, while the British herds were preserved intact.

The following chart, prepared from the figures given by the British Ministry of Food, shows in an interesting way the rise in the cost of beef, bread, butter, and milk in allied, neutral, and enemy countries during the war period:

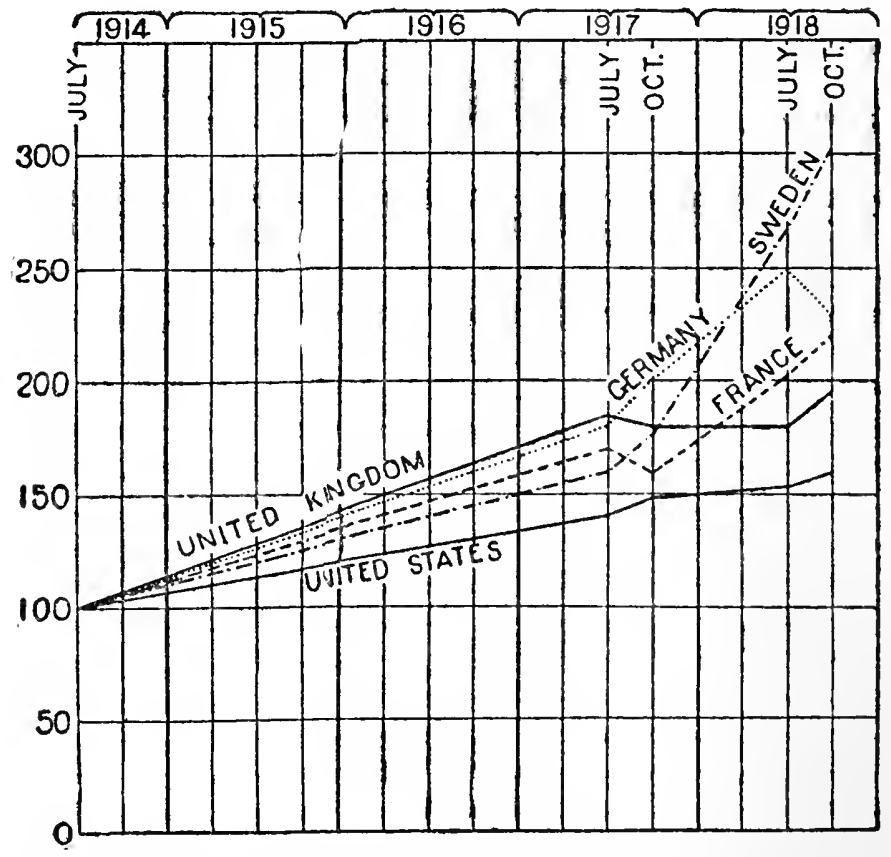

Fig. 2.-The percentile ise in price of beef, bread, butter and milk in allied, neutral and ermy countries during the period of the war. 
It is evident that food control in the United States and Great Britain kept prices down from the time of the inauguration of such control, whereas in other countries the prices rose.

\section{AN INTERPRETATION OF THE FUTURE}

The wheat crop of the United States in recent years has been as follows: I9I6, 636,000,000 bushels; I9I7, 651,000,000 bushels; I9I8, 919,000,000 bushels. A thousand million bushels and more of wheat for I9I9 is at present forecast.

Our ordinary home consumption, plus seed, is $600,000,000$ bushels of wheat, but through eating corn bread the American people sent abroad I3I,000,000 bushels of their I9I 7 wheat crop. Of the crop of I9I 8 there will be $300,000,000$ bushels for export and of the I9I9 crop, for which the government has contracted to pay the farmer $\$ 2.26$ per bushel up to June I, I920, there may be 500,000,000 bushels available for export.

This constitutes a great reserve of food for the world, a factor of safety for the prevention of starvation. In the one year extending from July $I$, 1917 , to July I, I9I8, the value of our food exports to the European Allies amounted to $\$ I, 400,000,000$. This was a part of a total of $\$ 8,000,000,000$ loaned to the European Allies from the time of our entrance into the war until January I, I9I8. These loans were made to purchase materials in this country at war prices. We have seen that, rather than inflict war prices for bread upon the workingman, Great Britain taxed herself $\$ 200,000,000$ annually by subsidizing bread so that the cost of bread to her workingmen remained low. The United States should now do the same thing. Bread should be sold at less cost than corresponds to the government price for wheat. What if the loss should be a thousand million dollars to the government? It would mean the cost of only two weeks of war at the rate we were spending in December, 19r8. But part of this cost would be a present to foreign nations, it may be objected. What of that, when bills have already from time to time been presented to Congress absolving the Allies from all financial obligations to us, which would mean the cancellation of a debt of eight billions of dollars?

It might be worth while to see what effect a plenitude of food 
at lower prices would have upon the population of the United States. With a bountiful wheat crop, mill feed should fall in price and, with this, should come a fall in the cost of production of milk and of beef. If bread and milk fall in price, say to their pre-war level, then indeed will be ushered in a welcome era of cheap foods. But this cannot talse place without a fall in the cost of farm labor. If the farmer must continue to pay high wages and high prices for his clothes, his barns, and machinery he will receive no profits if he sells food cheaply. Under conditions which maintain high wages no cheap food can be produced ${ }^{9}$ and the period of cheap food, if inaugurated, would be short lived and would mean certain disaster to the farmer and to the country as a whole.

If to produce a pound of pork requires seven pounds of corn (estimate of T. B. Wood), it is obvious that the price cf pork will be seven times the price of corn plus the cost of labor plus transportation and commissions. If the price of corn falls, the cost of pork production will fall also and with diminished cost of food the intermediary labor factor should become less costly, thus further reducing the cost of pork. With the fall in the price of food there should be a fall in wages throughout the economic structure so that the cost of the production of the farmer's or workman's clothes or boots, for example, may be reduced, thus equalizing the reduction in wages. The excess profits tax would prevent the manufacturer from unduly profiteering. Unless wages fall the cost of building houses and homes will be high, and the bouses built in pre-war years at a lower labor cost will become relatively of greater value. A reduction in wages is highly unpopular doctrine, but it is obvious that if $\$ 3.60$ a day will purchase the same commodities which $\$ 7.20$ will purchase the sum and substance of the situation remains unchanged. The advantage of a reduction in wages lies in the increascd ability to carry on foreign trade. In the payment of indemnity by Germany to France this must be largely exacted in terms of the products of German labor, such as machinery, for example. It is certain that our war prices for machinery, ships, as well as for food, are out of line with world prices under peace time conditions. The British Labor Party announced a

${ }^{\circ}$ Of course, Chinese coolie labor might be imported for the specific purpose of farm work, a procedure heretofore vigorously opposed. 
year or more ago that after the war a minimum weekly wage of thirty shillings $(\$ 7.20)$ should be established. This is less than half the cost of so-called common, foreign born labor in the United States. The states of Europe are impoverished by a long war and they cannot trade with us indefinitely upon a basis of inflated prices. Labor leaders interested in the welfare of the wageearner should give serious attention to these principles.

\section{EPLLOGUE}

In the prologue an estimate was given which showed that of the family incomes of the fiscal year ending July I, I919, $\$ 6,770,000,000$ goes to families receiving more than $\$ 5,000$ income per annum and $\$ 40,600,000,000$ to those who had between $\$ 1,000$ and $\$ 2,000$ per annum. If each family of the upper group were reduced to $\$ 2,000$ per annum there would remain $\$ 6,000,000,000$ to divide among the lowest group, which would give an increase in wages of 15 per cent. At the present time, however, with the income and inheritance taxes in operation, the disparity between our present system and the socialization on an equal basis of financial resources would not yield a ro per cent increase in wages to the workers. This is the price we pay for our present form of civilization. The corporations, such as the railroads, which produce a part of this Io per cent, are harassed and persecuted without limit and to the detriment of the country at large, whereas the farmer, who produces materials which cost the workman one-quarter of his income, has a Secretary of Agriculture in the cabinet and gets every encouragement to make all the profit that he possibly can. As a matter of fact, no one would say that the farmer gets more than his due, but the truth remains that the consumer has been very little thought of. The difficulties are great, as has been seen both here and in Great Britain, in the endeavor to come to some agreement between producer and consumer regarding the marketing cost of milk in the cities, for example. No rational arrangement has yet been reached.

But it seems that the adequate provisioning of the 85 per cent of the non-agricultural public should become more a subject of national concern. The abolition of the United States Food Administration on March I, I9I9, removes from the field an establishment primarily created for the protection of consumers 
of food throughout our own nation and the world. Should this be superseded by any other agency? The Inter-Allied Scientific Food Commission recommended to the governments of the United Kingdom, France, Italy, and the United States that each establish a National Laboratory of Human Nutrition. Part of the preamble reads as follows:

"The importance of, and the need for, the researches which would be carried out in such laboratories is evident if it is remembered that at least one-quarter of the income of a nation is devoted to the purchase of food by its individual citizens. Moreover, the poorer the individual, the greater becomes the proportion of his wages devoted to the purchase of food. It is therefore of the highest importance for the welfare and prosperity of a country that the methods for utilizing its food resources in the best possible manner for the benefit of its citizens should be sought out and, in time, definitely established on reliable, scientific data."

Such a National Laboratory of Human Nutrition might be established under the Department of Labor, or better under the proposed Department of Public Health. It would seem sufficient to point out that the nation expends nearly, or quite, one-fourth of its income for food, in order to assure that this subject be given attention. Some scientific coöperation between the farmer and the industrial worker must be evolved that the material needs of these two great classes of individuals be coördinated for the highest welfare of the entire state.

A proper understanding of the food resources of Russia on the part of her government might have prevented the collapse of her civilization. As long ago as 1755 Benjamin Franklin wrote, "Where there is Hunger, Law is not regarded; and where Law is not regarded, there will be Hunger." Russia, according to Sherman,,$^{10}$ raised in the pre-war days only ro per cent wheat more than the country needed, and this was largely accomplished by primitive methods on small land holdings. Military mobilization removed farm hands from the land and a decreased production

${ }^{10}$ Sherman, H. C.: Columbia University Quarterly, January, 19I8, $\mathrm{XX}, \mathrm{II}$. 
of food followed which led to ultimate ruin. This is national disaster spelled in its simplest terms.

The modern state should not only protect its people from disaster but also indicate to them those methods of daily existence which will bring the highest welfare to the greatest number. Science teaches the relation of man to his environment. Through science man acquires the possibilities of betterment. Can the state afford to neglect the subject of the science of nutrition when one-quarter of the income of its citizens is spent for food? It would seem incredible. 



\title{
CHAPTER XXIV
}

\section{INDUSTRIAL HYGIENE}

\author{
By J. W. SchereschewsKY ${ }^{1}$ \\ Assistant Surgeon General, U. S. Public Health Service.
}

Man-Power a National Asset.-If one reads rightly the lessons taught by the recent conflict, the basis of national happiness, efficiency and prosperity is man-power. This is the direct measure of the ability to produce. Man-power as such, however, represents potentialities only. To translate man-power into production it must be applied under such effective and favorable conditions that the individual may freely convert the creative impulse, innate in most of us, into productive effort.

"To work and save" is indeed a panacea for the wounds of civilization. To the hygienist the possession of physical health is the sine qua non to the filling of this prescription. The relation of health to industry, or the application of the principles of industrial hygiene to the life of the worker, is vitally important.

To repair the losses of war it is essential that each worker be able to produce continuously, with minimum effort and during a maximum life. In the past we have largely ignored this principle, although industries teemed with hazards, which, unless guarded against, sent the worker to the industrial scrap-heap at an early age.

This past state of affairs arose from the very nature of our former industrial conditions. Let us consider these for a moment

${ }^{1}$ A.B., Harvard, I895; M.D., Dartmouth Medical School, I899; served in the Medical Corps of the U. S. Army in the Spanish American War; United States Public Health Service, 1899-_; specialized in bacteriology, child hygiene and industrial hygiene; from 1913 to 1918 was in charge of a field office for investigations of occupational diseases conducted by the Public Health Service and made numerous studies in this field; contributor to medical and technical journals, author of Public Health Bulletins on industrial hygiene and related subjects. 
in order to establish a point of departure for our discussion of the new order.

Before the war there was an abundance of unskilled immigrant labor in the country. The attempt to utilize this great supply effectually led to the development of our present industrial system. Automatic and semi-automatic machinery and processes of all kinds which could be tended by the comparatively unskilled were devised and used. Industrial operations became specialized, each worker playing but a snall part in the production of the finished article, in contrast to the industrial workers of former days, who were, for the most part, skilled artisans producing individually the complete article.

What wonder then, if, in devising automatic machinery which enabled the unskilled worker to produce a hundred or a thousand times more than his skilled predecessor, that we emphasized output and lost sight of the value of the man behind the machine. We regarded him as a piece of machinery, necessary to production, which wore out and had to be relegated to the scrap-heap along with the machine he tended!

We know better now! The greatness of a nation lies not in its machines, its commerce, its industry. These are but the outward signs of the activities of its people. The true greatness of the nation lies within, in the spirit, concepts, and ideals of its citizens. The men and women in the nation constitute the basic national asset.

It must not be thought that no laws or machinery were provided before the war to safeguard industries from the hazards to health which surround them. Such is iar from the case. Progressive employers in this country have long realized the wastefulness of permitting unwholesome industrial surroundings and occupational hazards to destroy the usefulness and impair the health of their employees. They have tried to better the industrial environment so as to provide healthful working conditions, medical service and safeguards against occupational hazards.

Again, in mere volume alone, the legislation to protect life and health in industry passed by the various states is impressive. Nevertheless, adequate nation-wide enforcement is still lacking because state legislatures are loath to provide for the establishment of adequate machinery for the enforcement of such laws. 
Moreover, an unfortunate lack of uniformity still exists, both in the laws and in the machinery necessary for their effective administration. We have, as yet, no national concept of what essentials should be provided to safeguard the health of the industrial worker nor of what constitute reasonable minimum standards of protection.

In view of the fundamental importance of initiating nationwide measures for creating adequate machinery for conserving the health of the industrial population, it behooves us to consider the scope of the problem, the needs of the situation, and how the proper remedies may be applied:

Scope of the Problem.-There are probably 45,000,000 persons engaged in gainful occupations in the United States, of whom some $25,000,000$ may be classified as industrial workers. While it has not been possible, owing to the lack of statistics, to obtain exact figures, from the best of our information these workers average a loss of time annually, due to illness, of about 9 working days. This is equal to an annual loss of 225,000,000 working days, or, counting 300 working days to a year, 750,000 working years. This is an economic loss, at present wages, in the neighborhood of $\$ 900,000,000$. To this must be added the costs of medical treatment and a larger and indefinite loss due to lowered working efficiency until recovery is complete, increased liability to illness because of lowered vital resistance and, in many instances, definite shortening of the span of the working life because of the development of chronic diseases consequent upon acute illness. It may be conservatively stated that fully one-half of this illness is preventable.

Besides, the medical statistics compiled in the draft examinations have shown that about 34 per cent of the population of draft age suffer from physical defects and diseases of such gravity as to unfit them for military duty. As the average age of the industrial worker is about 30 years, and as increase in age tends to increase rather than to diminish the frequency of physical impairments, the percentage of physical defects and diseases is probably at least as great among the entire industrial population as in the group examined for military service.

Indeed, in a group of 2,000 male garment-workers examined by the United States Public Health Service in I9I4, only two per cent were found entirely free from physical defect or impair- 
ment, although many of these impairments were of a minor character. Furthermore, a number of them were of such gravity as to make it evident that these workers, as a class, were not enjoying full health and efficiency.

Appearance of New Industrial Health Hazards.-Besides the numerous health hazards existing in this country, prior to the war, a number of small industries have undergone great expansion because of war conditions. For instance, certain branches of the chemical industries have developed considerably. Because of the poisonous nature of the substances handled in such industries, the hazard of occupational diseases is high and constitutes a menace to the health of the workers unless due precautions are taken.

In order to be a source of national prosperity, work must conserve rather than impair health and prolong rather than shorten life. Indeed, work may be the medium of attaining these ends, but only when we, as a nation, adopt some national policy towards the conservation of health in industry.

Nature of Industrial Health Hazards.-Generally speaking, an occupational health hazard is any industrial condition which may impair the health of workers. Such hazard may operate in a general or in a specific way. Thus, improper ventilation of work-places, exposure to excessive heat or dampness, gross overcrowding, the use of the common drinking cup may be taken as examples of general occupational hazards, because, while not producing a specific disease or injury, they nevertheless serve to impair health, to lower vital resistance, to increase the liability to disease, or to facilitate its spread.

On the other hand, industrial exposure to mineral and metallic dusts, carbon monoxide gas, increased air pressure in caisson work, and poisonous substances such as benzol, lead and mercury, constitute specific occupational hazards, for these conditions produce distinctive effects which a diagnostician may recognize.

Finally, there is a third class of health hazards, the community health hazard, which cannot be ignored in considering the subject of industrial health hazards. It is clear that it is of little avail to provide ideal factory conditions in which the worker spends but one-third of his time, if upon leaving his place of 
work he is exposed to the hazards of wretched housing, of impure water and milk, and of overcrowding in slums and tenements, in short, all the defective conditions which may arise during the mushroom growth of industrial communities, or the conversion of an agricultural or rural to an industrial community.

The field to be covered by industrial hygiene is very broad. As a matter of fact, industrial conditions affecting the health of a worker can never be separated sharply from his total environment, nor is it possible to say where the field of industrial hygiene ends and that of public health begins. Industrial hygiene is not a separate science but is the science of public health applied to industrial conditions.

How then shall we apply the principles of public health to the field of industry so as to secure for all workers, irrespective of the part of the country in which they live, the same measure of health protection? Clearly, an answer cannot be properly formulated until we have considered on whom the responsibility for the existence of untoward conditions rests and the agencies whose duty it is to rectify them.

These responsibilities are ably discussed in Warren and Sydenstricker's Bulletin on "Health Insurance-Its Relation to Public Health." 2 They place the responsibility for industrial conditions causing ill-health as follows:

1. Conditions for which the employer and the industry are responsible.

2. Conditions for which the public, through its regulatory and welfare agencies, are responsible.

3. Conditions for which the individual worker and his family are responsible.

They point out that there are some conditions for which the responsibility is joint or overlapping. As an example, the public is responsible as well as the employer for defective conditions in work-places because the public constitute the regulatory power. Again, there is a personal responsibility in the case of the individual worker, because, in many instances, the practical application of health measures requires coöperation on the part of the

${ }^{2}$ Warren, B. S., and Sydenstricker, E.; Health Insurance-Its Relation to Public Health. Treasury Department, United States Public Health Service, Public Health Bulletin No. 76, Washington, D. C. 
worker himself. Thus, if adequate washing facilities are provided in the lead industries, for instance, they will accomplish little good unless the workers make use of them.

Passing to a more detailed consideration of the responsibilities of the several groups, let us begin with the responsibility of the industry itself.

Responsibility of Industry.-The industry must be regarded as primarily responsible for the tolerance of factory conditions tending to impair the health of employees. This responsibility may be extended to instances in which the industry also is owner of workmen's houses. Apart from sound business considerations, which dictate the reduction to the minimum of preventable illness, there has been legal recognition by the highest courts of the principle that the employer may not permit conditions dangerous to health to exist in the establishments be controls.

As previously mentioned, this is a principle which is gaining recognition among employers themselves. In many instances they have voluntarily set up sanitary conditions in their establishments and eliminated, so far as possible, health hazards resulting from the operations in their plants.

Conditions for Which the Public Is Primarily Responsible.We must consider the public primarily responsible for defective sanitary conditions in the community except, perhaps, in those few industrial villages or communities which are owned and controlled by the employer. As previously pointed out, it is useless to insist upon ideal factory conditions if the living conditions outside the factory are insanitary. It is hopeless to expect in industrial communities diminution of the sickness and death rates by improvement of factory conditions if we permit the distribution of polluted water and milk, over-crowded insanitary slums, breeding places of the malaria-mosquito, or inadequate facilities for the care of communicable diseases. Fortunately, the work accomplished by the United States Public Health Service in conducting the sanitation of the areas surrounding our military cantonments, munition plants, and other military areas, by which the sickness and death rates were notably reduced despite intense congestion due to the sudden increase of population in these areas, and the lessons taught by numerous sanitary surveys, are rapidly molding public opinion to the realization of the urgent necessity for the healthful community. 
The truth that bad community conditions are in the long run incompatible with national prosperity is at length being impressed upon the public mind.

In community sanitation, as applied to industrial centers, large industrial corporations may exert great influence for good in the communities in which they are located. While industrial corporations are large tax-payers in their respective communities, they seldom exercise their powers in improving local sanitary conditions, in spite of the fact that they should be vitally interested, from a purely business viewpoint, in the maintenance of good conditions of community health. Only too frequently such firms assume an attitude of aloofness with respect to local affairs, chiefly because of the desire to escape the suspicion of playing politics in order to derive selfish advantage. Yet if it is the duty of the individual citizen to play his part towards community betterment, it is certainly the duty of industrial firms to do likewise, for they benefit directly.

There is one other aspect of poor community conditions on industrial health. Bad conditions in the factory affect the worker directly and his family indirectly if only because of the reduction in earning power they entail. However, bad conditions of health in the community affect both the worker and his family. Even if the worker himself resists the effect of the insanitary conditions in the community for a while the illness of wife or child may readily absorb any reserve he may have saved. Another factor is the reduction in his earning capacity because of worry and time lost due to illness of his loved ones.

Responsibility of the Individual Worker. - The individual worker himself cannot escape responsibility for the improvement of industrial health conditions. We are coming more and more to the view that it is one of the duties of the citizen to keep well. This cannot be done unless the individual himself will obey the laws of health, and avail himself of the facilities for health protection provided both in the factory and in the community. It is conceded that, in order to fulfill these conditions, a knowledge of the laws of health is necessary, which should be provided by health authorities, the school and the employer.

Program for the Improvement of Industrial Health.-We have now roughly blocked out the field for the improvement of industrial health and discussed the responsibilities for the existence 
of bad conditions. The improvement of such conditions is a national concern of highest moment. This will be accomplished as soon as public opinion has been crystallized into action. It is worth while to examine briefly the parts which will be played by the various agencies of government in the improvement of defective conditions.

To produce nation-wide results it is plain that federal, state and local agencies in this country should coöperate in improving conditions, so that overlapping may be prevented and yet no power usurped. In the following discussion federal activities are considered at length because they are essential factors in the ultimate result. They are capable of great extension and, at the same time, may stimulate state and local activities for health improvement. It is not possible to discuss the exact scope or functions of these separate agencies of government independently, because they are necessarily so interrelated.

Scope and Limitations of Federal Agencies. - The federal government has a definite part to play because improvement in industrial sanitation has a profound influence on the national welfare. The extent to which the federal government may act, however, is limited by the federal constitution. Broadly speaking, under these limitations, the powers of the federal government are investigative, advisory, and coöperative. The federal government has certain regulatory powers, particularly in matters relating to taxation, the control of foreign and interstate commerce, the spread of disease through interstate channels and matters concerning the national defense. These powers involve the exercise of federal police power.

Under our system of government the exercise of the police power is regarded as the right of a state and, generally speaking, the federal government may and does exercise such power within a state only when it is voluntarily delegated to the federal government by a state. Under these circumstances it should be noted that a federal ofincial exercising such police power over intrastate sanitary matters acts as a state official, clothed with powers derived directly from the state.

The taxing power of the federal government has been used to improve industrial conditions. A conspicuous instance is the abolition, through the Esch law, of the use of matches made of white phosphorus. A prohibitive tax was levied on matches con- 
taining this substance when shipped in interstate traffic. In this manner, one of the most painful, disfiguring and loathsome of the industrial diseases, "phossy jaw" or necrosis of the jaw bones, has been wiped out in this country.

Again a recent attempt to use the federal taxing power to regulate the employment of child labor by the passage of the federal child labor law has been declared unconstitutional. Thus, in the last analysis, the regulatory power of the federal government rests within constitutional limitations. In reality, of course, its power in this direction is determined by public opinion. So, if in the future public opinion will demand an extension of the federal powers of regulation of health matters, the constitutional powers will either be more broadly interpreted or enlarged by amendment.

Nevertheless, for those who desire largely to increase the power of the federal government in this respect, it is well to note that, in a country such as ours, what we really need is not so much an extension of federal authority in the regulation of health as the development of a sense of responsibility for conditions of good health in the people of the state and the locality. A larger and purposeful development of this sense of responsibility will enable the federal government to play a greater part in improving health conditions.

Existing Powers of the Federal Government.-Let us consider the existing powers of the federal government and examine briefly the manner of their application. In the main, federal health activities are exercised through the United States Public Health Service, a branch of the Treasury Department, although certain other federal departments engage in activities more or less related to public health, such as the Census Bureau in the Department of Commerce, and the Children's Bureau in the Department of Labor. The Public Health Service, however, is clothed with all the powers which under the constitution may be given to a federal health agency.

Under these powers, so far as the improvement of industrial health is concerned, the United States Public Health Service is authorized (a) to investigate any producing disease conditions, (b) to coöperate with state and local authorities in carrying out health measures, and (c) to disseminate information to the public. 
Under this authority the Federal Health Agency may undertake the following functions in a national program for improving industrial health. ${ }^{3}$ The section of this program dealing with industrial health is as follows:

(a) Continuing and extending health surveys in industry with a view to determining precisely the nature of the health hazards and the measures needed to correct them.

(b) Securing adequate reports of the prevalence of disease among employees and the sanitary conditions in industrial establishments and communities.

(c) National development of adequate systems of medical and surgical supervision of employees in places of employment.

(d) Establishment by the Public Health Service, in coöperation with the Department of Labor, of minimum standards of industrial hygiene and the prevention of occupational diseases.

(e) Improvement of the sanitation of industrial communities by officers of the Public Health Service, and coopperation with state and local health authorities and other agencies.

(f) Medical and sanitary supervision by the Public Health Service of civil industrial establishments owned or operated by the federal government.

It is proper, here, to discuss the needs for each of these sections of the program just given and the benefits to be derived.

Health Surveys of Industries.-The study of industrial accidents and the compilation of statistics which has resulted from the enactment of accident compensation laws has increased our knowledge of the nature, extent and cause of the losses. Industry, labor, and the general public have come to realize the preventable annual toll caused by the accident hazard in industry.

It is far otherwise in the case of industrial disease. But little exact information is available in the United States regarding the occupational hazard, apart from accident and the evaluation of the factors creating these hazards. It is true that intensive

\footnotetext{
${ }^{3}$ This program appears in Supplement No. 35 to the Public Health Reports of May 9, I9I9, as part of a general health program, proposed by the Public Health Service and intended to meet after-the-war needs. This program meets urgent needs by aiming to protect the national health and to diminish the annual toll of lives taken by preventable diseases and avoidable insanitary conditions. It was presented to Congress by the Secretary of the Treasury with an urgent appeal to provide the funds required for its execution. So far, however, Congress has not appropriated the funds.
} 
studies of certain industries have been made, such as the lead industry, the steel industry, and the chemical industry, by federal and state agencies, but a survey, national in scope, of American industries is still lacking. We must know the facts and causes of industrial ill-health. For instance, we must determine the reasons why the percentage of deaths from the degenerative diseases affecting the heart and kidneys is far higher among the industrial than among the rural population. It is not sufficient to study an industry locally. The survey must be extended to cover all the typical geographical locations in order to determine what are the differences in the occupational hazards because of variations in location, type of management, provisions for the safeguarding of health, and degree of local health organization.

In addition to the need of comprehensive knowledge of the hazards inherent in our industrial fabric, there should be conducted a study of the many new industries which have been established as a result of the war which will become permanent features in this country.

Morbidity Statistics. - We shall have no measure of the effciency of steps to improve industrial health unless we have a nation-wide system of recording cases of industrial disease. Only in this fashion can we proceed intelligently. Occupational diseases have been made reportable in some states, but so long as reporting is optional with the physicians, and so long as physicians display greater interest in treatment than in causes, advance in this direction will be difficult.

I believe that the United States Public Health Service may perform a national service by enlarging its function as a clearing house of information on industrial disease and by aiding and stimulating its collection. There is urgent need to improve the collection of statistics not only of industrial morbidity but of general morbidity as well. The method of reporting deaths is now fairly satisfactory in an area containing about 75 per cent. of the population of the United States. The compilation of mortality statistics gives a good idea of the general causes of death. But there is little more than statistical satisfaction in such knowledge.

If we wish to prevent industrial disease and death we should have means of obtaining early information of when and where 
disease is occurring so that any unusual incidence of disease attracts attention before it results in the death of large numbers. The U. S. Public Health Service has already made a beginning in this direction by drawing up standard forms for the reporting of industrial morbidity and by making arrangements with several large industrial corporations to furnish the data.

If, however, further progress is to be made the states must be assisted to collect such statistics and to forward them to a central office in Washington. Inasmuch as the regulation of intrastate health matters is a police power, exercised by the states, it is desirable that the primary means of collecting morbidity statistics should be a state agency with which the federal government would coöperate.

Medical and Surgical Supervision of Industrial Workers.Much has been written on the necessity for the medical and surgical supervision for industrial workers. The key to medical and surgical supervision of workers is health service. The object of health service is not to select the physically fit and to reject the unfit, but to induce a condition of positive health rather than to tolerate the negative condition of absence of disease. Many of us are but half alive. Far too few enjoy life to the full. Mark how good health produces a "beneficent circle" which is the antithesis of the "vicious circle" of ill health. Good health is merely the normal action of all the body cells. Energy can be properly released in work and subsequent restoration in the minimum time can be effected only when all the organs react normally. In a state of health, our energy output always falls below intake and there is a constant reserve on the credit side of the health ledger. The individual should, without strain, maintain himself and his family under confortable living conditions and have a fund of energy besides for recreation. Good health means the ability to live a full and rounded life. Its possession translates the impulses to that end into action.

To those who seek to investigate the causes of the present social unrest and to evaluate the underlying factors, industrial ill health must come in for consideration.

The policy of industrial health service is to furnish the facilities whereby workers may keep fit at all times. This object may be attained by providing in industrial plants an adequate nedical and sanitary personnel to perform the following tasks: 
r. Supervise the sanitary conditions of the plant so that proper hygienic conditions prevail; that is, provide the proper design and cleanliness of work-places and yards, a pure water supply, adequate sanitary toilet and washing facilities, suitable locker rooms, inspection of the sources of food sold in factory lunch rooms, measures to prevent the spread of communicable diseases among the plant personnel.

2. Supervise the plant processes from the standpoint of general and specific occupational hazards; that is, put into practice special precautions for avoiding occupational diseases.

3. Furnish periodic medical examinations to employees, so that they may be made aware of their physical condition and detect impairments before irremediable damage has been done.

4. Furnish diagnosis of disease and give the proper advice regarding their treatment and cure.

5. Furnish emergency relief for trifling ailments which are often the cause of much lost time, or if neglected, may develop into serious disability.

6. Furnish health education in a stimulating and interesting way.

A health service of this character is no Utopian fancy. Progressive employers have in all essential details already put such plans into effect. Such a health service is but the expression of the thought that the man-power of the nation depends on the health of the worker. A health service of this character is not a device for the exploitation of the worker. Nor is it a scheme of philanthropy. It is a sound business proposition, which may be counted on to yield a rich return to the worker, the industry and the nation. The federal government should study and standardize such systems of industrial health service, outlining the best methods of conducting it and create a demand for a qualified personnel. ${ }^{4}$

Establishment of Minimum Health Standards.-In a comprehensive program for the improvement of industrial health, health standards should be set up. Most of our laws relating to the protection of industrial health are vague in their specifications. Thus

${ }^{1}$ For a more extended treatment of this subject the reader is referred to the following: Selby, C. D., Studies of the Medical and Surgical Care of Industrial Workers, Treasury Department, U. S. Public Health Service, Public Health Bulletin No. 99, Washington, D. C. 
the words, "reasonably," "adequate," and the like, are used in referring to prevention of hazards, of which we have no measure of safe tolerance. If, for instance, it is desired to establish the limit of safe tolerance of carbon monoxid in the air of workrcoms, in which this intensely poisonous gas is produced in quantities, we must establish a permissible amount for the air of interiors. It would be unreasonable to demand that the air of workrooms shall contain no carbon monoxid, for it is a universal, though minute, constituent of the out-door air. This gas has a great affinity for the blood and by combining with it permanently displaces a corresponding amount of oxygen and so prevents the aeration of our tissues. We have not been able as yet to determine the exact "co-efficient of combination" of carbon monoxid with the blood and until this is determined we shall not be able to specify the permissible minimum contamination of the air of workrooms with carbon monoxid.

This is but one instance of many. It is clear that much research is required to formulate practicable standards of industrial hygiene and in this work the federal government is the national agency for research and fixing of standards. Within the limits of its appropriations some work of this character has already been begun by the Public Health Service, but to extend the work adequately will require much greater appropriations than Congress has been willing to give up to the present.

Improvement of Sanitation in Industrial Communities.-Under federal laws the United States Public Health Service is empowered to coöperate with state and local health authorities in preventing disease. Coöperative demonstrations in rural districts between the Public Health Service and state and local authorities have recently been authorized by Congress and modest appropriations made for this purpose. The Public Health Scrvice lends supervision, assistance, and advice in these demonstrations and contributes part of the funds. The state and the local community severally or jointly contribute other sums, often on a basis of one dollar of federal money to three or four of state or local funds, but in no case in any greater proportion than fifty per cent of federal money.

This is the application of the principle of the extension of federal aid to the solution of public health problems. In practically all instances the results have been highly satisfactory, 
often spectacularly so. Instead of increasing the sense of dependence of communities upon the national government the reverse is true. There is an increasing tendency on the part of these communities to develop a greater sense of responsibility, so that they perfect and extend, with local funds, the health organization which the federal government has aided them to establish. Having been taught the benefit of such work, they now wish to hasten and take full advantage thereof. A similar system, applied to industrial communities, in coöperation with states, will aid greatly in banishing all too prevalent insanitary conditions.

The coöperation of the federal government in such enterprises is abundantly justified, because the benefits are enjoyed not solely by the community but by the nation as a whole. Thus improved rural health conditions promote food production and the industrial sections of the country profit because of the increase in the food supply. Again, the farmer profits by improved health conditions in industrial centers, which make possibie a greater variety and quantity of products he must purchase. Improved health conditions increase both the productivity and the purchasing power of the nation.

Civil Industrial Establishments Owned and Operated by the Federal Government.-We have for final consideration the medical and sanitary supervision of civil industrial establishments owned or operated by the federal government. During the war the Public Health Service supervised the sanitation and medical service in many of these establisnments, but was handicapped by the great shortage of medical personnel, which was drawn on so heavily for military purposes.

As the government is the greatest employer in the country, it is fitting that it should be progressive and match the achievements of progressive private corporations. Yet it must be admitted that, up to the present time, the provisions made for the sanitary and medical supervision of civil industrial establishments owned or operated by the federal government fall below the standard maintained by numerous private corporations. The results obtained by the Public Health Service during the war in the sanitary and medical supervision of government plants are abundant justification for the continuation and extension of the system. It is earnestly to be hoped that the govern- 
ment as an industrial employer will become a model whom all private corporations may imitate.

Part to Be Played by States and Communities.-So much then for the part to be played by the national government. We have seen that this consists essentially in leadership, advice, coöperation and education. Through it all the evident intention is to supplement, not to supplant, state and local health organizations. There is at present a great need for coördination of state and local health activities. General supervision of health is exercised by state departments of health for the states and by local departments for communities. Supervision over industrial health, however, is maintained by state departments of factory inspection, which operate as agencies distinct from the state health department. In local departments of health but little provision, as a rule, is made for the improvement of industrial working conditions. This condition needs to be changed and improved.

In view of the fact that the public exercises its regulatory and police powers through the state machinery, this should be improved. The efforts of the federal government will provide information of conditions requiring to be remedied and minimum health standards to go by. States and communities should play their part by furnishing the funds and organization to put these standards into effect. In this manner we shall secure over the entire country a reasonable uniformity in sanitary industrial conditions, and efficient measures for the conservation of industrial health.

Yet, in organizing such health activities, federal, state, or local, the purpose to be kept in view is not to multiply upon statute books laws so arbitrary or radical as to defeat their purpose, nor to develop machinery for political purposes, but to develop administrative agencies to give expression to the newly developed sense of responsibility for conditions of public health, and to create a favorable environment for the development of the citizen and of future generations.

Education of the Public.-Underlying the whole question of health promotion is the need for a national realization of the terrible handicap needlessly placed upon national well being by the toleration of preventable disease and suffering, and the need 
for a crystallization in the public mind of the extent of the problem and of the imperative need for action now.

We shall advance only as fast as the popular demand is expressed for sane and effective protection of the public health, and as the knowledge becomes general that no public money returns greater dividends in the welfare of the citizens, in the man-power of the nation and in its service to mankind. 
I 


\title{
CHAPTER XXV
}

\section{DELINQUENCY AND CRIME}

\author{
By William Healy ${ }^{1}$ \\ Director, Judge Baker Foundation, Boston
}

\section{A TASK FOR CONSTRUCTIVE EFFORT}

For several decades prior to the Great War there had been very gradual spread of interest in better methods of treatment of delinquents and criminals. From the smallest beginnings, about the middle of the last century, through the efforts of a few far-sighted individuals who contended for the development of progressive measures in treating prisoners so as to improve and reform them, or who advocated handling some offenders under probation, we in this country have almost completely accepted these proven principles. Indeed, in most of our communities it would be impossible to revert in our courts and institutions to anything like the attitude and procedure of a hundred or even fifty years ago.

The war itself has emphasized certain cardinal features of prison administration and brought more clearly into view some major causes of law breaking. From a number of centers we have received new data conceming the possibility of improving the treatment of prisoners. All the recently demonstrated facts serve strongly to reënforce the opinions which practical workers in the field had held.

Workers in the field of reconstruction must take into account the treatment of delinquency and crime, and to this end should

${ }^{2}$ Physician, psychologist; A.B. Harvard, M.D. Rush (Univ. of Cliicago), Director, Judge Baker Foundation, Boston; formerly Director Juvenile Psychopathic Institute, Chicago, etc.; scientifically studied delinquents and sat with the judge in the Chicago Juvenile Court; author of a text-book on Delinquency and Crime, The Individual Delinquent, and several other works on the psychological aspects of conduct problems, etc. 
build upon foundations laid in more stable times, and apply also what has been learned during the world strife concerning offenders against the social order.

\section{IMPORTANCE OF THE SUBJECT}

The immensity of society's task in keeping delinquency and crime at a minimum is itself proof of the need for constant study and discussion of the problems which are encountered in the daily routine of social offense. Figures show the size of the undertaking. We know from census reports that every day upwards of one-tenth of one per cent. of our population is in the various institutions for offenders. In the State of New York over 120,000 individuals are committed to penal or reformatory institutions each year. Then, many offenders are on probation, and many others offend who are not caught, or, being caught, get off without commitment. Or, viewing the matter in the light of dollars and cents, we may safely assert that in ante bellum days, next to the sum spent for education, the largest public expenditure was for the ever continuing fight against the transgressor. The cost of crime in the United States has been estimated as between $\$ 2,500,000$ and $\$ 4,000,000$ a day. When we consider the expenses of police forces, courts, probation systems, jails and many other institutions for offenders, we can understand the reason for the magnitude of the figures and perhaps appreciate that in these forms of public service there is little suggestion of over-spending. Nor with the advance in the complexity of civilization need we expect any lessening of the task. Human nature is hardly likely to change, while with the development of new living conditions, as the use of the automobile, those who might never otherwise have been offenders appear on the scene as potential or actual delinquents. Unless some of the main causes of delinquency are greatly mitigated as we depart from simplicity in life, the number of offenders against society's laws is bound to increase absolutely and relatively.

\section{SCOPE OF CHAPTER}

Our discussion must be confined within very definite limits. (a) We shall speak of delinquency and crime as being practically 
synonymous. In this country there is a well-marked tendency to restrict the use of the term delinquency to offenses committed by juveniles; exactly the same offenses by a person over I 7 or 18 years old are termed misdemeanors or crimes. For reasons which we shall point out below, it is not possible to differentiate in any such way. The child is truly father of the man in the development of an anti-social career, and there is no precise point at which the individual in any real sense suddenly becomes adult or responsible or where the offense becomes differently motivated and therefore subject to any new classification. (b) Next, we shall consider, except at one or two points, conditions as they exist in America only, although there is a great deal to be learned from the criminology which had been developed abroad. (c) Through the impossibility of doing any sort of justice, we shall not undertake even to mention by name the considerable number of fine spirits who in this country, for the most part without any effective state support of their endeavors, have opened our eyes to the real facts of the situation. (d) In this sketch we shall attempt to discuss both prevention and treatment. We see nowadays that they are closely interwoven. Indeed, in the search for causes or in studying the results of the various types of treatment or of the lack of it, we perceive that prevention means treatment and that effective treatment results in prevention. (e) Finally, we would make it clear that these few pages can present only the barest summary of the subject.

\section{PRESENT WEAKNESSES}

Surveying our subject, we find at the outset that empirical knowledge has governed procedure in law and penology. At the present time one finds much bare tradition guiding the management of courts and institutions for offenders. It is correct to say that in these fields a state of affairs prevails comparable to medical practice in the days before scientific pathology and therapy developed. In our dealing with offenders we have utterly neglected the scientific procedure of reckoning with causes and evaluating the results of efforts at modifying conditions. In this country we have not even taken the trouble to collect statistics to show us the national trend. One of the primary 
steps towards social self-knowledge has, thus, yet to be taken by us.

Our impotence to stem the iendency toward social offense, even in the lives of single individuals, is readily attested by many facts that may be obtained from courts and institutions. Repetition of the same type of offense by the same individual, over and over, may be observed. What has been done in many instances has been totally ineffective and no one has taken any cognizance of the repeated failures. Very remarkable is this lack of study of the effect of society's effort. Many of the largest institutions receiving offenders have failed to record with any degree of accuracy the criminal status or the previous incarcerations of individuals committed to their care. Often it is not known whether the prisoner has been in any prison before, or, in big institutions, whether he was ever there before. In our important metropolitan courts the prisoner comes up before a judge who often has no information as to whether the accused has ever been in the same court before, particularly if a number of judges sit in the court, to say nothing of knowledge of conviction in another court in the same city or elsewhere. Often a card system of identification and registration is not maintained. Imagine a business concern so indifferent to the results of its policies. As a matter of fact, there are large numbers of offenders who have been ineffectually committed dozens of times. Partly on account of the changes of judges through elections or through rotation of service, an effective procedure depends absolutely upon careful registration of the facts concerning the offender. This requires coöperation between courts. There is more genuine coöperation between the police of various countries in Europe, for instance in London and Paris, than there is between the courts of different jurisdiction in our large cities.

\section{HISTORICAL FACTS AND PRESENT ISSUES}

The Reformatory Idea.-Our country is to be credited with establishing the first thoroughly equipped reformatory. The idea of reformation has since so developed that in most of our states there is at least one institution dedicated to the scheme of reforming offenders. Various criticisms might be offered con- 
cerning the results of the efforts in this direction, but as one of the leading authorities pithily said: "Reformatories cannot reform unless they are given reformable material." Up to the present time, unfortunately, there has been a lack of discrimination by the court, and very frequently individuals are given a reformatory sentence who have not the capacity to profit by the commitment. Because of this, the reformatory management is often obliged to work with defectives. When these do not turn out well after release, the institution can hardly, on account of their failure, be held responsible. As a matter of fact, it is successful treatment of suitable types of individuals that fosters abiding faith in reformatories.

Probation.-Probation as a scheme of treatment for offenders has grown from its earliest beginnings forty or fifty years ago until now, under various forms of state or local administration, it is a recognized factor in the penal system in nearly all large communities. Taken as a whole, probation officers may well be proud of the results of this plan of treatment. Its value consists in that offenders can be handled less expensively and with better results in reformation under probation than by the older method. In Massachusetts one of every two offenders is placed on probation. In the State of New York probation has been found so effective that over ten times as many (now exceeding 20,000 a year) offenders are cared for under this plan than there were ten years ago. In some places probation is merely a fiction. The prisoner is freed from the court and has only to go through the formality of reporting again at rare intervals. Of course there is no fair trial of the plan under such lax practice. Probation can only be real when the characteristics and needs for social adjustment of the offender are known and adequately met. After all, it must be said that in some courts and under state probation commissions there is distinct striving towards this ideal. One of the leaders recently said: "The development of probation has reached the state where extension is not as important as are a critical study of the system and refinement of its methods, and the willingness to allow experimentation in certain features of its administration." As matters now stand, the most progressive and practical effort in the fight against delinquency and crime is being made under the banner of pro- 
bation. Knowledge and technique have yet to be extended, but with the present attitude of the public there is considerable progress in this direction.

Juvenile Courts developed first in our country and the principle has proved so sound that we now have many such courts and other countries have established them. More progress, by far, is being made in these courts than in any other part of the field of the treatment of delinquency. Here, again, there are vast differences between the various attitudes and procedures of different courts. There is no doubt that the original idea was to have young offenders handled separately so that they could be adjudged and treated by parental methods, which are based on a sympathetic understanding of individuals and conditions and designed to obtain better results. To-day in our best courts there is a distinct and growing endeavor to work by these human and therefore scientific methods. In our own, the Boston Court, the judge obtains from us a synopsis not only of the offender's physical and mental characteristics, but also of the factors acting as probable causes of delinquency, obtained by consultation with relatives and others, and from a knowledge of environmental conditions, habits, previous experiences, type of mental life, etc. Nothing else will ever really satisfy scientific requirements. Without a well rounded picture and history of the case one factor or another may be too heavily stressed. At present in sixteen or eighteen cities in this country psychologists are making examinations which, together with the medical report, give considerable information to the judge or probation officer.

Other Modern Ideas.- - There are various modifications of old methods of treatment which have been retained in modern procedure. Notable are the following: The indeterminate sentence, the extensive parole of prisoners, and the use of prisoners at occupations outside prison walls. None of these need defense, for when judiciously employed-after thorough study of the individual prisoner and the genetic factors of his delinquent tendencies-they work out very well indeed, both for the individual and for society. With proper management these methods are bound to spread.

Changes in Official Attitude.-Considerable alteration of the official attitude in courts and institutions has taken place during the last fifteen years, but observation shows that these 
changes are not at all general. In many courts and still in many institutions the first rays of the new light have hardly penetrated. As I see it, the main trouble is that authorities handling human beings in the interest of society are not taking themselves seriously enough to become students of the problem. They are treating these human problems as if there was no need for special investigations and for the development of knowledge and technic. The most pressing practical issue is to get a changed attitude towards the work. The scientific attitude must take the place of the hit-and-miss methods of court procedure and the housekeeping ideas of institutional officials. To be sure, we have some institutions in this country, particularly the Minnesota penitentiary, which are administered from a business-like point of view and are necessarily much better than is the old type of prison, but even such an institution is not the result of any deep study of the problem of crime nor of any scientific effort to combat it.

\section{RECENTLY DEVELOPED TENDENCIES}

There is no doubt that during the decade prior to the war certain new tendencies have arisen in the treatment of delinquency and crime, tendencies which indicate the possibilities of a scientific attitude in this field. We may especially mention the following:

Type of Buildings.-It is noteworthy that in planning the new institutions for offenders (as at present in New York and Illinois) principles of the penal sciences are being taken into account. Colonies as well as institutions with walls must be planned so as to do more than merely house the offender or get him to work. The causative factors in crime are being considered. The fact that there is any proposal to classify individuals according to mentality and habits is a step in the right direction. It is an advance towards the psychological study of delinquency. Mental life and mental habits above all must be influenced if a prisoner is to be safely placed again in society. It is beginning to become clear to some state authorities that society's main requirements in the treatment of offenders after conviction are two in number: that the prisoner be prevented from escaping and that he be influenced for the good. The architecture and other 
features of penal institutions are now being conceived by the forward-looking in the light of these requirements.

Gathering Facts.-Within the past few years the need has been felt of presenting the facts upon which progress alone can be built. This is to be seen in recent reports of a few courts and of some institutions and probation commissions. From these it is possible to gather enough information to make predictions concerning the desirability of future action in some directions. As might well be imagined, however, these reports frequently contain exaggerated statements which need criticism and comparison for their proper evaluation.

Problem of the Feeble-Minded.-As an example of the recent gathering of facts we may cite the additions to our knowledge concerning mental defectiveness and its relation to crime. In absurd contrast to the total lack of appreciation of this problem fifteen or twenty years ago we now sometimes hear that nearly all delinquency and crime is committed by the feebleminded. The trouble with figures often cited is that they do not by any means include a sufficiently extensive study of offenders. The statistics often emanate from institutions which house those who are of such a mental calibre that they are not regarded as fit for probation. Then, again, these institutions do not include many of the offenders who are infrequently caught because they are shrewd, or who, if caught, are rich or clever enough to set up a defense which misleads the jury. And statistics frequently come from courts as well as institutions where recidivists (many of them stupid offenders, who are easily caught) are particularly apt to be found. I have yet to see a study of offenders which has emanated from some court where a more subtle class of criminals are tried. And, finally, there is the general fact that many offenders, the particularly clever ones, are very rarely apprehended, and so are not included in the statistics.

In brief, the facts that are available enlighten us concerning selected human material in a given court or institution, but do not necessarily indicate that they may be safely utilized in the explanation of delinquency and crime elsewhere or in general.

But some of the facts gathered in recent years have outstanding value. Despite exaggerations and discrepancies in figures, it is clear that among the factors making for delinquency and crime, mental defect and mental aberration are very prominent. 
Because they are a cause of recidivism they must be reckoned with in any immediate step toward progress.

Studies of Beginnings.- It has been known for half a century and recently emphasized that during the periods of childhood and youth tendencies toward misconduct begin. Following up cases in juvenile courts and Glueck's studies at Sing Sing show conclusively when the trouble begins. It is thus demonstrated that causes can only be directly studied during the formative period of life. The natural corollary is that such causes can most efficiently be overcome during this period.

Mutual Welfare Work Among Prisoners.-Of no little significance is the movement for mutual welfare work among prisoners. Of course, the need for this varies in different institutions, but the spirit of it is desirable everywhere, even in institutions for juvenile offenders. It is sound policy to ask a man to care not only for himself but for his fellows where they are housed together and where the influences of prison life are deteriorating. Such mutual welfare work is a godsend in practice. For its influence upon the lives of men it should be extended greatly. It has received very little attention in institutions thus far.

\section{EFFECTS AND LESSONS OF THE WAR}

We were fortunate in the United States to have escaped the great increase in delinquency and crime which prevailed in other countries. In Europe there has been a great increase of offenses, particularly of juvenile delinquency. The figures from different cities in this country vary greatly. Probably the situation in Chicago represents an increase due to other than typical war conditions. In other cities there has been no increase, and in at least one large city there was a diminution of delinquency last year. The reasons we experienced relatively no increase of delinquency are many. However, one obvious cause of juvenile delinquency, the removal of parental authority, has not been extensive in the United States. Not many parents who had children old enough to become delinquent have been pressed into military service.

Influence of Parental Care.-One of the great lessons of the war is that the prevention of delinquency is to be achieved by normal family life. At the age when young persons first tend 
to become delinquents, the breakdown of parental authority, due to alcoholism or other conditions which break up the home, may be considered as a great causative factor, to be earnestly combated.

Intelligent Discipline in Institutions.-Reports from the Disciplinary Barracks at Fort Leavenworth show that discipline aimed at self-realization of the offender and at the inculcation of selfrespect offers big returns. A large number of offenders were returned to the army, and on account of the discipline they had received soon became noncommissioned officers. However, this plan was carried out not indiscriminately, but only after a careful study of individuals and selection of those mentally fit. Psychological study and guidance of prisoners has been vindicated.

Utilization of Prisoners as Soldiers.-Excellent reports have come to us from abroad of the utilization of prisoners as soldiers. Some of the English offenders drafted in this way have given splendid accounts of themselves. Students of the personality of offenders have no doubt of the truth of such reports. Indeed, the very qualities which make a good soldier, as fearlessness and love of adventure, have led some of our offenders into crime. Years ago I commented on this very point. These traits under army discipline and activity produce heroes in warfare.

Priscners in Useful Occupations.-In road building in Colorado and in farm work elsewhere, prisoners have for years demonstrated their value to the community and the possibility of leading a more normal life than is possible behind penitentiary walls. During the war the demand for food caused large numbers of prisoners in various states to be set at work raising farm products. Their contribution to the national weal has been substantial, as prison reports prove. If prisoners can do useful work during war times, why not as well in time of peace! In selecting convicted offenders for positions of trust in the open there is much to be gained. In one reformatory the women experienced great joy in establishing a workshop where large numbers of flags were made. The thought that these flags would stimulate the national spirit at the front or at home was a remarkable incentive to industry and good behavior. Perhaps it would be difficult to duplicate such an occupational interest, but the results challenge an attempt.

Other Lessons.-Workers in the field have noted some other 
striking facts during war times. Many of them were known before, but not so well. It has been demonstrated that continuous employment militates against the commission of offense, even by those whose delinquencies had no basis in poverty.

We have also learned as never before the danger of permitting girls to cultivate undisciplined habits of life, such as becoming friendly with casual acquaintances. The attraction of a uniform has again been proved. However, a very considerable number of the girls who have been attracted to encampments to their own detriment, like moths to a flame, have been found to be mentally defective. It would be most unfair to the men in service not to note that, on the whole, there has been relatively little sex immorality on the part of our army and navy, compared to the other countries or our own previous wars. This has amply demonstrated the value of specific educational measures and of decent amusements provided for men who have been drawn away from normal home life.

\section{A PROGRAM FOR CONSTRUCTIVE EFFORT}

A consideration of society's relation to crime and delinquency will prove the value of scientifically directed effort. Shall we not desire to achieve results in this undertaking as well as in the many other fields of national endeavor?

A General Program.-However, a general constructive program is not as feasible with us as in a country where local affairs are under centralized control. The outlook upon the problems of delinquency and crime in the different states varies widely, and those who manage institutions or administer the treatment of offenders have quite different conceptions of their work. Definite ideals based upon professional training are lacking. It is difficult to make an appeal in the interests of progress. There is no appreciation of scientifically ascertained facts. Professional writings are not generally read. In fact only a small minority of officials of courts or penal institutions ever make any sincere attempt to study the fundamentals of modern criminology. The first step must be to create a proper attitude on the part of those who deal with offenders under the law. A new spirit must be developed, whether by criticism from without, or by the growth of a professional spirit within the ranks, or 
by supplanting non-progressives by men with the outlook of the forward-looking American to whom an obstacle is something to be investigated and overcome.

A Federal Program.-A good deal that might be part of a constructive program has already been indicated in this article. Primarily, national statistics must be collected before we can make any progress in our methods of treatment of offenders. Figures are necessary, not merely to enumerate offenders and to present the routine facts that comprise the statistics of older countries, but to trace clearly the effect of a specific treatment. For this purpose the facts must state the type of the offender, his psychological and physical characteristics, the nature of the offense, his heredity, his antecedent living conditions, habits and experiences-in short we need to know the causative elements leading to the particular offense before we can evaluate the effect of treatment given or prognosticate the results of proposed treatment.

The establishment of a national bureau of identification of convicted offenders is imperative for any country-wide campaign against crime as a profession. Under present conditions it is very easy for a professional to play the game in various states under the disguise of an alias.

Closer coöperation between different courts, institutions, and police forces must be fostered, both in a state and between different states. The impetus to this might well come from a federal bureau. Indeed, in the publication of scientific data lies the possibility of arousing healthy competition between communities in the task of combating delinquency and crime.

Best Time for Intensive Treatment.-In criminal careers public attention for the most part is focussed on results. It is the adult criminal and the adult prisoner who are generally under discussion. The formed individual and formed career is the chief subject of penology only because of the present public attitude and not because criminologists think measures applied at this late time of life are of as great value as treatment of the young at the beginning of a career of crime. Indeed, an important point is the fact that offenders have a criminal history which usually begins in early life. Accurate and relevant statistics would emphasize this fact as no ex-cathedra statement or citation of particular cases possibly can. 
Conditions of the Discharged Prisoner.-We shall take up the various elements of a constructive program from the end of a career of crime backward toward its beginning. At the discharge from custody there is "a parting of the ways," as Whitman, a leading penologist, termed it. Indeed, this was the name of the association which he created for the purpose of giving individual aid to men just discharged from the institution which he directed. The plea for an understanding of the plight of newly discharged offenders is based on fact and common sense. The bodies of these men have become softened and, because of the emptiness of prison life, their minds are divested of energy and initiative. If we want these men not to become repeaters, we must give them something like a fair chance to reëstablish themselves. Decent clothes, enough money to last until work can be found, a helping hand towards employment-these are their basic requirements. Imagine the bareness of the world to the man discharged without these. If only for society's self-protection, it is our duty to establish bureaus of rehabilitation of offenders in connection with each institution or else systematically to turn over such work to a well supported Howard Society or local Prison Association. The discharged offender should fare as well as the paroled prisoner.

Parole of Prisoners.-It is fundamental that the paroled man be given a fair chance to succeed. The system of parole and the efficiency reports of parole officers rest upon this basis. Hence, opportunities for earning a living are found before prisoners are paroled. Perhaps the weakest point in this method of treatment is the lack of scientific study of the paroled and of the causative factors in their offense. More than the warden's report of prison behavior is required for prognostication of behavior outside. What is the prisoner's physical make up; how does he grade mentally; what special abilities has he; what influences caused him to become an offender; in what environment is he then likely to succeed as a non-delinquent? This is the minimum of practical inquiry and should be made with scientific care. Much might be said concerning the various points of the inquiry and about the unsatisfactory nature of the old-fashioned "prison behavior" report. A single fact may be mentioned. It may be the dullest man and hence the one most unlikely to succeed in the outside world who can stand 
the monotony of prison life best, or it may be the professional with previous experience who knows how to act so as to make the best record. The idea that the will to behave properly in prison is necessarily an indication of probable conduct outside of prison is quite erroneous. It is therefore clear that paroles granted without a scientific investigation of individuals can not show a large percentage of successes. Such sound investigations before parole as are made under the leadership of Moore in Rahway, New Jersey, should be introduced everywhere. The women at Sherborn, Massachusetts are studied perhaps more carefully than male prisoners anywhere. The predicability of behavior on parole is vastly increased thereby.

Treatment in Prison.- - There is need to-day, just as there was in the time of John Howard, for the application of common sense in the treatment of offenders. The future of the offender should be the cardinal consideration. Without introducing any sentimental tinge and without denying that the prisoner whose tendencies need to be checked by penal methods, is a human being, we should never lose sight of the best interests of society. If the person in prison is again to live among his fellow-men, it must be the part of common sense to keep him so fit in mind and body that he can reënter the world with a fair chance to resist his peculiar temptations, and to master his anti-social tendencies and to support himself honestly. To cause or even to permit his deterioration through confinement and then to set him free, that is surely the antithesis of common sense. But, unfortunately, that is exactly the effect of life in the vast majority of our penal institutions. The psychology of prison life, the inexorable laws of the mind, are not considered in the treatment of prisoners; hence the astonishing figures of recidivism, of repetition of offense. The many causes of prison deterioration cannot be here enumerated; that they exist may be readily understood. The silences, the idleness and the empty-mindedness are sad to contemplate. As one professional said to me, "What in the world do you suppose we think of in all the long hours?"

The specific problems of treatment, cell life, prison colonies, the length of term, advancement in grade and in privileges for good conduct, stripes versus ordinary clothes, silence versus conversation, outdoor exercise and other recreations, and other points can only be solved properly by the results of experiments 
on individuals classified by a diagnostician competent to investigate the mental as well as the physical make-up of prisoners. Take the comparatively simple matter of prisoners' work. Until the war, never was the problem of the idleness or ineffectual labor of prisoners so clearly brought forward. What a contrast to the manner in which every one else was working! And why should they not be employed? As a matter of practical interest, the efforts of officials to develop industries for prisoners during the strenuous war time has been well received by the prisoners themselves.

The whole method of treatment in prison will have to be revamped sooner or later, so as to produce results. The test will ba, What is the outcome of the case? What other form of human endeavor is not checked up by final results? The conduct of the man after prison treatment is the criterion of what has been accomplished.

And out of our prisons surely should come such studies of the causation of crime that society may be enlightened concerning the possibility of prevention or early treatment. As a pattern should be taken Dr. Bernard Glueck's noteworthy study from Sing Sing, perhaps the most authoritative and enlightening analysis of a prison population that has yet appeared. The main lesson of this study is that delinquency has early beginnings. In studying the phenomenon of crime, Glueck follows the method of scientific medicine. While the patient is under treatment the trained student of disease has his mind on causes, on treatment so early and so efficient that vicious complications may be forestalled, or he thinks much about prophylaxis, the prevention altogether of the disease.

Probation.-Probation as a form of treatment of offenders is bound to grow because of the excellent results it has achieved. Its further development will depend mainly on two points. In the first place, probation is impossible without some attempt at a proper adjustment of the individual to his environment. To consider merely the new desire of the offender to do right is to appreciate very little of the factors in human conduct. The necessity for scientific diagnosis of the traits, trends and needs of each offender before the term of probation begins is paramount. Here as elsewhere adequate treatment without prior diagnosis is impossible. 
And in the next place, probation officers shall have only such a number of individuals in their charge as can be properly looked after. Under present conditions we hear of the farce of probation officers having 300 and even more offenders under their "care," so that it is impossible for them to see their probationers for months at a time and in the majority of cases there is no real attempt at adjustment of the individual. This is not a test of probation. What a contrast to the condition in institutions, penitentiaries and the like, where even with bars and high walls, there are many officials in proportion to the number of inmates. Probation should be truly constructive, dealing with the individual as a potential asset of society, in contrast to institutional treatment where the individual is a liability and an expense, and where treatment is negative.

Court Procedure with Offenders.-The problems of treatment in conjunction with court procedure in a constructive program are numerous. How can any judge who has to decide for the individual or for society so serious a question as allowing or disallowing an offender his liberty come to a conclusion without having before him a survey of the individual physically and mentally, and of his character and tendencies and of the causes of his delinquencies as ascertained by a scientific study of all the factors? The effects of commitment or of freedom under probation are bound to be most important for the individual's future. It should be the task of the judge to consider what the result is probably going to be.

Perhaps the high cost of an original competent study may be urged, but what is it compared to the large sums that are expended for individuals in institutions or to damages that may be caused by future misconduct if an offender is set free or to the loss to society if a parole case becomes nonproductive? As a matter of fact, the average cost of getting an adult offender committed as a criminal is hundreds of dollars. A diagnostic study upon which so much should depend can be undertaken for a cost between ten and fifty dollars a case.

Scientific adjudication of cases must be based in the future on sound diagnostic study of cases. The Lombrosian exaggerations of a generation ago have their echoes nowadays in sundry superficial generalizations correlating some special mental disorder or defect or alcoholism with crime and delinquency. But 
the only permanent basis of better court procedure will rest on studies of individuals which include all the causative factors, environmental as well as personal.

If more effective settlement of cases is to be made in the court, then there must be an extension of the parental attitude which is now characteristic of juvenile courts. The law, of course, must be enforced, but yet there must be such an understanding of human nature, of psychology, and of sociology that shall in the court be the basis for the adjudication of the case, and give the opportunity for constructive measures to follow. Justice to society demands much more than literal interpretation of laws made before the development of the scientific study of human motives and conduct.

Prevention of Crime.-But treatment of offenders with pronounced criminalistic traits is bound to seem difficult and to prove ineffective as compared with preventive work. Here again there is an analogy to the treatment of disease; the condition. of the adult offender is often chronic for the individual is set in his habits. Society is vitally interested in the processes or causes that antedate the anti-social conduct. Of course we know of the relation of alcoholism and sex habits and gambling with crime, but there are many other causative conditions that may be controlled about which we know all too little.

How to prevent a career of crime when the first signs of it are recognizable-that is indeed a vital question that social workers are struggling with now. We have stood by and watched our pessimistic predictions come true in hundreds of instances where no treatment related to the diagnosis was carried out. How can the situation be altered? In a program for constructive effort, the study of prevention must ever be foremost and should be regarded as of national importance. Surely it is of as much importance as the prevention of disease in hogs or sheep, which is a matter of such earnest study in the laboratories and experimental stations of the federal government.

Early Treatment.-A study of causes inevitably leads to a study of child life, because of the proof, amply given over and over again, that criminal careers do begin very early. On the influences surrounding children and on the tendencies and personality, attention must be focussed as never before. After years of observation I am convinced that in the development of 
well-staffed child-study departments in the public schools lies the hope of the future.

Thus, not only in institutions, courts, organizations dealing with offenders, but also in the public schools, where children form the earliest social contacts outside of family life, there should be the development of a scientific attitude toward the potentialities of the individual.

The prevention of delinquency requires also the control, under the law, of contributors to crime. At present this is one of the weakest points of our system of treatment of delinquents. The offender is punished, while very frequently the contributing agency or individual does not even appear on the scene. Many concrete illustrations could be given if there were space; some of the situations would appear absurd if they were not so tragic. The contributors towards delinquency fall under many categories. We recognize some of them by our censorship of theaters and "movies"; most of them, however, are quite unreckoned with. Often we find the actual instigators of crime never appear in court as such. These contributors to crime should be brought under the same jurisdiction as the offenders themselves. Frequently the older people who abet delinquency do not desire to make the younger person, often a mere boy or girl, a delinquent, and can be influenced by social service methods. A boy connected with a club of semi-delinquent older men, non-arrestable, can hardly be said to be intentionally led by them into ways that bring him into the grip of the law. It is infrequent that even the most miserable parents desire their children to follow their careers. One finds it sometimes possible to instill a rational attitude into these older people and thus to prevent the delinquency of the children.

It should be clear from the above recital of facts that the old order must change if the situation in delinquency and crime is to be improved. That betterment is possible nobody will doubt who has been a student of causes of crime. Without a study of causes, however, methods of treatment are merely theoretical and are bound to result in the continued growth of criminal careers, and in the recidivism which is patent in the records of courts and institutions under the present unscientific régime. 


\title{
CHAPTER XXVI
}

\section{VENEREAL DISEASE}

\author{
By Paul Popenoe ${ }^{1}$ \\ Secretary, American Social Hygiene Association
}

\section{Conditions Revealed by the WaR}

Fow diseases have been more successfully studied by men of science than the venereal diseases. Yet though all the facts necessary for their control were known the problem of controlling them on an adequate scale had not been attempted prior to the war.

It is easy, therefore, to understand the apprehension with which medical men viewed the situation a couple of years ago, for almost every war in history (the present one included) has resulted in a notable spread of these infections.

As an essential part of its preparation for the conflict the War Department took up the control of the vencreal diseases. It had the hearty coöperation of the Navy Department, the United States Public Health Service, the Red Cross, the Council of National Defense, and other war agencies public and private.

The measures adopted comprised little that was original; they were based on the intensive studies that had been made during the preceding ten or fifteen yars. Nor was there anything radical about them. They merely proposed that venereal diseases be treated as other infectious diseases are treated; that the

${ }^{1}$ Educated Occidental College and Leland Stanford, Jr., University; spent two years traveling in Europe, Asia and Africa as agricultural explorer; editor of Journal of Heredity (organ of American Genetic Association) Washington. D. C.; assistant to chief, medical section, Council of National Defense; Lieutenant and Captain, Sanitary Corps, U. S. A.; director of Section on Vice and Liquor Control, War Department Commission on Training Camp Activities; now executive secretary, American Social Hygiene Association, New York City. 
methods which had been applied to the control of typhoid and diphtheria be applied to the control of syphilis, gonorrhea and chancroid.

The great and successful effort made to apply these measures turned a flood of light on the ignorance, superstition, and prudery in which the venereal diseases had long lain, and brought about a marked increase in clear thinking on the subject.

\section{MOST INFECTION FROM PROSTITUTES}

It was demonstrated more clearly than ever, for instance, that the preponderating rôle in the dissemination of these diseases is played by the professional prostitute. This had often been denied and the blame had been placed on the casual offender, largely, it appears, through the not disinterested reiteration by prostitutes themselves of the claim that the professional did not carry disease.

The absurdity of this might have been seen in a moment by any one with an elementary knowledge of contagion. In fact it is now indisputable that the amount of disease spread by a woman is roughly in proportion to the number of opportunities she has; and as the professional prostitute exposes ten men to infection for every one who is exposed by an amateur, the damage the two do is measured pretty nearly by the same ratio. The experience of the Surgeon General's office indicates that from 75 per cent. to 90 per cent. of all infection of men is due to professional prostitutes.

\section{AMOUNT OF INFECTION AMONG PROSTITUTES}

This finding argues a very high amount of infection among prostitutes themselves, and the army's experience has furnished abundant data to prove it. Those who have been associated with the fight against venereal diseases have fallen into the habit of assuming, a priori, that every woman who is sexually promiscuous is infected; and this assumption is not far from right. Examination of thousands of cases has shown that from 80 per cent. to $9 \circ$ per cent. of such women are infected with one or other of the venereal diseases, while those who are not definitely diseased themselves may yet spread disease to other persons. 
In short, it is now well established that intercourse with practically any woman of loose morals is almost certain exposure to infection.

\section{AMOUNT OF INFECTION AMONG MALE CIVILIANS}

As to the amount of venereal infection among women not of loose morals, the war has naturally furnished no data. But it has furnished unparalleled information about the amount of infection in the male population capable of bearing arms. The results of an examination of the first million men sent to camp by the local draft boards have been compiled by the U. S. Public Health Service. It was found that 3 per cent. of these men had a venereal disease when they reached camp. Of course many of the worst cases had been rejected at home. Moreover, the first draft was made up almost wholly of white men.

Some of the northwestern states made the best showing, with less than I per cent. of their drafted men infected. The Solid South was at the bottom of the list, with the percentage of infected men running up above eight in South Carolina, Virginia, Alabama and Florida. The reasons for these differences are naturally varied, including differences in law enforcement, education, racial composition of the population, and other factors.

There were some astonishingly bad individual records, running to the extreme, perhaps, in one county in the Oklahoma oil fields, which sent 500 white selects to Camp Bowie of whom 90 per cent. were found to be infected with some form of venereal disease. The investigation of this county which the War Department promptly made showed, as was to be expected, that there was an almost complete failure of law enforcement there. It was the only county in Oklahoma, in fact, where red-light districts were tolerated.

\section{INFECTION AMONG NEGROES}

Among the male negroes the amount of infection has always been notoriously large. Data from various camps show that from 40 per cent. to 60 per cent. of the negro selects arrived with venereal disease.

The hundreds of negresses examined showed little more in- 
fection than the white women of corresponding morals. That is to say, practically all were infected.

\section{PECUNIARY COST TO THE ARMY}

Altogether, the medical department of the army spent perhaps $\$ 100,000,000$ in curing venereal disease in soldiers. It was roughly calculated that it cost $\$ 500$ to cure each case-a high figure due to the fact that many of the cases were chronic and had been botched by quack "specialists" or made worse by selfmedication.

\section{EFFICIENCY OF LAW ENFORCEMENT}

Probably less than one-sixth of these cases were contracted after the man was in uniform. One of the striking discoveries of the war-though it only bore out the claim which experts had made on theoretical grounds at the beginning-was the responsiveness of the infection statistics at army camps to the extent of law-enforcement in the neighboring civilian communities. Within certain limits, in fact, it was found to be much easier to clean up a city than any one had anticipated. A relaxation of police efforts for even a few days was followed a week or two later by a new crop of hospital cases.

As the War Department and its associates were particularly attacking commercial prostitution-because that was where the damage was done-they made the attack on business lines. The prostitute, it was argued, is not in business for her health but for the money she can make out of it. Therefore, if the conduct of her business is made so expensive that she comes out on the wrong side of the ledger she is bound to give up and try something else.

In some states which had no laws under which prostitutes could be sent to jail repression had to be wholly by police court fines, and the argument in the foregoing paragraph was found to be relatively sound for any given city. So long as fines of $\$ 5$ to $\$ 25$ were imposed on prostitutes, in accordance with the time-honored custom which made the fining of prostitutes a "tariff for revenue only," the women could continue in the business. But when police judges raised the fines to $\$ 100$ and $\$ 200$, 
the professional prostitutes simply quit, at least in that city. They saw it was a losing game.

\section{QUARANTINE OF DISEASED WOMEN}

This left in the field only the semi-professional and the amateur, the girls who drifted into an irregular life through love of excitement, or sexual hyperæsthesia, or more frequently through feeble-mindedness of some degree. Since really adequate machinery for handling these was almost everywhere lacking, they were dealt with by quarantine, being committed to hastily improvised detention hospitals so long as they were in an infectious state-i.e., from one to four months. When they were released from quarantine an effort was made, usually by representatives of the War Department Commission on Training Camp Activities, to find proper employment for them or send them back home, or in other ways get them out of danger of a "relapse."

It was this follow-up feature which most clearly distinguished the procedure from that which had accompanied various segregated and officially licensed districts for prostitution in the past. The latter and futile plan had assumed that the purpose of hospital detention was to "cure" the woman and send her back to the business. On the contrary the new and successful plan assumed that its purpose was to render the woman non-infectious and prevent her from going back into the business. A woman is rarely "cured" of gonorrhea in chronic form, which most prostitutes have.

\section{SEGRIGATION DISCREDITED}

So far as can be judged at present, the war experience gave a death-blow in this country to the policy of segregation, which had led many cities to set aside districts where prostitutes were allowed to carry on their business with occasicnal medical inspection, police protection, and the payment of a monthly license which put the city in the position of a super-pimp. ${ }^{2}$ At this dis-

- The underworld, and those who unknowingly took their opinions from the underworld, felt sure that law enforcement in the cities would (a) drive prostitutes from a segregated district into the residential dis- 
tance it seems almost incredible that segregation could ever have received the support of intelligent men as a proposal for controlling venereal disease, to say nothing of the moral aspects. It artificially stimulated the demand for prostitution and increased the supply correspondingly. The medical examination on which so much conversational stress was laid was rarely anything but a farcical graft. The fact is that segregated prostitution existed largely through political corruption, which it unceasingly fostered. In another sense it existed almost wholly by its alliance with the liquor traffic, for the "crib" and "parlor house" detained few visitors who were not under the influence of liquor. In states that went "dry" it was very commonly the observation that honest enforcement of the prohibition laws inside the "district" as well as outside almost wiped out the redlight districts.

\section{LACK OF PROTECTION FOR YOUNG GIRLS}

Under war-time scrutiny most American communities were found to lack an adequate amount of clean and attractive recreation for young people and otherwise to have made little provision for the protection of young girls. Commonly a juvenile delinquent was sent to jail because there was no other place to which she could be sent. The disgraceful condition of the jails in most small communities was glaringly exposed.

\section{IACK OF PROVISION FOR FEEBLE-MINDED}

It had previously been weil established that a large proportion of prostitutes are sub-normal mentally, and often grossly feeble-minded. But no state has yet made sufficient provision to isolate all such cases which need custodial care. Indeed, a few states have no provision whatever. Consequently, many girls who were picked up around military camps had to be sent

trict and (b) drive them from the city to the small country towns. Both of these ideas have been found, on the basis of abundant experience, to be almost wholly imaginary. Commercial prostitution, like other businesses, depends on the presence of a large body of potential customers and on the attraction of these customers by suitable advertising. These conditions cannot be met in the residence districts of cities or in small country towns. 
to jail or to a hospital simply because there were no institutions to receive them. They were then turned loose on the community again, although it was certain that they were mentally quite unable to resist the advances of the first man who came along.

\section{LACK OF HOSPITAL FACILITIES}

Hospital space was lamentably lacking almost everywhere. Many good hospitals would not accept a patient with venereal disease, because they alleged it would "put a stain on the name" of the institution. All sorts of expedients were adopted to meet this emergency. President Wilson even contributed for this purpose a quarter of a million dollars from the funds which Congress had appropriated to be used at his discretion for war purposes.

\section{LACK OF FOLLOW-UP WORK}

Even more lacking were attempts to follow up the cases admitted to hospitals and jails and to see that the girls, after release from custody, did not drift back into prostitution simply because they had no other way of making a living.

\section{THE PLACE OF MEDICAL PROPHYLAXIS}

On the other hand, the efficiency of medical prophylaxis, or early treatment after exposure to probable infection, was found to be perhaps greater than expected, when administered by the army medical department. After a soldier has had intercourse with a prostitute, he is required to report promptly to his surgeon for a disinfecting treatment. This procedure has been widely criticized on the ground that it amounts to a tacit official sanction of promiscuous intercourse. But such a criticism seems ill founded. The War Department did not sanction such promiscuity, but urged against it with all the force at its command. If in spite of this the soldier exposed himself, it was a fact (in view of the almost universal infection of prostitutes, shown above) that he had not only exposed himself but probably had actually been infected. The medical department gave him immediate treatment with a view to cutting short the course of the disease. To abandon this policy would be to 
assume that the fear of contracting disease is an adequate deterrent from prostitution. But abundant experience has proved that such is not the case. The real deterrents are law-enforcement, to make the prostitutes hard to find, and recreation and education for the men.

On the other hand, such compulsory prophylaxis does not present itself as a possible method of control of venereal disease in a civilian population, because it can only be carried out successfully with a trained personnel and with men under discipline. Nor is much more to be said for current methods of personal prophylaxis or self-treatment, because they are usually hastily and ill administered and frequently when the man is under the influence of alcohol and not capable of protecting himself. Above all else, the experience of the War Department has solidly established the fact that continence is the only real safeguard against venereal infection.

\section{THE PATENT MEDICINE EVIL}

The evils of self-medication by proprietary remedies have been displayed more vividly than ever. The man who acquires a "dose of clap," who is assured by his friend that "it is no worse than a bad cold," and who is informed that the druggist's nostrum will "knock it out in four days," usually ends with a chronic case which he thinks cured and which leads him, often quite unwittingly, to expose an innocent wife to infection. The War Department started a campaign against these nostrums, which the U. S. Public Health Service is carrying on. Only a total abolition of their sale will be satisfactory.

\section{APPALLING IGNORANCE REVEALED}

Finally, the war brought home in a way that cannot be forgotten the colossal ignorance of everything pertaining to sex and to venereal diseases which exists even among the educated public. General education in social hygiene is needed everywhere if the gains of the war are to be consolidated and made permanent.

So much, in summary, for conditions which bave long existed but which were more clearly defined during the war. It 
speaks well for the thoroughness with which the pioneers had studied the problem, that the great experience of the war added little that was really new to their work. The extinction of the red-light district was practically completed, principally through the efforts of the Law Enforcement Division of the Commission on Training Camp Activities. But it had been well started some years before. Perhaps no one, however, had imagined that the complexion of such cities as New Orleans, San Antonio, Fort Worth, and El Paso could be so remarkably changed in such a short time.

\section{FEW WHOLLY NEW CONDITIONS}

On the whole, there is little that is novel in the combating of venereal diseases to be recorded, although the existence of a modern army which officially encouraged continence and fought prostitution is almost unprecedented. The low rate of infection of venereal diseases in the entire army has not been matched in modern military history. It is somewhat lower in the United States than in France. However, this fact is doubtless a reflection of the greater possibilities of law-enforcement in this country.

\section{Outline of An After-war Policy}

\section{CONTINUATION OF THE WAR PROGRAM REQUIRED}

Turning now from war-time conditions to the policies of the future, one can have no doubt about the road to follow. The ravages of gonorrhea have within recent years come to be recognized to a large extent and the widespread suffering of the innocent has also been more clearly revealed. Ten per cent. of the blindness in the United States, for example, is due to the gonorrheal infection of the infant at birth. The suffering of innocent wives is even yet largely concealed by medical euphenisms, and the number of abdominal operations on women which are due to infection by gonorrhea from the husband, although popularly ascribed to some other cause, is startling. From a social point of view, these secondary effects are perhaps more important than the primary effects on the individual, although gonorrhea manifests itself in a wide variety of forms, including heart disease and a so-called rheumatism. The sterility and 
barrenness produced by gonorrhea are really serious, inasmuch as they are widespread, not easily diagnosed, and most difficult to cure.

Syphilis is now generally recognized as being just as bad as gonorrhea if not worse. The primary effects as graphically displayed in medical museums and in the lantern slides of lecturers are easily recognized, but the heart disease, paralysis, insanity and other more remote effects of syphilis are rarely ascribed to their true cause by the layman. One of the particularly unfortunate facts about syphilis is that it is often congenital, the infant being born with syphilis as a result, most frequently, of the infection of its mother by its father. Syphilis is, of course, not hereditary in the proper sense of the term any more than any other disease carried by germs is hereditary. It is the cause of frequent miscarriages in women and therefore produces, as does gonorrhea, an effect on the birth rate that is of great social significance. The celebrated 606 , and its congeners, are now generally recognized to be not at all a cure for syphilis, although they produce almost miraculous results in suppressing the symptoms.

The general program for combating venereal diseases which was adopted by the federal government at the outbreak of hostilties was drawn up in the light of the best pre-war experience and research and it stood the test so. well that no change of any consequence was made in it. For the immediate future, nothing more need be done than to carry forward that program.

Fortunately, the continuation of this program is well started by the United States Public Health Service and other agencies. Bureaus of Venereal Disease have been created in the health departments of most states, with specialists in charge of them to carry on the program in all its parts. The Commission on Training Camp Activities devoted special attention during the winter just past to getting needed legislation in all states where the legislature was in session. The educational side of the work is receiving continual stimulus from the U. S. Public Health Service and the American Social Hygiene Association. The United States Inter-departmental Social Hygiene Board, consisting of the Secretaries of the War, Navy and Treasury Departments, and of representatives of the Medical Corps of the Army and Navy and of the Public Health Service, should become an 
important factor in continuing federal activities and in coordinating with them the work of the states and of private organizations.

If the problem of controlling venereal disease is to be solved satisfactorily it is essential that no distinction be made in the treatment of whites and negroes. This is an especial difficulty in some of the southern states with a large negro population, where the feeling sometimes exists that all negroes are infected, that it is useless to try to reduce this infection, and that to clean up the white population is quite as high an ideal as can be striven for.

Such a feeling finds no support in sound epidemiology. It is admitted that the task of stopping the dissemination of the venereal diseases among negroes will be a big one. But it is nearly or quite futile to attack the problem among the whites and to permit the negro population to remain a source of reinfection.

The same clinical and hospital facilities must be provided for both races, and the same degree of law enforcement-so far as possible-must be maintained in the two races. In the southern states, which, it will be remembered, now show the largest amount of infection, any program that fails of this is only half a program.

The various measures comprised in the accepted program may be grouped under the heading of law enforcement, medical control, education, protective work for girls, and recreation.

\section{LAW ENFORCEMENT}

A continuation of stringent enforcement of laws for the repression of prostitution and the sale of liquor is essential if the venereal diseases are to be put where they belong. It is futile to suppose that the gain which has been made-and it is a great gain-will stand of itself. On the one hand, prostitution is one of the most lucrative businesses that has ever existed. On the other hand, it is based on the strongest human passions. Moreover, a certain proportion of both men and women are so defectively constituted that they can be restrained from prostitution only by stringent measures of society.

System of Fines.-The system of fining prostitutes should be 
wholly abandoned. It may be retained for punishing the male patrons of prostitution, in cases where these are free from disease, and for punishing property owners who allow their premises to be misused. In the past it has been practiced mainly to produce revenue or court fees, and where most "intelligently" administered it resulted always in a fine measured by the roll of bills in the prostitute's stocking, so there was no danger of her "laying it out" in jail through inability to pay. In certain jurisdictions which could be named, a fine of $\$ \mathrm{r}$ and costs (which amounted altogether to $\$ 12.50$ ) was the standard for this offense. A court which consistently imposed fines high enough to break up the business was almost unheard of before the war.

Institutional Care Necessary.-The ideal penal treatment of prostitutes includes thorough medical and mental examination of the woman. If found to need institutional care for life, she should be committed to a colony for the feeble-minded. Otherwise she should be given an indefinite commitment to a reformatory, where her diseases can be cured so far as is possible, where her will power can be stiffened up by several years of discipline of the right kind, and where she can be taught some gainful occupation that will not expose her too continually to the solicitation of men, nor to the temptation of soliciting them. Such a program naturally involves a great increase in the number of reformatories and in the personnel to run them, inciuding trained psychiatrists. It also involves a large increase in the number of institutions for the feeble-minded and others requiring lifelong custody. It seems possible that some of the army camps could be converted to this purpose. While the program is costly of execution, it is less costly in every way than the present state of affairs.

Commercialized Prostitution Easily Destroyed.-Given the necessary machinery, the actual job of repressing prostitution by law is, as indicated above, much smaller than has sometimes been thought. Critics have harped on the fact that "you can't change human nature" until some of them have actually believed that commercial prostitution-and it is commercial prostitution, it must be remembered, which is principally responsible for the spread of venereal disease-could not be eliminated. The underworld has been particularly assiduous in spreading this propaganda. 
The war experience has shown, however, that the business of prostitution can be broken up with relative ease. Really all that is necessary is for the denizens of the underworld to realize that the city is in earnest, and they will quit, for they can flourish only with police protection, active or passive. Not only can honest police administration break up this business with relatively little difficulty, but it can even be done by a thoroughly corrupt police force which has been assured that it will lose its job if it does not get rid of the prostitute, pimp, and procurer. When it sees that a city administration means business, the underworld will not fight. It may be laid down as axiomatic that the existence of any considerable amount of the traffic in women in a city proves that the city administration, whatever it may say on the subject, wants commercialized prostitution there.

Law-Enforcement Commituces.-Of course, when a city has once been more or less cleaned up it will not stay clean, any more than an apartment or a street will stay clean without continued work. Police enthusiasm flags just as does that of other people. To keep up a continued campaign, therefore, it has been found desirable in many instances to have a group of influential citizens with a paid executive officer who can keep in touch with all departments of the work, smooth out difficulties that arise, and assure the police that they are being watched by their masters, and that efficiency will be appreciated as well as inefficiency reprobated.

In almost every state there is plenty of law to repress prostitution. The difficulties lie not in securing laws but in enforcing them. But the technique of this has been worked out all over the United States, and henceforth any city that wants to get rid of prostitution can do so if it will but make the effort.

\section{MEDICAL MEASURES}

On the medical side the general outline is simple. Nothing more is necessary than to treat venereal diseases just as other infectious diseases-e.g., smallpox, typhoid, cholera, or yellowfever-are treated. It is required to keep up all routine sanitary measures, which in this case means law-enforcement in the sense outlined above, and then when a new case of the disease 
is reported to trace it to its source, isolate the source and prevent further infection from it.

Cases Must be Reported.-This means that doctors must report their cases, and nearly all states now require this by law. In most states the physician reports by a number rather than a name, thereby securing privacy for his patient as long as the latter complies with the rules laid down for him. A greater effort than hitherto should be made to investigate the individual sources of infection and render them harmless. This will require, among other things, more hospital facilities, both free and pay, together with compulsory quarantine for both men and women whose known conduct is such as to indicate that they will not properly safeguard the public of their own accord.

More Clinics Necessary.-It will require a great increase in both free and pay clinics, open at night for the benent of those working during the day and with adequate social service departments to follow the cases into their homes, educate and protect the families, and ensure that the patient continues treatment until cured. This is a particularly difficult task in syphilis, where a cure usually requires two or three years.

Quack and Nostrum Must Go.-It will require ruthless suppression of the quack doctor who preys on "men only" and of the proprietary "cure" for gonorrhea which spreads more disease than it cures. Indeed in Arizona the bealth department found justification for suppressing the sale on the ground that it tended to disseminate infection.

Venereal diseases have so long been in a fog of ignorance, prudery, and bigotry that it is difficult to get even medical men to put them on the same plane with tuberculosis and bubonic plague. But that is where they belong. If the public can be educated to the fact that in principle they should be dealt with in the same way as any other diseases of serious and communicable nature the battle will be half won.

\section{EDUCATION}

The need of universal education in regard to social hygiene is now so vrell recognized that it need not be argued. As to the way in which this should be given there are differences of opin- 
ion. It is becoming clearer and clearer, however, that emphasis must be laid on continence for the male, ${ }^{3}$ since it is his demand, in large part, that creates the supply of prostitutes. The photoplay has been used with great success in this work. On the whole, the lack of men and women to do the work and of money to do it with is the chief obstacle to education. There is no lack of methods, at least for use among adults.

One point here cannot be overemphasized. As the control of any infectious disease is sought through the prevention of infection rather than through the cure of those already infected, it is imperative that education in regard to the venereal diseases be not limited or even primarily directed to the dissemination of knowledge about the diagnosis and cure of such diseases, important as that knowledge is. The education that will be most useful in the long run is that described as social hygiene in the broadest sense, including an intelligent study of the biology of sex, sounder views of the marital relation, a new canonization of love, and emphasis on the supreme nobility of parenthood.

\section{PROTECTION OF GIRLS}

Measures to protect the young girls of the community and keep them from drifting toward a career of prostitution are among the most important from every point of view. But few communities have made any attempt to supply them. Protective workers to restrain the wayward girl who is on the border line, policewomen to deal with female offenders, and probation officers to keep track of them after they have passed through the courts are universally needed. Detention houses should be provided in every city so that the girl who has never before been in the

'In connection with commercialized prostitution, the continence of the male is most important because (a) the number of male patrons is much greater than the number of prostitutes, and (b) women of the professional prostitute class being mostly of inferior mentality and lacking in inhibitions, it is a waste of time to try to teach them continence. But in connection with the larger program of social hygiene, it is in some communities quite as necessary to teach the need of continence in the female as in the male. Biological research in late years has firmly established the social value of monogamy and the singla standard of sexual norality, which must therefore form the basis of all progress in social hygiene. 
hands of the law will not have to be thrown in with hardened criminals and stamped forever as a jailbird. The "Big Sister" movement is promising in this connection.

Education of the girls, and of their mothers, is needed-that goes without saying. Much more careful supervision of amusements is essential in most cities. In this connection the public dance hall raturally comes to mind. It has been a source of contention for years, but the experience of the war has not cleared up its status. It has been pretty definitely found, however, that dance halis where the girls are paid a certain sumusually $2 \mathrm{I} / 2$ cents or 5 cents-each time they dance with a man, tend to create new prostitutes. The War Department's policy has been to suppress such places.

\section{RECREATION}

Recreation is closely connected with the foregoing topic. But it is inextricably tied to the whole campaign against venereal diseases. It must not be forgotten that the primary purpose of the War and Navy Department Commissions on Training Camp Activities was largely to protect the men in uniform from venereal diseases. Their inception was in the experience of the Army on the Mexican border. Raymond B. Fosdick, chairman of the commissiors, has given a graphic picture of the great base camp for General Pershing's expedition at Columbus, New Mexico. There was not a decent place of recreation in town, not even a room where a man could sit down and write a letter home. As a result the soldiers almost inevitably drifted into the flourishing red-light district. They would start just to kill time and would end too often by destroying their health, to say nothing of their morals. Mr. Fosdick felt that the prostitutes should at least have a little competition. The endeavor of the War Department in the cantonments was to keep the men so agreeably cccupied at all times that they would, in any event, not be driven into the house of prostitution from sheer boredom.

The experience of the War Department here can easily be generalized to fit all communities. More recreation of the right kind is needed by both sexes and at all ages in nearly every American community. This problem is a specialized one which is in the hands of its own students. Consideration of it in de- 
tail is outside the scope of this discussion. It need only be said that every step made toward an adequate recreational program is a step away from prostitution and venereal disease.

\section{$1 \quad$ SUMmary}

To sum up: The war bas brought the venereal diseases out into the light of day. It has proved, by actual experience, that they can be brought under control just the same as any other infectious diseases, if the accepted measures of epidemiology are applied to them. The task is costly, but the price of neglecting it is national decay. 


\section{CHAPTER XXVII \\ RECREATION AND PLAY}

\section{By Henry S. Curtis ${ }^{1}$}

Formerly Secretary of the Playground Association of America; organizer of play movements; writer and lecturer on play

The play movement, which has swept over the United States during the last two decades, has been world-wide in extent. It had its beginnings in Germany and in England. In the German movement there are two parts, one initiated by Froebel and aiming to organize the play of little children for educational ends, the other developed by Johan and being largely military in purpose.

In England the movement has arisen primarily from the abundance of leisure of the titled classes. In America it has been rather a social movement, arising from the realization that idleness bred delinquency.

The first city in America to take up the movement was Boston (1886). But this step had very little influence on the rest of the country, and the significant beginning was about ten years later, when the School Boards of Philadelphia and of New York City made their first appropriation for play.

The Playground Association of America was organized in Washington in 1906. There were at that time twenty cities in the United States maintaining playgrounds. There are now

${ }^{1}$ A.B. Yale, I895; Ph.D. Clark University, I8g8; general director of playgrounds, New York City, I89S-Igor; supervisor of playgrounds, Washington, D. C., I905-1909; 1906 organized Playground Association of America; sectetary of Playground Association of America, I906I909; since I909 lecturer and author; has organized many play systems and lectured at many universities and public gatherings; during the war, first a physical director under the Y. M. C. A., a fterwards lectured at many camps in France; author of Play and Recreation in the Open Country, Education through Play, The Practical Conduct of Play, The Play Movement and Its Significance, and Recreation for Teachers. 
more than six hundred, largely as a direct result of propaganda carried on by the national association. During the early years most playgrounds were maintained in whole or in part from private funds, usually by a Woman's Club or a special playground association.

Changed Conditions.--There are still many persons who do not believe in the organized playground because they never enjoyed its benefits themselves, but they do not realize how greatly conditions have changed since their childhood.

At the beginning of the past century about three per cent. of our people were living in cities and at the beginning of this century nearly fifty per cent., while in some of our eastern states, such as Rhode Island and Massachusetts, the proportion is ninety per cent. or more. There is reason for assuming that this proportion will increase, for farm machinery is becoming more effective and is enabling one man to work more ground. Farms are increasing about one acre in size each year, and the rural population is decreasing in all our older states. Not only is the proportion of people living in the city increasing, but the open spaces of the city are rapidly built upon, leaving less space where the children can play. In a study made in Washington of all the open spaces within The District in 1909 , one hundred and thirteen were located. Sixteen of these were built upon the next year.

The nature of farm work is changing. Fifty years ago a farmer held the handles of his plow; to-day he is riding a gangplow. Formerly he cut his wheat with a cradle and threshed it with a flail; to-day he cuts it with a harvester and threshes it with a threshing-machine. He cuts his hay with a mower, and loads it with a hay-loader, and farming is becoming a very genteel occupation. A similar change is taking place in every field of industry. And with the increase in the application of electrical and mechanical power, all heavy work is being done by machines. We can no longer depend on physical work to give us bodily strength.

As physical work is lessened the strain upon the muscle is eased, but the strain on the nervous system is becoming more severe. With the speeding up of machinery and the demand for human adjustment thereto, nervous diseases and insanity are everywhere on the increase. 
The school year has been lengthened from three or four months to nine or ten in most states and the laws compel attendance. A few years ago the age of leaving school was twelve; now it is fourteen or sixteen, and child labor laws forbid children to work. There is, therefore, little in the citics that children can do during the plastic period of muscular development and the acquiring of coördinations.

During the last two decades there has been a shortening of the working day from twelve hours to ten and then from ten hours to eight, and now there is a strong tendency in the direction of the forty-four-hour week. This has added several hundred millions of hours each year to the leisure of the working men of America. The saloon, which has often been the poor man's club, has recently been closed and it is necessary to furnish a substitute for it. All of these changes emphasize the need for places to piay, for time to play, for life in the open and for exercise to develop the body.

There are four phases to the play movement in America-the organization of play at the school, in the park, at the community center, and the general out-of-door's movement.

Play at the School.-When the school is in session only three or four months a year and the children absent themselves at pleasure the child is injured but little by a poorly adapted school. But when the school undertakes to organize nearly the whole life of the child, the play factor must be taken into account.

The early playgrounds in school yards were usually maintained for six weeks during the summer, with volunteer or poorly paid leaders, and with little apparatus. The next forward step was to pay these teachers from school funds. Then a number of systems began to keep their grounds open after school and a little later, largely due to the influence of the Gary idea, play was put into the program as a part of the school day. There are still many educational systems which are not making this provision. With the play movement has come the demand for larger school yards. Few schools are now being built on less than a block of ground, and in many cases far larger areas are secured. Many of the older school playgrounds either are covered with trees and thus prevent play or are entirely without playgrounds. In many cities these grounds are being enlarged by buying and demolishing neighboring kouses. There are probably three or four hundred 
cities in which school boards are furnishing the volley balls, basket balls, footballs and other articles of play. Where play is to be put into the program it follows that these must be furnished just as gymnastic equipment is.

High Schools.-The high schools are in a peculiarly difficult situation, as neariy all of them are located in the center of cities where land is expensive. Most of the older ones have no ground, but many are purchasing outside fields. The new schools have larger grounds. Whereas, a few years ago, the athletics of the high schools were almost entirely of the intercollegiate type, to-day there is a more extensive participation by the student body. Instead of a coach, who is hired to win games, many schools have physical directors, who are seeking educational results.

The most difficult play problem has concerned the girls. From early childhood girls are dressed better than their brothers and are required to keep their clothes cleaner. Their clothing is always a disadvantage. $\mathrm{A}$ girl in skirts and light underwear cannot as freely climb, jump or fall down. When she gets old enough to put on a long skirt, especially a hobble skirt, she might as well be put in a museum, as far as play is concerned. Her shoes are generally tighter than her brother's, and on account of the shape and high heels more poorly adapted to play and exercise. She reaches puberty with practically the same body weight but only three-fourths of the lung capacity of her brother. Yet, in every way, physical training is more important to women than to men. Every giri recognizes the value of a good complexion, which is a by-product of play in the open air, of a full, well developed chest, which results from vigorous exercise. Girls who have not had a normal physical development in youth suffer unnecessarily at their monthly periods, and because of nervousness and undeveloped physique the American woman of to-day has an abnormal dread of child-birth. Many women, also, are unable to nurse their children, and thus hurt the welfare of the child.

College Athletics.-Twenty-five years ago, college athletics in America were confined almost entirely to intercollegiate contests. To-day, intercollegiate sport is rapidly becoming a mere incident in the athletic life of the college. Universities are acquiring larger fields and each year increasing the requirements 
for participation on the part of the student body. At Columbia every student must learn to play at least six different gamesbasketball, volley ball, hand ball, football, baseball, tennis-and he must become proficient in at least two of these. He must learn to swim and to take part in at least two kinds of field athletics. Credits in physical training are counted for graduation much the same as laboratory work is. When we consider the dominant position of Columbia in the educational field, the number of other schools that have already taken a similar stand, and the effect of athletics and games under the S. A. T. C., it seems probable that physical training will soon be a generally prescribed course. The Department of Physical Training has a new status and dignity in all universities, and the tendency is to give the Director the rank of full professor on the faculty.

Although the significant development in college athletics has been furnishing athletics and ezercise to the general student body, there has been no decrease in intercollegiate sports, and many of our larger colleges and high schools now have splendid stadiums seating as many as eighty thousand people.

State Laws. - The first state in the union to pass a law requiring a certain minimum amount of physical training for children at school was Illinois (June 26, 1915). Since that time twelve other states have followed-New York, New Jersey, Nevada, Rhode Island, California, Maryland, Delaware, Michigan, Maine, Oregon, Utah and Washington.

In the state of Illinois no provision was made for the enforcement of the law and it seems to have had little effect. In four other states, however-New York, California, Michigan and Utah - there is a state supervisor of physical training, and a considerable appropriation is set aside for the enforcing of the law.

The laws in the thirteen states are similar. The stronger ones require or advise annual examinations of all children with a view to the removal of physical defects. They provide from two to six hours a week of physical training and organized play for all children. In a number of states they advise or require the employment of physical directors by the cities and towns, and in several states a part of the expense of these directors is borne by the state.

Owing to the general indifference to such matters among the school boards in rural sections and in the absence of adequate 
supervision, these laws cannot be wholly effective, but they are in the right direction, and are furnishing millions of hours of play and physical training in most of the states in which they have been adopied. The Playground Association of America, which has now become the Community Service, has a national office in Washington, devoting its time to securing the passage of such a law by each of the state legislatures. Five passed such laws during rgrg. The disclosure by the draft of physical unfitness of our population has had a profound effect, and it seems probable that within a decade every state will have such a law upon its statute books.

Rural Recreation.-The rural school has been much neglected. Although located where ground may be had for one hundred dollars an acre or less, not more than four or five per cent. have an acre of ground. Often a site was selected for a school because it was good for nothing else. However, most communities are now doing better. The committee of the National Education Association on minimum standards for rural schools, recommends that three acres be the minimum size of grounds. The numbers in most schools are too small to permit playing our traditional games. Volley ball, playground baseball, croquet and tennis should be introduced. In some states where standard schools are encouraged, a certain amount of play equipment is required. On the whole play is not regarded as sufficiently important that school authorities should furnish the equipment.

The greatest difficulty in the play situation in the country is the fact that most rural teachers have grown up without the benefits of organized play, know few games, and have little interest in the matter. In many of the teachers' institutes, games are now being taught, but the number of teachers thus far reached is inconsiderable. Under the new laws of the states there should be provision to instruct the teachers in the games and athletics which are to be carried on.

Beside the state director of physical training there is also an assistant in the office of the county superintendent in some of the larger counties, whose work consists mostly of the organization of play in the rural schools. Under the New York law there are a number of rural play supervisors. Some five years ago, Maryland began the practice of appropriating several thousand 
dollars a year to hold a play festival and tournament in each county in the state.

But the large movement in rural education is in the direction of the consolidated school, and with the coming of the motor-bus and of good roads this is sure to spread rapidly. At the consolidated school there are enough children to play all sorts of games. For the most part, these schools are getting several acres of ground. In some places they are also securing a picnic grove in order to have a center of community life during the summer.

Some states have officially promoted the rural social center idea, and the rural school has been used extensively for entertainments, motion pictures, singing, and debates. With the great increase in the number and variety of moving pictures and with the possibility of securing reels through the state Departments of Education at the Universities, or the National Bureau of Education, it seems likely that this work will be greatly extended in the near future.

Probably the one thing which has done the most to revolutionize the rural spirit and bring into it the desire and opportunity for play has been the good road and the automobile, which has placed at the disposal of the farmer all the facilities of the city and has given him the opportunity to take long trips and sometimes a vacation. California and Michigan have established a county park system which owing to good roads is quite as available to the rural people as the city park system is to city residents.

The Municipal Playground.-The small municipal playground, so called, is an anomalous institution in our American cities. It attempts to furnish organized play and athletics to school children, and as such, should be a part of the schools. Such grounds are necessary in some cities because the schools are without grounds, but as they are primarily for the school children they should be operated by the school authorities and be used by various schools during every hour of the day. Under present conditions they are used only after school hours and curing the summer, and often the directors are political employees, untrained for the work.

The Cumulative Effect.-Since the time of the organization of the Playground Association of America in rgo6, there has been an 
increase of from twenty to fifty per cent. every year in the play facilities of the cities. Evidently the total effect is becoming very great. The growth is in many directions. At the new schools the grounds are larger. The play apparatus and equipment are better and more adequate. The play leaders have had training and experience. But even more important is the new spirit of play and the new realization of its value.

The Training of Teachers.-In the beginning there were no trained play leaders. Those who had grown up under the old system knew few games and had a meager conception of their value. The Playground Association of America, itself, grew out of a series of conferences, which were called by the writer, in New York in I905, with a view to developing a course for the training of play leaders. Many schools of physical education have since been developed and are giving a considerable time to training in play. The Russell Sage Department of Recreation enumerated fifty such schools in I9I2. A course in play has now become a part of the summer program of most of our larger normal schools, and from a hundred to two hundred such courses are given every year. The students now in the normal schools have had more play themselves at school and on the playground, and are better prepared for these courses than were the students a few years ago.

However, play does not necessarily belong to physical training. Play has not only physical but also social and intellectual ends. It represents the whole life of the child. It is in play that he forms his habits, acquires the ability to lead or be led, makes his friends and learns to take his place in the social world of childhood.

The Community Center.-The community center is chiefly for the use of adults. It includes evening classes, Americanization programs, evening lectures, a health center, and similar activities. It aims to bring the community together, to promote acquaintance and friendliness.

Probably the most significant movement in this direction is the utilization of the public school. The school has great advan tages. It does not belong to any religious sect or political party and arouses no antagonism. The old-time school was not weil fitted to be a club house, as it had only class rooms, and these were furnished with immovable desks, much too small for adults. 
The modern school buildings are usually provided with auditoriums, and some with moving-picture machines. It is, therefore, possible to hold public lectures, concerts, oratorios, theatrical or moving-picture performances. There is no rent charged and the audience is assured so that these forms of recreation can be furnished more cheaply at the school than elsewhere. A majority of our new city schools, also, have a gymnasium, and many of them a swimming pool. These have always been the chief drawing cards at the Y. M. C.A. and the Y.W. C. A. The domestic science rooms give an opportunity for furnishing light refreshments at entertainments and dances, or even for a real community supper.

Reading is a large element in the recreational life of any community, and the school and the community both need the libraiy. In the new school buildings of Erie, Pa., Gary, Ind., and Grand Rapids, Mich., and a number of other cities, there is, as a part of the building, a community library which may be reached either from the school or from the outside.

Many of the new schools are seated with Multhrop or similar desks, which are not attached to the floor and may in a feiv minutes be replaced by chairs for adults. Each of the new schools of Alameda, California, and Houston, Texas, has one or two social rooms for the Mothers' Club or the Community Civic Club. In several of our cities, certain school grounds are lightes for playing volley ball, basketball, or playground baseball, at night.

The community center should be the outgrowth of the iife of the people, and should represent local interests and leadership. In many cases it is largely supported by membership fees and managed by local committees. In others, the entire expense is borne by the local board of education. One hundred and onc cities maintained community centers during the year I9I8.

The school, however, is not to be the only center of community life, and in cities where the schools are without grounds, auditoriums, gymnasiums, swimming pools or domestic science departments, it is difficult to use them as community centers. In Chicago magnificent buildings have been erected in the parks, with facilities for gymnastics, swimming, dancing, reading and other recreation. Every church has something to offer to the social life of its community, and some churches have a great 
deal. The Church World Movement has, as a part of its program, extensive plans for the social organization of the community around the church as a center. Besides these there are all sorts of private organizations and clubs such as the Grange, Masons, Elks, which are making their contribution to recreation in the community.

Memorial Buildings.-Soon after the entrance of America into the World War, an agitation was started to secure suitable memorials in the form of community buildings. It was thought that much of the art which commemorates the soldiers of the Civil War is not of a high type and does not add to the attractiveness of the cities, or perform any useful purpose. It was suggested that a building in which the community might gather and where the veterans of the war might meet for reunions should be selected as a memorial, and that this building could be furnished with trophies, pictures, and statues which might represent the conflict. A national committee for the promotion of memorial buildings was organized, but was later merged with the Playground Association, now Community Service, as one of its bureaus.

Three hundred and six of these buildings have thus far been authorized and a number of them are already completed. In the state of Indiana a bill was passed by the last legislature which provided for the erection of such a memorial building by the state near the Capitol in Indianapolis, and that one should also be erected in each county near the county court house. Congress has authorized a memorial building in Washington to cost $\$ 10,000,000$.

These buildings will have auditoriums, trophy rooms, and most of them social rooms and gymnasiums. In a good many cases there will be athletic fields or playgrounds attached to them. These buildings should add considerably to the recreational opportunities of the communities in which they are placed.

The Community Service Association.-Early in the war the Playground Recreation Association of America, which had been for ten years promoting recreation and organized play for children in American cities, was asked to take over the problem of recreation for the soldiers at military camps. Its annual expenditure had been about one hundred and fifty thousand dollars, but in the first year of the war this sum was increased to about 
four millions in War Camp Community Service, and in the second year to fifteen millions. Something over six hundred cities were organized.

The coöperation of the communities around the camps was helpful, community singing and dramatics were begun, and in many cases community houses opened.

The Playground Association has changed its name to Community Service, and is now organizing in a permanent way one hundred and twenty of the communities, where War Camp Service had been maintained. It is seeking to promote acquaintanceship and friendliness and the coöperation in community undertakings among all groups. As such, it will help to make our cities more attractive as places of residence, to promote the Americanization of foreigners, and perhaps through its community singing, pageantry and drama ultimately to create a new form of art.

Commercial Recreation.-Commercial recreation facilities include skating-rinks, dance halls, pool rooms, moving pictures, theatricals and musical entertainments. The sex appeal is an important means of securing attendance, and until recently at dance halls and pool rooms especially drinking has been encouraged. Our age is too sex-conscious, and anything which causes it to become more so is an unqualified evil. As the sex appeal is one of the most effective devices to promote the spending of money, it cannot well be separated from commercial recreation. Taking these institutions over by the public would serve the common good.

In several cities, chaperones are now required at all public dances, and the moving pictures are censored by Departments of Public Recreation. In some of our new public schools, and most of our Y. M. C. A.'s, there are bowling alleys and pool rooms. Dancing is provided in schools, community clubs, churches and many other public or semi-public places. Most of our new high schools and elementary schools are provided with moving-picture equipment. The community pageant and drama, and community singing, are being organized in many cities by paid leaders, employed by the Community Service of New York, for example, and by the extension departments of a number of our universities. It seems likely that within a few years a large part of the drama of the average city will be furnished either by 
volunteer organizations or by community. players who are paid by the city, as is the case in Northampton, Mass.

In connection with our new high schools there are facilities for dramatic performances and it is quite possible that the better type of drama could be routed from city to city to perform in the high schools. During the war, every kind of musical and dramatic performance was furnished free in our military camps, both at home and abroad. The theaters of Greece and Rome were free to all citizens, and most of the large theaters abroad are subsidized. Apparently we are moving in the direction of making music and the drama an expression of the community life and, therefore, free or at least cheaper.

The Recreation Commission.- The play of school children should be organized under the local board of education, because play and physical education are, or should be, a part of the program of the school. School boards are also organizing much social recreation for adults through the community center, but the organization of the recreational facilities of the parks, boulevards, outlying camps, and vacant spaces, the control of bathing beaches and amusement resorts, as well as the development of the community drama, singing and pageant cannot well be handled by a board of education. In a number of cities, notably Los Angeles and Oakland, California, and Detroit, Michigan, there are strong recreation commissions.

The powers of these commissions are expanding, and it seems likely that in the end they may have control of the parks and boulevards, of the outlying camp sites, of the licensing and regulation of commercial recreations, and of the organizing of community pageants, musicals and dramas. In fact, the possibilities in such a department are limited only by the vision and efficiency of the person in charge. Efficiently organized it might do much to increase neighborliness and make the city more attractive as a place of residence.

Park Playgrounds.-Park is a French word and referred originally to the private gardens and hunting preserves of French châteaus. The first parks were aristocratic institutions and were mainly used by people with carriages. The park, a democratic means of recreation, is older than the playground, as the first organized park was laid out in this country about seventy years ago. During the last two or three decades there has been a 
great development of athletics. Under school authorities, play is definitely organized for educational purposes. It has been the aim of the park departments rather to furnish the opportunities for play. This play represents, for the most part, games which require a large amount of space, such as baseball, football, tennis, swimming in summer, skating in winter, boating and golf.

Inasmuch as parents coming to the park bring their children with them, parks usually provide swings and seesaws but without supervision, in the expectation that the parents will look after their children. The development of the small parks of Chicago and a few other cities is a radical departure from this rule and represents a type of activity and organization such as seems to belong more naturally to the school.

The Outdoor Life.-Not only has there been a great increase in the facilities for organized play, but there is a greater fondness of the outdoor activities. There is a great increase in picnics and outings. Many parks now make provision for picnics by furnishing tables and places for fire, and in some cases even wood. In a number of the large parks in the west there is provision for campers, and our National Forest Service is advertising the national forests as the great national playgrounds. The Boy Scouts, the Girl Scouts and the Campfire Girls are all giving new emphasis to the camping idea, and an ever larger percentage of our older boys and girls are spending part of each summer in the woods. During the last decade, more than half of all the first-class councils of the Boy Scouts have acquired permanent camp sites. A number of Young People's Societies or other religious organizations have done the same, and a considerable percentage of the cities have acquired sites, usually through the department of playgrounds. Los Angeles has three. The first of these is located in the San Bernardino Mountains, seventy-five miles from the city. At this camp one may have two weeks in the woods at a cost of ten dollars.

Walking trips are growing more popular. The Mazima Mountain Club of Portland, Oregon, the Sierra Club of San Francisco, The Appalachian Club of New York and Boston, for years have had a series of walking trips for Saturday and Sunday afternoons, and summer trips from two to six weeks in duration. All the mountain clubs of the country have since become associated. If this movement grows into a national organization 
of walkers with definite insignia, with directions and with maps for each section, it should popularize cheap and invigorating recreation.

The automobile is doing much to promote outdoor life and sight-seeing. There are probably twice as many automobiles in the United States as there are in all the rest of the world. The number of people taking motor trips across the continent is increasing and the enormous program for road building upon which we have now embarked seems to promise much for the future of this form of recreation.

The Effect of the War.-The direct effect of the war upon recreation for children in this country was, in many cases, to curtail appropriations and, by taking these children into gardening or other forms of work, to reduce the number of children in attendance. In some localities playgrounds were discontinued, but for the whole country the reports of the Playground Association show a slight increase in number of playgrounds and workers in I9I8 over I9I7, though the attendance of children was less in many cases.

The great development resulting from the war was in recreation for adults, and here the progress of a century, seemingly, has been made in the last two years. At the beginning of the war we were spending about ten cents per capita for children. During the war we spent in the neighborhood of fifty dollars per capita, or five hundred times as much, on the recreation of our soldiers in this country and abroad. Around the camps the War Camp Community Service organized the facilities of the cihies to render hospitality to soldiers on an unprecedented scale. Hostess houses were established, where, under proper chaperonage, girls and women might entertain the soldiers. Club houses in town, with facilities for games and dances, were opened to them. Many churches gave weekly suppers, and the soldiers were invited to homes for dinner. They were taken on automobile trips by clubs. Various special entertainments and athletic meets were planned for them.

In the camps, mainly under the direction of the Y. M. C. A., there were moving pictures, public lectures, dramatics, musicals, and boxing matches so that some form of entertainment was given every evening of the week and often in the late afternoons. In the camp fields there were football, basketball, base- 
ball, volley ball and mass athletics nearly every day, and nearly all of the men learned to play. Sunday athletics and boxing were popularized. In France this organization of athletics and entertainment was carried still farther. There were excursions to points of interest, including châteaus, cathedrals, and fortresses. Every four months each man was entitled to a ten days' leave, during which he was the guest of cne of the great rest resorts in France, which had formerly been the exclusive possession of the titled classes, and put up without cost at one of the best hotels.

The Y. M. C. A. buildings in France were social centers such as have never existed before. Every evening of the week great numbers of men assembled there to write letters, to read, to see pictures, to attend the theater or to take part in boxing and wrestling.

The effect of this organized recreation was evident, although the statistics have not yet been published. The outdoor exercise kept the men in good physical condition and gave them initiative and fighting spirit. In the long rainy days of winter when there was nothing to do and the barracks were unlighted and unheated, the entertainments offered at the "Y" or at the huts of the Knights of Columbus were the only things to keep the men from absolute homesickness and despair. At the beginning of the war, the venereal disease rate in the army was eight per cent., and it remained there despite all the methods of prophylaxis which the army was able to employ, until organized recreation was established at the camps and the surrounding communities. Then the rate ran down to one and ninetenths per cent. in American camps and to three and fourtenths per cent. in camps in France. When this rate is compared with the nineteen per cent. found in our army in the Philippines, and fourteen per cent. in our army in Porto Rico, and eleven per cent. in camps in America during the SpanishAmerican War, the value of public recreation in the promotion of public morality is demonstrated beyond doubt.

The Outlook.-On the whole, the outlook for play and recreation in America is very hopeful. In nearly every branch we have been making steady progress for twenty years. The war has given a tremendous stimulus to community organization and cooperation, and has made American communities conscious of 
their power. There are four essentials to the development of recreation. They are leisure time, surplus energy, a play spirit and money. The United States has all of these elements at present as no other country has or ever has had them before. The shortening of the working day has increased free time and surplus energy. Our play spirit has been growing steadily for twenty years, and America alone, of the great countries of the world, possesses the means to carry on her program of social recreation. 


\title{
CHAPTER XXVIII
}

\section{NERVOUS STRAIN AND MENTAL HYGIENE}

\author{
By E. David FriedMan ${ }^{1}$
}

\author{
Adjunct Neurologist, Bellevue and Mt. Sinai Hospitals; Instruc- \\ tor in Neuropathology, University and Bellevue Hospi- \\ tal Medical College
}

\section{DEFINITIONS}

Somatic: Relating to the body.

Glands of internal secretion: Structures such as the thyroid gland in the neck, the adrenal gland above the kidney, the pituitary body of the brain, furnishing the biood with hormones, substances which seem to be necessary for life.

Trauma: Physical injury.

Hyper-thyroidism: A disease due to excessive activity of the thyroid gland.

Arterio-sclerosis: Hardening of the arteries, occurring with advancing age, or occasionally early in life, due to specific poisons.

Locomotor ataxia: A disease of the spinal cord due to syphilis.

Moron: A mild form of mental defectiveness.

Psychosis: Any mental disorder.

Neurosis: An affection of the nervous system, attended by marked functional disturbances and occurring without infiammation or any other structural change which can be detected.

Psychoneurosis: Mental disease withcut organic lesion.

Dementia-pracox: A form of insanity usually beginning at puberty and characterized by progressive mental deterioration.

Manic-depressive insanity: A form of insanity in which there are alternate periods of exaltation, or mania and depression.

General Paresis: A progressive paralysis characterized by impairment of the various motor functions and by nore or less disturbance of the nervous system. There usually is also exaltation of mind with delusions of grandeur, and final mental deterioration. The cisease is due to syphilis.

${ }^{2}$ B.S., 1903, College of the City of New York; M.D., 1907, University and Bellevue Hospital Medical College; post-graduate work in Vienna, 1908-9, and Berlin, 1913; instructor in medicine. University and Bellevue Hospital Medical College, IC13-1919; in neuropathology, I919-_-_; Herter Fellow in Research Medicine, I9I-15: assistant attending physician, Central Neurological Hospital: adjunct neurologist, Bellevue and Mt. Sinai Hospitals; contributor to journals of medicine and reurology; contract surgeon, United States Army, 1918. 
The World War was a gigantic test of scientific progress. Every branch of science was called upon to contribute toward military victory. From the medical standpoint, surgery and epidemiology have played the chief rôles, but neurology was a branch not less vital. It is the consensus of medical opinion that no new forms of mental disease have developed. The war has merely brought to the surface psychoses that are met in civil life and has increased the incidence of those forms of derangement known as traumatic neuroses, such as shell shock.

We shall discuss our problem in the following order:

(a) The effect of war on mental diseases.

(b) Means of reducing the incidence of mental derangement in the army.

(c) The treatment of the war neuroses, or the mental disturbances directly due to war.

(d) The cause of mental diseases in civil life, and

(e) The lessons of the war.

\section{THE EFFECT OF THE WAR ON MENTAL DISEASES}

War makes its influence felt in various classes of the population, the combatants, their relatives, and the general population subjected to altered social conditions. Combatants are exposed to the horrors of actual fighting and supposedly would return from the battle area stark mad, but the facts do not bear this out. The human mind is adaptable to great extremes of experience. Among the first to be called to the service, the war has merely brought to the surface latent general paresis, dementia-præcox and epilepsy. Among relatives of the combatants, the mind is dominated by anxiety for their living dear ones and by grief for the dead. The general population has been affected by economic change and social upheaval. Among the well-to-do, there have been financial losses and business worries, upsetting their mental equilibrium.

It is still too early for one to be able to speak definitely of the effect of the war on mental disorder among civilians. Weygandt, a German observer, thought that psychoses did not increase in civil life as a result of the war, but that old chronic cases acquired a war content, just as after the discovery of the $\mathrm{X}$-ray many mental cases referred their abnormal state of mind 
to the X-ray. Pollock, statistician of the New York State Hospital Commission, says: "Comparing the admissions on account of mental diseases for the period I9II to I9I4 with the period I9I5 to 19I8, there was an increase in senile cases of $5^{\mathrm{t}} / 2$ per cent.; in general paresis of 14.2 per cent.; an increase of $171 / 2$ per cent. in the manic-depressive and allied groups; an increase of 37.9 per cent. in involutional melancholia; an increase of 42.9 per cent. in dementia præcox and allied forms, but a decrease of $121 / 2$ per cent. in the psychoneuroses, and a decrease in alcoholic cases of 22.3 per cent. It may reasonably be inferred that the war, like all great emotional disturbances, has been a precipitating factor in the development of mental disease among the civilian population.

Mental Derangement in the Army.--It was the Franco-Prussian War that first gave rise to statistical studies along these lines. Mental disease increased in the Prussian Army during the war and for a short time after its conclusion. However, mental disease in the German Army in peace times showed a steady increase for the period of 1882 to 1912 , which was probably due to increasing recognition of mental disorder by the military surgeons. During the Spanish-American War, the incidence of mental disease in the United States Army rose; it fell only after the Philippine insurrection. During the Boer War, there was an increased incidence of mental disease; it fell considerably one year after the conclusion of peace. During the Russo-Japanese War mare than one-third of the officers suffered from chronic alcoholism, general paresis and neurasthenia. Among the soldiers there were many cases of epilepsy, alcoholism and confusional insenity. Voss found that 3.I per cent. of the officers and 3.6 per cent. of privates in the Russian Army showed evidences of traumatic psychosis. The relatively lower incidence of mental disorder among the Turks and Balkan peoples is explained by their decreased consumption of alcohol. In the United States one-fifth of the discharges of enlisted men in time of peace were due to mental disease. Of the total number of Canadians invalided home in this war, nervous and mental cases constituted ten per cent. Nervous and mental diseases accounted for 7 per cent. of the discharges from the British Army up to May, 1918. Our own statistics are not fully available at the date of writing.

Types of Derangement.-True psychoses were rare in the 
army. Some observers found manic-depressive cases as well as hypomania. For instance, soldiers developed a battle psychosis in which they rushed from their trench alone as if in attack on the enemy. These cases may be recognized by their excessive talkativeness and psychomotor unrest. Epilepsy was fairly common. The effect of war on epileptics no longer is doubted. They are often somnambulists, roaming about and often absent without leave and committing unconscious infractions of military discipline. The clouded mentality of epileptics may lead to disaster. The occurrence of many cases of locomotor-ataxia in the 'eighties in Germany was said to be due to the results of infection with syphilis in 1870 . War sometimes is the immediate occasion which brings a latent tabes or general paresis to the surface or aggravates mild cases. Most cases of dementia-præcox in the army antedated war. In view of the fact that the age of incidence of dementia-præcox is the same as the age of early military service, the occurrence of this type of insanity as a result of war is not at all surprising. If imbeciles, morons, feebleminded and idiots are not rejected at the entrance test by competent psychologists, their condition is aggravated during war. They, too, are incapable of conforming to discipline and lack initiative. Alcoholic psychoses were rare in the army because for good reasons the use of liquor was forbidden. There was a mobilization psychosis which was due to dislocation from civil life and to the uncertainty of the life of the soldier. Cases of imbecility, degeneration and hysteria become especially prevaient. As a result of the national exaltation of mind which accompanies the initial outburst of patriotism, latent cases of mania break out.

Psychoneuroses.-The psychoneuroses constitute the most important group of mental derangements resulting from war. Psychoneuroses most frequently follow definite injury, but sometimes occur in individuals not subjected thereto. There is a smaller group of cases with obvious lesions or well marked symptoms which are the result of shell explosion. These are due to sudden atmospheric compression, asphyxiation from burial, and gas poisoning. This form of injury results in plugging of the cranial blood vessels. The larger group of the psychoneuroses consist of cases of shell shock, or war shock, in which there is no apparent physical or chemical cause for the symptoms. In the beginning 
of the war, psychoneurotics were frequently subjected to courtmartial. The military surgeons did not understand the cases until the neuro-psychiatrists called attention to them. The importance of early diagnosis and experienced treatment is indicated by the fact that one out of every five discharges from the British Army was a case of psychoneurosis." Psychoneuroses are rare among the wounded whose minds are occupied with actual injuries and also among prisoners for whom the war is practically at an end. Some psychoneuroses are the result of simple exhaustion and disappear quickly after a short respite from duty.

War neuroses are really due to both faulty heredity and the lack of an adjustment to environment, which is difficult for sorne individuals even in times of peace, and much more so in war. Some persons never find themselves, and are confused in their responses in times of stress. The predisposing causes of war neuroses are, first, hereditary, such as alcoholism, insanity, epilepsy, tuberculosis or constitutional degeneration, and, secondly, personal, such as hypersensitiveness, moodiness, worry, anxiety, fatigability, head injuries, indulgence in vice, mental deficiencies, insomnia. In the army an individual subject to such influences is thrown into a rigorous and continually changing environment to which he fails to adjust himself. He becomes a victim of doubts and fears, and his defects come to the surface. Exhaustion from overwork, loss of sleep, insufficient food, monotony of drill and trench life, worry over those at home, fatigue of long marches and exposure, fear of failing in duty, pain and discomfort of wounds and injuries, exposure to the sun, anticipation of a charge, the killing of a comrade, the fear of shells, of the ground opening beneath him to engulf him, the sights of horror and destruction about him, all tend to fan into a flame the predisposition toward a neurosis. The exploding shell is the last straw which upsets his mental equilibrium; "it presses the button." Even a normal man may occasionally develop war shock, as a result of external factors. Occasionally a single horror may bring on a neurosis. Kennedy, a noted American neurologist, for example, mentions the instance of a British officer at

"These are the figures given by Sir John Collie, President of the Pensinn Board on Neurasthenia of Great Britain, from his analysis of $\mathbf{1 7 0 , 0 0 0}$ cases. 
Gallipoli, who jumped on to what he took to be solid ground and found himself in a mass of decomposing Turkish dead. $\mathrm{He}$ promptly developed a psychoneurosis. ${ }^{3}$ Weygandt, a German observer, mentions the fact that the drowning of great numbers of Russians in the Masurian Lakes after the battle of Tannenberg shattered the nerves of many Germans who heard the shrieks of the drowning enemy during the night. Soldiers so affected frequently go through dreams of battle as though they were reliving their experiences. They have "trench" dreams and jump out of bed "over the top." They duck beneath their bedclothes on hearing any sound. The blow-out of a tire produced the effect of a shell explosion on one case. "Catching shells" to ward them off is one of the forms of defense reaction. Stewart Paton, an American psychiatrist, has described an "avoiding reaction," in which the embryo of a guinea pig would turn its head away from a stimulus, thus proving the very fundamental character of the defense reactions of the psychoneurotic.

Neuroses are explained as a reversion to the mental attitude of civil life upon the part of the soldier. In war, the herd instinct dominates conduct; in peace, the instinct of self-preservation is uppermost. A neurosis would then be the loss of the normal war attitude and the cropping out of personal fear. As a result of the development of the neurosis the soldier may even express pity for the foe and resentment against his own country. The psychoneuroses have been ascribed to the loss of the services of the higher centers of the brain and to the uncontrolled supremacy of the reflexes.

Some observers note a relation between the war neuroses and the glands of internal secretion. This relation is confirmed by the frequency with which mild forms of hyper-thyroidism are seen in recruits, observed by Mendel in Germany and by Brooks in this country. Cannon demonstrated that in fear, rage and other emotions the adrenal glands are very active. This is evident in the dilated pupils, the pallor, the rapid heart action and the general attitude of the organism. According to Cannon there is in fear a mobilization of all the physiological resources. Apparently continued demand due to the repeated emergencies of military life eventually leads to exhaustion of bodily energies. Babinski attributes the development of psychoneurosis to sug-

\footnotetext{
s liennedy rejects the term shell shock, and calls it simple nervousness.
} 
gestion, ${ }^{4}$ and has suggested a new name, pithiatism, from the Greek for persuasion. His theory is corroborated by the fact that there was a higher incidence of psychoneuroses among the automatically responding Germans than among the more ind:vidualistic Frenchmen.

There have been various classifications of these disturbances. The most acceptable is the division into hysteria or suggestion neurosis and neurasthenia or anxiety neurosis. Both of these are found in civil life.

Hysteria or Suggestion Neuroses.-The symptoms of hysteria are manifold, inability to walk, paralysis of various muscles, loss of speech, deafness, forms of anæsthesia and convulsions and clouded mental states. Salmon, for example, mentions a few suggestive cases of hysteria. A soldier who bayonets his enemy in the face may develop a facial spasm. Hysteric blindness occurs in those who see horrible sights; hysteric deafness in those who hear the cries of the wounded. Aphonia, or loss of speech, may be the result of suggestion at a critical moment. For example, a noisy private under nervous tension before an engagement was ordered to "shut up." $\mathrm{He}$ developed mutism immediately. There may be a loss of memory with occasional lapses of consciousness. One soldier, for example, automatically ran up and down a trench at the beginning of a bombardment, until a sharp command from his officer brought him to. Another left his trench and found himself walking alone along a lane; a third case on hearing the peal of thunder dashed from his trench to the nearest tree, where he crouched, trembling in fear. A fourth mimicked the hissing and bursting of a shell, constantly repeating the syllables, sst! boom!

Hysteria occurs especially in the private. The aim of military training is to make the soldier respond automatically under all circumstances so as to act in harmony with his fellows. He must sink his individuality and act on suggestion. For example, Ferenczi, during his military service, observed an iniantryman fall asleep instantly at the command of his lieutenant. This increased suggestibility upon the part of the private is favorable to the development of neuroses. Indeed, Russell in England and

- The psychoneurotic prefers to resort to generalities, or class judgments rather than to solve his problems. Therefore, Christian Science and similar cults appeal to him, for they take him away from himself and relieve him of the burden of meeting the realities of life. 
Babinsli in France attribute hysteria to careless suggestion on the part of the examining physician. The ridiculous exploits of the gay tailor of Koepenick, clad in the cast off clothes of a captain, bear evidence to the suggestibility of the private, particularly in Germany. While it is the rule that only the predisposed develop hysteria, Marburg, a German observer, found that healthy stolid peasants were affected with mutism, paralysis and convulsions. The symptoms of these individuals are really defense reactions. Their symptoms, unconsciously exaggerated, are very real to the sufferers. The hysteric capitulates to his symptoms, and unconsciously does not want to get well. His incapacity is a refuge to him and a means of escape from service.

Neurasthenia or Anxiety Neuroses.-Anxiety neuroses are much more common in officers, and arise from the conflict between the instinct of self-preservation and the desire to conform to the prevalent social standards according to which fear is reprehensible, except in children. In civil life, the adult has few fears. In war, however, the situation is different, and while the private solves the difficulty by succumbing to mental disability which incapacitates him for service the officer can not solve the conflict in the same way. He "carries on," depressed by exhaustion, illness or strain until finally the instinct of self preservation gains the upper hand. The difference in education between the officer and the private makes the officer less satisfied with disability as a means of escape. He has been taught to suppress fear. The private, because of obedience by suggestion, can tolerate a bad superior officer. He is less affected by narrow escapes and disgusting sights because conviviality and freedom from restrictions permit blowing off pent-up feeling. He can give vent to his emotions in the "oath of the trooper." The officer, however, cannot sidetrack his emotions in the same way. He must practice repression even in the face of great danger. The difficulty of keeping up an external calm leads to anxiety and to the fear of being unable to control his men. He acquires. a sense of unfitness, and finally breaks down completely. The symptoms of neurasthenia are extreme fatigue, pallor, exaggerated reflexes, sweating, vaso-motor symptoms with alternate flushing and pallor, cold hands and feet, nervous exhaustion, sleeplessness, lack of concentration, a sense of oppression and anxiety, an attitude of despair. 
MEANS OF REDUCING THE INCIDENCE OF MENTAL DERANGEMENT

IN THE ARMY

The means of reducing the incidence of mental derangement in the army were the result of the experiences on the Mexican border. The men were bored by the monotony of camp life; they had nowhere to go, reading matter was not available. Therefore many went to the saloons, and to the red light districts, where at least they secured relief from ennui. This condition was regarded as the inevitable accompaniment of camp life until Raymond B. Fosdick set out to create a normal environment for the soldier. Out of his efforts grew the Commission on Training Camp Activitics. For the first time in history the authorities looked beyond the machinery of fignting to the personal and moral welfare of its soldiers.

When one considers that each training camp contained about forty thousand men, but no women or children; that there was no home life; that men were cut off from all relationships, clubs, churches, or coileges; that there were neither libraries nor theaters, neither athletic felds nor ball rooms, one can readily conceive the tremendous call upon the soldier's ability to maintain his mental equilibrium. It became the object of the commission to achieve a wholesome and diversified environment and to suppress alcoholism and immorality. Dr. Cabot's theory that a normal life needs work, play, love and worship was applied to the military régime. The men were kept occupied almost continually. During their leisure moments, facilities for recreation were provided, as boxing bouts, dramatic and musical performances, and singing and dancing. The atmosphere of the home was furnished by the hostess-houses. Club life and human fellowship were promoted by the Y. M. C. A. and allied bodies. Church services were held under the auspices of the various denominations. The post exchange took the place of the village store in the life of the community. The courses in English and in technical subjects constituted a substitute for the school in society. Contact with the outside world was maintained by means of newspapers, "Trench and Camp" and "Stars and Stripes." In short, the program was to create a normal human 
environment, which would require the minimum possible mental readjustment.

Other measures of mental hygiene were resorted to at the front. There was frequent rotation of men in first line trenches and rest periods were interspersed between those of military duty. Compulsory rest under discipline with regular hours of sleep were prescribed. All these means were potent factors in keeping the soldier mentally fit. Mirth among the men made war less terrible, and it was a common adage "the farther from the front, the more gloom, and the nearer to the line, the more optimism." Laughter was the best antidote to fear. The funny man of the company always had a responsive audience and the convivial comradeship of the boys helped them to withstand the strain of war. Men laughed at the freaks of shell fire. They would bet on life and death, and joke about who was going to be hit first. They often laughed in battle, and after being wounded.

The consciousness, too, of the presence of God on the battlefield undoubtedly proved among the religiously minded a powerful factor in maintaining their mental integrity. The insurance of the soldier's family in case of death or incapacity helped keep up morale. Frequent letters from home assuring the boys that all was well, that loans were over-subscribed and that the country's heart was in the war, all helped to maintain normal optimism among our troops. In the Army of Occupation in France, a university was established at Beaune some miles south of Paris, where over 8,000 American soldiers were registered as students and given the benefit of university training under teachers who vient over from the United States. This undoubtedly was a factor in conservation of mental health.

The fact that there was less idleness because everybody was helping in some way toward the achievement of the national aims was probably a considerable factor in maintaining mental equilibrium among civilians. Rich women played their part in Red Cross work, in the Motor Corps, in the War Camp Community Service work, and in canteens. Older men, formerly idle, were doing welfare work and aiding in the floating of loans. The resulting decrease in so-called nervous disorders or psychoneuroses was an episode in the war-time play, the "Inca of Perusalem," in which a nerve specialist lost his practice and served as a waiter during the war. 


\section{TREATMENT OF WAR NEUROSES}

America profited by the experience of the French and the British and established neuropsychiatric units near the front. Such a unit was part of each tactical division and a neuropsychiatrist was present in each "triage," the most advanced field hospital. A second hospital was placed on a second line near the front. The number of soldiers brought to the triage with signs of concussion and nervous and mental disease ranged from 3 to 12 per cent of the total casualties. Under favorable conditions 80 per cent of such admissions were returned to duty after a treatment of less than three days.

Treatment varied from rest and common sense to Kaufman's elaborate and typically Prussian "brutality treatment," Ueberrumpelung. The treatment usually began early and where properly carried out was successful in forty-eight hours, according to Chavigny, the French surgeon. Chance suggestion or unguarded diagnoses were avoided so as not to fix the disability and the transitory and functional nature of the symptoms was emphasized. The patients were not treated too near home in order to eliminate the sympathy of relatives. The psychic examination was private and the patient was encouraged to talk and to tell his dreams. The next day, hypnotism was practiced for a brief interval. If, after five days, there was no improvement, suggestion was practiced on the patient, awake. Reëducation was the treatment for cases of paralysis. Those with war neuroses were usually unfit for further service. For the severer concussion cases rest and quiet with protection from the mental sequelæ were necessary. To avoid fixation of the psychoneuroses physical methods were not used too early. With the unintelligent cases, hypnotism, psychanalysis, and counter-suggestion were applied. For example, W. Brown, R. A. M. C., cured a case of mutism by applying electricity to the abdomen, and asking the patient to call out "enough." The patient quickly responded and was thus cured of his mutism. To the intelligent patients, the mechanism at bottom of their neuroses was explained and the patient encouraged to practice mental catharsis, to unload himself as it were.

Brown practiced what he calls "working-off," releasing the 
emotions. His theory was that in battle fear is repressed and this internal repression finally leads to the "blowing out of the fuse" and the consequent release of fear or its manifestation in altered form. The suppression of emotion and relief therefrom is frequently sudden, for example, two functicnally mute patients were curce' when they tried to cheer on hearing that Roumania entered the war.

Drugs were of secondary importance. Cheerful and airy wards, prolonged warm baths, diversions by the use of books, games and music were all means to the desired end. Rest, quiet, sleep, agreeable environment, good food, hydro- and electrotherapy, suggestion, persuasion, hypnotism, all were used to reenforce temporarily the patient's will power. Cases were not herded, although the new cases were given an opportunity to meet the convalescents.

\section{CAUSES OF MENTAL DISORDER IN CIVIL LIFE}

Before discussing the lessons of the war, it might be profitable to review briefly the causes of insanity in civil life. The causes of mental disorder are heredity, alcoholism, syphilis and head injuries. The fact that mental and nervous diseases are often transmitted was known to Hippocrates and has been verified by hospital statistics. Even moderate indulgence in alcohol, if habitual, ${ }^{5}$ causes ultimate impairment of muscular power and coördination and of mental efficiency. Frequent drinking to excess produces the alcoholic psychoses. Syphilis is the cause of general paresis, locomotor ataxia, cerebral syphilis and of a large proportion of the cases of cerebral arterio-sclerosis. The more important mental disorders resulting from head injuries are believed to be delirium, neurasthenia and epilepsy. (Experience with head wounds in the war has cast doubt upon this statement). Contributory causes of mental disorỏer are pregnancy, child-birth, domestic infelicity, business troubles, loss of relatives, and worry or grief in general.

Particular races are predisposed to specific types of psychoses, for example, the Irish to alcoholic psychoses; the Jews, to psy-

'It can not be gainsaid, however, that occasional moderate indulgence frees man temporarily from the many restraints which society imposes, and to that extent relieves nervous strain. 
choneuroses; negroes to general paresis. Environment seems to play a rôle, for the urban population yields two and a half times as many insane as the rural population. Idleness is the short cut to mental deterioration. Work and order are essential to sanity. Occupaiion also plays a rôle. Bartenders, brewery and distillery employees and hotel waiters suffer from alcoholic psychoses, and sailors, soldiers, salesmen, from general paresis, more than the rest of the population. Physicians, engineers, architects, clergymen and lawyers show a relatively low incidence of mental disorder. Systematic education has a tendency to lessen the incidence of mental disease. There is no evidence to show that there is greater prevalence of mental disease among the foreign born than among the native population.

Conduct is the basis on which the community judges the sanity of the individual. In return for the benefits of community life, the individual owes the duty of conformity to the standards of society. Upon the manner in which he discharges his duty society passes judgment. It does not tolerate departures from the established standards. Social inadequacy and eccentric conduct are, however, not always due to mental inefficiency. Failure in adjustment is responsible for many apparent mental disorders. Men engaged in vocations which repress their native gifts often seem to depart from the normal. The mental pressure is relieved by illusions or undertakings in which the individual "compensates" for his cramping routine work, as depicted in Ibsen's "Wild Duck." Society imposes too many restrictions on human conduct and many variations from the accepted standard need not be considered abnormal. Under altered conditions, individuals who seem to be anti-secial develop virtues of a high order. For example, the Apaches of Paris proved to be most resourceful and valuable soldiers. So, too, the New York gangster, Monk Eastman, established a record for gallantry in the army.

\section{LESSONS OF THE WAR}

The lessons of the war will be discussed from the point of view of cure and prevention, under

(I) the psychiatric clinic

(2) prophylactic measures

(3) delinquency 
(4) feeble-mindedness

(5) vagrancy

(6) venereal disease, alcoholism and drug addiction

(7) marriage

(8) immigration

(9) psychologic tests for children and adul ${ }^{+}$

(IO) popular education in mental hygiene

(I I) mental prophylaxis in industrial life

(I2) social medicine.

On January I, I9I8, there were 239,820 insane patients under treatment in institutions in the United States, which number shows an increase of 3 per cent over I9I 7 .

What can be done to prevent the enormous human and financial toll taken by the mental diseases? Prevention is the most efficient means of combating them. The seeds of insanity are immoral habits, excessive use of alcohol, drug addiction and bad heredity. Insanity is no longer regarded as incurable. In fact, 25 per cent to 30 per cent of the admissions to state hospitals can be cured, 25 per cent may be returned home without harm to the community or to themselves and of the remainder, obliged to stay in institutions, 70 per cent may be taught useful work.

The Need for Psychiatric Clinics.-Provisions should be made for the early treatment of incipient cases of mental disorder. The limiting of alcoholism and of lues is only a small part of the remedy. The same causes are operative in war as in peace, and to cope with them the psychiatric clinics should be established. Here the patient may be treated without the social stigma which now attaches to commitment. Within the past decade there have been established in connection with the medical clinic and the general hospital the Psychopathic Hospital at Ann Arbor, Pavilion F at the Albany Hospital, the Boston Psychopathic Hospital, and the Phipps Psychiatric Clinic at Johns Hopkins. Borderline cases should not be committed to an asylum. Treatment in a clinic would avoid breaking up the home through confinement of the bread-winner and would lead to recognition of the fact that insanity is a curable disaase and that patients may be restored to usefulness.

Such clinics exist at Giessen, at Munich and in connection with many German universitites and hospitals. Patients come and go freely, and are not committed. At Giessen there were 
seventy beds, and during the year 1907 three to four hundred patients were admitted. At Munich there were $\mathrm{I} 20$ beds, and in I 907 nineteen hundred and fourteen patients were treated. The clinic, open day and night in both cases, is in charge of trained specialists. No ward has more than ten beds and noise is thus diminished. The proportion of nurses to inmates is about one to five. In the ordinary asylum in the United States the proportion of doctors to patients is much too small for effective work, varying from one to four hundred to one to six hundred. The clinic is more expensive to maintain than the asylum but its aim is to save the case and prevent the final breakdown.

The reforms suggested include, first, psychopathic hospitals associated with medical schools for purposes of investigation and in charge of competent men for the treatment of early cases; secondly, the legal procedure in cases of mental derangement should be changed so that cases may be cared for quickly without having to go through the formalities of a commitment. The war has proven that thousands of shell-shock cases have yielded to early expert therapy.

The psychopathic hospital is exceedingly important. In terms used by a noted neurologist, the psychopathic hospital in society is like the field hospital in the army. Out-post duty would be performed near the fighting line, that is, in the courts, in the out-patient departments, in dispensaries, in wards of the general hospital and in the police and health departments. From these, the cases might then be transferred to the psychopathic hospital for observation and finally evacuated to the base hospital, the latter being the state asylums. The milder cases could be returned to the community, either recovered or under supervision. An out-patient department would be an invaluable adjunct to the psychopathic hospital because discharged cases could come back for observation and treatment at intervals. The social service department could be made use of in a follow-up scheme.

Provision for out-patient treatment is rare and a mental clinic in any community is a conspicuous institution. Compare the 73 mental dispensaries and out-patient departments in the United States with the existing innumerable clinics for diseases of the body. The psychiatrists of the army discovered nervous and mental disorders among the troops at the rate of 2,000 a month for which there were almost no facilities of treatment. One can 
truthfully say that the tendency of to-day toward extra-asylum treatment is a measure of communal efficiency. There has been recently established a training school for psychiatric social workers at Smith College to help in salvaging the human wrackage of war. This undertaking might well be continued in time of peace. Its graduates could attend to the numerous difficulties, financial, industrial, and domestic, that confront discharged patients of free hospitals. Many of the hospital and dispensary cases benefic by the help of women who can understand and meet the patient's problem. Social workers will play an ever increasing rôle in the conservation of mental health in the future.

Prophylactic Measures.-Mental factors of ten underlie the inability of an individual to earn a living and are thus responsible for anti-social conduct. Hence the school and the factory, the children's court and the prison, all are affected. The problem of the future consists in the recognition of the preventable causes of mental disease. It has been suggested that mental tests be utilized for the selection of vocation and life activity of the individual, so that he will undertake that for which he is best fit. Criminology and penology have received an impetus from the study of psychiatry. Modern criminology no longer aims at mere retribution; it seeks to elicit the good in order to displace the anti-social tendencies of the delinquent.

Anomalies of feeling and behavior need to be studied and motives for abnormal conduct should be sought. The value of these tests has been vindicated. In psychologic tests of aviators at Mineola, a noted psychiatrist, Paton, observed certain signs of "staleness"; a lack of irterest in the work, absence of confidence, nervousness in getting started, and too detailed analysis of every part of the task. These conditions were considered indications of mental inefficiency and out of six aviators, whom Paton rejected on the basis of psychologic tests and who were subsequently accepted by the military authorities, four came to grief. The social importance of these tests in the future is apparent.

Ficeblc-mindedness Controlled.-Feeble-mindedness is more common than is generally thought. Among a group of $2 \mathrm{I}, 000$ m:en rejected by the United States Army over 7,000 were feebleminded. The first step in solving this problem would be the registration of all feeble-minded persons. Since April 13, I918, 
New York has a commission on feeble-mindedness whose duties are to administer the law in relation to feeble-mindedness, to take a census of all the feeble-minded, to provide accommodations for and keep a record of all those who need custody, to prepare a commitment law, to provide clinics for feeble-minded, and finally to provide farm and industrial colonies. Virginia, Pennsylvania and Kentucky have also taken steps in this same direction.

Feeble-mindedness may be detected in the school, in the juvenile court and in the reformatory. Because of the compulsory education law the school is the most important from the standpoint of registration. The following agencies also could be made to serve in the detection of feeble-minded: Probation officers, orphanages, societies for the prevention of cruelty to children, public charities, lodging houses, charity organization societies, clinics and hospitals, and finally mental hygiene societies. The registration of the feeble-minded is of value in cases of subsequent delinquency, vagrancy and pauperism. The means of determining feeblemindedness vary. A standard method is the Binet Simon test on an age basis, and the study of the family history, the economic condition, and the moral reactions of the case.

Special schools should be established for feeble-minded children, with kitchen, shop, gymnasium and music class. Nature study, manual training, weaving, basketry and sewing should receive more attention than the three $R$ 's. Institutional care frequently makes of the feeble-minded fairly useful members of society and it is fortunate, in a way, that such individuals do not unlearn quickly. In institutions, their abilities rather than their handicaps are emphasized. This in itself prevents much irritation which is inevitable in ordinary community life, especially in the large cities. The mentally handicapped are more vulnerable to various forms of social temptation and exploitation. They react readily to suggestion. They are childish and irresponsible. With the help of an expert body of field workers some cases may be retained in the community, particularly those who without harm to themselves or others can live among their fellowmen, supported by their own labor rather than by the state.

Delinquency Checked and Controlled.-Mental defectiveness has an important bearing on delinquency. It was once thought that there was a "criminal type" with a definite physical and mental make up. Lombroso used to speak of particular stigmata 
of degeneration. But workers in criminology, notably $\mathrm{Dr}$. Wm. Healy of Boston, have helped to explode this "criminal-type" theory and have laid emphasis on the importance of the study of the delinquent as an individual. However, delinquents are by no means all mentally abnormal and not all anti-social behavior may be attributed to mental defectiveness.

Dr. Healy in a study of 1,000 cases of juvenile offenders found I 7.9 per cent. to be mental defectives, 6.9 per cent. psychopathic, and about 75 per cent. who varied in mental capacity from superior intelligence to dullness. The psychopathic clinic connected with the juvenile courts of Manhattan and allied Boroughs found that 44.6 per cent. of the cases examined in I9I 6 were diagnosed as mental defectives. The delinquency of the remaining 55 per cent. was probably due to conditions of the environment. In a study of 608 cases admitted to Sing Sing in I916 Dr. Bernard Glueck, the psychopathic director, found 58 per cent. below average mentality. For more than six years the New York Probation and Protective Society has been making an intensive study of sexually delinquent girls. The mental states of these individuals were diagnosed by means of various psychometric and psychiatric tests and by means of reactions to their social environment and to emotional crises. Careful investigations were made of home conditions, and of the history of the case at school and at the occupation. Among 500 cases Dr. A. T. Bingham found 37.2 per cent. mentally deficient, including subnormals and morons; 26.4 per cent. inferior, including psychopathic personalities; 5.8 per cent. afflicted with definite mental disease, and only 28 per cent. normal. The term subnormal was used to cover a group standing midway between the normal and the feeble-minded, capable of greater education than the latter but clearly defective in some direction.

The Control of Vagrancy.-The problem of mental hygiene touches social life at another point of contact. It is estimated that there are five hundred thousand vagrants in the United States in and out of the penitentiaries. Many are feeble-minded or suffer from dementia-præcox. Among the older, senile deterioration and chronic alcoholism are the causative factors. Tilmanns in Heidelberg examined one hundred and twenty professional tramps and found one hundred and four unrecognized insane among them. Bonhoffer in Germany found 74 per cent 
mentally unsound. Our own vagrants should be subject to examination by trained psychiatrists. Only those should be released from custody who are capable of self-support. The mentally infirm should be sent to hospitals. Some may be put to work under supervision of field workers. Detention in a.colony may be necessary for others. Such a régime instills habits of industry and makes them self-supporting so that after a time they may be released on parole. For the insane vagrant nothing is left but commitment; for the feeble-minded, segregation. It is conceded that vagrancy will probably increase after this war because many will return with impaired minds and restless after the excitement of military life.

The Control of Venereal Disease, Alcoholism and Drug Addiction.-The influence of the venereal diseases in producing mental disorder is well known. Thirteen per cent of the male and eight per cent of the female inmates of state hospitals for the insane are general paretics. The figures indicate the need of warning men and women against promiscuous intercourse. The value of continuous medical treatment in cases of infection must be taught to the public. The danger involved in the marriage of the venereally infected should be pointed out and laws relating to the reporting, quarantine and compulsory treatment of patients must be enacted. In combating mental disease, through an attack on the social evil, it should be noted that a large percentage of women prostitutes are of foreign birth and of low education and come mostly from poor homes, from the ranks of underpaid and unskilled workers. The mere recital of these factors suggests the remedy.

Alcoholism has always taken its toll of mental derelicts. Fortunately, there has been a decline in the number of alcoholic psychoses. In New York State, for example, the admissions on this ground from I 909 to I9I3 amounted to ro per cent. of the total and for the period of IgI 4 to I 9 I 8 only 6 per cent., showing a decrease of 40 per cent. in five years. Where little alcohol is consumed, cases of alcoholic insanity are few. The war has decreased the consumption of alcohol. Movies have contributed to the innocent recreation of the poor and golf-links and gymnasiums have done the same for the rich. Employers of labor have helped by insisting on abstinence among employees. The schools have taught the bad effects of the use of alcohol. The 
institution of prohibition as a climax will undoubtedly greatly reduce if not eliminate the occurrence of alcoholic psychoses.

The dangers to the human mind from the use of drugs is insufficiently known to the public. Although only a small part of the total number of drug addicts develop psychoses (only .35 per cent. of the first admissions to the state hospitals for the period 1909 to 1917 were drug addicts) their social efficiency is considerably impaired. The federal Harrison Narcotic Law provides for sale of habit-forming drugs only upon a physician's prescription and under specific restrictions. A commission of control of the sale of narcotic drugs has been appointed in New York State, which compels the registration of addicts and thus brings them within the sphere of preventive medicine. With the adoption of nation-wide prohibition the number of addicts is likely to increase. The conservation of the human resources of the nation demand that this tendency be kept under control.

Heredity and the Regulation of Marriage.-The tendency to insanity is frequently hereditary, but may be overcome by good food, fresh air, cheerful surroundings, correct habits, congenial occupation and eugenic mating. Mental disorders due to maladjustment to environment, or other non-hereditary factors, are not contraindications to marriage.

It is a biological anomaly that women morons are very prolific; according to some authorities twice as fertile as normal women. The famous Juke and Kalikak families are examples. Society must control the reproduction of the feebleminded. Women defectives of child bearing age and men defectives with strong sexuality should be put under restriction by the agents of court and state. A limited guardianship over feeble-minded should be maintained, like the curatelle of the foreign countries which supervises occupational and social relations. Perhaps, ultimately the public will be educated to the need of sterilizing these individuals. The psychopaths and imbeciles should be prevented from having children. Attempts have already been made in this direction in some of our western states. Under a better social system, society for its own protection will stress the consideration of hereditary traits in the contracting of marital relations.

In order to forestall hasty alliances it has been suggested that no license for marriage be valid unless posted for three weeks by the civil authorities and that the contracting parties be asked 
specifically whether the one wants the other and the other alone to be the parent of the offspring of the union. For reasons of mental health, childless marriages should be discouraged; an important step in this direction would be the development of economic security by means of adequate vocational training, medical care, and social insurance. Prenatal clinics are of great value in order adequately to care for the mothers and to develop such personal habits as will insure relatively healthy offspring. These would be a boon to the ignorant of our cities.

Immigration.-In order to insure the rejection of truly undesirable aliens they should be further classified. At present, only idiots, imbeciles, feeble-minded, insane, epileptics, persons of constitutional psychopathic inferiority, and cases of chronic alcoholism come under the excluded class. In order to detect other mentally inferior individuals there should be a staff of psychiatrists with a clear understanding of the nature and cause of neuroses, in general, and with a knowledge of the history of each patient to determine whether the condition resulted from former social conditions or from constitutional inferiority. The need for psychiatrists at immigration stations has been emphasized in order to exclude not only the patent defectives and insane individuals, but for the surveillance of the mild cases of social misfits who subsequently become delinquent in many cases. Under certain conditions these might be admitted on parole, subject to report to and deportation by the immigration authorities.

Psychological Tests for Children and Adults.-The failure of adaptation to the social environment reaches back to school age. Therefore mental and psychologic tests should be carried on during the school career of the child. These are as important as the physical tests or medical examinations, which are now almost universally in vogue. Professor Terman of Leland Standford University analyzed the general intelligence of one thousand unselected children. He found 7 per cent. feeble-minded, 15 per cent. dullards, 60 per cent. of average intelligence, 15 per cent. slightly above average and 3 per cent. of very superior intelligence. Professor Thorndike of Columbia has suggested that a national mental census of children be taken. Professor Gazelle of Yale has suggested the use of psychological tests to disclose both the superior and the atypical child, of psychological nurses for the detection of nervous children in the schools, and of 
reconstruction schools staffed by neurologists and educational psychologists. In this way, by developing the child of superior intelligence through a very favorable environment, we shall practice the conservation of human resources.

A mental rating card for school children has been suggested, involving a study of home influences, of special aptitudes demonstrated at play or at work, a study of the character and the degree of coördination of movement, and of manual dexterity. A study of the child's emotional balance should show whether it is easily disturbed and seclusive, or aggressive and sociable. A study of the child's characteristics in facing critical situations should reveal whether it is frank and open, or shows prejudice, whether it has intelligent curiosity and inquisitiveness, whether it has lapses of attention, whether it is capable of concentrated effort, whether it is conscious of the sense of achievement and whether it is developing any special interest in life.

Mental tests for adults have been undertaken on a large scale. In the army, psychiatrists tested and graded two million men up to the time of the armistice. The purposes of the tests, as outlined by Professor R. M. Yerkes of Harvard, who was in charge of the section of psychology in the Surgeon General's office, were to aid in segregating and eliminating the mentally incompetent, to classify men according to their mental capacity, and to assist in selecting competent men for responsible positions.

The army intelligence tests grouped men into several classes. The middle class, representing 25 per cent. of the population, may be called men of "average intelligence." Above this average group there are three others, the group called men of "high average intelligence," forming about 18 per cent. of the population; the group called men of "superior intelligence," representing about Io per cent. of the population; and the highest group of about 5 per cent., called "very superior intelligence." The army tests laid emphasis on speed in responses. Imperfect as this test is, it is still capable of determining whether a man has capacity or potentialities. It was found in the army that the grading of intelligence as manifested by the rating the individual obtained in the test was vindicated by subsequent experience.

By classifying our civil population we shall be able to determine those fit to continue their study and by giving them opportunities to bring out the best in them add to our national equipment. 
Mental tests may form a better basis for admittance to college than entrance examinations. The faculty of Columbia University has recently voted to select its students by means of mental tests to measure the fitness of applicants for admission. The conclusion may be drawn that the better record for achievement and service of college men in years following graduation is not due primarily to their education but to their native intelligence. One may say that the college selects these men for much the same reason that the world later on enlists their services.

Professional and Popular Education.-The public must be taught the importance of mental hygiene. A book like "A Mind That Found Itself," by Clifford W. Beers, illustrates the need for and the application of mental hygiene. The widespread dissemination of the official organ of the national committee on mental hygiene and of the reports of the 18 state societies, the use of exhibitions and moving picture films, emphasizing the importance of mental hygiene, are essential parts of preventive medicine. Elaborate publicity methods including advertising posters and other devices adopted during the war should be made use of in furthering the campaign for mental conservation.

Asylums should be made centers for research and for the development of methods of prophylaxis. Psychiatry should be taught thoroughly in the medical schools and not in the present indifferent manner. The students should have an opportunity to observe borderline cases through personal contact with them in the psychiatric clinics or asylums. Research should be stimulated by providing an adequate staff which is able effectively to utilize clinical material. In Germany, every medical school has a psychiatric clinic in which research and instruction are carried on.

Industrial Prophylaxis.-Singlemindedness is important in life in order to avoid dissipation of energy, especially in this age of specialization. On the other hand, the shut-in personality should be taught to broaden his outlook on life. The layman and labor leaders should recognize that doing work that we are interested in is not irksome, but is rather an opportunity for self-expression. In order to avoid monotony in the repetitive occupations, the hours of labor of employees should be short. More leisure, if the masses are educated to utilize it properly, and healthy recreation would permit a maximum of self-realization and perhaps relieve 
the current discontent, which is psychological as well as social.

On the part of large corporations the physical examination and medical care of employees, periodic medical examinations of policy holders by the insurance companies, movements for life extension and the promotion of public health, all tend toward the preservation of mental health. Health, unemployment, and accident insurance and pensions for the aged would be important factors in lessening worry and anxiety and in reducing the incidence of mental disorder. Investigation into the causes of poverty and provision for the elimination of extreme hardship, by means of state undertakings, perhaps, should be undertaken. Profit sharing and the greater coöperation of the industrial worker in management would not only increase output and the distributable surplus but would establish a new status for the employee, more than that of a cog in the machinery of production, would inculcate greater self-respect and would relieve the repressed mental conflict which smoulders under our industrial peace.

Social Medicine.-With the establishment of prohibition and the removal of the acknowledged benefits of club life of the saloon from the life of the working man, it will be necessary to establish other institutions to maintain social contacts for him. The Salvation Army has attempted to use the stores left vacant by the passing of the saloon as community centers, in which opportunities for social intercourse will be afforded. Apparently man cannot live a full life without it. The popular appreciation of art might develop new and broader interests of the masses and thus check the constant and morbid reflection on their wrongs, real or imaginary. From the days of King Saul to the establishment of the modern psychopathic hospital, music has had a recognized place in calming troubled spirits. Community sports, resembling the Greek games and the Roman circus, popular priced theaters, operas and concerts would add to the harmony of life for the citizens of a republic and aid in sublimating mental conflicts. Of greater value would be the promotion of forms of communal art which would afford opportunity for the expression of latent gifts, which is the psychological keynote of democracy. Social recreation should be fostered in the form of the community drama, the masque, the pageant, the carnival. In Europe these 
have been beneficial institutions for æsthetic expression of the individual through the medium of his social group.

Finally social medicine would be a great help in reducing mental disease. Dr. Cabot includes under this term the work of physicians in state and city sanitaria for tuberculosis, school physicians, health inspectors in industry and elsewhere, social workers in the campaign for better babies and for the diminution of infant mortality, physicians working in prisons, reformatories, almshouses and asylums, in shor the medical missionaries, the health officers of the city, county, state and nation, and those engaged in community service and social work.

The increasing application in our social system of the principles of social justice will be a great factor in diminishing the incidence of mental disease. 



\section{BIBLIOGRAPHY}

\section{American.}

Bingham, A. T.-New York State Journal of Medicine, Vol. I9, No. 3, March, r9i9, pp. 85-88.

Brooks, H.-Paper read before the Section in Medicine, of the New York Academy of Medicine, I9I5.

Cannon, W.-Bodily Changes Produced by Fear, Pain, Hunger, and Rage, New York, D. Appleton \& Co., I9r 5.

Collie, Sir John-Mental Hygiene, Vol. 2, No. I, Jan., rgr8, pp. 615-22.

Farrar, C. B.-American Journal of Insanity, Vol. LXXIII, No. 74, April, 1919.

Farrar, C. B.-Boston Medical and Surgical Journal, Vol. CLXXIX, No. 19, pp. 583-89.

Fernald, G. G.-Mental Hygiene, Vol. 2, No. 3, April, r918, pp. 448-62.

Glueck, B.-Mental Hygiene, Vol. 2, No. I, Jan., I9r 8, pp. 85I 5 I.

Kennedy, Foster-Journal of American Medical Association, Apr. 6, I9I8, Vol. 7I, pp. I7-2 I.

MacCurdy, J. T.-Psychology of War, London, Wm. Heineman, I9r 7.

MacCurdy, J. T.-War Neuroses, Psychiatric Bulletin, July, I9I7.

Paton, Stewart-Harvey Lecture before the New York Academy of Medicine, April 15, I918.

Russell, Wm. L.-Mental Hygiene, Vol. 2, No. 2, April, I9r8, pp. 245-53.

Salmon, T. W.-Military Surgeon, Vol. 4I, Dec., I9I 7 , pp. 674-93.

Yerkes, R. M.-Mental Hygiene, Vol. I, No. 3, April, r9r 7, pp. $371-76$. 


\section{British.}

Eder, M. D.-War Shock, London, Wm. Heineman, I9I8.

Elliot-Smith, G., and Pear, T. H.-Shell Shock and Its Lessons, Manchester University Press, Longmans, I9I 7.

Emslie, Isabel-Edinborough Medical Journal, Vol. I4, May, I9I 5, pp. 359-67.

Myers, Chas. S.-Lancet, London, Sept. 9, 1916, pp. 461-67.

\section{French}

Babinski, J.-Revue Neurologique, Vol. 23, April, 1916, pp. $52 \mathrm{I}-72$.

Babinski, J.-Forment, J.-Hysterie, Pithiatisme et Troubles Nerveux d'ordre Reflexe en Neurologie de Guerre, Paris, Masson, I9r8, 295 pages.

Chavigny, P. Paris Medicale, pp. 8-13, Jan. I, I916.

\section{German}

Marburg, O.--Jahreskurse fur Ärztliche Fortbildung, Vol. 4, I 9 I 5 , p. I.

Mendel, K.-Neurologisches Centralblatt, I9 I5, p. I.

Oppenheim, H.-Berliner Klinishe Wochenschrift, No. 48, I9I5, p. 1853 .

Oppenheim, H.-Berliner Klinische Wochenschrift, Vol. 52, March, I9I5, pp. 257-6I.

Weygandt, W.-Medizinische Klinik, Vol. ro, Sept. 27, I9I4, pp. 103-05. 


\section{INDEX}

A

Adams, R. A., 145

Adams, S. O., 52

Administration, public, inefficient, 193; in England, 194; in Russia, 194-197; in United States, 197; pre-war policy, I98-200; draft administration, 201; decentralized administration, 202, 203; new war organizations, 203 ; centralization, 205 : importance of, 207; education in, 2092 II

Adolescence and spiritual devotion, 287, 288

Alcoholism, control of, 485

Alien and Sedition Laws, xxviii

Aliens, treatment in United States, 236, 237

Altruism, as motive in industry, xxvi; in health movement, 358

Amendments to Constitution, 216 $218,224-225$

American character, 272

American form of government, I9, 20

Americanism, an attitude toward social problems, xxvii

Americanization, 174-176, 235-236, $265,334-336$

American revolution, 4, 84

Ames, Edward Scribner, 28

Assimilation of immigrants, 236

\section{B}

Bacon, Francis, 270

Balfour, A. J., 8

Barbarism, relation to war, 3I-35

Beri-beri, 376

Bolshevism, 51, 78, 83, 96, I49, 194-197, 204

Breckinridge, Sophonisba P., 3II

Budget, lack of interest in, 199
C

Cabinet, President's, 228, 229

Cecil, Lord Robert, 44

Centralization in administration, 205, 206

Childbirth, death in, 318

Child labor, 222, 223, 311-314, 322

Children's Bureau, 312, 318, 319

City administrations, efficient, 200

Civilization, a recent development, 32 ; mores of, 39, 40, 44, 45; a new civilization, 46; achievements, 60; dominant influences, 71,72

Civil service reform, 200, 206, 207

Coal, production in Europe, xxvi

Commission on Training Camp Activities, 475

Community centers, 458

Community Service Association, 460

Commission, Immigration, 172 , 173

Commissions, Land, 143, I44, 147 , 148

"Common sense," 66

Congress, coöperation with executive, 226-230; police powers, 219-223, 404

Constitution, 216-219, 224, 225 . 249

Cooley, Prof., 288

Coöperation, in food distribution, xxvii; economic and social, I04

Corporations, powers of Congress in dealing with, 223

Cost versus value of services, I Io, II I

Crime, cost of, 416 ; prevention of, $43 \mathrm{I}$

Crowder, Gen. E. H., 234, 235

Culture, human, three stages, 3 I

Curtis, Henry S., 45I 


\section{D}

Davenport, Charles B., 30I

Dawson, W. H., IIo, III

Deity, democratic idea of, 290

Delinquency and crime, 4I5

Delinquent children, 315

Demobilization, possible effects, 238

Democracy, xxviii, 17, I8, 5I-55, $211,243,244,253,26$ I, 262, 264, 270,290

Department of Education proposed, 314

Department of Public Health, 394

Dickinson, John, $2+7$

Dietary family, $377-380$

Discharged prisoner, the, 427

Draft administration, 20I-203

Drugs, cause of mental disease, 486

E

Education, importance of, xxv; nature and purpose, $\mathrm{I} 3$; in social reconstruction, 45,46 ; serves special interests, 69,70 ; agricultural, I 8 ; training for, 200, 210; anti-materialistic, 264; education and the spiritual tradition, 277 ; education and modern religion, 295; administration of, 3I3, 3I4; present status and new demands, 323-336; vocational, $342,346,347,348,350$, 351 ; inadequacy of present, 339 , 348 ; development of, 340 ; effect of war, 341,342 ; chief end. 343: program for, 349,350 ; health, 412 ; in preventing crime, 432 ; in venereal disease, 447 ; in mental hygiene, 489

Ellwood, Charles A., 3I

Ely, Richard T., 127

Emigration. I7 I

Eugenics, I1, 12, 304, 355, 356

Experts, administration by, 211

\section{F}

Families, size of, 307,308

Farm implements and houses, I 55-159
Farms, size of, 131, 140, 143, 160; decrease in population, I5I-I53, 164; geography of, I54, 157

Feeble-mindedness, 422, 482-484

Fertility in marriage, 306,308

Fite, Warner, 95

Fitzpatrick, Edward A., 193

Food, production in United States, xxvi ; pre-war cost, 369 , 370 ; situation during war, 371 ; individual requirements, 373375 ; vitamines, 376,377 ; diet elements, 377,378 ; cost, 380 , $381,386-391$; rationing in Europe, 382-386; grain, 384-392

Fosdick, Raymond B., 475

Freedom of speech and press, 4I, 42

French Revolution, 3, 77, 78, 79

Friedman, E. David, 467

Friedman, Elisha M., 3, 15, 42

G

Germany, spiritual collapse, 278

Government, forms of, in United States, 257, $25^{8}$

Government ownership and control, 105, 106, 107, I49

Government, readjustments in United States, 2I5

Grain, 384-392

Grey, Sir Edward, 79

Group interests, conflict of, 267269

\section{$\mathrm{H}$}

Hamilton, Alexander, 265

Health, public, 353; and evolution, 354 ; limitations of conservation work, 354,355 ; necessity of eugenics, 355 ; need for national morale, 357,358 ; altruism in health movement, 358 ; principles of health work, 358; lessons from the war, 359,360 ; world health league, 36r; voluntary organizations, 362; infection, 359-363; education, 363 ; effect of war, 364 ; health in industry, 399-41 3

Healy. William, 4I 5

Heredity, 301, 302, 308, 309; and feeble-mindedness, 486 
Hibbard, Benjamin H., I5I

Hill, Hibbert Winslow, 353

Historical forces, theory of, 250

Hobhouse, L. T., 5, 8, I I

Hollander, Jacob H., II3

Holmes, Justice, I8, $25 \mathrm{I}$

Holy Alliance, 78,89

Hoover, Herbert, xxiii, 382, 383, $386,387,388$

Howe, Frederic C., I67

Humanity, principle of, 5, 6, 43, 83

Hygiene, industrial, teaching of, 328,397 ; mental, $467 \mathrm{ff}$.

Hysteria in war, 473

\section{I}

Idealism, American, 272, 273

Ideals, Hebraic, 27, 28; political, $247,248,25 \mathrm{I}-254,270$

"Idea" politics, 249, $25 \mathrm{I}$

Illegitimacy, 319

Illiteracy, xxv, 278, 3.32, 34I

Immigration, 24, 167; problems, I68; legislation, I69; economic causes, I70; policy of, 170-172, I74; commission on, I72, i73; selection of immigrants in Europe, I73, I74; selection needed, 309; regulation of, 487

Incomes, family, in United States, 370

Individualism, 95-112; of farmers, 135,136

Individual liberty, 259

Industrial democracy, 75

Industrial unrest, $\mathrm{xxv}$

Infant mortality, 317, 318

Infection, in disease, 359-364; in venereal disease, $434,435,439$

Insurance, health, 401

Inter-Allied Scientific Food Commission, 375, 394

Internationalism, 5, 55-75; internationalism and the American spirit, 245

International mind, 5I, 59-75

Isolation, as American policy, 86

\section{$\mathrm{J}$}

Jews in America, 24, 25

Juvenile courts, 316, 317, 420

\section{K}

Kallen, Horace M., 49

Klapper, Paul, 323

\section{L}

Labor, 4; returns from increased production, $\mathrm{xxv}$; group consciousness, 57 ; effect of war, II8-122 ; movement from country, I6I-163; women's labor in war, I77-I82; in peace, I83-I90, 222; use of better conditions, 262 ; immigrant, 398

Laissez-faire, 6, 102, I03, 142, I45

Land problems in United States, I 28-I 49

Land, definition of terms, 132, 139 , I40, I4I ; utilization of, I33; tenancy and ownership, I33-136, I 38 ; settlement, I36; classification, I4I, I42; private and public control, I44, I45, I46; land policy, I29, I30, 137, I42, I43; land "shark," I36, I37

Lane, Secretary, 208

League of Nations, 4, 44, 49-5I, $68,7 \mathrm{I}-75,81,87,89,90,93,289$, $32 \mathrm{I}$

Legislation, on labor, in Kansas, xxix; on immigration, 169 ; child-labor, 3II-3I3; educational, 3I3, 3I4; juvenile-court, 315; non-support and mother's aid, 317; school legislation in England, 322; industrial health, 398 , 399; physical training, 456 Lenine, Nicholai, 195-197

Lippmann, Walter, 68

Literature, American, spiritual note in, 273

Lloyd George, David, I6

Locke, John, 232

Lodge, Henry Cabot, 92, 93

Lowell. President, 208, 211,264

Lusk, Graham, 369

M

Macktpolitik, 35, 81, 82

Marriage, control of, $305,306,486$

Marx, Karl, 250

Materialism, American, 271. 272 
Medicine, social, 490

Nemorial buildings, 460

Mental derangement in armies, $469,470-478$; in civil life, 478 ; prevention and cure, 479-49I

Mental disease, relation to war, $468,470,47 \mathrm{I}, 472$

IIilitary service, effects on soldiers, $24 \mathrm{I}-243$

Military training, 333, 334

Mill, John Stuart, 87, 88, 96

Monroe Doctrine, 78, 79

Morale, in health movement, 357 , 358,363

Morbidity, statistics of, 407

Mores, I3; of barbarism, 36, 39, 40 ; of civilization, $39,40,45$; relating to marriage, 306

Munroe, James Phinney, 339

\section{$\mathrm{N}$}

Nationalism, 25-28, 55, 59

Nationalism and American consciousness, 233

Nationalization of medicine and nursing, 365

Negro problem, 23

Negroes, venereal disease among, 435,443

New cults, 292, 293

New Era, the, 3-7

Neuroses, war, 470-473; suggestion neuroses, 473; anxiety neuroses, 474 ; measures to combat, $475-478$

Nutrition, before and during war, 372-375, 394

\section{$\mathrm{O}$}

Open-air classes in schools, 327

Outdoor recreation, 463

\section{$\mathrm{P}$}

Parole of prisoners, 427

Party government, 19, 20, 225, 226, 230

Patent medicines, in treating venereal diseases, 440

Pauperism, reduced by war, II5II 7

Peabody, Francis G., 27I
Peace, permanent, $38,4 \mathrm{r}$

Personality and religion, 29r

Playground Association of America, $45 \mathrm{I}, 456,457,460,46 \mathrm{I}$

Playgrounds, 45I, 457, 462

Play in schools, 453-457; legislation, 455

"Poor Richard" philosophy, 263

Popenoe, Paul, 433

Population, readjustment of, 164

Postal service, 107, 108, 219

Pre-vocational school, 329

Prices, I2I, I22; of farm products, xxvii; of food, I65, 370, $37 \mathrm{r}, 380,38 \mathrm{r}, 386-39 \mathrm{r}$; of farms, I 60,161

Prisoners, treatment of, 428

Probation in treating criminals, 419, 429

Progress, social, 7-13, 15, 16, I7

Progressive Party, I99.

Propaganda, organization of, 68 , 69

Prophylactic measures against mental disease, 482

Prophylaxis, medical, against venereal disease, 439; mental, in industry, 489

Prostitution, 434, 436, 437, 438, $443-445,448$

Prussianism, possible danger in United States, 256, 257

Psychiatric clinic, 480

Psychologic tests, 345, 346, 487

Public Health Service, 405, 406, 407, 410, 4I I

Public opinion, as a force, 17, 18 . $49-51,65,68,91$; on women in industry, $182-85$; on administration during war, 204; and the spiritual tradition, 280

Public service, training for, 2092 II

$Q$

Quarantine of diseased women, 437

$\mathrm{R}$

Rationing in war, $382-386$

Reconstruction, 42-46, 79, 80, 83, $127,128,205,215,319,323,324$

Recreation, in combating prostitution, 448 
Recreation Commission, 462

Reformatory, $4 \mathrm{I} 8$

Religion, 25-28; organized, afterwar duties of, 277; science of, 285 ; psychology of, 286 ; as social idealism, 288; religion and doctrine, 289; and personality, 291 ; traditional faiths, 29I, 292, 293, 294; progressive movement, 294

Religious life, American, demands of, 295,296

Responsibility, social, 97, 102, 103

Rights, individual, 96-98, 102, 106

Rogers, Lindsay, 77

Roosevelt, President, 3I6

Russia, Bolshevik administration in, 194-197

$\mathrm{S}$

Sanitation, 402, 403, 404, 410

Schereschewsky, J. W., 397

School administration, principle of, 201

Schurz, Carl, 275

Scientific study of spiritual traits, 286,287

Segregation of prostitutes discredited, 437

Self-expression as radical aim, 260

Sherman, Henry C., 379, 394

Shipbuilding, training for, 346

Social conscience, $\mathrm{xxix}$

Social efficiency, education for. 325

Socialism, 53, 96: state socialism, 98, 105-107, 149

Social life, organic nature of, xxiii

Social organization, 100-103

Social problems, scientific method in handling, xxiv

Social service, 43

Society, origin of, 303

Soldier-citizens, 240

Sovereignty, 52, 90, 107-109

Spirit, American, 232, 233, 275, 276

"Standardization" movement in administration, I99

Standards, health, 409; labor standards for women, I80, I8I, I85, 190
Suffrage, industrial, $7 \mathrm{I}$

Supreme Court, 221, 222-224

\section{$\mathrm{T}$}

Taxation of land, American system, I3I, I32, 139

Taxation, powers of Congress through, 220

Taylor, Graham, 23I

Teachers, status of, 336, 337

Tenancy of land, 133, I34, 135, 147

Trade Unions, 4, I05, I83

Treaties, observance of, 87,88 , 90

Treaty of Peace, 19, 20

Tuberculosis, 363

\section{$\mathrm{U}$}

Unemployment, II8-122

Unpreparedness for war, 200

Usher, R. I., 269

Utopias, progress through search for, 92

\section{V}

Vagrancy, control of, 484

Van Kleeck, Mary, I77

Venereal disease, spread by war, 433 ; infection from prostitutes, 434 ; infection among male civilians, 435; among negroes, 435: cost to army, 436 ; law enforcement, 436 ; quarantine, 437 ; compulsory prophylaxis, 440 ; ignorance of, 441: after-war policy, 44I : in Southern States, 443: medical treatment, $446^{\circ}$ control of, 485

Vitamines. 376,377

Vocational education, 320

Vocational rehabilitation of soldiers, 348

Vocational training during war, 347: after war, 348

Voluntary associations in the war, 258 ; in peace, 260

\section{W}

Wages of women, 186

War, 9, 3I-34, 38-40, II 3 , I I4-I 24 
War, the Great, xxiv, 3, 7, I0; caused by mores of barbarism, 34-37; recovery of social losses following, 40- 42 ; basic social change brought by, 79-8I ; effect on pauperism and labor, II5I20; on country labor, I6I-I63; women's work during, 178-182; public administration, 194, 200203 ; effect on working world, $24 \mathrm{I}$; concentration of authority, 255,256 ; voluntary associations, 258 ; spiritual lessons, 274-276; some good effects, $280,28 \mathrm{I}$; effect on child labor, $320,32 \mathrm{I}$; on education, 341,342 ; educational lessons, $343,345,347,348$; vocational training, 347 ; health lessons from, $359,360,364$; food situation, 371; rationing, 382386; crime in United States, 423 ; venereal disease, treatment in, 433 ; recreation, 464,465 ; medical science, $468,479-491$

War Labor Policies Board, 178, I79, I8I

Welfare work in prisons, 423

West, Victor J., 215

Wilson, Woodrow, 12, 19, 24, $49,73,83,89,90,91,93,213$, 276

Woman in Industry Service, 178 , I82, 184,185

Women in industry, $177 \mathrm{ff}$; $\mathrm{em}$ ployment in England, I77; United States war measures, 178; importance in war work recognized, I79, I80; labor standards, I80, I8I; effects of war on employment, I82 ; public attitude after armistice, I82, 183

Wood, T. B., 384, 392

World consciousness, 233 

. 


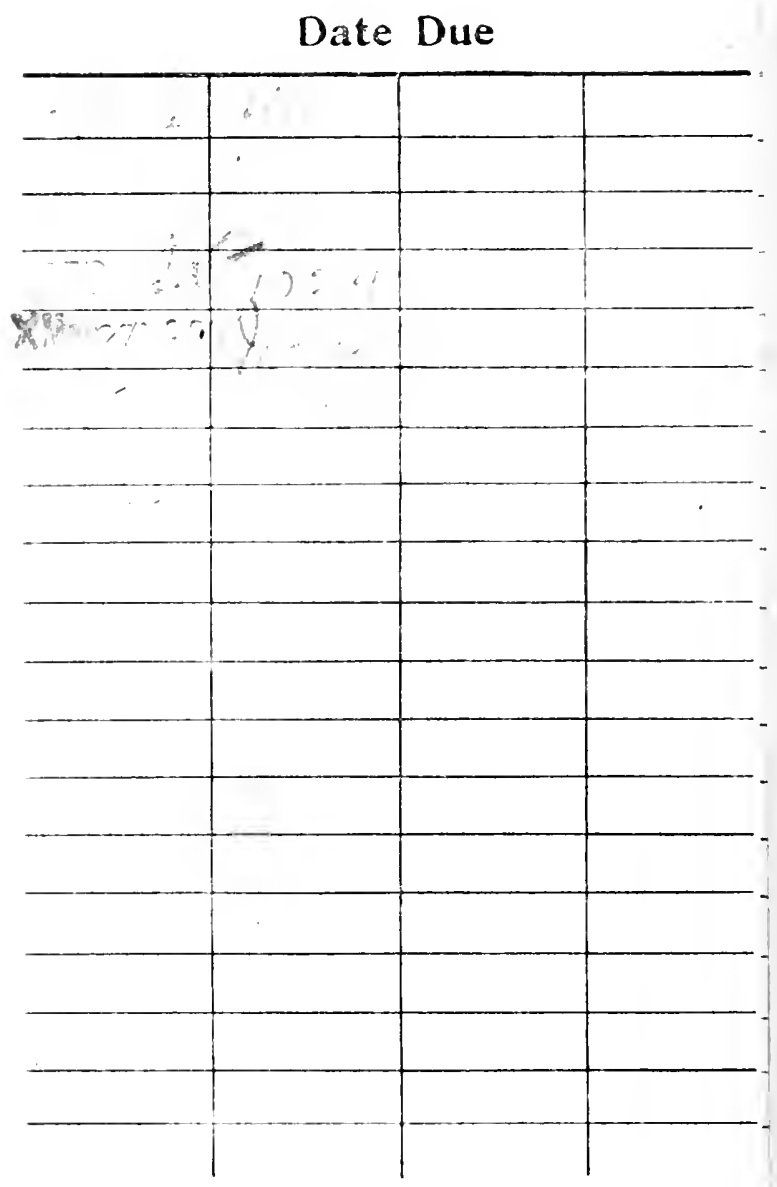



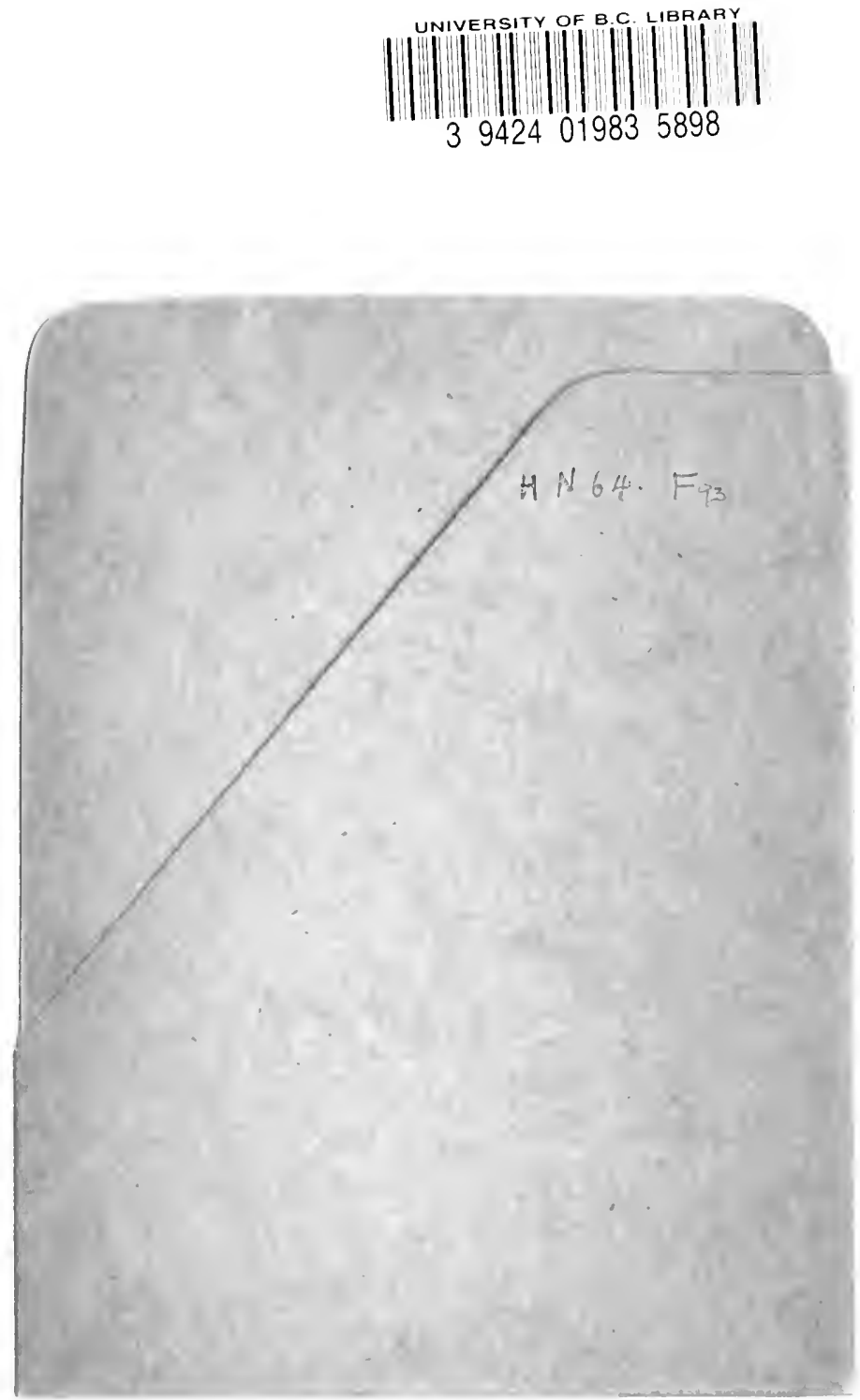


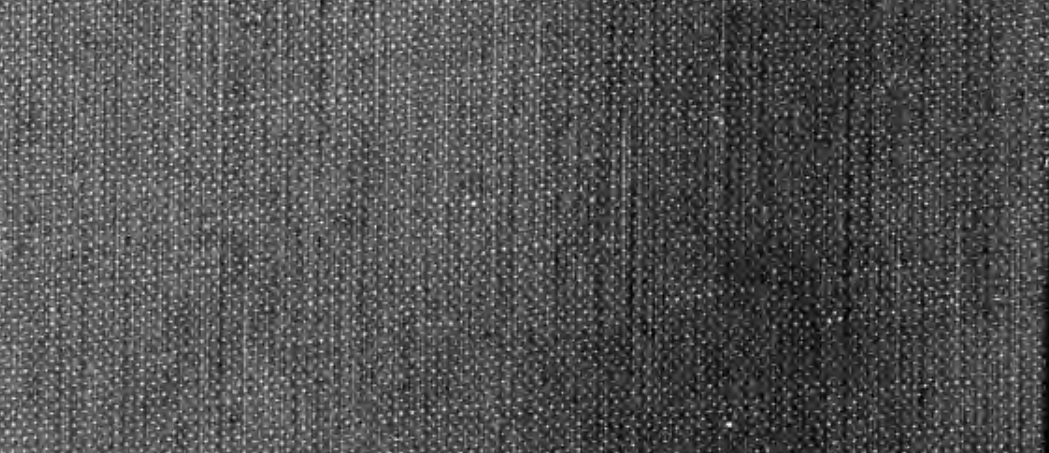
\begin{tabular}{l}
\hline \\
\hline
\end{tabular} 